\title{
An Oral History of Camp Swift: 2004 Interviews
}

\author{
Martha Doty Freeman \\ Center for Archaeological Studies \\ David L. Nickels \\ Thad Sitton \\ Center for Archaeological Studies
}

Follow this and additional works at: https://scholarworks.sfasu.edu/ita

Part of the American Material Culture Commons, Archaeological Anthropology Commons, Environmental Studies Commons, Other American Studies Commons, Other Arts and Humanities Commons, Other History of Art, Architecture, and Archaeology Commons, and the United States History Commons

Tell us how this article helped you.

This Article is brought to you for free and open access by the Center for Regional Heritage Research at SFA ScholarWorks. It has been accepted for inclusion in Index of Texas Archaeology: Open Access Gray Literature from the Lone Star State by an authorized editor of SFA ScholarWorks. For more information, please contact cdsscholarworks@sfasu.edu. 


\section{An Oral History of Camp Swift: 2004 Interviews}

Creative Commons License

(c) (i) (8)

This work is licensed under a Creative Commons Attribution-NonCommercial 4.0 International License 


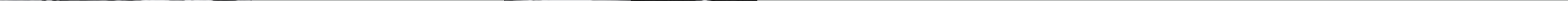




\title{
An Oral History of Camp Swift: 2004 Interviews
}

\author{
Interviews by \\ Martha Doty Freeman, David L. Nickels, and Thad Sitton
}

Principal Investigators:

C. Britt Bousman and David L. Nickels

Archaeological Studies Report No. 9

Center for Archaeological Studies Texas State University-San Marcos 2006 
The following information is provided in accordance with the General Rules of Practice and Procedures, Title 13, Chapter 26, Texas Administrative Code:

1. Type of investigation: Oral history interviews.

2. Project name: Camp Swift Oral History Project, 2004 Interview Transcripts

3. County: Bastrop

4. Principal Investigators: C. Britt Bousman and David L. Nickels

5. Name and location of sponsoring agency: The Adjutant General's Department of Texas, Directorate of Facilities and Engineering, Environmental Branch, Austin, Texas

6. Published by the Center for Archaeological Studies, Texas State University-San Marcos, 601 University Drive, San Marcos, Texas, 78666-4616 (2006)

Texas State University-San Marcos is a member of the Texas State University System Copyright (C) 2006 by the Center for Archaeological Studies at Texas State University-San Marcos

All rights reserved.

No part of this book may be reproduced or utilized in any form or by any means, electronic or mechanical, including photocopying, recording,

or by any information storage and retrieval system without permission in writing.

For further information on this and other publications by the Center for Archaeological Studies, please contact:

Center for Archaeological Studies

Texas State University-San Marcos

601 University Drive

San Marcos, TX 78666-4616

www.txstate.edu/anthropology/cas/

Editors: Maggie Moore and Jessica Hurley

Front Cover Photograph: Ruth Allen Hancock and her five children in front of the Hancock House in Oak Hill; photograph provided by Ruth E. Smith.

Back Cover Photographs: Interviewees in the Camp Swift Oral History Project.

Printed in the United States of America

by

Ginny's Printing Inc., Austin 


\section{Table of Contents}

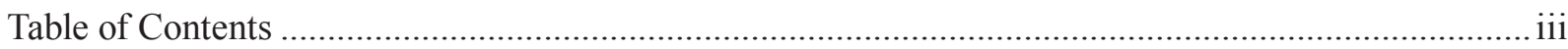

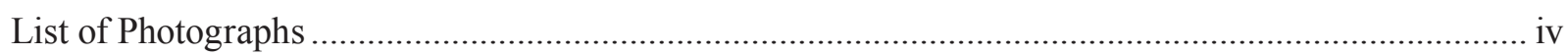

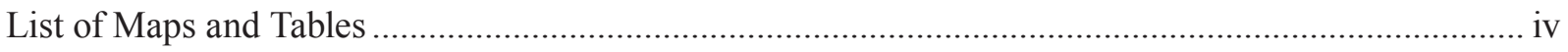

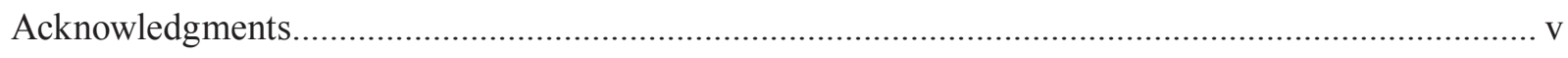

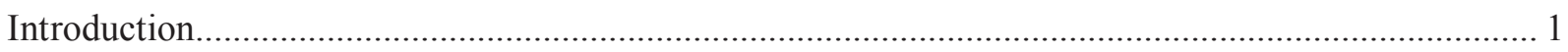

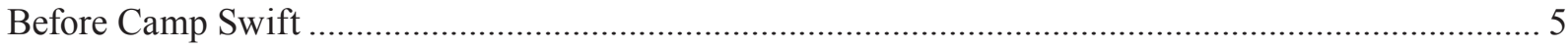

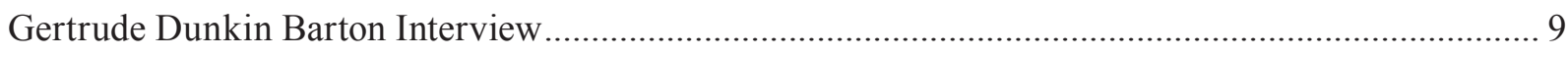

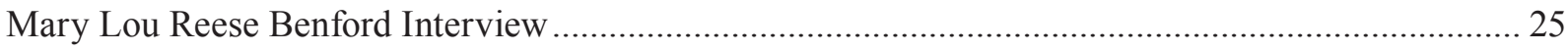

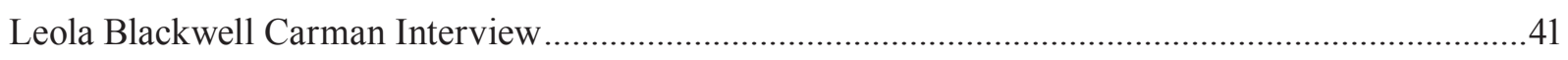

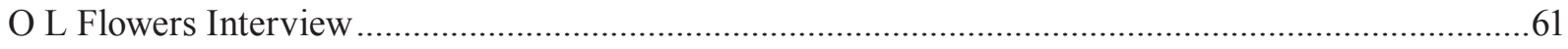

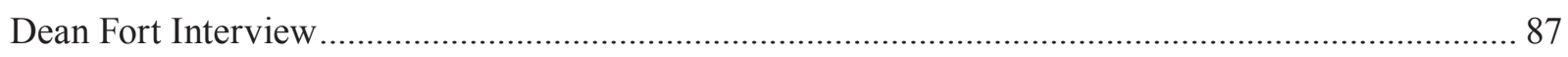

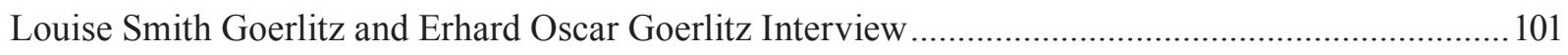

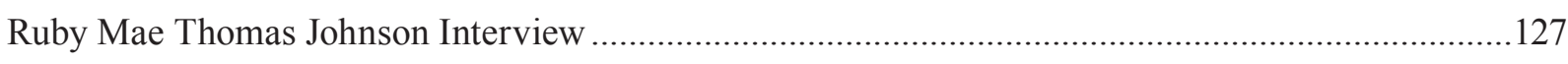

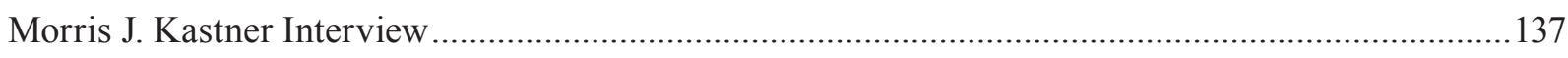

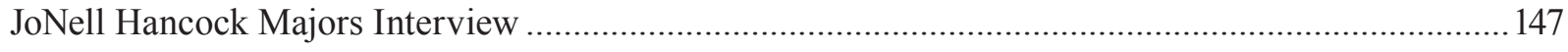

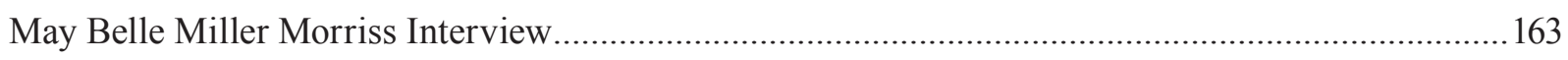

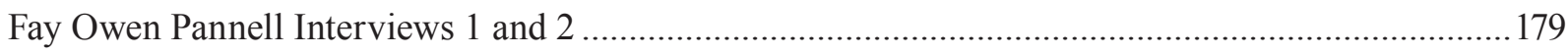

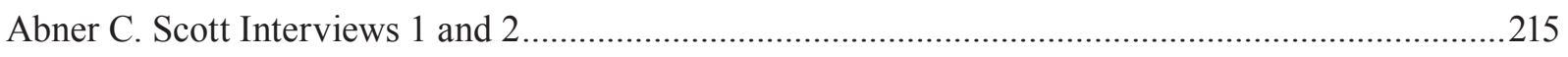

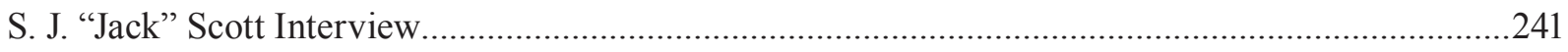

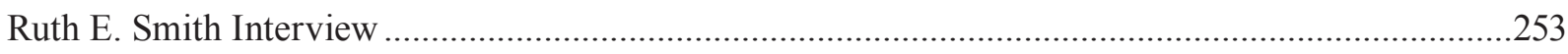

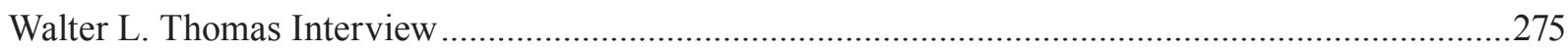

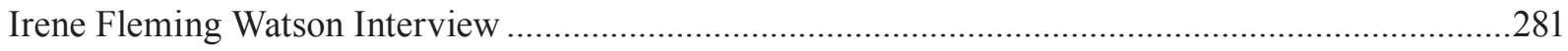

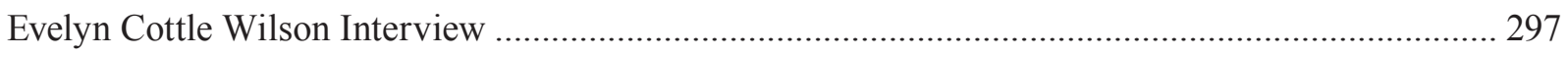

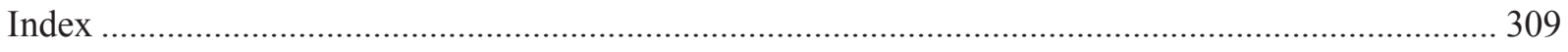




\section{List of Photographs}

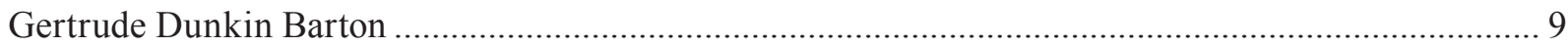

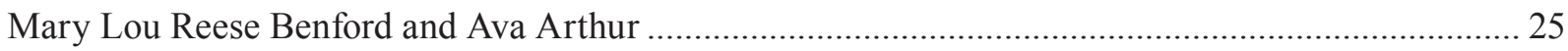

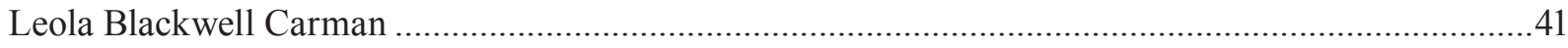

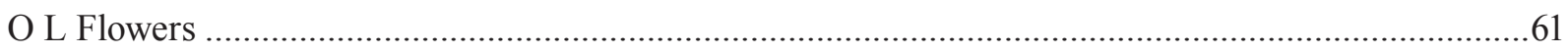

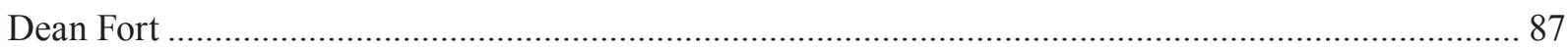

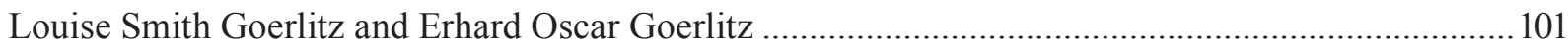

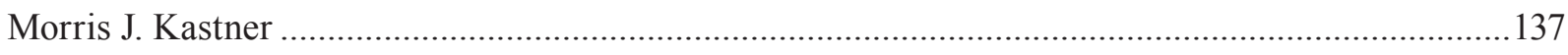

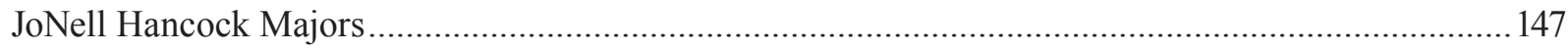

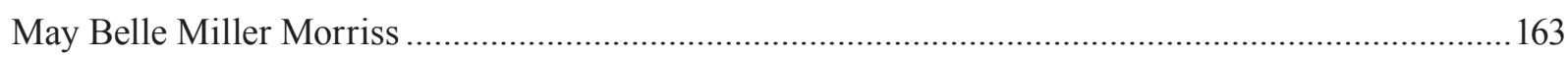

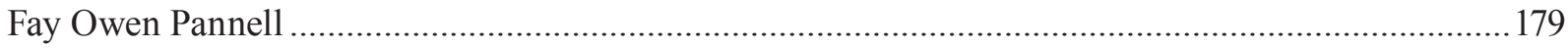

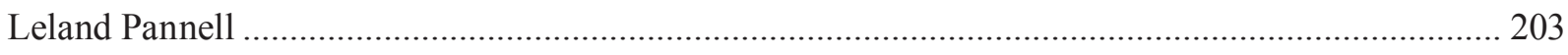

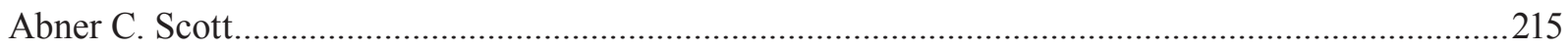

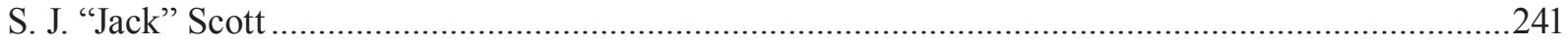

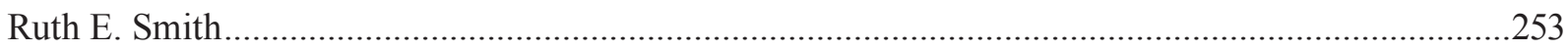

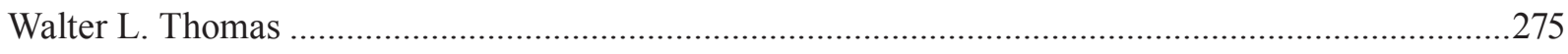

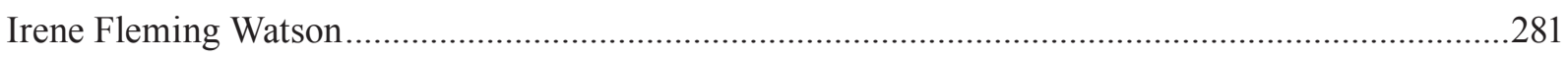

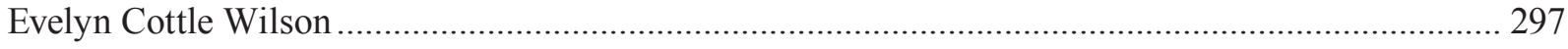

\section{List of Maps and TABles}

Map 1. Historic communities within and near the current boundary of Camp Swift............................ 6

Table 1. Community and school affiliations of the interviewees.......................................................... 7 


\section{ACKNOWLedgments}

The interviewers would like to thank all the individuals that participated in this project. The success of this type of project is directly related to the interviewees and their enthusiastic willingness to record their thoughts and memories. These individuals include Gertrude Dunkin Barton, Mary Lou Reese Benford, Leola Blackwell Carman, O L Flowers, Dean Fort, Louise Smith Goerlitz and Erhard Oscar Goerlitz, Ruby Mae Thomas Johnson, Morris J. Kastner, JoNell Hancock Majors, May Belle Miller Morriss, Fay Owen Pannell, Abner C. Scott, S. J. “Jack” Scott, Ruth E. Smith, Walter L. Thomas, Irene Fleming Watson, and Evelyn Cottle Wilson. Also the interviewers wish to thank Ms. Shellie Sullo and Ms. Kristen Wenzel, the previous and current Cultural Resource Managers for the Texas National Guard who made this project possible and were extremely helpful throughout every phase. Several staff and faculty members at the Center for Archaeological Studies at Texas State University-San Marcos assisted with the project. C. Britt Bousman and David L. Nickels served as Principal Investigators. Jessica Hurley contextually edited the report, David L. Nickels prepared the index, and Maggie Moore edited and prepared the final version for publication. Carole Leezer provided logistical and administrative support. 


\title{
INTRODUCTION
}

\author{
By Martha Doty Freeman and Jessica Hurley
}

The Adjutant General's Department of Texas contracted with the Center for Archaeological Studies, Texas State University-San Marcos (CAS) to conduct an oral history project at Camp Swift in Bastrop County. The oral history project could provide information useful in determining National Register of Historic Places (NRHP) eligibility assessments of archaeological sites. The facility's use by the Texas Army National Guard for military training began during World War II, and the Adjutant General's Department has overseen management of cultural resources for the camp since the passage of the National Historic Preservation Act in 1965. Archaeological inventory of the area began as early as 1979 and has continued with surveys that have provided the National Guard with recommendations concerning the eligibility of sites for nomination to the NRHP.

Some projects completed by CAS have involved research about the historic occupation of the Camp Swift area prior to World War II, and a number of CAS's reports have described sites associated with that history. In 2004, recognizing that another important historic resource - the former occupants of the land and creators of those sites - was rapidly disappearing, Shellie Sullo, former Cultural Resource Manager for the Texas Army National Guard, Directorate of Facilities and Engineering, Environmental Branch, conceived the idea of identifying former residents and collecting their histories. The goals of the resulting project were to compile historic information about the pre-military history (ca. 1820-1950s) of Camp Swift, archive it for future generations, and to make the information available in a variety of formats to researchers and the general public.

Specific tasks to achieve the project goals included: (1) developing an oral history project in a cooperative effort with former residents of Camp Swift and various local history groups, (2) conducting an oral history workshop for the interviewers that also would be open to interested faculty and students at Texas State University-San Marcos, (3) conducting oral history interviews and transcribing the tapes, (4) photographically copying historic images held by the interviewees, (5) archiving the tapes, transcripts, and photographs in a permanent repository, (6) producing an indexed technical report consisting of the transcriptions and photographs of each interviewee, and (7) publishing a popular oral history report.

A similar oral history project conducted at Fort Hood, Texas, from 1998 to 2001, in which two of the historians had participated, provided a model for the methodology for the Camp Swift Oral History project. The first task required identification of a permanent repository for the archival materials (tapes, photographs, and transcripts) from the project. The Center for American History at The University of Texas (CAH-UT), selected because of its proximity to the project area and the appropriateness of its facilities for housing the products, agreed to receive the materials.

Next, the acquisition of oral memoirs and photographs required the development of a Deed of Gift Agreement that briefly explained the purpose of the program; identified the participating agencies; and allowed the participants to agree to assignment of their rights, title, copyright, and interest to $\mathrm{CAH}-$ UT as the curatorial facility. In addition, project personnel developed an information form that they provided to all interviewees. The form explained the purpose of the project in greater detail, the goals of the project, anticipated products, and the meaning of the conveyance of copyright. The information 
form also provided contact information and accompanied letters inviting potential interviewees to participate. Finally, each interviewer received a Memoir Introduction to be read at the beginning of each interview that identified the participants, date, number of the interview (to be used when an individual was interviewed more than once), the location of the interview, and the project sponsors.

The third phase of the project consisted of a review of reports about the historic occupation of Camp Swift so that all participating historians would be familiar with the area. The interviewers then identified common themes pertaining to agriculture, community life, education, religious practices, the impact of the governmental taking of property, and other topics that would guide them in their work. The historians then participated in a workshop held at Texas State University on March 22, 2004, that focused on a description of the Camp Swift cultural landscape, an explanation of oral interviews as one of the three forms of historical evidence, and a review of the technicalities of collecting oral interviews.

There was some anticipation that, given the relatively small geographic study area and the amount of time that elapsed since the early 1940s, it might be difficult to identify potential interviewees. Fortunately, a group of individuals who either had been former residents of the Camp Swift area or were interested in Bastrop County history offered to help with the identification task. A meeting with the members of the Sayersville Historical Society on March 7, 2004, yielded a number of names, as well as a suggestion that the interviewers might find it helpful to attend the Oak Hill Cemetery reunion in May.

Contact of potential interviewees by written correspondence and telephone occurred in March 2004; interviews took place between March and June. Typically, the interviews occurred in the informants' homes or other places of residence (such as a retirement center), where each one was asked to sign the Deed of Gift Agreement. Following the interview, interviewers asked informants to share any historic photographic images they had of family members, farmsteads, buildings, or other depictions of community life. A portable copy machine allowed for on-site copying of the provided images and informants recorded on pre-printed forms the name, address, and telephone number of the owner, along with a description of the photograph (date taken, photographer, location, approximate size of the image, and description of the subject matter).

Historians interviewed a total of eighteen informants who lived in the communities of Bastrop, Elgin, McDade, Lockhart, Sayers(ville), San Antonio, Austin, and Johnson City. They collected thirtysix and one-half hours of taping on high quality, sixty-minute audiotapes. Interviewers conducted seventeen of the interviews with single informants; two informants underwent the interviewing process twice. One interview involved two informants simultaneously interviewed; several others included comments by family members. Eleven women and seven men ranging in age from sixty-seven to ninetyfour and representing approximately four different historic communities at or adjacent to present-day Camp Swift contributed to the project.

Upon completion of an interview, each original tape was duplicated, the original retained for archival purposes, and the copy given to the interviewer who then transcribed the tape; in one case, an individual who did not participate in the project as an interviewer, but who was conversant with the tasks of interviewing and transcribing oral history projects, provided transcription services. Transcriptions were prepared using guidelines provided by the Transcribing Style Guide developed by the Institute for Oral History at Baylor University (1977). The interviewer, now acting as transcriber, paid careful attention to words and particularities of speech in order to complete as accurate a record of the interview as possible. The interviewer then returned the draft transcription to the interviewee with a request that the informant review the text, make corrections, and return the interview within one month. All interviewees complied with the requests, generally correcting spellings of proper names and 
places and erroneous dates, when necessary. Some changed the speech patterns or spellings to delete repetitious phrases or to create a text that more nearly mirrored Standard English; one interviewee made major changes to her text. The interviewers then made the requested corrections to the computerized versions of the interviews and produced a master list of non-standard words, phrases, and spellings to assist the project editor in her work to bring a degree of consistency to all the interview texts.

Jessica Hurley of CAS completed textual editing; her objectives included preservation of the content and context of the dialogue, while supplying structure and a uniform presentation for the interviews. Alphabetical presentation of the interviews by interviewee's name avoids any suggestion of priority of one interview over another. Details of the interview, including the interviewer, date, location, and year of birth of the interviewee, appear at the end of each interview. The voice of the individual, colloquial expressions, and the dialects present in the dialogues are elements that can provide insight into the experiences of the interviewees. Therefore, Hurley worked to convey those mechanisms of speech in the text accurately. Inherent editing difficulties associated with attempting to communicate spoken words through a written medium arose because of a number of factors, which included, but were not limited to, fragmented sentence structures, misspelled and misspoken words, intentional and unintentional disruptions, and adherence to emotion-specific punctuation. The deliberate inclusion of thoughtful pauses on the part of the interviewee, colloquialisms, laughter, and other background noises provide the reader with an accurate portrayal of the tone and setting of the interview; they also offer an intimate glimpse into the lives of the men and women who participated in the project.

Preservation of the distinct voices and experiences of the participants in the Camp Swift oral history project required careful consideration of how best to capture the sentiments expressed in the interviews without distorting the manner of speech from the original context. With this consideration in mind, there were minimal changes made in the texts from transcript to final draft form. Standardization of slang terms and cautiously placed punctuation, typically to indicate pauses or discontinuity in speech, allow for easier readability and offer insight into the types of speech and colloquialisms commonly spoken in the region. Aside from these minor modifications, which were primarily aesthetic, the text replicated the words of the individuals interviewed, thus enabling them to communicate their emotions and experiences. Their candid responses to the interviewers' questions revealed a wealth of information about life in the first few decades of the twentieth century on and around the land that is now Camp Swift.

Concurrently with the textual editing, historian Thad Sitton selected photographs that might be appropriate for use in a popular report. The project photographer, Diane E. Williams, then contacted the participants and arranged to make black-andwhite copies of the original photographs. Some of the photograph copies developed poorly and were later digitally scanned. Diane also photographed each interviewee or, in cases where the individual was deceased (two project participants died in 20042005), she reproduced an appropriate photographic portrait supplied by the family. One interviewee declined to have her picture taken but her interview still appears in the text.

Upon completion of the final editing and layout by Maggie Moore of CAS, Daivd L. Nickels prepared an index to the volume of oral histories. The detailed index includes not only place names and personal names, but also broad themes and specific subjects. Thad Sitton prepared a popular report based on the oral history data, which he organized according to themes such as agriculture and community development, and replicated selected historic photographs for inclusion in the publication. Maggie Moore edited and prepared the popular report for publication, and Sitton prepared an index following the guidelines of the oral history volume index. CAS produced both reports and provided them to the Adjutant General's Department in both paper and digital formats. 
The final task entailed copying the transcripts on archival paper and submitting them, along with the original tapes and copies of the historic photographs, to CAH-UT for curation. The archival collection also includes files developed by each participating historian and is open for use by historians and the general public. 


\title{
Before Camp Swift
}

\author{
By C. Britt Bousman
}

In the years leading up to World War II, in an area north of Bastrop bounded by State Highways 21, 290, and 95 , some 350 families lived by subsistence and small-scale cash-crop farming. This area, which was to become a major United States Army training center called Camp Swift, was home to numerous small farms and communities such as Wayside, Oak Hill, Spring Branch (Scott Falls) and Sayers(ville) (Map 1). These communities were not much more than groups of farming families. Most had a church and possibly a school, but little commerce. The few businesses were small enterprises, such as the single store and a small lignite mine at Sayers. By June 15, 1942, all of these communities and farming families had moved off their land so that Camp Swift could be built. Most families moved to other farms or surrounding communities such as Bastrop, McDade or Elgin, making way for Camp Swift. By the end of the war the camp had become a sizeable community in its own right that covered 55,982 acres.

By 1940, the descendents of the original pioneers and other people who came later supported themselves by Southern sandy-land farming. Cotton, the wellknown Southern cash crop, no longer grew well on these sandy and depleted soils. Instead, farming families grew watermelons, cantaloupes, sweet potatoes, peanuts, field peas, and a variety of garden vegetables. They also raised a menagerie of animals such as chickens, turkeys, guinea fowl, geese, hogs, and some cattle. Hogs provided meat, chickens laid eggs, and cows gave milk, which in turn was used to produce other dairy products, such as butter, cheese, and curds and whey. Most produce was for household consumption, but any surplus was sold in town or bartered for the special items that country peddlers brought to the farms. Turkeys were among the most important farm animals because they could feed themselves on grasshoppers, acorns, pecans, and other open range foods, and then be sold for cash at
Christmas and Thanksgiving. Cash from the crops and stock could be used to purchase the flour, sugar, salt, coffee, kerosene, and tobacco that could not be produced on the farms. Horses and mules were used to pull plows and wagons that were still the primary means of transportation. There were numerous dirt roads that crisscrossed rural Bastrop County. Most were poorly maintained, but they were the only link between the isolated farm houses and the small communities.

In January of 1942 the United States government began to acquire the land for Camp Swift. By early summer all the families had moved off to other farms or to towns and cities. They were paid at or below market price for the land, but paid nothing for any of the improvements such as their houses, barns, or other outbuildings. The families could take these buildings with them, but they were given no money, no help, and little time to do so. No one had a choice of moving or staying - all left. Soon after, their homes and outbuildings were demolished in order to provide an appropriate military training facility. This action eliminated the possibility of most families returning after the war to their farms and communities where they had lived, some of them for generations.

At its zenith, Camp Swift had 44,000 military personnel, 2,750 buildings (including a 750-bed hospital, churches, a fire department, swimming pools, and theaters), utilities, a German prisoner-ofwar camp with 4,000 prisoners, and many miles of roads. This expansion nearly tripled the population of Bastrop County and dwarfed the town of Bastrop, which in 1940 had a population of only 1,976 people.

After the war, nearly half of the 55,982 acres in Camp Swift were returned to private hands, but not always to the original owners. The government required the new owners to pay the original purchase price, 


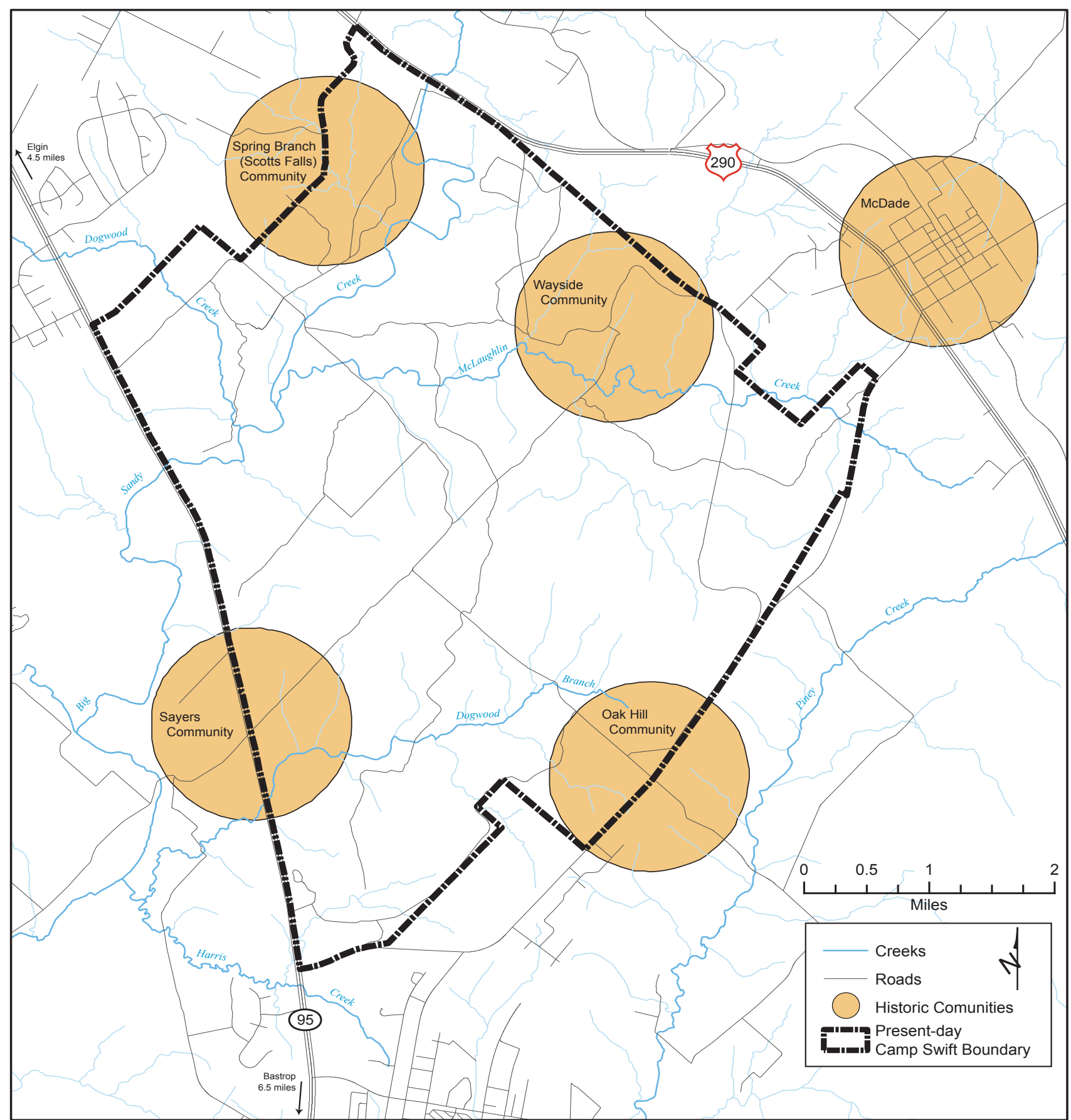

Map 1. Historic communities within and near the current boundary of Camp Swift.

with the cost of rebuilding houses and outbuildings to be borne by the new owners. Obviously, this was an economic obstacle that many of the original landowners could not overcome. Over half of Camp Swift was retained by Federal and State governmental agencies. The Adjutant General's Department of the Texas Army National Guard still uses 11,500 acres for training. The remainder of the kept land is controlled by the Texas Parks and Wildlife Department (leased from the Lower Colorado River Authority) and The University of Texas at Austin.

The Camp Swift Oral History project is an attempt to record life at Camp Swift before the Army arrived. This rural lifeway ceased over 60 years ago, and very few people who participated in it are still alive. The 
Camp Swift Oral History project has recorded, in the words of the original occupants, what life was like in this portion of Texas before World War II. Eighteen former residents of the area agreed to be interviewed in 2004 by Martha Doty Freeman, Thad Sitton and David L. Nickels (Table 1). Two reports resulted from these interviews. The first consists of the verbatim transcripts of all the interviews, and the second is a popular history of life in a portion of the Bastrop County countryside before the war. This report, the verbatim transcripts, provides a view of midtwentieth-century life in northern Bastrop County in the words of the people who lived there. As such, it is a primary document.
The removal of people from their land is not in question. The issue of whether they were treated in a fair and equitable manner is not established or determined in this report. However, the report does attempt to provide a record of the families and their lives before they were forever changed by events at the beginning of America's involvement in World War II. Was it right; was it wrong? These questions can never be fully or correctly answered. World War II, an event of such enormous magnitude, affected so many people and in so many different ways, that these issues are beyond the scope of the oral historian. But while it is still possible, let us record these stories, events, and people before the witnesses are gone forever.

Table 1. Community and school affiliations of the interviewees.

\begin{tabular}{|l|l|l|}
\hline Interviewee & Community Affiliation & School Affiliation \\
\hline Gertrude Dunkin Barton & Oak Hill & Oak Hill, Bastrop \\
\hline Mary Lou Reese Benford & Sayers & Sayers \\
\hline Leola Blackwell Carman & McDade, Oak Hill & Oak Hill, Bastrop \\
\hline O L Flowers & Sayers, McDade & Sayers \\
\hline Dean Fort & Scott Falls, Oak Hill & Elgin \\
\hline Erhard Oscar Goerlitz & McDade & McDade \\
\hline Louise Smith Goerlitz & Oak Hill, McDade & Oak Hill, McDade, Bastrop \\
\hline Ruby Mae Thomas Johnson & Sayers, McDade & Sayers, Elgin \\
\hline Morris J. Kastner & McDade & McDade \\
\hline JoNell Hancock Majors & Oak Hill, McDade & Oak Hill, Bastrop \\
\hline May Belle Miller Morriss & Glenham, Phelan, Oak Hill & Glenham, Oak Hill \\
\hline Fay Owen Pannell & Oak Hill & Oak Hill, Bastrop \\
\hline Abner C. Scott & Wayside, Spring Branch, Oak Hill & Wayside, Oak Hill, Elgin \\
\hline S. J. “Jack” Scott & McDade, Wayside, Scott Falls & N/A \\
\hline Ruth E. Smith & Oak Hill & Oak Hill, Bastrop \\
\hline Walter L. Thomas & Sayers, McDade & Elgin \\
\hline Irene Fleming Watson & Oak Hill & Oak Hill \\
\hline Evelyn Cottle Wilson & Oak Hill, Wayside & Oak Hill, Bastrop \\
\hline
\end{tabular}




\title{
Gertrude Dunkin Barton Interview
}

\author{
By Martha Doty Freeman
}

\section{May 2004}

\begin{abstract}
Martha Doty Freeman: This is Martha Doty Freeman. Today is May 31, 2004. This interview is taking place at the Golden Age Home in Lockhart, Texas, in the room of Gertrude Dunkin Barton. This interview is part of the Texas State University-San Marcos Camp Swift Oral History project, sponsored by the Texas National Guard and conducted in conjunction with the Center for American History, The University of Texas at Austin.
\end{abstract}

Freeman: Well now, tell me about your family.

Gertrude Dunkin Barton: Well, there was eleven children. My mother and daddy had eleven children, lost one baby girl. She was about fourteen months old. She was the third one. I had older brothers, Leon and Clyde. And, let's see, what was her name? Adele. And she's the one that died. And then I had Lawrence and Woodrow, two more brothers, and then I was born, and then the rest of the sisters after me was born.

Freeman: And what were your younger sisters' names?

Barton: Let me see, Naoma Dunkin. No let's see, after me was Doris Dunkin, Katherine Dunkin, Naoma Dunkin, Ola Mae Dunkin, and Laverne Dunkin. I think that's all of them.

Freeman: And what were your parents' names?

Barton: Garland Huff Dunkin and Jess Dunkin. That was their names, mother and daddy's names.

Freeman: Do you know where they were from?

Barton: Jess Dunkin was born at Oak Hill. Garland Huff Dunkin was born close to Paige, Texas. My dad, I guess his mother and daddy lived there. I guess he was born there on the land. My mother was from around Paige, Texas. She was Garland Huff. Then she married Jess Dunkin. She was from around Paige. That's all I remember.

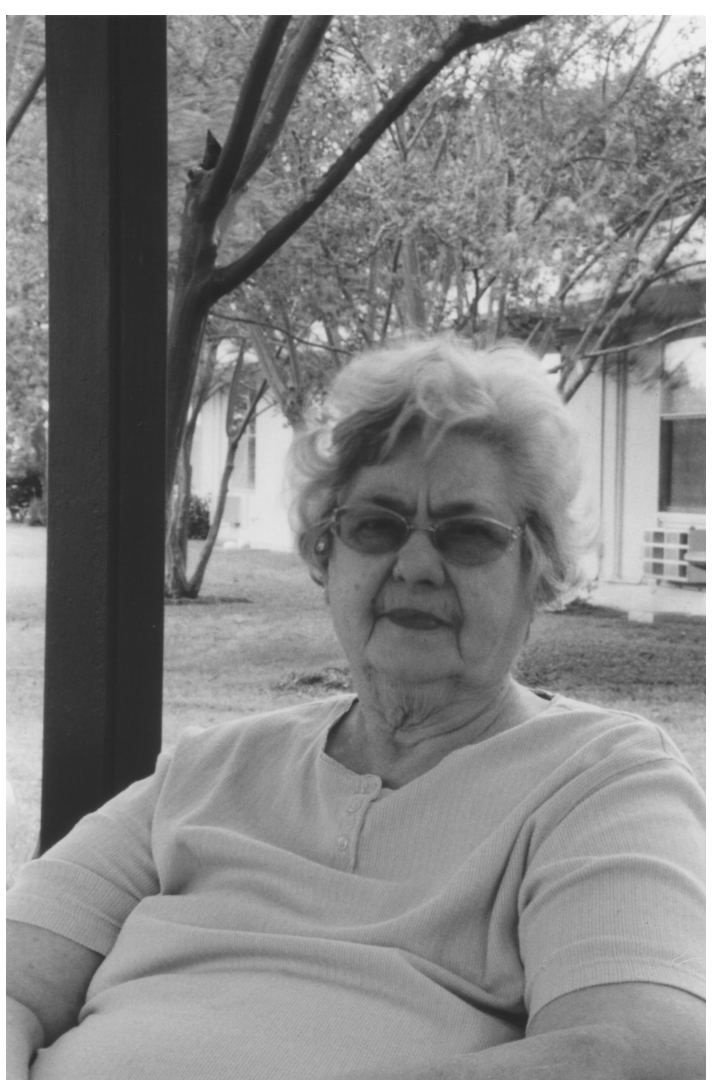

Gertrude Dunkin Barton

Freeman: Do you know anything about when they were born? Do you know the dates of their births?

Barton: Let me see, my daddy was born, I think, in 1887. My mother was nineteen. No, let me see, eighteen. And then my mother was born 1891? Was right after Daddy.

Freeman: So she was a few years younger?

Barton: Yes, she was a few years younger than my dad. And they had eleven children. But my mother was so healthy, and she raised all of us on the land, you know. She went to the fields and worked, and she raised the best garden in the country, and it was sandy loam, you know. And we could raise the best peanuts and sweet potatoes and watermelons. Daddy had watermelons 
that long. Cantaloupes, tomatoes, and black-eyed peas would be big as your - (showing her thumb)

Freeman: As your finger?

Barton: Oh, big! You know, black-eyed peas. You can't find 'em like that anymore. And we just lived. We didn't have no money. We just lived off the land and bought very little from the store. Coffee and sugar and flour and salt, that's about it. And we didn't have a car. We had a wagon, and the best pair of mules in the country, they always said. And the wagon had a seat on it. We'd put a board across the back, and all of us kids got in the back of the wagon and we went to church on Sundays. We didn't go a lot because, I don't know. My daddy, he's about the only one that'd hitch a ride to McDade to buy a few little things. But wasn't much money in those days. We just lived off the land. Now ask me some questions.

Freeman: Well, you're doing great! Do you have any idea how far back your father's family was in that area?

Barton: You know, I don't really know that. I know, I remember heart troubles seemed to run in the Dunkin family, and I know my dad was just sixty-eight when he died. His brother, one of them, was sixty-six, and one brother was thirty-two when he died. It was kind of a big family of them, too. And I remember Dee, one of his brothers, he never got married. But he lived there in that other house after grandpa and grandma died, and he accidentally, he smoked, and I guess he fell asleep and it burned the house down.

Freeman: Did he live through it?

Barton: Yes, he lived through it. Then he went on, travelled around, Fort Worth. I had a brother lived in Waco, and he went there. Then had a sister that lived in Rockdale, or up there somewhere. He just roamed around, kind of, from one place to another.

Freeman: What do you remember about your grandparents?

Barton: They were great people, you know. They always were good to us as children. And Aunt Ellen Dunkin, one of their daughters, she helped take care of us. She'd come down. You know, we lived right down the lane, and I remember she always helped Mama with the girls, all of us girls.
Freeman: So when your parents married, they went to live in the same neighborhood as your father's family?

Barton: Yes, in this big house. They had a big house, two bedrooms in the south, and a huge hall. At the end of the hall and the back porch was this big cistern, and had fresh water, you know, rain water. And we had good water. And the boys always had to stay where it was cold, and us girls has a fireplace and a big wood stove Mama cooked on. And that was all the heat that we had, but we had lots of wood. There was woods, and my brother and them'd go in the wagon and get lots of wood. We had a big wood pile, and they'd chop the wood to put in the stove for Mama to cook. She was a great cook. Not fancy food, but good food for all of us, you know, vegetables. And she was just healthy. My dad wasn't well. He taken diabetes. He wasn't as well as my mother was, but she kept everything going. I can't believe how strong she was.

Freeman: Think of all that work she did.

Barton: Oh! And we had washtubs and have to, you know, wash by rubboards and a big wash pot. I can remember helping. Well, I was eighteen when I first left home. I can remember helping. We'd help wash dishes in the kitchen with a big aluminum pan. You'd get your water. We had a good life. We were poor. But everybody was poor. We had a good school. We had to walk to school. I'll bet that was, I don't know, at least five miles. Everybody walked to school through the mud. It rained, it seemed like it rained all the time. Just rained.

Freeman: Give me some idea of where you all lived out there on what's Camp Swift.

Barton: Well, we lived about, I guess, five miles that way to the school and the church and Oak Hill Cemetery. And then thataway was McDade, the nearest town. I don't know, it was, say, ten miles.

Freeman: Were you west of the cemetery, of the school?

Barton: Let me see, we were right, we were west, and we went thataway, south, thataway to the school and the cemetery, the school, and the church. It all was there. And once a year they had a big thing. My dad used to barbecue for everybody. Oh, that was fun! You know, I remember they had big things of ice cream cones you'd get for a nickel, and soda water for a nickel. And oh, 
Mama, all the women, they cooked and brought dinners to that. Cooked pies and cakes to take for us to eat dinner there, fried chicken and potato salad. That was kind of an association to help raise money to take care of the cemetery, you know. The Owens, I think, worked the cemetery as well as I remember. Andrew, and I remember Mrs. Owens [Owen]. She lived a long time, Mrs. Owens [Owen] did. Have you talked to Fay?

Freeman: Yes.

Barton: Isn't she the only one living?

Freeman: I think so.

Barton: I don't believe she had any more brothers living, does she?

Freeman: Andrew died several years ago.

Barton: I remember 1994, August the thirtieth. I lost two sisters right before him. Doris died the eighth of August, Katherine died the twentieth, and he died the thirtieth. Nineteen ninety-four. We lost a lot of people in '94. And then I said, "Well, surely '95 is going to be better." Well, guess who was the first one? My husband. Tomorrow will be nine years, June the first, 1995 he passed away. He had a massive heart attack. But I live for my kids. I've got seven children of my own, twelve great-grandkids, another one on the way, and, let me see, on October 29 will be my thirteenth great-grandchild.

Freeman: Tell me who your neighbors were out there.

Barton: Stagners, ah, let me see. Mary, no Marie and Horace Stagner. They had Bradford Stagner and Mildred. She was my best friend. She lives in Houston now, and she's my same age. May thirteenth. She was eighty-four. But Bradford died, I think, about a year ago. And then the old Stagners, they lived right across from where Horace and Marie - she was the school teacher-And then on this other way, let me see, I have to think of his name now. Laura and Albert Cottle. They had, let's see, three boys and a girl, I think. They were over at our house all the time, or we were over at theirs. I remember that. In fact, Rex, big boys wouldn't let him play, and he played with us girls. We let him. He was my age. And we had more fun, you know. We made up what to play.

Freeman: What kinds of things, how did you play?
Barton: Oh, we would play like, we'd ask my mother when she got the empty spools, you know. She would give us the spools, and we would tie them on our heels and make high heels with the string, yeah. We walked around. Well, we had play houses, and we just entertained, and a lot of us would go down to the creek. That was a big thing. Of course, one of my brothers got bit by a copperhead and he almost lost his foot. But Mama doctored. See, we never went to the doctor, hardly. Only time, I think Naoma fell out of a tree and she cut her arm with barbed wire. The chicken coop was right there, and they had the chickens cooped with barbed wire, and I remember Marie Stagner-they had a little Model T - she taken her to the doctor. But everyone of us were born at home. Can you imagine? And it was right up thataway from us. It was a black lady, Miss Flowers, and she would come and help my mother when each one was born.

Freeman: Were you allowed to stay around the house when that was going on?

Barton: No, we were sent up to Grandma's house. Oh no, we all went to Grandma's house and we weren't there when the baby was born.

Freeman: Tell me what your mother did when your brother got bitten by the copperhead.

Barton: She had this big crock, and she put kerosene oil and salt and soaked his foot in it. 'Course it didn't, you know, it really didn't help a lot. Later they did have to take him to the doctor because that wasn't curing it up. But there were copperheads all over the place there in that sandy land. Were coachwhips and they were running around everywhere. I didn't like snakes.

Freeman: Did your mother or your father have any other cures or ways of treating you kids when you got sick?

Barton: Oh yes, we had black draught.

Freeman: What's that?

Barton: I don't know, but she would cook it and give us a little bit of it to clean our system out. Seemed like castor oil was something else that she gave us.

Freeman: Did she just do that at certain times of the year? 
Barton: Yeah. Well, when we'd kind of get sick. And then I remember way back there when Ola Mae, when she was just little, she taken diphtheria. Now we did have to take her to the doctor. And Dr. Bryson - that was the old doctor in Bastrop - and he said, "Now you watch the younger daughter, Laverne. If she has any signs, bring her." And he gave her medicine, you know, and I think, I still think it affected her life. Ola Mae always was sickly, sorta, all of her life. She was just sickly. And I lay it on to that. I just think that did something to her system.

Freeman: Do you know if anybody was affected by that flu? You know, right after World War I there was a terrible flu epidemic, just a little before you were born, I think. Did you ever hear of people dying from that?

Barton: I think so. Well, I remember Lawrence, he was nine years old, I remember him telling me at one time our whole family was in bed with the flu, and he cooked for all of us. He told me that. And you know, another thing he told me, when my sister died - now I don't know if that was true-I guess it was, that my daddy made her casket out of an apple box and lined it in little blankets, and they buried her. Now, I guess that was true. Well they didn't have no money that could take them anywhere. I just remember my mother saying that hurt so much. I don't know how we all lived! Well, ten of us and three of us still living. Me and my two sisters, younger sisters. But so far, the Dunkins didn't live long lives. Like I said, my dad was only sixty-eight, and his brother was sixty-six. One brother was thirty-two. And I can't remember, but I don't think Dee was more than forty, or something like that. They all-And then my sister, one of my sisters, my oldest brother died at the age of fifty-one, and Sweetie, she died at the age of fifty-two, and then Clyde died at the age of sixty-four. And just a year ago, Woodrow - he lived in Alabama - he passed away. He was eighty-four. Lacked one month and a half being eighty-five. That's the oldest one. Now I'm eighty-four and a half. I hope I'm going to make it to eighty-five. I don't know yet.

Freeman: Well, I'm sure glad you've made it this far.

Barton: Yeah, I am too!

Freeman: I'm a little confused about the houses that the Dunkins had. Was there your grandparents' house and then your house? Or, how many houses were there right in the area of your home?
Barton: Two. Well, it was just our house, and then up the lane was Grandpa and them. And then the Cottles. Oh, I don't know if it's half a mile or about a mile. And then up that away the Stagners, about a mile, and then further down about a mile was the Allens and then the Owens. And then thataway, well, I remember, let's see, it was some people. Almost forgot what their name was now. Glandon. DeGlandon. And then a little - oh, Mrs. Ligon, Mr. and Mrs. Ligon lived right up. She had the most beautiful flowers. I remember. They didn't have any children, but she helped my mother out a lot. She always had a lot of milk, extra milk. She'd call my mother and say, "Send your daughters up." We'd go, carry buckets of milk. She was real good to help us out. All were good in the community, helping each other out.

Freeman: Did you have to walk down to her house to get the milk?

Barton: Yes. And then Doris, we'd put a stick between each one's pail. One time we slipped and fell, spilled a whole gallon of milk. But most of the time we made it, you know.

Freeman: Tell me again what your grandparents' house looked like. Was it a real old house, or-

Barton: Kindly. It wasn't as big as our house was. We had a big house. Two bedrooms on the south and then that great big open thing where the cool wind came through. We had no air conditioning. You know, you didn't have nothing like - we had lamps. We made out fine. Iron, little iron we'd put on the stove, press something.

Freeman: What did your grandparents' house look like?

Barton: Well, it had a front porch, a porch across the front, and then kind of a big living room in there where it had beds. I remember two beds. And then seemed like it was just one bedroom back there. And then it was kind of a kitchen was back there. And then, seemed like there was another little room thataway. And they had a well out at grandpa and grandma's house. They had a well that they got their water out of.

Freeman: They didn't have a cistern? 
Barton: No. That was the best water, that cistern. It was cool. And I remember we had a big bucket that we'd draw water and, you know, we drank it.

Freeman: Were any of the houses in the area made out of logs?

Barton: I think that was at Bastrop State Park. Now, they were made out of logs. But I don't, now as far as I know, they weren't any of them made out of logs. But I remember going to the state park in Bastrop, and they had logs.

Freeman: So, tell me how your big family lived in this big house.

Barton: Well, Leon, he was always so big, he had the little bedroom over there. And then the three boys, they slept in the big bedroom.

Freeman: In a separate room?

Barton: Yeah. And Mama always quilted, and she made the quilts. They'd weight you down. And then, 'course, us girls, two big beds in the fireplace room. Well, we had it good 'cause it was warm. Always had a big fire going, you know. And then it was another, right off, there was another little bedroom there where Mama and Daddy, in the winter they slept. And then a big kitchen was off from there.

Freeman: Describe the kitchen for me.

Barton: Well, it was just a plain ol' kitchen. A big wood stove. We had a long table, benches, and then Mama and Daddy and Leon and Clyde sit in chairs around the outside. And then Mama did have a cupboard that, you know, she put the stuff in. And then it was built against the wall, kind of a board that we washed dishes on. Had to have something, our big aluminum pan, we washed our dishes on that. That was it. No, we had two cupboards, and then we had another cupboard at the end of table. And I remember we used to go, a molasses mill was pretty close to our home, and we would go and get big things of molasses. And my mother, she made the best biscuits and cornbread. We didn't know what a loaf of bread was. We didn't, 'cause my mother cooked all the time. But it was good. And these little iron pots, I never will forget, they were about this big around, and tall, with little legs on them. And my mother, she'd have a big pot of fresh blackeyed peas. And then, when they'd get done, she'd go and get a whole bunch of little bitty pods of okra and drop 'em in there and cook, and then they got done. Oh, that was good! Oh, she could cook, let me tell you. And corn, when fresh corn came, she would cut it off, and with milk and butter and bake it in the oven. Talk about good! That was good. Sweet potatoes, she'd bake sweet potatoes and she'd parch us peanuts in the stove, and we'd get us a potato and stick peanuts in that and eat it. It was good. And she raised chickens, turkeys and guineas, and everything that was - and she did all that. And she had a block out there, a little hatchet, and if she wanted a turkey she'd, she'd do it. She didn't ask nobody to help her. Or chicken. And that's the way it was. And it was real good. In fact, they let the farmers on credit, they didn't get much, but then when the crops came in, you would go and pay up, which saved us a lot, a whole lot. And I remember way back there in the Depression, when the government-Do you, no, you probably don't remember. Do you remember, when cattle, they bought cattle? I mean they slaughtered some cattle, and the women, they would can a lot of that. And my mother canned. Oh, she canned all summer long. In the winter, we had, everything was canned. Dewberries. She could make the best dewberry pies. I'm not exaggerating! I'm telling the truth about this! That's the way it was. It's absolutely the truth.

Freeman: Tell me about the cattle shoot. Were you there when the government agents came?

Barton: Yeah, I must have been fairly young. I don't know, maybe, I was born in 1920. Maybe I was about fifteen. Maybe not quite that old. But all I remember, Mama and them talking about it.

Freeman: Did they shoot any of the cattle that your parents had?

Barton: Yes, because, I guess-Did they give us money? Probably a little. And then a lot of the women, they, maybe some of the younger cows or bulls or something, they made good with the meat, you know.

Freeman: Do you remember hearing anything about what the adults were saying about it?

Barton: I guess they were happy if they could just get anything. You know, relief from anything. Depression was terrible, you know. I said, I hated to even ask my daddy for a nickel 'cause I didn't know if he had it or not. And you know, Daddy always raised these big watermelons, and he would take a whole wagon full 
to Bastrop and sell 'em cheap, I know. But anything. Probably a quarter for them big watermelons. Or fifty cents. Anything. And I can remember one time, I was so happy. I guess I must have been seventeen or eighteen. My mother ordered this dress for a dollar from the catalog. I just remember, and I went with my boyfriend with that dress. And I remember I was so happy to have that dress for a dollar.

Freeman: Did they get much out of catalogs?

Barton: Oh, my mother, she never went nowhere to shop. My daddy, when he could afford it, he would buy Mama a pretty dress and bring it home to her. And he could fit her. He knew what size. And anything she ordered was from the catalog. And we used the catalog - I shouldn't even say it — out in the outhouse. We saved in every way we could. Everybody was in the same boat around.

Freeman: Well, it sounds as if you remember the Depression being harder than the time before.

Barton: Yes, I think so, 'cause I kinda remember it seems like, when my younger sisters were born, it just seemed like we had nothing, hardly. And my mother was so worried that she didn't even hardly have things for diapers. I can remember that. But my aunt was a nurse, I think in Smithville, and she always could get things to help Mama. I can remember that. Well, and Marie Stagner, she had only the two children. I remember she gave Mama a big box of baby clothes. I didn't know, I found them, they was hid under the bed. And I thought, well, what are those? And it was for my sisters, little sisters, you know. I remember Ola Mae just weighed five pounds when she was born. She was cute. And then Laverne was a little bitty thing. Mama was forty-four and my daddy was forty-eight, and that was the last one. I had all of my children before, well, let me see. By the time I was thirty, I had four, I believe. Three boys and a girl. And then I had the others next generation. Nancy and Brenda Carolyn. I have wonderful children. They are so good to me. In fact, the twenty-second of May we had a big get together out of Doug's. Him and his wife bought thirty-seven acres, and they built a big house, and now they - I said "That's what you get for building a big house." Now they have everything out there, and May 22, my youngest daughter and her husband and little girl, they came for several days and I got to see 'em every day. Oh, it was wonderful. She's lucky, my youngest, she married a doctor, my youngest daughter.
And, you know, he is so nice to everyone. All my children married well.

Freeman: How big were your parents' and your grandparents' farms?

Barton: You know, I couldn't even tell you. But big. I remember we had land across the road. That was in front of our house. A lot. And then at the back, there was way back there. And woods, which was great for fireplaces. You know, we had our own wood and our own water and everything. Oh, I couldn't even-I don't remember how many acres, but hundred of acres, I know. And we all went in wagons back there every day to chop cotton and plant, and we was busy all the time.

Freeman: You mentioned that there was a creek that went through the property.

Barton: That was down below our house. We had more fun on that creek, all us kids.

Freeman: Did it have a name, you know?

Barton: No, it was just a creek that ran. We were on a little hill. The water ran down the creek, just water, water, water. We had more fun.

Freeman: What did you kids like to do down there?

Barton: Run, splash in the water. And we did fix us a play house on the hill right there where the water - That's where Woodrow got copperhead bit. There. But, oh, we just had fun. I don't know, maybe with ropes, just playing, we just made our own things. Couldn't afford to buy anything. But we just had a lot of fun, you know.

Freeman: You've talked a lot about your mother's cooking. Was there some special thing that she did that you especially liked?

Barton: Well, what do you mean? We liked the food that she cooked. She made it good out of nothing. She never wasted a crumb. She'd keep the biscuits left over and then she'd make us a big thing with, beat up eggs. I think she did get vanilla extract, and then milk and sugar and poured over those biscuits and put it in the oven. That was good. Well, everything she cooked was good. Well everything from the garden. We had cabbage. 
Freeman: Tell me about her garden.

Barton: It was huge. All Daddy did was plough the garden. Mama planted all the stuff. And they had a big wire fence around the garden, and stuff was always growing up on the fence. English peas, fresh English peas, and okra. Well, name it, she had it in the garden. She had all types of turnips, big turnips. Well, just everything. Squash and big tomatoes and okra. Well, butter beans, pinto beans, green beans. You name it. And we saved everything that we could dry, and we'd go and dry black-eyed peas and then pinto beans when they got dry. And then Mama cooked them later. And we had a big smokehouse. When daddy would kill a hog, he would put, you know, a lot of the meat in there in salt, and then she always cooked with that. Little squares in the black-eyed peas and the pinto beans. Well, everything she cooked. And then she even made the homemade soap.

Freeman: Tell me how she did that.

Barton: I don't know if I remember exactly how she made that, but anyway, it's something about lye or something she would put in this oil. I don't know exactly. I can't remember exactly how she made that soap.

Freeman: Did she have a special thing that she used to dry the beans, or to dry fruit?

Barton: Well, we always had this, out there and a little further, we always had this place where we put sweet potatoes. I guess all that underground, kinda, you know they used to build -

Freeman: Like a root cellar.

Barton: Yeah, those little cellars. And she always had all of that. And the sweet potatoes. And I remember that we had a corn grinder. We made our own cornmeal and cornbread. And we always had a lot of eggs. And that made it good.

Freeman: Tell me the kinds of crops that your father raised.

Barton: Well, cotton. But cotton never, in that land, it never did get real big. I think watermelons was better, and peanuts and sweet potatoes. And we did, we had corn crops and then, seems like we did have cotton too. But seems like it didn't grow real big. But we had cotton, you know.

Freeman: How late did you all have cotton? I mean, how old were you when it wasn't around any more? Or did you always have it?

Barton: Well as long as I was at home. 'Course, when I left home, I don't think Mama and them did that much. They were getting a little older, I remember that. And it wasn't as many home to help. We all started leaving home about the same time, nearly. And I went to work in Austin, and my brother, he went to work. My oldest brother was always sickly. He had this, some arthritis that crippled kindly. He never got married. Then Lawrence got married and Woodrow. They were all, my brothers were all in some type of service. My husband had to go overseas, too, but later, when World War II wasn't so bad anymore. And I remember my brother, Woodrow was in England four years before he got to come home. That's when the war ended. My husband's brother got killed in World War II. Left his wife and three little boys. She got pregnant when he came on his furlough, and then he got killed pretty soon after he went over there. In that World War II. And then Clyde, he was in service. Lawrence. But they didn't have to go overseas, those brothers.

\section{Freeman: Did any of them work for the CCC?}

Barton: Yes. Woodrow, and my husband. Oh yeah, and then that Allen boy, Clyde Allen. You know, he-My boyfriend was Leroy Creel. They had go to Wyoming to that - and you know, they had that big forest fire, and Clyde Allen got burned up. But Leroy came back. Creel. No, my brother was in there, and Max. Little did he know that I was going to marry him later. Isn't that funny how - it was a lot of boys. Now that out there at that, that's where those logs, at that Bastrop State Park. Now they helped build those logs, little log cabins. Now I remember that, you know. Yeah, Woodrow, you know I'm not even sure if Lawrence was in that or not. I guess he was. I can't remember. But I know Woodrow. And later he said, "Your husband was always in trouble!" That's what he said. I remember that about him.

Freeman: Well, what kinds of crops did you father raise for money?

Barton: Well, cotton sold. Well, let's see, I guess they sold corn. But you know, a lot of it they preserved and 
kept it for grinding. But I'm sure they sold some. But cotton, I guess, was the main. Well, peanuts, I think, and sweet potatoes. But then we ate a lot of that too. But sandy loam is good for raising peanuts and sweet potatoes and corn and watermelons and all of that. Big red tomatoes and black-eyed peas and all of that. You can really raise good things like that.

Freeman: Did you water the crops. Or was it, did you just-

Barton: There was enough rain. No, unh-uh. We never watered the crops. It was enough rain. I remember the rain, rain, rain. We had to go - our feet would get muddy walking to school. I remember that a lot.

Freeman: So did you-you mentioned earlier that you helped your parents with the cotton. What did you do? Tell me about that.

Barton: Oh, chopped cotton. We chopped cotton.

Freeman: How do you do that?

Barton: With a hoe. We chopped cotton. And then when you picked, break your back because, you know, like I said, it never grew real high. It never did.

Freeman: Did you use big sacks?

Barton: Yeah. Oh yeah.

Freeman: Was there a gin any place in the area?

Barton: Yeah, McDade. They'd take it in the wagon to McDade. Oh yeah. And I guess everything else you'd take in the wagon because we didn't have a car. Later on in life, I remember Clyde bought a little Model T. I can remember that. We rode in the rumble seat. We thought we were in high cotton when we rode in the rumble seat. And I remember he took Mama one time on her birthday. She had one sister that lived down close to Paige, and Clyde taken Mama to see her only sister that day. And all the women in the community was going to surprise my mother on her birthday, the sixth of October. And he scared my mother to death. When they come, and she saw all them cars, she thought something had happened to daddy. Then that ruined her surprise. All the women had come. They had brought cakes, you know. Well we always had a lot of grapes, and we always had a lot of good grape juice. That was our juice to drink. And the big crock, and they had filled that with ice and everything was great. But it scared Mama to death.

Freeman: Now, tell me about the grapes. What kind of grapes were they?

Barton: Well, they were just regular grapes, you know, that you could cook and get juice. And then you could make grape jelly and everything. But I remember Grandpa Dunkin up there, he had, right beside his house, he had a kind of a fruit orchard. I remember Grandpa. And he had these little green grapes that were sweet. I don't know, and all kinds of strawberries. And Grandpa, he always had all kinds of fruits. We loved that. We always went up there and got some.

Freeman: So did he make grape juice out of these sweet grapes also?

Barton: Well, I'm sure he did. But we ate a lot of them too. Especially those little green-colored grapes. But Mama used to made a lot of grape juice, and she canned dewberries and then, and that's what we'd have to drink.

I guess I was eighteen when I left home and went to Austin. That's where I met my husband, and we got married. We was both just twenty. I was almost twentyone when I got married. September the thirtieth, 1940. And you know, right after that is when that World War II broke out. They had that big thing - where was that - that killed so many people? I had a first cousin, Clifton Huff, and he didn't get killed in that. But lots of 'em did. And then that's when we went into war.

Freeman: You mean at Pearl Harbor?

\section{Barton: Yes.}

Freeman: So he was at Pearl Harbor?

Barton: Yes. My first cousin.

Freeman: Well, he was lucky, wasn't he?

Barton: You better believe he was lucky. It killed so many people. His dad was in World War I, Byron Huff and Levi Huff. They were in World War I. My mother's brothers. And they both got to come back from World War I. And then this World War II, it was lots of them that got killed. Everybody in that community went. 
My husband, and Doris's husband, and everybody's husband went over there in that war. But, you know, we was fortunate. 'Course, my husband's brother got killed and two of his first cousins. Within two or three days, those three boys got killed. They were all first cousins. But you know, from my side, my daddy and mother gave, when they all came back, they gave a big barbecue, and everybody in the community brought food and Daddy barbecued. You know, they all got to come back! The Owens boys and Doris's husband, Harry Owens [Owen] and then Andrew Owens [Owen]. All of the boys got to come back! But then they lost a lot in Rockne where my husband's people all were from. Those three first cousins got killed. Joe was just twenty-nine. And his wife was just twenty-seven. And then my husband, we felt like, well Max felt like, if he got to come back, God let him come back, he tried to help those boys. And they all said, when my husband died, well, he was a better father than their own. Well, they didn't know their daddy much. They were little when he got killed. It was sad.

Freeman: Ah, I'm curious still a little bit about your farm life. Did you have any way to keep your milk cool?

Barton: Mama had this kind of a metal stand up square thing, and she had kind of sheets, and she would wet 'em with the cool from the cistern water and put it all around, and it kept it. And then we churned. We had a lot of butter and I know it was, well we didn't have to worry about food left over with all of us. Ten of us, twelve with Mama and Daddy. We ate not picky like these kids are now. When Mama called us to come to eat, we all ran, and we all were hungry and we ate all the good food.

Freeman: How many times a year would your father kill a hog?

Barton: Well, mostly in the winter time. I don't know, I just remember, seemed like the one time. Maybe they killed more than one at a time. And they did all the grinding of the sausage and fixed it. Oh, that was great, good. And then I always think about my mother. And all of us went to school, and she had to fix us lunches. And she always either, she'd cook little slices of ham in between a biscuit, or sausage, and then she'd make us little homemade fried pies. Were good. She fixed 'em on the stove, and she'd fry 'em and put, I believe, cinnamon and butter and sugar. They were good.
Freeman: Did they ever have fruit in them? Or were they fried with the sugar on top, or was it inside?

Barton: It was inside. Yeah, and then she'd put it over and pinched it around. Yeah. And [that] seemed like more or less what we took to school. But she made the best custard pies. She had lots of milk and eggs, and she could make good custard pies and cakes. And you know lard from the hog. We never had Crisco! Or oil. We had all of that. She did everything from the hog. And I'm sure that's the way the soap was.

Freeman: Would the neighbors come and help at the hog-killing time?

Barton: Ah, well, no, because I had enough brothers and we did everything ourselves. Oh yeah. And Daddy could make the best sausage. He mixed it up himself.

Freeman: Do you know what he put in it?

Barton: Sage and salt and pepper. I guess that was it. Black pepper and salt and some kind of sage or something. Anyway, all I know was it was good. It was just good.

Freeman: What kinds of things did you kids help with around the house?

Barton: Washed dishes, us girls, and we swept and made the beds up, and we went out and gathered the eggs. Mama always had lots of hens. We had to look for chickens, for eggs. And then she'd have turkeys, and she'd have turkeys settin' on the eggs and we'd have to go and see if they'd hatched. Oh brother! And you know, we just helped. I guess I kind of, I'd help cook some after I got a little older. But we mostly did the dish washing and dried the dishes and got 'em ready for the next meal.

Freeman: What did your brothers do to help out?

Barton: Well, they chopped wood. That was their main - and they plowed. They helped in the fields. I remember Leon would help plow, plow the land. I guess Woodrow and Lawrence, they just helped whatever it was. Picking cotton and then - they would help plant Irish potatoes. We'd plant lots. We had to dig, dig the potatoes up, and they helped everything. And then we'd put a lot of them in that storage, down in the ground, in that thing which would help a lot. Always had something to eat. My mother always had 
something to eat. We never went hungry. Maybe we didn't have everything we wanted, but we had a lot of fruit. We had a lot of plum trees.

Freeman: So you had fruit trees also.

Barton: Oh yeah.

Freeman: What different kinds did you have?

Barton: Peaches and peaches and plums. Then we had dewberries. That was fruit, you know, dewberries.

Freeman: Did your brothers ever go hunting?

\section{Barton: Yes.}

Freeman: Tell me about that.

Barton: They had these hound dogs. Mama had to feed. They and a lot of the boys got together and they'd go huntin'. In those days they could sell the hides. They'd skin the animals, and they would put 'em, stretch 'em out, and let 'em dry. And they could sell 'em. I don't know, for not much, but every little nickel helped. Everything helped, you know.

Freeman: How many dogs did they have?

Barton: Well, I can remember at least two or three big hound dogs. Mama'd always have to feed 'em scraps, and maybe she'd cook a little something that she had extra for them. Oh Lord, I don't know.

Freeman: Do you know where they got the dogs? Was there a breeder some place out there?

Barton: I have no idea where those dogs came from. I really don't know that. All I know is that they were there. And I remember in the south part, they built two big, against the wall, for them to sleep in the winter. They'd go in there. And they were open, but they faced the south, and they were warm for the dogs in the winter. What amazed me is my brothers, how they kept warm, over in those-

Freeman: What did they do?

Barton: They had these heavy quilts on 'em. Oh, my gosh.
Freeman: Did your mother ever have quilting bees or quilting parties?

Barton: No, she just quilted herself. She just quilted. She had this thing hanging from the wall that she did her own quilting. My mother never went anywhere hardly. She always taken care of us. My daddy was a goer. He'd catch a ride even if it was a black guy came by in a car or something. He'd get in there and go with 'em to McDade. And he always brought us a little sack of peppermint candy. I bet he got, for a nickel, he'd get this whole little sack of peppermint candy. We looked forward to that every time he went to McDade. And this boy that I went with, he had a car about as long as that wall. You know, way back there, they had those big long cars, and he just had, he had his little sister, a little younger. Well, she came with him everywhere we went. She came with us. Then all my brothers and their girlfriends, we all got piled in that car. We'd go somewhere. Just, we weren't ever alone, I don't think. It's a lot different now, isn't it? They don't have any morals about 'em. They live together. They have babies. They aren't married. I don't like that. But what you goin' to do about it? It's in our family. We can't - you know, my daughter, her daughter, got a divorce, she had a little three-year-old daughter, and now she's, he's living with her, and she's going to have another baby. So, what are you goin' to do? They don't think anything about it. If we had done that, woohoo! Way back there. We didn't do anything like that.

Freeman: Did your parents discipline you?

Barton: Well yes. My mother was the disciplinarian. She was the one that did the switching. Daddy never whipped us. He, I just say I had the greatest daddy on earth, I know. He was the best Christian. And every time my mother got pregnant, that was okay, you know. That's the Lord's will and everything. And he just, he never. I can remember one time, it was snowing everywhere, and us girls ran out there in the snow, and my mother said, "Jess, get a switch and whip those girls." And he switched us a little bit, but it wasn't - Mama was the one that whipped everybody.

Freeman: Did you all celebrate holidays much? Thanksgiving or Christmas or birthdays.

Barton: Well, not too much. At Christmas, if we could get a box of apples, we were just happy. We really didn't have money for, you know - I can remember maybe my younger sister getting a little bitty doll. But 
we never, we never had money for stuff like that. Just if we could get fruit and stuff, apples and oranges. That was great. Daddy would get a big box of apples. And, well, you know, we thought that was okay because we knew they didn't have the money. Especially having eleven children! Oh my gosh! When I think about what my mother went through. How did she-And then she outlived four, she outlived my daddy four years. She was seventy-two. Her heart, she had heart trouble after, but Daddy had the diabetes, and that was really bad. Now I have diabetes. I had a sister that died with it, a brother that died, and my daddy. It's, it's all in our family, you know.

Freeman: Well, tell me about your school days. Tell me about going to school.

Barton: Well, we all walked and went to school. I can remember some good - They had a little program in there that they would cook. I remember they would cook a big pot of pinto beans, I remember that. And they would have milk, and they would fix that chocolate milk. That's been so long ago I hardly remember, but you know it was good to have that hot food. It was kindly a government project that helped. And seemed like everybody was in the same room at the school. This big old room. First graders would be here and, no I believe then later it was two rooms. I believe it was two rooms. And Marie Stagner was one of the teachers, and Mayme Fleming. Now the Flemings lived way over that away from the school, and the DeGlandons lived way over that away from the school. And she was a school teacher. And I do kind of remember we'd have recesses, and then we'd have lunch, and I don't know.

Freeman: Did you play games at recess?

Barton: Yeah, we would.

Freeman: What would you do?

Barton: Seemed like we'd have a ball and we'd play. Well, I was one of them, and Doris, my other sister, oh, we played volleyball. We played volleyball and then we had baseball. Seems like a lot of the boys had baseballs. That's all I can remember. It seemed like, you know, wasn't just a whole lot, one of the other we's doing around.

Freeman: Was it a big school? Were there a lot of kids who went there?
Barton: Quite a few children. Yes, it was, it was quite a few children. I don't know. Maybe altogether it might have been a hundred. A lot of children. They lived all around the communities and everything. Maybe it wasn't quite that many, but they'd take pictures of all of them, groups of children at the school. I can remember my brothers wearing overalls. I don't know, we just had some kind of dresses, I don't know.

Freeman: Did you all wear shoes, or did you go barefoot?

Barton: No, we had some kind of shoes. About once a year we got a pair of shoes, and that was all year round. I think Mama ordered them from the catalog. That's the way I remember. Most everything we got was from the catalog. 'Cause, you know, it wasn't a lot of dress places or - I remember at McDade, it wasn't a lot of things. It was mostly, seemed like, a feed store and another store where they had groceries. It wasn't a big thing in McDade. And that's what I remember, you know.

Freeman: Do you remember anything about the subjects that you studied?

Barton: Well, we just studied arithmetic and English and reading and stuff like that, you know. I know we didn't go into, wasn't a whole lot of-As far as I remember it was just kindly math and English and all the stuff like that.

Freeman: Did you go to the Oak Hill School?

Barton: Yes.

Freeman: And how long did you go there? When did you start school?

Barton: I started school when I was six, I believe. Yeah. My birthday's January the sixth, so I missed that first, and I would be six in September. Yeah, I was six years old. And then I went there to Oak Hill until, I guess, let me see, maybe through the ninth grade, and then we went on the bus to Bastrop, tenth, eleventh, twelfth, no the ninth, tenth, eleventh, and twelfth. And we went there to high school.

Freeman: Would the bus come around the countryside and pick you all up? 
Barton: Yes. And then would bring us back home. Which was real nice, really.

Freeman: Did you all have electricity by the time you moved out of there?

Barton: We had no electricity, no running water, nothing. But I was thankful to have that good cistern water we had from the rain. It'd be so cool down under, the cistern. I was thankful to have good water like that, and that big hall, the breeze, we all got in the hall after we'd worked, and we'd cool off. Wasn't anything of air conditioning or radios or TV's.

Freeman: What about telephone?

Barton: My mother had a - one of those crank. And if it rang, everybody in the community picked theirs up and heard what you said. You couldn't say anything you didn't want public. No I remember when my mother's dad passed away. I remember they called, and I'll never forget, my mother in the night, she went and answered. And that's when her daddy had passed away. And I remember my daddy got up and went and hugged my mother. And, you know, my mother and daddy were in love. You know what I mean? They were Christian people, and my daddy was the greatest man. He always told us girls, "Don't ever say anything about anybody, anything __ " Let's see, how did he put that? "Don't talk about anybody." Oh, "Don't say anything if you don't have something good to say about them. Don't say it at all." That's what he'd always tell us. My mother, she mooched around sometimes, but she had a reason, having all those kids. And some of them so close together, you know. Gosh! I know, but my daddy always kept his faith, and he'd always say, "The Lord's going to help us and carry us through it." And he did.

Freeman: So did they go to church? Did you all go to church?

Barton: Oh yeah, every Sunday. All pile in the wagon. My mother and daddy set in the seat, and if it was a baby - I'm sure one was a baby — she'd hold it in her lap, and the rest of us, we'd put a quilt, and then sometimes we had a board. We all set back there and all went to church. I remember that church.

Freeman: What did it look like?

Barton: Old timey, was old timey things you sat on. Big, I remember that just as well.
Freeman: Where was the church?

Barton: Right there in front of the school. The school house was right down from the church, and then right this away was the cemetery. It was a big cemetery. Lots of people buried at that cemetery. In fact, all the Dunkins. And then my sister was buried there. But none of the rest was buried there. My mother and (??) were buried there at the Ridgeway

Cemetery.

Freeman: One of your brother's babies?

Barton: Uh-huh, Lawrence and Bernice. The fourth little baby girl. She was a blue baby. Her heart-so it died, and he buried it. And my mother and daddy and Bernice, Lawrence, they're all buried there, all of them. All buried at the Ridgeway Cemetery.

Freeman: Was that church a particular denomination?

Barton: Baptist. That was a Baptist. I can't even remember the preacher's name now. I can't even remember the preacher's name, but we had a preacher, and we all sang. We had these little song books, and we sang, and the preacher preached. I'll never forget that church house. It had these big, long, wooden, hard benches. But everybody would come to there and they would - and then when we had that picnic once a year, everybody brought their dinners. That was a whole day.

Freeman: Did you ever have any neighborhood parties?

Barton: Oh yes. I remember the Stagners had, and we played ring around the rosy, all that. Oh yeah, we had parties like that. I remember, way over there, Wayside, they had parties. I remember we'd go in a wagon over there to parties. Oh, I don't know. I guess we didn't have any better sense. We were all happy. Everybody was the same. Everybody, we had each other, lived off the land, were just happy.

Freeman: Was there music at the parties? Did any of your neighbors play music, or was anybody in your family musical?

Barton: My mother played. She had an organ, my mother.

Freeman: In the house? 
Barton: Uh-huh. And she sang, my mother sang. I guess I taken after-I sing here at our chapel. Well, everybody sings, you know. We go up 11 o'clock on Sunday morning. We go chapel. I guess I sing pretty good. I got that from my mother. My mother was pretty. She won being the prettiest lady in Paige. She won this big suitcase-looking outfit. They gave her. I remember that, 'cause she was chosen the prettiest woman.

Freeman: And this was after she was married.

Barton: No, that was before she was married. And Daddy said, "Well, she's still pretty." My daddy always thought she was pretty.

Freeman: I wonder where she got the organ.

Barton: I have no idea about that. All I know is, I remember in that one room, where the boys - and she played the organ and sang. And used to, a lot of them got together and had these dances, older, and they danced around. I don't know what kind of music they hardly had. Probably not too much music. Probably somebody played the little guitar or wasn't too much music. But it was fun, you know.

Freeman: Well now, how long did they live out there?

Barton: How long my mother and dad? Well, I was married, and I had several children before the Camp taken my mother's and them's place. And I remember me and my husband in the car, and James was talking about it. He was a little boy, and Doug, and most our - we'd go to Mama and Daddy's down there at Paige, after they sold out to Camp Swift. They had to get out of there. They bought out. And Dr. Bryson had this place around Paige down in the country, way down in the woods. And he told my daddy, "If you've got guts enough to move down there, you can have it for fifteen hundred dollars." I mean a lot of land. I know it was about 200 acres. The house wasn't real great, but that was cheap, it really was.

Freeman: Did they get enough from selling their farm to buy that?

Barton: Oh, yes. And they had money left over. And then they sold out down there when my daddy's health started getting bad, and they moved and bought a little place in Elgin, and Leon, my oldest brother, said, "Well, I'll give my daddy six months to live in Elgin, 'cause he can walk to town." And he love barbecue, and he was hungry for all- $-\mathrm{He}$ had that diabetes. He lived six months and died. He had a stroke and killed him. Leon died November the second of 1962. He passed away, and then that following July the fifth, on July the third, my mother passed away.

Freeman: So she lived quite a while after.

Barton: She lived four years after my dad passed away.

Freeman: Did you ever hear your parents talk about having to move off?

Barton: Well, they didn't have any choice, you know. They just come, and they needed the land for this Camp. And I don't even remember what they got for that, but I know it wasn't enough for that land and the house and everything. I know. Well, Dee had already burned up that other house. It was a cigarette. And anyway, I know they didn't get enough money. You know, a lot of extra money for the land that was at that place. But they got it cheap enough down there, you know, and then they resold that for, seemed like thirty-five thousand. They made some money and then bought that place in Elgin, which was kind of an old house, and, you know, it was sort of run down.

Freeman: Well, did the family, did the kids go back to help them move off of their farm?

Barton: Oh yes.

Freeman: What was that like?

Barton: Oh! A lot. Well see, they took the mules and the wagon and farming things. Oh, a lot. But seemed like me and Max helped them more when they moved from down at Paige to Elgin. Now we helped 'em more then. I can't remember helping them, I don't think we helped them a lot. I probably had little ones myself, and from Oak Hill down there, I don't think we helped much. Of course, the older, Leon was always there. So I remember helping from, I went, me and Max helped them from Paige to Elgin. And see, they sold out a lot of the farm equipment. When they moved to Elgin they - that was no farm anymore. No farming thing. They sold out everything, the mules and the wagon and everything that was equipment.

Freeman: Did you ever go back to where the farm was that you grew up on? 
Barton: The only thing is we would pass by, going to the Oak Hill Cemetery, where they had those dinners to make money. Now I remember we kind of had to go from McDade through that away, you know, but it was all cleared, just the land whenever we went that far.

Freeman: You mentioned that you had turkeys. Did you sell those for money? Were they a cash crop too?

Barton: Yes, Mama had quite a few turkeys. She sold them, and then seemed like some of the neighbors, I remembered one came in and wanted to buy one or two of 'em. I remember that. I'm sure, we didn't eat that many turkeys, you know what I mean. She'd have a big slew of them.

Freeman: Did she put a bell on any of them? Did she bell her turkeys?

Barton: It seems like it. That I don't remember exactly. But anyway, she'd round them up.

Freeman: How did she do that?

Barton: I don't know. She just-with feed - a lot of times you get your turkeys with feed, call 'em. And the chickens, they're always around. We had this pen, chicken pen. And then Mama always had turkeys.

Freeman: Did you have trouble with snakes getting the eggs?

Barton: Now, some chicken snakes, but not just real bad. It seemed like we had more coachwhips, and they didn't bother eggs or stuff like that. But I'm sure we had some chicken snakes that do mess with eggs. But I can't remember a lot of them. And of course, copperheads don't do anything like that. They just bite you without giving any warning. See, they're worse than rattlesnakes.

Freeman: Why is that?

Barton: Rattlesnakes will make a sound, rattle, and they give you a warning, but copperheads don't give you no warning. They bite you. Just like that. They don't get real big though. Rattlesnakes get big. My people, my husband's people have the rattlesnakes down near Rockne and Red Rock. See, I still own the Barton place, and my middle son has cattle on it to keep the tax down. Isn't it strange how \$98.70? We have 110 acres. And cost a lot of money. And Doug found out when he bought that 37 acres. Oh, the tax was going. So he's gone to goats. He has forty-six goats on it now, and he's selling goat, which a lot easier to keep and less expensive than cattle are. So he's got the most beautiful place I've ever laid my eyes on out there. They keep it perfect. They've got the perfect fences, you know, all around, and they have where the goats can go down here, and they go all around the house. But they've got the fences where they can't come up to the house, and he has a little barn out there for the goats to go in bad weather. I asked him, I said, "Well, how did the goats like the snow when we had it?" They didn't like it, so he built 'em a little shelter. And he has a little baby dog and then he has a big dog, and he built a fence, a pen out there for the big dog. The little dog is something else. He follows Doug around. He says, "Mama, that's my baby." That dog, it hops up on his shoulder and kisses him in the neck. That dog is so attached to him, it's terrible. Well, we better get back on.

Freeman: That's all right. Family things are interesting.

Barton: I know.

Freeman: You mentioned something about a molasses mill.

Barton: That was way over, over that direction. Leon, us girls went with him and we'd buy these, oh, big things full of molasses, cheap. I remember Doris stepped kinda in the coals of the fire where they cooked these canes that made syrup. Oh, it was so good. That was what we had for breakfast with our biscuits and butter. And, well, Mama made jelly out of plums. She made jelly, and she made jelly out of dewberries and everything. We had all kinds of -

Freeman: Do you remember who ran the molasses mill?

Barton: No, I really don't. I don't remember what that man's name was. I don't really remember what his name was.

Freeman: Did you raise any cane?

Barton: Well, you know, it seems like we did. I can't remember too much about that. But it seems like some, but I don't know. I can't say too much about that because I don't remember that much about the cane. 
It seems like, maybe a little bit, but I don't remember that much about it. All I remember is us going and buying that molasses.

Freeman: Did you have crocks that you put it in?

Barton: Yeah, we had big containers. We'd get a lot of it, and it'd last us year round, you know. We'd have it for breakfast, which was good. It was good for your health too.

Freeman: Did you ever have honey?

Barton: Yes, we had some honey. Let's see, Grandma Huff, my mother's mother, now they're the ones that always had a lot of honey. They lived down towards Paige. I don't know, down in that direction, and Leon would usually take Mama and us. I remember she always had the best biscuits and butter and honey. $\mathrm{Oh}$, it was so good. She always had good honey. I remember that. But I don't know, I don't guess, I don't remember if we had much honey. Maybe some in the community, maybe, had some. I'm not sure.

Freeman: So you don't remember anybody keeping bees or anything like that.

Barton: No. Like I say, most of the honey was down at Grandma Huff, was where I ate most of the honey.

Freeman: What kind of livestock did your parents keep? Like larger animals, what did they have?

Barton: Well cows, and then pigs. They were born. And bull and mules, and that's about it.

Freeman: Were the cattle any particular breed?

Barton: No, they were just mixed breed of cattle, I mean of cows. They were light reddish and

colors like that. I remember Mama always milked cows. And we churned and had butter and milk.

Freeman: So did they keep the cattle mainly for the milk, or for the meat too?

Barton: I think, well, seemed like Daddy and them would kill a young bull for the meat, but not a lot. Now, that was more on the Barton side. I remember Max, they had a club, and each one of the families would give a bull that would make meat. Now, I remember more about that. And they had that club, and every week they got meat for Sunday. The families had a lot of meat for Sunday.

Freeman: But that was more around Paige, is that right?

Barton: No, that was more around Rockne, Red Rock, over in that direction.

Freeman: And did anybody in your neighborhood do that?

Barton: I can't remember much of that. I really can't, I can't remember too much. Maybe some of them, maybe the Owens. They had a lot of cattle. But in that community, I think they raised them, they sold animals, they sold 'em more than they slaughtered them. I think they sold animals more, you know, for money.

Freeman: Sure. And then you said that your father liked to barbecue.

Barton: Oh yes.

Freeman: Now, how often did he do that?

Barton: Well, I can, I can remember he barbecued, once a year he always barbecued for the Oak Hill thing. And then I remember him barbecuing one time for the Ridgeway Cemetery, down there he barbecued. And then one time we had that, when the war was over and all the boys got the come home, we had that big barbecue, and everybody brought food. We had a big thing. And then one time, Daddy barbecued. I remember when Mama's brothers, they lived in Austin, and they came one time, and he did that.

Freeman: How would he fix it? What did he do to fix it?

Barton: Well, he would dig a big hole, a long hole, put a grate over it, and he'd put the meat on top and had the fire underneath. And he would, I guess he would add stuff to it. I don't even know what he added to it, but it was always so good when he barbecued. He always cooked things like that. When people were sick, he used to set up for the sick all the time, nights. He'd go and set, help set with the sick in the community. $\mathrm{He}$ was always doing that. I remember one time, $\mathrm{Mr}$. Lillian got real sick, and Daddy went and stayed all night with her - with him. Different - The Lewises, I remember that one time. 
Freeman: And then I wanted to ask you about weather. Do you remember anything special about the weather? I understand there was a bad drought at one time.

Barton: Well yes. But that real bad drought was - I was married, and I remember at the Barton place, it killed those great big pecan trees. They had a lot of pecan trees on their land, the Bartons, and I remember about that drought. Well, see, I wasn't at Oak Hill anymore. We weren't at Oak Hill when they had that drought, that bad drought. I know it was at the Bartons.

Freeman: Do you remember anything from when you were a child, about.

Barton: Well, it'd come these big windstorms, I remember. We'd get scared. Seemed like it would just blow everything over, nearly. I remember that. It rained all the time. It snowed. We had the biggest snowstorm. It was cold in the winter. I remember that, so cold.

Freeman: Did you have any kind of storm cellar to get out of the weather?

Barton: No, we just had that big house. We just weathered it out. We didn't have any - I remember over on this was a great big huge tree. It'd just sway that tree down. I remember that. Scared us to death. The wind was blowing so hard, you know.
Freeman: Were there any peddlers that came by?

Barton: Oh, yes, ma'am. There was always peddlers. Always wanting to sell something.

Freeman: What did they have with them?

Barton: I don't know. But I can remember way back there when they wanted to sell Watkins salve. That was one of them. Always wantin' to sell some kind of salve or somethin'. 'Course, Mama didn't have the money to buy that stuff, and I remember going to the Bartons too.

Freeman: Could she trade something for whatever they had to sell?

Barton: Probably did, maybe, but I don't remember that. I just, I probably was too little or something. I don't remember too much about that. But I know Mama always had something to doctor us with. I don't know were she got it. But she always had something to doctor us with. One thing or the other.

Interview with Gertrude Dunkin Barton Interview conducted by Martha Doty Freeman Date: 31 May 2004

Place: Golden Age Home, Lockhart, Texas Year of Birth: 1920 


\title{
Mary Lou Reese Benford Interview
}

\author{
By Thad Sitton
}

\section{April 2004}

Thad Sitton: This is Thad Sitton. This interview is with Mary Lou Reese Benford at her home in Austin, Texas, on April 21, 2004. [Benford's granddaughter, Ava Arthur, also is present.] This interview is part of the Texas State University-San Marcos, Camp Swift Oral History Project sponsored by the Texas National Guard and conducted in conjunction with the Center for American History at The University of Texas at Austin.

Sitton: Everything is working properly. Could you tell me where you grew up over there? Where did you grow up?

Mary Lou Reese Benford: Well, we started near Sayers. That's where that little old store was. So long, I can't think - but I grew up down in Bastrop County. It was in Bastrop County.

Sitton: Was it, ah-Which direction was it from Sayers? Was it east?

Benford: The house, the place? It was on this side of Sayers, right up the road there, not too far away from where Sayers starts and come on over there, our home.

Ava Arthur: Is it the same main house that's on Big Sandy?

Benford: Yeah, he would call it on Big Sandy. Yeah.

Sitton: And Big Sandy was the biggest creek?

Benford: Yes, the largest creek. And it goes down just outside of Sayers and on down there.

Sitton: What did y'all — Did y'all rent, or were you landowners?

Benford: Well, that's home place, my grandfather's and mother's property, and we lived on that, oh, until I was about five or six, something like that. That was

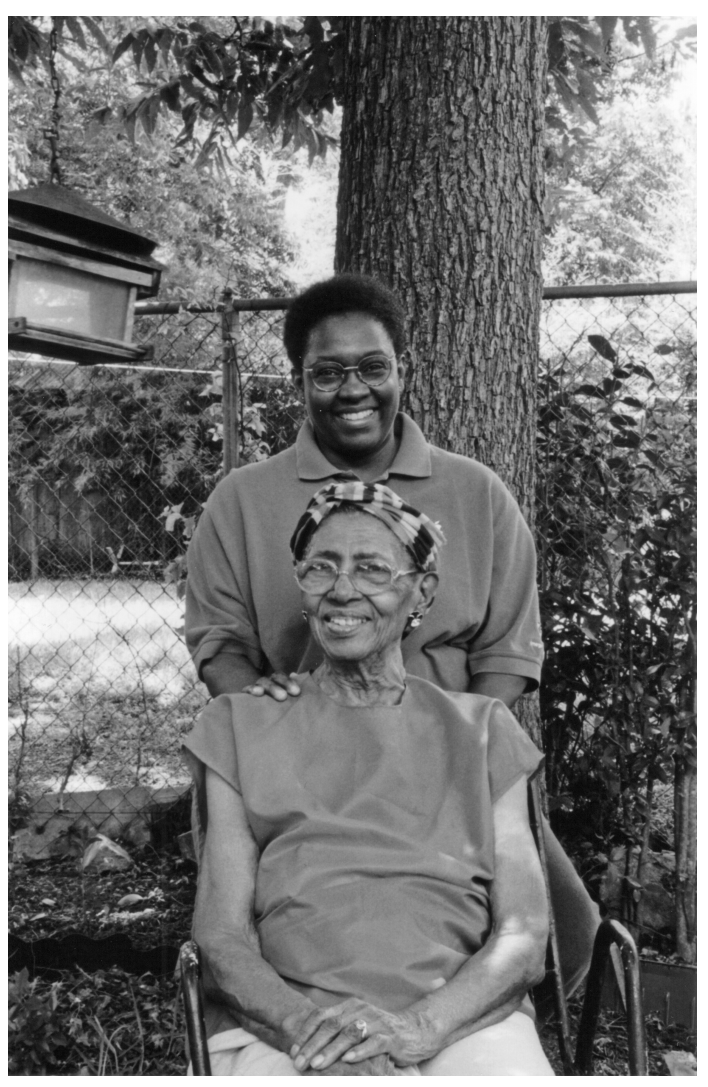

Mary Lou Reese Benford and Ava Arthur

all during my younger days, real young days. Started school down in Sayers when I got old enough. It was just a little old store and a little old stop-I'm trying to think of that place where you catch the train - depot. It was just a little community.

Sitton: But y'all basically farmed, right?

Benford: Right. Everybody around there did. Used to, they've all grown older and not too much farming going on. Brother and them did more farming down there than anybody around there.

Sitton: What was your name? You were a Reese, is that right?

Benford: Reese, right. 
Sitton: What was your brother's name?

Benford: My brothers? Sam, Ernest, Earlie, Woodie, Ruben, Isom. 'Course, Willie, but he passed away earlier.

Sitton: What year were you born?

Benford: Nineteen ten.

Sitton: Well, you sure don't look your age. I'm sure they've told you that, right? You hear that all the time.

Benford: Well. (laughs) But there's an age in there.

Sitton: What did y'all raise on the farm?

Benford: Cotton, corn, mostly anything. Had big gardens.

Sitton: Well, did you help do that?

Benford: Did I! I was the oldest kid in the family, Papa had me all up on those cane stacks and hauling everything. I was the boy in my family, 'cause I was the oldest.

Sitton: That's what my Grandmother Sitton said. She was the first child, and they didn't get a boy for three or four-She said, "I was made the boy."

Benford: Yeah, well I was too. I said, "I'll be so glad when them other little boys get up big enough to plow." I even did that. Not too much, but, Papa'd put us out there until we grew our cotton. We'd do it.

Sitton: What do you remember about the cotton? Were you good at picking cotton, or were you one of those people that don't like to?

Benford: I didn't like it. I don't know anybody that would, but - We'd pick cotton, went on the prairies and pick cotton, you know. 'Cause, down there it's sandy, cotton - wasn't too much into cotton growing around Sayers, we'd grow corn and vegetables. But people planted cotton. Um-hm, yeah, they planted cotton and-

Sitton: But what you're saying is y'all would go out and pick on the prairies.
Benford: Yeah, we did that too. You just name it and we done that, when we were growing up. 'Course, that was the methods of parents in those days. 'Course, I remember when our children grew up, they just hated the cotton patch. Well, I couldn't blame them, I never did love it, really. But I made it.

Sitton: Well, cotton was the - Now, a good many people around Sayers grew truck crops, too, right?

Benford: Well, they did, but there's not much going on, just a few people down there that - Oh, they grow enough to probably live on or sell, maybe, if they can go to market with a few things, but not too much anymore, specially the cotton.

Sitton: Well, you don't see any cotton over there. Now, you see it all over the prairie, the blackland prairie.

Benford: We'd scrap our little cotton, you know, and then go to the prairies.

Sitton: What do you mean by scrapping?

Benford: Well, I call down at Sayers, that poor cotton! (laughs) Not a cotton community, but everybody planted cotton, you know, that had farms.

Sitton: Well, if it rained it would grow pretty good on the sandy land, but it didn't always rain. I was reading about 1925. It didn't rain in 1925 , that was the terrible year.

Benford: Yeah, that's right.

Arthur: Were you married then? Were you married in 1925 ?

Benford: Uh, we were married in 1928.

Sitton: So, this was your grandfather's land, is that right - that came down from your grandfather?

Benford: Grandfather divided his land early with his kids. And so Mama had so much, and she had another sister, one more sister. She had three brothers, but somehow or another it ended up with like about two brothers that lived a long time. But they farmed and raised that cotton and corn.

Sitton: Were you - I'm still trying to figure out if your land - was your land on what is now Camp Swift? 
Benford: No, it's outside of Camp Swift.

Sitton: It's outside, across the highway.

Benford: Uh, my - If you go pass our place, you turn in and go on down to that - make a pretty good piece down the road there toward Bastrop.

Sitton: So, y'all didn't get your land, the family didn't get their land, taken by the government in 1942 .

Benford: No. 'Course, in those days Grandpa was living, and, well, everybody pretty well-Several hadn't passed away.

Sitton: Well, so you went to school at Sayers, of course. What was the Sayers School like when you attended it? Could you talk about the Sayers School? Anything that you can remember about the Sayers School.

Benford: Well, we classified as pretty good school, 'cause we had a professor, and he had been - he was a native of down there. But he was pretty smart, he was pretty smart. It was a three-room school. First, it was a one, but I didn't go when it was a one, I went when they got three, had three different, uh, well you wouldn't call it classes but different classes, you know, there. One goes to the fifth grade or some other grade, then you get promoted to high school, your certain other age, you know. I started my high school years there.

Sitton: So, you're saying there were three teachers.

Benford: Yes, we had three. When I first started school, there was just two, but our community grew for some reason.

Sitton: Well, Mr. Flowers said they trekked in there from several miles away to Sayers School because there wasn't another school close by.

Benford: Yeah, I never did know exactly about where they lived, but we saw them on Sundays, we'd go to church, and through the week they'd visit the neighbors. It's kind of neighborly, back there.

Sitton: People were more neighborly, right? They would visit?

Benford: Yes, they really were. They were more neighborly, that's true.
Sitton: Would they help out, help each other?

Benford: Sure would. That crop over there was so you couldn't gather it all, Papa would bring his herd over here or go and get somebody else's family and join in with us, and they helped each other. They don't do that now, 'course they don't have all that curriculum now.

Sitton: Now they say, "Isn't it too bad that their house burned down. Well, that's too bad." (laughter)

Benford: But Sayers was always a little neighborhood with our churches and used to have a post office, and the train would stop there, you know. They used the few buildings they had there for different auxiliary or something, that we need. We had smart people from McDade would come down and talk and just visit around with you. Everybody knew everybody pretty well.

Sitton: How did the teacher deal with having more - No teachers today have more than one grade in a classroom, but those teachers had several grades in a classroom. How do you deal with having, say, one through four?

Benford: Well, I don't know, but it's work. Yeah, they did. We had, when I started to school down there they had two teachers, and in a year or so they got three teachers. Well, we had three rooms then, you know. Once upon a time we had classes over at the church, which was nearby, until the superintendent would come out, and he'd make some kind of arrangements to maybe build another room for classes.

Sitton: So you had kind of a spillover class at the church until - Right? You know, there were too many students to fit in the school, is that right?

Benford: Too many classes, yes.

Sitton: Well, what did you do for recess at the school?

Benford: Play ball, mostly we'd play ball. And then we got up to basketball when it come in. Had several curriculums going on. Our superintendent, he lived in Bastrop, and they were good about coming out and checking on the schools, the students, see how many, and some of them had to walk so far to get to school. You know, transportation.

Sitton: But you didn't have too far to walk, right? 
Benford: I guess maybe three miles.

Sitton: Well, that's a good-So, you were south of Sayers is where your, your land was, right?

Arthur: It's north. As you come in from Elgin, you hit Big Sandy, then you hit Sayers, then you hit Camp Swift.

Sitton: I see. So they were north off the Elgin highway, okay. Well, three miles. So how did you get to school, did you walk?

Benford: We walked to school, and Papa would pick up a bunch of us when it's raining, and we'd have to stand up in the wagon - the neighbors' kids that lived on our way out from school. But we walked to school, and that was about three miles. We'd make it.

Sitton: So, the wagon was at least keeping y'all out of the mud or out of the sand.

Benford: Well, my dad I believe was the only dad to pick up, and a bunch of kids would get on the wagon with us, and some would have an umbrella and some wouldn't, and we all be standing up on that wagon. (laughs)

Sitton: Well, it sounds like there wasn't room for y'all to lie down or take your ease on the wagon so you had to stand up.

\section{Benford: Oh, no.}

Sitton: Didn't have a cover, didn't have a canopy over-

Benford: Yeah. No. Everybody stood up, and that thing bounce, well, somebody was all around.

Sitton: It's too bad we don't have a photograph of that.

Benford: We was down to visit one of the older citizens, some of them still live down there. She's younger than I am, Fay Owens [Owen]. We still go back down there and visit her. They had a store, a grocery store - I like to say "uptown," uptown! They had a grocery store, and everybody patronized that one way out in the country.

Sitton: So, the Owens were running the grocery store at the time you were coming up there.
Benford: Oh, yes. And the Evans, Charlie Evans, had it a while but - it was between the families. Had a pretty good neighborhood. It was old fashioned, but it wasn't bad. Had a blacksmith shop around there, somebody had that, and a barber shop.

Sitton: Well, what about-Did the school have programs like Christmas, school closing? Can you remember about that?

Benford: Whatever they had going on in Bastrop, we had it going on at Sayers. I guess they copied-you know, communicated with each other, teachers back there did, probably like they do now, only they're more (??) now.

Sitton: Can you remember what would happen at school closing at the end of the year? They usually did something, had some kind of celebration.

Benford: Yes, had some kind of celebration, some graduation. 'Course, I graduated there from the tenth grade, several of us did. That was the top grade they had down there, they didn't go any higher than that. But that was a good school, we had-It was important, we wasn't just out there ourselves. We had friends in Bastrop and Elgin that always come if you want to put on something and you feel like you wanted their assistance, you know, we had help. Those teachers knew others.

Sitton: And the county school superintendent would sometimes come out?

Benford: The superintendent, yes, he would come. Just like the president coming, you know.

Sitton: Well, what about - what kind of a garden did y'all have on the farm? Could you talk about, tell me about, the garden?

Benford: Oh, they go way out for that, they used to. Have gardens - peas, just different vegetables. We didn't know anything about going to the store and buying nothing like that. Some people put away some suitable to use later on.

Sitton: Did your mother run the garden?

Benford: Yes. Mama ran everything, near about it. She grew up on the farm, but my dad, they didn't have a large farm or nothing like that, but Grandpa, Mama's 
daddy, they had the big farm and very successful. Couldn't raise a lot of cotton, but then they grew some.

Sitton: What was your mother's maiden name?

\section{Benford: Evans.}

Sitton: How had they come by their land? Did they tell about that?

Benford: Uh, they come by their land by, what? [looking for document on coffee table] I don't know if I can find it, now.

Sitton: Yeah, I've read those. [Sayersville Historical Society Bulletin] That's the old ferry at Utley on the cover.

Benford: Yeah, I got these from Fay, that's the girl that's still down there. (still looking) I don't see nothing here that's suitable for showing you.

Sitton: It just takes over when you can't find something that you're looking for. It can ruin your whole day. (laughs) But what you were looking for is about the Evans family?

Benford: Not really, just the whole thing.

Sitton: Where did you go to church?

Benford: Sayers. We used to have three churches there.

Arthur: The names, do you remember the names, the names of the churches?

Benford: Pleasant Hill was ours, Sweet Home was the other one, and that Methodist church - I don't know, we just called it the Methodist church. I don't remember the name of that one right now. But we had three, used to have three churches going on in Sayers.

Sitton: Was it Pleasant Hill Baptist?

Benford: That's our church, yeah.

Sitton: Well, what was the church life like when you were young?

Benford: Oh, seem like it was good. Sang in the choir and Sunday school, we had everything just like they have now. I haven't been down there in a long time to these services. Probably got a little change, I don't know. Added a little more or something.

Sitton: Did the Pleasant Hill Baptist have a summer revival?

Benford: We had a revival.

Sitton: Could you describe that? What would happen, what would happen at the summer? It was a protracted meeting, right?

Benford: Yeah, yeah, we always called it, what?

Arthur: It was like the association?

Benford: Well, sometimes we had a camp meeting. That's when I was a little girl.

Sitton: What — can you tell me about that?

Benford: Well, I was just a young kid then, and jumping - I guess the same thing. It's different now and more enlightened.

Sitton: Would that be out under a brush arbor?

Benford: They had a brush arbor when I was real little, I remember the arbor, but I can't tell too much about it because I don't think we attended, I was so little, then. Mama and them would leave us at home and go to night meeting, called camp meeting. They'd go. We were old enough to stay home, and she'd get her younger brother, maybe, to stay there with us while they'd run to Sayers to the meeting. They went to church, some by horse and buggy and some by wagons - come from as far as McDade to church, you know.

Sitton: Have some good preachers?

Benford: Yeah, we had good preachers. The main man, he grew up down there. They really had some good meetings then. They looked forward to his coming like he was Jesus or somebody. (laughs)

Sitton: Who was he?

Benford: He was a minister, but I don't remember names. He grew up down there but gone somewhere else and would come back home to a meeting or something like that. Had that once a year. 
Sitton: What kind of stock did y'all have on your farm?

Benford: Mules and horses.

Arthur: You didn't have cows?

Benford: Oh yes, we did have cows. Hogs, we had hogs. And how!

Arthur: You guys, is that what you would eat? From your stock, or would you go to the store to get your meat?

Benford: Oh. Well, we'd try to kill enough hogs or save enough hogs to have meat. Mama'd cure the hams that we didn't eat right now and smoke it in the smokehouse.

Sitton: Did you help out with that?

Benford: Very little, 'cause I was kind of young, then.

Arthur: That's the old smokehouse.

Sitton: I see. [tape interrupted] We've got a photograph of the smokehouse here. Got a metal roof-

Arthur: I remembered when you started talking about that.

Benford: Yeah, oh yeah, the smokehouse and smoke that bacon. Kill three or four hogs, you know, and away Mama'd send us to neighbors to deliver it, take it over there to them. 'Cause I think we were the biggest neighbor, had more family, than anybody down there. And we always shared, and whenever they'd come through with their killing, why they'd share back, but it wouldn't be like that Mama would send out. She was free-hearted.

Arthur: What was her mother's name? What was Grandmother's name?

Benford: Huh? Anna, Anna Evans.

Sitton: Well, hog-killing time would come when it got cold, right? First cold, you couldn't have hog-killing time before it cooled off, right?

Benford: That's right.
Sitton: So when you killed the hogs and cut up the meat, she would send some around to the neighbors.

Benford: Yes, Lord, yes. She'd give it to all the neighbors. Mama was very free-hearted. But Papa always had the most stuff going on, like hog killing and all that stuff. Neighbors didn't do that much, 'cause they never would save over one hog.

Sitton: So he basically had more stuff to give away, and the neighbors were living a little closer to-

Benford: They were a little bit less, kind of. My mama would share. People were neighborly, then, if you look way back and see how they treated each other. We shared, and they shared.

Arthur: What was Grandma Anna's husband's name?

Benford: Sam.

Arthur: And how did he get the land?

Benford: Well, when Grandpa was a slave or what and they gave them so much land. Somehow it happen, I never did try to go through the details. That's how he come by his, they didn't buy it. It was given. But nearly everybody had a homestead.

Sitton: There was a community over on Dogwood Creek, there were various people who lived over there from Emancipation on, and some of them bought their-It's hard to say how they got their land, but they were over there, and they ended up on their own land.

Benford: That's the way everybody I think mostly did, if Grandpa got this. 'Cause he was back in slavery, way back there.

Sitton: I talked to a lady in Houston County, this is out from Crockett. Her father was born a slave. He was very old when she was born. This is 2002 that I talked to a lady whose father was born before Emancipation! I didn't think I would find anybody like that.

Benford: Grandpa, I don't know how old he was when he passed, but he was up there.

Sitton: Did people have a-Was there a place for Juneteenth around Sayers? What do you remember about the Juneteenths that y'all would take part in?" 
Benford: Well, I can't remember nothing real, real good, but Mama'd take that ice cream freezer out there and we'd have to turn and make that ice cream. (laughs) I remember that better than anything else. We had real good dinners, and that was a big time with us. To go to the Nineteenth of June, wow.

Sitton: So, you're talking about a Nineteenth of June at home, right?

Benford: We'd have it all the way down to Sayers. The neighborhood or anybody could come on, you know.

Arthur: Did you have fireworks back then?

Benford: No, we didn't have fireworks, and we didn't have night services much because we didn't have lights outside. And it's dark down there until you get inside.

Sitton: There was kind of a difference of opinion about the Nineteenth of June. There were some of Junes that religious families, they would have it at the church. Then there were the blow-out, secular Nineteenth of June, and some people were leery of them. So y'all would have a Juneteenth at the church.

Benford: Around the church. That was the best place around there, with all the trees. And it was neat and not a lot of weeds and grass. You know, not weeds. We always took our ice cream freezers, Mama'd have a little one and a big one with ice cream all ready. She'd done fixed it 'fore we left home. And we'd have a Juneteenth. And the school house was right there across from the church, see. There's no school house over there now, but that and the church, it's kind of combined, you know.

Sitton: So you could spread out over — Would anybody give speeches?

Benford: Oh, maybe one. Somebody might talk or give a prayer, if we didn't have nothing else.

Sitton: But it was mainly a big picnic, is that right?

Benford: Uh-huh, but see they would pray over there-church people.

Sitton: Well, how often did you go into Bastrop or Elgin?
Benford: Well, they went a lot of times by wagon, and Saturday would be a good day. Start out early and get up there and back. Till we got a car. And when they got cars, then they go any time you get ready.

Sitton: What was it like at Bastrop on Saturday back then?

Benford: Well, I didn't go too many times, but it was just a big gathering and the happiness of the day, going up and down the street! They didn't have a lot of stores in Bastrop. But it has grown somewhat now.

Sitton: But that was the day that people from the country would go into town, if they went into town at all, right? Saturday.

Benford: Well, that was a big day for them, yeah. 'Cause my dad'd want to go when he wanted to get some groceries. When he used to work at the coal mine, when the coal mine's down there, and deliver groceries from this coal mine store to that one up there near us. He'd take the wagon, and I guess they paid him, I don't know. But anyway, he hauled groceries way back when they's giving - flour had gotten so dark they didn't want to eat it. But we ate white bread, 'cause they put his bread, his flour in there, said, "This is yours, Isom."

Sitton: So, he was hauling groceries out to the stores at the mines?

Benford: The mine down there, going toward Bastrop, it was two, I think, down there.

Sitton: There was one close to Sayers, and there was one farther down toward Bastrop that I've heard about.

Benford: He hauled for one of those stores. That was during a kind of depression year. I don't know now just what year that was, but it was, and so we enjoyed the real flour. They put his on there, "That's yours, Isom." And he'd take that wagon and haul that other down to another store.

Sitton: So, he was supplying the stores?

Benford: No, he'd pick it up at some other place. He did that for them. I just remember, I was very young then, but I remember, that day come for him to go take them groceries from one store to another'n. 'Cause, this one up near us was just one, but back down that way was about two, I think. 
Sitton: Did you every go look at that mine operation? What do you remember about that?

Benford: I don't remember anything, I've often wondered about that. I never did, I was afraid to ask somebody to go with them, and I don't think too many of us went, either. But we lived near one coal mine.

Sitton: That's the one that's on Swift, that's the one that they lived closest to. What was that guy's name, I can't remember? It was just the Sayers coal mine.

Arthur: Grandma, when did you move over to Camp Swift? When you two guys had a house over there, when you got married?

Benford: Oh, yes.

Sitton: Thank you very much. Tell me about the house that you moved to after you got married.

Benford: Where was that house? Oh, on the Bob Moore place. That's near Oak Hill. Have you ever been by Oak Hill? We used to live near Oak Hill right in that house, one house. And it's still there, we were by that way just a little while ago. I don't think nobody's living [in] it. We lived in that house after we got married, but all our neighbors and people who owned it has passed, passed away. They got some children here and there.

Sitton: Well, how did you make a living on that place, what did y'all do?

Benford: Farm. We farmed, raised cotton and corn.

Sitton: So, you were still in the cotton and corn business.

Benford: Never get out of that. (laughter) Cutting them tops. My sister and I, we'd get out there early in the morning, we done downed all them corn tops, put them over there, boys come by and tie them up. We didn't care how they tied them or whether they tied them, Dovie and I would cut them, put them down there.

Sitton: Use that for the cows, right?

Benford: Uh-huh, and we'd stack it, stack it like that. And I remember this. Papa - I'd gotten old enough to stack it on there and put it in, and I said, "I'll be so glad when I get away from here!" (laughter) He didn't have no big boys, so I had to stack fodder. I couldn't do that now, I wouldn't know how.

Sitton: Would you stack it around a pole?

Benford: Uh-huh, yeah, have a pole standing up there. But on the wagon it was just heaped on there, and I'd be riding on there, be glad when this day is gone by. And then Dovie and I, we could chop, just chop and sing, we just loved that.

Sitton: Chopping wasn't so bad, right?

Benford: No, it wasn't as bad as riding on that wagon with the hay, that was for the boys. But he didn't have no big boys or nothing.

Sitton: My grandmother was a very small woman, but she had to help plow and split rail fences and get firewood. There wasn't any - somebody's got to hold the other end of the saw, and there wasn't anybody else but her.

Benford: I've been through all of that - anything, you name it in the country, we've seen a little of it, you know.

Arthur: Well, how long did you live in that house - over in the Camp Swift area?

Benford: I'm trying to think. Maybe about a year, because - What was going to happen? We was going to build a house back up on our place. But we did move in there, we moved over in Bob Moore's place. He's a man from McDade owns some property down there.

Sitton: Do you remember, what was the deal with Mr. Moore? Were y'all - Y'all were renting from him and living on his place, were y'all on halves or thirds and fourths?

Benford: I think it was thirds and fourths. They had that half business, but I think ours was third and fourths.

Sitton: When you had some of your own stuff, like your own work stock and so on, it was usually thirds and fourths.

Benford: I imagine so, but at that time I never added up that, I never thought about it. I just look back some years and see where we were once and what went on. After we got married, we came back and stayed over 
on the McDade road. I don't know how many years we stayed over there, and then we started spreading and moving away. But we did live up there on the road going to McDade. Probably two years or something like that. That was after I was married.

Sitton: Did y'all have children by then?

Benford: Uh, had one.

Sitton: Can you remember what that Oak Hill place looked like? What did the house look like, that you lived in with your husband?

Benford: Well, it's sitting up there now looking just like it did then! About last summer we passed there, and it's still there. And just this side of it is where my mother and them lived, way back down in there off the highway, you see, at that particular time. We lived around this side of McDade. They call it McDade, I call it partially Oak Hill, 'cause that cemetery is up there.

Sitton: Yeah, they're still keeping up that cemetery pretty well.

Benford: Well, we was by there about four months ago or something another, when my son was here, and we didn't get out and go, but it looked kind of woolly over there, and we didn't go out in there. I want to go back sometime when we have time to see whose name, if we can find them, 'cause I have a brother over there and several friends and some kinfolk too.

Sitton: You remember pulling corn?

Benford: Oh, do it! Couldn't forget that. I did that on the farm.

Sitton: Yeah, I know. I'm just trying to record that sort of thing, because people today don't know what it was like to harvest corn. How did y'all harvest it?

Benford: Well, sometimes, just depends on how big the field was, if we didn't have the wagon there, sometimes it's too much trouble to have a wagon and mules, they trying to eat, you have to muzzle them, keep them from eating, 'cause they'll eat up that up there ahead of you. So, Dovie and I would go out there and pull these corn and go down the row and put them the pile, then we'd go back with the wagon and pick them up. And Papa could help us unload, but he wouldn't always. He'd come out and help us pick up some, but he didn't always pick up. But Dovie and I were the boys of the family. And we didn't mind it, we'd tackle it. Didn't know no better. It wasn't bad.

Sitton: That was better than cutting the corn tops, right?

Benford: Oh, we did that too. Well, all of them 'bout the same, 'bout the same.

Sitton: But picking cotton, that wasn't the same.

Benford: Oh, yeah. But we didn't grow too much cotton while I was on the farm, but we went to the prairies.

Sitton: What do you remember about going out there and picking for other people on the prairie?

Benford: Oh, we used to do that, that was our-We looked forward to that.

Sitton: Well, there were the people that kneeled down to pick and the people that bent over. What were you?

Benford: Oh, yes, all kinds. I was the bent over kind, I couldn't crawl, I was too short to crawl. But I picked.

Arthur: She still bends over when she does yard work.

Sitton: Well, how much could you pick in a day?

Benford: I never thought about it — pretty good. I had a little brother, he's in California now. He would get down under a cotton stalk and sing, he loved to sing, and he would get down there wasn't doing nothing, just rustling and shaking bushes, and I'd have to stir him up a little bit. One day he told me, "Now, listen, I ain't no kid no more." He wasn't taking a switching. (laughter)

Sitton: So, the oldest kid is in charge of everybody else, right? And he was saying, don't tell me what to do anymore.

Benford: Uh-huh, he's done grown, he's growing up, now.

Sitton: But he would kind of get down and-

Benford: Sing, he just loved to sing, get down under a cotton bush and sing. Oh, he was a songster. Get 
down there and shaking them limbs, he ain't doing nothing, getting farther behind us. What a life, and what a blessing to grow up.

Sitton: Well, you know, the whole family ran the farm and everybody worked.

Benford: Yes, my mother worked, and she really knew more about farming than dad did, 'cause he didn't grow up on the farm much, 'cause they lived way off somewhere in there, and he didn't have a big farm. They wasn't really farmers, you know. They got vegetables and fruit trees and stuff, and I guess they made a living taking that uptown to Elgin and people'd buy it, I don't know. But there was different ways of making a living in the country.

Sitton: Well, if you had a little place, you'd live on it the best you can, and then you had to work out, right? I mean, if you didn't have enough land, you couldn't live completely off your place.

Benford: Yeah, well, we had a big farm, Grandpa had a big farm, and I know he got it when he was in slavery.

Sitton: But the farms keep getting split up as they go down.

Benford: Yeah, that's right.

Sitton: Did y'all ever go fishing? Tell me about how y'all fished.

Benford: Well, I'm not a fisherman, so I didn't go that much. You could fish in the creek right down there, and there's always somebody coming in, out of town or in town, and asking your permission if I could go down and fish awhile. Lot of people come down there and go down on the creek [Sandy Creek] and fish. I didn't know anything about these other places at that time, you know. Even after I grew up, I wasn't a fishermen no way. I had my hook sitting out on the creek one day and went back down to look at it and pulled it up, and it was such a big fish on there I threw the thing down and ran. I went and got somebody to get this fish off the hook. I threw that down.

Sitton: You didn't want to deal with that, it was just too big?

Benford: Yeah, too big for me. You could fish in tanks and catch them little old small things.
Sitton: But there'd be these bigger holes in Sandy Creek that had fish in them, right?

Benford: Yeah, used to be some pretty good fish in them. People used to come down and camp down on the creek down there. They always kept it kind of clean around places where you could fish. And spend the night, put the tent up, and fish down there. I bet they don't think about doing that now. Probably can't get in there.

Sitton: You were not a big fisherman, but you did some fishing, and you used a pole.

Benford: Yes, and I threw that one so far that day. I caught him on there and I just kept dragging him, got up on the hill, wasn't nobody down there on the creek but me. But I was calling for somebody to come help me. I drug him on out, I run up the hill, it wasn't too woolly, ran up back a way, away from the water.

Sitton: So, you hauled him out of the water, but what you didn't to do is take him off the hook?

Benford: Yes! He was wriggling 'round there on the ground, I was scared of him.

Sitton: What about hunting, did anybody in your family hunt or trap?

Benford: Well, my older boy and my daddy and whoever else could go, they used to go-hunting at night. Yeah, they used to do that. Bring anything home except a polecat.

Sitton: So it was just, whatever we find out here.

Benford: Not a polecat.

Sitton: I was reading in the Bastrop paper yesterday, over at the archive, and in the 1930s, there were people buying a whole lot of pelts. Somebody would come to town and set up there and buy pelts - furs - would buy thousands of pelts from people all across Bastrop County. What would your fathers and brothers bring home? Was it possums and coons?

Benford: Oh, a bunch of men would get together down there - that friend or that friend, you know-and they'd go hunting, 'specially for opossums, polecats. They would sell the hide off of them, you know. I 
don't know how they did it, but — That was a big thing going on, way back.

Sitton: So it was a group of men and boys.

Benford: Um-hm, yes.

Sitton: Did you ever hear of — ? There was something mentioned way back in the Bastrop paper from one of the community reporters - from Oak Hill - about rabbit drives. Do you know anything about rabbit drives? It's a sporting occasion, men and boys go out and have a rabbit drive.

Benford: No, I guess I didn't hear that-one way of hunting I know about.

Sitton: But this hunting that you're talking about, it would be night hunting?

Benford: Uh-huh.

Sitton: And would they have guns?

Benford: Not at night, I don't think they took guns at night.

Arthur: What they'd kill them with?

Benford: Well, I don't know, I didn't go into it. Never did inquire. (laughs) They might have had a gun, might have, could have.

Sitton: I bet they had dogs.

Benford: Yeah, they had dogs. They had them dogs.

Sitton: That's your gun, see. Well, you know, a opossum, you just can go and pick one up. You can go up the tree and shake it. You don't need a gun to get opossums.

Benford: A opossum is a funny thing, if they decide to sull they'll sull, freeze, right there.

Sitton: Would y’all eat opossums?

Benford: I never did like them, myself, but I liked the rabbit.

Sitton: How would they get the rabbits?
Benford: Well, just go out rabbit hunting.

Sitton: Your father or your brothers, did they trap with steel traps any?

Benford: Some of them did, but I never did hear about how they come out. 'Cause I didn't believe in that, I was scared of it. I don't know why.

Sitton: Well, did you prefer to work out in the field, or did [you] prefer to do house work in terms of chores?

Benford: Well, it was about equal, I guess. Had to go out in the field, they needed me out there. Oh, we'd get out there, and them kids that over there at that house, lived way up there, they had a farm, they'd come over and help us chop awhile, and we'd take our hoes and go over there and chop, and we'd chop and sing and talk.

Sitton: You know, in sandy land, when the grass starts to get in there, you got to go like you're fighting a fire.

Benford: That's the reason we helped one another, I guess. So when we go out there we could make a showing. But the kids over on that field over there, we'd go over and help them wipe out that spot, then they'd come over here and give us that - about that much time - finish or unfinish, you know.

Sitton: Did they call that swapping work?

Benford: We're just singing and just enjoying it. We'd sing songs we don't sing Sunday at church. That one be alto and that one do something else! (laughs) Go to watermelon patch, Papa wasn't ready for us to eat them yet, boy, we'd pull watermelon, so many green, half-ripe ones, went in the corn patch and buried them - thought we'd buried them. Papa went along a week after that and saw where we'd eaten watermelons in the corn patch. He didn't say nothing but just wanted an honest reply. Had plenty of them anyway. Had a big watermelon patch beside the corn patch.

Arthur: You hid yours that you were going to eat in the corn patch?

Benford: And we'd go down on the end there and eat them, eat them on the wrong end. (laughs) And he wouldn't think we did it, he'd think somebody just passed through the field. Kids would do anything, you do, wasn't no penitentiary thing. He wouldn't mind 
it, but he didn't want you to get those he was going to take to the market.

Sitton: I interviewed one man in Houston County, his father was real strict. When his father was away, he would sometimes eat a chicken. You know, when father and mother have gone to town? He would kill a chicken, and fry chicken, and eat it, and he'd bury all the guts and feathers and smooth the ground.

Benford: We've done that. Kids is going to think about it and do when they're at home. We'd kill a chicken. Mama told us to kill one, but she and Papa went somewhere, I don't know, we'd kill two. And Mary and I had to eat and help the others eat. Every chicken got two things, you know, be sure that it's not three. [laughter] And they'd do anything Mary said, you know.

Sitton: So, you didn't want three wings showing up.

Benford: No, no! She and Papa'd go off in the wagon, we's supposed to kill a chicken, but she didn't say two. We'd cook it. We were big kids then, and we could cook.

Sitton: You didn't have chickens to eat all the time, right?

Benford: But we had quite a few chickens. And they told us to kill one and cook it. Well, when we-how many of us was it then? Four or five, I guess we was four or five kids, we'd kill two, and we had plenty chicken, and save Mama and Papa some.

Arthur: You remember that you told me how you guys had to make entertainment for yourself? Y'all didn't have money for fireworks, but sometimes you made your kerosene rag.

Benford: Oh, sure. Mama taught us that. Use old material you had, and might put a rock in it, maybe, not too heavy. Take needle and thread and go through there and work that ball up and soak them in coal oil, and boy, we'd have Christmas throwing those balls.

Sitton: That is absolutely new, I've heard a lot but I've never heard that.

Benford: I don't know whose mind that sprung into, but I lay it on Dovie and myself.
Sitton: Well, how do you throw a burning ball? I mean, you got to grab it, don't you?

Benford: Have a string tied on there, and that's goodbye string. And if it goes out, we got another string back there.

Sitton: So, you wait till it gets dark, and you can throw it way up in the air.

Benford: And we'd have gloves, if we didn't have the string, have gloves on and catch it and throw it up there. But it's kind of dangerous 'cause it'd be soaked with coal oil.

Sitton: Well, that's as good as a skyrocket, though. Did you ever know people to make lamps out of bottles with a little wick-kerosene?

Benford: Yes, I've seen that. I never remember doing that, but I've seen it. I saw it at an association once.

Sitton: Just take a regular old bottle, a Coke bottle, any kind of close-necked bottle and push the rag down in, in the kerosene and it would work like a lamp. You would do that out in the country somewhere.

Benford: Uh-huh, we did that at an association one time, and other people did too - have stands - would make a lamp like that. But I always doubted that. Sometimes that place gets so exciting till anybody can do something, knock it over, you know, throw it at somebody else. That wasn't the right thing.

Sitton: You could throw one of those. That's a Molotov cocktail is what you got there. The Hungarians were fighting the Russian invaders with things just like you're talking about.

Benford: 'Cause my husband used to, when they'd have association back out here at Saint John, now he was always into that. Way back when he had them lights where you stick that thing down in there and let it burn, but later on they got lights out there.

Sitton: What would be happening at the association meeting?

Benford: Well, they have church meetings going on for a week. Used to have it for two weeks, but that's kind of lengthy. They'd have church every evening 
and night. We were out there last Sunday, and we had a great time.

Sitton: So, it's an association meeting at the church, the churches would have them, right?

Benford: Well, people'd have stands outside, and they have church off and on all day and then one at night.

Arthur: They have snow cones, ice cream, hamburgers, barbecue, fish, you name it.

Sitton: So, it's a fundraiser for the church, right?

Benford: That's for your pocket, not theirs. (laughter) It was the church's pocket that's paying the bills. They charge you to settle down there.

Arthur: It was like a carnival or something, no rides, but plenty of food and games and things at the associations for the kids. All day and all night picnic.

Benford: You been all the way down to Sayers?

Sitton: Yeah, I've been down there to just take a look. And I haven't been anywhere on Swift, but they tore everything there up anyway.

Benford: Well, they don't have much going on around Sayers, but they have a church there. Used to have three churches in Sayers when I was little. People have just moved on out from Sayers, we was down there not long ago. The Owens is the only ones live back there, you know, that you can talk to. And then we lived by them as neighbors for years.

Arthur: Do you remember very many people that lived over there off of Camp Swift, over in that neighborhood where you used to live? On that side of the highway?

Benford: I don't know what's over there nowadays, but it's a road that goes down through there.

Sitton: It's just pretty much nothing over there now, but we're talking about going back before Camp Swift, is what she was asking about.

Arthur: Do you remember any of the families that used to live over that way? Back then when you used to live down there, do you remember some of the names of the people?
Benford: Well, Fay Owen, that's the only place we got to go around Sayers, that place.

Arthur: Did they always have the pea patch and all of that when Andrew was alive?

Benford: Uh-huh, he tried to have a garden with a few things in it.

Sitton: Did y'all have - ? One thing I didn't ask you about, everybody had to have syrup. How did your family — ? Did y'all raise cane, and did you take it to the syrup mill? Can you remember anything?

Benford: I remember one time, they were making this syrup, it wasn't at our place, it was down to a cousin of mine, and we went down there. And he didn't have a wife, I went to cook, and my husband went to help him making this syrup. They had a mule out there going around grinding these stalks, and they made syrup, and it was good, too. This cousin, he had a barrel, and he had that thing about half full, he had a lot of syrup. That was good syrup, too.

Sitton: So he had a big old iron pot, or he had a barrel?

Benford: It was a barrel-like pot, a barrel-like pot. It was the first time I seen that. I couldn't cook for watching that mule go around with that - (laughs) $\mathrm{He}$ runs the thing there, I think he squeezes that juice out, I reckon that's what he does.

Arthur: He's trodden it down?

Sitton: Well, they're running it in, there's kind of a grinder, and somebody's feeding the cane in piece by piece to the crusher. There's a device about this big around with gears that crushes the cane, and the mule on a pole is powering the thing by walking around, just going round and round. But he's cooking in one big pot.

Benford: Uh-huh, that's right.

Sitton: That's the old way. I believe that $\mathrm{Mr}$. Flowers - They normally had great big old flat pan, kind of a big copper, rectangular pan, but this is older, what she's remembering. It's just one big cooking receptacle, it's like cooking on the stove. But you raised some syrup, I mean cane, right? 
Benford: I don't remember us growing any cane, but Mama's brothers raised some. And how come I was down there, I don't know.

Sitton: But you had syrup to eat? You had to have syrup.

Benford: Oh yeah, yeah. I like syrup myself. Some of them could really make some nice syrup, and some of it was kind of strong.

Sitton: I talked to one lady, they liked syrup so much, they would put it on fried chicken. (laughter)

Benford: Oh, no, I eat syrup and biscuit, that's far enough. Sometime now, I just get me some biscuits and eat some syrup. But I don't eat syrup like we used to. Just for a change, it's good.

Arthur: Did Grandpa ever make homemade wine or brew?

Benford: No, Grandpa didn't make nothing like that.

Arthur: Well, how did you guys learn how to make it?

Benford: Oh, just out of our own mind. (laughter)

Sitton: Well, there's lots of wild grapes over there.

Benford: I get mine in the country, but I make mostly jelly, now. Don’t make too much but jelly.

Sitton: Did y'all pick dewberries?

Benford: Oh, did we! Mama used to have us gather and we used to sell dewberries by the tub-full. Somebody would come down from Austin, somebody we knew come down and pick them up. And I believe we sent some on the train once. What is that place? My cousin Annie lived there, I can't think of that place.

Arthur: You sent some to Spain.

Benford: I did? Did it get there?

Arthur: I ate it, yeah. (laughter)

Sitton: So that is serious dewberry gathering, right there. I mean, you gathered lots of them.
Benford: Yeah, we gathered lots for people from Austin that ask you. They'd come pick them up on a certain day. We'd pick lot of dewberries.

Arthur: Tell him about poke salad.

Benford: Oh, I don't know, I just like it. I used to didn't.

Sitton: What is poke salad?

Benford: Well, that's a weed that grows, I got one about that tall out there in my back yard. Somebody else might have another name for it, but we grew up with poke salad. It's like spinach, but I think they say it's kind of a poison.

Arthur: Yes, if you don't do it right, it can kill you.

Benford: So, uh, that's kind of rich. When I cooks it I puts in some fried meat grease. I think that'll cut the poison.

Arthur: Where does it usually grow?

Benford: Anywhere. You can set it out.

Sitton: Well, it grows wild, too, doesn't it?

Benford: Yes. Wherever it grows it's mostly wild.

Sitton: Well, you have to put some grease in it or it just tastes-

Benford: Got to put the grease to it, and that why I say I can eat some, but I can't eat a whole bunch. It's too greasy, too much grease.

Sitton: Did y'all have a sweet potato patch?

Benford: Did we! We had everything on the farm, pretty well. Except ducks, we never had no ducks. Had chickens, pigeons -

Sitton: Pigeons?

Benford: Pigeons for years. They wandered away somewhere, you know. Guess we wasn't feeding them right or something.

Sitton: Turkeys. Tell me how people used to grow turkeys. Its totally different from what people think. 
You don't just grow them up in a pen like chickens, right?

Benford: No, they got to have some range. Everybody don't live in a vicinity that's just right for turkeys. They all right living way out in the country, 'cause sometimes they go off and stay all night. But seldom. Lot of people used to raise turkeys down home there.

Sitton: But the turkeys would go out, right? They'd go feed themselves, they'd wander out across the landscape and feed themselves? And then they'd come in.

Benford: Uh-huh, and eat themselves again, if you feed them. Got to feed them to show them where home is.

Arthur: But they were turned loose?

Benford: Oh, yeah, they're loose, just like the chickens out there.

Arthur: Huh. What about guineas?

Benford: Same way. I think they're a little wilder.

Sitton: But you could sell the turkeys, right?

Benford: Sure could. Mama'd sell hundreds of dollars when she grew turkeys, and some of the neighbors grew turkeys for the market.

Sitton: How would they sell them?

Benford: Now that, I don't believe I could answer. By the pound though.

Sitton: I mean, would you take them some place, or would people come out and buy them from you?

Benford: Sometimes somebody would come, depending on how many. They'd come and then you can take them to them, they have a place in Bastrop, one of the towns, that you can sell your turkeys.

Sitton: Would peddlers come out?

Benford: Oh, lots of times.

Sitton: What kind of peddlers? I'm interested in peddlers. You know, when you're stuck on the farm, and you can't go to town lots of times, that sets up for people to come out to peddle to you. What kind of peddlers would come by your place?

Benford: Well, you'd be surprised sometimes, you know. Book peddlers and oh, just anything anybody can think up and come by. Just couldn't put my finger on it. I got a set of books in there. I bought from a peddler, oh I bet you forty or fifty years ago. I picked up one the other day, thought I need to start reading these books. (laughs)

Sitton: You hadn't got your money's worth out of those books, right?

\section{Benford: I guess so.}

Sitton: I've heard people talk about the Rawleigh man.

Benford: Yeah, he used to come by. We'd look forward to seeing him.

Arthur: What was that other one, Watkins?

Benford: Watkins, too. He had extract and-

Sitton: They were kind of chain -

Arthur: Wasn't there a Fuller Brush guy, what kind of brushes did he sell?

Benford: Fuller Brushes is what the sign said, and that's all you can say.

Sitton: Years ago I was talking to somebody who grew up in this little sawmill town called Diboll, and there was a kind of peddler who would come on the train. He was a pots and pans peddler, and what he would do, he would go from house to house with - What you would see was this guy who looked like a walking pile of pots and pans, all the stuff hanging off him. And he'd just go from door to door in the town, say, "Do you see anything want to-

Arthur: You ever see a salesman like that, Grandma?

Benford: I've had salesman, but not like that.

Sitton: People have talked about gypsies coming around.

Benford: Well, I wouldn't, I never had got that in my mind. But we used to have peddlers come to the 
country, though. Bibles, you know, people selling Bibles and different kind of magazines. And 'course, I liked to read so much I'd have to try to get one.

Sitton: You must have done real well in school if you liked to read.

Benford: Um, I loved to.
Interview with Mary Lou Reese Benford with contributions by her granddaughter, Ava Arthur Interview conducted by Thad Sitton Date: April 21, 2004

Place: Home of Benford, Austin, TX

Year of Birth: 1910 


\title{
Leola Blackwell Carman Interview
}

\author{
By Martha Doty Freeman
}

\section{June 2004}

Martha Doty Freeman: This is Martha Doty Freeman. Today is June 2, 2004. This interview is taking place at the home of Leola Blackwell Carman, 1107 Cedar Street, Bastrop, Texas. This interview is part of the Texas State University-San Marcos Camp Swift Oral History Project, sponsored by the Texas National Guard and conducted in conjunction with The Center for American History, The University of Texas at Austin.

Freeman: Why don't we just start with your telling me about your family, about your parents, your grandparents, anything you know about them.

Leola Blackwell Carman: They were just farm people. That's all we knew was farm. They came from McDade originally. Well, I say they came from McDade originally. That's where they lived at the time when we were living in the Camp Swift area. Daddy inherited some of the property, and so we lived there. But Mama was from around McDade. She was born there. She was a Kelton and Daddy was a Blackwell.

Freeman: Did you know their parents?

Carman: No. Well, I knew Daddy's mother, Mary Smith Blackwell. But Great-grandpa died just before I was born. And I knew Mama's mother and father.

Freeman: Do you remember your father's grandparents' names?

Carman: Yes, John Lindsey Blackwell and Mary Floyd Blackwell. My father's parents were Julius Watson Blackwell, and Grandma was Mary Smith Blackwell.

Freeman: So is this how you're related to Ruth Smith?

Carman: No. There was Smiths on both sides. No, the Smiths you're talking about were on my mother's side. Her mother was a Smith. And then Daddy's mother was a Smith on the other side, but they weren't related. Or they didn't claim kin. They came from different

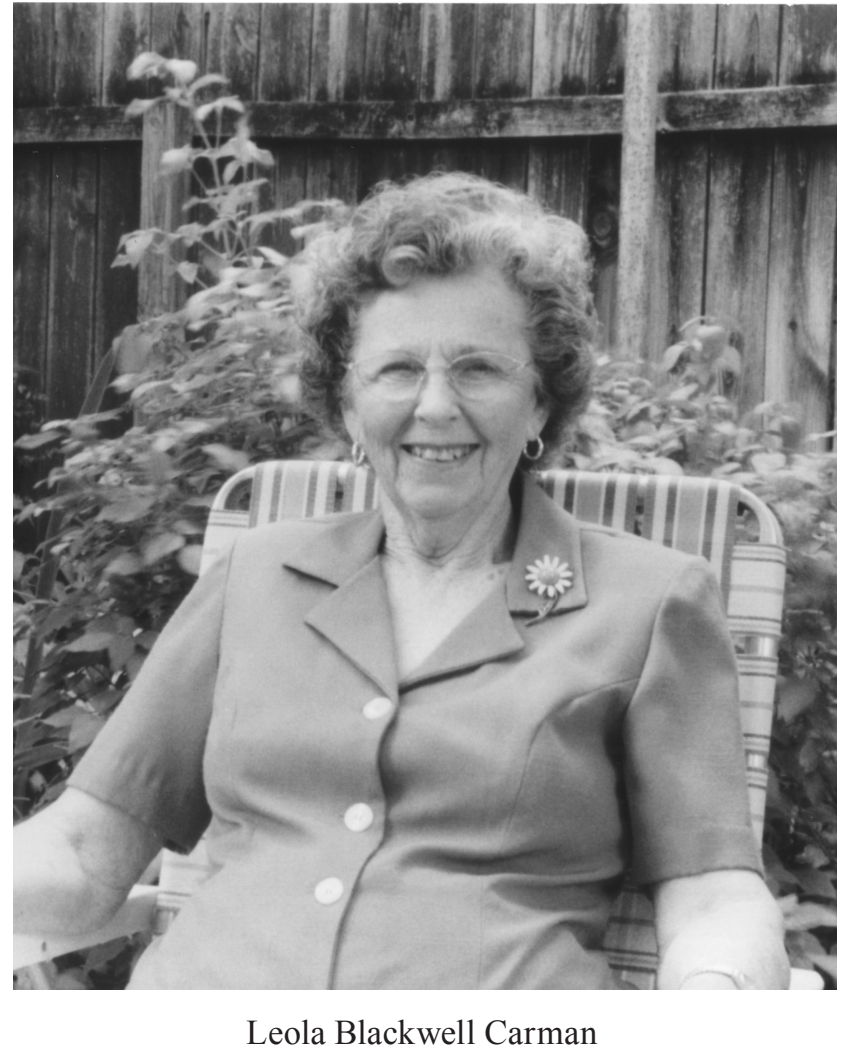

parts of the United States, and so I don't suppose they were related.

Freeman: And then what about your mother's parents?

Carman: My mother's parents were Oscar Kelton and Eva Mae Smith Kelton, and they came from Tennessee originally, and they were around McDade. In that area.

Freeman: And then what were your parent's names?

Carman: Ethel Kelton and Willie Blackwell.

Freeman: Do you have any idea where they were born or when they were born? 
Carman: Mama was born in McDade and Daddy was born in McDade too, I guess. Well on Piney Creek near where the place was that was out here. It was out about six miles from town on Piney Creek. Was where he was born.

Freeman: And what about your immediate family? How many brothers, sisters?

Carman: I had a brother and a sister. There were three of us. George and Bettye. Just the three of us. Just farm kids, and like I said, that's all we'd ever known. And it was quite a traumatic thing when we were uprooted and had to find another place. 'Cause we never had been anywhere before. Bastrop and McDade, I guess, was the furtherest we had ever been.

Freeman: So, when, can you give me the dates of, your birth date and then your brother and your sister?

Carman: You mean you want the month and the day?

Freeman: Sure.

Carman: Let's see. George was born December the seventh. That was when it all started was because he was home. He was, was going to work in Austin. He was home for his birthday on December the seventh when we heard he was getting ready to go back to work, and we heard it on the radio that Pearl Harbor had been bombed. Anyway, his was December the seventh, 1925, and Bettye's was, mine was February the fourth, 1928, and Bettye's was August the, same as LBJ. (laughs)

Freeman: Okay.

Carman: Daddy's was on the first of August and hers was on the last.

Freeman: Just August 27, 1931.

Carman: Yeah. Nineteen thirty-one. I think that's her birthday but I'd have to look. I have it all written down.

Freeman: Tell me something about where you grew up. I had the impression from your sister's write-up that y'all lived in a couple of different places.

Carman: After the war. I mean, after they took the place. That's what she was talking about.
Freeman: So where was your farm before, when you were growing up?

Carman: Oh, okay. Well, right in the middle of Camp Swift. I can show you. This is [Highway] 95. This is Pershing, and right here, right here was the - This is what he bought back the second time. This is part of the place. But our house was right in this area. But it was right in the middle, so this is Camp Swift, but this is where our place was. Right in the middle.

Freeman: And did your, did your grandparents have a place nearby?

Carman: No. At that time they lived, Grandma lived in McDade. They had a place. Let's see, right over here. What we called the old place. We lived there first. That's where I started school. I went to Oak Hill School, and it was three, about three miles. The first year I went by horseback with my brother, and then the next year, I don't know what happened to the little ol' horse, but anyway, we walked, and then I walked until I was in the fourth grade, and then started to Bastrop. We were transferred to Bastrop.

Freeman: Okay. Well now, tell me about the house that you lived in at first when you were youngest. You said it was your grandparents' place.

Carman: It was an old house that my grandparents had lived in. And they had moved to McDade and so Daddy took us there. We didn't own it. But Grandma still owned it. And it was an old house and had been lived in before and wasn't in very good condition. But anyway we lived there until I was, I guess, about three years. Bettye was born there. And then Grandma had another place. She owned the other place, too, what we eventually moved to. And so she gave Daddy the place that we eventually moved to. And we torn down the old house that we lived in and put it on the place that we was living when Camp Swift took our place.

Freeman: And that was the one down on Pershing, or near present-day Pershing?

Carman: Yes. And we lived there, [but] we didn't get to finish it. And it was cold. It didn't have the windows, I mean the doors in between. We didn't have doors up, and didn't have it sealed out good. It was so cold that year. (laughs) We had a, if I remember right, we just had the cook stove at that time. A wood stove. This one year in particular was a bad winter, and we 
couldn't go to school actually. And so Mama gave us breakfast and we went back to bed and stayed the rest of the day because it was so cold. That's the only way we could keep warm.

Freeman: What did it look like at your grandparents' place where the house used to be?

Carman: The old house?

Freeman: Yeah.

Carman: It was just an old wood house, and seemed like-It's like Bettye says, when you were looking up. She couldn't have been more than three years old. I don't know how she can remember it, but she said she could look up and see daylight through the top. (laughs) But I can't remember that. But it was, I know it had been papered inside with newspapers, I think. I don't know who had lived there before unless it was - I don't know. But anyway, it had bedbugs in it. (laughs) And Daddy tore, I remember Daddy tearing the paper off of the walls to get rid of them. So he could spray the, get rid of them. Anyway, that was a bad thing when we found bedbugs. He got busy and we got rid of them.

Freeman: Probably knew his family wouldn't stay there if he didn't do it. (laughs)

Carman: Oh yeah, I know. But it was just an old place that had a tank on it, a stock tank, and we had a garden and corn and crops.

Freeman: What did you all grow while you were there?

Carman: Just corn and potatoes. Just the regular crop. We was talking the other day, I was telling my husband, that people do things so different now than we did. When Mama and Daddy had a garden, and it wasn't close to the house, but tomato plants, you go and buy the little cubes now that have the tomatoes in it. They planted them in a big tub or a big container with rich dirt, and they grew 'em up till they got so big. They would go in and pull a handful, put 'em in a wet paper, take 'em to the field and put 'em out. We just had tomatoes. You didn't have all these little pots like you go to the store now. Like I said, we had a tank.

Freeman: Now where did you get your water from?
Carman: At that time? I can't remember. I don't remember having a well. I really don't. I know where we got it after we moved.

Freeman: What was that?

Carman: It was a deep well that an old man, black man had, named Gabe Williams, and Daddy would haul it with a barrel.

Freeman: And where was Gabe Williams relative to your house?

Carman: Now, this is the place that we moved to after we moved from the old place.

Freeman: Yeah, right.

Carman: It was about three miles. No it wasn't, it must have been about two miles east of where we lived. And I don't know what happened to the well. Like, the Army, when they took it over, they filled in a lot of the wells. But it was a deep well. You had to draw it by hand, bucket by bucket. And it was good water.

Freeman: And so, okay, was it at Gabe Williams's house or just on his property?

Carman: Yes, yes, it was on his property right near his house. It was in his yard, well, right outside his yard.

Freeman: So how was it, did — he had neighbors who just came over and used the water?

Carman: Oh yeah, he had a well. We just-

Freeman: Shared.

Carman: Yeah, yeah. But that's where we got our drinking water. Now we had a little tank. It was more or less a spring below the house, and that's where we did a lot of washing, washing the clothes.

Freeman: How did you do that? What was involved with washing?

Carman: Washing? Well, you took your tubs and your clothes and wash pots down to the spring and got your fire and heated your water.

Freeman: Where did you get the soap? 
Carman: Ah, Mama made some of it, but I don't know if, at that time, what she used, but (??) it was. You could buy soap, but I don't know if she did or not. But she had made soap.

Freeman: What kind of livestock did your family have?

Carman: Cows, horses, mules. Mostly mules. Work stock was mules, but my brother had a horse. I remember when we lived there and, but Daddy's work stock was mules. Crazy ones.

Freeman: Really. Tell me about that.

Carman: One in particular, she was shy, and this one time he had been, Daddy had been to Elgin to get some cotton seed hulls. That's what he fed the stock. And he came back and stopped, and actually I had to climb in and get in the cotton seed. Something scared her and she took off running with me in the wagon. And I don't know how Daddy finally managed to get her stopped. I don't remember that part. But it scared me to death.

Freeman: So how many mules did he have at any one time?

Carman: I think he just had a pair at that time. And we had hogs and chickens.

Freeman: Was your brother old enough to help your father out with the plowing and everything?

Carman: Yes, oh yes. He was big. He was a big boy for his age. In fact, he had quit school and was working in Austin at Cotton's Dairy, and he was, Bettye says he was seventeen on his birthday. He was having his seventeenth birthday. I think it was his sixteenth when Pearl Harbor was. But anyway, he was home for his birthday. He was working in Austin.

Freeman: So when had he left home to go to Austin?

Carman: Ah, just shortly before that. He hadn't worked there that long. He always was big for his age. He was six-three-and-a-half when he finally got through growing.

Freeman: So why was it he left home so early?

Carman: To work. He wasn't in school, and he wanted to work.
Freeman: But he couldn't work on the farm.

Carman: He couldn't make any money. And when he did work, he worked all day long for, I think he said, for about seventy-five cents for picking up the potatoes for somebody in McDade. But anyway he worked for Mr. Cotton in Austin, and he was good to him. In fact, he drove the car. He let him borrow his car to come from Austin home for his birthday.

Freeman: Now, did you all have a car?

Carman: Yeah, we had a T Model most of the time. I'm sure there were times that we didn't. We just had the wagon. Bettye said she can't remember when we didn't have a T Model, but I can. We just had a wagon.

Freeman: Did having the car make a big difference to you in terms of where you could go or how far you could go?

Carman: Well, I'm sure it did. But he never did have a very reliable vehicle. Just an old T Model that never was a new one. But, I'm sure it made a difference, because we could, we went to McDade after we got the T Models. And we would go up there to Grandma's and aunts that lived up there.

Freeman: Were you fairly close to your aunts and other relatives?

Carman: Oh yeah. We had lots of cousins.

Freeman: And did they all live in Elgin, McDade? Did any of them live down around your farm area?

Carman: No, unh-uh. We had some, a few cousins on different sides of the family that lived in that area like Grandma Blackwell's side of the family. The Smiths? They lived in that area and we went to school together.

Freeman: So tell me about going to school there. How did you, what was your school year like? Was it a ninemonth year, or what months did you go?

Carman: I think it was nine months, if I remember right. We had to walk and it was cold. It rained and your feet would get wet, and you'd get cold on the way. It was just a hard time. People wouldn't think about sending their children to school like that now. To go that far. But we would go so far and then we would 
meet up with another family, the Hoffmans, Jake Hoffman, that lived about half way between where we lived and school, and we would go with them. People can't really visualize how it was when we went to school, to walk that far. Lots of times you were late getting to school. And this one particular thing that I can remember. There was an old lady that lived on that road on the way, and there were berries on the fence row. It was on her side, but it was on the road, public road. (laughs) Anyway, she turned us in for, we wasn't getting to school because we were playing. But what it was, we were picking her berries. (laughs) We didn't particularly care for her after that. But we enjoyed it. It was all we knew. We enjoyed it.

Freeman: Sure. So, did you take your lunch with you?

\section{Carman: Yes.}

Freeman: And what was it? What did you usually take?

Carman: Mostly we didn't have a lot of light bread when we were young, you know, the bought bread. Biscuits, there was an egg biscuit, like you get, now you get at McDonald's? (laughs) People think they have something when they can buy one at McDonald's. A McMuffin. We had eggs, and biscuits and jelly, and biscuits and things like that.

Freeman: What time did you have to start out in order to get there?

Carman: When we walked, we started not near-It was near after daylight. We were supposed to have been there, I think, at nine o'clock, but I don't know. Sometimes we were late. It'd be on our report card, we were tardy. (laughs)

Freeman: Were there a lot of you who were tardy?

Carman: Well, yeah. That walked as far as we did.

Freeman: So what, what was sort of the spread of kids in terms of who went to that school? Were they from five miles away, three miles, what?

Carman: I would think we were the furtherest away from what I can remember. Of the ones that went to school. Some of the ones that were over, like JoNell, now she lived just a short distance from there. And I don't even know if she went to that school or not. Did she say where she went?
Freeman: She did. She went there for a little while and then wound up going into Bastrop.

Carman: Yes. Her daddy drove the bus. I really don't think there was anybody that lived any further away than we did. Maybe the Cottles. I'm not sure.

Freeman: Now where were they?

Carman: They lived directly across from the road that went to the Oak Hill Cemetery. It's Army property now. It's still part of Camp Swift or whoever has it. National Guard, I guess. But they lived, it'd be west, I guess.

Freeman: Now are any of the Cottles still around?

Carman: Not here. I talked to the lady up at the cemetery. First time I'd seen her since I guess we went to school. And she came to me and asked me if I knew who she was. And I didn't. And it was Evelyn Cottle. I told her, I said, you know, I have a book that belongs to Albert Cottle. My husband, my first husband worked out at the state park, and he was in charge of a lot of old things. And they would, the state would delete 'em off of the inventory, and I don't know how the book got to be there. But it was just a little religious book about so big, and he brought it home, and it had Albert Cottle's name in it. And I told her, I said, "I thought about this so many times, giving it to some of the family." So that was his daughter that was at the cemetery the other day. So I asked her if she'd like to have it, and she said, "I'd love to." So I sent it to her Tuesday, yesterday.

Freeman: And where does she live?

Carman: She lives in San Antonio.

Freeman: Now, is she your same age?

Carman: She's probably not. She may be George's age. I'm not sure. I just don't know. I didn't talk to her that long, and I'm not sure. But she, I have her address.

Freeman: I might like to get that from you.

Carman: Okay. Remind me.

Freeman: Okay. Now, I understand that you had other things. Well, first let me back up and ask what you did at school. You got there at nine in the morning, or so, and then, what was the day like at school? 
Carman: We had some classes, and it was one teacher would have three or four-Well, she'd have four because I went through the fourth grade. So she'd have four classes. Well, she would teach the first grade while the others would be studying or doing something else. But you were listening, probably, to everything that was going on. I don't know how we ever learned anything.

Freeman: Was the discipline a problem in a situation like that, or how did the kids behave?

Carman: I don't remember. The only thing that I remember getting really scared about was one teacher. I chewed my fingernails. I guess I was nervous or something. I don't know. But anyway, she walked up to me one day and hit me on the back of, on the desk or something, and said, "Quit chewing on your fingernails." Scared me to death, but I stopped. (laughs) I don't ever remember having that problem any more. So we had good teachers, had real good teachers.

Freeman: So you had more than one while you were there?

Carman: No, I had just the one teacher. Now there was two rooms. Miss Stagner taught the lower grades, and Dot Griffith - was it Griffith or Griffin - taught the higher grades. But I never did go into her class because by the time I got to that age, we were transferred to Bastrop.

Freeman: So was it a one-room schoolhouse originally?

Carman: It was two.

Freeman: It started out as two.

Carman: It was two.

Freeman: And how was that arranged? Was there a door that went-I mean, was there a wall between the two?

Carman: I think it was-As best I remember it had two doors. We didn't go from our side to the other one. If I remember right.

Freeman: And how was it heated?
Carman: We had a wood stove. And in the wintertime it was, the boys would set traps, and they'd work their traps on the way to school. And if you caught a skunk, it was bad. (laughs) Every time you get close to the stove, it was bad.

Freeman: You could tell who had caught the skunk.

Carman: The boys got sent home a whole lot. Anyway, it was just a country school. We had plays, we had recreation. We had swing sets, a good swing set and a merry-go-round. We played ball at recess. Naturally we had the outdoor toilets. Seemed like we had a cistern where we had our water, if I remember right.

Freeman: So did you have lunch outside or inside?

Carman: Wherever you wanted to, I guess. I don't remember.

Freeman: And you'd drink water at lunch?

Carman: Yeah. We carried milk 'cause on the way home, by the time you got home you would have a little ball of butter from walking, you know. But we carried milk most of the time.

Freeman: And I understand that there were other things that went on in the school house. I think a couple of people have talked about Christmas celebrations or-

Carman: Oh yeah. They had the Christmas plays and Christmas tree, and everybody would get a sack of fruit or fruit, nuts and candy, hard candy usually. It wasn't any big deal.

Freeman: Now who would organize that? Who would put that all together?

Carman: Just the teachers and some of the parents. I guess the trustees would, people would give money. Each family, I guess, would give so much money to go into getting, making the bags of fruit. But we didn't get - It was good for us, but when you think about just a bag of fruit and candy, it's not very exciting by today's standards, anyway. But I guess it was nice. We had sparklers and little fireworks. I remember one of the Smith girls, one of-I don't know if it was Ruth Smith's cousin, yeah, cousin, Gloria, she was, had a play or something, and they was on this 
little stage, and somebody had a sparkler and got her hair on fire. She had thick hair, anyway, and got her hair on fire. And that was exciting. (laughs)

Freeman: So it sounds as if that area where the school and the church and the cemetery were was like a little community center or something. Is that how it functioned?

Carman: Well, I guess probably the cemetery and the church. Well, that was just that school district. I really don't know if the school was connected to the cemetery, if somebody donated that. I really don't know if the school went with that or not. But there was a church right across the road from the cemetery.

Freeman: So the church and the school were on the same side of the road?

Carman: Uh-huh. Yeah. I should have gone over there the other day, but I went out there once and got chiggers so bad that I don't, I don't get away from the cemetery very far.

Freeman: Your curiosity is limited. (laughs)

Carman: Yeah. And it's grown up. It's all grown up now so you can't, you can't really tell where it is. But I'm sure there is pictures somewhere of the school and the church.

Freeman: Did your family go to that church?

Carman: No, unh-uh.

Freeman: Did you go to church at all?

Carman: No. That's it.

Freeman: Was that your parents' preference? Or were they not raised in the church?

Carman: Daddy just, they just never did. They didn't live, really live close to a church, and they just never did go to church. No, we never went to church.

Freeman: Tell me some about, you know, your home life. First of all, what did the house look like after it got rebuilt from the old house? How many rooms were there, and-
Carman: It was, let's see, there was a kitchen and where the table - and we also had a bed in there where we had the table.

Freeman: In the kitchen?

Carman: No, no. The kitchen was separate. It was separate. But the room next to it was where we had the table, and Mama had a big quilt box. And I don't know what happened to her quilt box. (laughs) Can't remember. But anyway, there was bed and a quilt box, and then, let's see, the front bedroom and a living room where we had a, we did have a couch and we had a stove, and seems to me like we had a bed in there too. It was a pretty good-sized room. And we had a front porch.

Freeman: Did it go all the way across the front of the house?

Carman: Let's see, the bedroom and the porch was on the front, and the living room was, it was more or less square. It was more or less square. And we had a wood stove, a wood heater.

Freeman: Was that enough to keep it warm in the wintertime?

Carman: In that room. (laughs) The kitchen, you know the kitchen would stay warm, but like I said, that first year before they got the doors up and got it all sealed out, it was so cold.

Freeman: Now what year would that have been?

Carman: Um, probably thirty, in the thirties, thirtyeight, something like that. Thirty-seven, thirty-eight.

Freeman: And you said you remembered it raining a lot too, and somebody else has mentioned that. Was that just in general, or just at a certain time?

Carman: I don't know, but I know it seemed like it rained more in the spring, and rained longer than it does now. Maybe it was because I was a kid and I thought it never would quit raining. But it would rain, seemed like for weeks without really getting clear. In the spring especially, when the potatoes-like it is this time of year when the potatoes come time for them to be dug - they would rot. I mean you couldn't 
get in the garden to get 'em, it would rain so much. That happened a few times.

Freeman: So what did you do when the crops ruined that way?

Carman: Well, I don't know. I wasn't old enough to have to worry about that. (laughs) But I don't know what they did for potatoes. Maybe somebody else fed the family. I don't know.

Freeman: So, what kinds of things did your mother do?

Carman: Mama worked in the fields just like Daddy, and she sewed, and she, she had a yard, and she enjoyed the yard, and-But she worked hard.

Freeman: Did she, did she raise flowers and vegetables and that sort of thing?

Carman: Yeah, well she had a garden. Like I said, she worked in the field and in the garden and whatever needed to be done around the place. She worked just like Daddy did. He plowed, but she would hoe, you know, hoe the crops and all.

Freeman: And what was in her garden?

Carman: She raised English peas and potatoes and corn and tomatoes. That kind of thing. And squash. She raised, which I never had-We've had a garden ever since I was big enough to remember. She always had the patty-pan, the little flat squash that they called patty-pan. The green, so round like this. I never knew of them having a yellow squash when I was growing up. They always had that little patty-pan.

Freeman: Interesting. Did any of your-

Carman: I never did see the yellow.

Freeman: Uh-huh. Did any of your neighbors have that kind of squash?

Carman: Everybody had that kind same kind.

Freeman: The patty-pans?

Carman: Uh-huh. I don't ever remember them having another kind. Now they had pumpkins and the big winter squash, you know, like you - But I never saw the little crook-necked squash or the little yellow squash.

Freeman: I think your sister mentioned that she also had moss of different colors, or something.

Carman: The moss rose, the little-They call them moss rose, rose moss. See those yellow ones out there that I've got? By the fish pond. It's that little small, just a little succulent-type plant.

Freeman: Was there something that she used to make dyes or colors?

Carman: That was what she was, Bettye was talking about that we'd play with. The red? We would paint our face with the flowers.

Freeman: So the color actually comes off?

Carman: Oh yeah. Anyway, if that's what you read in Bettye's book, that was what it was. It was really good for dry soil. We didn't have to water. They were good for dry areas. Mostly what she had was that type of plant. She had the hollyhocks and the zinnias and things like that.

Freeman: So it wasn't just an edible garden, it was an ornamental garden as well.

Carman: Well, no, it was in a separate-This was just the yard where she grew the flowers. She didn't have any flowers in the garden where we had our vegetables. It would have been in the yard where she had her[s]. It was fenced. We had a fenced yard. We had peach trees. We had fruit and we had wild grapes. A lot of wild grapes.

Freeman: Did anyone around there make wine or alcohol with the grapes?

Carman: Ruth's, let's see, Ruth's uncle that was her daddy's brother, Harvey Smith, made the best wine. He lived, he lived near Oak Hill where the old house was that I was telling you about that they used to bombard during the Camp Swift. Anyway, he made wine. He had a beautiful, he had a grape arbor and raised some good grapes. And he had real good wine.

Freeman: So did you all just use the native grapes? 
Carman: Yeah. Well, now we did. To make the jelly? They had a post oak grape, that we called it, but they weren't as prevalent as the mustang. The mustangs were everywhere and were real strong. Eat your mouth up if you ate 'em. But the post oak grapes, you could eat those. They were wild, but they were still edible. The first time that I found out about what the mustang would do to you, this was after the war and my husband, he brought me some grapes and he wanted me to make some grape juice, grape jelly. So I got in there and I got 'em all squeezed, you know, getting the juice out, and for a week, my hands was like this. They was swelled and I couldn't close my hands, I was so, I guess, allergic to them. That was the first time. I didn't do that again. I mashed them other ways.

Freeman: So, I don't think I've ever heard of a post oak grape. Are they, do they still exist, do they still grow down here?

Carman: There are very few of them. Out here on the place that Daddy had where he was when he died, there was one vine out there. But they were a bigger grape and they were more or less like the tame grape. They were all around. But they were good grapes. They were lighter colored than the mustang.

Freeman: Still a purple, or-

Carman: Uh-huh. Light, lighter. Made lighter jelly. They weren't as strong as the post oak. But it's been a long time since I've seen the post oak grape because they just, they just weren't as hardy a vine as the mustang.

Freeman: Uh-huh. Did your mother make your clothes? Or where did your clothes come from?

Carman: Yes, yes. She did our sewing. In fact, she sewed for other people too, my aunts. And she made quilts. Made beautiful quilts. That was mostly after she retired from helping with the farm. She did lots of quilts.

Freeman: Do you still have any of those?

Carman: Yes. We made her an album for her birthday one year. We got, went to everybody that had any of her quilts and took pictures of them and gave it to her for her birthday. And it just thrilled her to death.
Freeman: Did she have favorite patterns that she did?

Carman: Ah, she liked, she didn't like to piece quilts, although she did one that has the little hexagons about, the little flower garden, about so big. But she started on that when we lived at the old place when I was just five, before I started to school, and she worked on that over the years, and she finally finished it and she had it quilted for Bettye. I guess it must have been in about 1980. I think she finally had it quilted. So that, but that was an old quilt that she'd started years ago, and she finally had it quilted. But she liked the applique, the applique quilts. That's what she liked, that was her pet.

Freeman: And what was her setup in the house to do that?

Carman: To quilt? Well now, she put hers on chairs. She had a big, some long wood strips that they made with clamps on each corner. And she would put hers on four chairs. A lot of people hung 'em from the ceiling, but she never did. She put 'em on the chair, and then she'd set 'em up against the wall, you know, when she wasn't working on it.

Freeman: How did she find the time to do that?

Carman: Well, just at night or, you know, whenever she could.

Freeman: Were there ever any quilting parties?

Carman: Not with her. Unh-uh. But my greatgrandmother, Elizabeth Sowell Smith, was an avid quilter, they said. I didn't know her.

Freeman: Now that would have been her grandmother?

Carman: No, that would have been her mother-inlaw's mother, Mary Smith Blackwell. And she came from Tennessee. She was a Sowell. S-o-w-e-l-1. And she was an avid quilter and did beautiful work. I've seen some of her old quilts. Real tiny stitches. They said that she would go to these quilting parties. She would want to go so bad, so she would set the clock so the men would come in from the field early (laughs) to eat lunch. She would call 'em in so she could get off to her quilting party. When they came to her house to quilt, if somebody, if it was her quilt, if somebody didn't quilt just like she thought they should, after 
they left, she would pick it all out and do it over. She'd do it over like she wanted it done.

Freeman: Now you said she was a Sowell. There was a real early Sowell in Bastrop County, wasn't there, who was an Indian fighter?

Carman: Yes. I don't know if they're any relation or not. I really don't. Because that was long before these others that came. I really don't know.

Freeman: So they came in here what, in the $18-\mathrm{Did}$ they come after the Civil War?

Carman: No, they came before the Civil War because the Sowells, some of the Sowells were in the Civil War and they had a place out near Paige. Said he was so heartbroken when he got back. He didn't have anything. I mean, he was just getting started, and then he went to the Civil War. And they said he just, he never did recover from losing everything. So they were here before the Civil War.

Freeman: Interesting. Ah, what did she make your clothes out of? I mean, did you buy some of them, and then she made some?

Carman: No, I don't ever remember buying any when we were growing up. I don't ever remember buying any clothes, except socks. Now, we did buy socks and shoes. But Mama made clothes out of, like, feed sacks. I'm sure she bought, maybe bought fabric too, because at that time, Sears, you could buy material. And we were great fans of Sears, we could buy fabric real cheap. Say, ten, fifteen, twenty cents a yard. I do know she bought some from Sears.

Freeman: Did she have a sewing machine?

Carman: Yes, we had a, she had her grandmother's old Singer sewing machine, the pedal type. But she'd had that machine ever since, I guess, she married. Maybe Grandmammy - we called her Grandmammy - Grandmammy Smith gave it to her when she married, because she had it when we lived at the old place before we moved to the other place. And Mama had had surgery, and she couldn't, or wasn't supposed to use her feet to use the treadle. So I was big enough that I would, I was turning the wheel so she could sew. I do remember that.

Freeman: What kind of operation did she have?
Carman: She had a hysterectomy. And at that time, if you had any kind of surgery like that you, they'd put you to bed and you stayed there for weeks. And she wasn't supposed to do anything for I don't know how long. But anyway that was my job, was to do the treadle so she could sew.

Freeman: Where could she go to have an operation like that?

Carman: Here in Bastrop.

Freeman: And who were the doctors?

Carman: Dr. Bryson. John Gordon Bryson, I believe was his name.

Freeman: And did, did the doctor ever visit you out at your farm? Were you ever that sick?

Carman: I think I was the only one that he ever came out to see. And he came once when I had strep throat, and bad ears. He came out, but that's the only time I can remember. He may have, I don't know. I do remember that once. And he did come see Mama too because she had an abscess when she had her surgery, and he lanced her side. So he did come to the house.

Freeman: So did she just do the doctoring if you got an infection? Did she have any home remedies that she used?

Carman: I guess. I know we used sulfur and different things.

Freeman: Like what?

Carman: The itch. (laughs) We got itch at school one time.

Freeman: Now what is itch?

Carman: Well they called it seven-day itch. But it's something that gets under the skin. It's usually on your hands, and I remember I got it playing at school. The family that had it, we knew who had it. And anyway, Mama asked the teacher, she says, "Should we keep 'em at home and not let 'em come to school?" And she says, "No." She says, "They got it here." They didn't make us stay at home. But anyway, they did put that on our hands in the bath. And for risin's, boils, we had a lot of those when we were kids, and I don't know why. 
Freeman: I wonder why.

Carman: I don't know why. If it was maybe just the water, cleanliness. I don't know. But we was always getting 'em on our feet and all. What we called stone bruises. We went barefooted all the time, but they would take prickly pear and heat it and scrape, you know, get the stuff off.

Freeman: The spines.

Carman: Get the spines off. And scrape it and then bind that onto the boil, and that either softened it. They said it would draw out the poison so it would run. Or whether it would just soften the skin and it would automatically come out. I don’t know.

Freeman: Was it painful? Were the boils painful?

Carman: Oh yes. Yes. But they don't have those anymore I don't guess.

Freeman: So how much did you wear shoes?

Carman: Just to school, mostly. We went barefooted all the time.

Freeman: What kind, what were your shoes like?

Carman: I don't know. I really don't, I can't remember. But I do remember that I had a cousin that lived in Austin. Her mother was at work and her daddy was a brakeman on the railroad. And her mother worked for the state. So she was pretty well up, you know, could afford things, so we got her hand-me-downs. And she always had good shoes. And that was really a pleasure. And a coat, you know, a good coat. But really, I can't remember. I know summer, in summer I had shoes. It wasn't a sandal, it was a, what do you call it, a Mary Jane? And it was a shoe with a-

\section{Freeman: Strap.}

Carman: Strap across it. But as far as having a school shoe that we wore, I can't remember. You know, there's lots of things I can't, that don't register.

Freeman: Well, you're doing okay. (laughs) Ah, tell me about your father. What are your memories of him?

Carman: My daddy, Daddy never grew up.
Freeman: He sounded a little like a character.

Carman: Huh?

Freeman: He sounded a little like a character.

Carman: He was, he was. And he never did, I guess he was serious at times. But he always had time to play, to enjoy what was going on. He hunted a lot, his own pleasure, and he fished. Played with the grandkids. Yeah, he was a musician. Knew how to play the accordion.

Freeman: Did he play, I gather he played a number of different instruments.

Carman: He played the harmonica and accordion. Was the only thing. He could play a little bit on the piano, but not much. Not organ.

Freeman: So do you remember parties where he played? Would he entertain people?

Carman: In the community, he had a, people would have parties, and he would play. He didn't get any money, it was just something that he liked to do. And we would occasionally have a dance. They called them house dances, and it was mostly young people.

Freeman: Did you ever go to those? Were you old enough to go?

Carman: Oh, I was there. Yeah.

Freeman: And what kinds of things went on? What was a house dance like?

Carman: They would just dance, have the music and dance. I'm sure there were people there that drank, but I never did see 'em 'cause Daddy didn't drink and he didn't allow any drinking. But I'm sure there was outside. They'd come from McDade and around the - But anyway, he always liked music.

Freeman: Were there, I was curious about songs that y'all might have sung or particular songs that he might have played that were favorites.

Carman: Ah, I can't remember. "Over the Waves," something like that. "Missouri Waltz," that was one he played. I think, right off hand, I can't think. He did all the old, like the fiddle songs. It was all by ear. 
I mean, he didn't read music. And he had a button accordion. I think two rows or three rows on one side and the accompanying base on the other.

Freeman: Now, was that something that was typical in his family? Did he have parents or grandparents that were musical?

Carman: As far as I know, none of the others played. Now, Grandma had an organ in the house, but I don't know who played it, because I never did hear anybody play it except Daddy occasionally. But he's the only one that I know of that played. He played the accordion and the harmonica. And when George got big enough to have one, he got him a guitar and a relative gave George a fiddle.

Freeman: And he learned to play too.

Carman: Yes. And I played. He taught me.

Freeman: What do you play?

Carman: I play the guitar. Still do. I play. What he taught me, I still use. We go to the, we have three nursing homes that we go to.

Freeman: The Miller, and (unintelligible)

Carman: Oh, was she at the cemetery the other day?

Freeman: Uh-huh.

Carman: Okay. Foster Miller. Yeah, I remember her. She played up there last year. She had her guitar with her last year.

\section{Freeman: Did she?}

Carman: Uh-huh. But when I learned to play, my brother and me used to play all the time. He taught me to chord with him. He played the rhythm, I mean the melody, and I played the rhythm. He went to the Navy, and I got married, and what he taught me was, say, when I was about fourteen years old. I married when I was sixteen. So, I never played any more until I married Charles, which was forty-seven years since I hadn't played.

Freeman: And you were able to just pick it up again? Carman: Yeah. I learned, what I learned just stayed with me.
Freeman: Well, she had something like ten instruments and she played a whole range of things and makes tape recordings. And she said her whole family, except for two boys-

Carman: Foster Miller played, Foster played the fiddle, I remember that. He used to play, come to our house and play.

Freeman: So y'all would all play together?

Carman: Uh-huh. Yeah, he would bring his fiddle and play, he and George.

Freeman: So what else did you do for recreation or for games, or-

Carman: Ball, played ball, and swim in the creek or the tank. George had a horse, he rode the horse. We never did ride that one. It was a young horse, and we never rode it. I had pets, animals, you know like pigs, and daddy would let me claim a pig. You know, to play with. And I always picked the least one, and I would play with it and enjoy it till it come time to eat it, I guess. (laughs)

Freeman: Now, how do you make a pet out of a pig?

Carman: Oh, they make beautiful pets.

Freeman: Really?

Carman: Oh yes. They're sweet animals. You know, when you're with them all the time, they follow you around just like a dog. And I had doves, pet doves.

Freeman: Did you keep 'em in a coop?

Carman: Well, just, mostly in the house in a box. I'd keep 'em till they got grown. I'd get 'em in the spring and then I'd keep 'em till they got big enough to let go.

Freeman: You didn't eat them?

Carman: Oh no, no, no. And, let's see, we had a skunk. But we had a number of skunks.

Freeman: Pet skunks.

Carman: Pet skunks.

Freeman: Did you de- 
Carman: Oh yes, yes. (laughs) First thing. You did it before they learned how to spray when they were babies before they learned how to.

Freeman: Would your father do that, or your brother?

Carman: Yes, it was Daddy. He did the neutering, or whatever you call it. But they make cute pets too. The last one he had, he had it for quite a while. And when we moved-I guess it was the last time we moved, before he bought the place that he lived on when he died - he had this skunk, and he finally let it go. He just turned it loose and let it go. And it would come back every so often and come on the porch, and you could hear him thumping. (raps on the table) You know they thump. They thump. It's a greeting, I guess. But he got to where he didn't come any more. I don't know what happened.

Freeman: Where, did they just sort of wander around the place, or did you keep them somewhere?

Carman: They just kind of wandered around. Stayed with us, just like a dog, a cat. More or less like a cat, I guess.

Freeman: Were they good for keeping the rodents down?

Carman: I don't know. We just kept them for pets. I don't know if they did or not. But they were sweet pets. But we just had, we made our own entertainment, I guess. We didn't have movies to go to all the time, and we didn't have TV or radio or, we did a lot of - When we were small, like play house, like girls would play, play house. And all the boys would hunt, just country kids.

Freeman: So what kind of, tell me about the hunting that your father did.

Carman: Daddy was always a hunter since I can remember. Even before we moved to the old place. You know, when we lived with Grandma for a while. And he always hunted. He had friends, that they would go on weekends and stay all night. They called it the sand hills. It was close to Oak Hill was where it was. It'd go from McDade to say the Oak Hill area. And they called it the sand hills, and it was real thick brush. It was a sandy-type place. They would go. He called it wolf hunting, you know, hunt wolves. But I think they were coyotes. But he called them wolves. They looked like the coyotes today.

Freeman: Did he do it for the furs?

Carman: No, no. He just did it for the fun of hunting. They had hounds, and they would go out and listen to 'em tree and run or whatever they do, bark. They would catch them occasionally. I don't think they did it for the fur. I had pictures of Daddy. We had a pet one, one time.

Freeman: A pet coyote?

Carman: Uh-huh. Or wolf, he called 'em a wolf. But I think it was a coyote.

Freeman: Well, how did it do with his dogs, I wonder?

Carman: I don't know. He had a pet fox one time, and he kept it fenced.

Freeman: And what about his dogs? They sounded kind of interesting.

Carman: He had hounds. The first that I can remember was when he, he could hunt with when he was younger. And they were all hounds, wolf hounds, and he'd have greyhounds. He'd go through the thing. He always had dogs of some kind. He had greyhounds, and he'd hunt rabbits. And then he'd have beagles, and he belonged to the beagle club where they had, they'd all get together and have a beagle hunt. And he always, like I said, he always had dogs of some sort.

Freeman: Were there any favorites of yours?

Carman: Oh, not really. Because, they were just dogs. There were some, I'm sure, that I liked. The greyhounds were sweet. They were real, to me, were better-natured than hounds. And the beagles, they were sweet.

Freeman: I think your sister said something about how you all used to read. And she got magazines or newspapers in.

Carman: Mama, yeah, they subscribed to farm magazines like Farm and Ranch or Progressive Farmer, and the fellow would come around and sell subscriptions to the magazines, and he'd take eggs or 
chickens or whatever, whatever you had. Well, that subscription, like if he was getting probably paid for how many subscriptions he got. I don't know what he did with all the eggs and chickens. (laughs) But, anyway, it had recipes and patterns and dress patterns. Mama used to order the dress patterns through the Progressive Farmer.

Freeman: Do you think your dad ever got anything out of it in terms of farming techniques or-

Carman: I doubt it. Daddy did his thing. (laughs) He just did what he did as far as doing his watermelons. He raised beautiful watermelons. And he had a certain way of doing it, and it worked, and that's what he did. I don't know who showed him. Maybe his daddy. I really don't know.

Freeman: Was it relatively easy to make money off of watermelons?

Carman: Oh yes, that was a good crop.

Freeman: How did it compare with cotton, do you think?

Carman: Well, I don't know. It probably was easier for him than cotton. He was raising cotton. We only did cotton, I think, one year that I remember. We had corn and grain, peanuts, watermelons, and-

Freeman: Did you say you did grain?

Carman: Yeah, well, like maize and like feed.

Freeman: Sorghum?

Carman: Like chicken feed. No, we had raised milo, maize. You see fields of it up on the other side of Elgin. It's some kind of - They grind it, put it in feed. I can't remember him raising sugar cane, but I remember going to the mill where they made the syrup from the sugar cane. So somebody around there raised sugar cane, because they made syrup. But I don't ever remember us raising sugar cane. We may have.

Freeman: So you used it in the house.

Carman: Yes. Uh-huh. And honey. Daddy had bees.

Freeman: Ah now, see, I haven't heard of anybody else out there keeping hives.
Carman: Well, Daddy always had hives. If he didn't have hives, he hunted bee trees. And cut the tree down to get the honey. And sometimes he would find a great big old hollow tree that you'd get a tub-full of honey. You'd have to cut the tree down to get it. If he didn't have a hive, he would hunt the bee tree.

Freeman: Did you ever go with him when he did one of the bee trees?

Carman: Oh yeah.

Freeman: Tell me, how did he find it, and what would he do to get to them without being stung?

Carman: Ah, he would go to a, say, a tank of water. When they come to water - and he would watch them, you know, for maybe which direction they went, and he would find 'em that way. But he had, he just put on long sleeves, and he had a smoker, you know, the thing that made smoke, and usually the bees weren't that bad. I mean, if you had the smoker. But he had a hive of bees one time that, it was after World War II. Well, it was before he bought his last place. And he had some hives, and he and his brother-in-law were going to rob the hive. Well, evidently, it got a strain of bees in there that were, I would say it would be like the African bees. And both he and his brotherin-law got stung. Daddy ended going to the hospital. He thought he was going to die. His throat swelled up and they just, it really, really hurt him. So he burned that hive. I don't ever remember him having bees after that. But we always had bees. We had honey when we were at home.

Freeman: Now, was that something that he could sell, or did you just use it?

Carman: No, he didn't sell it.

Freeman: And then what about turkeys?

Carman: We raised turkeys.

Freeman: It seems like a lot of people had them.

Carman: Yes. That was a pretty good crop, paying crop. And that was my job after they got up big enough to leave the pen, the little ones got big enough to follow the old hen to the field to graze for the insects. That was my job, to follow 'em, to see where they went. Because if you wasn't there when it come 
nighttime, they would go up in a tree, and the next morning, they would just keep on going. They'd go further, they'd just kept getting further and further away from home. So you had to kind of stay with them so you'd know where they were, and then drive them back home at night.

Freeman: Well, how did you keep them from flying away?

Carman: Oh just-

Freeman: Did you clip 'em at all, or-

Carman: No, no, they were tame. But they were just crazy. (laughs) I don't think a turkey has much brain. But anyway, I would stay with them and keep at a certain distance from the house. It wasn't too far from our place. Sometime they would get over into the neighbor's pasture.

Freeman: But then how do you herd turkeys?

Carman: Just kinda keep the old hen going in a certain place. Just kinda walk around them and turn them around and get 'em going back the other direction. Usually they would, you could take care of 'em.

Freeman: Sounds like something that would require a lot of patience.

Carman: Yeah, a lot of sittin'. You'd sit and watch them while they were out eating, and then Daddy would come to check on them, he would know where they were. He would come during the day from the field. He would be not too far away, and he would come and check on me and see where they were. Nowadays people wouldn't send a little girl off half a mile or so from home to sit with a bunch of turkeys. (laughs) But that was one of my jobs.

Freeman: Did you have others?

Carman: Other jobs?

Freeman: Uh-huh.

Carman: Oh yeah, we had little, not hard jobs. Like I said, Daddy raised watermelons, and we turned watermelon vines so he could plow. Watermelon vines will just keep growing out to the side and you can't plow when they - So anyway we would turn them upside. Like this is the vine, and they would go out thisaway, well you'd take a stick and you'd turn it back to the row up. Well, it'd be up and down the row like this so he could plow beside 'em. So he would do that until they got up, oh, till he couldn't, the vines would be too thick to turn. He'd have to pick 'em up and turn 'em. So that was one of our jobs that we did was to turn the vines so he could plow.

Freeman: What else?

Carman: Oh, a lot of other jobs, like around the house. Like picking chips for starting fires, bringing in the wood, and things like that. I don't remember working hard. (laughs) Mama never did, she never did have us doing too much. She didn't teach us to cook, which we was always around it, but she never would let us get in and cook. She said she'd rather, she'd just rather do it herself. Well, evidently it rubbed off because both my sister and me can cook. (laughs)

Freeman: You just absorbed it.

Carman: I guess so.

Freeman: Ah, and I understand that your father had cocks.

Carman: Fighting chickens. He did that all my life. He always had chickens, fighting chickens. And that was one of his great loves that he did. And he raised them and he shipped them and he fought them.

Freeman: Where did he ship 'em?

Carman: To the Philippines and to Mexico and different places.

Freeman: I wonder how he made those connections.

Carman: I don't know. I know he subscribed to a magazine. I think it was in South Carolina. Gaffney? Gaffney, South Carolina, I believe was where it came from. And he subscribed to that book, and other people that had chickens. I guess. I don't know how he got their names, but anyway, he shipped all over.

Freeman: Interesting. Well, were there cock fights in the neighborhood on a regular basis?

Carman: Ah, not really. Because it wasn't, you weren't supposed to do it. He would go to east Texas. He had 
a friend that went to the fights, and Daddy would go with him, and they'd go to somewhere out in east Texas, almost to Louisiana, or close to. And he would go there and they would fight. And he did out here at the home place. In fact, that's what he was doing when he died. He died doing what he loved to do. He had a game rooster under his arm. I said, he couldn't go any better than that. Had a heart attack.

Freeman: I wonder, was that all okay with your mother, and I wonder what she thought of that.

Carman: Well, it nearly drove her crazy at times. (laughs) But, anyway, he had been doing it so long I guess it didn't matter.

Freeman: It was part of the package.

Carman: It was part of it. Yeah.

Freeman: Ah, I realize that you weren't very old when the Depression came.

Carman: I was born during the Depression. That's what wrong with me. (laughs) I was born in '28. I don't know when it, did it start about that time? Or the early thirties?

Freeman: Well, really early thirties, it kind of settled in.

Carman: I'm sure we was already in it before it got to.

Freeman: Did it seem as if there was, as if that was a really hard time, to you?

Carman: Like I said, we were probably already in the Depression, so it really didn't, probably didn't matter to us at all because we probably, if I know how it was, say - When I was growing up, people raised most of their stuff that they ate, and I don't know if they really knew. I think the Depression hurt people who worked for a living, say for public work, more than it hurt the people that might stay on farms because they did, they could raise their own. They gardened, they canned, and they had their own meat and stuff like that. But I don't know if it affected them that much or not. (??) didn't think it hurt their family because, just like us, they raised their own.

Freeman: Did you have a radio? Some of the time?
Carman: Yes, we had, we probably had it for a year or so before the war because we had a radio at that time because we heard it on the radio when Pearl Harbor was attacked, we heard it over that radio. But we had one for probably a couple of years before that. But that was a big thing for us.

Freeman: Tell me what you thought of it when it came into the house.

Carman: Well, we enjoyed it. It was something that, the music, the soap operas, and things like that. I don't know that we listened to the soap operas that much, but there was certain programs that Daddy liked, especially the news, the farm news and things like that we listened to every day. The news, I imagine, was the big thing. You had a certain time of day, you had the news, and then you had a program that maybe come on right after that, like a music show. But we didn't listen to it much. We didn't leave it on all the time, I'll say that.

Freeman: Was it more of a special thing during the day?

Carman: Oh yes, it had to be, because it used the battery, and a battery would only last so long. But the battery was just about this long and about this wide (measuring) and about that tall.

Freeman: The size of about half of a place mat.

Carman: The radio would sit on top of it.

Freeman: And how did you recharge it?

Carman: You didn't. You bought a new battery.

Freeman: Oh, that was expensive wasn't it?

Carman: Yeah. Well, if I remember right, the battery cost about six or seven dollars, I believe. Like I say, if I remember right. But you used it sparingly. Like Bettye said-and I don't remember, but she remembers things that I don't - that when it started getting low, Daddy would put it on the stove. The heat, he thought. Well I wouldn't think it would, but anyway, that's what she said. He'd set it on the stove and let it warm and it would strengthen the battery.

Freeman: And what did you do for lights? 
Carman: Kerosene. Was a lamp.

Freeman: Were there lamps in every room, or were they wall lights?

Carman: Yeah. No we had table lamps. Just a plain ol' lamp.

Freeman: And did you get electricity at the end, or was it too late for that?

Carman: Well that didn't happen until after World War II. Was when we got it. Now they had electricity in McDade, but there wasn't any rural electric at that time. It didn't happen until after World War II. Didn't have a washing machine, didn't have anything that took electricity. You had to do by hand. When we first got married after World War II, we didn't have electricity, but we had, we had a kerosene stove, cook stove, and a little wood heater. Things changed after we got electricity. Water was a big thing out in the country, too.

Freeman: How so?

Carman: If you didn't have a well you had a cistern or you had to haul water.

Freeman: Now was there a black community near you?

Carman: Yeah, the black community was, we were all in the same community. We had black neighbors.

Freeman: So it was pretty much mixed in together?

Carman: Oh yeah.

Freeman: Did anybody think anything of it?

Carman: No, they were just neighbors and they went to their church, they went to their school. They went, you know, to different things, and we went to ours. We didn't know any different.

Freeman: Now where was, did they have a church and a school?

Carman: They had a, let's see, where was their school? I don't really remember where their school was. I know where the churches were. But I don't remember where the schools were.
Freeman: And where were the churches relative to Oak Hill, for example?

Carman: Ah, from where we lived, there was a church about, I guess about a mile or less from where we lived, there was a black church.

Freeman: What direction, do you remember?

Carman: On the east. It was just a short distance from where we lived. They had a church. But as far as the school, I can not remember where the black school was, unless it was, if it was, they had one at Sayers off of [Highway] 95 going towards Elgin. But I don't remember where the kids went to school.

Freeman: And did you kids all play together, or were you kind of segregated that way?

Carman: I don't remember playing together. We would go by their house, and we may talk from the road or-But as far as sitting down and playing, the kids playing together, unh-uh. Our closest neighbor, our place joined, and his name was Green Taylor. I guess maybe that was his mother's name, Green. I don't know how he got that name. But anyway, he had oxens. He worked, he worked oxens, plowed his field with oxens. And that was the first and last that I ever saw anyone do that. He's the one that had the syrup mill that did the sugar cane for everybody. Had this big press that went around. Had to drive this horse around and around to squeeze sugar cane, and then he cooked it for 'em. He had the big vats and the fire, and he cooked it for 'em. Good people.

Freeman: I know something I wanted to ask from the thirties. Was there ever a home demonstration agent who came around?

Carman: Well, they had them in the neighborhood, but there wasn't one right in our neighborhood. But they had it in-This lady that I was telling you about that fussed about us stopping and picking her dewberries. There was a home demonstration agent in Oak Hill, and that was the nearest one that I ever knew of. Mama's aunt, Fay Pannell, Fay's mother belonged to that and I don't know who else.

Freeman: But your mother didn't participate in that?

Carman: Unh-uh. 
Freeman: What kinds of things did they do, I wonder?

Carman: Oh, they taught 'em to can different methods, I think. Different embroideries. Different handwork and stuff like that.

Freeman: Did your mother do canning?

Carman: Huh?

Freeman: Did your mother do canning?

Carman: Oh yes. Lots of it. She did the hot baths. Put it in a pot and boil it with its cover. But she never did have a canner. Like a pressure canner. I don't remember her having a pressure canner. She canned tomatoes and beans, never meat. She didn't can meat.

Freeman: That's what I was wondering about, if she did that.

Carman: Unh-uh. They had a, I don't know what year this was. I think it probably was before World War II. I think it was. They had a thing where they taught 'em to make mattresses. It was a federal thing, and they had a lady go to McDade to do that, and it was cotton mattresses. And they showed them how to make the ticks and how to put the cotton in. She went to that. I remember that. And also they had a cannery. Had the cans and the lids and you would buy the cans and the lids and you could go there and can whatever they was canning. I don't remember that, but I do know they, they sealed it in a can. I don't know if it was meat or what.

Freeman: So you didn't sleep on mattresses before that?

Carman: Oh yeah, we had mattresses, but these were, they would remake, I think they would remake mattresses, put new ticks on 'em. No we had cotton mattresses, (??) old wire springs. One mattress. Feather pillows, we had feather pillows.

Freeman: Were those from chickens or what?

Carman: Yeah, chickens. No we didn't have geese. Grandma Blackwell, I think, is the one that did the pillows for us, if I remember right.

Freeman: I had a feeling that there were some families out there that were just really, really poor.
They were large, very large families that were pretty much hand-to-mouth. Was that something you were familiar with?

Carman: Yes, there was people like that that didn't, either didn't try or didn't have the know-how, but there was families that [were] worse off than we were.

Freeman: How did they get along?

Carman: I don't know. Maybe, I really don't know. Maybe they, other families helped them. I just don't know, but I know that there was people that was worse off than we were.

Freeman: Did anybody in your family participate in the CCC or WPA?

Carman: Yes. Daddy worked on the roads for a while.

Freeman: Do you remember which road he worked on?

Carman: I think it was the one that went from Bastrop to McDade. It's not the same road it is now. It went in out here. You know where the vet clinic is out here? Just on the other side was the road that went to McDade. We went through that way. But I really don't know exactly which road he worked on. But he did work for them for a while.

Freeman: So you were fourteen when they started moving people out? Or how old were you?

Carman: Let's see. I was born in '28, and this was about '40. Let's see, Pearl Harbor was '41, and it was about '42. I don't know. I was about fourteen, I guess.

Freeman: Were you aware of what was going on?

Carman: Well, I knew there was a lot of turmoil. Right now, it just didn't, I don't guess it really registered on me what was really happening. I knew we had to move. But I'm sure it was really hard on Mama and Daddy. But it, I don't know, it just didn't, in my mind I can't remember. I know there was a lot of talk and a lot of turmoil. It was a big thing. I should remember more than I do, I guess, but I just don't.

Freeman: But you don't remember hearing them talk about it. 
Carman: Yes, just that we were going to have to move, and naturally Daddy was upset, and he wasn't agreeable with the people that was trying to make him move. And he wasn't going to move, but he did move, and then they only gave him, after it was all settled, they only gave him a certain, what, about thirty days to move? Or something like that? And it was hard to do because there wasn't that many vacant places around.

Freeman: Do you know how they found a place?

Carman: I don't know. Really don't. I do know where we moved to, Ray Hancock place. It was up there just right down from the cemetery where we was, that Oak Hill Cemetery. He had gone to the military service, Ray Hancock had gone to the service, and his house was vacant, so I guess that's how we got his house. And we stayed there for, I don't know, I can't remember how long, before we moved. Daddy worked at building Camp Swift for a while till he could get, kind of get things organized, I guess, and find a place where he could move and move the stock and farm or whatever he was going to do. I'm sure it was hard on them.

Freeman: How old would he have been when that happened?

Carman: Let's see, he was born in 1901, and this was 1941? He was forty years old. Wasn't he?

Freeman: Yeah.

Carman: But anyway, he was, he didn't like to do public work. He didn't enjoy working at Camp Swift. So he worked as long as he had to, so we could get things kind of organized. But he never did enjoy working with somebody telling him what to do. He'd always done everything, he never had had a boss, so it was kind of hard for him to work public work. He worked for this contractor, I guess as a carpenter helper. And when they were building, he said, one thing he remembered, he was doing the forms for the foundations, these contractors would have all their steel here for the inspectors to see, and just as soon as they was gone, they would move that to another site so they didn't - You was supposed to come up to specifications, but just as soon as the inspector was gone they would move it to another site. But some of the foundations must have been pretty good, because they're still out there now, if you've driven through there and seen the slabs where they poured them, still there. Evidently, they was done pretty good.

Freeman: Tell me again where they moved to.

Carman: The first time?

Freeman: No, after they were, they left the Hancock place and moved out to -

Carman: They moved out on the river. It was on the river road. It's west of town. People by the name of Lindener, I think they had it. But anyway, it was a better place. It had a better farm place. We lived there and George worked from there. He went to work at Camp Swift at the post exchange, and we rode the bus out there, and we rode to the Camp Swift entrance. That's where the bus, that's where we rode there, and the bus picked us up there and took us, brought us into school. We rode with the black family that was neighbors to us, and they worked in the Camp Swift in the laundry. So we rode that far with them and then caught the bus.

Freeman: So where was he living? Was that where he was living when he died?

Carman: Oh no. He was living out here. See after, after all this happened and he moved, he was able to buy part of the place back again, original place, part of Camp Swift. Korean War came and they took that place again. So it had a little house on it. It was an officer's quarters was what it was. So he was going to move it. So whoever was in charge of it come one day, and he already had it on the truck to move it, and the guy said, "You're not going to move it." Says, "It's not yours. You can't have it." The mover told him, he says, "He hired me to move this house." He says, "I'm moving it." And he just took off, and the man just stood there and didn't say anything. (laughs) So anyway, that's the house that they lived in when he died. The officer's quarters. It was a little, it had a bedroom and a living room and a kitchen and a little hall entryway. It was big enough for the freezer, and it had a bathroom. And that's what they, that's what they lived in after.

Freeman: And where was it from Bastrop?

Carman: Do you know where the lake is?

Freeman: Yeah. 
Carman: Okay, it's just about half a mile or less from the lake on the other side of the lake. And that's where, and I sold the property year before last, and they're building a new school. In fact, they've already got it built, a new school on it for kindergarten through third grade, I think.

Freeman: Now, what happened to your brother?

Carman: He retired from the, worked for Pepsi Cola, and he retired from that and he lived in Austin and he had Lou Gehrig's disease. He had two sons, which they inherited part of daddy's place and they built houses out there. But anyway, George died about, I say three or four years ago, but time gets away from me. I guess it's probably been maybe five years now.

Freeman: And you went in to Austin and worked for a while when you were younger?
Carman: No, I worked in town.

Freeman: But your husband was at Camp Swift?

Carman: He was from Kentucky, and he was one of the soldiers that was down here training, and we got acquainted. In fact, I went with my brother to the post exchange where he worked and got acquainted with him, and we married in 1944. He went to Germany and came back alive, thank goodness. He lived here. He died in 1990.

Interview with Leola Blackwell Carman Interviewed by Martha Doty Freeman

Date: June 2, 2004

Place: Home of Carman, Bastrop, Texas

Year of Birth: 1928 


\title{
O L Flowers InTERVIEW
}

\author{
By Thad Sitton
}

\section{April 2004}

Thad Sitton: This is Thad Sitton. Today is April 6, 2004. This is an interview with O L Flowers at his home three miles south of Elgin, Texas, on Highway 95. This interview is part of the Texas State UniversitySan Marcos, Camp Swift Oral History Project, sponsored by the Texas National Guard and conducted in conjunction with the Center for American History, The University of Texas at Austin.

Sitton: Tell me about the place where you grew up. Where did you, where did you, grow up?

O L Flowers: It was down here close to the old Sayers mine, coal mine. That was about four miles north of Sayersville but about three miles south of McDade on the old Dennison farm. When we moved there, I was five years old. And I went to school over at Sayers, little one-room school house over there at Sayers, about four miles from where I lived. You had to walk to school. The first time I went to school, my daddy put me on a horse, and I was just big enough to ride a horse going to school. And we farmed that place until I was twenty years old, and I left from there and decided I wanted a better life, and I went to San Antonio and stayed a while and come back and went to work for Camp Swift.

Sitton: So, you left, you left the country before Camp Swift got here, right?

Flowers: Right, right, right. But then they come in and started work here, well then I come back. And we moved out of Camp Swift, moved up here to McDade and stayed there on a better place than the other one. Then the house that we was living in down on Camp Swift, guy gave it to us, said we could have it, and we tore it down and moved it to the other one and we built a house on the other one. So we owned three acres up there in Elgin after Camp Swift come in. We moved up there. And so-

Sitton: What was on the Dennison place? Describe the Dennison place. Y'all were renting?

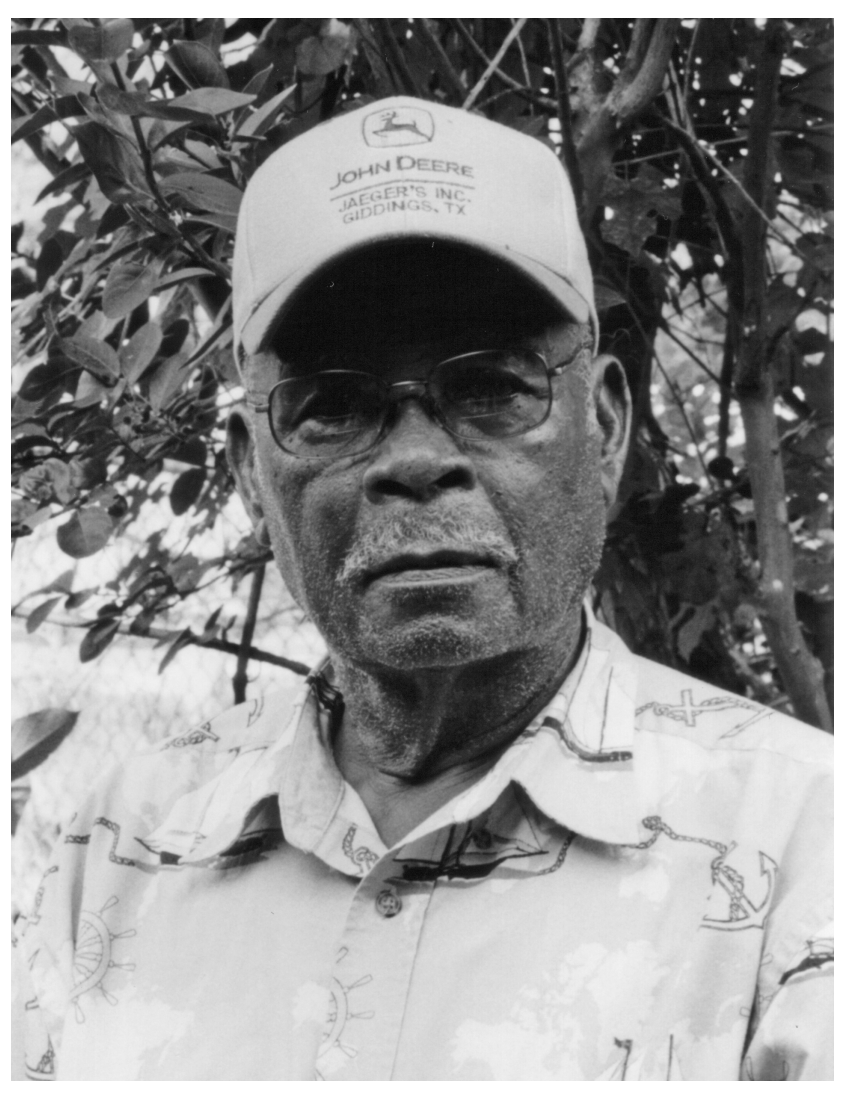

O L Flowers

Flowers: Yeah, we were renting thirds and fourths. That farm was right next to the coal mine there, and we went from that, from the farm, to the coal mine, and we'd go over there and watch the guys go down in the coal mine and dig coal and come out. Spanish people ran the coal mine, they's the ones done most of the work.

Sitton: It was Dennison's coal mine, wasn't it? Mr. Dennison was the owner.

Flowers: Yeah, uh-huh. Frank Dennison. There was two brothers of them, was Frank and Jimmy.

Sitton: Well, they're very few people that have any kind of eye witness knowledge of that coal mine, and we're very interested in it. Can you recall anything about that coal mine, anything about that operation? 
Flowers: Uh, yeah. We kids we used to go over and go down in the coal mine. They had an elevator, had the mules down in there, and the coal shaft, what they hauled coal on, we'd go down in there and watch them pick that coal out of the ground and load it on them cars. Had a track down in there. That mule would pull them cars up to a certain point of that track and unhook them, and that track would roll on down to where they'd dump that coal. And another elevator would bring it up to the top, and they'd dump it in the boxcars outside.

Sitton: So y'all actually went down there and got to see them do it? You may be the only person that remembers that.

Flowers: Yeah, we used to go over there and watch them, we were little kids. After we growed up the coal mine finally disappeared because coal got to where they couldn't sell it, and the coal mine closed down. They had a big store there and we'd go over there to store and then watch them guys around there, then go to the coal mine and watch them go off in there, and sometime they'd let us go on in there, but they'd have a grown-up person with us, an individual to watch us, 'cause like kids we might get to playing. But I did actually go off in there and watch them dig coal.

Sitton: How many of them would be working down in there? Like, I don't have a good idea about how big it was. I know it wasn't a huge operation, but — did they have fifteen or twenty?

Flowers: Yeah, uh-huh. The coal was in tunnels. Some of them were working like over here and some were working over here, they worked certain areas certain days, 'cause they didn't want to stay in one place too long, because they'd work and then brace it up behind them, where they could work on farther.

Sitton: Were they picking it out?

Flowers: Yeah, picking it out, uh-huh. Yeah, picking it out, and some of it would get so tight they couldn't pick it out and they had to chisel it out to work their way through.

Sitton: What about the commissary, what did it look like? The store?
Flowers: Well, it was just a-you might describe it as a - you might seen kind of old stores like you see out in the open country, you know, just one big old store and offset roof on it, and one porch. Walk up the stairs and go in the store. Big old store, something like that, it wasn't nothing fancy. Everything was in cages, if you wanted something you'd tell the fellow what you wanted, and he'd have to go get it and put it in a paper bag. Like that, and everything that come in the store then come in bulk. Had a barrel over here and a barrel over here, different stuff was in it.

Sitton: Did any of those Mexicans speak English?

Flowers: Some of them, yeah, some of them speak pretty good English. But on the average most of them didn't. See, there was another coal mine down there closer to Bastrop. It was actually two coal mines there called the Glennon [Glenham] Mine, that was the one down closer to Bastrop, and this one was the Dennison Mine up there close to Sayers.

Sitton: And the Dennison Mine is the one on what's now Swift.

Flowers: Right. Well, actually both of them, 'cause - naw - the Glennon Mine's not, because it was 'cross the tracks. You been to Bastrop lately? You know where the old switch track used to cross the road coming in to Camp Swift?

Sitton: Yeah, I think I do.

Flowers: Well, that mine was right back across behind there, over 'cross the other track there. That's where the other store was down there.

Sitton: But it was the same sort of mine.

Flowers: Right, right.

Sitton: Kind of a slope going down — the carts — mules would pull the carts?

Flowers: Yeah, uh-huh, and then when they get ready to bring them out they put them on the elevator and ride them on up, ride the elevator on up to the top. Used to ride the elevator (??)

Sitton: It seems like there was one superintendent who was killed by a mule, kicked by a mule, there. 
Flowers: Might of been, I don’t know.

Sitton: Fay Pannell's father was the last superintendent there in 1926-1928.

Flowers: At that old mine near where we stayed at. Right?

Sitton: Well, what was Dennison like, do you have a sense - What was Mr. Dennison like?

Flowers: Well, he was a nice fellow, he was kind of a coal miner and a farmer. He had a farm up at Little River, and he run back and forth between here and up to Little River, and run his coal mine. There was one while he tried to get us to move up to Little River on a farm up there. Well, we almost went, and Mama backed out, she said, "No, I ain't going up there."

Sitton: That's up on the black land, right?

Flowers: Right, um-hm, yeah, just this side of Temple, Little River and Academy right there together.

Sitton: What did y'all raise when you were on the Dennison place?

Flowers: Mostly cotton and corn, and a few peanuts. And we raised molasses cane, that was mostly for our own use. Yeah, we'd strip it and take it to the mill over there and have them make molasses out of it. But mostly raised cotton and corn.

Sitton: Well, you know, I try to get people to talk about - There's a sort of living-on-the-place side of the farm, and there's the money crop side of the farm. What did y'all raise for your own use?

Flowers: Well, Mama had a garden. Everything she planted in the garden we eat or some of it we canned up. And we raised sweet potatoes for our own use, and then in the fall of the year, after we gathered the corn, well then we wouldn't have to buy no corn for cornbread, because we had our corn. We'd shell it and take it to the mill and have it ground, make our own cornmeal. We mostly eat what we raised on the farm. We didn't sell everything, mostly what we sold was cotton. Kept corn for cows and mules, and give the other portion back to the landlord.

Sitton: Uh-huh, thirds and fourths.
Flowers: Yeah.

Sitton: Well that means, if y'all were on thirds and fourths, you had your own work stock and your own gear.

Flowers: Right, right, we had our own equipment there.

Sitton: How'd you do the sweet potatoes? Probably not in the garden itself — did you have a separate-

Flowers: Had a separate place, had half an acre, two acres of sweet potatoes. That'd be off in a separate field.

Sitton: Talk about that a little, because people don't - I've had a few people tell me about how sweet potatoes were raised, but I don't think most people know.

Flowers: Well, you start off with what you call the slip. You take a small potato, you make you up a bed, and you put them potatoes in there, and you cover them up. And then in a couple of months they start to sprouting up. The sprouts comes out of the potato and makes what we call a slip. And you pull that slip off the bed, then you take it to the field and you set them out just like, well - Sometime we take a hand and push them in the ground, sometime we take a stick to push them in the ground, put a little dirt around them. And then they can be grown from that, then they make sweet potatoes from that.

Sitton: Would you hill up around them as they grow?

Flowers: We'd keep dirt piling on them. We'd take mules, and we had a plow kind of set to where it would throw dirt up against there. And when we put them out, we wouldn't put them in too high a bed, because you couldn't get no dirt up to them. And after that sweet potato grows, it makes a long vine. And then (unintelligible, gas stove repairman converses with Mrs. Flowers in background) we had one mule and what we called a slide, and it had knives on the top of it. Like on the side there? Slide down through there and cut them vines, then they'd be away from the row. Then we'd get back up in there and get a mule, two mules, to plow, and you go down through there and they throw them potatoes out to the top of the ground. Then we'd come along 
behind them with a basket put them in a wagon and take them to the house.

Sitton: Well, that sounds like the easy way. The hard way — Now, that's how to deal with them if you've got two acres.

Flowers: Yeah, yeah. If you got more than that you got to get something or another to help pick them up. This guy over here on the Old McDade Road, he's a regular potato man, he's really fixed up for them. Nobody never gets on the ground. He had about seven or eight men riding a trailer, and them potatoes comes up, then they sitting there picking them out, the good ones and the bad ones, putting them in different baskets. But we had to get them by hand, stooping over going down that row, getting them out.

Sitton: But still, you did as much with the mule as you could. I mean, the little sweep plow would throw the dirt up to the hill, so the hills - You wanted them to grow up on top.

Flowers: Yeah, you wouldn't want them to be too deep in the ground, because if they went deep enough in the ground, well they get weevils in them, and you cut up too many of them trying to plough them up.

Sitton: Well, this thing that would cut the vines, what did you call it?

Flowers: We called it a slide.

Sitton: And it would be sliding right down the side of the mound cutting off all the vines.

Flowers: Yeah. And we'd get just like this in the row (hands demonstrating inverted V-shape), that we could straddle that, and then that [the vines] come away from the row. Then we'd put them on a wagon and take them to the house and pile them up, get some corn stalks and set them up like that [hands making teepee shape]. And then kind of plat them around that stob, and then your dirt, fill all that up with dirt, and that's where we keep them in that during the winter. And have a little trap door there where we could go in there, stick our hands in there, and get sweet potatoes out during the winter to eat them. That's the way we'd kiln them up for the winter.

Sitton: Well, you were making more sweet potatoes than you could use yourself.
Flowers: Sometimes, yeah.

Sitton: But you wanted to make sure that you had-

Flowers: Had enough for yourself.

Sitton: The cotton might, might go down the drain, but if you had enough sweet potatoes -

Flowers: Yeah, between the sweet potatoes and what Mama raised in the garden and canned up, we could make the winter.

Sitton: What did she-Talk about her garden, what did she do with her garden?

Flowers: What she did with her garden is canned up most that we didn't eat up in spring and fall. Everything that look like was going to waste, she'd take it and can it up and put it in a jar and set it up for the winter. During the winter we never did buy so much because we raised everything. Had our own hogs to kill, had our own meat. After we'd kill a hog, we'd cut all the fat off of him, boil it out, and have our own lard and everything. Had a big smokehouse there, we'd cut them hogs - kill them hogs and lay them on a board, and Daddy would salt them down real good and let them lay there for three or four days, and they'd hang them up in the smokehouse and we'd put smoke on them. Smoked them, that dried all the moisture out of them. And that meat be dry, you's ready to go, then. Go out to the smokehouse and get something and take it to the skillet. You could smell that meat cooking, but the meat you can buy now, you can't smell it.

Sitton: I was going to ask how many hogs you killed every year, but - How many brothers and sisters did you have?

Flowers: I just had one brother, there were only four of us in the family.

Sitton: What were your father's and mother's names?

Flowers: My father was named Shirley, and my mother was named Pallie, P-a-1-1-i-e. My first name is O L, that's it. (laughs) And my brother's name was $\mathrm{S}$ T. We've had little run-ins about changing the names, but Mama said no, wasn't going to change. Back in them days when they were giving away rations, you know, back sometimes when your crops didn't raise, 
well they had a setup in McDade that you come there and get some lard and some sugar, something like that. And told Mama if she didn't change our names, give us a name, she wasn't going to get nothing. She said, "Well, I just won't get nothing. I ain't going to change." But they went on and give it to her.

Sitton: So, it's not "Oliver Lawrence," it's just O L, and do you put little periods by the $\mathrm{O}$ and $\mathrm{L}$ ?

Flowers: Sometimes I do, and sometimes I'm just plain O L. Yeah. Some of them say, well, you ain't got no name. I say, "You can call it whatever you want. That's the way it is, and that's the way it's going to stay." You start changing names this far down the road you going to run into some trouble.

Sitton: Well, so just you and your brother. How many hogs did you kill every year?

Flowers: Well, sometimes just depended on what size they was-from two to three. (phone rings, taping interrupted)

Sitton: We, uh, what about corn? You had to have corn for the work stock and you ate corn. Corn was the crop that you absolutely ran on, right? (Mrs. Flowers talking on telephone)

Flowers: Right, right, 'cause we had to have corn to feed the horses while we worked them, and then you used some corn to make us some cornbread. (taping interrupted)

Sitton: The thing about - This was sandy land farming we're talking about, and the things about sandy land farming, if you get enough rain it will make cotton, it will make anything, but-

Flowers: Yeah, yeah, right, but you had to have the rain. The way we used to do, we'd plant ours, ours come in early, and so we'd maybe get a bale or maybe two bales of cotton. And Papa would get out there, and we would gather all our stuff, and he and my other brother, S T, they would go out in the black land and pick cotton until school got ready to start, and then they'd come in. And me and Mama would stay at home and take care of the livestock.

Sitton: So, you'd try to get your cotton. The sandy land, does it make the cotton a little faster?
Flowers: Well, they mostly planted earlier. The sandy land didn't make as good a cotton as it did out in the black land, but it made pretty good cotton, back in them days. There was about a hundred acres there [on the Dennison place], and we were working about twentyfive acres of it. Most of it in woods and pasture.

Sitton: How much do you think you'd have in cotton?

Flowers: Well, some years we might have eight to ten acres, sometimes fifteen acres. It just depends on how much corn we had left over from last year to try to plant enough to know we'd have enough for the next year. Save some spots for sweet potatoes, some for molasses cane, and some for other feeds that we grow, like hygear and maize. We didn't do like the farmers do now, sell our maize, we fed it to the hogs and chickens.

Sitton: So, y'all were-Really, this sounds almost like a landowner, the kind of stuff that y'all raised. Y'all were diversified.

Flowers: Yeah, we usually did just about like we wanted to on there, just so we give him a share of the cotton and corn.

Sitton: You know, some of those landowners would want the renters to grow mostly cotton and corn, and would not like all this sweet potatoes.

Flowers: Yeah, yeah, but this guy, he just let us work it like we want. Just so he got something off the farm, he wasn't particular about making a lot of money off of it.

Sitton: And he didn't try to tell you how to do it.

Flowers: No, no. We kind of half way figured out about what he wanted, you know, to keep him satisfied, and so that's the way we did.

Sitton: Well, what do you remember about the cotton? You didn't go out there on the black land and pick like your brother, but you got plenty experience with cotton-

Flowers: Right at home, yeah. And then sometimes me and Mama'd go out there on weekends, something or another, maybe Thursday or Friday, and kind of pick around a little bit with them. (phone rings, taping interrupted) 
Sitton: What did you feel about picking cotton?

Flowers: I never did like it. I hated it! And I swore if I ever got grown I wasn't going to pick no cotton. (laughs) One thing, I couldn't pick. My back has never been no good, I couldn't stand a lot of stooping over. Never have, ever since I was a kid. Hadn't never been hurt, but just never was no good. But Mama, she loved to pick cotton, and she could pick cotton. She could pick more cotton than Papa could. She bent over, she never crawled.

Sitton: Some people crawl and some people bent over and-

Flowers: Yeah, I could get down on my knees and crawl all day and still couldn't pick no cotton. I just couldn't, I tried just as hard as anybody, but I never could pick none.

Sitton: So that's one reason you preferred to stay-

Flowers: To stay at home, yeah.

Sitton: Well, I've heard that, I've heard people. I think the back was the biggest thing. It hurt some people's back, and some people it didn't.

Flowers: Some people it didn't, yeah, but I just couldn't move my hands fast enough to get enough to do no good. I could be picking right along singing on the next row aside another guy, we get to the end and get to the scale, he'd have fifty or sixty pounds more than I did, and we's going right along together.

Sitton: There was one man's interview that I read, I didn't talk to him but read the interview, and he was a bad picker, and his older sister, who was much older, occasionally got so exasperated that she'd tear up a cotton plant and whip him with it, but this didn't do any good.

Flowers: (laughs) That's the way my wife used to do her brother when they's out there picking cotton when they were kids. I used to go out there all the time. Where they lived there, they didn't do much farming there. Yeah, that's the way a lot of them old timers did, they wouldn't go hunt a switch, they'd just get them a cotton stalk right there and kind of strip it down a little bit. (laughs) Yessir.

Sitton: But there's a lot of people that decided out there in the field that whatever they were going to do, it wasn't going to be-As soon as they could escape-
Flowers: Having to do that they would, right, and I don't blame them. Now, I liked living in the country, and I don't like living in town. And when I come out of the army, I started to buy in town, but I said, no, I don't like town, and I bought this place here. Bought this place in ' 49 .

Sitton: Well, this is pretty. I like this stretch down to Fay [Pannell], I don't know where it changes. Would they have had a name for that community? If somebody came by and asked your parents where they lived, would they say Sayers?

Flowers: Yeah, they'd have said on the Old Sayers Road between Sayers and McDade. There were a couple of farms there lot of them knowed, we were close to the Scott farm, and they would identify from that Scott farm, on the Dennison farm.

Sitton: What was on the Scott farm?

Flowers: He mostly raised watermelons. That was Abner Scott's grandpa. Part of his property was across the road from us, but his house was just up the road about half a mile from us.

Sitton: Well, sweet potatoes were a good sandy land crop and so were watermelons. Talk about the molasses, tell me about how y'all did that.

Flowers: Well, we planted them just like you was going to plant cane for feed, but the stalks was different from the feed stalks that we fed to animals. They'd grow to about six or eight foot, maybe sometimes ten foot, tall. Then we'd get in there with what you call a cane knife and strip it, strip all the leaves off it. Then, we'd go back and cut it down and load it on a wagon and take it to a mill. Lay it down up aside the mill, and they had a mule, going around and around, pulling the molasses mill, and they'd lay the cane in there, then they had a deal that come along and squeezed the juice out of it, and they'd catch that juice in a bucket. And then after they got so much they'd put it in a pot and cook it, and that's when they'd make the molasses.

Sitton: Did you watch them doing that?

Flowers: Yeah.

Sitton: How did they - Were they using one of those big old pans? 
Flowers: Big old pans, right. Some of them had a big old aluminum pan, and they had a big old metal kettle, and they poured it in there. And they'd cook it so long, they'd stir it and watch it, and every once in a while they'd hold it up and let it run and look at the color of it, and in a certain length of time you could cook it and make different colors. And sometimes they let it cook too much, and then when they put it in barrels to cure it for the winter, a lot of it would turn to sugar.

Sitton: But they were using a big pot? I know what those big - Fay Pannell has a couple of great big iron pots, that I think were syrup pots, by her front door. But what I'm most familiar with is the kind of big old compartmented pan where they put the juice at one end and it works its way through, but you're talking about-

Flowers: Right, some of them had a, when the pan gets so full they had a faucet on the end. They never had to pick it up and carry it, they just put a smaller bucket under there to catch it.

Sitton: But you're telling me about something a little different than the one big pan.

Flowers: Yeah, uh-huh. There's some of them do it different ways, some of them was a little more fancy than the others. The one I was looking it was kind of the old timey.

Sitton: Yeah, that's what's so interesting. So, they carried it in buckets and put it in-

Flowers: In the pot that they going to cook it in - big pot, what they going to cook it in.

Sitton: So, they cooked it in the pot for awhile, and tested it, and then-

Flowers: Then they take it out. Some of them had wooden barrels that they brought over there for the guy that when he'd make it to put it in. And some of them would put it in jugs or even cans, and they'd take it home, and then they'd put it in the barrels, because they didn't want to move them barrels after they got it in there. They'd take it home and set it up, and in the bottom of that barrel they had a faucet on it, and whenever you want syrup out of there to eat, you just go there and turn that faucet on and get the amount you wanted out of there.
Sitton: That's the old way, and you're the first person I've ever talked to that's seen them doing it the old way. And what you're saying, if I understand you right, is that the cook did most of the cooking right in the pot. He cooked it in the big pot until in his judgment it was ready to put in the barrel. He didn't, like, have a second pot and move it, he didn't try anything like that. He just cooked it in the pot-

Flowers: Yeah, and tested it, 'cause each one of them that bring cane there it was always kept separate so he could ask each individual, "Well, what do you think about this? Think it's about right, about like you want it?" Said, "Naw, I believe it ought to be a little bit more," well, he'd cook it a little bit longer.

Sitton: It was custom syrup.

Flowers: Right.

Sitton: And was not putting it up on those one-gallon tin cans.

Flowers: No, no. Put it in one container, maybe two containers, then when you take it home you could put it up like you want it.

Sitton: Where was this, the syrup maker?

Flowers: Well, now - let me think-it was right across those woods over there, that's where he would finally wind up.

Sitton: Tell me again who he was.

Flowers: His name was Edward Clark. Everybody called him "Tobe" Clark, but his name was Edward Clark, and he was the old syrup maker. We'd cut it down and take it over to his place, and sometimes the sand was so bad we had to hook four mules to a wagon to get it over there. He made good syrup. He had a brother named Charlie, and he made syrup too. He lived right across over here. Back in them days everybody lived - You know, hook up a wagon and go to this one's house and go to that one's house.

Sitton: He was related to your wife?

Flowers: Yeah, that was my wife's daddy's, uh-

Sitton: Well, people in those days knew who could make syrup good- 
Flowers: Yeah, and they knew who can't, too! (laughs) Yeah, and in the fall of the year, after we get through chopping cotton, waiting for cotton picking to come in, what we would do then, two or three wagons would get together, and we'd follow these creeks and go fishing. And everything we caught in the morning, when twelve o'clock or one o'clock comes, well we'd cook and eat what we had caught. Then after then, what we caught the rest of the day, then we'd take it home.

Sitton: I see.

Flowers: We'd go from one end, hit the creek almost up there close to McDade, and we'd come out down here at Sayers. Where this creek crosses the road down here, you'd come out down there.

Sitton: Well, what creek would you be going down?

Flowers: Down Sandy Creek, Big Sandy, and then before you get to Big Sandy would be what they call McLaughlin. It runs into Big Sandy. Bunch of us get together, and we'd just travel the creeks, go swimming, fishing, hunting.

Sitton: Just in a light wagon or something?

Flowers: Right, uh-huh.

Sitton: How were you fishing?

Flowers: We'd use fishing poles, and sometimes we'd just get in the water and what we call "muddy it up." Get it real muddy, then the fish in there, well, he comes to the top, and we catch them like that.

Sitton: Would you call that "muddying?"

Flowers: Yeah, yeah.

Sitton: I've heard of that. They're not many people who know about that.

Flowers: Yeah, and my grandpa, Mama's stepgrandpa, what he would do if he knowed a bunch was going to fishing, he'd go to a walnut tree and get him a whole bunch of walnuts, put them in a sack, and beat them all up, and then take them along with us, and if it was a hole he thought was fish in it, he'd throw them in there. And then them fish would come to the top when they'd get drunk off that walnut juice.
Sitton: Green walnuts.

Flowers: Green walnuts, rights.

Sitton: Yeah, that's the sort of thing that works in a creek, you need kind of a small, deep.

Flowers: Yeah, right, just kind of a hole cut off to itself like, not no running water.

Sitton: Did you ever get in there and feel for them?

Flowers: Some of them did but I didn't. I didn't like that because you gets feeling around in there, there might be a snake back up in that hole there. I've seen some of them do it, but I didn't want to do that. Them old catfish, certain time of day they get back up in them dark places where it's cool, and they'd lay there.

Sitton: Well, this would be the family or a bunch of boys?

Flowers: It'd be families, different families.

Sitton: Just work your way upstream, right? And just cane pole fishing mostly.

Flowers: Yeah, um-hm, and muddying, and sometimes we's hunting with that rifle, shooting rabbits, squirrels.

Sitton: So, hunting at the same time.

Flowers: Yeah, um-hm. Maybe about twice a year we'd do that.

Sitton: How many miles would you go?

Flowers: I guess if you average it out maybe four or five miles.

Sitton: The creek is not all fishy, they're little deep holes where the fish are concentrated, so naturally you need to move up the creek, you can't just camp all day at one little hole.

Flowers: Not, we'd just follow the creek on down. Stay at one place, then we'd have to go back, back where we come in. But if we hit up here, we want to come out down here.

Sitton: How would you muddy it? 
Flowers: Just get barefooted and get in there and start kicking it around, and maybe take a pole or something another and kind of stir it around

Sitton: So, after a while, the fish start (clutching throat) "Agggggh!"

Flowers: Yeah, start coming up.

Sitton: Catch them in a net?

Flowers: Sometimes, yeah. But sometimes we'd just see them out there, and we'd just reach and grab them.

Sitton: Just be out there in the water when they came up.

Flowers: Right. Water never would be too deep, maybe about knee deep or a little better.

Sitton: How did y'all hunt? I understand what you're talking about there, you're going along the creek, rabbits show up in the daytime, rabbits or squirrels, using the .22 .

Flowers: Yeah, we'd just take it along with us, and one jump up there we'd see one. At that time we'd just mostly stay with the creek, didn't hardly go out in the woods or nothing. But whenever we went out in the woods hunting, we just take a .22 and a dog and go out there.

Sitton: Uh, coons and opossums, hunt them?

Flowers: Yeah, we used to hunt them at night.

Sitton: How would you do that?

Flowers: Well, if you had a dog that would really tree a opossum, you take a light and shine up there, and you can see his eyes up there, and you tree him and take a gun and shoot him, a .22 and shoot him. Or you could go up there and shake him out and let the dogs kill him. But a coon, he's - we never did — when we was coming up, we never did fool with no coons, hardly. We really didn't have no coon dogs. That coon dog, he get out there, he's liable to run a coon all night.

Sitton: A coon will run, a dog has to be able to run to make a coon-

Flowers: Yeah, uh-huh.
Sitton: Any deer around here in those days?

Flowers: No, wasn't no deer around here in them days. Naw, if you seen a deer back in them days, you'd be surprised.

Sitton: Well, you said that different people took their sorghum cane to him. Did some people grow ribbon cane around here too? Well, there's all different kinds.

Flowers: There's all different kinds, yeah. Mostly what they really made molasses out of was ribbon cane. But some of them had a different type, some of them might grow a little bigger, some of them a little smaller, but it all wind up about the same thing.

Sitton: What about field peas or peanuts, did y'all grow those?

Flowers: Yes, mostly for our own use. There's lot of peanut farmers around here, but was little farmers. Couldn't get nobody to come thrash them, because there wasn't but maybe an acre of two, and we just growed a few to eat and feed the hogs. But there was some pretty good peanut farmers around.

Sitton: Well, those blackland farmers-It's like on the sandy lands, sandy lands are good for some things that can help you live on the place - field peas like the sandy land and the potatoes.

Flowers: Right. Now the black land, they'd grow some pretty good gardens out there on the blackland, but on the average that's about all it was good for, just for corn and cotton and feed stuff. But they did raise pretty good gardens out there.

Sitton: Like, you can ride around out there now, and you see corn, cotton, or sorghum, and that's all.

Flowers: Yeah, that's all, but see down through this country, say from Elgin back this way, you can see a lot of peanuts, sweet potatoes, they grow a lot of it back in this way. But we didn't, we was small farmers, we go round help the other farmers.

Sitton: You said y'all usually made maybe two, three bales a year? That would be an average?

Flowers: Yeah, right.

Sitton: Well, if you got the rain- 
Flowers: Yeah, it could make pretty good cotton.

Sitton: If it hadn't been just totally worn out. Did y'all fertilize?

Flowers: No, we never fertilized. Only thing we fertilized was watermelon, and then we'd use barnyard fertilizer. We'd go to the lot where we keep the cows in at night. We'd take a shovel out there and pick up all the manure and pile it up in a pile. And then when we'd get ready for watermelons, we'd lay the rows off and checks them and put that fertilize right there in them rows. That was the only fertilizer we used. Hardly anybody used no sack fertilizer or liquid fertilizer back in them days. But the land was in good shape and it'd grow just about anything you put down there, but after so long you had to start using fertilizer in order for it to make something.

Sitton: What would you do with the watermelons? I know you ate some.

Flowers: We'd sell them. Sometimes we'd make a pretty good crop of them and we'd sell them, have a truck coming in to pick them up. Or, we had a little old truck, we'd load them on it and take them out to the highway somewhere and set there, and people'd come by and buy them. Or take them to town and just drive from house to house and sell them like that. They said back in them days was hard, but I think it was the good old days according to the way it is now, because we didn't know no different. We got by, we never did go hungry, we always had clothes to wear, so I think it was all right.

Sitton: Well, there were some good things. It was kind of satisfying to raise to much of your own stuff and to live off - that's basically satisfying. What did your mother, what would she grow in her garden?

Flowers: She'd grow just about anything that's eatable - in the vegetable line. Carrots, beets, spinach, cabbage, beans, just about anything in the vegetable line. Squash, cucumbers. She'd can up so much this year that maybe next year she wouldn't have to can quite so much because we didn't eat it all during the winter. She had a lot of it left, and then a lot of it she'd give to different people in order to get hers down to where she could can up some more.

Sitton: You know, you said about the corn that if you'd had a big crop last year, you wouldn't have to grow so much this year, and so could grow more cotton.
Flowers: Yeah, that's right, and then we canned a lot of corn too. Canned a lot of corn. We'd catch it in roasting ears, and we'd get us a sack and go out there in that field and pull it off and bring it to the house, and Mama would can it. You'd slip the shucks off of it, then take a knife and just strip it off the cob. Take two cuttings, cut about halfway and then go back and cut the rest of it. That way it wouldn't be too big grains.

Sitton: So it wasn't the whole grain, about half a grain.

Flowers: About half a grain, yeah, 'cause you cut it in two cuts.

Sitton: I've helped somebody do that, and it flies all over.

Flowers: Aw, yeah, if you don't watch it, it'll (??) the world over.

Sitton: What about chickens? Did you have chickens, did you have turkeys? All that stuff ran on corn, too.

Flowers: Right, um-hm, yeah, we had chickens, ducks, turkeys. Turkeys, we'd sell them in the fall.

Sitton: Yeah. Talk about the turkeys, because most people don't understand about that, that was a strange thing.

Flowers: Well, you take a turkey, he's kind of like a guinea. Now, a guinea, he's more wild, he's kind of like a watch dog. Whenever you hear a guinea cutting up, there's something or another around there. But a turkey, he's more devilish like a hog, he'll get into anything. But, after you grow them up, well then you had a certain amount that you's going to sell, well then you'd keep them off to themselves. And have a guy come by and pick them up, we'd have them in a coop penned up already for him when he come by so he wouldn't have to be out there running them down. But say we had a little patch of maize, we'd let the turkeys raise in there. They'd feed themselves and you wouldn't have to pen them up to feed them.

Sitton: Well, the turkeys did a lot of feeding of themselves, didn't they?

Flowers: Yeah, catch grasshoppers and something like that. 
Sitton: There was something funny about their nests, they would make their nests -

Flowers: Oh yeah, you would have to find their nests. Mama made me watch those turkey hens a half a day to try to figure out where she's laying that day. Find out you're watching them, and they'd just try to fool you. They'd go this way and they'd go this way and go this way (laughs), and you'd finally find it. Yeah, we used to raise turkeys.

Sitton: Well, they'd wander out in the woods.

Flowers: Oh, yeah. Naw, they wouldn't stay around the house. Turkeys, they'd go all out in the woods, sometimes you'd have to get them in the evening and bring them back. And they mostly stayed together.

Sitton: What about, did people mind your turkeys getting on their land?

Flowers: No, back in them days, everybody roamed across each other's property. But now you can't get out of the road.

Sitton: Well, like these fishing trips, you're just going through different one's places and nobody would think-

Flowers: No, nobody would care. Probably there's a gate over here, open that gate and go through there and go on back to the creek. And 'cause we was living there, we knowed just about the whole country, knowed where every road was and every gate was, and so we didn't have no problem.

Sitton: Well, it was mixed up, it was white and colored both around Sayers? The Scotts were-

Flowers: Uh-huh, yeah. The Scotts, they was right near us, kind of a more bigger farm than we had, most of them. You had the Scotts and the Flemings and the other guy up here, used to own this place, uh, heck, I can't think of his name now. They was pretty good watermelon farmers.

Sitton: What was this Dogwood community over here?

Flowers: They got this place across the road named Dogwood, but Dogwood Creek is down there close to
Fay's, it comes from back up in that way. And so I asked the guy, I said, "Where'd y'all get this Dogwood?" He said, "Well, we looked it up on a map." I said, "Well, it's wrong. This ain't no Dogwood. I don't know what this creek is. Y'all's the one discovered this creek."

Sitton: Well, I knew it was really across from Fay over there. But it was a colored community, right?

Flowers: Right, yeah, all around Sayers there, most of them. And see, and then on back, back toward McDade, well there was more mixed, more white back thataway than there was around Sayers.

Sitton: Well, did a lot of them, the Dogwood, did they own their own land?

Flowers: Yeah, lot of them did.

Sitton: How were they making a living?

Flowers: The same way we was. Most of them just had little piddling stuff that they'd raise and sell, then in the fall of the year they'd get out and pick cotton, stuff like that.

Sitton: Well, that was a - You could get your cash, almost all your cash, in the fall of the year, because, you know, there was a huge area of cotton.

Flowers: Yeah. See, some of them - That's what we'd do, when it's the fall of the year, Papa and my brother, they'd go out and pick cotton, and that's where we buy our winter clothes and stuff like that to last us until next year.

Sitton: And if you needed a little more money, you just picked a little longer, that right?

Flowers: Yeah, and then, see, after Christmas, getting ready to start the new crop, well then Frank Dennison, he would let us come to the store and buy groceries on credit, and then pay him during the fall.

Sitton: Yeah, I hadn't had that thought, but it was Dennison's store. So y'all would have been run out of Dennison's store, you had a line of credit, I'm sure.

Flowers: Uh-huh, right. Everybody — well, we didn't buy too much, but about once a month Pa'd put me on a horse, and I'd go to the store and bring stuff back on a horse. 
Sitton: What would you be getting?

Flowers: I'd be getting sugar, flour, stuff that Mama couldn't raise.

Sitton: So, we're talking about the commissary store there at the mine?

Flowers: Right.

Sitton: So, it was not just for the miners, but the general community used it like a regular mercantile store.

Flowers: Right.

Sitton: Who worked the store?

Flowers: There was a colored lady by the name of - um, um, um, um, um - what was that woman's name? I can't think of it.

Sitton: Well, don't torment yourself.

Flowers: I can't think of it now. And she finally owned that place up there at Dennison's up there where we were living on, 'cause she bought that place from him. And then after the war was over with, we come back home, she asked me if I wanted to buy it, buy it back. And I told her naw, and I've wished a-many times I'd have told her yeah. Because at that time it was back over in there by itself, and I just figured it's cut off, nobody be back in there but me, and I just didn't buy it. Could have got it back for what Uncle Sam paid her for it. What was that woman's name!? (laughter) I can see her, but I just can't think of it. Mary!

Sitton: I'm, I'm terrible about that, and it's not that I'm getting older. I've always been terrible about remembering names. Where did y'all go to church?

Flowers: Well, at that time, we were still down in the Camp area, but not too far, about two or three miles from where we were living, it was back what you call down on Piney. There was two churches down there, a Baptist church and a Methodist church, and we went to the Methodist church most of the time.

Sitton: Piney Creek?

Flowers: Yeah, uh-huh.
Sitton: That's kind of south of the present-day Swift, but that was part of what the government took over too, right?

Flowers: Right, right. Yeah, this church is right down the road this side of Fay's. After we come out of Camp Swift down there we bought that property there - from Fay's daddy - and built a church down there. We first built it on this side, you noticed where the garage is there, there's a road going through it, we bought three acres right there and built a church there. But then on account of the highway under the hill, we asked Fay's daddy if he would trade that three acres for another three acres on top of the hill, and he did. And so that's why we got up on top of the hill, on account of the traffic coming out from church there. Now this church that there now, it was moved off of what we call Magalene, that was farther on down from Sayers. They built a newer church, we went together, so we tore that church down and moved that one up here. That's why that church is up here, that church was built in ' 35 .

Sitton: Now, is that the one that's for sale?

Flowers: Right, right, it's supposedly sold, now. We're just waiting on paper work. See, we quit that one, and we went to town when the two churches went together. We went to town and all went together up there. And we're going to sell this one and take the money and fix that one up, uptown.

Sitton: Yeah. Did you sell it to a church congregation?

Flowers: Yeah, that's who bought it.

Sitton: Well, that's good. We don't need a Dogwood-Well, that is good.

Flowers: That's what's lot of them scared of, somebody is going to buy it for a junk yard or something another, you know.

Sitton: Yeah, or make a private home out of it - you know what they do.

Flowers: Naw, a church school bought it.

Sitton: Well, the land values around here have to be gone way up, right? 
Flowers: Yeah, gone way up, right. And paying taxes on it is gone way up, too. (laughs) Yeah, just waiting on the paper work, now.

Sitton: Well, what was church like when you were on the Dennison place? What do you remember about going to church? What was the Sunday service like?

Flowers: Well, I know one thing, every Sunday that was church day, Mama made us get up and go to church. She said we're going to church first, and then we could go wherever we wanted to go, after then.

Sitton: So, first you went to church. But church could last a good long time, couldn't it?

Flowers: Yeah, yeah, sometimes. Most of the time we'd go in the wagon, and sometimes it takes a good little while to get there and come back, well when we get back home we probably - Well, we was little then, we didn't hardly, but after we got up to where we could go around a little, we didn't go anywhere, we had an old car and drive that.

Sitton: Would they have a revival once a year?

Flowers: Mostly, yeah. See, every year we would have the Nineteenth of June, and then we would have, and then every year they would have a revival.

Sitton: What would the Nineteenth of June be like here? Where did people go? Did they have one place that they'd usually go for it?

Flowers: Right, down on Piney down there [Mt. Pleasant Methodist], or either over here at Sayers. It'd be pretty close to a church or either a school. Guys would meet together there and play ball, first one thing and another. Just kind of a picnic thing, and they'd start cooking that night. They'd dig a hole in the ground and put a piece of wire over the top of that hole, the old cow leg on this one and half a cow over on that one, that's the way they cooked the meat. Had an old pitchfork to turn that meat over.

Sitton: And people would stay up-

Flowers: Stay up all night cooking that meat. We'd go down there at night and play around down there and sample off that meat. If you think a piece was about half done, we'd get a knife and cut a piece off.
Sitton: Well, people have told me that the night before a Juneteenth, that staying up around the barbecue and listening to the men talk and just hanging around the barbecuing was the best.

\section{Flowers: Yeah.}

Sitton: There was one lady down on Alum Creek - no, it was a man - that described it as "a bunch of men lying and burning up meat."

Flowers: (laughing) Sometimes it worked like that. Then during the day everybody eat outdoors, have a big old long table, women would cook different stuff and bring it. And you'd cut that meat up, you'd have all the meat already there, and all they had to do is bring cakes, pies, and stuff like that. Yeah, back in them times we looked forward to them days. Sometimes we'd have a parade. Some of them, back in them days, they were still working oxen, and have oxen to wagons and a bunch of wagons meet up the road, and then they'd come on down. Have the wagons decorated just like they do cars nowadays. They'd meet up a couple of miles back up the road up there from where they was going to have the picnic.

Sitton: They'd be parading down to the picnic.

Flowers: Right, um-hm.

Sitton: But some people were still using oxen?

Flowers: Yeah, I can remember my uncle, he had a pair of oxen. He worked them for a long time, I can remember him working them oxen.

Sitton: How would he do it? You didn't work them like a mule.

Flowers: Yeah, something similar. They had them around the neck, and then the wagon tongue was hooked on to that in the middle, they didn't have a harness on like mules. They worked them like that. And they had a hole in their horns and put a rope in there, and that's what they kind of handled them by.

Sitton: But it's not a painful thing. The bit hurts their mouth, and that's your control over a mule or a horse, but the horn is just- 
Flowers: Yeah, you could control them by the horn. Then if you train them right, all you have to do is just talk to them, and you can handle them like that.

Sitton: So, you talk to them.

Flowers: Yeah, he understood you good as a person could.

Sitton: People have told me that you could hear somebody working oxen. You would know they're working oxen because there'd always be, they'd be talk[ing] to them, yelling at them.

Flowers: Yeah. See, you didn't have lines on them like you did a mule, you could pull him over here, pull him over here, just had to talk to him to tell him what to do and which way to go. And they understood it pretty good, too.

Sitton: Well, that's a lost art, and I guess working mules is a lost art, too.

Flowers: It's just about it, you don't hardly ever see a mule, now. You see a mule in a parade every once in awhile, that's about it. Yeah, you don't see no mules in the field. Tractor run him out.

Sitton: Yeah, but y'all were still using mules until you left the farm, right?

Flowers: Right, uh-huh, mules and horses.

Sitton: What do you remember about y'all's work stock, any peculiarities of some of them?

Flowers: Well, we had one mule we used to ride all the time. Papa told me to go to the store one day. He say, "Get that mule out there and ride that mule." I said, "Oh, I'll get my jenny," I had a jenny. I said I'll get my jenny, and he said "No, go on and get that mule, the mule's already out there." I got on the mule and went on to the store, come on back, and we lived two or three hundred yards off the road and we had a gate up there at the road. I got off and opened that gate, come on in, shut the gate and got back up on that mule, and that mule throwed me high as the top of this house. First time that mule ever pitched, I don't know what happened. And he stood there, and I got back up on him and rode him on to the house. Yeah, that's the only way we used to get around, me and my brother we had two jennies, and that's what we mostly rode.
Sitton: Tell the tape recorder, what's a jenny? What's the distinction between a jenny and a mule?

Flowers: Well, a jenny is smaller, got longer ears, and they're mostly for riding or either working small crops like a garden or something or another. But on the average, a jenny is a whole lot slower than a mule. But the ones that we had, I'd put them in the road with a horse. And they were snow white. And some of them, you just couldn't get along with them, you just had to beat them all the time to try to get them down the road, but the ones we had you didn't.

Sitton: But a mule comes from a stallion horse and a mare burro, right?

Flowers: Naw, you got it reversed. A mule comes from a mare and a stallion jack. That's the way you get a mule.

Sitton: Oh, okay. But how do you get a jenny?

Flowers: Well, from jenny to jenny. See, you can take that same jack - See, an old fellow had a store down there, and he a little old white jenny down there. We wanted him, me and my brother wanted him, and Papa didn't have the money to buy him. So, me and my brother had two pigs, and we went down and asked that old fellow would he take a pig for that jenny. And he said yeah, and so my brother traded his pig for the jenny. So we taken the jenny we got from this guy for a pig, and we bred him, and so she had a jenny an old jenny, and both of them were snow white. The one we raised was just like the mamma was. So that's how we got a hold of two jennies.

Sitton: Would you ride them with a saddle?

Flowers: No, ride them bareback. They wasn't the type that you had to beat up and down the road. We'd take a notion we'd ride them off, and we didn't want to bring them back home, we was going some other way, we would get off of them, turn them a loose. And they go home.

Sitton: What were the roads like around here? I understand it was deep sand, right?

Flowers: Deep sand, yeah, and when it rains plentymud. At that time we didn't have no county roads - county workers - just every once in a while had an old Cat 
pulling a blade. And about time he worked the whole county, the old roads messed up again!

Sitton: There wasn't a lot of hard surface road, is what you're saying.

Flowers: Naw, only time we had any hard surface road, well they'd either be a bunch of rocks there or hard clay. And man, when it rains, you better stay out of it, specially if you're in an old car.

Sitton: What about the creek crossings?

Flowers: Well, they'd get pretty bad. They were low crossings, there wasn't no bridge. You had to watch them, yeah.

Sitton: Fay has one photo of a guy standing out on the hood of his Model A in the middle of a creek, and the water-Clearly, he's stalled out. But he's just standing there on the hood, and he's a man with a problem.

Flowers: (laughing) Yeah, I imagine so. Yeah, us and Fay and her brothers was just raised up together. There's one of her brothers, we could track him good, 'cause he had real short toes, and he went barefooted all the time, and we used to see his trail about that long, say, "Uh oh, here go Jack." (laughs loudly)

Sitton: Well, you leave tracks in the sandy land, and when y'all would be going around the countryside you'd see the Owens' tracks. And so her brother left this -

Flowers: Yeah, we knowed him. Naw, me and them boys, the other brother's Jack - See, there was Jack and Joe and Andrew, and we all played together. Spent a good many nights over at their house.

Sitton: What would y'all play at?

Flowers: Just anything we could find, we would climb trees and first one thing and another. And snakes, Jack he would chase snakes and catch them and put them in his pockets. We wouldn't allow him to come close to us.

Sitton: What about-You know, I'm just jumping around, you'll bring something up and I'll ask you about it, but I know we're covering the waterfront, here. What about using wild plant foods, did you pick berries? What would y'all get?
Flowers: Well, dewberries and plums. That's mostly what growed around, dewberries and plums. Mama'd can a bunch of them and lot of times we'd pick them and take them to town. And different people that couldn't get out to pick them, we'd sell them to them.

Sitton: I was looking beside Fay's driveway, and it looks like the dewberries are going to have enough rain, this year.

Flowers: Aw yeah, if you don't get a late frost. Yeah, them dewberries that Mama wouldn't can, me and my brother would take them to town, and different people would buy them from us. Might stay out there half a day and take a gallon of berries to town and didn't get but thirty-five cents a gallon for them. But that was money, and back in those days -

Sitton: Well, when I was a teenaged boy, I picked berries, I'm from Lufkin, Texas, and I picked berries and sold them in my uncle's little store. I liked to do it, for some reason. I don't think I'd have liked to pick cotton, though.

Flowers: Naw, unh-uh, I never did like to pick cotton.

Sitton: Poke salad?

Flowers: Poke salad, yeah, we used to go out in the woods and get poke salad. I liked it. 'Course, you don't want to eat too much of it, it might make me stay in the house for a while. But we clean us a good mess, and it'd give you a good working out.

Sitton: You're saying it gives you gas?

Flowers: Yeah, the first of it, then after you eat a few messes of it, well it ain't so bad. They claim poke salad is good medicine.

Sitton: Yeah, I've heard that. I know some people give the berry juice really diluted, some people use that to clean people out, and I believe it.

Flowers: I've never heard of that. Naw, it's bad enough to half cook the leaves. You got to cook them just right, pour the water off of them and reboil them.

Sitton: Did your mother give you a spring tonic or anything? 
Flowers: No, she didn't believe in that.

Sitton: You were lucky.

Flowers: Yeah, she didn't believe in that, but poke salad first come in, she said, "Well, we want to get the first mess of poke salad. That'll be your medicine for the year."

Sitton: There was one guy, one guy's mother believed in chicken-pip tea. Every kid needed to be cleaned out, and he said he dreaded the day that she went out to the hen house to gather the basic ingredient. (laughter) Now, that's a terrible tea.

Flowers: Yeah (laughing), I don't know if I could drink that!

Sitton: He said "she only got me to drink that when I was a little kid, because when I was older and could run off-“

Flowers: (still laughing) Yeah. Yeah, back in them days, there's a whole lot going on. Fact, we would be better off if a lot of it were going on now.

Sitton: I haven't asked you what was the Sayers School like, what were the teachers like? What do you remember about the school?

Flowers: Well, we had good schools. Back in them days, I loved to go to school at that time. I started to school when I was six years old, and I had the same teacher when I left from there, and I went through the eighth grade.

Sitton: It was an eight-grade school?

Flowers: Right. Know where that church is over there at Sayers now? Well, the school was right off in that next little spot there. There was a couple of trees, the old cedar trees is still there. Just a hundred feet off the road there, that's where the old school was.

Sitton: What do you remember about going to school? If you're four miles away, you ought to-

Flowers: I rode a horse, yeah, until I got big enough then I decided didn't want to fool with a horse, and I walked.

Sitton: That's a pretty long way to walk.
Flowers: A long way to walk, but we made it every day. Then after we got up a little bigger, then like I say me and my brother got these jennies, we raised a couple of jennies then, and we started riding them to school.

Sitton: What did the school look like? A one-room school, I know that.

Flowers: Uh, when I first started it was a one-room school, then they built another room on to it, and when I left from there it was a two-room school. It was just something built like this room here, but it's long - just one big long room. Wood stove, right. Yeah, every evening after we finished all the book work, we had to get out there in the woods and cut wood and pack it up there and pile it up in the corner to have it for the next morning.

Sitton: So, y'all got your own wood at the school.

Flowers: Right, and sometimes some of the parents would bring a load of wood there, and then we didn't have to cut it up.

Sitton: Well, what was this teacher like? You absolutely got to know what this teacher was like.

Flowers: Aw, yeah, only thing was, my first teacher until I got up to the second or third grade, she was good, she was left-handed, and she tell you to do something you better do it, or you get that left hand on you. But then after I got to the next teacher, she tell you to do something you better do it, because she had a strap about that long and had holes in it, and another strap on the end of that one, where you could kind of swing it. And I mean, she could hit too! (laughs) Yeah, but they were good, I liked them, we all got to be good friends. They both had cars, and if they had (??) somewhere they'd send me, let me take the car and go. And if they had to go to Bastrop or Elgin for something or another, well I'd do most of the driving.

Sitton: So, you'd learned how-Had your family got a car?

Flowers: Right, yeah, um-hm. And I got my driving license when I was fifteen or sixteen, I believe, something like that. Everybody couldn't drive, then, and lot of the boys that was going to school there, they didn't trust them. 
Sitton: Well, my grandfather, he got a car, and he never really learned. He turned it over to my grandmother, who was younger, and she was the driver in that family in Nacogdoches. He tried to put it in the garage one day and missed the brake and tore out the back wall, and he just said - (phone rings, taping interrupted)

Flowers: My daddy even - I remember when we bought the first car. Well, we had an old Model T, but I never did learn how to drive it. Had them three pedals down there, and I'd use the wrong foot. And so I can remember the day as if it was yesterday when he brought the first Model A Ford home. I was out in the field plowing, and I seen them coming up the road. I drove the mule on out to the end, I tied the mule, I went on to the house. And I told my daddy, I said, "I want to drive it down the road." Said, "Get it and go ahead." I drove down the road and was going to turn it around and I killed it. And went to start, and the starter locked, and we didn't know how to unlock it. We worked at that car half a day, finally a guy come along, said, "Put it in reverse and push it backwards." And so that's what we did and it unlocked that starter. And he told how to do it if it ever locked up again. But what happened, it had a bad flywheel in it, and he didn't know it when he bought it. He says, "You got to get a wrench and loosen the starter, and just shake it a little bit, and then pop it loose." Well, we didn't have no wrench, and so I went to town, and I knowed an old guy that run a shop up there, and I asked him, I says, "Hey, Mr. Boomer." He say, "What?" "My pa got an old car that the starter locks on it all the time, we need a wrench." He said, "I got an extra one over there, go ahead and get in that box and get it." So, we kept a wrench with us, and whenever it locked up, well just loosen the bolt on it and shake it a little bit, and go ahead on. But I was scared, I thought, "Oh, I done tore this thing up already!" (laughs) It happen, Papa didn't fuss at me, he just said well, it's one of them things.

Sitton: But he had already had a Model T.

Flowers: Yeah, he had a Model T. My brother could drive it, but I never did learn to drive that thing.

Sitton: You brother S T was older.

Flowers: Right, right.

Sitton: That's the other reason he got the cottonpicking job.
Flowers: Uh-huh, yeah. We stayed on that place from when I was six years old, and we moved off it when I was twenty. And we worked for different people down there on the farm after we kind of slowed up on farming, we hired out. And a lot of times we'd have to walk three or four miles to work, and that time, when you go to work on a farm, you was there when the sun rose and you stayed there until it went down. That was a day's work.

Sitton: Well, what sort of work would y'all be doing? Would it be picking, or would it be just different kind of things?

Flowers: Farm work-plowing sweet potatoes, cotton, and corn. No gathering the crop, but we would help them gather sweet potatoes, and like one guy we worked for around there, he raised a lot of okra. And so we had a lot of okra to pick.

Sitton: Would they come by and ask you, say I need somebody to work, would you be willing? Would they come to you or would you go to them?

Flowers: No, you just knowed pretty well everybody around there. If we started work for a guy, we liable to work for him a couple of years or something like that. Till we decide we didn't get along, something happen, and we'd go to the next farm.

Sitton: So, you would know when you left, you would know when he would need you again?

Flowers: Right, right. Only one guy that I actually walked off from and didn't tell him I's gone. I told him I wanted to get off work at Friday. I said, having a county meet at Bastrop, all the schools was meeting together for activities, and I told him I wanted to go. He told me I couldn't get off. I said, "Okay, but I'm going." He said, "Well, don't come back." I said, "Okay, thank you," and I left, and I didn't go back. And he said, "I see's you won't get another job around here on the farm nowhere." That Monday morning, I drove another guy's mules up across the road from him, right up in front of his house, and waved at him. (laughs) Turned around and walked back to his house.

Sitton: This business about putting out the bad word about you, it didn't work?

Flowers: It didn’t work. 
Sitton: Well, the nice thing about that kind of work is, there's always somebody else you can go to.

Flowers: If you'd work, you didn't have no problem getting somebody. 'Cause, me and my brother, we was pretty well known, I guess, by everybody around. We could get work anywhere, me and my brother would. If one didn't want us, another one wanted us. Once, we were working for this guy, this guy come up, said, "Well, can I use them tomorrow?", or something like that. "Yeah, go ahead, our work is slowing down."

Sitton: Well, when you get known by reputation, they know you. Neighbors knew who you were in a way they don't really today, it seems to me.

Flowers: Right, right, right. I don't know, it seems like today it's too much changing around. Most people don't stay on a job long enough to really get used to a job. A lot of time a guy go on a job, he just there from payday to payday. But when I went on a job, I went on there to learn something, what's going on. I worked at the brickyard over here thirty-seven years. When I went there, I was supposed to work two years and I's going to Utah and going in the civil service. But ever year it got a little better and better because my job, I'd learn my job and what the other fellow's doing, too. And when something happened on his side, I could get over there and help him, get his side straightened out. And if he leave, then I could do his job. I was driving a dump truck up there, hauling sand and dirt, and a foreman come at me, said "You want to go down on the other end?" I said, "For what?" He said, "Drive a lift truck." "I said, "Naw, I believe I'll stay where I is." He said, "Well, I'll tell you what, you want to go, go ahead, and if you don't like it down there, come right back." And I went down there, and I drove a lift truck for twelve years down there. And then when I got off, another guy was operating machine, and when I wasn't running a lift truck and a machine break down, I'd go over there and help him fix it. And then when he decided to retire, I got his job, and I stayed there another twelve years. My own boss and everything, all I had to worry with was the machine, didn't have nobody to answer to or nothing. But that was on account of learning what you was doing and then helping learn what the other fellow was doing.

Sitton: Uh-huh. There was something I was going to ask you about the school and forgot. How did those teachers deal with so many grades in the classroom at the same time? I don't understand, how do you teach four different grades at the same time?

Flowers: Well, sometimes, this teacher got one grade, like the first grade, and then this one over here got the second grade. Well, when they get through, this will be the third grade, he'll go over here, and they send the fourth grade over here. He just swapping them about like that.

Sitton: So, they moved them physically around in the room?

Flowers: Yeah. Until they built this other room on the school, and then they had certain grades would stay in one room, one teacher would see certain grades, maybe it's first and second and then the other one third and fourth and like that. They'd do them both in the same room.

Sitton: Would y'all carry your lunches?

Flowers: Right.

Sitton: What would you carry for lunch?

Flowers: Well, sometimes we'd have meat, bread, and molasses and stuff like that. Sometimes we'd have a biscuit in there with some butter in it. Papa bought us this little old lunch pail, kind of striped like, and we thought we's uptown, then. Yeah, I don't know how those teachers made it, but they made it, we didn't get all jammed up. You was in there eight hours a day, though, when we was studying. Only time you got was an hour at twelve o'clock, and ten minutes in the morning at ten o'clock, and then ten minutes in the evening at 2:30.

Sitton: What would you do at the recess? What would you play?

Flowers: We'd get out there and play volleyball and basketball, and sometimes just chase each other around there.

Sitton: Fay has a photo that came up there from somebody, from the Sayers School, and I think it's the basketball team. They're five young guys, and I think they're standing in front of the school.

Flowers: Yeah, I used to play basketball when I was growing up. It was a pretty nice school at that time, 
nice building and everything, and they built this other one. You went in two doors and come in the front, well they come on the back side and built another one back there.

Sitton: You ever hear them say whether that was a Rosenwald school?

Flowers: No, I never did hear them say. All I know it was just the old Sayers School.

Sitton: Well, in the photo you can see-Some of those schools were just real rough, and this has got siding. It's not board-and-batten.

Flowers: Right, we called it drop siding. Yeah it was a real nice building. But after so long the school went down over there. Well, I belong to a lodge in Taylor, and we bought that old school and moved it to Taylor.

Sitton: So that's where it went. Is it still in Taylor?

Flowers: Last time I was by there-see, I quit that lodge and I went to Bastrop - and the last time I's by there, they said they was going to take and put a twostory on it, and he said they were going to take the two-story off and fix the bottom. And I don't know if he ever did it or not.

Sitton: Yeah. Were there any lodges out here associated with the churches?

Flowers: No, not associated with the churches. No.

Sitton: You know, they have to be two stories so they can't look in the window.

Flowers: Right. (laughs) See, now, they done changed that. They can have them on the bottom floor, now.

Sitton: But it used to be required, 'cause you know you can't let them see the sacred, whatever.

Flowers: There you go, that's right. 'Cause I know when I got in, if I could have gotten upstairs, when I listened to them carrying another old boy in front of me, going through it, if I could of got out of there I'd of been gone. (laughter)

Sitton: So, what you saw going on, you didn't particularly-
Flowers: No! I could hear it, but I couldn't see it. But there was no backing out, then, I was up there in the door.

Sitton: Well, would the Sayers School have a Christmas program? What would happen at the Christmas program?

Flowers: Yeah, they'd have a Christmas program and have a Thanksgiving program.

Sitton: What would they do?

Flowers: It would be something similar, oh, well, have them sing Christmas carols and stuff like that, and have a Christmas tree out there, and every kid have something under the Christmas tree, and have a little play or something concerning Christmas. And the same was done Thanksgiving.

Sitton: What about at the end of the school year?

Flowers: They had the regular school closing, that was the big day. They'd have a picnic that day, and then we'd have school closing at night. We'd meet there in the daytime and have a picnic and play ball and first one thing and another. Kids of all different schools would come together, and we'd meet out there.

Sitton: So, other people than just the Sayers people would be coming to the school closing?

Flowers: Right, that'd be something similar to the Nineteenth of June, there's just a lot of people gather together and have a picnic at the school closing. But there wouldn't be no barbecuing, just our mothers would bring a basket, and everybody would eat. And then that night, well, then we'd have a program. It'd be like - Well, sometimes they'd be getting awards, some of them be saying speeches, and stuff like that. (taping interrupted) Watching the color.

Sitton: You'd watch the color, you watched how it came off the spoon, because some of the juice is darker than other juice, you had to adjust it.

Flowers: Right, that's the way it'd cook. Heating it makes it a different color.

Sitton: The way it slipped off a spoon, just like a cook cooking in the kitchen. Well, let me look at this [interview guide], this is like a reminder to me. 
Chickens, did your mother keep chickens? You had a chicken house, did you sell eggs?

Flowers: Sometimes, yeah, we sold eggs. Had to take them to town to sell them, then. At that time, used to take them to grocery stores, and they'd buy them.

Sitton: Milk cows?

Flowers: Milk cows, yeah. And we drank all the milk, we didn't sell no milk.

Sitton: Did y'all ever exchange food with neighbors? I mean like would they give you stuff out of their garden and you give them?

Flowers: Yeah, if they didn't have something, if they didn't have the same we had and they wanted something, yeah, we'd exchange like that. And then in a certain time of the year, we'd all meet together, it's called "community." We had an old abandoned house, and we'd all meet at that old house, and the women would make mattresses. They would all get together and make mattresses. I had to go with Mama every time she went, because I had to help them with the cotton, and then I tried to help them with them stitches. That's because you had to roll that corner, put a little cotton in there and roll that corner, in order to make that bead around there. They did a lot of that, and they did a lot of canning. Somebody would kill a beef, and a bunch of the community would get together and buy up a bunch of cans. And then they'd go to these old abandoned houses, they had a stove in there, and they'd cook that meat and can there. And I'd have to go along with them, me and Mama went to might near everything that went on. And then I'd help seal them cans.

Sitton: So, that would be a community thing, everybody pitching in?

Flowers: Everybody pitching in, yeah, to do it in a big way, and then at the end of the day everybody'd divide it up. Like when make them mattresses, we say, well, this one going to make a mattress for this one this week, and next week make a mattress for this one. That way, it would finally go around. And the same way by canning. Like when we can, if we have half a beef and cook it, and then after we all finished up, well then we'd just divide it up equally.
Sitton: Yeah, what we're talking about is that oldtime neighborly stuff that you don't have too much of today.

Flowers: Naw, look like nowadays people ain't got time to fool with each other. Back in them days, well - you take where Fay and them used to live over there close to us. They used to be an old water well over there. And I was down at Camp Swift ten years ago with the National Guard, and they got me to go down there and cut some weeds. And I was driving on down through there, said "Wait a minute, I know this spot over here." I went a little bit further, I said "That old well is up here." I ducked off the road, I'm scared to be there, might be a mine, I ducked off the road and I went up there, and I looked off in that old well. Well, I got a many a drink of water out of that old still water. And when I stopped down there the old boy told me, he said "What I want you to cut is back up here." Well, it's right there by that well, and I got a good chance to get a good look at it.

Sitton: So you could tell where the old place was.

Flowers: Right, we called it the old Minnie Wilson place.

Sitton: I guess the wells and the chimneys are about the only thing, and not all of them are left.

Flowers: Right, not all them are left, but that old well was still there. And I wanted to go up the road. We lived about half a mile, maybe a mile, up the road further, and I wanted to go on up there, but I was scared, 'cause I didn't know what was up there. In the Camp area, ain't no telling -

Sitton: How did it come about that y'all were making mattresses?

Flowers: Well, somebody just organized it. A bunch of womens got together and got to talking about it, and see at that time the government was furnishing the material and the cotton, and somebody got in the wind of it, how to get it, so that's the way it got started. And they said if y'all can get it, we'll do the work. So, women got together, and that's what they did.

Sitton: One of those New Deal programs, I bet.

Flowers: I guess so. And see, it's something just starting. 
Sitton: But the canning was done the same way.

Flowers: Was done the same way, yeah. But the canning, mostly, was like some guy had a bunch of cows, he might donate a cow, a yearling or something or another, to butcher, and then that's where they got the meat from. They'd kill it like this evening, and somebody had a big old freezer, and they'd put it in there. Somebody like furnished ice and keep it cool until the next day, then they'd get together and cook it. Yeah, it was a lot of fun.

Sitton: Well, what else would neighbors do to help? Would they come help you if somebody got sick?

Flowers: Oh yeah, yeah. Yeah, if somebody got sick or something another, we didn't holler, they's around there. There's always somebody that had time to do something another. And like it is now, nobody has time to do nothing.

Sitton: Telephone, did y'all have a telephone? I've heard that people used the telephone in Sayers Store. Did Mr. Dennison's store have a telephone?

Flowers: No, no, it didn't. In this old Sayers Store there was the Evans, Charlie Evans. But I don't know if there was a phone in that store or not. I don't think so. If it was it was just before it closed, closed down. And I know Dennison didn't have any. Telephone actually didn't get kind of started around here until the early forties. 'Cause I know I went in the army in '42 and wasn't no phones around there to amount to nothing then.

Sitton: Well, until the army came in in '42, I mean, there was no electricity, right?

Flowers: Right, right.

Sitton: And of course no water system or anything. But no electricity, so everybody was using kerosene.

Flowers: Kerosene, yeah, 'cause I went in the army in ' 42 , and - we went in after we built this house in Elgin. Let me see, did we have electricity when I left from here? I don't think so. Yeah, 'cause when we built that house, we used hand saw and built it. And so after I left and went in the army, 'cause I remember writing, said they had electricity and had telephone.

Sitton: Where did you go in the army?
Flowers: I went to Fort Sam, left Fort Sam and went to New Orleans, and left New Orleans and went to Newport News, Virginia, and left from there and went to Washington, D.C. And left from there and went to North Africa.

Sitton: Uh oh.

Flowers: Yeah, and from North Africa to France, and from France to Italy - no, I went from North Africa to Italy, then went to France. Yeah, and I stayed in France until I got to come home.

Sitton: That's pretty much the whole show, except for Germany.

Flowers: Yeah, well I was right at Germany one while, but we turned and went the other way. My brother, he was a jump ahead of me. He went to North Africa, and I caught up with him over there. (phone rings, taping interrupted) He was always a jump ahead of me, but I caught up with him in North Africa and we stayed together about three months over there. And he left and went to Italy, and I caught up with him in Italy and stayed with him about a month in Italy. And so he left Italy and went to Germany, and I left Italy and went to France. Yeah, when we got to North Africa, well I was driving down the street-We went to pick up our trucks next day after we got there, and I's driving down the streets, and I met one Jeep with his number on it. I knowed they was over there then somewhere, because that was the number of his outfit. And I stopped the old boy and asked him, he says "Yeah, he's right around the corner there." I drove on around there and I drove up there, "Say, boy, somebody's stole your jeep." And he looked to see who it was! (laughing) He said, "Come on in here, I got something for you, I know you ain't got none." I was chewing tobacco, then, and I'd done run out, and, shoot, he had about ten plugs of tobacco. He didn't chew, but he could get it with his rations, so he usually got it and kept it.

Sitton: Well, you World War II veterans, the ones that went through the whole thing, they're fewer of you than there once were.

Flowers: Yeah, yeah, we were the lucky ones. There ain't but very few of us left now.

Sitton: One thing I wanted to ask, that just came to me, was what would y'all do-we're talking about 
growing up, social life - what would you do on Saturday night? Would you go into town? Would you go to house parties?

Flowers: Go to house parties, either from house to house, kids meet up in the road and play or usually go to somebody's house and set around and talk. We didn't go to town.

Sitton: Talk about the house parties. Would people have house parties?

Flowers: Sometimes, sometimes we'd just meet up, bunch of kids meet up around somebody's house and just play and mess around, and get late at night we'd go home. But we didn't go to town. 'Cause, we didn't know nothing to go to town for.

Sitton: Well, I was thinking about, when you get in your teenage years, dances and stuff like that.

Flowers: Yeah, well I never was no hand to going to no dances, never did. Every once in awhile I'd go, but I never did learn how to dance. I got on the floor one time after I got in the army, and I was drunk that time, didn't know what I was doing. (laughing)

Sitton: I will go to my grave not knowing how to dance.

Flowers: Naw, me either-never. That was the first time and the last time I got on the floor and tried to dance. Naw, you take when we's growing up, a bunch of kids'd just meet up together and just play and mess around. Well, after I got up about half grown, then we started going up on Carter Drive, or maybe we'd go to town Saturday nights and mess around and drink a beer or two. It couldn't be too many, 'cause we didn't want Mama to know it when we got back home. We liable to get a beating.

Sitton: When you were courting, when you got to that age, how would it go on in the community? Would you visit the girl and hang around their house?

Flowers: Sometimes, for a little while. Wouldn't stay around too long, 'cause them didn't

Maybe would go down on Sunday evening or something another like that and stay for maybe an hour or an hour and a half, something like that.
Sitton: Right there practically under the eye of the parents.

Flowers: Yeah, um-hm.

Sitton: Let's see (looking at interview guide), to make money somebody was telling me that a lot of people cut firewood, cut stove wood.

Flowers: Right, back in them days, see, few people was selling wood, and they'd get somebody to go in and cut it. I never did cut none, but my brother and my daddy cut some. And what they mostly cut was for the other guy that lived on the next farm, the Scott farm. They had a little money, so they hired their stove wood cut, and my brother and daddy would cut theirs. That's a job I never did like. I had some friends of mine, some boys, they loved to cut wood. They could go in there and take an ax and go in the woods and in a couple of days they'd have three or four cords of wood cut. And they loved to cut, but I never did like it, and I'd always try to find something else to do on the farm, plowing or something another, besides cutting wood.

Sitton: Well, cutting cord wood has got to be up there with-

Flowers: Picking cotton, yeah. If I had another way, I dodged it.

Sitton: Well, you know, if you go back to where there were steam gins, those steam gins used a whole bunch of cord wood.

Flowers: Yeah, right, right.

Sitton: Where'd you gin your cotton? I didn't ask you about that.

Flowers: They had a gin in McDade.

Sitton: Do you remember taking it in there? How would y'all do it?

Flowers: Well, the way we would do, we had to borrow a wagon to carry it, our wagon wouldn't hold a bale of cotton. So, we'd pick it and lay it out, pile it out on the ground. We'd weigh it and pile it out on the ground, and when we would get a bale, we would go get this guy's wagon. We'd bring it that night, and we'd load it up, and then take it to the gin the next morning. Sometimes we had to hook four mules to it, 
it depended on where we had it at in the field, 'cause if we had it in the field where two mules could pull it out we'd just use two mules. Yeah, we carried it to the gin. We'd go to the gin with my daddy, and we'd watch them unload - pull that wagon under that sucker and suck that cotton off, and go in the gin and watch it come down and go up over yonder and directly seed going over here and cotton going over here. My daddy, he couldn't figure, but he'd carry a bale of cotton to town and he'd tell you exactly how much money he had coming out of it. But give him a pencil and paper, he couldn't figure. But he could tell you how much money he had coming out of that bale of cotton, to his part, you work on the thirds and fourths.

Sitton: He knew what the bottom line ought to be.

Flowers: Right, um-hm.

Sitton: But the price of cotton went all over.

Flowers: All over, up and down, yeah.

Sitton: That was a hard way to make money, it seems to me, because you couldn't even tell what - One year it could be worth three times as much.

Flowers: Yeah, next year it couldn't even be worth selling, even taking to the gin. But a lot of times they'd catch the gins, they wouldn't sell. They'd store it until the next year or either late on up in the fall, then they'd sell it.

Sitton: How would he do his cotton, would he sell it on the same day he ginned it?

Flowers: Right, um-hm, in order to pay the landlord, give him his money.

Sitton: He really didn't have the luxury of keeping it around, waiting for the price to go up, he had to take-

Flowers: He had to take whatever he got for it. And then go settle up with the landlord, yeah.

Sitton: But Dennison didn't have anything to do with him selling his cotton.

Flowers: No.
Sitton: He sold his own cotton and got the best deal - Would he go around and see who'd give him the best, the best deal?

Flowers: No. Whenever the bale of cotton come out of that press and set out on that platform out there, then that's when it was sold.

Sitton: So, he was basically selling to the gin?

Flowers: Yeah, right.

Sitton: Were there more gins around then, or was that the main gin at the time you're talking about?

Flowers: Let's see, let me think. Yeah, that was the only gin in McDade, had two or three in Elgin and had one in Bastrop, and there wasn't no other out in the country nowhere. Well, long time ago, yeah, there was another one on the old Hancock place. That was coming out of McDade over on the old road going to Sayers - going to Piney. Used to be an old gin over there.

Sitton: Well, you know, the further back you go, the more little gins there are around. Then they consolidate and finally at the time you're talking about, they're just a few.

Flowers: Just a few, yeah, uh-huh.

Sitton: Was the gin at McDade a diesel gin or was it steam?

Flowers: Let me think, what did they operate them gins with? You know, I don't remember.

Sitton: That's a hard question. Did it have a whistle? Did it blow a whistle?

Flowers: No, I never did hear one.

Sitton: Probably it was diesel.

Flowers: I didn't hear one. I know there was a gin there, I knew the guy that run it, old man Alton Thiele. Yeah, old Thiele run it, then his boy taken over, and he went into peanut business, he bought him a couple of peanut thrashers, and he'd go around and thrash peanuts during the summer, 'cause my brother and my two first cousins, they worked with him the whole peanut season. Man, sometimes they'd come in they'd 
be covered in dirt. Mama'd say, "I don't see how y'all can stand it." Yeah, but you got to make some money. Sometimes they'd work seven days a week, thrashing peanuts.

Sitton: Well, the peanuts are covered with sandy land soil, and flies up. I've never seen a peanut thrasher in action, but it must be in a cloud of dust.

Flowers: Yeah, all the time. See, way they did back in them days they didn't go up and down the row and thrash them. These guys would haul peanuts and stack them, and they'd pull that thrasher up beside that stack, and they'd get on the stack and throw it off in the thrasher. And it was dirty, man I'm telling you it was dirty!

Sitton: They'd stack them around a pole?

Flowers: Some of them would, that's when they're going to save them a long time. But if you're going to thrash them that year, you'd take them and put them in ricks, they call it. Yeah, and then just pull the thrasher up beside of there.

Sitton: So the idea is that the air gets to it and it all dries out and it doesn't mildew, but you get to it fast.

Flowers: Right, right, faster, because it's already right there together, you don't have to be bringing it there in a wagon. 'Cause sometimes you get behind with the wagon, and then the thrasher had to wait on them until they get there. But most of them, they had time to get them up before the thrasher, they'd put them in ricks.

Sitton: How much older was your brother than you?

Flowers: A year and six months.

Sitton: There's stuff that happens to the oldest son that doesn't happen - (Flowers laughs)

Flowers: Yeah, he kind of got out a little more than I did, and I stay around home most of the time.

Sitton: Some of the getting out sounds like real hard work.

Flowers: Yeah, yeah, yeah, he done some pretty hard work. Yeah, 'cause after he got out of the army, he done lot of construction work on the highway, building bridges and curbs and gutters, stuff like that.
And operating machines on the highway - he drove a truck for Harlan Paige for a long time, using that Roadmaster. And after he quit that, well then he went to work for Miller, was doing construction work on the highways, building roads and running backhoes, and first one thing and another.

Sitton: That stretch of country when you start to get into the pines, all the way down to Highway 21, now that was part of the World War II Swift. Is that kind of different country down there? Fay said something about they called it Sand Hills.

Flowers: Yeah, um-hm.

Sitton: What did people do down there? Was it different?

Flowers: Yeah, it was different down there, there wasn't nothing hardly going on down there, 'cause there wasn't no land to work, 'cause it's all pine trees. It's just a few people lived in there, but, like, they would come out and go to this one's farm to work here and yonder and there. And then, when the sawmill come in down there, well a whole bunch of them went to the sawmill.

Sitton: Tell me about what you know about the sawmill. I know they were cutting, that place was getting all cut out in the twenties, wasn't it?

Flowers: Well, let's see, let me think. Naw, the sawmill was right off of [Highway] 21, it was about three or four miles out of Bastrop on 21 going toward Paige. And then you could get to it from this side, but you had to go through where this church down here's moved from, going up the road a little piece and then you can cut across to the left and go back to the sawmill. Now, the sawmill must have come in there in the late thirties, yeah. Well, about the middle thirties, I'll put it that away, 'cause I wasn't big enough to work down there, then.

Sitton: Do you remember the name of it?

Flowers: Naw, sure don't. All I know, they come in here from Louisiana.

Sitton: And so they were cutting pines, they weren't cutting red cedar. 
Flowers: Naw, all they's cutting was pine. And they got all the pines they could cut, that people would sell to them, then they finally had to move out. I don't remember how many years they stayed there, but they stayed there a good while.

Sitton: Did they have like a company store for people who lived there, like East Texas?

Flowers: Yeah. Yeah, they had, they brought mostly their own crew in here with them and built little huts out there for them to stay in.

Sitton: Were they using railroads to log, or-

Flowers: Trucks, they just trucked everything out.

Sitton: So, we were into truck time?

Flowers: Yeah, truck time instead of railroad time, because it's too far to put a railroad back there, and then they wasn't going to stay there that long to build a railroad back there. They just contracted for so many logs and so much timber out of there, and then after they got all what they're going to get out of there, they taken up and left.

Sitton: Well, you know, the CCC, they were coming in there with the state park. Kind of after these people had cut out, is that right?

Flowers: Right. No, it was kind of rough times back in them days. I remember a couple of boys from Bastrop, they bought some trucks to help them haul them logs out, and one old boy when they left well he had to sell his truck, and he left and went to San Antonio. And I went to San Antonio and stayed over a while in '40. (taping interrupted) We hauled with a wagon and mule for a while. So, after my daddy bought that old Model A, we taken some boards and put them on the back, run them under the bumper, set the water barrel on back there, and we hauled our water back there on the back of the old Model A.

Sitton: So, you wouldn't have to lift the barrel down from-

Flowers: No, we could just drive over to the side of another barrel and dump that water out of there into another barrel then set that one off and get ready to haul some more. We'd set that barrel back up on the old Model A. It wasn't no truck, we just taken a board and stuck it under there. Set the water on there. Yeah, my brother said, "I'm gonna fix out a way to haul this water, we ain't got no trailer." So, that's what we did.

Sitton: People just take water for granted, but you don't take it for granted if you got to haul it from the well or the spring.

Flowers: No, and when you got a barrel of water, you had to use it for what you're going to use it for, no throwing away.

Sitton: This one lady told me that she was telling her grandchildren how they used to haul water in barrel from a spring on a sled.

Flowers: (taping interrupted) Right, I've hauled it on a sled, too. Hook the mule to it, and-

Sitton: And her grandchildren were looking at her like, this has got to be a joke.

Flowers: I've hauled a many a barrel like that, and sometimes the road get kind of rough and the old mule wouldn't do just right and turn that barrel over and have to go back and get another one. (laughs)

Sitton: Well, those sleds were just skidding along over the surface, right?

Flowers: Yeah. See, get two something like a fourby-four and nail your boards across there, and put you a stiff one across the middle, and then tie your deal out like that, and then hook the mules out there. And if you don't want it to dig in the ground, you kind of slope it in the front.

Sitton: And that would just slide right over heavy sand or mud.

Flowers: Right, yeah, yeah. Naw, you name it, I done done some of it.

Sitton: Well, you left here by the time you were twenty, or so, but by the time you were twenty you had done everything on the farm.

Flowers: Yeah, right, right, everything on the farm, because I stayed on the farm until I was twenty.

Sitton: You had participated in everything that went on from the time you- 
Flowers: Yeah, 'cause I'd always done little odds and ends, first one little thing or another. (taping interrupted)

Sitton: What's your sense of how the people reacted when the army came in here and took their land?

Flowers: Everybody was upset and wondered what it was [that] was taking my land and when was they going to pay me and how is they going to pay me and then where they going to send me. And when the first coming in and started taking land, they said they was going to set them up somewhere. But they didn't do it, they just said, well, you got so many days to get out. And so, when we got out, well, we went to McDade and stayed there a few months, and then the guy told us, say "Well, if y'all want that house, you can have it." Well we tore it down and moved it to Elgin, that's how we built a house in Elgin, we got three acres up there in town there.

Sitton: Well, as I understand it, they were not buying people's houses and improvements, they were just paying for the land. And they'd say, "Of course, you can keep that house, if you move it." But it's not easy to move your fences and your houses.

Flowers: Naw, back in them days there wasn't no house movers, and so if they moved it they had to tear it down, and that's the way a lot of them did. And a lot of them they stood up there and they said, "Well, y'all can have it, I'm gone."
Sitton: Scott Falls, did you ever go there? What do you remember about that place?

Flowers: Well, see, Scott Falls, you go across the woods here and it be about a mile across there. I really didn't go to it a whole lot but I had some friends lived up there close to it, worked it, and had watermelons around there. Scott Falls was more like a swimming hole. Lot of people went there to go swimming.

Sitton: Where that old German had had his wine operation. But anyway, what was left was a rock dam on the creek, right, and a swimming hole?

Flowers: Right. You know where this Exxon station is over here on the road going to Lexington, [Highway] 696 ? You go about a hundred yards down there, then turn back to the right, and it's right off down there about a mile, down in the woods down there. I think it's still there.

Sitton: Yeah, I've seen pictures of it. That rock construction-

\section{Interview with $\mathrm{O}$ L Flowers \\ Interviewed by Thad Sitton \\ Date: April 6, 2004}

Place: Home of Flowers, Elgin, Texas

Year of Birth: 1920 


\title{
Dean Fort Interview
}

\author{
By Thad Sitton
}

\section{April 2004}

Thad Sitton: This interview is part of the Texas State University, San Marcos, Camp Swift Oral History Project sponsored by the Texas National Guard and conducted in conjunction with the Center for American History, The University of Texas at Austin.

Sitton: I know the Forts were one of the old families of the lands that became Camp Swift, is that right?

Dean Fort: Yes. My granddad was born in land at Camp Swift. Do you know where what we call Scott's Fall? Scotts [Scott] used to live down there. His place is just right past Scott's Fall on the left, there, where my grandfather - my great-grandfather owned it originally, and it came down after my grandpa died. His brothers got the land, and it wound up with one. John W. Fort owned it at last. He was the last one that owned the property before the government took it, and he didn't move out. They actually forced him out. They packed up his stuff out, because he wouldn't move. He was born on that place. My grandpa was born on that place. But he paid all his brothers and sisters, and he wound up with it. And he never - we called him Doll Fort-like a little doll, but his name was John W. He never married; he lived alone over there. I used to ride my bicycle over and spend the weekends with him. He could cook just about as good as any woman could cook. He was a big man, and he was kind of a harsh man, but he was a good man. And we'd go over there and I'd gather eggs for him, and he'd make us a cake or a pie. And had Sandy Creek run down below his place, and I used to go down there and catch perch and bring 'em back, and he'd clean 'em and cook 'em for us. But he never had any electricity, any running water. He had nothing like that over in the sand hills where he lived. But he lived there until the government forced him out of there. Like I say, he wouldn't leave. He told 'em, no, he wasn't going to give away his property. $\mathrm{He}$ lived all his life - he was born there.

And then I had Uncle Auss Fort, which was greatuncle also. He lived down close to Oak Hill Cemetery. We were there a lot, and we used to travel the old road

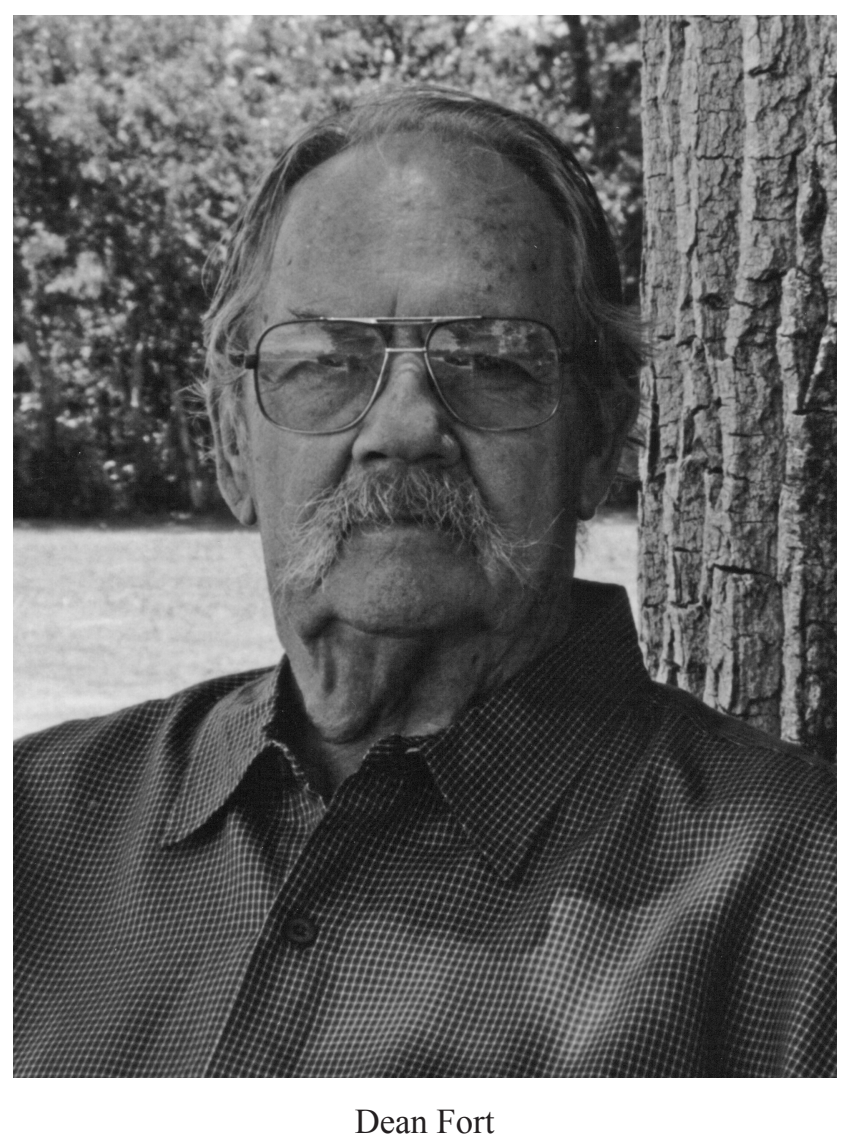

that went through Camp Swift going to Bastrop. I've traveled it a many a time. When I cross [Highway] 290 down here by Loop 223, and you circled around and you went past Oak Hill Cemetery, well, you came out in Bastrop. That was the old road. He lived there, and we had - I've known lots of people — we used to visit people down in there, you know, all the time. 'Cause, as I'm sure you know, 'round Oak Hill used to be a regular city anyway.

Sitton: What about Oak Hill? I've been reading Polly Owen's columns in the Bastrop paper. Yesterday, I read completely through 1925 , which was the big drought year. I knew what was going to happen in 1925, and I wanted to see what - Talk about Oak Hill. What was at Oak Hill? I know the cemetery and the school. 
Fort: They had a little store down there, but I don't remember exactly where the store was at. The Forts are all over the Oak Hill Cemetery. Anywhere you turn in the Oak Hill Cemetery you'll see the name Fort, which was all my relatives. During World War II, when the Camp had it, we used to meet down here at [Highways] 2236 and 290 as we had a family member pass away, and they would escort us to the cemetery, and after the funeral they would escort us back out.

Sitton: So the cemetery was just over the edge into it, right?

Fort: No, it came to 290. It came to 290, yes. Down here on 2236, probably a quarter of a mile maybe back from 290, they had a gate, and that was far as you could go. But on towards Elgin up here, I think it was right this side of Sandy Creek, she came over to 290, and then it had land almost all the way to Elgin. They just closed the cemetery off, and the only way, if you wanted to bury your people there, they would let you in, but you had to be escorted. We buried, I think, two - either one or two of our family members during World War II.

Sitton: What would you say about your Uncle Doll?

Fort: He was my great-uncle.

Sitton: Great-uncle.

Fort: He was my grandfather's brother.

Sitton: Could you describe his farm?

Fort: Well, he raised corn and watermelons, and he raised a little cotton. I don't remember-I think he had about a hundred acres left, I believe, and maybe not that much. My great-granddaddy sold part of it. Well, he traded part of it for cotton. In fact, that's the way my great-grandpa got the land the first place was trading bales of cotton for the land. He didn't pay, he traded cotton, which at that time, cotton was worth more than the land was. And he used to bootleg. During prohibition, he made beer-he sold beer. And he never owned an automobile. We used to go-my daddy'd go and take him to buy his groceries on weekends, and he wouldn't hardly go and spend the night with anybody. He wanted to stay at home. Like I say, he was quite a unique person. Had to be to live in them sand hills over there by himself. The Scotts were closest neighbors, and he had to walk, and the old road going down to his house was deep sand you couldn't hardly get there when it was real dry. Couldn't hardly get down to his house. But I spent a many a weekend over there with him, just he and I.

Sitton: Well, if you're just by yourself, by the time you get to be old, you're going to be a little eccentric. Did not marry, no children.

Fort: No children, never married.

Sitton: Did he have gardens?

Fort: He raised gardens, and he raised his own vegetables. And he had chickens.

Sitton: You know, we're interested in that sort of-I want to do a good job trying to describe that sort of subsistence side to the farm, which was so important. And the more you were on the sandy land, maybe the more you tried to live on your place. You couldn't grow a whole lot of cotton in that kind of country.

Fort: They used to grow a lot of cotton around McDade here. Fact, I believe they used to have a gin here, too. But he lived over there. He mostly raised food for himself, and what little truck farming he could do around there. People came and bought watermelons, cantaloupes from him. And I understand back during Prohibition, he made lots of money selling home brew.

Sitton: Did he ever talk about that?

Fort: Oh, yes. I remember when I was a little kid he was still making home brew. He made home brew for years.

Sitton: What did he say about his home brew operation during Prohibition? He didn't make any stronger stuff, right?

Fort: No, that was the strongest he made was beer, but I understand his beer was pretty stout. Remember my dad say about his beer. But he lived, like I say, until the government forced him out, and they actually loaded his personal belongings and moved him out. And then after the war was over, he got a letter the government was going to sell the land back to him at a very reasonable price, and it made him mad. He was already mad at the government, so he told them he didn't want it back, because the house and 
everything on there was gone. And there was a man here in McDade by the name of - oh, boy - Fritz Kastner I believe was his name. So Fritz asked him, he said, "If you don't want it, Doll, how about letting me buy it?" Uncle Doll told him, said well, "Give me the money, and I'll mail it" — had an address to mail the money to-so Fritz gave him a check, and he mailed it back to the government, and the check bounced, so the government kept the land after that, and they still have it.

Sitton: Yeah.

Fort: And they still have his place, yes.

Sitton: I shouldn't admit this, but I've gotten a Christmas tree upon occasion down that way.

Fort: Have you?

Sitton: Yeah, went over the fence and looked around for unexploded ordnance or something. And I've heard a lot about Scott Falls. What is at Scott Falls?

Fort: There was two brothers called Aussilloux. One of them is buried in Oak Hill Cemetery. They started growing grapes and making wine. That creek area is fed by springs, and there is always a little water running, never ceased running, and they went in and took these old sand rocks and built a dam. Built one pretty high, ten- or twelve-foot high - piled them up - I don't know why they was built up there for, but that's where they got their water to make the grapes from. But what I haven't figured out was where Scott's Fall is and where their land was, had to go over a hill. I don't know how they got the water. I never figured that and never heard nobody say anything about it.

Sitton: So they had to have had some kind of a ditch.

Fort: I guess, I don't know.

Sitton: But how do you get a ditch over a hill?

Fort: I don't know. They were from Germany, I believe. Sis might have told you something about the Aussillouxs. We call her Sis.

Sitton: I read a little about-

Fort: The last time I was back in there, the remains of their old house was still there-parts of the cellar - but most of it all has been destroyed. But you can see where the old foundation was - they were still [there] the last time I was there.

Sitton: How far back in there is it off the road?

Fort: Oh, Scott's Fall is probably not even half a mile, I guess. But the last time I was there, it grew up. It's right this side of the Scotts' land. I think the Scotts' land was between Scott's Fall and my Uncle Doll's place. But we used to go down there as kids swimming.

Sitton: What do you remember about that, because that's one of the landmarks of this area, and all the kids say that. What was it like to go swimming there?

Fort: Oh, it was nice. In the pond there was deep water. Water was clear and clean. And we used to go down there, and of course you know how it used to be days back then, and we lived at the old Elgin Standard Brick Company, where I grew up just across 290 from Camp Swift, and we'd go down there and all the colored boys from the brickyard would be over there swimming, and we'd sneak up on them and take rocks and run them out of there so we could go swimming. But maybe the next day if they came up and we were swimming, they'd rock us out of there. It all worked out pretty good.

Sitton: Whoever was on the bank had the rocks.

Fort: Um-hm. Yeah, but last time I was down there it'd growed up so you couldn't even see it. Now, I'm sure you've heard of Otma Scott. He was one of the Scotts that lived down there close to it.

Sitton: This is just starting; I haven't heard much yet.

Fort: He's dead. He and his wife both have passed away now, but he tried here several years ago to get a state park made out of it. Well, the government, when they first bought the land and they fenced it along that road there, they enclosed Scott's Fall. And here a few years ago they built a new fence, and they came around and they left - they went around behind Scott's Fall and left it out - so you don't have any fence across it. I'm sure the property belongs to the government, but they went behind Scott's Fall. But it had grown up so with wild plums that you couldn't even get down there to it. But it used to be a-you'd go down there on weekends, people would be having 
picnics and everything else around Scott's Fall during the summertime. It was a nice meeting place. And I guess most everybody grew up around here's been swimming in Scotts' Fall. I know I have many, many times.

Sitton: Well, is there still a big pool of water there?

Fort: I don't know. It may have filled in with sand.

Sitton: It just tends to fill in over time, you know.

Fort: Yes, but the pier and the dams and everything are still there. But Otma Scott, he never could get a state park made out of it. That's what he wanted to do, which I think would be very nice. I'd like to see a state park made out of it myself.

Sitton: Well, I have seen photographs in some of the research reports of the stonework, and the size of the big stone blocks that that guy somehow got-he must have been a real stonemason.

Fort: I don't know if both of them were or not, or if one of them - one of them had to be a stonemason, 'cause they cut them old stones, and they're cut pretty square, too. Then they had to haul them by wagon or sled. How they got them there, I don't know.

Sitton: And they're so big, the ones I've seen with somebody holding a measuring stick by it.

Fort: You need somebody to take you. I would take you myself, but I can't walk hardly anymore, I've got arthritis, and I'm seventy-six years old.

Sitton: I was going to ask you that. So you're seventysix, and you were born in McDade.

Fort: No, I was born down at Webberville.

Sitton: Oh, at Webberville on the Colorado.

Fort: Yes, at my grandmother's farm down there. You know where [Highway] 969-47 is? It's right past it; there's a trailer park in there now. That's where my grandmother owned that. That's where I was born at, but I grew up at the old Elgin Standard Brick Company, and I went to school in Elgin, except during World War II, when they sent my dad to Galveston. My dad was a millwright, and they sent him to Galveston to work at Todd [Shipyard].
Sitton: If you just said in general, what did people do for a living over there before World War II? I know a lot of truck crops

Fort: Yeah, that was it. They just farmed. There wasn't many cattle raised back then. They raised more hogs back then than they did cattle.

Sitton: How did they raise the hogs? Did they let them run out part of the year?

Fort: A lot of them ran out. In here, around - we still got, we call them feral hogs now that still - the leavings of those old hogs that they let run out. They used to round them up once a year, they called it, mark 'em.

Sitton: Talk about that, because people don't know, you know. When people think about people raising hogs, they've got this image of hogs in the pen, they stay in the pen all year. That old country way of raising hogs.

Fort: Well, they turned them loose like cattle. And then once't a year, like I say, they'd round 'em up, sell some of 'em, and they would mark the ears so they would know who they belonged to, and that's when they'd turn 'em loose again, 'cause if they kept 'em up, they had to feed 'em. This way, they hustled their own food. So now we've got a lot of feral hogs left around here.

Sitton: Yeah, wherever people raised hogs out like that, and wherever they didn't cut down all the woods, you have hogs. They're a curse in East Texas. I'm from Lufkin, incidentally.

Fort: Well, people that raises coastal [Bermuda] around here, they have a lot of trouble with 'em, because they can root a three-foot-deep hole. You get off in one of them holes with a combine or something, they break 'em and everything else, you know. That's the way the people raised the hogs. They did not pen 'em. They run 'em loose.

Sitton: Well, when they let them run loose-a hog will walk through a barbed wire, like a regular fence, right? That doesn't stop a hog. So, if you're going to fence your property for hogs, you've got to put up a hog fence, and most people didn't bother. And their hogs would get on your land, and your hogs would get on their land, and that was okay, right? But once a year you've got to deal with the pigs — to find the pigs 
that are with the sows to mark their ears, or somebody else will.

Fort: Well, if the ears were already marked and somebody else penned 'em up, they turned 'em loose. They wouldn't do anything with 'em. But the hogs ran free. But like when they closed Camp Swift-well, there's still a lot of hogs in there, but there was a lot of 'em there when it closed up that people never had caught.

Sitton: Because they're not exactly like — cattle are more domesticated animals than hogs raised in this way. They're half wild; they're semi-feral, and now they're just wild.

Fort: Just wild hogs is all they are now. And I don't like the meat from them. Around here they eat it, but to me it has a taste to it I don't like. We had a friend here that had killed one that he took it to the market and had it butchered and vacuum-packed, but I still didn't like it.

Sitton: Would they get them up in the fall and some people pen them and feed corn, or did they just let them -

Fort: If they could, they would do that. They would pen 'em up, which a lot of people couldn't afford to, so they just herd 'em in and penned them, butchered what they wanted and cure the meat.

Sitton: How did they work 'em? Did they use dogs?

Fort: Most of 'em used dogs. Dogs and horses is the way they brought 'em in, 'cause a lot of them old hogs was wild. They'll eat you up, at least the ones they've got now. You better not corner one of 'em, he's going to come out past you.

Sitton: Did you ever see any of that working of hogs, or participate in it?

Fort: No, I never participated in working of hogs.

Sitton: It's kind of weird as I understand. It's not like herding sheep.

Fort: Oh, it's definitely not herding sheep, because them wild hogs will hurt you. Like I say, if you hem 'em up, they will. But I remember a couple of occasions on Uncle Doll's place down there, he'd shoot one of 'em and get in touch with Daddy, and Daddy'd go over there and help him butcher it. And they cured the meat. We had pork all year round, because my dad always cured it. We had sausage. I remember that my mother'd go out in the smokehouse and get a ham, and that ham would look like green moss growing on it, and she'd bring it in the house and mix some vinegar with water, and she washed it with vinegar, and then we'd eat it. I doubt if people would even eat one. Actually, I'd be afraid to eat one now. And then sausage hanging out there - they'd dry. They just like a dried stick, and I've got more than one whipping for stealing sausage out of the smokehouse. Smokehouse was strictly off limits. Everybody had their own smokehouse, you know. Even growing up there at the brickyard, my daddy had one milk cow. That's all that the old man that owned the brick company would let us, his employees own is one. So, we had milk and butter, and we had chickens, we had eggs. So, we made it pretty good there, and then my dad raised the hogs. Usually raised two, and he butchered two of 'em a year.

Sitton: So y'all were having just as much of the old country subsistence stuff as you could get away with.

Fort: Right.

Sitton: Or were allowed.

Fort: And Mama and Daddy usually had a little garden, and they raised a few potatoes, tomatoes, and we had vegetables. And during berry time and these wild plums, we'd go out and pick dewberries and plums, and Mama would make jelly out of it.

Sitton: Well, there's a whole lot of wild dewberries and plums in that sand hill.

Fort: Lots of wild dewberries still around here. Lots of wild plums, too.

Sitton: Polly Owen and the great drought year of 1925, she said at a certain point the wild dewberries have failed. You know, not enough rain. You know, it's like doom is coming.

Fort: Well, you know them old dewberries, if it's real dry, they don't make and they don't come up, they'll lay there and wait till next year and maybe it'll rain. If it does, maybe they'll come up then. It's like the bluebonnets. About the same way. 
Sitton: Well, the story of life on the farm in this area is the story of the sandy land, which is a different kind of farming existence than, say, life on the blacklands. It's different, and it's more precarious, I think, right? I mean, the blackland retains moisture better and makes cotton better, but cotton is, sometimes you get it, sometimes you don't. Well, what about hunting and fishing?

Fort: They did lots of hunting around here, squirrels and rabbits back when I was a kid. I don't believe we had any deer around here then. I think the deer was brought in by the state and put in the park down at Bastrop - the first ones I remember, the deer. And now the deer is pretty plentiful all over Bastrop County.

Sitton: Yeah, they're really coming back. I mean, I can remember twenty years ago, I would not see-I was already in Austin - but I wouldn't see a deer in Bastrop County, but now-

Fort: Have you ever been down to Oak Hill Cemetery when they had a picnic? You need to make one of 'em, 'cause the last of the old timers will be there.

Sitton: That's in May, isn't it?

Fort: Yes, I think it's in May. But, there's not many of 'em left.

Sitton: What happens at that event, because the columnist, she was Mrs. Edgar Owen-it was Polly-I don't know what her maiden name was, but it was Fay's aunt by marriage. And she's already describing the cemetery association meeting - it was like the big event of the year by 1925 . What happens?

Fort: Well, everybody brings food. I know when I was a kid, you couldn't hardly get down there and find a place to park, it was so many people. And the main reason was to work the cemetery. And they used to not mow the cemetery. They chopped the grass up, and they had just a dirt - no grass growing in it. But now they're letting some of the grass grow, or else they may be spraying it; I don't know how they keep the grass out now, but used to, Oak Hill had no grass growing in the cemetery.

Sitton: And the cleaning the cemetery would be getting the grass that had sprouted since last May.

Fort: There was always plenty of food, and it's still now, when they have it now, the few old timers left, they're there. But like I say, that's not many of 'em left. Most of 'em are gone already.

Sitton: People come back from Houston or Dallas.

Fort: Far and near, they show up at Oak Hill.

Sitton: Well, what did they use to do, going back to when you were a boy and attending those, what would they do besides clean the cemeteries?

Fort: They played games. They'd play ball. Us kids, we just played and run through the pastures down there. But when I was a kid, we never missed a picnic. People'd come in there, and the farmers would donate a calf, and they'd barbecue that calf right there. You've been to Oak Hill Cemetery, haven't you?

Sitton: I have not. I haven't been there; I may go there today.

Fort: If you go back to 290 right here and turn left and go about two hundred yards, and the McDade Cemetery will be on your left. If you turn right, right there on 2236, Farm to Market Road, and you go down about four miles, you'll see - the cemetery sets off the road about one hundred to one hundred fifty yards to your left. You'll see a sign that says Oak Hill Cemetery, and that's it. It'll be on your left when you turn there.

Sitton: Well, if we talk about the sort of settlements that were on this land - and I know the big Camp Swift went all the way down to 21 , right? I know it filled out that triangle going south.

Fort: [Highways] 21, 290 and 95. They had almost all that.

Sitton: And the little Swift just fits in the top part of the triangle now.

Fort: (talking at the same time) And they've still got over fourteen thousand acres.

Sitton: They've got almost thirteen.

Fort: Almost thirteen?

Sitton: Yeah, but it was fifty-two orfifty-three [thousand acres]. Am I right that the biggest community that was on this land, anywhere in the triangle, was Oak Hill? 
Fort: Oak Hill, yes.

Sitton: Then what about—I've heard about Wayside.

Fort: Wayside there was a school. That was back up thisaway back in Camp Swift down there. Always a country school there. The Scotts and the Evans, and the Mundines. They all had places in there. The Doobies.

Sitton: But will people have said there was a Wayside Community?

Fort: Community. There was a school there.

Sitton: They would have? We're talking about informal communities, I know, but people back in that day would have said, I live in Wayside or I live in the Wayside Settlement or the Wayside Community.

Fort: Um-hm.

Sitton: Okay. What other settlements? What about that Dogwood? Would that be another one?

Fort: Dogwood - there's a creek back in there named Dogwood, but I don't remember too much about it.

Sitton: There were black people living back in there across from Fay. What about Piney?

Fort: Piney Creek runs down farther, down 95.

Sitton: There was somebody doing a column in the early 1920s from Piney, like it was a community.

Fort: Well, I think that along Piney down there somewheres there used to be a settlement, but I can't say.

Sitton: That's way down at the other end of it, anyway. Did your people - did they make any use of the red cedar?

Fort: They sold lots of it.

Sitton: Talk about that.

Fort: And they built fences and used the cedar. Cedar used to be a big deal around here - cedar and oak. A lot of people cut wood around here. Sold the cedar for posts, and they made lumber from the cedar. Anybody that owned land sold the cedar off their land.

Sitton: Mostly as posts?

Fort: Post oak. You got red oak.

Sitton: But I mean the cedar, would they have made posts and sold it as fence posts?

Fort: Mostly as fence posts, yes.

Sitton: So like when you were a kid, you know, your great-uncle and your uncle, and so forth - the cedar goes way back down and then gradually merges with the more part of the pines.

Fort: Well, I remember Uncle Doll-I don't ever remember his selling off his place. I remember people coming there and he'd give it to 'em, and they'd cut it for fence posts and haul it out, but I don't remember him selling any of it. It was just like the oak wood for fire. He had friends come in down there, and they'd cut it for firewood, but he didn't charge 'em for it, he gave it to 'em. So I don't know if he ever sold it or not, because I never did see him sell any of it.

Sitton: And of course, what he got was a little clearing out of - you tend to get too much cedar, right?

Fort: Um-hm.

Sitton: What kind of stock did he have, if any?

Fort: He had a few hogs and chickens, and two or three cows, milk cows. That's all he had. He didn't raise cattle - just him by himself, he never raised many hogs. You couldn't get anything for 'em when you sold 'em.

Sitton: Most people raised hogs for their own use.

Fort: For their own use, yes. That's what he did.

Fort: He chewed the old Day's Worth Chewing Tobacco in a plug. And he'd get him a big cut of it and chew it until he chewed all the juice out of it, and then his house had wooden windows, and he'd lay it up on the window sill and let it dry. And once it dried, he crumbled it up and smoked it in his pipe. But he lived to be eighty-something years old. 
Sitton: That's old bachelor behavior, right? Your wife would never let you do that.

Fort: No, but I remember him doing it ever since I can remember. You'd go out to his house and there'd be two or three plugs of chewing tobacco drying on the window sill, and you'd better leave it alone, too, because he was going to smoke it.

Sitton: Well, there was an old waste not, want not country tradition, and that's a new one. I've heard about after the cotton pick sacks wear out, all the things they get made into. But he would chew it until it was basically chewed out, and then he would put it on top of the - so he used it twice.

Fort: When he got rid of it, there was nothing left of it. But he did that for years and years until he got too old and finally quit smoking. And that old pipe, like in the wintertime, house was closed up, you couldn't hardly stay in the house with him with that old pipe, smelled so bad, because he never cleaned his old pipe.

Sitton: How did he get his water?

Fort: He had a well—right beside the house.

Sitton: Could you describe his house? What did his house look like?

Fort: What do they call them old houses made out of one by twelve planks that stands upright? That's the kind of house it was. It had a porch across the front of it, and he had one fruit tree, which is peach, and that thing made more peaches. Everybody in the neighborhood got peaches off it and made jelly. Mother used to go over there and get 'em and make jelly out of 'em. 'Course, he made his own jelly, too. He could cook anything anybody else could cook.

Sitton: What would he cook?

Fort: If I was over there and we caught fish, he'd cook fish. He may go out and kill a chicken, he'd cook a chicken, or he'd make stew. He could make real good stew. He just cooked dried pork or something that he had, you know. But he cooked just about anything, and he made cakes and pies.

Sitton: If he wanted to eat it, he had to make it.
Fort: He only had two ways out from down in there where he lived: he could ride his horse out or else walk from back in there where he lived, 'cause he could sit out there on the old dirt road three days and nobody'd never would come by. Not like it is now. And down that road there's a-I don't recall, I bet there's maybe one or two families that lives down that road now, because it goes back in there. Used to go all the way to Bastrop, too, thataway. 'Cross 95 by Sayers down there, but now the Camp has got it blocked off. You can't go through there anymore. I've been to Bastrop many a time thataway.

Sitton: I did not realize until I went by it today and read the sign that that road which I knew, which I had gone down, was the Scott Falls road. I've seen it on the old maps, and I knew it used to go right all the way across the country. How did you fish the creek when you were there?

Fort: Mostly grasshoppers or dig worms, or use maybe if it was watermelon season, you'd use a piece of watermelon. They used to catch them perch with watermelon. I caught a many of 'em on watermelon.

Sitton: Now, watermelon seed or piece of watermelon?

Fort: No, a piece of water-the meat of the watermelon.

Sitton: A little piece of red.

Fort: Um-hm. Used to catch 'em on corn. They liked corn, too.

Sitton: Now this is Sandy Creek.

Fort: Sandy Creek. Same creek that crosses right up 290. You crossed it coming out here before you got to McDade up here.

Sitton: I interviewed recently Mr. Flowers - elderly black man in his eighties - and he said they would go fishing down Sandy Creek. They would take a wagon and I guess fish in the big holes as they went, because one big hole on the creek you couldn't set up business there all day. You'd fish around a little. He said they also got fish by muddying, or muddin'. You know about -

Fort: Right, right. Mud 'em up and you get out there and catch 'em by hand. 
Sitton: How would you do it? Would you walk around on the-

Fort: You'd walk around and stir the mud to get the water real muddy, and they come to the top for air, 'cause they can't breath that real muddy water. You just pick 'em up.

Sitton: That's like a creek technique, right?

Fort: Right, right. Yeah, over there at the brickyard during the summertime when the creek'd just have a pothole or two in it, that was Sandy Creek too. Bunch of us kids would get down there and we'd muddy up them holes and we'd catch us a mess of fish. I'd bring 'em home and Mama would cook 'em. 'Course, when I was a kid, we ate - only thing we had for meat mostly was pork, squirrel, fish or rabbits. And then the people got where they'd raise a calf from their milk cow, and then maybe this neighbor this month would butcher his calf, and he'd pass it out to all his neighbors, and maybe the next month another one would have a calf big enough to butcher, they'd butcher it and they'd do the same thing. But it wasn't sold; they'd pass it out. That's the only time we had any meat - beef.

Sitton: That's that old beef club thing.

Fort: Well, that was before the beef club started. This was just neighbors over there.

Sitton: Just sharing. And you would sort of expect that when they did it -

Fort: Yes, because you couldn't keep it. You had no refrigeration. And my mother and a few of the other people over there, they'd put it in jars - seal it up in jars. It was canned meat, but it was good. My mother used to take sausage, pork sausage that her and my dad made, and she'd cut 'em into pieces of little short lengths and pack 'em in quart fruit jars, and then when she rendered the lard, she would take that hot grease and pour over 'em and seal 'em. And then July and August she'd open one up and get-just like they were fresh made. They would stay fresh.

Sitton: So that hot lard would completely seal.

Fort: Seal 'em over, put a lid on it, you know. And they kept.
Sitton: Yeah, I think I've heard of that being done in crocks, too, like, but this was a way to do the same thing in jars.

Fort: Well, my mother had some five-gallon tin cans, and she'd take them sausage and put rings of 'em in it and then fill it up with grease. Thataway she kept the grease, and she used the grease, then when she'd get down to the sausage, she'd take the sausage out and we'd eat 'em. Then they dried 'em and just left 'em in the smokehouse, and they'd dry, and that's the way I liked 'em, just dry as eating a piece of jerky or something.

Sitton: Turkeys. People used to raise turkeys out there, right?

Fort: Oh, lots of turkeys.

Sitton: Can you explain that, because I know that's not just turkeys in the pen either.

Fort: Oh no, the turkeys ran loose, and most of 'em it was the kids' job when the turkeys started laying to watch the old hen and to watch the nest so they'd get the eggs. And I know my grandmother, she always raised a lot of turkeys, and I had an uncle-he's passed away now, but he was about three or four years older than me, and that was our job. And we spent all day long trailing one old hen, trying to find her nest, and if she spied you watching her, she would not go to that nest, so you'd spend the whole day and then don't find no eggs. That and guineas. We had to look for the guinea nest, too, 'cause they lay the same way, you know. They hide their nest. But I spent a many a day following those turkey hens. Find a nest, and Grandma always give us a big spoon, and she said, "Don't put your hand in that nest, because they'll quit laying. Use this spoon. Reach in and get the egg out with the spoon and not touch the nest." And the turkey would go back to the same place, but once you found her nest, you could keep getting the eggs out of it.

Sitton: Well, what would you be doing with the eggs?

Fort: She brought it home and she set 'em and hatched turkeys. And she'd have an old turkey hen start setting, she'd put her in a coop and set her. Same thing with guineas. Most of the guineas, though, she just let them - you're not going to find their nest, and they'd bring little ones home when they'd hatch out. And 
turkeys are a little delicate - their babies, you can eat 'em up before you can take care of 'em. But she raised a many, many turkey.

Sitton: Well, what you're saying if I understand it right is that the turkey hens would start laying out in the woods, which is where they preferred. They wouldn't lay and go into the henhouse. And if you found their nest, you could keep removing the eggs back to the house where a turkey hen - a different turkey hen - so you had one hen brooding the egg, but the wild turkey hens might be still laying out there in the nest in the woods.

Fort: Right. You put your hand in there, they wouldn't lay anymore. I guess it was the human scent. These turkeys wasn't wild, though, these were domesticated turkeys. And that's the way she always raised all her turkeys. She always had lots of turkeys. Eggs. If she'd get more eggs than she wanted to set, we ate 'em. Just like eating a chicken egg. To me they're a little stronger, but they were all right.

Sitton: Would they come up to the house to roost?

Fort: Most times they would come way in at night to roost, and then if you had a turkey hen didn't show up, then you knew that hen was setting somewheres, that you hadn't found the nest. But they would eventually bring the little ones home.

Sitton: Just like the guineas. So sometimes you might never find a nest.

Fort: Right, and they would set and hatch the turkeys themselves.

Sitton: But she's coming in to get some corn at the end of the day. Little corn.

Fort: Yeah, Grandma raised lots of corn, and she had a crib. She put it in a crib, and then go out and shell that corn, she fed that corn to her mules she worked the crops with. She fed it to the cows, her milk cows, and she fed it to the chickens and the turkeys and the guineas. Whole grain corn. And then we'd go out there and shell maybe a fifty-pound sack of corn, and most of the corn by then was already full of weevils - you know, weevils used to be real bad-but the old McKann Store down there, we'd take it to the store and they had a mill where they made cornmeal, and there was no money exchanged. The man that operated the mill, he got a certain amount of cornmeal, and my grandmother got the rest of it, which was, I guess they called it barter, whatever they called it. Same thing she used to raise a lot of sugar cane. We'd take that sugar cane up there, and they'd squeeze the juice out of it on the mill and cook it and make syrup out of it. And the man that operated the mill, he got so much syrup and then Grandma got the rest of it.

Sitton: Where was the syrup-making operation?

Fort: This was at Webberville when I was a little kid down there. But we moved to the old Elgin Standard Brick Company I think when I was seven years old. My dad was already working there. He had been working there when he came all the way back in a Model $\mathrm{T}$ from Webberville to the brick plant. I had another uncle - my dad's brother worked there, and he stayed with them. And finally he got a house there at the plant, and so we moved to the brick plant. But my dad would drive back and forth in a Model T, but he only came home on weekends, 'cause he couldn't afford to buy gas.

Sitton: It's funny, there was a string of Model Ts - maybe not a Model T, I think it was Model As and somewhat newer cars going toward Austin. I just passed them - must have been twenty or thirty of them.

Fort: They were probably going to a show or something.

Sitton: Yeah, some kind of show. What were the roads like over there?

Fort: A lot of 'em, like I said-you've been down [Highway] 1704, haven't you? It wasn't even paved. Used to be a lot of big gravel rock in it. Some of the hills you couldn't hardly get up and down, and my dad had an old Model T, and the gas tank was under the seat. And he came up too steep a hill you couldn't pull it, because it would die out for gas. So some of the hills he'd turn around and backed up 'em so he'd keep getting the flow of gas, because it didn't have no fuel pump on 'em. But my grandmother, my dad's mother, she lived out at Eden, out close to San Angelo, and Daddy'd drive that old Model T out there. We spent almost all night long getting there.

Sitton: They don't go - they're twenty, twenty-five, like, [miles per hour], right? 
Fort: That's it, yeah. When you put 'em on long trips, you can't run 'em that fast, because they don't have a water pump and they'll overheat on you. But you get in them hills up there, you know, it'll overheat. But my Dad, used to we'd leave the brickyard, which was the old [Highway] 20 which runs downhill, and he'd have a flat, and nobody had hardly a spare back then - he'd have a flat in that old Model T, and if anybody came by and you were fixing a flat, they always stopped and helped you with that spare.

Sitton: Not today.

Fort: Yeah, and used to my grandmother would come to Elgin on a wagon, and to buy supplies - she traded with a man by the name of Rivers. He bought cotton, he owned a gin, and he had a grocery store. And she bought her groceries all year long, and when she gathered her crop at the end of the year, she'd take her cotton to Elgin, he'd gin the cotton, he'd charge her for ginning the cotton, he bought the seed from her - the cottonseed from her, and then she paid her grocery bill, whatever she owed, and if there's any thing left, which was always a very small amount, and that was it.

Sitton: Now this grandmother that's dealing in Elgin, where did she live?

Fort: She lived down at Webberville. That's where I was born at. That's my mother's mother. My dad's mother lived out at Eden.

Sitton: But a lot of people had that kind of relationship. The people out there on the Swift lands, where would they have traded? Would they have traded in McDade?

Fort: McDade or Elgin, between the two. But most all of the people that lived in the farms, they didn't have the money to pay for their groceries, so they paid when they got their crops. But they didn't buy like they do now, 'cause they raised everything they needed except flour and salt and pepper. So we never bought any lard, cooking oil. We used hog lard. My dad would never butcher hogs until it got at least five hundred pounds, so you imagine how much fat you were getting out of that hog. He'd get ten to fifteen gallons of hog lard out of it, and that's what Mama cooked with. And then when she cooked bacon, the grease she cooked that in, she saved that too. So we never bought any grease.
Sitton: There was something back in one of the earlier columns, I think before Polly Owen started, around 1920, that they mentioned that the men and boys at Oak Hill have been out on a rabbit drive. People have told me about it a lot, but I don't know what they're talking about.

Fort: Well, the rabbits used to be so bad, they'd eat the crops up, so a bunch of men and kids would get together, they'd go out and they'd drive these rabbits up and kill 'em 'cause there was too many rabbits.

Sitton: Well, how did that work?

Fort: They'd just get behind 'em and just go to driving 'em like driving cattle, is what I've seen, you know, just driving 'em up. And then they'd kill the rabbits and they'd eat the rabbits. They didn't throw them away. They ate 'em.

Sitton: So, it was good sport, it was getting rabbit for food, but it had a kind of agricultural purpose.

Fort: Right, right, to keep 'em from eating up the crops.

Sitton: Well, people on sandy land farms raised a lot of sweet potatoes, right?

Fort: Oh yes.

Sitton: Peas maybe.

Fort: Peanuts, Used to raise a lots of peanuts around here, and lots of watermelons. Watermelon grows good in the sandy land. Cantaloupes. And, they used to raise a lot of cotton in this sandy land - cotton and corn. 'Course, around here they don't do much farming anymore. But here in McDade, used to people that lived back in around McDade and out around Oak Hill out there, they brought their wagon loads of watermelons in, and they'd have the train here in McDade. They'd load their watermelons. When I was a little kid, I used to ride my bicycle from the brickyard down here and help them load watermelons. And the best part about loading the watermelons was if somebody dropped one it and it busted, then you could eat it. That was the best part about it.

Sitton: Well, so they would sell some of them along the road. They might do it that way, but if they had a bigger crop and more watermelons- 
Fort: Right, they might bring 'em in to either Elgin or McDade here and load 'em. And then the trucks got to coming in, too, the big eighteen-wheelers, and they loaded them. Most of 'em I think went up north, but they'd sell all the watermelons they could raise.

Sitton: I failed to follow up on-the turkeys were sold, too, right?

Fort: The turkeys were sold, but they would take them, like my grandmother, she used to take 'em to Elgin. You bought the chicken live. You took him home and butchered him yourself. You bought the turkey live. If you was going to eat him, you butchered him yourself. But they kept 'em in coops. You'd go out there and look and say I want to buy one, I want this one, is the way the people bought 'em.

Sitton: Would mercantile stores buy 'em too?

Fort: Yeah, most of these grocery stores or feed stores bought 'em - bought the chickens and the turkeys.

Sitton: Yeah, and those turkeys were kind of raised for Christmas or holidays.

Fort: Holidays. Turkeys used to be-well, chicken used to be a Sunday dinner. You know, we always said that when the preacher's coming home, you had chicken. We knew when the preacher was going to come home and eat dinner with us, you was going to have a good meal. It was like Christmas. 'Cause, we didn't kill too many chickens, 'cause we needed them eggs. We'd kill 'em occasionally, if a chicken gets too old, we'd kill him and make dumplings out of him.

Sitton: So you ate really more pork than anything else.

Fort: We did when we's growing up, we ate more pork.

Sitton: And the chicken with your family tended to be a Sunday treat, and the turkeys tended to be raised to sell. Is that right?

Fort: Yes, well as late as up into World War II, we was in Galveston, Dad was working at Todd Drydock, Mother'd go down to a store there about three or four blocks from the house and the chickens were live. That was during World War II. They was still selling 'em live, and you brought 'em home and butchered 'em yourself. That was during World War II.
Sitton: I can remember 1940s being sent out to kill a chicken. My sensibilities were such that, you know, I liked to ring a chicken's neck, which doesn't reflect well on me. But, you know, eight-year-old boys are not very nice. Yeah, so your great-uncle - we're back to the taking of the land - your great-uncle said, no, he wouldn't sell. But then what happened one day? Did they just come in?

Fort: I don't remember what they gave him for the place, but they took the money and put the money in his name in the bank, and then they moved him out. He didn't have any choice.

Sitton: Yeah, they just rolled up one day.

Fort: Right. All they have to do is condemn your land, and they said we're buying at $X$ amount of dollars, you have to move.

Sitton: Somebody might have read him a little piece of paper that day and said -

Fort: Maybe so. I don't know. They forcefully moved him out, 'cause he wouldn't move. Like I say, he was born and raised on that land. He was born in that house he lived in, and he just didn't want to leave. He didn't think the government had any business taking his land away from him. But then at the same time, when they offered it back to him, he told 'em, no, he didn't want it. He had bought a place here in McDade - after they moved him out, he bought a place here in McDade.

Sitton: Well, as I understand it, a good many people didn't want it back, or couldn't afford to get it back, considering that they hadn't been appraised for the improvements when the government bought it, and then all the training had taken place, and all their improvements were gone, and they couldn't afford to buy it back at the original price, and they didn't have money to then put the house-

Fort: Right. Well, and like some people like with Uncle Doll, he decided he didn't want his, so he was going to let another guy get it. You know, he had to send the money in himself, and they would have probably issued a deed in his name, and then he would have had to transfer it into the other man's name.

Sitton: But the other guy's check bounced, is that right? 
Fort: Yeah, his check bounced, uh-huh. He had the money, but the check beat him to the bank what I understand before he got the money in the bank.

Sitton: And the government wasn't understanding about that.

Fort: No, they said, that's it. We'll keep the land.

Sitton: What's your sense of how [people] generally reacted to what happened? Was your great-uncle an extreme case? Were some of them happy to sell the land to the government?

Fort: Well, everybody that I knew and that I talked to, especially the Forts that lived, you know, down there - we had two or three Fort families lived around Oak Hill Cemetery - they were all disgusted, because they didn't want to get rid of their land, even though the old land, some of it was so bad they couldn't hardly make a living on it no more. But that was their home. They wanted to keep it.

Sitton: Well, you know, the papers at that time were just full of everybody is just so patriotic, they're so happy to give up their land. It just doesn't ring true.

Fort: Not all of 'em were. Now, some of 'em were happy, you know, they were glad to get rid of it. They were glad to do it for their country, where some of the old people, they said, no, this is home. Like old Uncle Doll, if they'd never made him move out, he would have probably been buried on the land. But he sat there all week long by himself out in them sand hills.

Sitton: No radio, no TV.

Fort: No radio, no TV and no electricity. No running water. But when I was a kid, I used to enjoy going over to spend the weekend with him. Sometimes in the summertime I'd go over there and spend three or four days with him. And he'd get up in the morning, he'd fix breakfast. In the summertime, it's warm, he'd go sit on the porch. And he sat there just about all day until come time to eat and he got hungry, and he'd go and fix something to eat. And he had to cook his own food. He had a wood cook stove, he had to build a fire, cook his own food. He made cornbread and biscuits just as good as anybody else could.

Sitton: So he would just sit there and think, right?
Fort: I guess that's what he did. There was nothing to look at but trees - oak trees and cedar, that was all.

Sitton: When people say that was another world, this is what they were talking about, right? We think we have to have a lot more entertainment than he thought he needed.

Fort: My dad asked Uncle Doll one time how come he never married, and he said, "Well, I couldn't have the one I wanted, so I just didn't want nobody." And years later, I found out that the woman he wanted to marry, him and her got in an argument and she moved down around Corpus, and he was too hardheaded to get in touch with her, and she was too hard-headed to get in touch with him. And then this was after World War II, and Uncle Doll was getting old. We were right along there by the bank in Elgin on Main Street one Saturday. Daddy had gone down and picked him up and took him to Elgin to get groceries, and this lady came down the street, she stopped, he stopped, and they looked at each other but never spoke. And I'm standing there, you know, I'm gone, and I'm wondering what's going on. And after she went on and we started up the street, I said, "Uncle Doll, what was that all about?" He said, "Aw, nothing." So later I asked my dad, and my dad said that was the woman that he was in love with that he wanted to marry. But she wouldn't speak to him, and he didn't speak to her. I said, now man, that's what you call hardhead.

Sitton: That's incredible. So she finally came back from Corpus when she was an old lady.

Fort: Old lady, yeah, but he never had anything to do with her, she never had anything to do with him. Never spoke to each other.

Sitton: But he liked to have you as company.

Fort: Oh, yes, he liked company, but he'd sit there and he may spend three or four hours and never say over half a dozen words.

Sitton: He didn't try to entertain.

Fort: Oh no, he'd just sit there. He had an old rocking chair, he just sat there in that old rocking chair. He lived quite a colorful life, though, when he was a young man. I guess he did a little bit of everything. 
Sitton: Well, the bootlegging-you know, when the government completely shut down alcohol, a whole lot of poor people, among them some of my relatives and my wife's relatives, worked that into their money economy. You know, they made a little whiskey or they made beer, because a lot of people were accustomed to having some.

Fort: Well, around here these people started making home brew, they got to living pretty good, because that beer was selling. You couldn't go to town and buy beer anymore. Like old Uncle Doll, he made lots of money. Fact, he made enough that one time he bought a brand new Model T and paid cash for it, and he put it in one of his brother's boy's name, and I think he bought it one day and about two days later my uncle wrecked it, but Uncle Doll never learned to drive. He never tried to drive. You know, about the only thing he could drive was a wagon, the mules you know.

Sitton: But he had enough income for a luxury purchase.

Fort: He made lots of money off that home brew, because he made good beer, and everybody liked it. You'd see people coming down there in wagons buying his beer, and then my dad, he would take him to Elgin and they would load up croaker sacks with beer, because they didn't have any boxes to put it in, and they'd take it to Elgin, and my Uncle Doll sold it out of the back seat of my daddy's Model T. So he made lots of money. And in fact I think that's where he got most of the money he had. He had quite a bit of old things that he gave it to me, but he had a sister-in-law in Austin, and when he passed away, she came down here, and my dad told her, said, "He's give all this stuff to my son." And she said, "Well, does he have it in writing?" [He] said, "No, but I have plenty witness that he gave it to him," you know, but I never did get it. I got one little jar that candy came in that looked like a lantern that his dad, which was my grandpa, had brought home and gave it to him full of candy.

\author{
Interview with Dean Fort \\ Interviewed by Thad Sitton \\ Date: April 132004 \\ Place: Home of Fort, McDade, Texas \\ Transcribed by Dan K. Utley \\ Year of Birth: 1928
}




\title{
Louise Smith Goerlitz and Erhard Oscar Goerlitz InTerview
}

\author{
By David L. Nickels
}

\section{May 2004}

Introduction: Although the primary interviewee is Mrs. Alice Louise Goerlitz, Mr. Erhard Oscar Goerlitz is a major contributor. Their daughter and son-in-law, Mrs. Janice Payne and Mr. Roger Payne, also provided stimulus during the interview. The transcribed conversations and a reading of a manuscript prepared by Mrs. Goerlitz follow.

David L. Nickels: This is David Nickels. Today is the twenty-seventh of May 2004. This interview is taking place in the home of Mr. Erhard Goerlitz and Ms. Louise Smith Goerlitz at their home at 773 Old Highway 20, one mile east of [downtown] McDade, Texas. This interview is part of the Texas State University-San Marcos, Camp Swift Oral History project, sponsored by the Texas National Guard, and conducted in conjunction with the Center for American History, The University of Texas at Austin.

Nickels: Well, first of all Mr. and Mrs. Goerlitz, I want to thank you for allowing us to come in to your home, and the hospitality, and to visit with you, and your daughter and son-in-law. We appreciate it. Just for the record Mrs. Goerlitz, would you state your full name please?

Louise Smith Goerlitz: Well, it was Alice Louise, but I had dropped that Alice a long time ago on account of social security, because they always want to use your first name and everything, and I was called Louise.

Nickels: I see.

L. Goerlitz: So I just go by Louise Goerlitz.

Nickels: And, may I ask approximately when you were born?

L. Goerlitz: (chuckling) Well I'm not ashamed to tell you that.

Nickels: Okay.

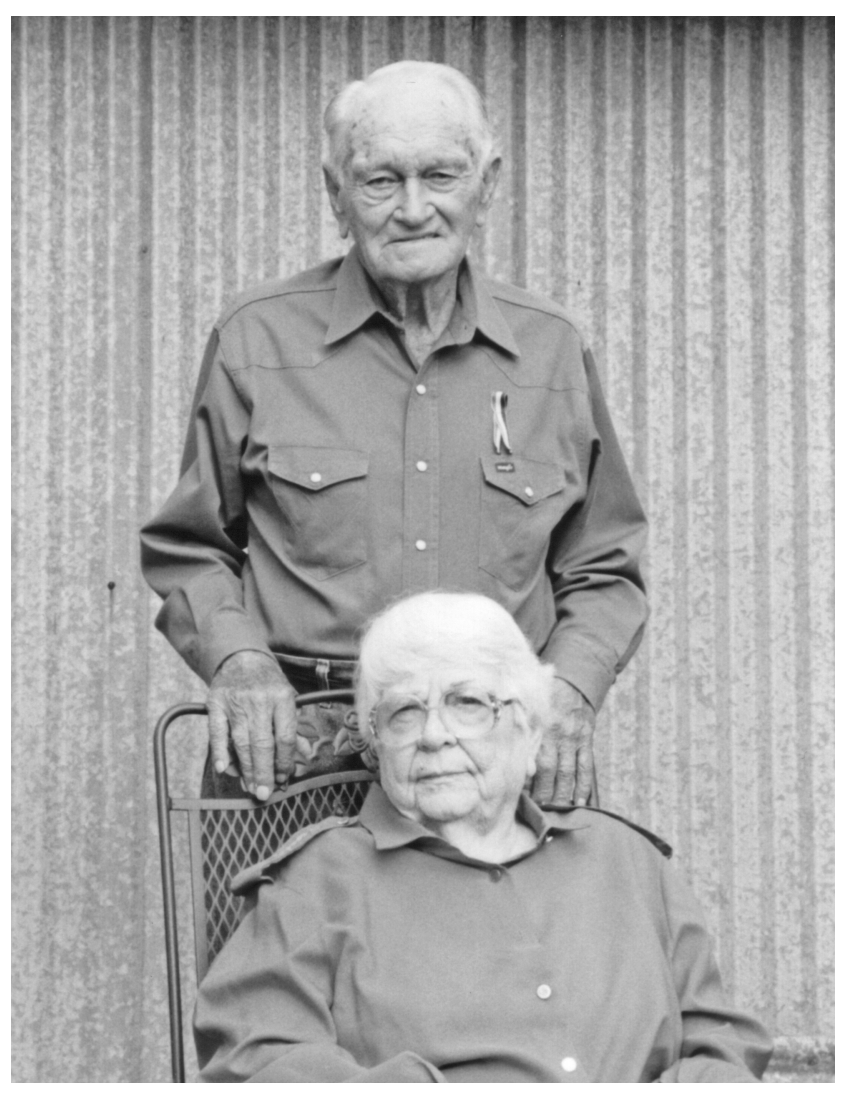

Louise Smith Goerlitz and Erhard Oscar Goerlitz

L. Goerlitz: I was born April 11, 1920.

Nickels: And where were you born?

L. Goerlitz: Right there in that little house that was there between my two grandparents, little rent house.

Nickels: And Mr. Goerlitz, would you please give us your full name?

Erhard Oscar Goerlitz: My full name is Erhard Oscar Goerlitz. I was born January the nineteenth, 1919, here in McDade. Dr. Southern delivered me for ten dollars. Plus he delivered my wife, at homes you know. 
Nickels: I see. We'll talk more about that later, for sure. Mrs. Goerlitz, your mother was Grace?

L. Goerlitz: That's the only name she had, Grace, that I know of.

Nickels: What was her last name?

L. Goerlitz: DeGlandon.

Nickels: And, she had several brothers and sisters? (phone ringing)

Janice Payne: I'll get it. (the phone)

L. Goerlitz: She was number nine. She was the baby of the family. (phone ringing)

Nickels: And where was she born?

L. Goerlitz: Well, Bastrop County, Paige I think, yeah I know it was. That's what it is on her birth certificate. Yeah, yeah.

Nickels: In $1899 ?$

L. Goerlitz: Yeah. [April 14, 1899]

Nickels: And the DeGlandon family moved to McDade area?

L. Goerlitz: Yes, uh-huh. I have a picture of the house. And, of my grandparents. Every year we have a family reunion. This one will be I guess the eightieth, I imagine, because I was four years old the first one I think they had - I have a picture of it.

Nickels: Your mommy and daddy moved to the Oak Hill area?

L. Goerlitz: Yeah, when they were babies.

Nickels: Oh.

L. Goerlitz: And you see, when they were nineteen years old they got married, and they lived in a rent house between her folks and his folks. I was, I think about sixteen years old when the older DeGlandon children - there was three of them living in McDade - they thought their parents had no business in the country, out in the Camp area, so they moved here in the town and bought a little house. Right back of the stores up here is where it was. I think it's been torn down.

E. Goerlitz: It's torn down.

L. Goerlitz: They wanted us to move in that house they left, because it was a bigger house than we were living in. And see, there was eight of us children. And we was all born in that little rent house. (chuckling) So we lived there several years until my Grandma Smith passed away. I guess it was understood that my daddy would get a chance, because we always had to go over there and milk cows. I started milking cows when I was nine years old! And I had to wash the milking utensils, and different things up there, by where we moved to last, you know. Well I really don't know, I guess we lived there-I don't know how long we lived there, really, and truly, but until Camp Swift said, "You have to leave." But I was not there when Camp Swift made them, when they had to get out. He [Erhard] was in the service; he had done finished his military training, and he was in-

\section{E. Goerlitz: California}

L. Goerlitz: - California, at Camp Stoneman. He went to Camp Stoneman to go to cooking school. He thought he'd be there for a year, so I went out there. I was in two different places though. I think I went to Engle-

\section{E. Goerlitz: Englewood}

L. Goerlitz: - Englewood, and then Camp Stoneman. That's where he took that training.

Nickels: So this was about 1941, '42?

E. Goerlitz: Forty-two. I went in the service, and I volunteered for my draft. I left in August 1941.

Nickels: So you did a lot of chores when you were a little girl?

L. Goerlitz: Yes, I had a lot of chores because I was the oldest, and I had to look after all the little kids. My mother raised turkeys as far back as I could remember. That was her money, like you know, if you went out and did secretary work; (chuckling) that was her money.

Roger Payne: Her mad money. 
L. Goerlitz: She raised these turkeys, and then she sold them in the fall, around Christmas time or Thanksgiving time. I think they even came and got them, some company did.

E. Goerlitz: Oh yeah, they picked them up; they had these people coming around, like these Watkins people, and buying turkeys.

L. Goerlitz: We had the Watkins and the - what was that other-

J. Payne: Stanley.

L. Goerlitz: No.

J. Payne: Stanley, or-

L. Goerlitz: Well, I don't think we ever had any of that.

E. Goerlitz: Leonard East was from Austin.

J. Payne: Rawleigh.

L. Goerlitz: Rawleigh extracts and salves, liniments.

E. Goerlitz: Leonard East was the guy that come around and picked the turkeys up.

Nickels: Leonard East?

E. Goerlitz: Yeah.

Nickels: Were the turkeys free ranging?

L. Goerlitz: Yeah, well, more or less. She always had some of the children helping. They'd take them out and catch them bugs and grasshoppers. And herd them all day, and then they'd bring them back and pen them up. They was a lot of them. They slept in the trees. Most of them, they had roosts, but most of them wanted to get in a tree if it was around.

Nickels: So you basically let them run through your garden and your orchard?

L. Goerlitz: Well I don't know, I tell you back then, it was mostly we had a dairy. Really, my grandfather [Smith] started it, but he got bad health, and he passed away when he was sixty-five years old. And so, well anyway, my daddy always dealt with them. We lived there you know, in between the grandparents. So we ran that dairy and it was mostly feed stuff anyway. But they raised some Irish potatoes, [which] was a big crop. They did raise some watermelons and some cantaloupes, and stuff like that, but turkeys didn't bother that stuff.

Nickels: How many acres did your daddy have?

L. Goerlitz: That's something I really don't know.

E. Goerlitz: Two hundred eighty-six.

Nickels: Two hundred eighty-six?

E. Goerlitz: Yeah.

Nickels: And how many head of cattle; do you recall?

L. Goerlitz: They were dairy cattle, those were. And I don't know, we milked I guess sometimes, fifteen cows. First, they separated that cream. They had a separator, and they sent that cream on the train to Taylor, to that creamery over in Taylor. But then, later on, for some reason, they got customers in Bastrop that wanted butter. So they made butter. And my Grandmother Smith, she molded that butter herself. They had to buy ice; we didn't have any refrigerators. And they had these old iceboxes that kept ice in them all the time. You could get that here in McDade. I think somebody brought it here; they could get it here.

Nickels: How far was it to McDade?

L. Goerlitz: Two miles I think, it was supposed to be.

Nickels: And so you made butter and cream. What about any excess milk?

L. Goerlitz: Oh we had a lot of that. But, they fed that to hogs! Or, my mother would let it clabber. She would let it clabber, and then she would hang it in a sack on the line [for the liquid to drip out]. Then she would give that to her young turkeys for feed.

Nickels: In a sack on the line?

L. Goerlitz: Well, that's to make curds you know. Then she would put it in a trough. They fed most of the milk to hogs.

E. Goerlitz: And further, people ate that too. That was really cottage cheese. 
Nickels: Yes.

E. Goerlitz: It's what they call it now.

L. Goerlitz: (chuckling) It wasn't the stuff you get nowadays, I guess.

Nickels: How was the butter and milk hauled to McDade and Bastrop?

L. Goerlitz: (??) My daddy had a pickup that he hauled it down there in.

Nickels: What about horses and mules?

L. Goerlitz: Well, we had those too. But, that's what they had to farm with, and when they made this hay. My husband's uncle was Frank uh-

\section{E. Goerlitz: Goerlitz}

L. Goerlitz: Goerlitz. He did the hay baling. I don't know if he lived here in town or what.

E. Goerlitz: Yeah, he lived here by this McDade Cemetery.

L. Goerlitz: He baled that hay, and he had these mules, and those mules would turn something and they-

E. Goerlitz: Why, they walked around and round, you know. They put the hay in there and they'd compress it, you know.

Nickels: So, it was pressure-

E. Goerlitz: Yeah, yeah, it was, made square bales.

Nickels: I see.

E. Goerlitz: Then they tied it with wire.

L. Goerlitz: They didn't have this coastal like we have nowdays. It was Johnson grass, mostly. Well, they planted cane too, but most of it was Johnson grass. You had a Johnson grass patch, well, it got to be pretty good, you know. (chuckling) We have a sample of this over here by the cemetery. That fellow just mowed that. That's Johnson grass too. He may be baling it now, I don't know. It's ready I guess, almost.

Nickels: So, the hay was stored in the barn?
L. Goerlitz: Yeah, they put it in the barn.

Nickels: And you said you raised cane?

L. Goerlitz: Yeah, well it was the same thing, it was just about the same.

Nickels: So, not sugar cane?

L. Goerlitz: Well, no, there was some sugar cane raised. My grandfather DeGlandon raised sugar cane. And he even had a press to make that syrup. But that was just syrup, he never made no sugar.

Nickels: Yeah?

L. Goerlitz: But, he came from a country where they made sugar out of cane; that was Louisiana.

Nickels: Where was his house?

L. Goerlitz: Just below where we lived in the little rent house. They weren't none of them no ways apart, you know.

Nickels: We have run across a molasses, sugar cane operation down on McLaughlin and Big Sandy Creek, that a colored fellow ran down in that area. And so, this is the second time we've heard of somebody making syrup from cane. What about hogs?

L. Goerlitz: Well, there was plenty of hogs raised in those days. When my Grandfather DeGlandon moved here at Oak Hill from Paige he had a awful big patch, oh I imagine a hundred or two, acres of hogproof. And he let them run and get the acorns.

E. Goerlitz: Four, four hundred acres.

L. Goerlitz: They would eat these acorns. That was more or less what he did. He had some cattle, but not many.

Nickels: Do you recall processing the hogs, making sausage, or smoking them?

L. Goerlitz: I even did that myself. We even did that ourselves. Now it ain't no fun, and I'm not wanting to go back to it either! (all chuckling)

Nickels: Would you tell me a little bit about how that's done? 
L. Goerlitz: Well I'll let him tell you. He can tell you better than I can.

E. Goerlitz: Now, first thing you did, well you shot your hog, and then you had to have scalding water in boiling pots. If it was a two hundred-pound hog, you could stick it in a barrel, and turn it around, and then pull it out on some boards, and scrape that side; that end of it. And then, put a little more hot water in there, and stick the other end in. But if it was a big hog, you took tow sacks - you know what I'm talking about? And laid it on top of that hog, and then poured the water on there. Then whenever you pulled up on that hair, you could pull them off. You scraped that section, then get on to another section. But, it was usually a two-day affair if you killed a big hog, you know.

\section{Goerlitz: It had to be cold weather. (laughing)}

E. Goerlitz: And that day and time people wanted fat hogs, because lard was a big thing. And the hogs, they wanted their hogs to weigh around four or five hundred pounds.

Nickels: The smaller hogs then, were processed in barrels; were these barrels mounted into the ground, or dug into the ground?

E. Goerlitz: Yeah, they were wooden barrels. And see what they did, you shoveled a little hole out over here, and you put a log down here. So the barrel would be like this, [higher at the top while laying on the ground]. And you stick the hog in there like that, and turn him.

Nickels: I understand.

\section{E. Goerlitz: Yeah.}

L. Goerlitz: Then you pulled him up on a singletree, something they used to hook horses with, and pulled it up a tree, and that's when they started butchering, you know, taking out them intestines.

E. Goerlitz: And they'd wash him off, they'd wash the hog off, and you'd have his legs stretched out like this, see. Then you'd take a axe and cut down beside the ribs, right down the backbone, center of the backbone. Then you cut the ribs out. Then, (clearing throat) first thing you did then was cut the head off. That's really what the first thing was. And then you get the ribs out. And then you cut the shoulders off. And the last thing you cut off is the, on top here. And that hog, as a rule if you did everything right, with this single tree, the hog pretty well hangs even. And then you cut him off and you take him in the smokehouse, and lay him on the table. Then you cut - All the scrapmeat goes into sausage. And all the lard goes in a different stack. And if you ain't got a big sausage mill, you cut it in little pieces. And then you put it in a washbucket next day, or that day if you have time. And cook the lard, part of it, and then you got cracklin's.

L. Goerlitz: Used these cracklin's in their bread lots of times.

E. Goerlitz: They used the cracklin's in the cornbread, that's what they usually did.

\section{Goerlitz: Well-}

E. Goerlitz: I ate a lot of them just like they was. And then the ham you cut, if it was real cold, you could leave the bone in the ham. If it wasn't very cold, you had to cut the bone out so the ham wouldn't spoil. And then to make brick bacon, you had another barrel. You put the bacon in there. I mean the sides, you know. Put it in there, then you could put the hams in there too. And you put the water in there. And the salt, it has to be salty enough that it could float [an egg]. And then, you left it in there for a week, I believe it was. Then you took it out, and you hung it up, then you smoked it with hickory. And when you walked by that smokehouse early in the morning, it smelled so good you could almost eat the boards! (all laughing)

Nickels: How long did you smoke it for?

E. Goerlitz: Well, you smoked it till it was good 'n dry. See, we didn't have no iceboxes and things. We put it in these jars -

\section{J. Payne: Crocks.}

E. Goerlitz: - Big [eight-gallon] crocks, big ones. And cut it up in pieces, put it in there. And then we poured the lard over it. That preserved it, and then in the summertime you could eat that ham without doing anything. Lot of people called it raw, but it wasn't, it was smoked good; and bacon the same way.

R. Payne: I didn't eat it like that, I cooked it.

E. Goerlitz: (laughing) I still think that if you eat bacon with the rind on, you can't beat it! (laughing) 
Nickels: What kind of bread did you put the cracklin's in?

L. Goerlitz: Well, he said cornbread, but I think they used it in biscuits too, some.

E. Goerlitz: They might have.

L. Goerlitz: Probably chopped it up, or ground it up. I never used any of it, but I just know they was some of them said they did that. I really don't know that my mother ever used any.

E. Goerlitz: And the sausage, the meat, you ground that up, you know. Then you put it in a washtub, you had a nice clean washtub, put the seasoning in there, we still got a real good recipe up here. If you fry a little patty of it, you see if it's seasoned good, fixed it up good. If it tasted all right, why you left it alone; you thought it needed a little more salt or something, add it in there, and fix it up again. Then you stuffed it. We still got stuffers.

L. Goerlitz: See, these intestines, you had to scrape them-

\section{E. Goerlitz: Yeah.}

L. Goerlitz: - and get all that off. They was real thin, you know. Then you soaked them in salt water, and then you uh, well some of them blew them up with their mouths, I think, (laughing) but I don't know the difference-

E. Goerlitz: That was the women's job, cleaning intestines! (all laughing)

L. Goerlitz: It wasn't a very good job, either (laughing); I don't think I wanna go back to it.

Nickels: Did you have chickens?

L. Goerlitz: Yes, we had chickens.

My grandmother [Smith] now, that lived in the house we lived in when Camp Swift came, now she had a chicken house. She had brown-legged chickens, always. And they shipped those eggs somewhere, I don't know even where they went, I think on the train, probably to Taylor.

Nickels: One more question on the hogs. I know they was your grandpa's primarily, but were those hogs free ranging? Were there certain times of the year where they would let the hogs roam from pasture to pasture, and folks didn't get upset, and there were basically gentlemen's agreements to let that happen?

L. Goerlitz: Well, yes, they had that. It was in the fall when everything was already harvested, crops.

E. Goerlitz: October fifteenth. October fifteenth was hog turnin'-out time.

L. Goerlitz: But see, my grandfather, he had lots of hogs, and he never turned them out. They had all the country they wanted to roam in anyway to start with. And we never did have any more hogs that we wanted to use for meat.

E. Goerlitz: And the fifteenth of February was pennin'-up time. You could turn them hogs out, and they'd get just as fat as they could. You'd be surprised how fat they got. And butchering them, well the lard wasn't quite as good a lard as it was corn-fed hogs, you know. And that's the way it was. Sometimes, in the spring you know, when, like now, if you had hogs, close to tops, but not quite ready, you fed them to bring them on up. Her grandpa was down here, and her uncle [Mann DeGlandon] Her uncle told me this, "I said, I come out and said, Pa, they got, uh, hog feed now where'n you'n [where you can] top out a hog in six months." He said, "What the hell is time to a hog?" (all laughing)

L. Goerlitz: Well, we bought a lot of cow feed when we had the dairy, you know. My daddy mixed the feed himself. It was kind of [cotton] seed meal and brand. I think some shorts they called it. It was finer, I think it came from wheat. I don't know really know what it was.

E. Goerlitz: They called it brand, brand, yeah.

L. Goerlitz: Yeah, it came in sacks, and they bought that.

Nickels: What kind of crops did they raise?

L. Goerlitz: Well, mostly corn, and feed stuff, you know. But my daddy raised a lot of potatoes. I guess he knew where he could sell them. He probably took them to Bastrop and peddled them, I don't know (chuckling), around to different stores, and people. 
Nickels: Irish potatoes, or sweet potatoes?

L. Goerlitz: Well, it was Irish potatoes. We never was much on sweet potatoes.

Nickels: What about melons?

L. Goerlitz: Well, they raised some melons. I guess they did the same thing, sort of peddled them to different towns.

E. Goerlitz: Uh, pardon me, but they shipped a lot of them out of McDade, watermelons (??)

L. Goerlitz: Cantaloupes too, by truck.

E. Goerlitz: Yeah, they raised a lot of watermelons. They'd ship from sixty to ninety carloads a year, you see. They always wanted you to plant a certain kind, you know. So that was the biggest income at one time, was watermelons. Never, was high you know. Well, you couldn't afford to buy them if they was high. Nobody had no money.

L. Goerlitz: They'd punch you, maybe you got a punch a dollar.

E. Goerlitz: And oh, my folks, now, they raised cotton. They had to plow up cotton, you know. They came, and my daddy worked for the government for a good many years, signing up these people, writing down the count so you'd know where, how much cotton you made, and add it. Roosevelt had a corn and hog program.

Nickels: Who did?

E. Goerlitz: Roosevelt, President Roosevelt. And her grandpa got a good bit of money I'm sure from the corn and hog program. If you had three sows, had pigs, you could be in the corn and hog program. And, most everybody around here got some kind of a little check; I mean, after the Depression had really set in, you know.

Nickels: How did the corn program work?

E. Goerlitz: Well, they had, (clearing throat) to reduce their acreage on the corn. And to reduce the hogs, they had to kill so many pigs, see. When I was a boy, steak was fifteen cents a pound, and it was too high to eat! So they had a over population of cows. So I helped drive the cows. Woody Townsend was the sheriff of Bastrop County. And Gus Wallace was his deputy sheriff. And they said, everybody bring your cows to a certain place, and all those that are unfit we'll butcher, I mean kill them. And they had a sharpshooter. So we carried the cows, brought them up to McDade first. Then we carried them back down to the sand hills, to Mr. Grosse's, had a big cattle pen. Put them in there, and the sheriff, his deputy, and the sharpshooter-I forgot his name-and the government man. Then the government man would point at one, and the sharpshooter would shoot it. And, anybody that wanted meat could have it. It was free, you know, but you had to get it there. Anything that was left over, you had to dispose of it. So Mr. John Smith across the road, he had seven hundred acres of land. He had a lot of hogs just like Mr. DeGlandon over "here." And he said, "Pull them cows over here, and my hogs will eat them." That's what they did. (groans in the background) And they was piled up. The only cow that they didn't kill from my Grandpa Goerlitz was a bull. And they had a few extras, and we had stock pens in McDade. So we penned them cattle up in them stockpens and shipped them out. Where they went, I don't know. But, they was people like me, and the Grosse boys, and Clyde Dungan, that did all the cowboy work.

Nickels: So these cattle were brought in on the trail to McDade?

\section{E. Goerlitz: Yeah.}

Nickels: Were there any slaughters where a lot of cattle were buried?

E. Goerlitz: Now I don't know about that. I just know about this community here. Yeah, we brought them from Mr. Grosse's place to the stockpens in McDade.

Nickels: About what year was that?

E. Goerlitz: It was in the early thirties. I don't really know what year it was. But it must have been between 1930 to '32, I would think. I ain't for sure.

Nickels: Were the farmers reimbursed for the cattle kills?

E. Goerlitz: Yeah. Everyone that they killed, they got so much money. And those that they kept, they got a little bit more. I remember two or three years later, my daddy sold a cow and calf for seventeen dollars. They 
said, "Man, lookit there, seventeen dollars for that cow and calf!" See what I mean? And you couldn’t sell them before then.

Nickels: Do you know perhaps, if any of that meat went in to the canning plant at McDade?

E. Goerlitz: Uh, I don't think so. We didn't have one, I don't think, at that time. But a lot of people canned that meat.

L. Goerlitz: Yeah, but when did the canning plant start?

E. Goerlitz: It started about that time. But I'm sure none of this meat went there because I don't think that plant was there. You could take meat to the canning plant, and the people that worked there got so much, and you got so much. Same thing with vegetables, you know.

Nickels: Can you tell me about canning at home?

L. Goerlitz: Yes, I did a whole lot of it, but (laughing) I don't know if I can really tell you just how. But I didn't after we had freezers. I froze more stuff than I did canning. But uh, I tell you, a lot of these old timers, when they made a pickle, or, jelly, they would cook this jelly on the back of the stove, ever what it was, and they'd put it in a jar like that, (pointing to a five-gallon crock) and put something around it. And then when they wanted some jelly, they'd go and get it. But I never made it like that. When I made it, I had to have Sure Gel, and then let it get firm, cook it on the stove till it got firm, then put it in jars. And sometimes I put it in what they call a hot water bath you know, a cook pot.

J. Payne: But he's talking about when you were a kid, Mom.

\section{Goerlitz: Huh?}

J. Payne: He's talking about when you were a kid, at home; how did y'all do that stuff?

\section{Goerlitz: Well-}

\section{R. Payne: Sauerkraut.}

L. Goerlitz: Well, I guess the same thing. He mentioned sauerkraut. A lot of them cut cabbage and put layers of salt; a layer of cabbage, and a layer of salt. And then, some more cabbage and salt till they filled up a jar like that. (pointing to a five-gallon crock) And then whenever they thought it was ready to eat, they would just put it in a jar, and seal it up. I guess it sealed itself, I don't know if it did or not. (chuckling)

Nickels: So you-

L. Goerlitz: So they didn't heat it no way.

Nickels: You lived in the Camp Swift area. Well, you were born in that area?

L. Goerlitz: Yeah, I was born there.

Nickels: And then you left there about, 19-

L. Goerlitz: Well, I guess in 19-[42], well, when I went to California. And I went before my folks had to move out

J. Payne: How old-

L. Goerlitz: They knew they were going to have to move.

J. Payne: How old were you Mama?

L. Goerlitz: Well, I was twenty-one, I guess. (chuckling)

E. Goerlitz: Twenty-two (??), already.

L. Goerlitz: Maybe I was twenty-two.

Nickels: So, when you were a little girl, all the way up through teenager, in the Camp Swift area, did your mom and dad have electricity?

L. Goerlitz: No. No, I remember kerosene lamps, that's about all I remember. But, in this house we moved to last, my grandmother [Smith] had, it was like a metal cistern. I think it was metal, maybe it wasn't metal, maybe it was cement. I believe it was cement. She had some company put this in the ground. And they put carbide in it. And they had to wire the house. That's in here, in this book, about how hard it was for those folks that was wiring the house for this carbide, or making pipes, maybe it was pipes instead o' wire. I imagine it was. And those cedar beams that they had in that house, it was so hard for them to bore a hole. I don't know what they had. Not, back then, much tools 
I don't imagine, something you had to turn by hand, I reckon. And, it talks about that, how hard it was to put this carbide into the house to have lights. I think lights was the only thing - maybe we did, seems to me like we had a, carbide, uh-

E. Goerlitz: Deepfreeze. Icebox, I mean, yeah.

L. Goerlitz: Icebox, yeah.

Nickels: What kind of heat did you have?

L. Goerlitz: Oh, it was wood. And, mostly fireplaces.

Nickels: Tell me about the fireplace.

L. Goerlitz: Well, you had to chop the wood to fit it, and most of the time when winter came, they kept coals in there and never let it go out. They kept putting wood in there. They'd dip out the ashes, and put them out around the trees or something for fertilizer (chuckling), I think. But most of it, it was all wood, no coal; we didn't have no coal. Now then, some of them may have had coal, because they had a coal mine down below Bastrop. Aah, seemed like they burned coal in the schools, at least, at Oak Hill School.

Nickels: So you lived in two houses in that area?

L. Goerlitz: Yeah. Well, really three. See, we lived in this little rent house that was my Grandpa Smith's. But then we moved when my DeGlandon grandparents left; we moved in their house for several years. And then, my grandmother [Smith] passed away, and so we all moved in to the house she lived in. The last one, the one we had to leave behind.

Nickels: This is going to be difficult, but tell me about the first, second, and third houses. Tell me what you remember about the houses.

L. Goerlitz: Well, when we lived in the DeGlandon house, we was all getting towards teenagers, Well, we had enough education, we knew how to play dominoes and cards. And we couldn't wait till we got out of the field, or doing whatever we were doing - more or less it was a big garden, I guess - and we would eat. There was one girl that always stayed home and helped my mother cook. And then, we'd eat, and there was another girl that always had to do the dishes. But, I don't know that she did the dishes right away, or they were through cooking. Anyway, there was always four of us to play, dominoes, or cards around a table. And, we played until my daddy - I guess he rested, maybe slept, I don't know what he did - he'd say, "Well, let's go kids, and go to the field." Well, we played until the last minute (chuckling), cards or dominoes. And that was mostly what that was. And when we were kids, before we ever moved out to the DeGlandon place, in this little rent house, well, mostly we just had swings in trees, or something. I didn't get to do much of that. I had to watch the other kids to be sure they wasn't doing something they wasn't supposed to be doing. And that's about all I know about that.

Nickels: Was it a frame house, wood?

L. Goerlitz: Yeah, it was just a frame house, yeah.

Nickels: How many bedrooms?

L. Goerlitz: Oh it had, well it had three rooms. Had a long kitchen. And then it had a long, porch. I'm talking about that little house we lived in first. And, my parents put up chicken wire, that the kids couldn't get out, off this porch. They even had a gate so they couldn't get out, you know. In the summertime we'd move the beds out there, sleep out on that porch. (chuckling in background) And you could see the stars, the shooting stars at night, (Louise chuckling) and all those things. I don't know if you can even see them anymore. There may be too much pollution.

Nickels: Did you have a cistern?

E. Goerlitz: Yeah, that's what they had.

L. Goerlitz: Yeah, there was a well. Most all of these places had wells. But we had to pull our water up by hand, with a rope, you know. And before we moved from the rent house, we had gotten a tin cistern, is what you call it. You know, holds the rain water, with a lot of stuff.

Nickels: And a privy out back?

L. Goerlitz: Yeah. (chuckling) Yeah.

Nickels: What about the second house?

L. Goerlitz: Well, it was about the same thing. Even that it was a bigger house, I don't, right now, let's see, it had five rooms and a big hall. And a long, L porch, on the second house. And then the last house, it had 
um, four rooms, and a kitchen that was built out away from, sort of away from the rest of it. I guess it had been built on in later years. It had a big hall, and it too was big enough to be a room. That's where they did most of their separating their milk, and the iceboxes was in this hall, and stuff.

Nickels: So you had eight children?

L. Goerlitz: Yeah, there was eight of us, yeah.

Nickels: And first, the three-room house, and then a five-room, and then a four-plus?

\section{Goerlitz: Yeah.}

Nickels: What were the sleeping arrangements?

L. Goerlitz: Well the girls had to sleep together, and, well the boys were younger, and they slept together and all.

Nickels: Was your mom a good cook?

L. Goerlitz: Well she wasn't the best cook. (chuckling) I don't think she liked to cook. I don't think she ever cooked till she was grown, (chuckling) because she was a baby. You know, they don't learn too much sometimes. (laughing)

Nickels: So your dad was a farmer?

L. Goerlitz: Yeah, that's what he was - until Camp Swift came. Then when he moved to the Knobbs, they milked the cows, but he went to Camp Swift to work. I have a picture somewhere of him and the fellow he rode with from on this side of town. They took care of the PXs or something, whatever, where they sold stuff to the soldiers. I don't know what they called it, really; commissaries, I guess, I don’t even know.

Nickels: Before Camp Swift came along, how did your dad make a living other than farming? Did he do anything to supplement his income?

L. Goerlitz: No, no it was all dairy stuff. But I want to tell you, if you work with dairy cattle, and do a little farming on the side, you got your day planned for you. Because, you have to clean all these utensils, and separate this milk, make the butter, take it to town. Well they didn't take it every day, but, you know, every other day, I'm sure.
Nickels: Were the eggs, butter, and milk sold, or traded for other things?

L. Goerlitz: No, they were sold. They was shipped away, I think. Somebody bought them, and, I guess they already had contracts with people to buy them in other towns somewhere. And everything left on the train, I think.

Nickels: Cotton - There was a gin here in McDade, I understand.

L. Goerlitz: Yeah. One at Oak Hill, too.

Nickels: Oak Hill?

E. Goerlitz: Yeah.

Nickels: Over by the school?

L. Goerlitz: It was pretty close to the school, yeah.

Nickels: Was there a lot of cotton raised here?

E. Goerlitz: Yeah.

L. Goerlitz: Well, he'll have to tell you about cotton. We weren't cotton farmers. (laughing)

E. Goerlitz: They ginned over a thousand bales a year here. You know, when I was a boy. Up until Roosevelt started to plow stuff, and stuff like that. And then, it was a decline. And now it went from cotton to vegetables, and watermelons, and cantaloupes. One time we even shipped tomatoes from here, you know. But, cotton was a big deal. My daddy worked for the government. That was the thing, to cut down on cotton, and hogs, like I told you, the hog, corn and hog programs, and the cows. And see, the gin kept records of the bales. And that's where they, my daddy got the records. If you signed up for the government check here for cotton, why you had to reduce it so much. And, when it first started, cotton was already in boles you know. It wasn't producing yet, but it was right at the stage, and you had to plow them acres up! And, you got your records from the gin. I don't know what they paid, but that fall, why everybody got so much money for what he plowed up. And the hog people. But the cow people got their money when they did this, you know.

Nickels: I see. 
E. Goerlitz: Uh-huh, yeah.

Nickels: Where did you go to school?

L. Goerlitz: Well I started to Oak Hill. I was supposed to start, I imagine at about seven years. Then, my sister just younger than me, we had dolls. Most of it was cloth, but they had a composition head, and hands. We had four big trees on each corner of the house almost. (laughing) And she threw my doll out next to a hackberry tree. Of course I went and got it, and I guess didn't look either. And a copperhead snake bit me. Of course, in those days, my mother soaked my foot right away in kerosene. We had kerosene. They didn't have no phones, but they hollered so loud that people usually knew what was going on. I don't know, I think my grandmother heard it, and she came, and finally they got my daddy and he took me to Bastrop, to the hospital. They had a hospital there then. And Dr. Bryson, he lanced my ankle, and he put potash in it, which is lye, I guess. Now what that was all for? Because everybody now days knows poison from a snake is already all over your body if it's going to get anywhere.

But, see I couldn't walk for six months. I had to hobble along. I couldn't go to school, because it was two miles to the Oak Hill School from where we lived. And we had to always walk. Well, I had some cousins down below me there. I think somebody's talked to the older girl in Bastrop. Well, the oldest cousin there, he would see that I got to school, and I'd walk. He'd walk with me. And he went to school there too. We're in the school picture somewhere; I don't know where, in some of this stuff. But I couldn't go to school that year. The next year, I started to school, and then they got that bad flu epidemic, that so many people died, you know, from. Well, my folks took me out, right out of school then because I was the only one going and they didn't want all the other little kids to get it. So they just took me out of school. So I was probably about near nine years old (chuckling) before I really got started to school! But I did graduate! There's my graduation, and it was 1940. And I think that might have been the last ones they took from this area to Bastrop, I don't know.

Nickels: So you started at Oak Hill, but then there was an epidemic one year?

L. Goerlitz: Yeah, yeah, and I finished the seventh grade. But then I would have had to go somewhere else you know, they didn't teach no other. So my daddy, he took us to McDade every day, all of us. And we went to McDade. I think I went to McDade two years. And then, they started a bus to go to Bastrop. Mr. Hancock, his daughter's in this group too, he drove the bus. We caught the bus down at the main road and we went to Bastrop School; I went two years there.

Nickels: What do you remember about Oak Hill School?

L. Goerlitz: Well, I imagine they had ballgames, but I can't remember it. I don't think I ever played no ball there. Seemed like we always just played games like "drop-the-handkerchief," or "Get-in-a-ring." Somebody would drop the handkerchief or what they call, rose; I forgot what they call it.

\section{J. Payne: Ring-around-the-rosy.}

L. Goerlitz: Ring-around-the-roses, or something, you know. Some kind of party games, I think that's more or less what it was.

Nickels: Do you recall any of your teachers there?

L. Goerlitz: Yes, but, (sigh and chuckle) they're all gone. I had a cousin's wife that taught there, Mayme Fleming. And then I had another cousin, Mozelle McCright she was to start with. And then she married a Stagner. And then, oh, gosh, Miss Sanders, Joe Lee Sanders' wife, Jewell -

E. Goerlitz: Rhodes.

L. Goerlitz: Rhodes. She came from below Bastrop, by Piney [Alum Creek], somewhere down there.

Nickels: Were there many kids in school?

L. Goerlitz: Well, not a lot. I couldn't tell you how many. I have some pictures I think. There's one in this book here. Yeah, here they are, but I didn't count them. Here's one of the pictures from Oak Hill. And these teachers were named - this was Mr. and Mrs. Smith, and one of them was Miss Holland, I believe that was her name.

Nickels: In 1929?

L. Goerlitz: Yeah. 
Nickels: What about discipline?

L. Goerlitz: Well, I don't know, maybe we weren't bad kids! (laughing) But they could whip you if they needed to, I could tell you that. But I don't think anybody ever really got a whipping.

Nickels: So, you walked to school?

\section{Goerlitz: Yeah.}

Nickels: And, what kind of vehicle did your dad have?

L. Goerlitz: I don't even know what model it was. (laughing) Well, the first one we got-

E. Goerlitz: Well, the first vehicle I saw him with was that '35, V-8 Ford pickup. He probably had a vehicle before, but that's the first one that I saw him with.

L. Goerlitz: Well they had to have something to haul their stuff to Bastrop-

E. Goerlitz: Yeah.

L. Goerlitz: - to town. But right now I wouldn't know.

Nickels: How were the roads?

E. Goerlitz: They was just country roads. I mean, they wasn't nothing but (??)

\section{Goerlitz: Muddy.}

E. Goerlitz: But, her Grandpa DeGlandon, you know, he had a '28 Ford pickup. That's what he had. I'm sure that's the only vehicle he had.

L. Goerlitz: See, I used to come to McDade (phone ringing) with my Grandmother DeGlandon when I was just, oh I don't know, a child. Because she had three children here living here in McDade, and we'd come over here in the buggy. And she always brought me along. And we'd visit maybe one Saturday with one child, and the next with another one, you know. (Erhard talking on phone in background) Their oldest son was a barber here. And another one was uh, well, it was Mrs. Hettie Clopton. She just was a farmer, but she lived right out of town here. Then the other one, her husband was a clerk in a store. He even owned the store at the last.
Nickels: So you remember riding in the buggy. Do you remember other trips in buggies, or by wagon?

L. Goerlitz: I don't know that I ever rode in a wagon, can't remember.

Nickels: Did you ride a horse?

L. Goerlitz: No (laughing), not until I was married. I got on a horse, but I didn't ride it. (laughing) (Erhard still talking on phone in background)

Nickels: What kind of fruit did you have out there?

L. Goerlitz: Fruit? Well, we had lots of pears, and peaches too! And I have a lemon bush out here. My Grandmother Smith had that lemon bush for years. Her daughter brought it from the Valley somewhere when she was down there, the one [Aunt Sula] that was just older than my daddy. And she [Grandmother Smith] had lemons. Then this cousin that, well, it was one of my older cousins [Woodrow Smith], he came and got some cuttings from her lemon bush. And he went to Edinburg, and he rooted those. Of course that's fruit country down there anyway. But, he rooted these, and then he brought some cuttings back after he'd rooted these trees. One of his aunts had to move out of the Camp area, down to Paige. He brought her a bunch of cuttings. But, she told my sister-in-law [Marie Patschke], his [Erhard's] sister, "I'm not gonna root them things, I'm not gonna fool with those things, you can have some of them." Well she took some of them, but I don't know if she even tried to root any. So they brought them up here to his [Erhard's] mother, and she rooted them. I think there was a couple of those trees. But I don't guess there's just one out there now. But she got too old. She had them in a pot, and she put them in another pot. Well they was just galvanized things that decayed after awhile, all rusted. She gave them to our son [Erhard, Jr.], which he wasn't about ten years old, was he, or something like that? He's planted it out there by that old garage, and it has lemons on it this year. One year it had a bushel or more on it.

Nickels: What about wild fruits and nuts?

L. Goerlitz: Oh well, we had hickory nuts, and we had pecans too. But the main thing that us kids really enjoyed was the huckleberries. We had lots of huckleberries out there [in the Camp area], which we don't have around here. And berries, you could 
always find berries this time of the year, you know. Huckleberries, an' -

E. Goerlitz: Don't forget the plums, Mom.

L. Goerlitz: Oh yeah, a lot of wild plums, which we don't have nowadays. There's some on the [railroad] track. I don't think they have anything on them.

Nickels: Grapes?

L. Goerlitz: Yeah, oh well, they was all kinds of grapes. Yeah. Some of them weren't too good to try to eat, but (chuckling) we did have, I believe they called them - I don't even know what they called them, but you could eat and they wouldn't burn your mouth. Those old mustangs, they would burn your mouth, you know. But we made a lot of juice out of them. We drank it. You know, weaken it with water, and they put sugar in it and it was a pretty good drink.

Nickels: How did you press the juice?

L. Goerlitz: I think we always put everything in a flour sack, and just smashed it you know, and got the juice out.

Nickels: Did you have a root cellar?

L. Goerlitz: No, we didn't have any.

Nickels: How did you keep your milk cool?

L. Goerlitz: Well, I tell you, they had this carbide icebox. Oh, but before then they had to buy their ice. There was ice brought here to McDade. You had to come get it and they had these boxes that you could put it in.

Nickels: You mentioned the snakebite, and potash. What else did your mom do for you for sickness, or for bites or stings?

L. Goerlitz: (chuckling) Well, about that, Rawleigh liniment company, (chuckling) they came around every so often. She'd buy liniment and different things; I don't know when this really came about, this [Vicks] Vaporub. That was our main medicine. Boy, if we took a cold to our throat or she thought we was, or had a earache, rub it on there, or put it in your ear or something, you know.
Nickels: What about for stomach ache?

L. Goerlitz: I don't know, I guess we just kept a stomach ache, I don't know. If you had bowel trouble, there was Baby Percy, and I think if you was constipated (chuckling) there was Syrup of Pepsom or something like that.

\section{E. Goerlitz: Or castor oil.}

L. Goerlitz: Oh yeah, they used a good bit of castor oil, but my mother never was too good on giving us castor oil. You know, that could really make you - My, I remember my brother [Harvey, Jr.], he was the third child. And he got real sick. And Dr. Bryson said - well — he gave him a big dose of castor oil. Well, they thought he was gonna die! So (chuckling), I don't know, she never was on that kind of medicine anymore, you know. And a lot of babies did [die] in those times. He [Erhard] lost a brother.

E. Goerlitz: Yeah.

L. Goerlitz: Some of these old country doctors didn't know everything, I tell you.

Nickels: Well, there obviously were a fair amount of snakes out there. What other wildlife do you remember?

L. Goerlitz: Oh, there was a lot of gray wolves, when I was growing up. Of course there ain't none no more I don't think. Because my daddy and uh, well he was my [father's] niece's husband, Willie Blackwell. I don't know if you talked to any or them or not. Oh, well, Willie had lots of hounds that would chase these wolves, and they would go on these - If the wolf had caught something, well they were out after him with those dogs.

E. Goerlitz: My understanding was there was a fifteen-dollar bounty on them.

L. Goerlitz: Of course, I don't know if there was to start with. Maybe it was, I really don't know. There was a bounty on them, but I don't know when it started or anything.

Nickels: Well apparently there was a fair amount of activity in hide processing, and the government paying for hides. What can you tell me about that? 
E. Goerlitz: (chuckling) I can't tell you much about the hide business. You mean cow hides?

L. Goerlitz: Yeah, well yeah, they even bought skunks and everything else!

E. Goerlitz: Oh, well, hey.

L. Goerlitz: That might have been one thing they did. They sold the hides.

E. Goerlitz: Eh, yeah, when I was a boy you know, well you didn't have no money. And I went possum hunting at night. I even skinned skunks. Possum was two bits, a skunk maybe fifty cents. They were a little bit higher. And ringtail was the highest. I made forty dollars one winter selling hides. And, man I thought I was really doing good, you know.

Nickels: About what year was this?

E. Goerlitz: (laughing)

J. Payne: How old were you, Daddy?

E. Goerlitz: I was about twelve, or fourteen, something like that.

\section{Nickels: Okay.}

E. Goerlitz: Yeah, yeah. And oh, squirrels. I tell you another thing about the Depression. And that was big families as a rule. They usually kept one of them in the woods, hunting squirrels and rabbits, and man if it hadn't been for all them squirrels and rabbits, hell, these people would have starved to death. That ain't no lie. And you could buy ten .22 shells. You know, .22 shells come in a fifty-count box. You could go to town here and buy ten shells, or fifteen. They had to do this because people didn't have no money. And when your old man sent you out to the woods, he wanted production when you shot that shell! (laughing)

Nickels: Have you, or did they have something called rabbit drives?

E. Goerlitz: Not here. But I tell you what we did. See, when we quit raising this cotton, plow it up, then we all went to cantaloupes, I mean watermelons. And jack rabbits, and cottontails. With these automobiles, we'd get in the back end with shotguns, and we'd ride around at night and shoot them, you know.
L. Goerlitz: I think we did that after we were farming here.

E. Goerlitz: Oh yeah. But I mean that's where we started. And I could go to town, be a ten- or twelveyear-old boy, and go to town and buy a bottle of strychnine here at the drugstore. We put it on sweet potatoes and something like that, in the watermelon patch, or cantaloupes. Why them rabbits didn't take but just a little, walk but a little bit. That was it.

Nickels: So was this just within your family, or was this kind of a group thing?

E. Goerlitz: No, it was just in our family. And, well, our neighbors, you know what I mean?

L. Goerlitz: I imagine every family did the same, but-

E. Goerlitz: Yeah, they was all the same. Yeah, when we went shooting them rabbits at night, well we did it with our neighbors, you know.

Nickels: I see. What about fishing?

E. Goerlitz: Well, the only fish I like is those that's ready to eat. (laughing) I never had no luck fishing. (laughing harder)

Nickels: Did your daddy?

L. Goerlitz: No, they weren't fishermen. The first (chuckling) - well, I had a brother-in-law that's a fisherman, (phone ringing) and we went up here on - I guess the kids, or my daughters, were just little kids, we went up here on the lakes by Austin. And there was a guy that rented a little cabin like. You could go up there and spend the night, and go out in a boat, and fish. Of course, my brother-in-law, [James Smith, Louise's baby sister Loraine's husband], that was his thing. So, the fellow that owned the cabin asked me next morning, "How did you like it?" I said, "That's the reason I work, so I don't have to do that kind of thing." He said, "Oh well, Mr. Smith sure likes it." (chuckling)

R. Payne: He still does.

L. Goerlitz: Yeah. (chuckling) Eighty years old and still goes down to Somerville (chuckling) fishing. 
Nickels: Do you remember ever, your mom going to home demonstration meetings, or a home demonstration agent coming around?

L. Goerlitz: Well, that was later, really, more or less. That was more or less, my day. (Erhard talking on phone in background) I can remember that they met at the Oak Hill School. I think her name was Miss Vest, was the first agent, I believe. She came and demonstrated how to can stuff. I think she even demonstrated how to can meat, and tomatoes. She went to those things, but she never really was a member of the club. But I just finished fifty years this past December. I've been in the Home Demonstration Club for fifty years. I'm still there. I'm not much, but I'm still there. (chuckling, then coughing)

Nickels: You were telling me about seventy years?

L. Goerlitz: Yeah, our club here in McDade; it's been seventy years, they stopped during the war for a couple years, I know, and they made bandages instead. But really-

E. Goerlitz: They didn't stop.

L. Goerlitz: - They really didn't stop, I don't guess. They always met and made these bandages for the wounded.

Nickels: Out on the farm, did you have peddlers come by?

L. Goerlitz: Oh yeah, we had peddlers. We had bums too, (chuckling) wanting something to eat.

E. Goerlitz: And Rawleigh people, Watkins.

Nickels: What was the first one?

E. Goerlitz: Rawleigh.

J. Payne: Rawleigh.

E. Goerlitz: Rawleigh, or whatever you wanna call it. And they had chicken coops on the back. See, nobody had money, and, well, just very little. And they'd trade you their products for a chicken, or some eggs, or an old car battery, or just anything, just about. And see, you could sell chickens at McDade, and eggs. And even eggs was high. At the very bottom, eggs was a nickel a dozen.
Nickels: What about mail, how did you get your mail?

L. Goerlitz: Well, we always had a mail carrier, far as I know.

E. Goerlitz: Uh-huh. Jeff Hudler was our mailman.

L. Goerlitz: Well, Will Stagner [was ours].

E. Goerlitz: See, the, the way the mail business started, they had to go around and sign up all these people. They had to have so many people that needed the mail. And then, the mailman was supposed to live on that route. That was horse and buggy days. We had four mail carriers at McDade. One by the name of Jeff Hudler, that was my mailman. These were the first people on these routes. Then there was Will Stagner.

\section{Goerlitz: He went out to the Camp area.}

E. Goerlitz: What was the man named that lived here?

L. Goerlitz: Arlie Sanders.

E. Goerlitz: Arlie Sanders.

L. Goerlitz: He owned this house. That's the reason he sold it, because he went to Lockhart to be a mailman over there.

E. Goerlitz: Yeah, I forget. What was the man's name that lived over here in the Willy Watson house? Joe Bryan Waterson, oh, Mr. Waterson. I forget what his first name was. It might have been Joe Bryan.

\section{Goerlitz: Oh.}

E. Goerlitz: He was a mailman. See, Mr. Hudler went out to the Knobbs. Mr. Stagner went out to Oak Hill. Mr. Sanders went almost to Paige. And Mr. Waterson went to Wayside. You know over here where the tin cans are? He went that road. That's where they went. And then, as time came on, and these old men retired, they'd add a little of that route to these other ones. And then when they got to where that one man could take care of the whole business, why they let Mr. Sanders go to Lockhart, and Mr. Stagner was it.

Nickels: The small communities back then were Oak Hill, Wayside. What other ones do you remember? 
E. Goerlitz: Knobbs.

L. Goerlitz: We had to go to the Knobbs.

Nickels: Spring Branch?

E. Goerlitz: Well, Spring Branch, that was Lee County.

L. Goerlitz: Knobbs was-

E. Goerlitz: No, yeah-

J. Payne: Knobbs was Lee County too.

E. Goerlitz: Well, Knobbs was Lee County, but it's in our community. It's on our mail route.

L. Goerlitz: (chuckling) Well, they get our mail at McDade.

Nickels: What about little communities the other way, like Sayers for instance? Were there any other little communities in there?

E. Goerlitz: The Wayside community.

L. Goerlitz: Well, I don't know much about any of that. I tell you uh, probably Miss Pannell, Fay Pannell has all that. She knows all that.

J. Payne: Y'all didn't do any community stuff?

L. Goerlitz: Huh?

J. Payne: Y'all didn't do any community stuff?

L. Goerlitz: No.

Nickels: What about sharecroppers?

L. Goerlitz: Oh well, there was a lot of sharecroppers?

E. Goerlitz: Yeah, a lot of sharecroppers. And (clearing throat) they was mostly white people that was sharecroppers. And Mexicans - Mexicans mostly worked on them farms And blacks the same way. We never had many blacks here.

Nickels: And they worked on shares, a third, or fourth, or-
E. Goerlitz: Yeah, or halves. You got a tomato patch, and the landlord furnished everything, and he did all the work. And then he sold it, he got a hundred dollars for it, he'd divide it fifty-fifty. A lot of times, they'd give them a cow to milk or something like that, you know.

Nickels: Were there little Mexican communities, or colored, black communities?

E. Goerlitz: Not, uh-

L. Goerlitz: They was sort of segregated all right. There was some blacks here, but they mostly lived in one part of the town.

E. Goerlitz: Yeah.

J. Payne: Well, they had a little chocolate school-chocolate-

L. Goerlitz: Yeah, well I-

E. Goerlitz: Chocolate was out there in between here and the brickyard.

Nickels: Did you have a telephone in your early days?

L. Goerlitz: We had a telephone when we moved out in my Grandpa DeGlandon's place, they had a phone. It was one of these that you rang, and ah, you had to ring so many rings. And everybody that had a phone could listen in when they wanted to. (laughing)

J. Payne: We even had that here Mama.

L. Goerlitz: Huh?

J. Payne: We even had that when we moved here.

L. Goerlitz: Yeah, I guess we did.

E. Goerlitz: See, the deal was, they had a phone office in McDade. If you wanted to make long distance [calls], you had to come to town. And if you wanted a phone line out to your house, you had to buy the wire-

R. Payne: Put it up.

E. Goerlitz: - and put your phone up. That's how all that worked. 
Nickels: And you had to put your poles up?

L. Goerlitz: Yeah.

E. Goerlitz: You had to put your poles up yourself, and your wire. Then they'd hook you into this office here in McDade.

L. Goerlitz: It's getting a little cool again, how about opening a door?

J. Payne: I'll get up and turn it [the air conditioner] off.

L. Goerlitz: Open the door there in back of you there.

Nickels: Did you go to church when you lived in that area before?

L. Goerlitz: No, we didn't go to church, because, I don't know. I think my daddy and his folks came to McDade. They had a-

E. Goerlitz: Methodist.

L. Goerlitz: - Methodist church here then.

Nickels: Did neighbors get together and help each other back then?

L. Goerlitz: I think a lot of them did, but I wasn't involved in any of that I don't think.

E. Goerlitz: Yeah, they all worked together. And they dug everybody's grave, you know, and stuff like that. If somebody died, the neighbors all pitched in and dug the grave.

J. Payne: And if somebody got sick, y'all went and stayed with them, and took turns.

E. Goerlitz: And then, oh, when I first come home from World War II, I spent for three months, one night a week with one old man. Setting up you know, set up with him one night a week.

L. Goerlitz: Well-

R. Payne:

L. Goerlitz: That was after the war.
E. Goerlitz: Yeah, it was right after the war.

Nickels: Before the war, how were the funerals and burials conducted?

E. Goerlitz: In the house. There wasn't no funeral home. My grandpa died in 1932. And, (clearing throat) they sold caskets here in McDade. That man had a ton-and-a-half truck. And they had the funeral at my grandpa's house. They put the casket on that truck and carried it to the cemetery.

Nickels: You mentioned before, the Herron Cemetery, the Herron land, before we started the interview here. And, you mentioned perhaps a little cemetery. Are there any other little cemeteries or isolated graves in Camp Swift today that you know of?

L. Goerlitz: I don't know any in Camp Swift, but they has been different places. We have one right over here in town that I think it's practically been destroyed though, on Alvin's place, no it's on Merryman's place.

E. Goerlitz: Milton, Milton.

L. Goerlitz: Milton, yeah, the old Milton place.

E. Goerlitz: But hey, about this Herron Cemetery, the state put up a-

J. Payne: Monument?

E. Goerlitz: Monument, in 1936 on that. They did it on every San Jacinto, Texas, veteran's grave.

Nickels: I see. We'd talked about neighbors getting together, and you said everybody helped everybody.

E. Goerlitz: Yeah.

Nickels: Things like grain threshings, or-

E. Goerlitz: Oh yeah, oh yeah-

Nickels: Goose pluckings, quilting, barn buildings -

E. Goerlitz: Oh yeah, they all worked together.

Nickels: Can you give me some examples, or do you recall? 
E. Goerlitz: Well-(chuckling)

L. Goerlitz: Well, I know they raised peanuts, I know everybody helped quiltings.

E. Goerlitz: Yeah, say if somebody got sick, they pitched in and hoed his cotton, or his peanuts, and stuff. And when at hog-killing time, why they all pitched in and helped kill them hogs, you know.

$$
\text { R. Payne:__? (?) a party, didn't it? }
$$

E. Goerlitz: Like my daddy, he was a good butcher. What I mean, he knew how to cut that stuff up good. They always wanted him to come over there and cut them hogs up.

\section{Goerlitz: Um-hm.}

E. Goerlitz: And this grinding was a big deal. That would make you pretty tired grinding that stuff, and you had to chop this, this lard was chopped in little bitty pieces, you know. And then you rendered it over there in that pot. That's how they made soap, too.

L. Goerlitz: And made a homemade soap, lye soap.

Nickels: Do you recall getting together for Saturday night dances, or Sunday afternoon socials?

L. Goerlitz: We didn't do those kind of things.

Nickels: Did you have a radio?

L. Goerlitz: Not till, well, (laughing) the war probably was going on. First radio we ever had, I think my brother [Harvey, Jr.] bought it, and it was a battery radio, and brought it home to us. He was in the service.

E. Goerlitz: Yeah, they had dances in my neighborhood, out this way [east of McDade], you see. And out this way [to Oak Hill] they had parties. (chuckling)

L. Goerlitz: Not very many.

E. Goerlitz: Not very many.

R. Payne: And I went to both of them. (laughing)

Nickels: Without getting into trouble, can you tell me about a little bit of that?
E. Goerlitz: (laughing)

Nickels: We know that there is a lignite mine out there. And we know that it was operational until about 1928, when it burned for the last time. And that was over toward Sayers.

\section{Goerlitz: Um-hm.}

Nickels: Can you tell me anything about that mine, or any lignite mining that may have gone on during that time, to include individuals, like your dad perhaps, who mined lignite for burning?

L. Goerlitz: No, we didn't ever use no coal. But they had one up here close to the [Butler] brickyard, too. But we never burnt it. They burnt it in the schools here.

J. Payne: None of your people ever worked in the mines?

L. Goerlitz: No, no.

E. Goerlitz: Yeah, they burned it there in the McDade School, I know.

Nickels: Are you familiar with where that mine was?

L. Goerlitz: Well, not right now. I had seen it. Because it's not too far across [Highway] 95.

J. Payne: 95

L. Goerlitz: But I think Fay Owens [Owen] Pannell probably gonna tell you all about those mines.

R. Payne: Miss Rivers

Nickels: Can you remember going by there any time when you were a little girl?

L. Goerlitz: Oh yeah, when we rode the school bus, why we even went down on the river, and we drove all along that, where the mines were, you know. And the trains was setting there, waiting for the coal. And now they got a settlement on this coal mine, and here a few years ago, somebody built a, didn't he build a tank-

E. Goerlitz: Um-hm. 
L. Goerlitz: - down there, and (chuckling) it filled up with water. And the next morning he got up and he didn't have no water. He wondered what happened to it. It all went down in the mine. And so that's about what's gonna happen to some of those houses.

Nickels: There was also, in the late 1800s and early 1900 s, a fairly substantial winery operation out there, ran by Mr. Aussilloux. Do you ever recall going by there? That would have been up in Mr. Abner Scott's area.

L. Goerlitz: No, you'll have to ask the Scotts about that. That was more Wayside, I imagine.

R. Payne: Grandpa, you don’t remember?

E. Goerlitz: No, unh-uh.

L. Goerlitz: I know I think it was.

Nickels: What about, I know in Bastrop County there, in the late 1800 s, early 1900 s, and through the 1950 s, there were actually some pottery kilns, local potterers?

E. Goerlitz: Yeah, uh-huh.

Nickels: Do you recall any of those in the Camp Swift area?

E. Goerlitz: Not in the Camp Swift area, no.

J. Payne: $(? ?)$

L. Goerlitz: We had one around here, this town.

E. Goerlitz: Um-hm.

J. Payne: Wasn't there a Duncan Pottery? Was that out there?

E. Goerlitz: Yeah, I guess it was, I don't know if it-

L. Goerlitz: Yeah, there was potteries out there, but I don't know nothing about it.

E. Goerlitz: See, when I was a boy I worked in the McDade Pottery. But the Duncan Pottery was either in Camp Swift, or in the state park, Bastrop State Park. I don't know just where.
L. Goerlitz: Yeah, I think they sort of don't really know just exactly where it was.

Nickels: What about banking and financing?

E. Goerlitz: Well, we had a bank in McDade. And I've seen some checks they wrote for a dollar. But that went; Roosevelt closed that bank up too. And that was the end of that thing.

J. Payne: Well Daddy, I thought you liked Roosevelt.

E. Goerlitz: Well I did. And he was a grand president, he was a great guy.

L. Goerlitz:

E. Goerlitz: He had to do all this stuff because we didn't know how to do it! (laughing)

Nickels: As near as we can tell this area was settled in the 1840 s perhaps, but certainly 1852, 1853 and onward. And in those 1850s and perhaps ' 60 s, there supposedly was an old fort out there. It would have been very small. Do you recall anybody, any of the older folks talking about that?

E. Goerlitz: No, I don't.

Nickels: There supposedly was a predecessor to the Oak Hill School.

E. Goerlitz: Oh?

Nickels: Do you recall any other old school that the folks in the late 1800 s or early 1900 s would have went to?

L. Goerlitz: Well, (??) remember back there in the early 1900s out there in the Camp area, it was just Oak Hill and Wayside.

Nickels: Okay. Just for the record-

L. Goerlitz: Oh well, Sayers, maybe that's counted in there too. I don't know how far they went down thataway, but I see some of them talk about, like some of the Sayers folks were in it. But I had nothing to do with Sayers. I don't know. It was colored folks. 
Nickels: Mrs. Goerlitz, with your permission, I would like to read this at the end of the interview, to get it on this tape, this document that you've written up.

\section{Goerlitz: If you can read it. (laughing)}

Nickels: Well, Mr. and Mrs. Goerlitz, that's pretty much the topics I wanted to cover. Do you have any other topics you'd like to discuss?

E. Goerlitz: One thing I'd like to mention. These stores were just like a bank. You bought on credit here till the fall. Then you paid up your grocery bill, in the fall. They okay'd you in the spring, see. And then, if you had a sharecropper on your place, you told the store man to let him have groceries. Then he could buy groceries on time there. And that's how everything worked. They paid up in the fall.

L. Goerlitz: I can add a little to that. I had a uncle that had a store here. But McDade Pottery, who was the head of it, Payne Williams?

E. Goerlitz: Yeah.

L. Goerlitz: He asked him to credit his workers. My aunt died with them owing her worlds of money. They never paid.

E. Goerlitz: Yeah, but I'm sure some of them did. Most of them paid, you know what I mean. And our uncle told me he still made money, with them owing him money, you know, beating him out of money, still made money. And you could sell a side of bacon you know, you could sell anything edible.

Nickels: We talked about hide processing, and selling hides.

\section{E. Goerlitz: Um-hm.}

Nickels: Was it steel trapping?

E. Goerlitz: Oh yeah. I did most of mine with dogs. What you did when you skinned them, you had boards that you stretched the hides on to dry.

L. Goerlitz: He turns the hide, eh, the fur inside on the outside because they-

E. Goerlitz: Uh-huh. So they would dry, and you'd cut the tallow off those hides. And then when they get good and dry, you could send them to Sears Roebuck, or Montgomery Ward. That's where most of them went, you know.

Nickels: How did it get to them?

E. Goerlitz: Through the mail. We sent them by mail. You put them in a box and sent them by mail.

L. Goerlitz: And they went by train.

E. Goerlitz: Or by train, yeah, that's how they went, by train.

Nickels: And then they sent you back the money?

E. Goerlitz: Yeah, that's right. Sears Roebuck and Montgomery Ward were great stores back there.

L. Goerlitz: Yeah, (chuckling) that's where all our clothes came from. I think I made a note in there that my mother, that was her thing. She raised these turkeys, and sold them. Then we always looked at the Sears and Roebuck catalog. And here several years ago they did away with that Sears and Roebuck, and I sure hated (chuckling), I sure hated that myself.

Nickels: So she didn't make many clothes?

L. Goerlitz: She didn't do much sewing. Just, maybe patch a little something. But my grandmother sewed for us. If something was worn out, if Grandpa's old shirt was worn out, and the shirttail was good, and enough of it was there, she'd make either the boys a shirt out of it, or us girls a dress out of something, maybe her old dresses, or somebody else's old dresses. But that didn't only go for Grandma. I had a sister that worked at a state hospital, and she was single. I guess lots of her clothes, she thought they were old. She wanted something new I guess. So she brought me those dresses, and I had two girls [Alice and Janice], the two oldest children. I have a son too, younger [Erhard, Jr.]. But I always made their clothes out of her clothes, you know. So that's been in the family a long time. (chuckling)

E. Goerlitz: Something else I'd like to tell you. You can still tell a man that growed up in the Depression when you eat dinner. (Louise chuckling) $\mathrm{He}$ eats everything on that plate! (laughing) And you can tell him too, when, how he wears his clothes. He wears it out! (all chuckling) 
J. Payne: Look at you too, Daddy. (all laughing)

Nickels: How about shoes and boots?

E. Goerlitz: You wore them out too.

L. Goerlitz: You must have made out, hand-medowns, hand-me-downs.

E. Goerlitz: And your boots on the sides here-you would wire them with wire. (Louise chuckling)

J. Payne: In your shoe?

E. Goerlitz: Yeah. And by the way, we had a-

L. Goerlitz: Shoeman.

E. Goerlitz: - A man and his wife that fixed shoes here in McDade.

L. Goerlitz: Uh-huh.

E. Goerlitz: Mr. Howery, Mr. Howery was his name. He was an old Texas Ranger. And he was ninety years old when he found out the Texas Rangers could get a pension. And so he got a big check. The state figured it from sixty-five to ninety. (laughing)

J. Payne: In the 1800s?

E. Goerlitz: Huh?

J. Payne: From 1865 to 1890 ?

E. Goerlitz: Well, his age, you know.

J. Payne: Oh, oh, oh sixty-five to ninety years old.

E. Goerlitz: Yes, uh-huh. Yes, that happened before World War II, you know. (laughing)

\section{J. Payne: My!}

E. Goerlitz: They made their living sewing up shoes and putting soles on them, and heels, and stuff like that, you know.

Nickels: What are your fondest memories of growing up in the Camp Swift area?
L. Goerlitz: I don't know if there was any fond memories or not.

Nickels: Tell them about riding around with that boy in that' 28 Chevrolet.

R. Payne: (laughing)

L. Goerlitz: Now, oh, be quiet. Be quiet. (Erhard laughing) Well I guess that's about the only thing. We went down to Camp, couple of cousins went down in that-

E. Goerlitz: State park.

L. Goerlitz: - State park and rode around. I guess I probably never would have never got to see it otherwise. (chuckling)

Nickels: Did he come out and romance you at the house?

L. Goerlitz: (chuckling) I don't know, I think that started at a party, I don't know.

E. Goerlitz: Well, I'll tell you what happened. (Louise chuckling) I lived two miles this way, she lived two miles this way, and we met in McDade, and she asked me to marry her. Now what could I do? (Louise laughing)

Nickels: Too far to walk home, huh? (all laughing)

L. Goerlitz: Oh boy. He tells everybody that.

J. Payne: Oh well, didn't you have some family gatherings? Surely you had some.

L. Goerlitz: Oh yes, well yes. Go get the - well I took the pictures out. You can bring them-

J. Payne: Well it sounds like y'all didn't do anything fun when you were a kid. Maybe you didn't. I don't know.

L. Goerlitz: Well, not too much fun. It was living! That's about what it was. (chuckling)

Nickels: Lot of work?

L. Goerlitz: Yeah. (chuckling) 
J. Payne: And her mother, her mother was sick a lot. So she had to care of the kids.

L. Goerlitz: Yeah. See, when my youngest sister was born, my mother got an infection. What did they call that disease?

J. Payne: Staph, staph.

L. Goerlitz: She was in the Bastrop hospital six months, and I more or less took care of the baby myself. And I wasn't but fourteen years old. Well, that's one of them, but you should have brought the pictures of the ones of the reunion.

\section{J. Payne: There's three of 'em}

L. Goerlitz: Well, that's the first, that's the first one, yeah.

J. Payne: So y'all did do something.

L. Goerlitz: I was four years. We have it every year and this'll be the eightieth reunion.

J. Payne: There's mom.

Nickels: So these reunions took place out there?

L. Goerlitz: Yeah, out there on, you know on Camp Swift. And they been having the last few ones here in the McDade VFW.

J. Payne:

L. Goerlitz: And we used the school. Then they quit that; I think they had a few in Bastrop, and then they came out to the Oak Hill Cemetery and had some.

Nickels: I see.

J. Payne: Depends on the weather, if it's not raining.

L. Goerlitz: Now for the last, I don't know how many years now, they been coming to the McDade VFW. And, we have a Kelton, and a Smith reunion too, on my daddy's side. That's Sunday, that we have that. You know the Oak Hill Cemetery thing is -

\section{J. Payne: Saturday.}

L. Goerlitz: - Saturday. And then Sunday we have this Smith and Kelton get-together over here to the
VFW. In October then, we usually had it on my Grandpa DeGlandon's birthday or as close to it we could have it.

J. Payne: Well that's the same picture.

L. Goerlitz: Well, you didn't bring the one that had the names on it, did you?

E. Goerlitz: Well, I didn't see it.

L. Goerlitz: Well it was in there with that.

E. Goerlitz: And this is her mother. What house was this?

L. Goerlitz: That's the one that we left out there [when Camp Swift came]. That's all of us kids there, I guess.

Nickels: Mr. and Mrs. Goerlitz, I would like to kind of end this conversation with me asking your feelings, your sentiments, both yours and your mothers' and fathers' about how you all felt about the land being taken by the military in 1941, thereabouts.

L. Goerlitz: Well, I tell you-

E. Goerlitz: Well, I tell you how I feel that the people felt. The people felt like they should have been given a little more time. But the people were patriotic. That was a big thing, and we all worked together to win this war. They promised to give it back, but you know, they kept some of it. But anyway, I think my people never complained about it. Her people, I don't think have really complained too much about it either. Because her father got the land back, and then he sold it again.

L. Goerlitz: Yeah, well, he didn't get too good at it. You can't sell land for when the house is gone and all the outbuildings, and the fences, and everything has to be redone. And another thing, when we went back out there, there was not one thing there that you would recognize, even that place. They was a chimney on the house. They was a brick walk. Do you know they got every one of those and threw them in the well? All of that stuff, and all the lumber was gone too. I don't know where it went. I see my cousin says there that they bombed that house [we lived in - used it for target practice]. Maybe she knows a little more about it than I do. She's a little older than I am. I guess then 
they maybe scratched it together and burnt it. I don't know what they did with it. Then the milk barn, all that cement was gone that was in the floor of it.

J. Payne: What did they actually do at the Camp on that property of yours?

L. Goerlitz: I really don't know, no idea. But you know - fellow right down below us, he's about two miles down, over 290 here - this year, they wanted to come out and look on his place for these explosives. I don't know what they really was hunting.

\section{E. Goerlitz: Shells that weren't exploded.}

L. Goerlitz: They had did that over in some of the Camp, further over in to the Camp area. And they came to him, and he's bought this place, and built him a house there. They wanted to, I don't know what they wanted to do, if they wanted to dig, or just take something and see if they could find something. He said, "It's been sixty something years, and if it's there, you let it stay there."

Nickels: Do you recall your mom and dad's sentiments at the time?

L. Goerlitz: Well I'm sure they weren't happy! Like I say, I wasn't there just right when they had to pack up and leave. I knew they had to leave, when I left and then went to California. But, I heard them say lots of times, "We had to leave this behind. You know, we couldn't move it." And all that kind of stuff. I know they didn't have the house that they had out in the
Camp area to live in. And never had another house that good.

J. Payne: Because they had to buy something in such a hurry, they just had to buy what they could find.

L. Goerlitz: And they wouldn't have known about that, but my oldest brother, which was the third child, he was going with a girl. Her daddy had been married to one of the Parker girls, and she passed away. And the old folks now had passed away, and she told my dad, "That place is gonna be for sale." You know, divide up the money among the heirs. So, he went out there and told them he'd like to buy it. So when they decided to sell, then they let him have it. So that's where they moved to, out at the Knobbs.

J. Payne: It was already an old house then.

L. Goerlitz: Yeah, it was.

Nickels: All right. Well thank you both very much, we appreciate it.

E. Goerlitz: Oh yeah, yeah, thank you.

L. Goerlitz: And this house here, the fellow lived here, he rented it to two other couples. I said to my cousin the other day, I said, "Gosh, I wonder what they did for a bathroom. It just has one bathroom, but I don't even know if it had a bathroom then." (Erhard laughing) She said, "Oh, it didn't matter." (Louise laughing)

\section{(End of taped interview)}


The following manuscript was read aloud and recorded:

Nickels: My name is David Nickels. With permission from Mrs. Louise Goerlitz, I will read the following manuscript prepared by Mrs. Goerlitz.

Louise Smith Goerlitz's mother, Grace DeGlandon, ninth child of Alcide DeGlandon and Elizabeth (Lizzy) Stagner was born in Paige, Texas, Bastrop County in 1899. The DeGlandon family of eleven moved to the Oak Hill area of McDade, Texas, to acres Lizzy inherited. It had an old house on it. But soon the Galveston hurricane hit Galveston, and high winds and heavy rain came to Bastrop County, and the old white sand waterlogged, and sunk the home into the ground. Then Alcide had to get busy and have a house built on higher ground. This land joined the Smith land.

Louise Smith Goerlitz's father, Amherst Harvey Smith, was born in Alief, Texas, Harris County in 1899. The youngest of five children. In the meantime, the old Great-grandmother Ransom of Harvey passed away and her land that joined the DeGlandon land was for sale. So Andrew Morgan Smith left his teaching job in Harris County and with wife Edith May, and son Harvey Smith came to McDade, Texas, to try to make it farming and raising livestock.

So, their babies married when they were just nineteen years old. Grace DeGlandon went to the Oak Hill School and Harvey Smith went to McDade, as he had a sister still in school in a grade too high for Oak Hill. In fact, the Smith children always went to McDade. The sister just older than Harvey drove a buggy to McDade, and a friend had a patch of grass they let them put the horse in until school was out and ready to return home, about two miles from the school.

The neighbor babies married at nineteen years, and lived in a rent house on the Smith land, about half way between the DeGlandon and Smith homes. Eight children were born there, and Louise Smith was the first of the Harvey Smith children. They lived in this rent house until Louise was sixteen years old. Then the DeGlandon grandparents' older children thought it was time for the DeGlandons [to move], as they had three of their children living in the town of McDade. So the DeGlandon grandparents wanted the Harvey Smith family to move into their home, as it was large. Then a couple or three years later the Grandmother
Smith passed away, and Harvey Smith bought the Grandma Smith place, which was a much stronger built house, with a milk barn where Harvey and children had been doing all the work for several years, and a nice chicken house was there. He had a dairy on this farm.

Entertainment: We had swings in the many large trees. We always had dolls. As Louise was fixing to start to school, her sister just younger than her threw the doll and it landed up the trunk of the big hackberry tree. And when Louise went to get it a copperhead snake bit Louise. Her mother Grace, soaked Louise's foot in kerosene oil until she could get ahold of Louise's father to take her into Bastrop hospital, where Dr. Bryson lanced the ankle and put potash in the wound. And as we all know, that was no good. The poison was in the body by a couple of hours. But Louise could not go to school that year, as it was six months before Louise could walk, and we had to walk two miles to school in the wet weeds and grass. Then the next year was the bad flu years, and when it started in the winter months about the last of December or January she was taken out of school because they could not afford to have all the younger children sick with flu. We had plenty of berries when spring came, that grew wild and poke greens which we thought was great after cooking in three waters, and scrambling eggs with them after taking them out of the third water.

Louise's life was always busy with seven sisters and brothers to look after. Our mother always raised turkeys for her spending money, and Sears and Roebuck Catalogue was the shopping place for about everything the family needed, especially clothes. Our grandmother DeGlandon sewed lots of our clothes. When a garment, a dress, or shirt had some good, Grandma DeGlandon found a pattern for a dress or shirt and cut the garment with a pattern she had made herself. Louise got into a lot of trouble cutting up outgrown garments to make her doll a dress. I took after my Grandmother DeGlandon. I like to sew. My sister just younger than Louise [Buela] helped with the meals, and fifth child, a sister [Gloria], did the dishes.

We didn't have any parties but we always looked for the Oak Hill picnic once a year, a benefit for the cemetery. And at school we played drop-the-handkerchief, or ring-around-the-roses. After we had learned figures and numbers we played a lot of cards and dominoes at home. When we got home from the field and ate our dinner, we had until 2:00 PM before we went back 
to the field. So we rushed to a table so we could play games.

I started milking cows when I was nine years old, and soon had to clean the milk utensils, and this was a twice a day thing. Seems at first the cream was shipped by train to Taylor Creamery, and in later years they started making butter and peddling it in Bastrop. Grandma Smith at first molded the butter in a pound, oblong mold until she had twisted an intestine and had to have surgery. After that my dad molded the butter. I think every child had a job, but different kinds of jobs. Then the government said "Move, leave now, within thirty days." First thing, find a place to go, and lucky if you could find a place, and maybe not enough money to make a good down payment on any farmland; and most were farmers. And all of my family had been in the Camp area since the 1830 s.

Grandfather Alcide DeGlandon came, or stopped off in Texas after making a cattle drive to Dodge City, Kansas. He liked Bastrop County, Texas. As a teenager he witnessed a murder in Hessmer, Louisiana, and the murderer gave him a horse, told him to leave Louisiana and not to come back. It was thirty years before he did go back, and his mother was still living, and lived to be 101. The Grandpa Smith came here from Georgia, as he had relatives here in the Camp area that said it was a good place to a home. And when he got off the train in McDade he saw all the men that had been hung the night before laying on the platform. He took the wrong road out in the Camp area and ended up down on Piney near Bastrop where the Ransoms and Harveys lived. He asked where the Oak Hill area was, and since it was in the late night he was asked to spend the night. There he got acquainted with Edith May Harvey, Sarah Ransom's granddaughter, who was teaching in the McDade area schools, and married her. A lady could not teach after she married.

The Stagners came from Kentucky and settled in the Bastrop Park area. Then the Civil War took most of the men from this area, and after the war they had to walk back to Bastrop County. Some never made it back. They ate different plants, and some say they ate something they thought was poke weed; we call it poke salad. Great-grandpa Stagner had just gotten back from the South, and my grandmother was his oldest child. She was the only one in school, and she was in school when it rained a flood and surrounded Bastrop. My Great-grandpa Stagner waded and got my Grandma Lizzy from school, carried her on his back, and waded through the water again. In a few days he took pneumonia and died. He is buried in the Oak Hill Cemetery. Then his widow moved closer in to the Oak Hill area. They are all buried at Oak Hill.

Louise's grandmother, Edith May Harvey, was raised, or lived with her grandmother, Sarah Ransom; and her mother lived with Great-grandmother Ransom, as did Edith May and brother, Amherst Harvey, as their father rode away one day and never returned. Grandmother Ransom's husband died on the way to Texas and was buried in Massachusetts someplace. I don't know where they started from. Anyway, she bought the land we, the Harvey Smiths lived on in Camp Swift when the government took it. All these relatives are buried in the Oak Hill Cemetery. The Harvey Smiths and the Andrew Morgan Smiths are buried in the McDade Cemetery.

Grandpa Andrew Morgan Smith was English

Grandma Edith May Smith was Irish

Grandpa Alcide DeGlandon was French

Grandma Elizabeth Margaret (Lizzy) Stagner

DeGlandon was German

Interview with Alice Louise and Erhard Oscar Goerlitz, with contributions by daughter and sonin-law, Janice and Roger Payne Interviewed by David L. Nickels

Date: May 27, 2004

Place: Home of the Goerlitzes, McDade, Texas

Years of Birth: Erhard-1919, Louise-1920 


\title{
Ruby Mae Thomas Johnson Interview
}

\author{
By David L. Nickels
}

\section{August 2004}

David L. Nickels: My name is David Nickels. Today is the tenth of August, 2004, and this interview is taking place in Bastrop, Texas, in Ms. Ruby Mae Thomas' home-

Ruby Mae Thomas Johnson: I'm a Johnson.

Nickels: - Johnson, thank you, excuse me-at 1716 East Spring Street in Bastrop. This interview is part of the Texas State University-San Marcos, Camp Swift Oral History project, sponsored by the Texas National Guard, and conducted in conjunction with the Center for American History, The University of Texas at Austin.

Nickels: First of all ma'am, I'd like to thank you for allowing me to come and spend a few minutes with you. Just for the record, would you please state your full name.

Johnson: Ruby Johnson, Ruby Thomas Johnson.

Nickels: And where were you born Mrs. Johnson?

Johnson: I was born about between McDade and Sayers, on a little creek.

Nickels: Would that be Big Sandy Creek?

Johnson: Big Sandy, Big Sandy.

Nickels: Yes. Approximately what year was that?

Johnson: I was born in nineteen and thirty.

Nickels: Nineteen thirty. And so, you lived out in what is now the Camp Swift area for about eleven years before the military -

Johnson: I finished the first grade in Elgin. I left there when I was, I guess about six and a half-

Nickels: I see

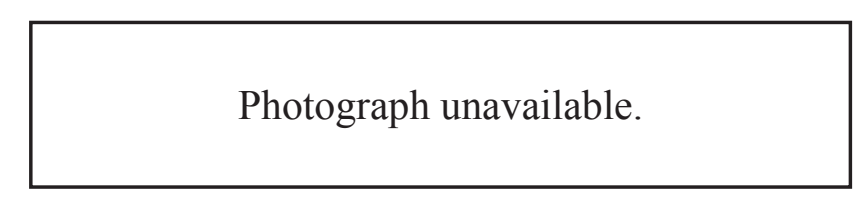

Johnson: - And I came to Elgin, and we moved there from Camp Swift.

Nickels: Did you have a large family?

Johnson: Oh yeah, yeah. I had four brothers and, well my sister, she was born in Elgin. But the rest of us five was born down there.

Nickels: And your dad, what was his occupation? Was he a farmer?

Johnson: Farmer. He was a farmer.

Nickels: And what did he raise?

Johnson: You know, vegetables and watermelons, but mostly vegetables.

Nickels: Do you recall much about his farming, and how he farmed, with mule, or -

Johnson: Yeah, he used mules, and he would help the neighbors. You know, go over and help them farm their land and vice versa. They helped each other. I know, Mr. Aussilloux, he didn't help anybody. He only helped himself. We had to pass through, we were kind of skeptical of going through his place, because he didn't much like peoples to come around his place. But we'd pass him and go to the Scotts, and that's what my daddy did. And if our hens had a nest on his place, well we would track our hens over to his place. He worked on one car all the time, ol' "T Model." And my mother would say, we needed the eggs bad. So we tracked the hen all the way over to his place. That's so that we could get eggs to cook with. We would wait until he kind of disappeared, go in the house. And 
then we'd run right back behind his old shed, and we'd get our eggs.

Nickels: So your hen laid eggs behind Aussilloux's shed?

Johnson: Um-hm.

Nickels: (laughing) I see. And did your mom and dad have, besides hens, turkeys or any other animals?

Johnson: Oh, we had hogs and cows. That's all I remember us having, hogs and cows and chickens.

Nickels: Were the hogs pretty much free ranging, eating acorns, or did you keep them penned up?

Johnson: Oh, we had a pen for them. You know, back in them days the pens wasn't like they have now. 'Cause I know my husband - all of that up there was hog farm - and we had it situated so beautiful. But out there you just did some old cut out cedar, and you know, made it up out of cedar poles and things, um-hm.

Nickels: Was hog-butchering time a big deal in the fall?

Johnson: Oh yeah, big deal. We didn't have no deep freeze, so we just hung it in the smokehouse and smoked it.

Nickels: Can you tell me a little about the butchering and how that all occurred?

Johnson: Oh, we just put on a pot of hot water. My daddy would just take a axe and hit him right there in the center of his forehead. He was out. Then he'd cut his throat and let him bleed out. We'd hang him up in the tree for about, I guess about thirty minutes, and the blood would just drain out. When all that blood drained out, my daddy would cut him down the center. And then take him down and lay him on the table and go to work on him. Cut him up in parts, and then we'd grind the sausage, old grinder by hand. Grind up the sausage, and Mama would season it with sage, and pepper, and salt. And we'd taste it. We'd have a fire out there and we'd just throw a piece on there and let it fry. Then we'd all taste it, [to see] if she was right. Then we had the hog intestines. We'd scrape them down for the lining for the sausage to go in. Then she'd put them on there, and make a tie in them. And we'd grind it, and they'd come out a long sausage. We'd rope it over a stick, put it in the smokehouse, and smoke it. Put a little fire in it, and let them, and smoke.

Nickels: About twenty-four or forty-eight hours?

Johnson: Yeah, yeah. You know I was small, but I remember that. I think I might have been six, coming seven, because I was seven years older than my brother. So, then we'd take the ham, put a stick between; my daddy'd cut a hole in the ham leg, put a stick between it, hang it down, and let it smoke with the sausage. That's what we had, ham and sausage. And the ribs, Mama would cook them up and put them in a jar, with the oil and all on them, and they would stay. We'd get them out, and we'd have ribs. That's how we kept our meat. And then sometimes she'd take it and make a stew out of it, and put it in jars. My mother was a great canner, great cook, great canner. It was all good, but (laughing) I wouldn't wanna go back to it.

\section{Nickels: Yeah?}

Johnson: Yeah.

Nickels: How did your mom cook, on a woodstove I guess?

Johnson: Yeah, and matter-of-fact, she had a cooker, a big canner that she would put it down in. But she had a wood stove. She had a wood stove, and she'd sit it on there. And we did not have a fan, either. Thank God for now. (chuckling)

Nickels: What was your house like?

Johnson: My house, eww, it was good. During Christmas time we would pop popcorn and make ornaments. But I never eat another jelly cake. My mama could make jelly cakes, and she'd make her own jelly. That was her icing. And I will never eat another jelly cake. (laughing) I hated that jelly cake. (Nickels laughing) But you know, she cooked jelly cakes.

Nickels: What did she make her jelly out of?

Johnson: Grapes, my grandfather had a grapevine patch up there. And after he died, she kept it up, and she'd make her jelly out of it, grape jelly. That's how she'd get her fillings, was grape jelly. I really don't remember no other kind of filling. That's the reason I'm never gonna eat another jelly cake. (laughing) 
Nickels: How far did you live from a little community?

Johnson: We had to cross Little Sandy to go to our neighbors. Mr. Richard and Miss Ella were the only black people that we could go visit on Sunday evening. But then we could go to the Thomas' kin. We'd have to cross up this highway from over at Camp Swift, across [Highway] 95. Wasn't no 95, just a dim, little dirt road to go to our other neighbors. So, we didn't visit too much. And then, I remember my first year, you know half a year going to Sayers. Well, we had to get up early, up at daylight. My brothers would pack me some half way, and then I'd walk. I had four brothers. I had three big brothers, and the baby at home. So, it wasn't too good, but we made it, you know, we made it.

Nickels: What did they pack you for lunch?

Johnson: For lunch, Mama did good. Mama'd get up, and she'd cook biscuits. We'd have ham, and sometimes she'd have baked sweet potatoes in there, and we thought we had a good lunch! You know, she always fed us good. And in the evening - we raised black-eyed peas, you know. Right now, I make a good living. I'm famous for Ruby Johnson's Famous BlackEyed Peas Gumbo.

Nickels: Really?

Johnson: Yeah. I have my sides, everybody know me. Ruby's Famous Black-Eye Pea Gumbo. I inherited it from my mama, and I just doctored it up. She didn't know to call it gumbo. She just called it black-eyed peas and okra. But I learned a lot from Mama. Now, I make it good also. Everybody wants my recipe, but I'm not giving it to them because my mama (??).

Nickels: When did your mom pass away?

Johnson: I think Mama died, passed away in '98, I think, '98, yeah.

Nickels: I see. Well, you obviously had some pretty good memories about that area out there; not all bad.

Johnson: I had forgot about it, until my brother say, "You know more than me." But you kind of tend to put that out of your mind. Well, it was all good. I remember we had to walk to church, across 95 to Sayers. And I remember Mama say we had to get home before night, because I guess there was wolves there, or something.
I guess she might have told me that to make me walk fast. I don't know, I never saw one. (chuckling)

Nickels: Other people we've talked to said there were wolves out there at the time.

Johnson: Um-hm. So, I would walk fast with her. My mama was a Christian woman.

Nickels: And what church was that?

Johnson: Over to Sayers. Golly, I was so young. It's the church that's still at Sayers.

Nickels: Baptist, or Methodist?

Johnson: Yeah, it was Baptist. But when we came to Elgin we came to the Methodist church.

Nickels: So, mostly you went in to Sayers if you-

Johnson: Um-hm, mostly. That's where we went to church at, in Sayers. Yeah, it was a Baptist church.

Nickels: Do you recall, did your dad work outside the farm anywhere, did he work in town at anytime?

Johnson: After we moved to town, but we barely could get to town. I think he had a Model T Ford. But we barely could get to town to go buy groceries. We'd go buy groceries on Saturday. I don't remember my daddy going to town through the week. I remember us getting dressed and going to town on Saturdays. But I don't remember him going. He might have did, but I don't remember it.

Nickels: There probably wasn't a lot of money back then.

Johnson: Oh no, we didn't have a lot of money. But, that's the reason I say the times was so hard back then. That's the reason now all my time-I strictly, I'm gonna tell the truth - I strictly won't pay for my time. (chuckling) I'm gonna tell you, because back then, like at Christmas we had ten cents. My daddy would give us a nickel and ten pennies, which was great. Every one of us got a nickel and ten pennies.

Nickels: At Christmas?

Johnson: At Christmas time. It was great. You'd buy a penny's worth of mixed candy, you would get a half of 
a little white bag. You go in now with a nickel and see what you get. "You better get outta here." (laughing)

Nickels: Tell me about your school.

Johnson: I was in school like I said. The first half a year I was in school in Sayers, and Miss McDade was my teacher. And it was the truest thing that was, and the greatest thing that was, Miss McDade left the same time I left and went to Elgin. So she finished teaching me out the first grade. And was that a miracle? It must have been a miracle, because I'm not knowing nobody at Elgin. It was big to me. [I thought] I'm going to this big school? The kids standing there looking at me. I didn't know if my clothes was going to be right. At that time I was beginning to get seven; you know, I knew things was different. And I was worried about going to school in Elgin because, I don't know, my clothes - but, my mama always ironed my clothes, and I do the same thing now. I'm a clean freak!

Where my kids went to school, they still shot marbles at school when my kids were in first grade. And my girls, they came up shooting marbles too. Only they could shoot a boy down to the ground shooting marbles. I had six girls. That's my baby boy there. He didn't do nothing but get spoiled. (Nickels chuckling) He doesn't live here but he came. And they used to bend over shooting marbles. And the teacher would say, "Maybe if you could tell them not to shoot them." Said, "Their panties are just white as snow, but could you tell them not to shoot marbles?" (laughing) They was my kids, my girls and stuff. They were rodeo girls, and their daddy was a rodeo man; he was a champion rider, you know. We traveled around, and my girls could ride rodeo like any other boy and everything. So they was tough! And, we managed the camp. That's the reason I worked so hard to send all my kids off to school. I had three in college at one time. And I worked hard to do that, because I didn't want them to come up like I did. My mama got sick, you know. And I had to take a job. I went back and forth from Elgin to Fort Worth working, and then come back and see about my mama. So I didn't want my kids to have it that way.

Nickels: Yes. That's commendable.

Johnson: Right. So, I worked hard to get my kids where they could just have things that I didn't have, and I wanted.
Nickels: In the Sayers School then, for fun you played marbles?

Johnson: No, we did a lot-my kids did the marbles - we did a lot of swinging, lot of swinging. We had a old swing with a piece of board in it. And then we had some barrels you rolled. You pushed the barrels. And they had tires, you pushed the tires. It wasn't too good, you know. We pushed tires, and-

Nickels: One-room schoolhouse?

Johnson: One-room school. Everybody in the same room, everybody in the same room.

Nickels: How about discipline?

Johnson: We didn't get too many whippings. Unh-uh, we did not get too many whippings. Sure didn't.

Nickels: Did you play ball?

Johnson: Yeah, basketball. This lady on the highway, Miss Lydia Tharns (??), she's way older'n I am, but I remember her getting a ball, and uh, giving it to me. She was a pretty lady. She hung out with my brothers, and I remember that. I remember we had a store right up from my school called Evans, Evans Store. They had bologna hanging down, and they had a big trough of vanilla wafers, I guess. You could go there, and you take a nickel. And he'd cut you off a piece, and dip in there and get you a big hand of them. And that was enough for ourselves. So we sometimes got a nickel to go to Evans Store. But uh, other than that-

Nickels: So you walked to school?

Johnson: Oh yeah, walked to school.

Nickels: And how were the roads?

Johnson: A trail, you got a trail. You just did a trail, that's all.

Nickels: Other than possibly wolves, do you recall snakes or any other animals out there?

Johnson: Oh yeah, my daddy had a horse. And we had to take him across a little, I guess it was like a little drainage, a little spring, and the spring drained off, and we had to take that horse across that. And they called 'em coachwhips; they would stand up 
and look at you. And you had better run because you wouldn't see them no more till they was right on you. You better get running! My brother take that horse, and tie him, and say "let's get him." I had a brother named Curly. He died, but he's still my guardian angel. When I get worried I go to his picture and I talk to it. But anyway, the coachwhips, the copperheads, oh, my God! A rattlesnake bit my brother. We was on the creek, and he bit my brother. And David, my brother David, he was real quiet. He told my oldest brother that what was with us. I'm with my brothers. I was a tomboy. I stayed with my brothers, because I was the only girl. We didn't know. Instead of us trying to get help for him, we looked for the snake to kill it. And he was getting sicker and sicker. We gonna find the snake. My brother, "I'm gonna find that snake and I'm gonna kill it." We looked for the snake.

You know God took care of us. Mr. Scott came by. He said, "What's wrong with that boy?" We had him laying out side of the road. "What's wrong with that boy?" Said, "A snake bit him." He said, "What kind of snake?" My oldest brother said, "Rattlesnake." He said, "Get this boy and let's put him in this water first." He laid him in the cool little water. We was fishing on Big Sandy. Laid him in the water. (rooster crowing) There was a old doctor man; they called him Mr. Press. (??) He said, "Go get Mr. Press." Mr. Press came and he give some kind of green stuff to my brother, and my brother started vomiting, vomiting, vomiting. Then he made a poultice, put it over that place where the snake bit him, and you could see that stuff draining out. He was the best. Called him Mr. Press. He was a Kemp, and he was our doctor. And he doctored on my brother. My brother laid out for days. My brother, his leg, we didn't know if he was gonna lose it or not. But we kept drawing water out of the well, dashing it on there. He told us, "Keep dashing that water on there." That water in that well was cool. It turned real soft. It was dark, darker than he was, you know. And we kept doing it and doing it, and finally we could see it coming back kind of red, had color in it. And we didn't have to take his leg off. But you know it was just amazing how God healed us down there without a doctor. We was just down there. It was kind of like in the wilderness. (laughing)

Nickels: Lot of woods?

Johnson: Oh! Good Lord, yes, a lot of woods! Um$\mathrm{hm}$ ! Lots of woods.
Nickels: What other poultices or remedies did your mom have for you, for sickness?

Johnson: Oh, right, now we had Watkins Big Salve in a big green thing about that big. That was all the medicine, Watkins Liniment, Watkins Salve. Mama could cure you with it. Mama had healing hands, because she could just rub you, and it looked like the pain would go away. You know, my daddy, he was a good man. I was his favorite because I was the only girl. I followed him. I wore overalls. The day he said I had to go to school, he called me (??) and said, "You gotta get out of them overalls." I wore overalls till the day I went to school. Said, "You gotta get out of them overalls." I had high top shoes on, overalls and a blue, denim shirt. That's all I ever wore. Yeah, "Ya gotta get out of that, you got to go to school. You have to have a little dress." Oh! That was the worst thing I ever did, was put on a dress.

Nickels: Did your mom make your dresses?

Johnson: No, another lady made my dresses, cousin Pallie Flowers made my dresses.

Nickels: Your cousin, Pattie?

Johnson: Unh-uh, Pallie Flowers.

Nickels: Pallie?

Johnson: Yeah, she made my dresses.

Nickels: Did you have a well or cistern?

Johnson: We had a well.

Nickels: Did your dad dig that, do you know?

Johnson: Yeah, I guess he did. There wasn't no other means. I guess he had friends and things would help him, you know.

\section{Nickels: A stone-lined?}

Johnson: No, wood I think. They didn't have no cement then. (chuckling) If they did, it was in town. But I think it was just wood. You know how you do that with wood, I think, block wood.

Nickels: Did you have a big garden? 
Johnson: Oh, yeah. I never seen greens no more look like Mama's greens and her collards. And she'd come walking with a big thing of cabbage this big, cabbage head. And she'd go to that smokehouse and cut a piece of that ham, or bacon. And that's what we had, cornbread and greens. That's what we had. I'm thinking, this neighbor, Mr. Moon, there, would take our meal because, back in them days, it was hard for a black, black man to go to the mill and get waited on quick, you know. So we had this white neighbor, who was really good. Me and his kids ran together. And I remember this good. We went to town Christmas, my they had beautiful girls. But they, my brothers, they thought we was all sisters. That's the reason I know-It's a mess now! My brothers and all us like sisters and brothers. We played together, we'd fall over and go to sleep together, and if we all fell out on a pallet, they'd fall on a pallet and we'd sleep. And I never saw my brothers touch them or nothing. So we all went to town, all of us was together. Oh man, like to been a stink. Those white boys wanted to whip my brothers, I remember that. I remember Mama and them got home and - and they explained to my Mama, "Why?" And my mama explained it to them. I had one bad brother though. He wanted to fight; he wanted to know, Why? And Mama explained to him, you know, the way it was. But, it, it was nothing like now. You do that, all the girls would be pregnant now.

Nickels: Times are sure different.

Johnson: Sure different. We ate at their house. I remember Mama saying, "We can't eat at dinner, we don't have enough to eat. " They ate a ten o'clock meal. I don't know, they had their time. Coffee, bread and something, tea, or something they ate-I don't know what - at ten o'clock. I don't know what you'd call it, but they ate a ten o'clock meal. But we only ate three times. We ate breakfast, dinner - we called it lunch - supper. Now, [it's] "I'll take you out to lunch, take you out to dinner." We didn't know nothing about that. (chuckling)

Nickels: What was the name of the black man who came to eat with you once in a while?

Johnson: Mr. Boss Coulters (??).

Nickels: Boss Coulters?

Johnson: Uh-huh.
Nickels: You said everybody helped everybody else. Did your neighbors come over and help your dad sometimes, or did he go over and help them do things?

Johnson: Um-hm, oh yeah.

Nickels: Was it mostly raising crops or plowing?

Johnson: Um-hm, yeah, plowing and raising crops. Um-hm.

Nickels: Mostly vegetables and melons, cotton or corn?

Johnson: I don't remember us having-I know the neighbor had some cotton but I don't remember my daddy having [any]. My daddy had watermelons, sweet potatoes mostly. Mama did the garden, but my daddy mostly had watermelons and sweet potatoes. That's what I remember the most of, sweet potatoes. He'd bushel them up, he'd set under the tree, wipe them off with a old rag, and have them pretty, and he'd look at them. Then we'd go out and pick berries. I remember I hated that - because of a spreadin'-out. We'd come all the way out to 95 , and we had all these berries. We was sitting down on the road; 95 was just a dirt road. So we was setting there just trying to sell our berries. I don't know where these people be coming from. I don't know, but they was stopped. Where I had been playing around my daddy all day, and just about when we thought we was [through], had about a couple of gallons of berries there, this spreadin'-out was right in my face, spread out, right in my face. He was just right in my face. And my daddy said, "Don't move. Don't move." And I go, "Why?" He said, "Just don't move." And I ain't even seen him. My daddy said, "You don't see that spreadin'-out in your face?" I go to look and he said, "Just don't move." And he came up and he killed it.

Nickels: What was it?

Johnson: It's called a spreadin'-out snake. You never heard of it?

Nickels: No.

Johnson: Why, when he'd get ready to bite, he'd just spread out. He'd be like that, and when he'd get ready to bite, he'd just spread out, like a cobra. 
Nickels: What about any old pottery kilns? Anybody make pottery out in that area?

Johnson: I don't remember. I don't remember no pottery being there. Now there could have. Did my brother say-

Nickels: I don't know.

Johnson: I don’t know about pottery.

Nickels: What kind of chores did you have?

Johnson: Oh, we had to feed the chickens. We had to shell the peas. We had to shell all the vegetables and to get them ready. And in the wintertime we had a heater. We had to stack wood. We had to go out and get wood. (train whistle in background) Bring it in and stack it up, and stuff like that.

Nickels: Did your dad take his sweet potatoes or melons to, maybe McDade?

Johnson: I don't know, I know he took them somewhere. I don't know if it was McDade, or, I guess he did. I guess he would take some to McDade.

Nickels: Did you ever have electricity out there?

Johnson: Oh, what is that? (laughing) No, and the first time I saw a gas stove - they called them then - we went to Elgin. It was Christmas. We never went to Elgin but Christmas. We went to town, Christmas. I went in the five-, ten-, and twenty-five-cent store, that was the name of it. And, I saw this heater, this thing setting there, (train whistle in background) was this beautiful red fire coming out of it. I thought, Oh, isn't that beautiful? Mama, "Come on baby." "No, I wanna watch this fire coming out of this heater." It didn't look like ours, you know. "Come on baby, come on away."

Nickels: Well, you sure didn't have a telephone then?

Johnson: Oh, no. No, we did not have a telephone. Let me see, I remember somebody they rode a horse through the neighborhood when somebody died, and told. I don't know who it was, but I remember it. It was somebody rode a horse through the neighborhood, telling people what happened. And our mail carrier, Mr. Bryan Waterson, if something happened he would tell us. Mama'd go mail a letter, he'd tell us. He sure would. He, "I passed so-and-so's farmhouse and their baby was sick" or something. But he would tell them. Something happen at our house, Mama'd tell Mr. Bryan Waterson, and he would go around telling, you know.

Nickels: So he was the means of communication?

Johnson: Yes, uh-huh, Mr. Bryan Waterson.

Nickels: Somewhere out there, in the early 1850s or '60s, some folks had an old fort. Did anybody ever talk about an old fort out there?

Johnson: (shaking head no)

Nickels: Okay.

Johnson: That's eighteen and fifty?

Nickels: Yeah.

Johnson: Aw, nah. (chuckling)

Nickels: Well, the Sayersville Mine; that was a lignite mining operation out there. It burned for the last time in 1928, the mines did. So it shut down.

Johnson: See, I wasn't born.

Nickels: Nobody's talked about the mine out there?

Johnson: (shaking head no)

Nickels: Well, another interesting thing you've talked about is old Mr. Aussilloux.

Johnson: Um-hm.

Nickels: And, Aussilloux had a winery operation; quite successful for awhile, and then Prohibition basically shut it down.

Johnson: I know he was secret.

Nickels: He was?

Johnson: You couldn't go around him. He had something secret going on. I don't know what it was. Now, I don't know what that was, but he had something secret going on around, because he didn't allow nobody around. 
Nickels: Some folks think he may have had some buried money there somewhere.

Johnson: Well, now I kind of remember them saying that. But, what become of him, I'm trying to figure out? Before we left, was he dead, or did he go back to Germany?

Nickels: I believe he died in 1925.

Johnson: Okay, well he died there. But they say he come from Germany, right?

Nickels: He was actually a Frenchman.

Johnson: Frenchman? Oh, he was a funny-looking man.

Nickels: What about funerals? When somebody died, how did folks handle the funerals at the time?

Johnson: My grandfather died, that's the only thing that I know. My grandfather died, and seems like somebody came and got my grandfather; somebody came and got my grandfather in a truck. They had them trucks made with a bed to them, you know. And they put him there. Mama dressed him. They didn't embalm my grandfather. They dressed him, and Mama put him in there. All the mens come and put him on a cutting board, a sleeping board or something they called it. And that's where he stayed that night dressed. They came and got him that next morning, I can barely remember. And they took him somewhere, the old cemetery's somewhere, and I guess Camp Swift took it up. But they buried him there. The mens dug the grave, and everybody brought food to the cemetery. I remember that. And everybody, after the burial, they ate and went on their way. That's the only thing I can remember; they come and got him, my mama dressed him, and my daddy helped her. People came, but they had to walk. It seemed like this truck this man had was a flatbed. But it seemed like he brought that casket, and then he took it away. I don't know if that was the ambulance or not. (chuckling) But it was a funny-made little truck.

Nickels: But the family sat up with you, and-

Johnson: Yeah, they laid him on, put his clothes on - They would take, like a board, and they laid him on there. And every now and then I'd go out there and see my grandpa. And the next day they followed that little deal to out in the woods somewhere. Now where it was, I couldn't tell you. Because you know, I didn't even think about this till my brother said, "You better rack your mind," 'cause - I had forgotten about all this, really and truly. (laughing)

Nickels: You're doing fine.

Johnson: He kept after me. But dang, I don't know why this is so interesting. Could you tell me why this is so interesting to my brother?

Nickels: I think it's a sense of history. I think it's a sense of being able to talk about your younger days. And a lot of people are reluctant to do that, you know. But believe it or not, young folks find it interesting. Young folks have no concept of what you went through, these days.

Johnson: Yeah. We really didn't, you know, we didn't suffer, because we raised our own food. And Mama made all the lard. So, basically, we ate.

Nickels: Made her own soap?

Johnson: Yes, yes, lye soap. She sure did, stirred it in a pot.

Nickels: Well Mrs. Johnson, that's pretty much all I wanted to cover. I appreciate your time. One final thing we always like to ask folks. The military, the government took over that land. Folks had put their life in out there, worked the land, built barns, built houses, had a community and a social life out there. And then the government came and basically paid money for the land but-

Johnson: Not much! I don't think we got much, not even close to a thousand dollars, I don't think so. And we never did sign our legal rights, lignite rights so I don't know, one day do you think they'll dig out there?

Nickels: I don't know of any plans to do so, no. There are leases all around it, and it has been surveyed for lignite through the Camp. But there's no active thing going on at this point. Do you recall what your mom and dad's feelings were at the time? Were they bitter or did they have enough time, could it have been handled any- 
Johnson: We didn't have enough time! A man came, and he just told us, you know, we had to get out. He came, just came and, and back in them days-I'm gonna be honest with you-back in them days the white man's word was what was. But everybody moved out too. I don't know if they had more sayso, the whites, than we did around there. All I know, my daddy and my mama said, "We gotta go." So they went, you know, to my aunt in Elgin, Aunt Irena (??). So she helped them find this place in Elgin, and that's where we went. Our first house we moved [into], bought in Elgin, burned up.

Nickels: Your dad didn't move any buildings when you all left?

Johnson: No. We could not. We left the old house there. It was so sad. We just moved out. We didn't have no means. I don't guess you'd have enough to have somebody to-you know, we were just, yeah, we was; pretty bad, we just - I heard my daddy and mama speak of it. And when Camp Swift left there, well, it was too late, and they was too old to go back. She asked him, did he wanna go back. He said, "No." He was too old to go down there and start all over again, with kids all grown. So it just messed his life up! It really did mess him up, hearing my daddy and mama talk about it. And we had a lot of land down there. I can't recall how much, but I remember seeing how big it was. The back field was way, way back. And then it went this way, and you know, oh, it - Buck, my brother, he still go down there and he say sometimes, "Look at all that land we gave away." People now, they gonna buy, whenever that land goes back, somebody gonna come in there and sell that lot. My same where
I was born, for so much a lot. They gonna do that. But I'm gonna get me a lawyer if they ever, you know-

Nickels: They never offered it back to your dad?

Johnson: No. No. Some people say they did to them. But they never offered it back to my dad. I don't know, I believe he would have, my brothers or some of them would have bought it back. Of course, all my brothers is dead. There's just two of us living, my brother in Elgin and me. So, I really think my daddy would have bought it back if they'd offered it to one of my brothers. Because they really put some work in there, really did. My poor brothers had to work hard.

Nickels: Well, I wouldn't mind talking with you further, but I know you've got things going in the house.

Johnson: Yeah.

Nickels: Do you have anything you'd like to add, anything at all?

Johnson: (shaking head no)

Nickels: Well you've sure been very kind, at short notice, and I appreciate it very much. Thank you.

Interview with Ruby Mae Johnson

Interviewed by David L. Nickels

Date: August 10, 2004

Place: Home of Johnson, Bastrop, Texas

Year of Birth: 1930 


\title{
Morris J. Kastner InTERVIEW
}

\author{
By David L. Nickels
}

\section{April 2004}

David L. Nickels: My name is David Nickels. Today is April 29, 2004. It's close to noon, and this interview is taking place at the home of Mr. Morris J. Kastner at 353 Knobbs Road in McDade, Texas. This interview is part of the Texas State University-San Marcos Camp Swift Oral History project. It's sponsored by the Texas National Guard, and conducted in conjunction with the Center for American History, The University of Texas at Austin.

Nickels: Mr Kastner, first of all I want to thank you very much for allowing me to come into your home, and consenting to share some of the tales and some of the stories that you remember of Camp Swift. Just for the record, would you state your name and date of birth please.

Morris J. Kastner: My name is Morris J. Kastner, born May the twelfth, 1932.

Nickels: All right, thank you. And I understand that you were born on Camp Swift and, and grew up there. Could you tell me of the circumstances?

Kastner: Well yeah, I was born there, and when Camp Swift came in, why we had to move. I was probably seven, eight years old when we moved in '41. I was about nine years old when we moved, and back then all we had was wagons, and mules. Everything was farmed with mules and horses, and no tractors. Back then there wasn't a tractor around, that I knew of, back then. And we had some sharecroppers on our place. We had four families that worked land on the place, and they was sharecroppers. My mother would get a little bit of an income from just whatever they raised, you know, a certain percent. I don't know what the percentage was, but we had four families working on the place that worked about thirty, forty acres apiece. We had 495 acres out there, and we raised cattle, we had chickens, we had turkeys, a few guineas. The turkeys we had, they was raised, or were put in our orchard every night because that's where they stayed penned up. And an orchard, we

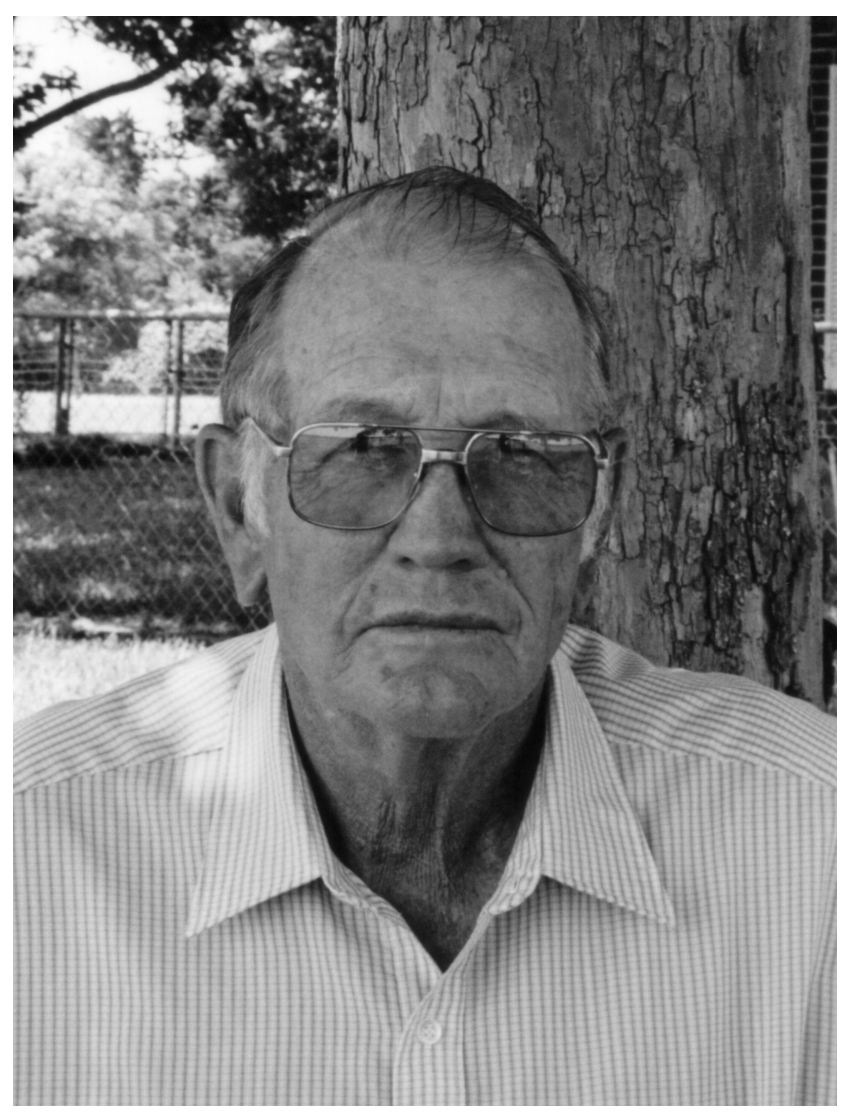

Morris J. Kastner

had a fruit orchard out there. It was probably about an acre big, or a little over, and that's where we kept our turkeys. Then we'd let them out in the morning. We'd have a bell on the lead turkey so you could know where they were at, so you could find them. That went on for as long as we were out there. We had to go to school in McDade, which is about oh, nearly two miles from there. We had to walk to school from back there, which back then I guess it wasn't very far, but now then people don't walk, (laughing) don't walk any. (laughing) So, we went to school here in McDade, and we had chickens and turkeys, and we had cows to milk, and we raised our own beef, and hogs, and stuff like that.

Nickels: Did you sell a lot of cattle? 
Kastner: No, we didn't have that many cattle, I don't know how many. Wasn't that many because the farm, the land was mostly used for the sharecroppers, and to keep our horses and mules, so that they could all make a living.

Nickels: Did you butcher your own cattle?

Kastner: Yeah, we butchered our hogs and cattle, but we butchered in the wintertime. The cattle, we didn't butcher very many of those, not that I remember. But the hogs, every year we'd butcher a couple hogs. We didn't have any electricity, or nothing like that out there at that time. We had to process our meat in the smokehouse, and after you got it kind of cured, you put it in these crocks, and poured grease over it to keep it so it doesn't spoil on us.

Nickels: Did you make sausage?

Kastner: Yeah, we made sausage and we hung that up in the smokehouse and smoked it for probably about, oh, four or five weeks, I guess until it got cured. I guess it's kind of like what they call dried smoke sausage now.

Nickels: Eggs, did you have a lot of eggs?

Kastner: Yeah, we had eggs and we would take what we didn't use to town. Why, we'd go to town probably about once a week, which was on the weekend, only on about a Friday or Saturday. We'd sell our eggs at the store there, and my mother would buy groceries or whatever we needed. But back then it didn't take a whole lot of money to buy groceries. You could buy a whole lot of groceries for just a few dollars.

Nickels: Did you trade eggs or anything?

Kastner: No, we sold them, and then we used that money for buying flour, and meal, and whatever we needed.

Nickels: And you had a garden plot, I guess?

Kastner: Yeah, we had a garden, and in this garden we had our tomatoes, and, oh, peppers, and whatever. We had grapes in our orchard, grapes, and peas, and peaches, plums. And that was something to look forward to! Whenever they'd get ripe we'd have fresh grapes to eat and stuff. (laughing)
Nickels: So it sounds like your mom did a lot of canning probably?

Kastner: Yeah, yeah she did lots of canning. Well, everybody back then did lots of canning, because that's the only way they had to keep their food and stuff, to keep it so it wouldn't go bad on them.

Nickels: When you say you went to town, was that Elgin?

Kastner: No, to McDade, back then, which was about two and a half miles, probably. But you, see we'd have to go to town in a wagon. These sharecroppers, they raised cotton, and they raised corn, sweet potatoes. But they didn't have the big acreage like some of them do today, you know, four or five or six acres of this, four or five or six acres of that. Then they would sell all of this stuff so they would have money to buy their groceries and stuff, and so they could stay on the place.

Nickels: What was your house like?

Kastner: Well, it was just (laughing) a house out there with single walls, no screens. You didn't have screens on your (laughing) buildings at that time that I know of. And it was, I don't know later in years, about ' 38 or '9 we got wallpaper put in on the single walls, (laughing) and that was something boy! Because you just had a one by twelve wall that was stripped. It was something, it's different. If people had to live that way today, they wouldn't know how in the world we made it back then.

Nickels: What was your water source?

Kastner: We had cisterns. We had some tin cisterns, and we had an underground cistern. And, we'd catch all the water that come off the roofs of the house, also on the barn part out there. We'd save water and stuff for the hogs, and whatever. You had to have this water for the hogs too, see, and you didn't waste any water back then. After you washed your hands, you didn't pour it our or nothing. It stayed there until that next day, probably.

Nickels: Was your mom a good cook?

Kastner: Yeah, she was a real good cook, sure was. She was a outdoor person, but she was indoor cooking too all of the time. We lost my dad when I was about 
four and a half years old, and she'd taken care of us until the army camp came. Then we moved out north of McDade, and she bought some property out this way.

Nickels: I see.

Kastner: So-

Nickels: And she had a wood stove?

Kastner: Yeah, wood stove, yeah sure did. We had a wood stove and a wood heater, and no running water; (laughing) no running water whatsoever. You had your, I don't know what you'd call it, a No. 2 or 3 washtub that you bathed in, (laughing) and everybody took a bath in that same water.

Nickels: Who was first?

Kastner: Uh-

Nickels: Or last?

Kastner: I don't know, just whoever was the last one there I guess. (laughing) But, aw, that was something. We didn't have any indoor plumbing. All our plumbing was outdoors. We had a outhouse, and at night you had a little bowl. I can't put the name on it, kind of like a port-a-potty something that you had in the house for the night, and then you'd empty it next morning.

Nickels: Yeah.

Kastner: We only had a wood heater in our, I guess you'd call it the living room and the dining room. That was a kind of combination room together. Then you had your little bedrooms off on the side there, but there was no heat whatsoever, except when it was real cold, mama would take a iron and iron the sheets to warm them a little bit, (laughing) so we could sleep. But we made it okay! (laughing)

Nickels: What about the sharecroppers? Were their houses about the same?

Kastner: Yeah, their houses was about the same. We had four of those little houses for them.

Nickels: Were they scattered around?

Kastner: Yeah, they were scattered around. They had four different families and two of them came when we came back out of the Camp, over here with us. The other two, I think one went to Austin, and I don't know where the other one went. But see, we didn't have as much land then. So they couldn't make a living. They had to go somewhere to make a living.

Nickels: And they had families also?

Kastner: Yeah, they had families also. Sure did.

Nickels: And you have two sisters?

Kastner: Yeah, I've got two sisters, one older than me, and one younger. And I've got a half-sister and a halfbrother. My mother was married for-let's see, I got a half-brother, he's fourteen years, was fourteen years older than I am and my sister. The other one was I believe thirteen years older.

Nickels: Were your two sisters born there also?

Kastner: Yeah, right.

Nickels: Were you born in the house?

Kastner: Aah, I'm not real sure about that. I don't know if I was born in the house, or the doctor came out there, or what. Our doctor was in Bastrop or Elgin. I think it was Bastrop, that was my doctor at that time, I think.

Nickels: How did your mom remedy your coughs and your cuts, and your bites, and-

Kastner: Well (laughing) you taking that honey, and a little whiskey (laughing) and stuff, for a cold. That was a kind of your cough syrup.

Nickels: Your main source of transportation was horse and buggy?

Kastner: Well, it was wagon, wagon and mules, yeah. We didn't have a buggy, we had just wagons. They were for hauling produce, and bales of cotton and stuff like that. Whenever they'd get a bale of cotton, well then they'd bring it into town for the gin. I remember when I was little, I would be the one that would have to stay with the wagon till it was our turn to get ginned. And set under the tree over there. They had lots of cotton back in those days, and you had to wait. But now it's not any cotton around, or nothing like that around now, not like it was then. 
Nickels: Did you grow melons?

Kastner, Yeah, yeah we grew watermelons, cantaloupes, and peanuts, and sweet potatoes. They had Irish potatoes. You'd plant so many, and then whatever you didn't need, you'd sell. I think some of them was even given to your neighbors if they needed some. Everybody kind of helped one another back then.

Nickels: They did?

Kastner: Yeah, it was a experience.

Nickels: What did you do for fun?

Kastner: For fun? I guess we just played marbles, (laughing) marbles and that's about it because we didn't have no bicycles or nothing back then. And if you had to go somewhere, like going to town, we had to walk.

Nickels: How'd your mom do her washing, do you recall that?

Kastner: Yeah, they had a washpot, and you had a wash rubboard, and you scrubbed that, washed clothes on it till it got clean, and you rinsed it. Then you hung it up on the line for it to dry. And see, and all of this here was out of that homemade soap, which was made from hog lard.

Nickels: I see.

Kastner: But nowadays, nobody makes any soap anymore.

Nickels: And, it was all kerosene lamps?

Kastner: Yeah, yeah we had kerosene lamps, and whenever you'd go from one room to the other you always had to carry your light with you at night. Mama would always put it in there for us, and then when we went to bed, well there wasn't no lights there then. You had to do your schoolwork after you did your little chores around the place. That was at night usually. And that's when we did our little schoolwork. Because we had to work too; all of us worked.

Nickels: Um-hum. What were your chores?
Kastner: You name it. Chickens, turkeys, follow the turkeys, bring them in to the orchard and pen them up, and put feed out for them. They would come in because that's when we would feed them. They would come in and we'd close the gate so they would stay in the orchard for that night, so that none of the varmints and stuff would bother them. I don't know, they probably had lots of coyotes back then. I don't recall any, but I know they penned them for some reason.

Nickels: What do you remember about any wild game out there, if anything — skunks or critters?

Kastner: Oh yeah, you had skunks and opossums, and raccoons, and there was a few civet cats. I guess that's a cross on a skunk. Outside that we had a lot of gophers and stuff like they still got today.

Nickels: Do you recall whether a lot of land was cleared, or forested mostly?

Kastner: No, there were a lot on our places there, it was quite a bit of it cleared. I don't know, over half of it was farmed for farmland, and the others was run for the mules and a few cows. But see, the farmhands had to have work land, so that they could plant a crop. We wasn't bothered with mesquites and stuff like they are today, we just didn't have them.

Nickels: Did you ever get a telephone?

Kastner: Yeah, we finally got a telephone, but aah, that was probably about '39 or '38, '39, somewhere back in there. It was one of the crank deals. I don't know how many people on the line. You had different, one long, two shorts, two shorts or one long. (laughing) You could call and they had the switchboard in town then. But that, that was something else. (laughing)

Nickels: How about a radio?

Kastner: No, we didn't have a radio until we got electricity. I didn't even know they existed back then. (laughing)

Nickels: How about your mail?

Kastner: Our mail? Yeah it came out on the road over there, and you had to walk. It was about a mile or so to get the mail. I don't know, I guess they ran every five or six days a week. I don't know if they ran that often or not. But we'd have to pick the mail up there. I know 
you wouldn't just go over there every day. I know we didn't pick it up every day.

Nickels: Did you attend church at all at that time?

Kastner: Yeah, we attended church here in McDade, the Lutheran church. I been a member there for a long time until we moved to Austin. And then after we moved to Austin and came back. I'm still a member here now again.

Nickels: Well, at nine years old going into town must have been a big deal.

Kastner: Oh it was! It was something, it sure was! It was an experience. I mean, when you went to town, you didn't see no automobiles. (laughing) When I was going to school, why probably in the first grade there was only one person there that brought his kid to school in a car. I thought, my gosh, that this here is something. (laughing) Everybody else is walking.

Nickels: And did you used to like to shop like at drugstore or anything?

Kastner: Yeah, yeah. Well, oh yeah. You'd get you a sody water or something, a bar of candy, or something like that. See, at that time, when I was a little kid we had, what, four groceries there in McDade. And some of them, boy they liked us little kids to come in, because we would spend a penny or two, whatever. (laughing) Oh me.

Nickels: What about funerals, or what about the railroad. Do you remember that here in McDade?

Kastner: Oh, funerals back then, you would set with the families. You spent the night, set up the wake like, and set with the family till whenever they had the funeral.

Nickels: Um-hum.

Kastner: That was an experience too.

Nickels: Do you recall, like, peddlers, drummers coming through the area?

Kastner: Oh yeah. People would come by and wanted to buy livestock and stuff like that, a cow or something, or a calf. You didn't have to haul it to the sale barn or nothing. You had these, uh, I can't put a name on what you call those people, traders come by and want to buy whatever you got, and they would haul it. They'd had a vehicle. And see, we didn't have that modern equipment to haul them in.

Nickels: I know that on Camp Swift today there's the lignite mine operation and a Mexican community was there. Then there's a Mexican cemetery, and I know that there's a black cemetery out there. Were those folks living around your place out there?

Kastner: There was one colored family that lived over there. And she was the one that would take care of us when we were little kids. I guess mama was working out in the field and the garden, and she would come over, which they lived probably about a mile or so from us. But, I think she had to walk all the time because there wasn't no transportation. I don't know how long, probably till we got four or five years old, I guess. I don't know how long she came there. But she was there helping Mama a lot. And these hands that was working, they had some kids and we all played; the kids all played with their kids, and that's how we passed our time away.

Nickels: These are the sharecroppers' kids?

Kastner: Yeah, the sharecroppers.

Nickels: But you don't recall what shares, a third, fourth, or-

Kastner: Ah, they probably got three-fourths and we got a fourth. It wasn't much, four-to-one, or something like that.

Nickels: I realize you were nine when you left, but for most folks that was very traumatic to be moved off their land.

Kastner: Yeah.

Nickels: At that age, what do recall about your feelings or your mom's?

Kastner: Well, we had to get off, I knew that. We had to get off, and my mother, she found these places up here north of town, so she bought those. I don't know, can't say how long we had to get off, whether it was about six or eight months. But, we had to tear down all our buildings, and we brought our lumber and stuff back over here and we built a little house and stuff 
out here where I'm living today. There was a little house built out of some of that lumber. But see we didn't have no running water or electricity in that little house! (laughing) And that was in about ' 41 or '2.

Nickels: That was a board-and-batten kind of style?

Kastner: Yeah, right.

Nickels: Pier and beam, or what is it?

Kastner: Yeah, just a single-wall, single-wall building. Yep.

Nickels: Did you do any fishing or hunting out there?

Kastner: We fished. It would have only been in our tanks; that would have been it. Hunting? No, I didn't go hunting, unless you saw a rabbit or something. You had this little old thing, I don't know, what do you call it, with two rubbers on it, you shoot a marble or a rock?

Nickels: A slingshot?

Kastner: Slingshot. (laughing) That was your weapon.

Nickels: You mentioned tanks. Y'all dug ponds or tanks out there, I guess?

Kastner: Yeah, we had oh, I don't know, about five tanks or so on the place there. You had to have them close to where the sharecroppers lived so they could tend to their mules. They was our mules, but they was using our mules. We had to have a place for them to let, and like all our feed and stuff, for the mules and stuff, well that was grown on the place. Like, you cut your tops from your corn, and your cane and stuff. You stacked it in a little stack, and when you ginned a bail of cotton, well you brought your seed back home so you could feed the cows. And it [was] an experience. I mean you didn't waste anything hardly.

Nickels: Did you have a corn crib?

Kastner: Eh yeah, we had a little old corn crib, sure did. And we had a corn sheller that you shucked the corn, you turn it and it shells the corn off. You had to do that for the chickens and the turkeys. For the cows and stuff we'd take some of these bigger ears and split them, cut them in about three or four pieces, and feed the cows pieces of corn. Corn on the cob. (laughing)
Nickels: What about a root cellar?

Kastner: No we didn't have a cellar.

Nickels: But you had a big smokehouse?

Kastner: Yeah, we had a smokehouse, we sure did.

Nickels: What kind of wood did you use for that?

Kastner: They used mostly mesquite wood back then. But mesquites, we didn't have many, or they would use some of this old dried up oak wood to smoke too.

Nickels: Did you have pecan trees on your place?

Kastner: Nah, I don't think so. I don't think we had any pecans in the orchard, I don't remember any.

Nickels: Did you use the mules to plow with?

Kastner: Yeah right, oh yeah, mules, that was your working mules. You took care of those mules. (laughing)

Nickels: And what was the barn like then?

Kastner: Well, the barn was where you put your corn in, and you had your place in there where they had kind of a big bin that they put your cottonseed in. It wasn't that big but see all, like your tops and stuff, they was cut and then put in a little, I don't know, pile. You had to tie them, I don't know, about a dozen or two together. And then we'd stack them up on a pole. And all that kind of feed, hay and stuff, was outside all the time. We didn't have any feed. There wasn't no square bales back there. So, no, it was lots of work back then. Ah, well everybody did it and thought nothing of it!

Nickels: But the neighbors helped a lot?

Kastner: Yeah the neighbors helped, and we'd go help the neighbors if they needed some help.

Nickels: Did you not have a fireplace?

Kastner: No, we didn't have no fireplace.

Nickels: What were the roads like?

Kastner: The roads, they was not paved! (laughing) And you could get stuck in the road with the sand. Of 
course there you were with your mules and stuff. You never did get stuck with that. The roads was just little old trails going through the pasture, and around the fencelines.

Nickels: Did the creeks flood?

Kastner: Yeah, they would flood, and you'd had to watch it. But back then we didn't have that much trouble with the wagon or nothing like that, because if it wasn't but six or eight inches deep, the wagon would go across. But now I don't know, you know the automobile and stuff? I know after I got older and married, and run cattle out there in the Camp later years well, you can get stuck in a creek and it wouldn't be no (laughing) nothing, no water hardly, see? Ah, we never did get stuck that I know of, back then.

Nickels: So you leased some of the land back for cattle grazing in the fifties or sixties?

Kastner: Yeah, in the sixties, yeah, I guess it was in the early sixties. And then they kept it, for I don't know, about ten years or so. And see, my mother, you know they was gonna sell all this land back to the original owners. Well, my mother, she sent them the money in to buy all our land back, and they kept it I don't know, about eight or ten months; they sent the money back and we still never did get our land. We was supposed to have gotten it back at that time, but we didn't, and it's still out there.

Nickels: When you were living out there tell me about-I know we recognized some names here off this old map - about your neighbors and any relatives that lived out there.

Kastner: Yeah, I had an uncle that lived in front of us over there, Uncle Fritz, Fritz Kastner. And kind of northwest over there I had two more uncles, Arthur Kastner, and Kelly Kastner. And you get further up the road, Martin Kastner lived up there. He had property on both sides of the road. And I had a aunt that had a place down there around Old Sayers Road. After they sold some of the land back, one of my uncles bought some down there around Old Potato Road, which is close to Paige, which was Cecil Kastner. But none of my relatives moved back out there that I know of, except Cecil. Cecil lived out there when he bought that place. Oh, I had another uncle that bought a place out there, which was Julius Kastner. He bought close to the Oak Hill Cemetery. He bought a place out there and he kept it for a number of years. I don't know who owns it today.

Nickels: Well, why so many Kastners in the area?

Kastner: Well, my grandpa didn't have too many kids, just sixteen kids, (laughing) had eleven boys and five girls, (laughing) and everybody had to work. And that's the reason he probably had a big family. Lots of families back then was big families! My dad worked in the store with my grandpa. My grandpa had a store there in town.

\section{Nickels: In McDade?}

Kastner: Yeah, in McDade, yeah. I can only remember my dad twice. I remember him riding up on his horse coming I guess from work, from town. And, then I can remember him, me setting in his lap. And that's all I can remember because I was just a little kid! I don't remember nothing. I wished I remembered more about him, but I didn't.

Nickels: Sure. Well, your dad lived on the farm with y'all, but he worked in town to supplement his income?

Kastner: Yeah. Supplement, yeah, because he helped my grandpa in his business up there. Yeah, that was something else.

Nickels: Your grandpa must have been one of the early landowners at Camp Swift, then?

Kastner: Yeah, I guess. He had lots of kids. Their kids had four, five hundred acres of land. There's several up here north of me where I live now that had land, which would be my uncles, like Jimmy Kastner, and Alfred Kastner, and Leonard Kastner.

Nickels: What was your grandpa's name?

Kastner: Julius Kastner. Julius Kastner, yeah.

Nickels: What are your best memories of living out there?

Kastner: Best? Well, the best memory I guess is when it got dark you went to bed, (laughing) because you couldn't do nothing! (laughing)

Nickels: Where did you sleep? 
Kastner: I slept in one of the little bedrooms there. That's all I can remember. We was all on that one side of the house there. And one side of the house was the bedrooms, the other side was the living room, and the dining room, and the kitchen. That's all kind of a combination deal.

Nickels: So, the whole family slept in the same-

Kastner: Same area, yeah. So, (laughing) yeah.

Nickels: Did you watch out for your sisters, or did you pick on them?

Kastner: Well, I don't know, I guess we looked out for each other. (laughing) That's all I know about that. And like I said, back then, you didn't lock anything up, you didn't have to lock your doors, or windows, or nothing!

Nickels: No trouble?

Kastner: No trouble whatsoever!

Nickels: Did your mom sew?

Kastner: Yeah, yeah she'd sew and, oh make this, make clothes and stuff out of these feed sacks, or flour sacks. You got flour sacks, which you'd make you a shirt, or dress for girls. You, didn't waste any of this stuff. (laughing)

Nickels: Did you like to read?

Kastner: We didn't have much time. At night, well then it was time to do your little homework. Then it was bedtime! We had our little chores to do before, when we got out of school.

Nickels: The sharecroppers, are there any ones in particular you remember more than others?

Kastner: Yeah. Marcelino Ocho, and Margarita Martinez, and Marcelino's son, which, was a sharecropper. He had a family out there too, Jesus. And he had, I don't know, probably five or six kids. And see, I played with his boys, and stuff. There was a couple of them. I think one lives in Taylor, and one in Austin, but I haven't seen them in years now. But we played with those kids.
Nickels: What about your preacher or your teachers? Any memories of them?

Kastner: Well, yeah, a little bit, but not that much. You know, I don't remember a lot of the people. I've got some pictures in there of me when I was going to school there. And the faces kind of look familiar, but I can't put a name on them. It's because it's sixtyfive years ago! (laughing) I guess we had real good teachers, because we all made it through school!

Nickels: Did you go on from McDade, did you continue there when you moved off of Camp Swift?

Kastner: Yeah, yeah, we continued there till the ninth grade. And then we had to go to Elgin to finish, to get our high school education. And that's when we rode the bus, then. And I think, back then, the transportation, you had to live so far out of town before they would give you a ride to school.

Nickels: McDade was a pretty bustling little community at that time. What other communities, such as, for instance, Wayside, or any other little, small communities do you remember?

Kastner: Well, we'd go to Paige every now and then because my, I had some relatives down there. And very seldom we'd go to Lexington. And Bastrop, that was where our doctor was. When we'd go over there, well that was an all-day trip, to go over there. And we went to Elgin. Outside of that, hey if you went to Austin buddy, you went a long way! (laughing) So, everybody stayed within just whatever little distance they could go.

Nickels: Well, you came to Elgin, or to McDade more than anything, and spent a fair amount of time at the cotton gin. What do you remember about the bustling activities at the time?

Kastner: Well at that time, when we had the cotton gin, see we had those four grocery stores, and we had a uh, blacksmith shop, two service stations, and another place up the road that you could get gas. And then finally, I've forgotten what year it was, whenever they cut [Highwway] 290 through. It was old highway, what do you call it, 20? And see, it went right through town. Then you had your depot. Up there you had your buses that would run from I guess Austin to Houston. And they would stop in town. And everybody, well, it's just amazing to see. "Hey, here comes a bus!" (laughing) 
And when you didn't have nothing but your feet, and shoes to walk on - (laughing)

Nickels: What about the train-was that pretty regular?

Kastner: Yeah, yeah, the train was pretty regular, sure was. Long, long, way back there, you'd hear that train whistle blowing, and well, here comes the train! In later years there, well when they had lots of watermelons here, they would load train carloads. We loaded lots of train carloads up there, and they'd ship them to, I guess up around Chicago, somewhere up in that area. We had that platform up there by the depot, and a platform where they put their cotton on, after the cotton bales was ginned. Then they would load them on the train and ship them off. Right below the cotton platform there was a big cattle pen. And that's where they would load cattle on the train.

Nickels: Did you bring any cattle into town at any time?

Kastner: No, I don't recall bringing any in. Now my grandpa might have did, but I don't recall us ever bringing any in.

Nickels: Where did your grandpa live?

Kastner: He lived over there by where my uncle Arthur lived, which is about three quarters a mile out of McDade. It's on this side of 290. He lived there, and then I don't know where he lived in the earlier years. But that was where in the later years. Then he stayed with my uncle after he got old, up there with my Uncle Martin. He stayed with him up there. His wife died, I think when I was probably about seven years old, or something like that.

Nickels: So you don't remember your grandma much?

Kastner: Just very little, just very little. I know we would go over there, and, and see them. It wasn't but about two miles or so, but hey, that's a long trip!

Nickels: How about hay, did you raise any hay?

Kastner: Yeah they had cane, and hygear. But all that hay and stuff you raised then, you cut and you shocked it, and you stacked it, and that was what you fed your mules and cows, and made it through the winter and stuff. And I mean you didn't waste anything. You cut it, and you put it up.

Nickels: And what about the cane? What was that used for?

Kastner: The cane, that was to feed the mules and horses.

Nickels: Well Mr. Kastner, that answers many of my questions. Do you have anything that you would like to add, or any thoughts on anything at all?

Kastner: Well, it's been a pleasure talking to you, and trying to answer some of these questions. I wish I knew a little bit more about it, but I was too young back then.

Nickels: You've done fine. We appreciate it.

Kastner: Yeah. I would like to go back on our old homeplace and just look around sometime. I haven't been down there in a long time. You know you can't get on there now. I don't guess you can get on there.

Nickels: You think you could find it?

Kastner: Yeah! I know. I've got a pretty good idea. I believe I could walk the fencelines. (laughing) But it's growed up since then. You know, like a lot of these fields and stuff, I know that runs off that farm to market road out there. Well that was open ground, now it's trees forty foot high.

Nickels: Yes sir.

Kastner: Right below the creek there we had a little old barn that we kept feed in for the horses and the mules, and whatever, corn. And nobody bothered, and that was about three quarters of a mile from the house. Our place zigzagged and went back there, oh it was probably a mile and a half deep, or over. It's narrow, but it's something else.

Nickels: You have fences?

Kastner: Yeah. Well, I don't know if it's fenced now or not. I don't know what they did now in the last, what thirty-some years? I don't know what they did out there. Because it's maybe, nearly forty years, because I think I had to get out in about '66; I believe that's when I had to move out. But it would be nice to go out 
there and look, and just see, look around. I believe I could find where all the houses sit, because they were close to the tanks. (laughing)

Nickels: That would be nice.

Kastner: Yeah. Yeah.

Nickels: Well thank you very much for your time.

Kastner: You bet.

Nickels: You were telling me about not wasting water?
Kastner: Yeah. Well you didn't waste the water. If a rat or something got in your cistern or something, and it died in there, you just dipped it out, got rid of that rat, but you kept your water, and you used it! (laughing)

Interview with Morris Kastner Interviewed by David L. Nickels Date: April 29, 2004

Place: Home of Kastner, McDade, Texas

Year of Birth: 1932 


\title{
JoNell Hancock Majors Interview
}

\author{
By Martha Doty Freeman
}

2 June 2004

Martha Doty Freeman: This is Martha Doty Freeman.
Today is June 2, 2004. This interview is taking place
at the home of JoNell Majors, 1304 Meadow Cove,
Elgin, Texas. This interview is part of the Texas State
University-San Marcos Camp Swift Oral History
Project, sponsored by the Texas National Guard
and conducted in conjunction with The Center for
American History, The University of Texas at Austin.

Freeman: Start off by talking about the house and the farm.

JoNell Hancock Majors: Well, or maybe where I was born. My family?

Freeman: Yes, that'd be great.

Majors: I was born in 1927. I was the middle child of Arthur and Vivian Hancock, and I had an older brother named Harrell Hancock. He was nine years older than I. And then I had a younger brother who is nine years younger than I. So my mother had children in school for thirty years. And I think every time she had a child, she decided "This is the last one I'm going to have." But, anyway, I had a very happy childhood. I loved the outdoors, loved the flowers and the trees, and everything about it. Loved the animals. My dad had horses and cattle and pigs, and my mother raised chickens and turkeys, and I was very happy as a child there. And it was very distressful for my mother when they lost their property. If I shed a few tears while I'm talking about this, you won't be surprised.

Freeman: I'll understand.

Majors: So, ask me some questions.

Freeman: Okay. Are you the surviving person?

Majors: No, I have a younger brother. His name is Seth Hancock, and he lives in Georgetown.

Freeman: And your older brother's name was what?

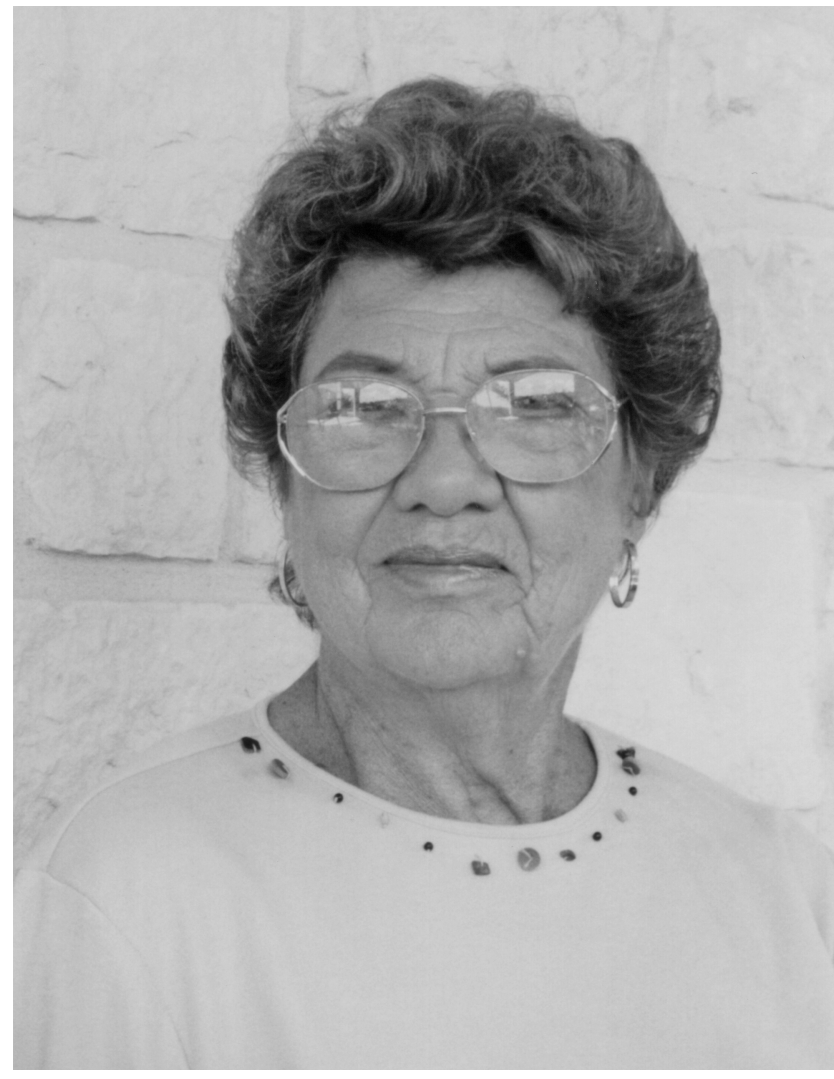

JoNell Hancock Majors

Majors: Was Harrell Hancock. And he died when he was sixty-four. He was born in 1918. He died when he was sixty-four. Had cancer.

Freeman: Tell me what you know about your parents' families.

Majors: Okay. My dad's father, John Hancock, came from Alabama when he was one year old with his mother and his stepfather because his dad, his father, Evan Hancock, had died and he was the baby. And his mother was Mary Ann. Just a minute. (checking a record) His mother was a lot younger than his father. This is John Hancock. (showing picture) That's my grandfather. Don't have a picture of his father. I have a picture of his mother that married King Henry 
Barbee. And he and his bride brought John Hancock from Alabama.

Freeman: Your father.

Majors: My grandfather.

Freeman: Your grandfather.

Majors: My grandfather, and came to Texas. So that's how the family got started here.

Freeman: Do you know where they came to?

Majors: They came to Rockdale, I think. Around Rockdale. And he married, my grandfather, married Elizabeth Dunkin and had four children. I have a list of them somewhere. I think Kay took it home with her. Anyway, there was Sam, Eva. I'm not sure what the other two were named. They were half brothers and sisters to my mother, to my daddy and his brothers and sisters. Anyway, she died, and then he married Ruth Allen, who was my grandmother, and had the Hancock, other Hancock children, which was Arthur, and Ray, and Lucy, Tabitha, and Ruth's mother, Bertie.

Freeman: So when did they move? They eventually moved to Bastrop County?

Majors: Yeah.

Freeman: And when did they do that?

Majors: After his first wife died, he married, well, George Allen lived somewhere on Sandy Creek. He was the mayor of Bastrop back in 1851, I think. Anyway, he courted Ruth and finally decided that, she decided that she'd married him. And they had the rest of the family then.

Freeman: So, did they settle out on what's now Camp Swift at some point?

Majors: Yes.

Freeman: Any idea when?

Majors: King Henry Barbee brought money with him from Alabama, and this was my grandfather, John Hancock's stepfather. Okay. And he bought lots in McDade. He bought lots in Elgin. He bought property in the Oak Hill community. And that, I suppose, is how they got started in that area.

Freeman: And then what about on your mother's side?

Majors: My mother, her mother was Ida Scarborough, and her father was Faustina Buffa.

Freeman: How is that spelled?

Majors: F-a-u-s-t-i-n-a B-u-f-f-a. He ran the store at Phelan Coal Mine, and this is what has been told to me. I never saw my grandfather. He and my grandmother lived part of the time in California and part of the time in Texas. And my grandmother was sort of a, she was one-of-a-kind back then. She traveled a lot, and my mother lived with her grandparents. She lived with William Scarborough. And my grandmother's sisters helped raise my mother. So the only real father that she knew was her grandfather became my grandmother. And Mother called him "Buffa." She never called him "Father." Lived in San Antonio part of the time. They lived in California part of the time. Back then, that was kind-of unusual, you know, lifestyle. And they didn't think their daughter needed to be in. And they had a saloon in San Antonio, and they didn't think that was the place for a girl. So she never did live with her mother and daddy. She lived with her grandparents.

Freeman: And where did the grandparents live?

Majors: They lived in Oak Hill. William Scarborough lived-When you go towards where we had the picnic, they lived on the road from Bastrop that goes into the Oak Hill picnic area. On the other-I don't know what side of the cemetery you'd call that.

Freeman: It'd be on the west side?

Majors: On the west side, uh-huh, they had property there. And he, her grandfather, William Scarborough, sold Singer sewing machines. He was a peddler, I guess you'd say, and he was in the Civil War. He was a Civil War veteran. And she really loved her grandparents, I think, and her aunt. I have a picture of her, one aunt that helped raise her.

Freeman: Did he make his living as a peddler?

Majors: Yes. And I think he did quite well. This is my mother and daddy, and this is the aunt. (showing 
pictures) This is the aunt that helped raise my mother, and this man was William Scarborough's son-in-law. He taught him how to sell Singer sewing machines, so he was also a Singer sewing machine man, and also a barber. He went to barber school, and they lived in San Marcos when they married. But Aunt Meme was, she was my favorite. She was actually my great-aunt, but she was really real close to me.

Freeman: What, do you have any idea what the Buffa nationality is?

Majors: Yes. From Austria. And Kay was looking on the internet because they did live in California at one time, and she thought, "Well I'm going to see if there's any." There's no Buffas around in this part of the country anywhere. So she said, "Well, I'm going to check." She said, "Man, they just fell out of the woodwork in California." And my mother's brother lived with them, and he died when he was thirty-three with pneumonia. He had a lot of health problems. He was an epileptic and had pneumonia and died in California. So did my grandfather. They both are buried in California. I'm not sure where exactly.

Freeman: Did your mother have any contact with her parents after she grew up?

Majors: Oh yeah. Her mother lived with my mother and daddy. Yeah. My grandmother and I did lots of things together. Yeah. She and I, Mom didn't like the circus, and she didn't like a lot of things, and my grandmother did. And she took me to the snake farm in San Antonio, and took me to the circus every time the circus would come. Any kid's show that came to town, we'd go together. Yeah.

Freeman: She sounds like a Dutch uncle.

Majors: Uh-huh. She was very good to me.

Freeman: So you had family on both sides who lived down in that area.

Majors: Uh-huh. William Scarborough.

Freeman: Were their farms anywhere near each other?

Majors: Yeah, they were not too far. They were on opposite sides of the school. The school was right across from the cemetery, and there was about five miles difference. And my mother was real good friends with my daddy's sister. And when my mother finished school at Oak School, she went to Austin to work at the State Hospital, and while she was there, she said-Lucy, my daddy's sister said-"If you want Arthur Hancock, you better come home, 'cause there's another lady after him." So she said, "I came home, and I got him." So that's how they, the families sort of interacted together.

Freeman: Give me some general sense - If I'm at the cemetery and I'm looking south, I guess, towards the meeting area, where would the farms be?

Majors: Okay, right next to the cemetery, that belonged to Daddy's brother, Sam Hancock.

Freeman: Across the road?

Majors: Across the road and from the corner of the road. You know, before you turn off, from that corner all the way to the creek. Now, I don't know how far back it went, but it belonged to Sam, his half brother. And then Daddy and Ray bought the property adjoining that, that went across the creek and over to the Herron Road. So it was a kind-of a block of land. I did have the, what do you call it?

Freeman: The legal description?

Majors: Yeah, of the land, but I didn't find it when I was looking through my stuff.

Freeman: So did they operate that as a unit, altogether, or did they have separate farms with separate farmhouses?

Majors: Well, okay. It was separate. My grandfather, he was a Methodist preacher. Ruth never did tell you that. No. Well, she wasn't very proud of that I don't think, because he would go off and leave the boys and the girls at home to take care of the farm, and her whole family resented this man, right here, because of the way he treated their mother, I guess. I was not very close to the family because my dad and his brother, Ray, bought this property together, and then Ray went off to the war, the First World War, and Daddy kept the cotton gin going. They had a cotton gin. He kept the gin going and took care of the cattle, and when Ray came back they had an argument about the cattle and the property, and so they just divided the whole thing. Ray took his half and Dad took his half, and 
that was it. And I never did see my grandmother. I never did see her, but my grandfather, he died before I was born. He died in 1917. And then my grandmother lived, I guess, I was about eight or nine years old. And I never did see her. And it was almost a stone's throw from their house to our house because it was bad blood between the two brothers.

Freeman: Yeah. What was her house like?

Majors: I have a-Ruth — she didn't show the picture that I painted of the Hancock house?

Freeman: I don't think I saw a painting. Maybe I saw a photograph of it.

Majors: You may have seen the photograph. Yeah, she has a photograph of the Hancock house. It had the dogtrot through the middle. It had a porch all the way across the front. This is a side view of our house. (referring to a hand-drawn picture) And it was not, it was made out of, what do you call it? Batten board?

Freeman: Board-and-batten?

Majors: Uh-huh. And it had a tin roof. It had a fireplace on both sides of the house and one in the middle. Okay. This is the floor plan as well as I can remember it.

Freeman: Now, this is not her house?

Majors: No, this is my mother's and daddy's house that they bought. This was an unusual house for that time period.

Freeman: What made it unusual?

Majors: Well, it was better than any other house in the community.

Freeman: In what way?

Majors: Well, it had beaded board walls and it had this hall down the middle. And then we had a washroom with a cistern inside the washroom, and we had a fireplace here in the dining room that the kitchen stove was put into and went out the top. And we had running water from the cistern into the house, and it was just - They were going to remodel this house and upgrade it just before it was confiscated by the Army.

Freeman: It looks very spacious.
Majors: It was big, it was a big house. These rooms were as big as my living area there. Each one of the rooms was that big.

Freeman: So if this cistern here outside of the kitchen supplied the kitchen area, what was this cistern back here in the washroom for?

Majors: Well, this was the washroom.

Freeman: So it was used, you literally had kind of a laundry room.

Majors: It was the laundry room. This was latticework here. And this was the chicken brooder, in the shed room. Now, this little room was sort of like added on, and it had windows all the way across the back. And it was just used when we had excess company, or somebody would come and need a place to stay. But I can remember checking the little chickens in the chicken brooder to see that they were all okay. And Mom let me turn the eggs.

Freeman: The chickens must have been really important to be part of the -

Majors: Chickens and turkeys both. Oh yeah.

Freeman: Someone told me about their parents having chickens in their bedroom.

Majors: Well, these were hatching, not exactly the bedroom, but attached to the house because you had-It was a kerosene brooder, so it had to be watched all the time.

Freeman: Did that help with varmints and that sort of thing?

Majors: I guess so. Then, when they were hatched, they were put in a brooder house, which was not exactly a chicken house, but it was better than a chicken house. So they were well taken care of. And we had lots of chickens. And I loved the old red rooster. My mother used to say "Put that rooster down." And I'd say, "Well, I've got to have something to love."

Freeman: So how many chickens did you have at any given time?

Majors: Oh, my goodness, I don't know. Maybe thirty, forty, fifty. They just went all over. They did 
get into the garden sometimes. This is the house. (showing a drawing of the farmstead) That's upside down. But anyway, Mother grew flowers all over. She had flowers. This whole yard was full of flowers. And, also, my grandmother had a buggy, a horse and buggy, and this was the buggy shed. This was the garage, and this was altogether one house that we had a black man that lived here to help with the chores. His name was Don Lewis. I don't remember when Don came to live in our house. It was before my little brother was born. He lived there until the Camp took the land. This was where the cotton gin [was]. It was right next to the Herron Road.

Freeman: It was right there out near the house.

Majors: Well, yeah, it wasn't very far. It was maybe a quarter of a mile. This may not be scaled right. I could walk to the mailbox and the gin. My brother said that the gin, that a tornado came and blew the gin away at one time. And I guess it did because there was tin and stuff scattered all over. And then there was a big pond here that they used for water for the gin, and this was a wooded area down below the gin, and then Daddy had pigs. The pigpen was here. I think he sold the pigs for five dollars apiece when the Army took the land. He must have had thirty or forty pigs. And my mother raised turkeys. They were sort of, roamed in the trees and everywhere.

Freeman: How did you keep track of them?

Majors: I guess they just came home at night to roost. That's about all I can remember. I have a picture of our mother and her turkeys somewhere if I could just find it. I'll find it.

Freeman: I would like that.

Majors: Yeah, I have a picture of her feeding her turkeys.

Freeman: And then I see you've got two separate gardens here. What were those?

Majors: Yes. This was the big garden. It was more like a field. This was the vegetable garden here. But this had sweet potatoes. And I remember at one time we did have tomatoes in there. Daddy would raise his own tomato plants. He had a, what do you call it, a cold frame with a window over it, and he raised his own tomato plants. And we had to carry water, of course. He'd have a big barrel on the back of the wagon or truck.

Freeman: And where did he keep the wagon?

Majors: Here by the barn somewhere, I guess. Out here. It was just out here. This was the horse lot, and this was the cow lot. And this was the back of the barn where they'd put the hay in. This is the outhouse. And then when we had hog killing in the fall, the winter, okay, we did that right along in here close to the smokehouse. Between the garage here and the smokehouse.

Freeman: Did you have a special apparatus set up for the hog butchering?

Majors: Yeah, they had a kind of sloping boards or something to put the hog on to. Daddy killed the hog with his Winchester. I can remember the sound of that. And then they'd put him up on these boards, and the black folks in the community would come and help because he'd give them part of the pork. So, they'd put the hog on this kind of slide-like thing and then scald it. We had a wash pot out there somewhere, and he'd dip the water out of the wash pot and pour it on the hog so that they could scrape the hog. And they'd do that.

Freeman: Did they hang the carcass at all?

Majors: Yes, Daddy had something that, a pulley or something, I remember, that they hung him up so that they could butcher him.

Freeman: And then what did you do with the meat?

Majors: Okay. We smoked some of it in the smokehouse, made sausage out of most of it, all that was really good. They made sausage, and then we had the lard. They rendered the lard out of it, and my mother made lye soap out of that. And I remember one time we canned some of it with, I don't know what it was. It was in a jar of grease. I wouldn't eat it, and my mother wouldn't eat it. She told Daddy finally, she said, "I want you to sell the hogs, and I'll buy my bacon. I don't like it." In the smokehouse, well, the bugs would get in it out there in the smokehouse. You'd have to cut the bugs off it before you could eat it.

Freeman: So, you didn't salt it down?

Majors: Yeah, they salted down a bunch of it too. 
Freeman: And how did that keep?

Majors: It didn't keep good. It was salty, it was salt, real salty.

Freeman: What did you grow over here in this garden, that smaller one?

Majors: Okay, in the small garden, we grew tomatoes, black-eyed peas, green beans. We had lima beans. We had a fence here and had lima beans. Beets, cabbage, just about any vegetable. This was good soil. This was sandy loam because it was right off the creek bottom.

Freeman: So how far were you from the creek there?

Majors: Not very far, half a mile.

Freeman: And where did you father get the water to water the different gardens?

Majors: Well, there wasn't very much water to get except from the pond here. And there was another pond over here back in this part of the, behind this garden.

Freeman: Now, were you ever around when the gin was operating?

Majors: No, no.

Freeman: Was it already gone when you came along?

Majors: It was already gone. When the boll weevils hit the cotton crop that was the end of the good ol' days. But they did make some money to be able to buy the property that they bought with the gin in 1917, 1918, 1919.

Freeman: Were they growing any cotton when you were a child?

Majors: Yeah, they were growing cotton in that area. Yeah.

Freeman: So how late do you remember that going on?

Majors: Well, I must have been, I don't know, four or five years old, I can remember. I never did work in the fields, and my mother never did. Daddy always hired people to work in the fields. She said, "I'm not a laborer." My mother was sort of a snob. (laughs) She said, "I'll keep the household garden, but I'm not doing any field work." And, of course, he didn't want her to anyway. I really, I can remember one time the creek got up and Uncle Don and I rode the horse across the creek to get me to school.

Freeman: Describe the kitchen for me. What was it like?

Majors: Okay, okay. This was a little cabinet here. (referring to drawing) My dad could build anything. He was, as a matter of fact, he could do anything. And he built this cabinet. And I remember this wash pan sitting on that, and then there was a bucket there too. I guess we drank the water out of that cistern. I don't remember, but I guess we did. We didn't drink this water because I think the rats and stuff could get in this cistern. This is the water-

Freeman: Eaves troughing?

Majors: Uh-huh, eaves trough that goes into the cistern. Okay, and then there was a window here and this was one of those cabinets that had the flour bin and the sugar, place for sugar and flour and all that, meal, and stuff in it. And then this was some shelves. And then my daddy and my grandmother milked a bunch of cows, and we always had the milk separator to separate the cream from the milk.

Freeman: Did you help with that?

Majors: Oh, I turned the separator. Yeah, I could help with that. The cook stove would always, she baked sweet potatoes in it, and I remember coming home from school, and the sweet potatoes would still be warm. So I'd get a sweet potato and put a lot of butter on it, and have my afternoon snack when I got in from school. And I could walk to school 'cause it wasn't that far.

Freeman: So who ate at the kitchen table?

Majors: Who ate at the kitchen table? Well, we ate most of our meals there. We ate breakfast, and then the field hands would eat there, and we had two guys. Their names were Mex and T. Brice. I don't know if you've interviewed any of the black people or not.

Freeman: One of the other people working on the project has interviewed a couple of black people, but those are not familiar names. 
Majors: They're not familiar.

Freeman: No. Who are they?

Majors: Well, Manch Brice was their dad. And he was like a horse whisperer. He was as good as a vet. If Daddy ever had any trouble with his horses or anything, he'd go get Manch to come and help him with it. Anyway, his two boys would work for Daddy, and Mom would cook for 'em, and they'd eat at the kitchen table. And I always entertained them. I always put flowers on the table for them. I would sing to them while they were eating. I imagine they had indigestion. (laughs) I sang to them while they were eating.

Freeman: So how old were they?

Majors: Oh, they were probably twenty-one or -two. Mex is still alive. I see him occasionally, and I haven't seen him recently, but his wife died a while back. And, anyway, he and I go over old times every time I see him, and I keep saying I'm going out and check on him. He lives on [Highway] 95 out here. They lived in the Camp Swift area, too, but they lived across the road over towards Sayersville.

Freeman: And his name was T?

Majors: One was T, and one was Mex. And their last name was Brice.

Freeman: Is that with an $i$ or a $y$ ?

Majors: I don't know. I think an $i$ though.

Freeman: And it's T. Brice who's still alive.

Majors: It's T. Brice.

Freeman: Well, he must be very elderly.

Majors: Oh, he is. Uh-huh. He must be in his late nineties. 'Cause I was born in 1927 and he was a young man at that time. When I was six or seven years old, he must have been in his early twenties or somewhere along in there.

Freeman: Was it customary at that time to have the field hands in the home, in the house to eat?

Majors: No, I don't think so.
Freeman: How would you account for that?

Majors: Well, 'cause my mother was, she didn't like anybody to not be comfortable, you know. She was very hospitable to everybody. And then we also had another family, black family, that helped out, and that would come and help Mom with the laundry. And she'd bring her little girl with her, and I always enjoyed playing with her little girl. Their name was Reese. Isom and Viola Reese. And Isom helped daddy too on the farm, 'cause he raised corn. This was quite a large area. It was two hundred acres I guess.

Freeman: And how much of that was cultivated?

Majors: Nearly all of it.

Freeman: Really.

Majors: Uh-huh, nearly all of it was in some kind of cultivation, either corn or cotton or maize or watermelons. My brother raised watermelons on the creek bottom one year and went to the Dallas Fair with his watermelons.

Freeman: What about peanuts?

Majors: About what?

Freeman: Peanuts? Did you raise those?

Majors: Yeah, some, but he didn't raise too many peanuts. Just for our home use, I guess, was all the peanuts that he raised.

Freeman: So, I guess, let me see, so there were only three men in the family who could work, and I keep hearing about these really huge families.

Majors: Yeah, my immediate family was - My older brother did not like the farm, so as soon as he got old enough he joined the Army. He went in the Army, I think, in 1940 maybe, '41, just before the war got really bad. He was military police in the Army.

Freeman: So, I was just thinking maybe that's why your father had hired help.

Majors: I guess so, because he couldn't, you know, he couldn't do it all. And he had to have hired help. 
Freeman: Did any of the hired help actually live on the place with you?

Majors: This Uncle Don lived in the little house here that was part of the garage. Right here.

Freeman: Now, did he do any, did he help your mother in the house at all?

Majors: Uh-huh.

Freeman: What did he do for her?

Majors: Chopped the wood, fed the chickens. He was older. His daughter brought him and said he needed a place to live. And Daddy said "Well, okay." And this was before my little brother was born. And so he must have lived with us eight or ten years. I don't know. A good while. So he did the chores around the house and he helped in the garden.

Freeman: Did you grow up helping with things around the house?

Majors: Oh yeah. I helped in the house. I didn't ever do anything in the field. I liked the garden, I liked to garden. I helped with cleaning the house and cooking.

Freeman: How old were you when you started with the chores?

Majors: I don't know. I know one time my mother sent me - this is the only time my mother ever spanked me, my daddy never did - she sent me in the far corner of the pasture to get a cow. Well, I got a senny bean switch. You know what rattle beans are? And I beat that old cow all the way back to the house. Mom saw me hitting that old cow with that stick. She took that stick away from me and she said, "I'm going to show you how this feels." She said "That old cow didn't do anything to you." And she swatted me with that senny bean switch a couple of times, and that was the only time I ever remember her spanking me.

Freeman: Well, how did they discipline you all?

Majors: I don't guess there was any disciplining going on. We didn't need any discipline, I don't suppose. We sort of did what we were told, you know. Back then you did.
Freeman: Tell me about your mother's cooking. What kind of things did she fix?

Majors: Oh golly. She fixed meals for company nearly every Sunday after church. She would fry chicken. We'd have to get up on Sunday morning and kill the chickens and dress the chickens. And one day, Seth, my little brother, was watching us, and he said, "Hum. Why do you call it dressing those chickens? Looks to be like you're undressing 'em." But anyway, yeah, we had fried chicken a lot. And all those mashed potatoes and maybe green beans or black-eyed peas out of the garden, and corn on the cob, and peaches. See our peach orchard? (pointing to the drawing) We had Elberta peaches, and there must have been twenty-five trees out there. It was a big peach orchard, and I can remember this one. I didn't put the peach tree here where it is supposed to be. There was a peach tree here in the corner from the washroom and the peaches were up on top of the house, and they were this big. They were huge.

Freeman: Did you ever dry peaches?

Majors: Yes, we dried watermelon rinds too. And my mother made cottage cheese and she'd feed that to her turkeys, and I'd eat part of it, and she'd say "Nell don't eat that. That's turkey feed." Tasted good to me. She'd hang it in a bag on the clothes line and let it drip dry, and then crumble it up and mix it with cornbread to feed to the turkeys. And I couldn't ever figure out why the flies didn't get on the watermelon rinds if you put 'em on the top of the house. Well, flies don't fly that high. Did you know that?

\section{Freeman: No.}

Majors: Uh-huh. Flies don't fly that high. So there's no flies to get on 'em up on top of the house. I'd climb up on the ladder and get up on top of the house and put out the watermelon rinds.

Freeman: Well, now, what did you do with the watermelon rinds after they dried?

Majors: Make preserves. They're too watery. You don't let 'em dry completely. You just let 'em dry partially and then make your preserves.

Freeman: Well what, tell me what a typical meal would be like for breakfast, lunch, and supper. 
Majors: Um, probably hot biscuits and bacon and eggs. Milk, coffee, whatever. Jelly. All kinds of berries and all kinds of grapes. Wild berries and wild grapes was real plentiful.

Freeman: Did you cultivate any grapes at all?

Majors: No, unh-uh. Ruth's daddy was a grape grower.

Freeman: And then I guess you took your lunch to school.

Majors: Yeah, I usually had white sliced bread. Now some kids took biscuits. I didn't like biscuits cold. Only wanted my biscuits hot. And I'd take an apple or an orange and a sandwich. And my mother made my favorite sandwich, which was pork and bean sandwich. She mashed up the pork and beans and put - she made her own mayonnaise - and put mayonnaise and pork and beans on. That was my favorite thing.

Freeman: So where did you get the white bread?

Majors: From the grocery store.

Freeman: How often?

Majors: We went to McDade. It was only about five miles to McDade.

Freeman: And how often did you go in there?

Majors: Oh, I guess every week. 'Cause Daddy always had a car. I don't remember. I've got a picture of my mother and grandmother in front of the car he had. He had one of the earliest cars in the community. And his family always said, well, my mother had to go to Austin to get a loaf of bread.

Freeman: What about special times of the year, like Thanksgiving or Christmas? What, how did you celebrate those?

Majors: We just, our community always had a Christmas tree at the schoolhouse. And we had a community party. All the community went to the Christmas tree at the school. And I, the only thing I ever remember really wanting was a Shirley Temple doll, and somehow my mother got ten dollars, I guess from her turkey sale, and bought me a Shirley Temple doll for Christmas. I still have it.
Freeman: So you didn't have a tree in the house.

Majors: Yeah, we did. We, I can remember one time we had a tree in this room (pointing to the drawing), and it took up nearly the whole room. But we didn't decorate. We did our own decorations. We made those chains and string berries and stuff like that. But we really didn't do all the decorating that's done now, of course.

Freeman: What about Thanksgiving?

Majors: You know, I can't really remember much about Thanksgiving. I guess we always had turkeys, so I guess we had a turkey at Thanksgiving. I really don't remember.

Freeman: Where did you mother sell the turkeys?

Majors: Where?

Freeman: Uh-huh.

Majors: I guess either in Bastrop or in McDade. I don't remember. I don't know where she sold 'em. But she always bought our school clothes with the money that she got from the sale of the turkeys.

Freeman: How did she get 'em there, do you suppose?

Majors: You mean the turkeys?

Freeman: Uh-huh.

Majors: I guess daddy took 'em in the trailer, or in the car. I don't know. I don't remember.

Freeman: What were the stores there in McDade where you used to shop?

Majors: Oh, it was pretty good. We had a drugstore and mercantile store that sold a lot of everything. Now, I think, this was before my time, some of the Billingsleys had a hat shop there, and I guess they sold dry goods. I mean they had a bank. It was a pretty good little community. And I went to Sunday school there.

Freeman: You didn't go to the church at Oak Hill? 
Majors: Well, they didn't have a minister there. No. They just had preachers that would come and go, you know.

Freeman: So you all drove in to church every Sunday?

Majors: Yes.

Freeman: And which one did you go to?

Majors: We went to the Church of Christ in McDade. And sometimes my mother didn't go, and my daddy would take me. And I guess that was before Seth was born. I can't remember. And he'd always come by Hillman's grocery store and get me a bag of candy.

Freeman: What about the meetings at the cemetery? Did you go to those as a family?

Majors: Yeah. My mother didn’t like 'em.

Freeman: Why was that?

Majors: She said, you cook all this food and you put it out there, and some of the people don't bring anything. And then somebody took a bite of one of her lemon pies and threw it on the ground. And she said "That's it, I'll never make any more pies." They said, "That's old egg pie." And she said, "It was not, it was a lemon pie and I'd worked hard making that lemon pie." Anyway, Daddy was the school trustee, and he worked in the concession stand. They sold soda water, and I don't know if they had cokes. I don't remember anything except orange and red soda water back then. I don't know what else they sold. But it was a cedar brush arbor at that time. Ruth said they had barbecue there some, but I don't remember that. Everybody always took their own fried chicken. That was the main thing, fried chicken, pies and cakes, potato salad, that sort of thing.

Freeman: So how did your father make a living?

Majors: With the farm.

Freeman: And did he make, I mean, did he have enough production beyond what you all used to actually sell crops?

Majors: He ended up driving a school bus to Bastrop in later years. And he was a craftsman, and he also worked in the cedar furniture factory in Bastrop. So that was toward the end of our time there.

Freeman: When [did] the school bus start coming around?

Majors: I guess, I was trying to remember. I was in the fifth grade, I guess, or sixth grade. So I must have been, I started school when I was five. I was born in '27. Probably about 1937, something like that.

Freeman: I wonder if it was tied together with the school consolidation somehow. Was there any of that going on when you were in school?

Majors: Well, they only taught to the sixth grade in later years. They only taught to the sixth grade and then everybody transferred to Bastrop after the sixth grade.

Freeman: So how big were your classes at school out there at Oak Hill?

Majors: Oh, I guess there were maybe six or seven children in each class. At one time, my mother said there were eighty, at least eighty students in the school.

Freeman: So did she go to school there?

Majors: Uh-huh. My daddy went to school there, Ruth went to school there, and all her sisters went to school there.

Freeman: Tell me what you remember about school.

Majors: Okay. I can remember, I started school when I was five. My birthday was in December, and I guess I started in September before my birthday. Anyway, I always liked to draw pictures. And this one teacher I had, Marie Stagner, she let me draw pictures instead of doing my class work. So, I think when I was about in second grade, I was reading the funny papers. My mother said, "Are you reading that?" And I said, "Well, certainly." And she said, "Well, I didn't think you even had known how to read. All you want to do is draw pictures." I said, "Oh, that old teacher made me learn how to read." But I can remember we sat in rows, you know, one seat behind the other. The first grade would be here and the second grade here and the third grade here and the fourth grade over here. And then we had two rooms in the school later on, and it seems as if we had school lunches at one time. 
Freeman: Did it start out as a one-room schoolhouse?

Majors: Well, I guess it did. And then they added on to it. I can't really remember.

Freeman: What sorts of things did you study?

Majors: I guess we studied reading, writing, and arithmetic, and geography and history. I know Ruth said she couldn't graduate in Bastrop because she didn't have lab, you know, for her science, because she finished school at Oak Hill. And I guess she had to take the science to be able to graduate.

Freeman: So what was it like, shifting from going to this little Oak Hill School to going into town?

Majors: I guess I just thought it was the normal thing to do. I don't know. You know, kids, they just sort of bloom wherever they're planted.

Freeman: Let's see, give me a sense of who your neighbors were and how they were spread out.

Majors: Well, we were spread out pretty much. I had a real close girlfriend, a Dunkin. All the Dunkin girls were real pretty and real smart, and real neat. And Naoma and I were real good friends. But they lived pretty far away from where I lived. I was sort of isolated. I didn't have anybody to play with much. So, Naoma and I were really good friends, and we'd visit each other and spend the night with each other.

Freeman: Would you just walk back and forth to each other's houses?

Majors: Well, we had a car. Most of the time Daddy would take me wherever I wanted to go.

Freeman: And then who else besides the Dunkins were your neighbors?

Majors: Well, I guess the Hancock cousins were my neighbors, but I didn't associate with them because Dad and his brother had fallen out, so I really didn't know much about them. They were the only ones close. And then Ruth's cousins, the other Smiths, lived way on the other side of us. It was pretty far between farms. It wasn't easy to get from one place to the other unless you did have a car.
Freeman: So what did you do to spend the time? Did you play by yourself, or with your brothers? Or what did you do?

Majors: Oh, well, I played by myself most of the time. I talked to the birds and to the flowers and went down on the creek. Uncle Don would take me fishing. I forgot about that. We'd go down to the creek. That's when the creek had water in it all the time, and we'd get a can of worms, and we'd go down to the creek and go fishing. If I could talk him into it. I just sort of played with the animals. My mother never would let me ride the horse because she said it's dangerous. My older brother got his foot stepped on and nearly lost his foot from a horse stepping on it.

Freeman: What did they do if one or the other of you got hurt? Did they have home remedies, or-

Majors: Probably take you to the doctor. We'd go into the hospital in Bastrop. Dr. Bryson delivered me at home at my home there, and then he delivered my daughter, too, back in the forties.

Freeman: What did you do if you got hurt, though, or you got sick?

Majors: My dad was asthmatic, and he was sick a lot, and he had pneumonia. And I can remember when I was eight years old, my mother, she always told things like it was, you know. She didn't paint any rosy pictures. And she said, "I think your daddy's going to die, 'cause the doctors said there's no way he can recover." But she said, "I'm going to see that he doesn't die." And I sat on the back porch, on the back steps and cried, thinking he was going to die, because I could hear him breathing all over the house. And she heated bags of salt and put on his chest, and I guess she rubbed him down with Vicks Vaporub. We had Vicks Vaporub all over us all the time, and put that salt on his chest. Broke up the pneumonia, and when Dr. Bryson came back out to the house, he said, "I don't know how you did this, but he's going to be okay." It was, yeah, you have home remedies, but you did have the doctor. He would come whenever you needed him.

Freeman: You were saying that your father was sort of a craftsman. Did he make furniture for the home?

Majors: Uh-huh. 
Freeman: Do you have any examples of it?

Majors: Yeah, I do. He made cedar furniture. I have a table out in my workshop, and I have a magazine rack upstairs. I have another table upstairs, and a cedar chest. Do you want to see the cedar chest?

Freeman: Yeah. (interview interrupted) Did he make the furniture for the home in general?

Majors: No, no, no, he didn't do that.

Freeman: (looking at the cedar chest) Oh, that's beautiful.

Majors: He made a desk. It's full of pictures. (looking at the cedar chest)

Freeman: So did he have a shop?

Majors: Yeah, they had a cedar shop in Bastrop, and that's where he made this furniture.

Freeman: Did he make any while he was actually working out at the farm, or just later in life?

Majors: Later in life. No, he didn't. He made a corner cabinet, a china cabinet for me. It's upstairs. But this was later. He didn't have time, I don't guess. He was too busy running the farm.

Freeman: Why do you suppose he stopped doing the farming and went to the bus driving and the cedar furniture?

Majors: Because there was not enough profit on the farm to make ends meet. Had to have a supplementary income.

Freeman: I've heard a number of people say that they just couldn't make it on a sandy land farm.

Majors: Uh-huh. Yeah. I guess that was the reason he did too.

Freeman: Did that happen to a number of your neighbors?

Majors: I don't know of any that had outside industries that they did. I really don't know.
Freeman: Were you old enough during the Depression to have any sense of what was going on?

Majors: No. No, I was happy. It didn't bother me because I had plenty to eat. We didn't really, the only thing I can remember, my grandmother, my mother's mother, did nursing. I guess it was just practical nursing, and she would, somebody would have a baby. She'd go and stay with them and take care of the mother and the baby. And that's the way she made her money. I can remember that Grandma always had money, and Daddy had a pair of shoes that had the soles wired on, and she said, "I want you to throw those shoes away. I'm going to buy you a pair of shoes." So she bought him a pair of shoes. And this was, you know, the only thing I really remember that, because we always had plenty to eat. There was no problem with that. And I guess they made enough money to pay for the farm and the land. When the gin was going, they made good money.

Freeman: Did he have a lot of cattle, a pretty goodsized herd?

Majors: Yeah. He had maybe, I don't know, forty, fifty head of cattle. Four or five horses, thirty, forty pigs. A lot. He had a lot.

Freeman: So was he in the business of buying and selling cattle?

Majors: Well, yeah, he did do that. But it was just not on a big scale. I remember the bull that he had. It was a big ol' white-faced bull. I was scared of it.

Freeman: Were they any particular breed?

Majors: Just white-faced cattle is all I remember. I don't know what they're called. They all had white faces and red bodies.

Freeman: Did y'all have a beef club or anything like that in the neighborhood?

Majors: My mother said something about a beef club one time, but she said she didn't belong to it, or didn't want to, or something. But I think they did have one in the community. And we did have a store. You know you asked Ruth about a store? Well, a Miss Polly Owen had a store, and I can remember my mother said that she helped Miss Polly take care of the store some when she was a girl. 
Freeman: I wonder where that was.

Majors: Well, I can tell you where it. You know, when you come from Bastrop and there are a bunch of houses along that road after you go by the Griffin Enterprises. Okay, it was on that road. It was not the same road, but that was in the area where it was, was on that road about five miles from the cemetery. Yeah. That's about where it was.

Freeman: Was there any kind of little community center there?

Majors: No, it was just her house. She had a big room on one end, on one side of it for the store. Fay Pannell should remember that.

Freeman: She probably did. What about peddlers?

Majors: Oh yeah, we had. Also, we had vagrants that would come by too. Of course, Mama would always feed 'em. And one time this vagrant came by and she gave him a plate of food, and he went out and was sitting out under the tree with Uncle Bob, and he asked Uncle Bob, "How much money do you make?" And he said, "Oh, I don't make much money." Said, "But I have plenty to eat and a place to sleep." He said, "Mr. Ocker gives me a dollar or two every now and then." Well, he said, "You're crazy, I wouldn't do that." When Uncle Don told Mom that, she said, "That's the last time I'm feeding anybody that comes by here." Yeah, we had Watkins Products and Jewell T.

Freeman: What's that?

Majors: Jewell T?

Freeman: I don't know what that is.

Majors: You've never heard of Jewell T?

Freeman: No, what is it?

Majors: Oh, gosh. They sell everything in their products. All kinds of baking stuff. And they would come by.

Freeman: So was it the Watkins man and then somebody else with these Jewell T products? Or did he just bring everything?
Majors: Yeah, the Watkins. I don't know what all they had. I don't remember, really. But I think his was more like medicine-type stuff. You know. And Jewell T was cooking stuff. As a matter of fact, I have some of their pottery, Jewell $\mathrm{T}$ pottery from that era.

Freeman: So did your parents have money to pay for that or did they barter?

Majors: I think so. No, I think they had money, I guess.

Freeman: I know some people bartered chickens and things like that.

Majors: No, they didn't do that.

Freeman: During the thirties, the government came around and bought up cattle and shot them. Do you remember anything about that?

Majors: They didn't buy any of ours and do that. Not that I know of.

Freeman: And what about cattle dipping?

Majors: I don't remember that, any of that. I can remember the flies being on the cattle, and ol' cows switching their tails to get the flies off. I don't remember any of the cattle ever being sick. They may have been, but I don't remember it.

Freeman: What about the lignite mines. Did you ever go over and see those, or did you know about them?

Majors: I knew about 'em. See, that's where my grandfather came from. He was a storekeeper at Phelan Store. And I guess my grandmother met him in there. She would take the school census, and she had a horse and buggy, and I would go with her sometimes, and I would go with her sometimes when she would take the census. I don't know how she met my grandfather, but evidently in some of her prowling around that she did. She always carried a pistol with her. Mom told her one time, "You can't have that pistol in my house. Go take that pistol and put it someplace else." So I guess she took it out and put it in her buggy. I know she still had it.

Freeman: Did, so did your father have a gun around the house? 
Majors: He had a Winchester.

Freeman: Did he go hunting at all, or did you all have dogs?

Majors: No, no. My mother didn't like dogs. I think she, he had some at one time. But they dug up her garden and so he didn't have dogs.

Freeman: And he didn't hunt either.

Majors: No, no.

Freeman: What about entertainment, or parties? Did you all do much of that?

Majors: I don’t remember any parties.

Freeman: So you didn't go.

Majors: I think my mother did. When she was young, they went to parties. It was before my time.

Freeman: In general, what kinds of things do you remember about your parents, just sort of personal things?

Majors: Oh, never heard 'em say a cross word to each other. If they did, it was not where we could hear it. I'm sure they did, but there was no, no arguments, no nothing.

Freeman: So were they just-

Majors: They were loving parents.

Freeman: Well, give me a sense, if you can stand to talk about it, about what happened in the late thirties and early forties with the government taking of the places. How old were you then?

Majors: Well, I was about eleven, twelve, I guess. I was, I guess I might have been thirteen. I know my mother cried a lot. And when they were moving, see, my grandfather had lots in Elgin was the reason my parents moved to Elgin, was because he did have lots here in Elgin. So, when they finished paying for the land, my dad told my mother, "Well, you know, this is ours forever." And she, after it was gone, she said, "Well, there's nothing here forever." And it was quite hard for them. They sent Grandma and I off to
Oklahoma while they were moving and while they were building the house that they built here in Elgin. We went to Oklahoma to her sister's and stayed the whole summer. So I really, I know it was a hard move. They had to build a house out of the old house. Daddy tore this house (pointing to drawing) down and all the lumber that was, that he could save. He even brought the foundation logs that were under this house and put them under the house here in Elgin. And he and my mother's uncle and, I don't know who else he could hire to help him build the house, but they built a little house here in Elgin. I guess they were more fortunate than some of the other people that had to move.

Freeman: Were you aware that something was happening before you were sent off to go to Oklahoma? Did you hear them talking about it, or did the agents come around when you were there?

Majors: Oh yeah, oh yeah, I knew. I just remember, I don't remember a whole lot about it. I know they just, they said, "We just don't have any place for you to move." Oh they moved this garage. Where is that? (referring to the drawing) They moved this garage to Elgin in one piece, and they lived in it while they built their house in town. And all of this, they tore down everything they could, everything they could salvage from that, 'cause you couldn't buy lumber because of the war, and so that was, you just had to do the best you could with whatever.

Freeman: And so what did your parents do after that, after they moved to Elgin?

Majors: I think Daddy retired. I don't think he worked any more after he moved to Elgin.

Freeman: How old would he have been then?

Majors: I guess that was in - Oh, oh, I know what he-He worked. I was trying to remember. He worked at the army camp. He worked, he was the bus driver, and then he was the dispatcher for the Camp Swift, army camp. And then he still drove the school bus. And he kept it in the country, I think at Fay Pannell's parents' house. He'd go and pick up the school bus there and drive it to Bastrop.

Freeman: And how much longer after that did your parents live? 
Majors: Oh, my Daddy died in 1972, and my mother died in 1991. She lived to be ninety-one years old. Had all of her marbles. Her body just played out.

Freeman: Well, what do you remember best about living down there?

Majors: Oh, I just loved to live in the country. It was just a happy life. I don't remember anything bad at all about it. When we moved to Elgin I was a sophomore in high school, and of course, when you go through your teenage years, you go crazy, so that was - All I can remember is how pleasant it was to live there in the country.

Interview with JoNell Hancock Majors Interviewed by Martha Doty Freeman Date: June 2, 2004

Place: Home of Majors, Elgin, Texas

Year of Birth: 1927 


\title{
May Belle Miller Morriss Interview
}

\author{
By Martha Doty Freeman
}

\section{June 2004}

Martha Doty Freeman: This is Martha Doty Freeman. Today is June 1, 2004. This interview is taking place at the home of May Belle Morriss, 1000 Morrow Street, Austin, Texas. This interview is part of the Texas State University-San Marcos Camp Swift Oral History Project, sponsored by the Texas National Guard and conducted in conjunction with The Center for American History, The University of Texas at Austin.

May Belle Miller Morriss: I didn't know my grandparents. Don't turn it on yet, 'cause - (laughs) Okay, my dad was Jephty Miller and my mother was Sallie Benight Miller. And I did not know - My dad's parents came from Germany, and I didn't know them. I was too young. And my mother and dad had twelve kids, eight boys and four girls. My mother died in 1925. She was only forty-two. I was seven, my younger brother was four, and the rest was on up. And of course we lived in the country there at Bastrop, between Bastrop and McDade. We raised our, everything to eat, except the flour and sugar and shortening, and my dad had a year-round garden, and my brothers cut fire wood and hauled it down to Bastrop - we was about nine miles out of Bastrop - for two dollars a load, and that bought flour, sugar, and shortening, and, I believe I got it all wrote down here. (pointing to notes) Anyway, then we raised the rest of the stuff. We had chickens and cows and hogs. I'm country. (laughs) And, we had all that we needed. Milk and butter and eggs. My dad raised a year-round garden, and we had a corn field and watermelons and some cotton. Picked cotton.

And I didn't know much about Camp Swift. It came in kinda after I left Bastrop, you know. In 1936 I came to Austin and met my husband. We married in '37. Knowed each other a while. Lived fifty-seven years, and he passed away. But my dad, well I have it here, in a little small town named Glenham. That was a school and coal mine. Three of my brothers worked in the coal mine. My dad hauled the timber for the coal mine, to build it, and there's another little place out

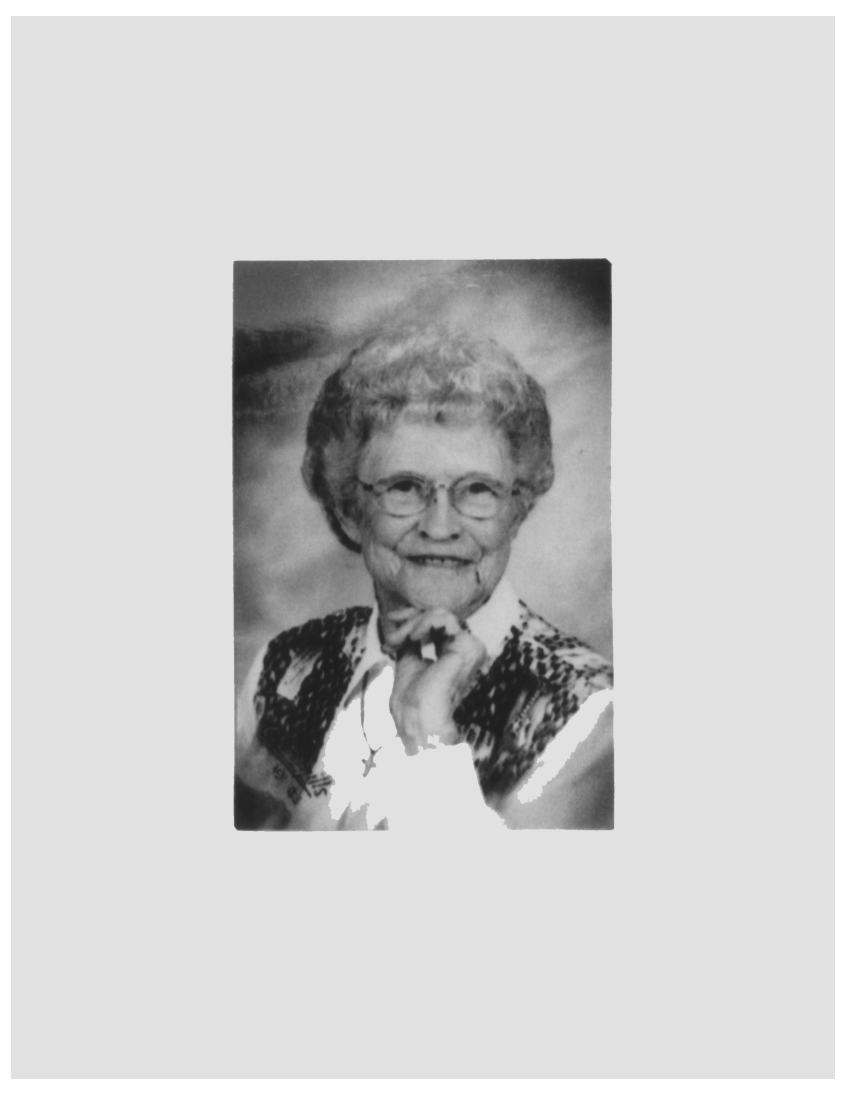

May Belle Miller Morriss

there called Glenham. That's where I went to school at. That's what I'm talking about, Glenham. Another little place on down out of Bastrop was Phelan, and that was a railroad station. My brothers worked on the railroad. None of that is there any more. It's all gone.

So, then we went to Oak Hill School. We walked. We didn't have a car. And everybody was in the same shape. We was all happy. Didn't know any difference. Anyway, we all had our own music. We played fiddle, guitar, and mandolin by ear. I don't know what the lessons was for, you know. And I still have a room full of music, still pick and sing. I sing for the nursing home and church, and I make tapes. I like to tell this because that is unusual. Now I have seven guitars, two fiddles, two mandolins, and a banjo, an organ. 
Back in the old days, as I say, my mother died when I was seven, and we had that tree army camp.

Freeman: What did you have?

Morriss: It was called tree army camp. It was an Army camp. And they built the Bastrop Park, cleaned it all out. Got it started. And I didn't know much about Camp Swift, as I say. And that Oak Hill Cemetery, that reunion has been going on since I was a kid, so it's been a long time. They meet on that same day, last Saturday in May. Keep the cemetery going. That's where my dad and my mother and some brothers are.

Freeman: Tell me, do you know when your father was born?

Morriss: Born October 21, 1877, and passed away in 1953.

Freeman: And how about your mother?

Morriss: Well, I would have to look at that. I don't know why I didn't put that down. [She was born December 29, 1879, and passed away February 15, 1925]

Freeman: Were they both born in that area?

Morriss: Yes, as far as I know. As far as I can remember.

Freeman: And you said that your grandparents, your father's parents, came from Germany.

Morriss: Yes. [They came from Belgum (sic), to Germany, and to America in 1847.]

Freeman: Do you know anything about that? Where they landed, or how they happened to be in Bastrop?

Morriss: No. I have it on one of the reunions. But I didn't ever know them. They came over, but they had five or six boys, and a daughter. But some of them passed away before I grew up. But, no, I didn't ever know them, when they came over. I guess after I was born, I mean before I was born.

\section{Freeman: Did they settle in Bastrop County?}

Morriss: As far as I know, they did. As long as they lived.
Freeman: Now tell me, did you know your mother's parents?

Morriss: No, not really. One of her brothers lived at Bastrop. Benight, Joe Benight. B-e-n-i-g-h-t. That was my mother's brother. But that was the only one that I knew of.

Freeman: And can you tell me the names of your brothers and sisters and about when they were born?

Morriss: Yes. The first one was named Gordon, and he died when he was two years old. And then it was Cerilus, two years between them all. I had eight brothers and three sisters. I was next to the youngest. I had a brother who was four when my mother died, and I was seven.

Freeman: So who came after Cerilus?

Morriss: All right, Gordon, Cerilus, Foster, Gilbert, Jeppie, and Jodie, and Bryson. And then my sisters Mary and Angie, and then Martha, and May Belle, and F. L., my brother.

Freeman: What was the last name?

Morriss: F. L.

\section{Freeman: F. L.?}

Morriss: Just the initials. Didn't stand for nothing. F. L.

Freeman: And can you tell me about where your family farm was? How would you describe it?

Morriss: Well, all I can remember is between Bastrop and McDade in the country. I think we was about nine miles out of Bastrop going toward Elgin. Nothing is there anymore. I wouldn't even recognize the place. As I say, I think we got the coal mines on that. There was coal mines. Just farmed on it.

Freeman: Do you remember how big a farm your father had?

Morriss: No, not, because I don't remember acreage. It was a pretty good farm. Had a big corn field and watermelon patch. That's all I can go by. Some cotton. We hauled the cotton. We'd pick it and haul it down to 
Bastrop. They had a cotton mill there then. I believe that's about all I can remember.

Freeman: Was there a gin any place nearby?

Morriss: Just in the city of Bastrop.

Freeman: So how did he get it from the farm down to Bastrop?

Morriss: In a wagon. We had a big wagon with sideboards on it. We called it sideboards. And my little brother and I would go with my dad. We'd climb up on the cotton, and he'd take us to the drugstore. We was small. And he'd tell the guy to give us big ol', you know, big goblet glasses of ice cream, and he'd pay when the cotton done. Ten cents for a glass. Bread was about seven cents a loaf, milk was about twenty-five cents a quart. For people who bought it. We had our own. And things was just so cheap. Of course, there wasn't no money. Everybody was poor, farming.

Freeman: Can you describe your house for me, the home that you grew up in?

Morriss: Yeah, it was an old house, probably three bedrooms, and the living room we used that as a bedroom, and then a kitchen. There was a porch. I loved that house. It was a long porch along and then a big room for the kitchen. We did not have electricity. We didn't have gas. We had a wood cook stove and a wood heater. I'd have a fireplace there. We had one fireplace one time. Just an old house with raw floors. We didn't have linoleum on 'em. But, you know, we didn't know any different. Everybody was the same way that I know of.

Freeman: And how did you get your lighting? What did you use for lighting?

Morriss: Coal oil lamp. A lamp with a, we called it a little chimbley. A glass cover over it. That's all the light we had.

Freeman: Did you have one in each room, or did you carry it from room to room?

Morriss: Yeah, yeah. We had one in each room. If we needed it, we could carry it. It burned coal oil, we called it.
Freeman: Do you remember much about your mother and what she did around the household?

Morriss: Well, I was so young, and she, seemed like she was sick. She had tuberculosis, they called it. That lung trouble. Doctors didn't know anything about it. They had us take her out west. We went out there and stayed a while. She couldn't breathe. We brought her back home. And as I remember, when we was all kids, we'd sit out in the back yard, and she'd sing with us when we sang. That part I do remember. And the rest of the time, really, she was sick. My two older sisters, it was a on a Sunday, when she passed away. My sixty-two-year-old neighbor was standing over by the fireplace, and she motioned for us to come here. We started but she passed on. My little brother was four. But as I remember, she had long hair, and we'd all brush it. She did some cooking. I remember when she did some cooking. But after that, she got sick. But every kid was born two year apart. Twelve kids.

Freeman: So how old were you when you started helping out and working around the house and outside?

Morriss: Just real young, about seven or eight. We all had our little chores to do. We picked cotton. My sister two years older than me, we did most of the cooking. My oldest sisters married off when we was still young. I was probably twelve or thirteen. And we did the cooking. I had one brother that would help us in the kitchen, cook. Had three meals a day. Wood cook stove. It cooked good stuff. And my dad raised sweet potatoes. He'd fill the stove full of potatoes and bake them. We'd all had our chores to do. Get up at four o'clock in the morning so they could take care of the outside stuff-milk the cows and then feed everything, and then go to the fields before it got too hot.

Freeman: So, tell me what would be a typical breakfast.

Morriss: All right. Every morning we cooked biscuits. I tell you, I didn't know there was light bread in the world. And we cooked our biscuits and had eggs and bacon sometimes, and jelly or syrup. Country breakfast. And we all ate at one time.

Freeman: So how did you all fit in this, how did you fit? 
Morriss: We had a long table and a bench on one side and that held all the, longer than this table. And we all could sit at the table. And we all ate at one time. If one of the boys happened to be up, getting to him, we changed, you know what I mean. But we all usually ate, at twelve o'clock we all ate lunch at one time. Usually cooked pinto beans, a pot every day, 'cause that's what it took. And we didn't have a whole lot of different things to eat like they have now. But my dad raised chickens. We had chicken and all the eggs and churned our butter. Made (??) butter. And usually at noontime we got cornbread. And a lot of times at night times we had cornbread and milk. Sometimes baked sweet potatoes with it. We had all we wanted to eat. But you know, we didn't snack between meals like people do now.

Freeman: Did your mother keep a garden before she passed on?

Morriss: I cannot remember if she was able to have a garden, but my dad had a spring and fall garden.

Freeman: Tell me about those.

Morriss: Well, he'd plant just about everything you could think of to eat. And we all kind of worked in it. Tomatoes and little hot peppers. They all liked, my dad and my brothers liked hot peppers. They're so pretty. A little bush of 'em, you know, red and green peppers, Irish potatoes, tomatoes, green beans, peas, and just about anything you can grow in a garden. We had a good garden. That's what we ate out of. We'd pick our peas and beans when they got dry and put 'em in a big barrel to shell 'em. That's what we had to eat on.

Freeman: Did you have any fruit?

Morriss: We didn't grow any fruit. Seemed to me like we had, in the woods, there would be plum trees or peach trees. Different people would let us come and pick that. But we didn't grow any fruit. But we would pick dewberries when we could find them. Made good jelly or pies. And we'd make cakes once in a while. We didn't have cake like we do everyday now. Christmastime we'd bake about seven or eight cakes 'cause my brothers, they could eat a whole cake in a day. And that's about it. Just when we'd want to, we'd bake a cake.
Freeman: What about grapes? Did you have grapes and make jelly or grape juice?

Morriss: I think that we found some grapevines in the country and made a little grape jelly. But not a whole lot. But we grew good cucumbers, too, in the garden. That was my job. I loved to go every morning and pick the cucumbers. And I even learned to put some up when I was fourteen, fifteen, I guess, or something. I learned to put up cucumbers in vinegar and water.

Freeman: Did you do much canning?

Morriss: Not a whole lot. I know I remembered I did put some fruit. I tell you, one time, the government had a canning machine thing with the cans. We would meet at different houses, I just remembered that. My brother lived not too far, and we'd all get together, and we'd can some corn and that was so good with this canner. And then when one family'd get through with it they'd pass it around to the others.

Freeman: So what did the government agent do? What was their job?

Morriss: Well I remember that I went with my brother and his wife down in a wagon downtown and we'd pick up commodities, I think that's what you call them. Have some blocks of cheese, and I forget what we did get now. The government helped some along in that time. That helped us go a little farther.

Freeman: Sure. What about sorghum? Was there a-Did anybody make syrup?

Morriss: Yes. One time, and you make that out of cane. See, we grew some cane and took it to-I guess they passed that machine around to make that sorghum syrup, 'cause one time we made it, made that.

Freeman: At your place?

Morriss: Well, we went to the person's house, I don't remember, and made it and then put it in gallon buckets and brought it to the house. I don't know what house that was at, but I remember we did it. But that was real black and thick. It was good, but I have one brother that couldn't eat it. Give him the heart burn. I don't know why. We had sorghum syrup. I had forgotten about that. 
Freeman: And what did you use it for?

Morriss: Oh, for breakfast, for butter biscuits. (laughs) Anytime through the day if we wanted it, I mean, at a meal, but used it for breakfast. That's when we had our sorghum syrup and butter biscuits cooked in a wood stove. That cooked the best. And pinto beans. It cooked good beans on top. We had a big ol' pot to cook 'em in. One time when we had a fireplace, we had a big iron pot with a bale on it, and we'd put our beans in it and hang it. We had a wire hanging over the fire in the fireplace. And cook 'em right there.

Freeman: Did you live in more than one house, then, when you were growing up?

Morriss: Yes. We lived, after my mother passed on, well, we lived in that house for awhile. It was out in the country. And then that little place I was talking about, Glenham, where the coal mine was, there was a schoolhouse there and then a house up behind it. So we lived in that house. And then the last place I lived was closer to the cemetery, over that way, between Bastrop and McDade. And that's the last house I lived in. But that's the only two houses that I remember living in after my mother passed on.

Freeman: Tell me about how your father planted. What did he use to plant, and what kinds of crops did he grow?

Morriss: He and my brothers had a plow that plowed the rows, that plowed up the ground, and then (??) had a planter that put the corn in, and they'd run it up and down and it was covered. And a lot of times, where he planted the sweet potato vines, all us kids, he'd go along and plow up the row of dirt and then he'd go along with his walking stick, I called it, punch a hole, and us kids would stick the vine in the hole, and then it'd take hold and start living, you know, and running and making potatoes underneath. And Irish potatoes, we'd buy a big bag. When they got what we called eyes on it — could be a little root — we'd cut that out, and the boys would dig up the row of dirt, and we'd drop 'em. You had to have the eye up, see, so it'd come up. We called that the "eye," the little root on the Irish potatoes, and we'd drop that about that far apart, about a foot apart. And then they'd grow. And then we'd usually plow that up when the potatoes got big enough, about like a golf ball or baseball, plow that up, and then we'd all pick 'em up and put 'em to the house.
Freeman: Where did you store your potatoes? Did you have some place to put them?

Morriss: Usually, some times, he'd put a board under the house. The house would be up off the ground, and we'd put 'em under there to dry. Put a tarp - I guess that what you'd call it - on the ground under the house, and put 'em on that. One time, I remember, we put 'em in what we called the smokehouse. It was just a little room outside, and we put 'em in there to dry.

Freeman: So the potatoes went in there to dry?

Morriss: Yeah. And that's where we'd keep 'em. In the cool. And then we'd just use 'em as we needed them.

Freeman: Did he grow cotton every year?

Morriss: As I remember, we did. No, I don't think. Seemed me like, there was a year or two that we did not have cotton. But I do remember that one time that we did, 'cause my brother and I rode to town on the cotton wagon. But I don't remember just how many years he did grow cotton, really.

Freeman: Was it a pretty productive crop out there, or not so good?

Morriss: I don't think, it's not so good, 'cause I didn't remember very many people having cotton every year. But usually it was corn and stuff that you could eat.

Freeman: Was there ever enough of the crop to sell part of it?

Morriss: No, we never never got to sell none 'cause we was a big family, and we ate just about everything that we could grow. (laughs) And then we had to end up, I think, buying stuff along before it'd grow again. But he had a spring and a fall garden. So we always had out of the garden to eat. And he'd kill a calf, like in the wintertime we had our hogs, hog meat and the calf. He killed a calf.

Freeman: What about peanuts?

Morriss: No, we, let me see, I know the neighbors did, because when we was walking home from school, we'd reach under the fence and get us some peanuts. (laughs) Which they didn't care. But I don't remember, I can't remember us growing any peanuts. We may have, but it's been so long ago, you know. But I know 
different people did, and they'd be so pretty, green on top, and you'd pull it up and there'd be a whole lot of peanuts on it. So we didn't grow a whole lot of peanuts at that farm.

Freeman: What do you remember about the hog killing? Did you ever help with that?

Morriss: Yes. Me and my sister and little brother, we watched it all the way through and helped. It's always something that we could help with. So, my brothers and dad, they'd do the biggest part. But then we'd take it in the house and cut it up in blocks. As big a family as we were, we could eat a whole ham at a meal. So, and usually, we didn't have meat through the week. Just on Sunday, my dad would kill chickens, you know, and we'd make chicken and dumplings some time, or fried chicken. Seemed like it wasn't a whole lot to eat. Because we couldn't afford to buy stuff. We didn't collect any money.

Freeman: So how did you preserve the meat that you didn't eat right then?

Morriss: Well, we didn't have an icebox. We usually, it didn't take long for this family to eat it up. So it would keep, as I remember. And the one time that the smoke, the smokehouse, the little room, why they'd hang it up on the bar out there.

Freeman: Did they actually smoke it, or did they salt it, or what did they do?

Morriss: Yeah, just kind of salted it. Some neighbors had a big barrel that they salted their meat in, and that keeps it when you salt it down. Our family used to eat it up too fast. (laughs) We didn't have to take care of it.

Freeman: What about milk? Did you try and keep that cool somehow?

Morriss: Yes. We had a, we called it a safe. It's a cabinet with screened wire on the doors, and my dad built this little out (??) of a window, shelf-like, and we could put some out there. But, see, we used it up pretty fast. Some of it would sour. We made cottage cheese out of some it. We called it "clabber milk" when it got - I don't know what to call it - jelled. And we'd put it in a bag and hang it out on a fence and let it drip dry and have cottage cheese. But we just used up all our milk, just about.
Freeman: So at any time, about how many cows would you have, or how many cattle would you have?

Morriss: Oh, I think we had about five or six cows at a time. 'Course they all don't have milk all along. When they have their baby calves, you can't use it right away, but after about nine days, then start using that milk. We always had plenty for the whole family.

Freeman: Do you remember who your neighbors were?

Morriss: Yes, we had some neighbors. We never had close neighbors 'cause it was fields, you know. I remember one neighbor, I guess Claude was about two miles from us. And we visited them. Their name was Guest, and, but neighbors didn't visit back then like now. Pretty close by it was, I think, it was three brothers. They was our closest neighbors. Just the three guys. And boy they could eat. They'd come to the house and play dominoes some and just visit. But neighbors, we didn't have neighbors to visit back there, close neighbors.

Freeman: So it sounds as if there were a fair number of German families in the area.

Morriss: That, these guys were German, and then, I call it about five miles from us, there was another family there, as I remember. So that was three neighbors that lived not too far. We could have walked 'cause you walked everywhere in the country, you know. And we did not have a car, just the wagon. When the church revival would come to the Oak Hill Cemetery, where we were at the other day, well, my dad would put us all in the wagon and go three miles, I guess, two or three miles.

Freeman: You stayed over there.

Morriss: No, we'd just go down there and come back. Wouldn't come back till eleven o'clock. Yeah, the revival would stay about a week, if I remember right. So that's when he'd put us in the wagon and go to the revival. That's the only way we had to go any place. We walked everywhere we went.

Freeman: Did a lot of people show up for those revivals?

Morriss: It seemed to me like it was, as I can remember, it was a pretty good bunch. Yeah, it was a pretty good bunch. 
Freeman: Did you go to church besides going to the revivals?

Morriss: No, we didn't get to go to church. As I say, we didn't have clothes to wear, fit to wear. We was so poor, and we didn't have clothes like they wear now. And I don't know, because my mother wasn't living, my dad, I guess, just didn't think. And I can look back and see, you know, why didn't we get to go to church? But really, we just didn't have clothes to wear like everybody else.

Freeman: Tell me about your clothes. What did you, what did the girls wear?

Morriss: Oh, just plain little ol' dresses. I had three dresses at this one time. In fact, I think I just had two at this one time. And I'd take out of school one day and wash and iron 'em, and like that. But the boys wore overalls and blue denim shirts, and my dad wore a shirt and overalls. Shoes wasn't too good, but we couldn't buy 'em. You ain't got the money, you can't buy 'em. But we didn't think nothing about it, you see.

Freeman: Did you mostly go barefoot?

Morriss: Yes, in the summertime we went barefoot around the house and I'd get stickers. The porch had loose boards, and I'd stick 'em in my foot sometimes, but we'd just pick 'em out and go on. But our feed sacks we got for the cows, the feed come in, was solid white. So I made me - this is going to sound funny - I made me two dresses out of those feed sacks. And one of my brothers had a red sweater. So I put it on the stove with some hot water and I dyed one of my dresses pink, and somebody told me, "Get you some of that green bark off this tree and boil it." I did and made one brown.

Freeman: Oh, my word.

Morriss: Yeah, I was just as proud of them as I could be. We had a sewing machine that was my mother's, with a pedal, and I just laid it on the floor and made a dress on it, and I cut it around, and then I sewed it and made it into a dress.

Freeman: Very clever.

Morriss: Yeah, yeah. You just learned all that when you were in the country growing up. 'Cause it's not given to you. You've got to work for everything. So that's what I did. (laughs)
Freeman: What about turkeys? Did you have those?

Morriss: One time, my dad raised some turkeys. I don't know why we didn't all the time. But, yeah, and we killed a turkey one time and baked it. And turkey eggs, they'd be big as a teacup. Yup. Probably three times as big as a hen egg. We had guineas. You know what guineas are? Little speckled things. And they make a lot of noise. They would be good as a watchdog. If a strange something come around, boy, could they holler. And they had their nest, and you don't reach in there with your hand to get the egg, 'cause they don't lay in there anymore. So my dad had this long-handled spoon, and we'd (??) the nest and get the eggs out. They hide their nest in those bushes.

Freeman: And if you put your hand in there, then they won't use that nest again?

Morriss: That's right. So we learnt, and don't put your hand on the spoon. You know, you learn all that. I bet a lot of people don't know that. But that's it. We'd take the spoon handle and push the eggs out.

Freeman: Well, turkeys hide their nests too, don't they?

Morriss: Well, we didn't have, I think they do, but we didn't ever raise enough turkeys. But, you know, a guinea is a little speckled white, it's just kind of cute and makes the oddest noise. (imitates the noise) And we could tell. They're as good as a watchdog. And their meat was dark. We didn't like much to eat them. It was dark meat.

\section{Freeman: So why did you keep 'em, mostly?}

Morriss: I don't know. (laughs) My dad had 'em, and I don't even know where we got 'em from and what we ever did with 'em. But it's good to have 'em.

Freeman: Did you have much trouble with snakes and varmints?

Morriss: Yes, we had, we called 'em chicken snakes. And they would get the eggs out of the nests. And my dad — this sounds like a dirty deal — but my dad punched a little hole in the egg and got the inside out and put some cement stuff in there and he put that in the nest, and that snake would swallow it, and you'd find it a day or two later where it crawled up a log or something to break that egg, and it killed the snake. 
But that's what had to be done. Chicken snake, they called them.

Freeman: Did you have much trouble with poisonous snakes?

Morriss: No, as I remember we didn't. Like rattlesnakes and stuff like that. I don't remember us having anything like that.

Freeman: And what about coyotes or foxes or bobcats?

Morriss: No, we didn't. As I remember we weren't bothered with that.

Freeman: So, what happened when you all got sick? Did you have any home remedies?

Morriss: Yeah, we didn't have to use the doctor a whole lot. I know one of my brothers, when I had a light case of typhoid fever, my one brother had typhoid fever, and the doctors would come to the house then. The doctors come out to the house. We wasn't that sick that much. So I guess the country life is good for you. We wasn't sick that much. And we'd take, Papa would give us medicine, black draught, it was like a tea. Castor oil, that was familiar back there when we needed it. But we didn't get sick a whole lot.

Freeman: And what is black draught?

Morriss: It's a powder, and you can put it on, boil it and make a tea, or you can take it straight, but it sure would stick to your throat and everything. It's about like coffee, only it's salt, it's little grainy stuff. I don't know where we got it from, but bottle of liquid that you could (??) with a

Freeman: So I guess the doctor didn't come around much.

Morriss: No, we didn't have to use him that much. But he would come to the house. Like when my brother had typhoid fever, well he come out. Don't remember him ever coming to the house that much.

Freeman: I think, not too long after you were born, there was a bad flu epidemic that went around. About 1918 or so. Do you remember hearing anything about that?
Morriss: No, I really don't. Can't remember anybody being that sick.

Freeman: Well, tell me about school. Where did you go to school?

Morriss: Well, I was going to say, this little place called Glenham, where the coal mine was, my brother and I went to school there. There was a lot of Mexicans, about five white kids and the rest Mexicans. Well, I just went through the fifth grade. One of my sisters was sick and had three little kids, and my oldest sister next to me had to stay and take care of her. You know, back then, that was what we did. We did go to Oak Hill School some. Had to walk, and it would snow. We had snow back then. Be ice on the ground. Well, we went some, but then when it was too much, we didn't go 'cause we had to walk. That's about seven or eight miles. When we were going to Oak Hill School, my sister and I, we had cousins there. It was a big school. One big room with all the classes in it. And this other school I went to was just one room through the sixth grade.

Freeman: Did you take your lunch with you?

Morriss: Yes, we'd take biscuits and jelly. That's what we had. I didn't even know about peanut butter and crackers until I seen some other kids eating it, and it looked so good. But see, we didn't ever get peanut butter. But I did later, 'cause my sister, I stayed with them some, and they got it. We didn't buy extra stuff like that. Couldn't afford it and didn't know about it.

Freeman: So how many kids were there at the Glenham School?

Morriss: Just my father and I was all that was there.

Freeman: But the whole class?

Morriss: Oh, it'd be about, probably twenty. Fifteen or twenty. A lot of Spanish kids. Mostly just a few whites.

Freeman: Do you remember anything about the mine?

Morriss: Yeah. I know my brothers and the Spanish people worked in it. And they brought the coal up. And my sister, the houses there, we lived around there at 
that Glenham place. The second place. The first place we lived at, my sister and her kids washed clothes and hung 'em on the line, and that coal dust from that would get on 'em. So you'd have to shake them all off. And we had a coal heater. You'd burn the coal at that time. Put the coals in there and it made a good fire.

Freeman: Was that pretty hard work, the coal mining work?

Morriss: I think it was, 'cause they had an elevator to take 'em down under the ground. And had a pick. You know what a pick is? They'd pick the coal in chunks and put it on, had a little railroad in there, like a railroad car. And put the coal in it and bring it back out. And you know, really, I don't know what they did with it. I can't remember what they did with it. Hauled it off. A railroad track come through. I guess they must have hauled it, but I just don't remember that.

Freeman: Did your father work in the mines too?

Morriss: He didn't go there. He just hauled timber when they was building roads and everything. He hauled timber. Two or three of my brothers worked in the mine. But he didn't. He had corn growing at that time.

Freeman: And you mentioned a little country store. Where was that?

Morriss: It was where the coal mine was. Just a little country store.

Freeman: Who owned that? Do you remember?

Morriss: No I don't.

Freeman: And what kinds of things did they have in it?

Morriss: They had a little bit of everything in it that you need, coffee and flour and sugar and just, like a little grocery store. Canned stuff. But we didn't use a whole lot of it. We raised just about everything we ate.

Freeman: It sounds as if wood cutting was a big activity out there.

Morriss: Oh yeah. My brothers did. I don't know who else, 'cause you don't know what goes on with all the country people. But we burned wood. We had a wood cook stove and a heater one place. They cut wood for us, and then they'd cut a load, big old wagon load and take it downtown. A lot of people in town used the wood for heaters. I don't know if they cooked with it. We did. It cooked better than gas. They'd cut the wood, cut down trees. We had a pasture of trees and they'd saw them down and cut 'em up.

Freeman: Where did you get the water for your household?

Morriss: Okay. I don't know how far this spring was. I don't know who built the dam. My dad had a big water barrel, wooden barrel, and he'd put it on the wagon and haul it from the spring. And it was good, cold water. And that was one time we'd haul it to the house. And he'd haul some to the schoolhouse. We had a big barrel at the school to hold water so the kids could drink. One place we had a tank, we called it. And, you know, I don't know where the water come from, unless it was from rain. We had a tank of water for the cows and everything. And when we washed clothes, we washed clothes with a rubboard, and had a big pot in the back yard. Iron pot, and we boiled the clothes, white clothes in it.

Freeman: What did you use for soap?

Morriss: Well, I remember my dad made some soap, lye soap, one time. And then we'd buy the bars of soap and have a rubboard, and then wash clothes like that. And then put 'em to rinse. And then you'd get that bottle of bluing, we called it, for the rinse, and squeeze 'em out and hang 'em on a - We had a barbed wire fence. We didn't have a clothes line. Hang 'em over the fence till they got dry. Big iron wash pot, build a fire under it. Put water in it for boiling the white clothes and overalls.

Freeman: Were the springs at that first house you lived in? Or were they over near the mines?

Morriss: Let me see, I can't remember which they were. They were over in the woods somewhere, 'cause I know we had to go in the wagon to get the water and haul it to the house. I believe it was in the second house.

Freeman: Do you have any idea where the water source was for that first house? Was there a cistern?

Morriss: No, we never had a cistern. And I wonder where we got the water. But I can't remember now. 
Freeman: And you said something about rock walls at the spring.

Morriss: Well, I never knew who built them or who, how they did it. But around the top was wood, you know. But I just don't know they built that. I never did pay attention or ask.

Freeman: I wonder if that was almost like a community spring.

Morriss: It could have been.

Freeman: Did lots of different people use that?

Morriss: I think so, I think so. Because I don't know where they would have got the water from. Some of them could have had cisterns, you know. When it rained. But I don't know. One time, one place where we lived we had a well of water. I was so young I didn't remember much about that.

Freeman: Did you have a telephone?

Morriss: No. Didn't have a telephone. No we didn't have a telephone. When I come to Austin and my husband built this house in the forties. We bought the first lot here in the early forties. He built this house. We had to haul the water from downtown. That's how we started here.

Freeman: Did you have any black neighbors?

Morriss: Yes, we did, a real good little ol' lady. I forgot her name. But the guy was named Bell.

Freeman: Was that his last name?

Morriss: Yeah, but when they come by-

Freeman: The Bells were the black neighbors?

Morriss: One man, elderly man. But, you know what, back yonder, and I don't know why, they didn't visit and, as I remember, never come in the house. Just come by and talk sometime. I don't know why. It was an elderly black lady lived not too far from us, and we'd just see her sometimes. And as I say, this elderly black man was, lived probably out there kind of close to us 'cause he'd come by once in a while. But I didn't see any of 'em living close to any white people, you know. Don't remember too many blacks out there. As I said, my brother and I [were] at that one-room school with Mexicans. Wasn't no blacks.

Freeman: Were the Mexicans actually from Mexico? Did they speak a lot of Spanish, or were they, had they been from that area for a while?

Morriss: As I know of, they didn't come from there. They just lived around and close to Phelan, Glenham after the coal mines. And they all spoke English. We tried to learn some. We'd learn from each other, and they usually stayed to theirselves, and we stayed to ourselves. Go out at recess, go play, all played together. Played ball or something, you know. Just friendly to each other, but didn't connect close like you would now.

Freeman: So what kinds of games did you play at school during recess?

Morriss: Wasn't a whole lot to play. Just played ball is all I know of. We had a soft ball and played ball, and then, of course (??). Did you ever play that "London Bridge is Falling Down"? Hold the hands up. Hide and go seek. That's about all we played.

Freeman: Was there a creek anywhere near your home?

Morriss: One place we lived at, and there was a creek. Papa would let us go (??). He let us and he'd go with us, the boys and girls, go to this little creek on Sunday evening. We'd have on overalls and shirts and clothes on, you know, and lay around in that little creek. Then go back to the house. But just on Sunday evening we did that some. But that's the only place that I know of that we could go. None of us ever learned to swim. I'm scared of water.

Freeman: What about bathing? Was it a once-a-week thing?

Morriss: Yes, usually on Saturday. We had a number three washtub, and we'd heat a bucket of water on the stove, usually in our kitchen with this tub, and we'd bathe in the tub once a week like that. That's all we knew to do. Wash your feet maybe every night. To think back, you know, it's something to think about, and everybody was in the same fix.

Freeman: Well, I'd say your memory's pretty good. 
Morriss: That's good to remember the things like that. And I walked in my sleep. My brother talked in his sleep. But I was a little teenager, I guess I was about sixteen, eighteen, something, and Papa would take us, one of my brothers and his wife and my little brother and my dad. We'd go cotton picking up toward Taylor. We'd camp out and pick cotton, but I walked in my sleep. One night, I have to tell this, it's so funny. My sister and her husband was camped out down at the river. All of 'em liked to go fishing. So I was staying the night with 'em. I dreamed I was going to somebody's house, and I walked off over a hundred-foot bluff, down through a tree, scratched myself all up, and I come on back up and woke my sister up and I told her what happened, and she said, "Well, lay back down." So next morning, her fatherin-law said, "Well, I heard that, but I thought it was a bunch of cows running through the brush." And so we'd go, as I say, pick cotton up around Elgin, camp out. But we had a little truck then, a little ol' pickup truck. So they'd sleep around on the ground, but they'd make me sleep in the seat and just tie my arm to the steering wheel so I wouldn't walk off that bluff. I'd wake myself up taking that thing off of my arm. I never did go walking. Yeah, I walked in my sleep a lot. My other brother talked in [his] sleep. And I don't know why that is. I don't hear of that no more. And we all, as I said, played music. That was our entertainment. Fiddle and guitar.

Freeman: How often did you go and pick crops on different places?

Morriss: Not too often around, just a couple of summers is all I remember. Going around Elgin. But then sometimes in the summer, two or three times, we'd go down to Damon, Texas, East [sic] Texas. We had a friend down there, and my dad and one of my brothers and my sister, well, my little brother, it was two brothers and my sister and I, we would go down there in this little ol' truck and picked cotton two or three different times. And my sister and I - It was a real good family, we'd stay in the house with them, sleep in the house. And [they] had a big barn, and all the guys slept in the barn. And we picked cotton there. It was about three different years that we did that, picked cotton. And then, Saturday evening, well, we'd all get on their big truck and go to this little ol' town, Damon, Texas, and go to a café there, and that was my first candy bar, Milky Way, to eat. (laughs) That was the best time. And we visited like that. And I have real fondness, real good people.
Three daughters and two brothers, and their mother was dead, and their dad. And were just good friends like that. But it was just about one or two times we went around and picked cotton.

Freeman: Did you have a car at that time, or did you drive up there in your wagon?

Morriss: Oh, we-

Freeman: When you went to Elgin and Taylor?

Morriss: Well, we had this little pickup then when we was picking cotton. But everywhere we went we'd be in a wagon. We'd go visit my uncle in Elgin. Papa would put us in a wagon and like that. And to go to church, we'd go in a wagon. We didn't have a car. Had a little ol' Model T when we went to East Texas to pick cotton.

Freeman: How long would a trip like that take in a Model T?

Morriss: Ah, probably, to go to East Texas, it'd be a half a day anyway. Leave early in the morning and get in there in the afternoon. Might near a day, 'cause you know you didn't drive fast. And we'd have a flat tire, maybe, that they'd have to fix. But in a wagon, go to Elgin or Oak Hill like that, it was just a couple of hours.

Freeman: What about hunting? Did your father or your brothers do any hunting?

Morriss: Yes, they would go out and kill squirrels and rabbits and sometimes - they weren't big hunters - but they'd go kill a wild thing for us to eat sometimes. Squirrels and rabbits.

Freeman: What about for fur?

Morriss: No, we didn't ever do that.

Freeman: Any deer out there at the Camp Swift area when you were growing up?

Morriss: Not that I know of. No, I didn't see any deer up there. In fact, I don't even remember seeing a deer out in the country there when I was growing up. But there were just some rabbits and something.

Freeman: Did your family have dogs? 
Morriss: Oh yes. We had two dogs. One of them was a very smart little dog. Now this might sound funny, but when the boys went somewhere at night, if something happened to 'em, this little dog had a funny way of barking. My dad'd say, "Well, he got hurt." Something happened. This little dog had a way of barking. We had two dogs, and one of my brothers loved cats. We had some cats. But I didn't like cats, and he cut a hole in the kitchen wall there [for the cats]. If they come in, well, I'd stomp my foot at 'em. Broke the heel off my shoe kicking at it one time. Only pair of shoes I had, and my brother that owned the cat, he took my shoe to town and got it fixed. Yeah, we had two dogs and the cats.

Freeman: Were they any particular breed? The dogs.

Morriss: No, just plain dogs.

Freeman: And did they go hunting with your brothers?

Morriss: Yeah, my brothers would take it along, but I don't think they was smart enough to catch anything. They were just dogs. It's good to have 'em around to bark if something come around. But the guineas were better watch dogs than they were.

Freeman: Did you have strangers who came through that you wanted to know about?

Morriss: At one house, when we lived in a house close to Phelan, at this place by the railroad, it was close to Glenham out there, but wasn't no coal mines at that time. It was a railroad between there and the city road, just a dirt road, and at Phelan, hobos - you've heard of hobos riding the freight trains - why this wasn't real hobos, but they was riding the freight train hunting jobs, work. Well, if the train stopped, we'd have 'em to come up to the house. Right there at the track. And we'd fix 'em something to eat. We didn't have a whole lot to eat, but biscuits and bacon and whatever, and we'd fix some stuff. One guy was very interesting. He picked the guitar. So we all got on the porch there, my dad and him, and I learned a little bit from him. He probably learnt from me. And he picked music. Dad was always - We had a few, and they always wanted to know, "Can I chop wood, or do something for a little something to eat?" And of course, we never did let 'em do nothing, but they'd visit a while and then they'd go on. We had a few like that. Just 'cause of the railroad.
Freeman: What about peddlers?

Morriss: Well, yeah, once in a while I remember a peddler coming through when we lived at one of the places in the country, and he had a big pot, aluminum pot with another pot, what you call a double boiler, and I think he wanted to sell it for a dollar or two dollars or something, but he took a chicken. Papa give him a chicken for it, and that's how we got the pot, aluminum pot. So every once [in a while] we'd have one coming through, selling. What was it that they were selling? Liniment, or something like that.

Freeman: What did you do at Christmas? Did you exchange gifts at all?

Morriss: We had, we didn't have no decoration, but, and I was already sixteen years old, I guess, at the place in the country that we've been talking about. My brothers would cut a cedar tree and put it in the house, and we'd take, like they do at school, paper and make them little rings. That was all the trimming we had. And one brother, two of my brothers, one of 'em bought me a pair of beads and the other one bought my sister a pair of beads. And that's all. My dad would buy a big box of apples and a big box of oranges. But we didn't exchange gifts. No money. But he'd get fruit for Christmas. And then we'd make about eight cakes. And he'd kill some chickens or something like that. We had plenty to eat. We didn't know any different. But we didn't exchange gifts. And one year, I remember my two oldest sisters, one of 'em bought me a doll, and the other bought my sister a doll. And we kept 'em (??). And then I remember, I expect it was like it is now. What do you call it? Take a box of toys or something to the poor kids. A car drove up with two ladies in it, and had a box of toys for us. I guess they heard we was poor people, you know. And one time, I remember that. I don't know what was in it, if it was a doll, or something.

Freeman: You know, people talk about the Depression in the 1930s. Was that something you remember as being different from other, earlier times, or-

Morriss: It was about the same, I suppose. Just, everybody was poor and didn't know it. As I said, we always had plenty to eat of what it was because we growed it. That's about all I can remember of, I guess. The poor times. 
Freeman: Did you ever hear anything about the government agents coming around and killing cattle?

\section{Morriss: Yes.}

Freeman: Tell me about that.

Morriss: As I remember, you couldn't have, I never could understand this, just a few cows. 'Cause I guess there wasn't no feed for them. I don't know why they did that. But, yeah, they'd come out and slaughter cows. I don't think we had any to kill 'cause we didn't have that many. But where they had a big bunch, they'd slaughter them, make 'em kill 'em. I never could understand that, I guess. And why, I don't know. 'Cause there wasn't no feed for 'em, I guess. But I don't know why they did that, but I do remember them killing cows.

Freeman: Did anybody in your family ever work for one of the government programs, like the CCC or-

Morriss: Yeah, my, CCC camp. Three of my brothers was in that. We called it the tree army camp. But that CCC camp was what it was.

Freeman: It was the tree army camp?

Morriss: Yeah. That's what we called it. I guess that was it. But that CCC camp, that's (??).

Freeman: And where did they work?

Morriss: Well, you know Bastrop? Out on the hill towards Bastrop Park, somewhere on, they call it (??) hills, just out of Bastrop towards McDade, that's where it was. And I had two brothers in that. J. B. said he thought (??) was in there. But I know two of my brothers was. And, you know, I'm trying to remember, did they stay there the whole week? I believe they did. And then come home on the weekends. But one went, and then the other one went. And they paid a dollar a day, thirty dollars a month. And that was money. And that made us so happy because when they took one in and then they took the other.

Freeman: Did that make a big difference to your family?

Morriss: Yeah, it really helped out, give us a little money to live on, you know. It really did. Other than that, wasn't no money coming in. My dad, when he got that age, fifty dollars a month, I believe, I believe that's all he got from the government, could buy medicine or whatever we needed, whatever he needed. I think it was about fifty dollars a month was all he got. I don't know if he ever got a raise in that or not. And used on medication.

Freeman: Do you remember anything about unusual weather, like bad droughts, or-

Morriss: Had a lot of sandstorms, you call it. The wind would be so high it'd just - If it hadn't rained none, be a lot of (sand). But when I was at one place - I was probably seven or eight year old - we had a, it would be called, I guess, a small tornado. It blowed some tin off the house, you know, and it just landed down in the field. A real bad wind. And we had snow back yonder, too. Not no good shoes on. We'd wrap newspaper, paper around our feet outside of our shoes to go out in that snow. Icicles hanging off the house. (laughs) That was good! I'd get me a hunk of cornbread and an icicle. Something different. (laughs) But we had a lot of high winds and little storms. In the night, Papa would get us all up and let us get dressed because it'd be so stormy, in case we'd have to get out and run, I guess. But he'd get us all up and put our shoes on and be ready. We had a lot of high winds back there, little storms.

Freeman: Well, was the snow just one-I know there was snow in that winter of 1929 to '30 or so. Were there other times when you had snow?

Morriss: Not so often for snow. Unh-uh. That I know of. But just a few times for the icy weather in the wintertime. Be icicles hanging everywhere. And we didn't have no good covers and fire, too, to keep us warm. But we had more cold weather back there than we have now. And icy.

Freeman: Well, you've mentioned music several different times. Tell me about that and how, how you-Did your brothers and sisters play music too? What did you all do?

Morriss: We'd sit around at night and some afternoons, and my dad played the fiddle real good. And we had an old guitar. I don't know where in the world we got that old guitar. Just a cheap one. And I don't know how we learnt that, but we, from him we just learnt to play the fiddle. By ear, you know, you can pick up 
anything. And we all played, all played the fiddle and the guitar. And then I had a cousin that lived in Dallas. She come down. She dressed like a man. Had her hair cut like a boy. She worked on cars in a garage shop. And that was unusual back there. She'd come in the summertime and spend a week with us. She'd bring a mandolin. That's the first mandolin we seen. But we all did that.

We'd get together, and sometime they'd have a little country dance and have my dad play the fiddle and we'd pick the guitar. And I don't know how we learned it, but we just learnt to pick the guitar and play the fiddle like him. One of my brothers was left-handed. He played the fiddle over the (??) like we have. And we just sat around and pick up and play the fiddle and guitar. And then mandolin, when she had it there, we all just jumped in on that. And my dad had an eight-note accordion. I don't know where he got that out of. Just a little ol' accordion. And we'd play that. He could play it and sing along. And so we all got to playing that. One of my brothers, had two brothers that couldn't play nothing. We woke him up one morning with it, and he got up, took it out of my hand and laid it on the fireplace. But he didn't leave it there long. He got it right off. Made him mad 'cause I'd waken him up with the accordion. But it just come natural, I guess.

Freeman: Did you play together as a group?

Morriss: Yeah. All we had was fiddle and guitar. Yeah, my dad played the fiddle, and we'd change about with the guitar and copy him. And when the boys played the fiddle, we'd just exchange out. We'd just play. We played at the country dances when they wanted to dance. And we could have 'em at our house for a little ol' party and dance. And we had our own music.

Freeman: So what were some of the popular songs that you'd play?

Morriss: Gosh, its hard to say. I got four songbooks. (laughs) Just country songs usually what we played. But now I do gospel and country 'cause I go to the Baptist church over here. I sing for the church and I sing for the nursing home one Saturday a month. And did I tell you how many musics I have here? I've got seven guitars, two fiddles, two mandolins, and a banjo, and an organ and tape players. I make tapes. Cassette tapes. I send them all over the world just for free. I do country and gospel. And we did mostly country when I was growing up. Yeah, that, see I got corns on my fingers.

Freeman: So were there other families in the area that played like that?

Morriss: Not that I know of. It was all, what neighbors we had, I don't know of 'em. Now, I had some cousins. They didn't live close by. But a cousin that played the fiddle, and when he'd get with us, why he'd be playing. We had a reunion. We started it in '64 at Bastrop Park. Then, a lot of my brothers was living and my sister, and my dad wasn't ever here. We started that after he went. So we'd take our music and set out in the park and play, just switch it around. "Here, you take the fiddle and give me the guitar." (laughs) All of us played music like that. It's fun.

Freeman: So tell me what happened to your family in the thirties and forties. Where did your brothers and sisters go?

Morriss: Well, they all stayed home. Two of my brothers, three of my brothers got married then, a little apart, you know. A few weeks apart. And some of them lived in the house with us, stayed in the house. And then my sister older than me, well she married this guy and come to Austin. So that didn't leave many, much of us at home. In '36, in '35, my brother got married, one of 'em. Then in '36, two brothers and my sister got married. And then I came on at the end and in '36 I come up and lived with her, and then in 1937 I met my husband. Met my husband in September and started going together, and we got engaged. It took us four months. We got married Christmas Eve night, 1936. Knew each other four months and we lived together fifty-seven years. He died with leukemia. Two kids. Had a daughter, and five years I had a son. So finally in '42, I guess, this land come for sale. We bought the first lot and he built this. He was an automobile mechanic and he built this house.

Freeman: Now, what happened to your father?

Morriss: All right, he got sick. He took lung trouble, and he was sick about, they called TB, tuberculosis, and he lived about, well he was seventy-five when he died. But he got just pretty sick. And my sister lived, they lived in Houston. She'd come. He lived in Bastrop, so she come and help out. I'd leave my kids, 'cause my mother-in-law lived in the backyard then, and took turns taking care of him. And he died with TB. 
Freeman: Were any of your family still living out there when the government took the property, took the land?

Morriss: Not that I know of. No, we didn't. 'Cause, as I say, I left there in '36 to come to Austin, and my dad stayed with one of my brothers for a while till he passed on. And I don't think any of us, any of my brothers was living there.

Freeman: Are any of your siblings still alive?

Morriss: Ah, J. B. and Bobby, you know them, my nephews. I'm the only one left out of twelve.

Freeman: Out of the twelve kids?

Morriss: Uh-huh. Yeah. I'm the only one left.
Freeman: Well, what do you remember most about living out there early?

Morriss: Well, what I had already said, I guess, is we'd play dominoes for a past time, and our music, and just working around the house is all, everyday stuff. That's about it. I think I told you about all I know. Maybe a little more too. (laughs)

Interview with May Belle Miller Morriss Interviewed by Martha Doty Freeman

Date: June 2, 2004

Place: Home of Morriss, Austin, Texas Year of Birth: 1918 


\title{
Fay Owen Pannell Interviews 1 and 2
}

\author{
By Thad Sitton
}

\section{Interview 1-31 March 2004}

Thad Sitton: This is Thad Sitton. These interviews are with Fay Pannell at Sayersville, Texas, on March 31, and April 2, 2004. [Pannell's son, Leland Pannell, also is present during the second interview. His photograph is on page 203.] These interviews are a part of the Texas State University-San Marcos, Camp Swift Oral History Project sponsored by the Texas National Guard and conducted in conjunction with the Center for American History, The University of Texas at Austin.

Thad Sitton: Tell me about the place that you grew up on. We're on it, right?

Fay Owen Pannell: No, I lived with my parents across the highway here in the Camp Swift area, not in what's now the Camp Swift. We lived right near Oak Hill, near the cemetery and school. Our place was right next to them. We had a picture of the house is in here-and I had four brothers, two older than me and two younger. When we were growing up, my daddy didn't much like the farming part. He did a little farming, but he didn't like the farming part. He liked raising cattle more, but he was one of these people that if he could round up cattle with a pickup, he did, rather than a horse. He didn't keep a horse for that. He loved to round up cattle with a pickup. He had land leased over here where the Sayers Mine was - all that Dennison property. He had that leased for cattle, although we lived over at Oak Hill. And 'course, my brothers - my two older brothers had to help with that. Then, I don't know when, but probably about the time the Depression hit - 'course, we had cattle and had milk cows anyway and my parents started selling milk — bottling milk and selling it [in] Bastrop. Had customers they sold milk to, and butter, fresh butter. My mother churned and molded that butter in pound packages, and they sold that.

Sitton: It was all hand-milked, too, right?

Pannell: Oh, yes. And my older brothers 'course had to help with the milking — did most of it.

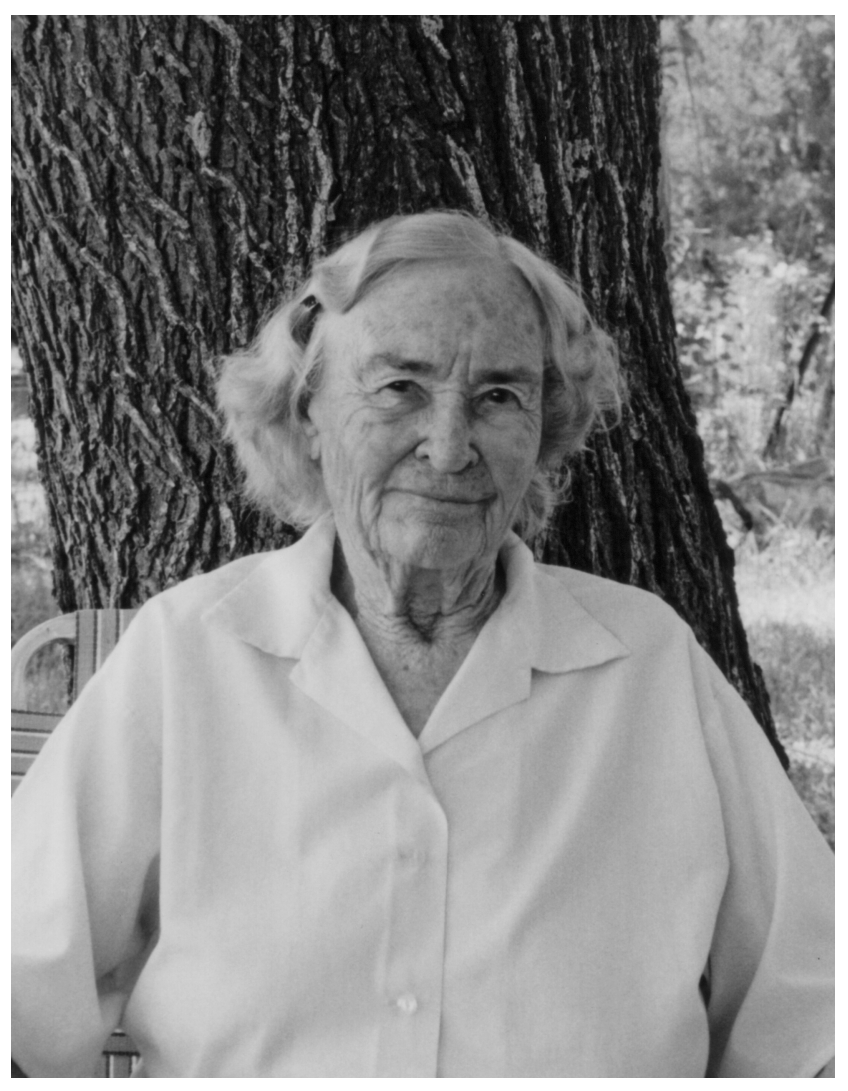

Fay Owen Pannell

Sitton: How many cows would you say, approximately?

Pannell: Oh, I don't know. They milked, I don't know, probably fifteen. It wasn't a big herd. Small herd. But they did sell the milk and butter.

Sitton: Well, how big is the Oak Hill place? What's on the Oak Hill place? You own that, right?

Pannell: We owned that at the time we lived there, but it was only eighty-seven or -eight acres, so we had to lease other land and kept the milk cows there on that place. But he had to raise the cattle then on the Dennison place that he had leased. And we had the milk separator. I don't know whether you've seen one of those. 
Sitton: Centrifuge?

Pannell: Hand-cranked milk separators. 'Course, they had to have one of those. My daughter has it now, and she's just done a picture of it. She's pretty good at artwork, and she's done a picture of that. You might want to see it when I find it. Then, across the road from us was a colored family, A. G. and Mary Lou Benford, and they had several children - four or five children - there must have been five, and one of the older ones was a boy, John Billy Benford. He lives in California now, and he calls me about once a month [to] check on me to see how I am. Real nice guy. He was in the service. Anyway, when he was a little boy, his daddy, A. G., helped with the cattle. Anyway, he'd bring John Billy with him when they would milk and tend to the cattle, and every morning my daddy gave John Billy a pint cup full of fresh whole milk and made him drink it, every morning. And he hasn't forgotten that. And that brought that kid out. I mean, he filled out, made a nice young man. And he's never forgotten. He said, "Your daddy was so good to me when I was a little kid." And if you can in the interviews, I want you to interview his mother, Mary Lou, and let me get her name and address right here. (tape turned off)

Sitton: They were part of the Oak Hill community, right?

\section{Pannell: Yeah.}

Sitton: I know Oak Hill graveyard has a black section.

Pannell: Yes, we're trying to take care of it, too, and they're not doing a very good job of it. Needs a lot of work on it getting it cleaned up, but we're gradually getting that cleaned up. But the black people don't want the help. They're not good at keeping up cemeteries there. Too superstitious.

Sitton: Yeah, I know. I've heard that.

Pannell: But there are some Reeses buried over there, but not Mary Lou's family.

Sitton: Did your father farm anything on that place? Did he have any cash crops there? What did he raise? I know he's mainly a cattleman.

Pannell: Yeah, well he raised corn mostly for his cattle, and hay - some hay. But, he wasn't too good at farming. He didn't like the farming part. He'd rather chase cows and talk - he was a big talker. He loved to visit.

Sitton: Describe the house that you grew up in on that place. Now, I know there's a photo here, but-

Pannell: Well, it was a small house-poor old ugly house. My daddy was not a carpenter, so he had to have the house built. This is it. That was it before they built on a room back there for a kitchen, because I had four brothers, and I was the only girl, and I had to have a separate room.

Sitton: It looks nearly square, board-and-batten, with I guess a peaked - what do you call that - a pyramid roof.

Pannell: Yeah, and it had a front porch; you can't see it, but a front porch there.

Sitton: And a front porch.

Pannell: Yeah, and they built the kitchen on back here, then they had the kitchen and dining room and three other rooms for bedrooms. And of course one of the bedrooms was also our living room. We had the wood heater for keeping us warm. 'Course, in the kitchen we had the wood cook stove in the kitchen. No running water and no electricity, so I was raised without all those good luxuries that people think they have to have now.

Sitton: Yeah. Where was the water source?

Pannell: Well, but it wasn't close to the house, and they had to haul water from the well to the house, and we always learned to be careful about water. We didn't waste any, and we didn't waste the wood, because they had to get out and cut it by hand, so we didn't waste wood either. But I learned to cook on a wood stove, and boy, cooks back then were good cooks, too, on those old wood stoves.

Sitton: My grandmother - father's mother-cooked real late on a wood stove. She lived [in a] very rural part of Nacogdoches County.

Pannell: You know how she lived, so you know what it's like. But everybody back then did that and lived that way, and it was just part of life. We didn't know any different, and didn't care. We were happy. 
Sitton: Well, some people had water closer to the house than you.

Pannell: Oh, yeah. Well, after they built this house here, they had a cistern, and we piped the water to the kitchen, so we had a luxury then, which was a big help-and electricity not long after we moved here. Well, soon after [we] moved out of the camp and over here, they had electricity. 'Course, it was nice to have that.

Sitton: What about in the hot summers? What would you do, just suffer?

Pannell: We didn't know any different. We just opened the windows. And, back then if we had an extra hot spell, moved the bed outside or on the porch, and sometimes out in the yard. Boy, that was good sleeping out there. No, we didn't have fans. Maybe a hand fan occasionally, but it didn't bother us. Growing up, we didn't know any different, and we just accepted it and was used to it.

Sitton: Well, what was your father like? He was one of those people that if he had grown up raising cotton, he didn't raise cotton when he had his own place.

Pannell: Well, when he was growing up as a teenager - now, he had to go pick cotton up on the prairie. He and his brother-older brother-picked cotton, and they gave all the money they made to his father and his stepmother to buy groceries for a year. They lived for a year off the money they made picking cotton, and he didn't like having to go get that cotton, but he did it.

Sitton: A lot of people didn't like — they don't really regard as a joy. Well, he grew up here? He grew up in the same area - his family - your grandparents?

Pannell: Well, no. He was-I don't remember just how old - maybe ten years old, eight or ten - when his father came to Bastrop County, so he wasn't born and raised here. Fact, I've never been able to find out where he was actually born. I haven't found out yet. So, but they lived here in Bastrop County, and his father - my grandfather - moved to Bastrop County in 1901. I do know that. And I have the article coming out in the next bulletin, which we hope that it's printed before too long. And it explains then in there about finding my daddy's mother - my grandmother - and it took me more than twenty years, because I was told she had died when he was little, but she didn't. But that explains then, and I talk about my grandpa in there. It kind of explains about him.

Sitton: I'm sure that'll be printed in time for me to read it.

Pannell: Well, if not, I have a copy of it. I'll get it out and give you a copy - just a copy of what's going to be printed.

Sitton: Okay, I've still got you there on the place that you grew up. Did y'all have a garden, chickens? What did you have along that line?

Pannell: Oh, we always had a big garden, yes, and some fruit trees - peaches, pears, and of course, there was always the wild berries, wild plums to pick. We always had those. We had always had chickens so we'd have plenty of eggs. And my mother also raised a few turkeys. Most of the women back then - see, they raised a few turkeys, and that was their cash crop to spend on themselves and the children, and my mother would have a few turkeys. They just run loose, and it was a job to find their nests.

Sitton: Yeah, I was going to ask you to talk about how-I don't think most people know how they managed turkeys, because they were different than the chickens. They were just yard chickens. I understand that they went out and scavenged, but how did they do the turkeys?

Pannell: Well, the turkeys, they tried to keep them home at night, but they left. They didn't usually have a pen for them even. Some of them did - had a pen they'd shut 'em in at night and let 'em out, because turkeys were good scavengers. They ate all the grasshoppers and bugs, and all that kind of stuff, and they were out all day eating. And the hens then would find a nest way off away from house, and if she didn't come up, they'd have to find that hen, and they could manage to follow her to her nest and find the nest that way, so when she had the babies they could herd them back up to the house.

Sitton: So the turkeys were kind of wild, right? They were wilder, and they went further away.

Pannell: Oh, yeah, quite a ways from the house, because they had a wide range to get all the insects 
especially - and seeds, you know, things like that they ate. And it was a pretty big job raising some turkeys.

Sitton: Well, people didn't mind if the turkeys came - they would get off your land, right, and cross the fence. They could walk right through a barbed wire fence I imagine.

Pannell: Oh, yeah, they can go over to the next people's place, but people back then were much more tolerant of things getting on their place and people getting on their place than now. We didn't think anything about going out in the country 'cross somebody's place, or wherever we wanted to go. We just went. And most of the kids were that way; they just roamed the country. That was part of the entertainment.

Sitton: You just literally wouldn't think about going through somebody's fence and walking around out there in the pasture. You know, the thought was: Now, let me see, will they mind me doing this?

Pannell: Now, you better ask permission, but then, no, everybody did that, especially the kids. They just roamed the country.

Sitton: How did you get the money out of the turkeys at the end of the year?

Pannell: Well, before Thanksgiving — that was the big time for turkeys, was Thanksgiving — they would round up the turkeys and take 'em to market. And the housewife got the money for those.

Sitton: Well, how do you round them up?

Pannell: They tried to keep 'em coming in to the house place at night, and usually they would feed 'em a little corn so that they keep 'em coming up, and feed 'em corn in the fall to keep 'em fat for market.

Sitton: I guess you paid by the pound; you want them to be as heavy as -

Pannell: Yeah, people wanted a nice plump turkey.

Sitton: But then at a certain point you just put 'em in cages and take 'em somewhere to sell 'em. Who was buying turkeys?

Pannell: Oh, there was always buyers in the small towns that would take 'em.
Sitton: Years ago I talked to somebody in Burton. There was a mercantile store owner-little, small mercantile store - and he bought turkeys and would just accumulate them, you know, around Thanksgiving and Christmas. There'd just be turkeys all over the place.

Pannell: Yeah, same thing in all small towns. And they'd sell turkeys mostly on foot; they didn't dress 'em. People bought a turkey back then, they dressed their own turkey.

Sitton: Have any trouble with foxes and coyotes or anything?

Pannell: Not too bad back then. We didn't have coyotes in this country that I know of back then. If there was, there was very few of them. We had a few fox, but you very seldom saw a fox. Not like it is now. We don't have fox now, but we sure got the coyotes.

Sitton: You just see them driving around in daytime.

Pannell: I know.

Sitton: I mean, they cross the road.

Pannell: They walk right up out here a lot of times - look out and see one. 'Course, we went to school over at Oak Hill — the school over there at Oak Hill when we were kids - and everybody walked, even two or three miles. No matter how far it was, they had to walk to school, and we had to take our lunch in a little sack or a little lunch bucket. I know we used, I think it was an old-timey syrup bucket - carried our lunch in. And the kids didn't have the dress clothes like the kids nowadays do. They just wore their old regular everyday clothes. 'Course, tried to keep 'em clean, but they didn't dress up. And we didn't have shoes. We got one pair of shoes a year; that was our dress shoes. In the wintertime when it got really cold, then we had to wear those shoes - finish wearing 'em out in the wintertime. Then in the spring, we'd get a new pair of shoes, but we couldn't wear 'em. We went barefooted, and the kids all went to school barefooted. And they would go to school barefooted until it got so cold they couldn't. But if you wore shoes to school when there's frost on the ground, you was chicken. You went to school barefooted with frost on the ground. It had to really get cold for us to put those shoes on, and the parents wouldn't allow for us to wear the shoes, 'cause that's all they could afford to buy for us - one pair a year. They had to last. 
Sitton: Well, you know, shoes - if you wear 'em in the wet and the mud, they're not going to last too well, but feet, you know - bare feet do better if you don't mind the frost.

Pannell: We always went barefoot. I was raised barefooted, and I still don't like to wear shoes. My feet just don't like them.

Sitton: Well, how far did you have to walk from the house to Oak Hill?

Pannell: Oh, we didn't have far to go. We were close. But a lot of the kids had a long ways to go.

Sitton: Well, talk about the Oak Hill - first of all, let me say, about when did you start attending the school? About what year were you in first grade, do you think?

Pannell: I started when I was seven. My birthday's in October, and I started school in September, and I guess I's seven in October, I believe. Most kids started when they were seven back then. It was a pretty large building. Two rooms - two big rooms, and they went through the eighth grade, I believe. But they had to divide those grades up and have probably four grades in one room. And the teacher then would have all those grades to teach.

Sitton: Sometimes the schools had a partition and not a real - but you had a wall. There was a wall between the two rooms.

Pannell: Two rooms, yes, but that's all. Otherwise, the kids were all together.

Sitton: How do you remember the teacher dealing with having several grades in the classroom at the same time?

Pannell: Well, she would have to teach a subject to one grade, but she would have homework - I call it homework - work for the other kids to be working on, either reading or writing, or something they had to be working on while she was teaching this other grade.

Sitton: So she'd just go from grade to grade. Little short periods, right? The teacher would be dealing with your grade just for a few minutes, and then she'd move on. She'd say, "Do this," or she'd have you recite. Do you remember anything about the teachers you had? Do any of them stand out?

Pannell: Well, I always liked the teachers. 'Course, I only went there through the fourth grade - four years I got to go there before we went to Bastrop. They were all women. They all had a lot of patience. Real nice. Nothing I can say about 'em really other than they were nice.

Sitton: No big discipline problems.

Pannell: No, we didn't have back then. Kids were taught before they went to school that you've got to behave in school. You don't cause problems. The parents took care of that. So, we just didn't have problems.

Sitton: What did y'all do for recess?

Pannell: We got to go outside to play, and we didn't usually have a ball. Sometimes they had a ball and a bat - could play with that. But one thing I do remember was - not a relay. The teacher built up where you had a stand on each end with a pole across. You jumped it. What'd they call that?

Sitton: High jump?

Pannell: It wasn't a high jump. You'd jump one right after another-keep going.

Sitton: Hurdles.

Pannell: Hurdles. I remember those, and they were on there where if you hit it, it fell off, and you learned to jump those. That was good exercise for kids jumping those.

Sitton: So he would set those up on the playground - there's enough distance between two hurdles for you to jump it and get control of yourself and then jump the next.

Pannell: We had plenty of playground room. Not much equipment out there, something like that. The teacher had to improvise, and sometimes they had a ball and a bat. But back then they didn't have the money to spend on things like that. Teacher had to figure it out to entertain those kids. 
Sitton: How was the school heated, and where did you get your water?

Pannell: They had a cistern right next to the schoolhouse with, 'course, gutters on it to run water in the cistern, and that was our drinking water. And it was heated with wood, of course. Had to be. Wood heaters. And the men of the community would see that there was wood there for the heater so there would be wood.

Sitton: What about school programs? You remember anything about — did you have one Christmas or end of school? What would happen?

Pannell: We would have a Christmas program. That was always exciting for the little kids, 'cause there would be a big Christmas tree, and each child got a[n] orange and a[n] apple and some Christmas candy, and that was exciting. And there'd be a little program, and all the parents in the neighborhood always attended. 'Course, for light they had to have lanterns and lamps, and the Christmas tree was decorated with homemade decorations, but they used candles to light on the Christmas tree. I remember that. Had those little holders that clipped on a limb. Had little candles. They'd light those little candles.

Sitton: Well, that's pretty, but you got to watch it.

Pannell: Well, there was always enough people around to take care of it and to see that it didn't catch fire. And the kids, 'course, knew to stay away from it.

Sitton: It's the sort of thing that when it's a room full of people and everybody's watching the candles, but you don't light up your Christmas tree and go visiting the neighbors.

Pannell: Oh, no. You sure didn't do that. Everybody knew better than to do that. Fact, in most homes, they didn't try to do that, so it was a dangerous thing. And they all knew it, but they always had a great big tree. It was a pretty thing.

Sitton: Well, what year do you think you started school, is what I was about? I usually don't ask what year, but approximately when were you attending Oak Hill School?

Sitton: In case it's not on the tape, about when you started attending Oak Hill?
Pannell: Okay, I was born in 1916, and I was, I think, seven years old, so you figure that out.

Sitton: So, that makes about' 23 or '24.

Pannell: Uh-huh.

Sitton: How many students do you think you had in it then?

Pannell: 'Course, to me it sounded like a lot.

Sitton: Just a guess. You would know your class. You were in the first four grades.

Pannell: The first grade I think there was seven of us.

Sitton: I was kind of thinking of the whole school.

Pannell: Well, you got to figure each grade'd be a[n] average like that.

Sitton: Yeah, so fifty, sixty, maybe, something like that.

Pannell: Well, by the time they got up in the higher grades, a lot of those kids dropped out, so it wouldn't be as many in a grade even up that far.

Sitton: Where did John Billy go? Where did the black kids go?

Pannell: Over here at Sayers. Sayers School - this is a picture of the Sayers School.

Sitton: This is a great photo of it-looks like a basketball team or an athletic team. May 1951.

Pannell: The teacher gave me some of those. I run it in the bulletin.

Sitton: Yeah, I've seen it.

Pannell: You've seen it.

Sitton: So anyway, they would have to go a longer distance to a school because Oak Hill didn't have a black-

Pannell: Oh, they were separate, and any blacks that lived down at Oak Hill - and there were lots of blacks - I say a lot, to me it sounded like a lot - of 
blacks in what is now the Camp Swift area, and they all had to walk over to Sayers to the school.

Sitton: So that was a pretty good walk if I understand the distances.

Pannell: Yeah.

Sitton: Several miles.

Pannell: Well, some of 'em had to go as far as two miles, I'm sure.

Sitton: Well, while we're on that, just talk about-where did black people live here? Were there any communities around that were just black communities and had names? Like we were talking the other day about Dogwood Creek.

Pannell: Dogwood Community. It was right across the highway, right across over here. And, of course, Dogwood Creek is that little creek right down there. There was a community over there, and those kids had to walk from over there to Sayers, which is even - well, there was a back road that went this way then that way to Sayers, but it was more than a mile - mile and a half, probably, even at that to get to school. They had small places over there they farmed.

Sitton: Owned their own land?

Pannell: Some of 'em owned their own land over there.

Sitton: Anything about that community while we're talking about - did they have a church? I know they're using the Sayers School over here-did they have a church associated with that community, or did they go someplace else?

Pannell: They've always had churches. There was a church at Sayers. Well, they have a church now, but the school building is gone, but they still have a church over there - not the same building as they had back then.

Sitton: How would they make a living at Dogwood?

Pannell: Just plain farming.

Sitton: Small farming.
Pannell: Small farms. And it was hard for colored people back then. They had small places and had to use their mules, and they'd raise some stuff they could sell, especially like watermelons. They all raised watermelons, and when they could sold watermelons and corn.

Sitton: Well, this is sandy land country around here.

Pannell: Most of it is sandy.

Sitton: That means it's good for peanuts and it's good for watermelons, and your cotton might-

Pannell: Sweet potatoes. That's one thing they raised - sweet potatoes. And peanuts - lot of 'em raised peanuts. They may have had to kept most of 'em for their own self, but they had peanuts to eat.

Sitton: Field peas. They do good in sand, too.

Pannell: Yeah, and they all loved black-eyed peas and also cream peas. They still do. They love peas. Needed peas. We always had peas.

Sitton: Well, tell me some more about the milk operation that you had on your farm. I understand there are four brothers, there's plenty of hands to milk the cows, and you told me about the separator. I know you turned the thing and it spins the milk, and it separates the milk from the cream. How would the family go about selling the milk?

Pannell: They bottled it in quart milk bottles for individuals, which my daddy delivered some to homes, but for businesses, cafes and such like, they sold it by the gallon-glass gallon containers. It was my daddy's job to deliver that milk, which he liked doing, because he liked to talk to those people. He enjoyed visiting with them anyway. But he would deliver the milk and pick up the empty containers.

Sitton: Was he going mainly toward Bastrop or back toward Elgin?

Pannell: Went to Bastrop. It wasn't easy to go to Elgin back then because you had to go to McDade, then to Elgin. There wasn't a highway out here. It was built I think in '36, just before the war, so you had people out in Oak Hill area had to go to McDade, and from McDade to Elgin, which was a long trip back then. 
Sitton: So Bastrop was the town. When you went to town, said let's go to town, it was Bastrop?

Pannell: Nearly always. Once in a while we went to Elgin, but it was usually Bastrop.

Sitton: Well, he had stores that took the fresh milk on a weekly basis or a daily basis.

Pannell: I don't think any of it went to the stores. He went to houses - delivered some, not a lot, some to houses, and to two or three cafes that took it by the gallon.

Sitton: It's got to be kept fresh, and so it has to go just almost to the places that are going to use it. It can't sit around in the store with no ice.

Pannell: Well, no, I don't know what the stores had where they kept milk, but the milk we had, we had $\mathrm{a}[\mathrm{n}]$ icebox. 'course, we didn't have electricity, so we had an icebox, and milk was kept in the icebox. It was kept cool.

Sitton: Did you sell the butter, too?

Pannell: Yeah, sold the butter. That went mostly to stores.

Sitton: So your father got it all in the truck and got to go into town, got to talk to people.

Pannell: Oh, I know. He could spend a half a day on the sidewalk in Bastrop talking to people. He just loved doing that.

Sitton: Have we said your father and mother's name? What were their names?

Pannell: Joe Owen-actually, his name was Joseph - Joe Owen, and my mother was Elgitha, but she was called Githa.

Sitton: How do you spell her name?

Pannell: E-l-g-i-t-h-a. Most people just called her Githa, just left E-1 off. And that's my middle name.

Sitton: I've never heard that name.

Pannell: It's an unusual name. It's an old name. She was named for an aunt, I believe, that had that name.
Sitton: I didn't ask you where your mother came from.

Pannell: Oh, she was a Smith, and her parents were Andrew Morgan and Edith May, and her mother was a Ransom and raised in this country.

Sitton: Well, the Smiths were very early settlers here, right?

Pannell: Some of 'em, but they weren't kin to some of the other Smiths here. My grandpa, Andrew Morgan, was from Georgia. He came here when he was twenty-one years old. He came by train, because they knew people that had already settled in the Oak Hill area, and he came from Georgia to stay with the people they knew here. So he came by train, and he got to McDade just in time to see the bodies from that McDade massacre laid out. And the train stopped and he looked out, there's all those dead people laying out there. He was scared to death. He had to get off the train. He was broke by then. He had just enough money to get there, so he had to get off. But when he left McDade - he probably had to walk then - going out to the friends where he was supposed to stay, he got lost, ended up at the Sarah Ransom home, where my grandmother was still living. She was a young girl, and that's where they met. He got lost and met there, and they later married.

Sitton: There were old roads going around everywhere, but they didn't have big signs on them. Everybody assumed you knew that that's the road down-

Pannell: Well, yeah.

Sitton: And a newcomer-

Pannell: They'd get lost if they didn't have good directions, because the road back then did not go straight. They went around people's places to go, say, along - this person here at his place, would go by his place and may have to turn this way and go that way, just - they didn't cut across.

Sitton: So they followed the property edges is what you're saying. So they would take a lot of right angle turns when they come around somebody's fence corner.

Pannell: Yeah. So that made it difficult. And they were just lanes; they weren't much road. 
Sitton: Did people walk across country? Were there school trails and things like that-beeline trails that the kids took?

Pannell: Yeah, they had as straight a line as they could go, and you had to cross people's property.

Sitton: Just climbed the fence.

Pannell: Yeah, just went on. That was the usual way to go. I'll tell you this, and you'll have to take this out and I'll publish it, but we lived, you know, over close to Oak Hill, and some of the kids had to walk right by our house going to school, and we had already gone on to school, and here come the two Smith girls, Violet and Pansy, bringing their young brother, Thurber. Starting him off in school - his first time to go to school. And they walked and went right on by the house and went right on to school, and Mother said it wasn't long till here come Thurber. She saw him coming, heading home, and got close enough she could hear him say, "I ain't going to no goddamn school." And said he just kept repeating that and just walking just as fast as he could right on home. Don't publish that. [Permission was given subsequent to the interview.]

Sitton: Well, we can edit that, but that's a great — even the friendly rural school, the first day - I remember when I first started to grade school, I wanted to go home. It didn't seem like a nice friendly place to me.

Pannell: Well, yeah. You may have known some of the kids, but it was strange. You didn't know what school was like. It was kind of hard on first graders, and the parents didn't take 'em unless they had to. If they had $\mathrm{a}[\mathrm{n}]$ older brother or sister to take 'em, parents didn't take 'em.

Sitton: Well, the older kids sort of took care of the younger ones, right? You're just starting school, if you've got older sisters and brothers, they'll show you the way.

Pannell: They would take you and show you the ropes and get you started.

Sitton: They might not be able to make you like it.

Pannell: Oh no, but you had to go in most cases, except like Thurber. He didn't go. He made up his mind he wasn't going, and that was that.
Sitton: A lot of schools had a big affair at the end of school. Did Oak Hill do anything special at the end of the school year?

Pannell: Not too much, maybe just a little end of school program, and the ones that got diplomas, finishing - I think the eighth grade got a diploma, and I don't know whether [any] of the other grades did, but they'd have a little ceremony. But by then, a lot of the kids had to drop out of school to help at home with the crops, so it was kind of hard to have an end of school program.

Sitton: Yeah, well I was going to ask you about that, because all over Texas, when people were still really farming, a lot of kids had to go to school when they could. Would some people be held out of school in the fall while they finished with the cotton?

Pannell: Yeah, some of them did. They couldn't start school right on time 'cause they's having to help with the farm work and would have to drop out then before the end of that school year to help at home.

Sitton: What is the story of how your father went to work at the mine? Let's just talk about the mine for a while. I have a sense of your father now, and I have a sense of why he might have liked that. He was the last superintendent of the mine, right?

Pannell: Yes. There should be a picture of him. That's my four brothers. That's Polly. This is her also, like in that big picture up there on the wall, that's Polly.

Sitton: I'm going to read all her columns.

Pannell: Well, they are in [the] library at the university.

Sitton: They'll have the microfilm.

Pannell: They have 'em.

Sitton: She published her column in both papers?

Pannell: No, Bastrop.

Sitton: Only Bastrop. Okay, not in the Elgin Courier.

Pannell: She never-I don't guess ever missed getting it in.

Sitton: But don't look for her name, because she didn't put it in. 
Pannell: No, she didn't sign. (looking for photos) Well, that's my daddy right there. That's his brothers and sisters. But that's him. That's when he was getting older.

Sitton: Well, how did he come to take the job over there?

Pannell: Well, he used to have the store at Sayers, and the Bells owned that store, and he started working for the Bells before he and Mother married. They were still there at that store when they got married. And he always liked that. He didn't like the farming much, and back then, he was glad to get away from home and go to the store and work. He liked that. And he had been working there, then they got the property over next to Oak Hill. When they left the store, they got the property over next to Oak Hill, and lived there, and he was living there, but he knew Dennison was a friend of his - Frank Dennison was a friend, and the superintendent of the mine - I can't think of his name. But anyway, he [the superintendent] was examining a horse's hoof - the horse was not the horse, the mule - they used mules to pull the coal carts. He was examining one of the mule's hoofs, it was limping, and that mule kicked him in the head and killed him. And so, they had to have another superintendent, and so my daddy asked for the job, and Dennison gave him the job then as superintendent. And, of course, we were living on the place over here close to Oak Hill, and it was about a mile across to the mine. And he had to live over at the store, because anytime he left there for any length of time, some of the Mexicans would break in the store, which is downstairs, and steal stuff. So, he couldn't leave.

Sitton: Well, I knew that in the past the superintendent's family had lived over the store - the commissary. I assumed that was for security reasons.

Pannell: That was it. My daddy had to live there by himself.

Sitton: He had to guard the store.

Pannell: Yes, that was part of his job-take care of that. Then we lived over here close to Oak Hill.

Sitton: Well, what did he say about that operation?

Pannell: He didn't talk about it, because I was a little bitty kid.
Sitton: Yeah, I know you were little.

Pannell: It was just part of life to us, he was just working over there, and we was at home with Mother taking care of the place at home.

Sitton: Would those Mexicans speak some English?

Pannell: Most of 'em, no. He had to learn Spanish. And he did. He learned to speak with 'em pretty good. No, Mexicans didn't learn but a few words of English, most of 'em.

Sitton: I had college Spanish, but of course I've forgotten it all. But I had this man build a rock walk up to the front door of my house, and some rock steps, and he didn't speak any English, and it just shows you I was desperately trying to resurrect my Spanish from thirty years ago. I had to have it, you know. When you have to learn it, you'll-

Pannell: I guess when you have to, you do.

Sitton: Well, what about-he took you down in the mine once.

Pannell: Well, that was when I was a little bitty kid; I was probably about five years old - little kid. And that was before they had the mine where he was superintendent. They had a sloping mine - the early first one built there was a slope, and I guess for entertainment, people just went to see things like that. And my parents went and took us kids. And I remember they had to use - maybe took a lantern, but most of 'em had those caps with the carbide lamp, so there wasn't much light going in there. Pretty dark, especially to a little kid. They'd have lights going out in front of 'em, and we had to stay close to the grownups - get off out in the dark, get lost. And that scared me so bad. I was a little bitty kid. I didn't ever say anything, but I was scared, and I don't want to go down in anything now. I don't want to go in a cave. I think about that.

Sitton: Well, it's funny what people would do for recreation back then, because they didn't have a lot of - like the school play could be good recreation back in those days.

Pannell: That was a good get-together.

Sitton: Going down in the mine might be a good- 
Pannell: That was another - it was just the recreation thing. Several families got together and went. And 'course, back then they took kids with 'em anywhere they went, and they had to take kids.

Sitton: Well, talk about that a little. What about going to the river or going on fishing trips?

Pannell: It wasn't so much fishing, it was just several families get together in the neighborhood and cook up a big meal and take it to the river, eat and go swimming. That was the big deal. Everybody went swimming. And they did that a lot in the summer. That was recreation.

\section{Sitton: Scott Falls.}

Pannell: We didn't go to Scott Falls. That was kinda out of our area. We went to the river. Also, we went to Sandy Creek over here at Sayers. There was some good swimming holes over there, and that's where I learned to swim was in Sandy Creek.

Sitton: Well, I remember that article about the Sandy Creek, it being a real gathering point, you know, the people would go to that. There was a big tree, I believe.

Pannell: Yeah, it's gone now, but it was-I've got some pictures - I don't think I have a picture of it laid out here, but I have a picture of it. And there's a picture in the bulletin, as you'll see.

Sitton: It was an elm, wasn't it? Sayersville elm.

Pannell: Yeah, been there seem like forever. But that was the type of thing people did for recreation.

Sitton: What about young people? Anybody have parties at their house and stuff like that?

Pannell: Not too much. As they got older-older kids would gather at some of 'em's houses. That's the way I learned to dance was we gathered at a friend's house, several of us, and had an old Victrola - little old windup Victrola, and we just taught ourselves to dance that way.

Sitton: Would they move the furniture out of a room sometimes?

Pannell: They'd have big rooms and very little furniture. People back then didn't have much furniture.
They'd just shove it back against the wall and you had the space. And also, back in the early days, they had what they called box suppers, too.

Sitton: How did they work? I know about box suppers, but I don't know what actually happened at a box supper.

Pannell: Well, it was usually the single women or nearly grown girls would cook up a supper and put it in a box, like a shoebox. Most of 'em went in a shoebox, but they decorated that shoebox up-whatever they had to decorate with, decorate that shoebox. And they would sell or auction off those suppers, those box suppers, and the young men would bid on them, hoping they'd get their girlfriend's box, which sometimes they would manage to find out which was hers and get to bid on it and get it. But a lot of 'em didn't, but whatever they got that was just fun. The couples, whoever they were, would eat together. That was it.

Sitton: Would this be going on at the school? Would this be a school affair or a church affair?

Pannell: Well, I think most of the time it was the church, but I'm not sure about that. I was pretty young back then. That church was right next to the schoolhouse.

Sitton: What was it, a Baptist? Oak Hill—what was the name of it?

Pannell: Oh, it was a community church. Any preacher that wanted to come hold a revival or Sunday meeting, they would just announce they were going to have church. Didn't make any difference what denomination. Everybody went.

Sitton: Yeah. You know, the Baptist would go to a Methodist, and-

Pannell: Yeah, it didn't make any difference who the preacher was.

Sitton: You just felt like you're going to have a preacher.

Pannell: Yeah, you had a preacher, which they didn't ever have a regular preacher, and any preacher that wanted to come and hold a meeting, he could, or hold a revival for a week or so, why, everybody went. 
Sitton: I've heard people call that a union church, or something like that. Anyway, it was a common church. Different denominations met in the church building.

Pannell: Well, I don't think it even had a name back then, just the church. Everybody went. And for the cemetery picnics, they had a brush arbor, and when a preacher wanted to hold a revival, they would move the benches out of the church house and put 'em under the arbor, because it'd be summertime, be hot. And they'd hold a revival week, two weeks, whatever. Everybody went. Didn't make any difference what the preacher belonged to, they just went.

Sitton: But they would go on that long. That's a long time. Protracted meeting.

Pannell: For a week revival - they always called a revival meeting. Most of 'em, I guess, was two weekends and then some during the week.

Sitton: So, the idea is you don't try to get it all done at once, but you kind of build toward the whole-

Pannell: That was a more of a recreation get-together, too. All the families -

Sitton: You were talking about the church.

Pannell: The cemetery.

Sitton: The cemetery, the funerals. That's where we were.

Pannell: Anytime anyone in the area died, the men had to get together and go dig the grave by hand. Everybody went to the funeral. Everybody in the community showed up for the funeral, and when I wanted to do a survey of the Oak Hill Cemetery, which had never been done - we didn't know who was buried where-and I got my mother to help me. This was several years ago - she died in ' 88 - this was before she died, I got her to go with me, and it took several trips over there, and she would show me a lot of the graves would just have some type of marker, no writing on it, and she knew where a lot of those were buried - the people were buried - that had no regular tombstones, so that I could get it down on paper who was buried there. And a lot of 'em, she didn't know, it went too far back, and she didn't know. But, by the way, I got a lot of them - made a pretty good map of the cemetery that way.
Sitton: A lot of people don't understand how the old country funerals were. Like if somebody dies out in the countryside, somebody that'd maybe been sick for a long time, what would happen, because I know the funerals were sort of do-it-yourself funerals, and they didn't involve funeral homes. What would happen after somebody died?

Pannell: After they were died [dead], they'd buy the coffin, take it to the home, and the people in the community - the neighbors - would go in and help prepare the person for burial, put it in the coffin, and it stayed in the home until the day of the funeral, which was usually the next day. They didn't keep 'em long. And take 'em then to the church, which would be a community church there, and have the service at the church. But see, there's no funeral home involved. They were kept in the home.

Sitton: They prepared the body in the home?

Pannell: In the home.

Sitton: What would they do?

Pannell: Well, usually they washed 'em some-in some cases, maybe not - then dressed them. They had to dress 'em in their dress clothes, whatever they was going to buried in-dress them and put 'em then in the coffin. And then, the people in the area would take turns staying in the home with the family, and there'd be some that would go sit up all night. You didn't leave the family with the dead person in the home without someone there. They'd sit up with 'em all night.

Sitton: So they'd lay the body out. Somebody told me once about taking down the door to lay the body on a door between two chairs.

Pannell: I've never heard that, but it's possible.

Sitton: The idea is that some neighbors helped out by being there, sitting up with the body so the family can feel like they can go to sleep.

Pannell: They can go to sleep and not worry about the dead one being in there alone, and be nervous about it. So, make 'em more comfortable. That was just - everybody did that. That's just the thing they did.

Sitton: Okay, so then they'd put it in the coffin and carry it to the church. 
Pannell: To the church usually in a wagon - put it in the wagon, take it to the church. The church was right across the road from the cemetery, and the grave by then would be dug. The men in the neighborhood gather and dig the grave so that then they'd have the service, then they'd just carry it right across the road into the cemetery. Bury it.

Sitton: Because there's no way to preserve the body, the whole process had to move right along, particularly if they died in a hot season.

Pannell: Yes, they couldn't tarry. They maybe died one day and buried the next. They didn't keep 'em, 'cause they had no way, especially in summer - no way to keep 'em cool even. They had to go ahead and bury 'em right away.

Sitton: Well, Oak Hill was the biggest settlement — the biggest community on what came to be the Camp Swift land, right? It probably had the most people. Like, if you went around saying, where do you live, where do you live, there'd have been more people that said they lived in Oak Hill. Am I right?

Pannell: I think so. I think that'd be right. It was a big community back then.

Sitton: But if we're thinking about other communities, you know, other places people would have said they were part of, okay, there's the black people at Dogwood.

Pannell: A few people lived at Dogwood, but most were blacks.

Sitton: But what else? Was Wayside another?

Pannell: Oh, Wayside was way up towards Elgin, and they had a school, and there was a good many white families lived up there, but it wasn't a big community.

Sitton: But if you've got to come up with a list of names of communities that were once upon a time that were there before Fort Swift_I mean Camp Swift_-Oak Hill's the big one.

Pannell: I think it could be listed as the biggest.

Sitton: And then some people who lived in Sayers were living over on Swift, right?
Pannell: Well, Sayers originally was mostly black people, and some of the people then when they had to leave the Camp Swift area, I guess two or three families ended up in or around Sayers, but Sayers was always a black community.

Sitton: And most of that community was off what came to be Swift. It was west of Swift, right?

Pannell: Yeah, well see, from here it's about a mile right over there, so it wasn't far from Camp Swift, but the colored people in this area, which around Sayers, had a cemetery that is now in Camp Swift called New Hope. And then after Camp Swift took that over, then they couldn't go in there and use that cemetery, so they had to - I think they went down on Piney Creek, had a cemetery way down Piney Creek, nearly to Bastrop. Some of 'em went down there, then later they established a cemetery right at Sayers, so there's a big black cemetery at Sayers now.

Sitton: Were there any communities between - and I don't know the landscape very well - between what is now the southern boundary of the Little Swift, and you know, we talk all the way down to [Highway] 21, the Big Swift, the fifty-two thousand [-acre] Swift - were there other named communities down there toward Highway 21 ?

Pannell: Not-it took in, I guess, Ridgeway, which is down right close to Paige-Ridgeway. There's nothing there but a big cemetery now, but that was pretty big.

Sitton: And so the Big Swift would have taken the land from some of those.

Pannell: Uh-huh, down in that area.

Sitton: Well, you get down into the pines pretty quickly, don’t you?

Pannell: Well, there wasn't many pines at that time. Pines have spread since then, but that was farming land down in that area - just farmers. And they have a yearly picnic - Ridgeway picnic — for the upkeep of the cemetery. And I think they have a church there now; off and on they've had church there.

Sitton: Well, you know, it just seems to me, I don't know where all the interviewees are coming from. The people we find I guess we're mostly looking up 
here, but I'd like to see somebody interviewed from down there to get their side of it.

Pannell: I didn't know those people down there well enough to tell you.

Sitton: What do you have? (talking at the same time)

Pannell: I didn't know just what you wanted, so I'm not prepared just to tell you.

Sitton: No, we're interested in anything about - for one thing, I'm interested in anything - we've been talking about the Oak Hill community. What about ways that neighbors would help each other? I know they would do it. Talking about the funeral is a case of the neighbors would come over and help you deal with the death.

Pannell: They did that, and anytime that, for instance, a neighbor got sick, they would go help, do whatever needed to be done. They would help each other that way, I know. Not get out and work their crops, or anything. For instance, a hog killing, they would show up and help 'em with a hog killing.

Sitton: Did y'all raise hogs?

Pannell: We did, and I hated them. I didn't like 'em; I still don't. But yes, we had to have a few hogs, so we'd have our hams and bacon.

Sitton: Well, what do you remember about the hateful hogs?

Pannell: Well, they kept 'em in a pen. Sometimes they'd break out, and as you saw in that picture, my yard always had flowers, and the hogs liked to get in my flowers and root 'em up. I didn't like it. But they had to stay in the pen, and of course, they had to be fed. And I even had to help feed hogs some. Fed 'em mostly corn. Kept 'em in not too big a pen, and the thing stunk. That's what I hated most, the odor from hogs. We always had corn crop on the farms, 'course, put in the barn, and we had a corn sheller, and we had to shell that corn. We didn't shell it by hand, thank goodness, but we had a corn sheller. It was a job. Even then you had to turn it by hand.

Sitton: You dropped the ears in the top of the thing and turned the - and it would just pop the kernels off. You turn it on the side like the centrifugal turner.
Pannell: You'd turn it and get that one out, and before that one finished shelling, there was another one right on top of it, and you have to keep going. And we'd feed the chickens, turkeys, hogs corn, shelled corn.

Sitton: Everything ran on corn.

Pannell: Yeah, and people. We took that to the mill and had our own cornmeal ground.

Sitton: Where was the mill? Where would you take the corn?

Pannell: I don't know now where the mills were. They had to be on a creek.

Sitton: But your older brothers would have done that.

Pannell: They may have helped taking the corn to the mill, but I don't know. That wasn't popular after about the time I got old enough to remember. That's old stuff then. You could go buy cornmeal.

Sitton: Yeah, people, as soon as they could just buy some meal, they stopped that grinding the corn. But what about hog-killing time?

Pannell: Well, in the fall, most all families had anywhere from two to four hogs they wanted to kill, and they always had a smokehouse. Smoked the hams and bacon, and made sausage and smoked that. Always had a smokehouse. And when they had the hog killing, why, they usually needed help, so somebody in the neighborhood would always come help with butchering those hogs and cutting 'em up, and making sausage. That making sausage was a big job, but it sure was good, too.

Sitton: Well, so much of the meat needed to be preserved, and sausage was just the best way to make use - a lot of the meat was not suitable for hams.

Pannell: No, they'd smoke the hams and the bacon, smoked that, preserve it, and make sausage out of the rest of it and smoke that sausage to preserve it. And everybody had a little smokehouse, be about maybe as big as this room here and just keep - no windows, anything, just a door going in - and just keep an old smoky fire in there, keep it smoked up.

Sitton: Even a renter family, if they were thirds and fourths, they'd have a couple or three hogs or something. 
Pannell: Yeah, everybody had hogs, because that was their main source of meat, that and chickens.

Sitton: I've heard about chickens for breakfast.

Pannell: Oh, yeah, nothing unusual about that. Chicken was always our Sunday dinner, too. And we didn't have sweets, except on Sunday.

Sitton: What would you have on Sundays?

Pannell: I learned to cook when I was real young; I learned on the sweets. I learned cookies, I guess, first, then cakes, then pies. And it was my job to bake those for Sunday dinner, and a whole cake would be eaten up on Sunday dinner. That'd be the only time we'd get sweets.

Sitton: Well, you would get syrup, wouldn't you?

Pannell: Oh, we'd have some biscuits and syrup, or biscuits and honey, but for baked goods, we didn't have. And one treat we would have, especially in the summertime, ever' two or three weeks, we always had $\mathrm{a}[\mathrm{n}]$ ice cream freezer - gallon ice cream freezer - and we always had ice, and we always had plenty of milk and eggs. That was just the main ingredients in ice cream. We'd have homemade ice cream. Maybe ever' two or three weeks we'd have a gallon, and that was always a treat.

Sitton: How would families get their ice? How did that work, because people don't understand - this is preelectricity, and families would have an icebox, maybe. How'd you get your ice?

Pannell: Had to go to town and get it. All towns had $\mathrm{a}[\mathrm{n}]$ ice house; they made ice in the ice house. Went to the ice house and bought a block of ice. And, 'course, our['s] was usually a hundred-pound block of ice. Put it in old tow sacks and take it where they could handle it, and they'd have what they called ice tongs for picking 'em up - picking that ice up, because it's hard to handle, big old hunk of ice - even in a tow sack. I don't know whether ours is still around here or not. Used to be in the barn. I'm not sure now.

Sitton: But, so you 'd get the ice once a week, so they'd put it in the icebox.

Pannell: I think they'd usually in our case probably had to get it twice a week, 'cause we got to have tea with our noon meal, and with ice in it and with sugar in it. But not everybody had ice. They didn't get to have tea.

Sitton: Well, a dairy farmer needed ice more than an ordinary-

Pannell: Yes, we had to have ice. And, of course, we had to drink milk a lot when we were kids. We had to drink that milk.

Sitton: Well, you know, some rural people would not drink very much milk, even though it's plenty. I have heard people say that my family didn't use much milk.

Pannell: Well, some of 'em didn't, and I don't like to drink just milk now. We had to drink it when we were kids. We drank milk. And butter. Butter's got to taste real good or I don't want to eat it. It's got to be real good butter, 'cause that's what I was used to was real good butter.

Sitton: Not that salty stuff that doesn't really taste like-

Pannell: 'Course, I use oleo now, but I don't like this butter you buy nowadays. To me, it doesn't taste like butter's supposed to taste. (tape turned off)

Sitton: Reminder list. It's not a list of questions, it's a reminder. It's a prompter. You mentioned that you had had a big garden - your mother's garden. What did she grow in the garden? That's the obvious question. What did she raise? I know she's got sweet potatoes, right?

Pannell: Well, the sweet potatoes were usually raised out in the field with the crops, not in the garden. The Irish potatoes were in the garden. Not the sweet corn like they do nowadays, because we had field corn. We ate that. We always had peas; lot of times they were raised out in the fields, too. If not, they were raised in the garden, especially the blackeyes. English peas. I can't think of everything right off. We usually had beets, carrots, and lots of tomatoes, and in the fall they had cabbage, turnips, the greens.

Sitton: Had a winter garden, too. Had a fall and winter garden.

Pannell: Fall garden so they'd have the greens and the cabbage up in the fall and winter. And maybe beets 
in the fall, too. Made beet pickles, which I love. Beet pickles.

Sitton: What else would you put up? What would she put up?

Pannell: Oh, we had green beans, too. You'd have to can. They couldn't freeze anything; you had to can it, so we had to can all the extra vegetables. Usually went in jars more so than cans. We'd have the beet pickles and cucumber pickles, could make those. Peach pickles, which I love, too. We'd make peach pickles. Wish I had some now. And we'd made preserves out of the fruit, and jellies. And you didn't have Sure Gel to make the jelly. We made it just with the fruit and the sugar. And canned the vegetables a lot. It was a lot of work. And every year we had to help Edgar and Polly. They always had a big garden. They didn't have any children, and we lived close to 'em, so they always wanted us to help when any project was going on. And Aunt Polly always had a big garden and canned everything. But when she went to put up tomatoes, they bought a big box - a hundred cans - to can their tomatoes. And we had to go help and sit and peel tomatoes to fill a hundred cans. And in one day we would help them can a hundred cans of tomatoes.

Sitton: Which was a whole lot. Probably quart jars.

Pannell: No, they put 'em in cans.

Sitton: She had a canner.

Pannell: Can sealer. I've got one in the kitchen up on the shelf there. No, that's a bottle sealer. I do have a can sealer, too. Looks almost like the bottle stopper. Yeah, you got the empty can with the lid, and you put it on that sealer to put that lid on there. Then, 'course they had to be cooked off.

Sitton: Basically, you had so many sweet potatoes that they were out in the field. They were not taking up some of your garden. They were a field crop? Did you sell some of them?

Pannell: We didn't. A lot of people did. They raised and sold 'em. That was one of the cash crops.

Sitton: So, peas in the field and sweet potatoes out there in the sweet potato land or sweet potato ground, or something out there. Anything else? Watermelons?
Pannell: Watermelons, cantaloupes, they were usually in the field, and the corn. That was all field crops, raised right out in the field with the regular crops 'cause they took more room.

Sitton: Yeah, you don't want to raise watermelons in your garden.

Pannell: I'm doing it now. Also, I take my watermelons to the McDade Watermelon Festival every year. I've been winning a prize last few years. Won a prize for my watermelons. Every year I keep saying, Well, I'm not going to do this anymore. I'm getting too old; I can't do it. But, I'm working on it now. Already got 'em started. And this is my trophy case. See right there. I had a friend last year, he says, "Now, if you win first place again this year, I'm going to get you a trophy case." I got first and third this last year, and the year before I got the trophy. And when I got the trophy, that's the first time they'd ever given a trophy, or anything. They'd just give us a little check for maybe twenty dollars. So, here he come after the festival. Here he come with that big case. And I said, "Well, I don't need that much room." He said, "Well, you're going to keep winning, and you've got to have a big case."

Sitton: Well, the people in Oak Hill, at this time that we're talking about, the 1920 s, what were people raising? What were their cash crops? Were a lot of people still raising cotton, or were they getting over into truck crops and stuff like that.

Pannell: Mostly truck crops, because this wasn't too good of a cotton area. Say some back before the twenties raised some cotton, but it wasn't too successful in cotton.

Sitton: It was sandy land.

Pannell: Good for watermelons. McDade was the watermelon capital of the area, and they rolled out watermelons by the trainload - load 'em on the train over there. So, a lot of people raised watermelons. They raised a lot of sweet potatoes. Sold lots of sweet potatoes.

Sitton: Well, the sweet potatoes love the sandy.

Pannell: Oh, they do. Sweet potatoes and peanuts did well in sand, and watermelons and cantaloupes. They all did well. And peas. That was always a good crop in sandy land. 
Sitton: Did Oak Hill people have much of a relationship to McDade? It's just a few miles. Did they go that way much?

Pannell: Some. McDade wasn't very much of a town back then. And back when we were kids raised up in the country, the people in the town, and the kids, too, didn't like country kids. They looked down on us.

Sitton: This is not just McDade.

Pannell: That was all towns. They wanted their trade - wanted to come in and buy stuff or sell their crops - but not associated with 'em. Didn't want their kids associating with those country kids. They didn't like that. So, I know when we started school in Bastrop - I started in the fifth grade, because my oldest brother had finished school here, and to go on to school he had to into Bastrop - in the fall to Bastrop. And 'course, we had to go in an old car to Bastrop.

Sitton: Yeah, I failed to ask you about this, because-you were going to tell me your first impressions of Bastrop schools.

Pannell: It wasn't good, and it still isn't. We were treated like poor dirt kids. We were never included in anything going on in Bastrop by the kids down there. They resented our coming to their school. They didn't like it, and they let us know it, too. So, we were never invited to anything other than just go to school; that was it.

Sitton: That's interesting. So, the thing that drove this for you was the older brother has reached the last grade at Oak Hill, so if he needs to be trucked down to Bastrop, why not send everybody. And you were the youngest?

Pannell: My youngest brother, Jack, started the first grade down there. He never did have to go to school here. I was in the fifth, my next brother the third, then my youngest first. Then I had two older brothers that went. And usually a neighborhood kid rode with us, too, that had finished here, then went down there with us.

Pannell: We went to school in an old car. It had to be an old touring car, because there'd be five of us, and maybe another kid or two that'd ride with us, so it'd have to be an old car. And open sides - open and cold. Maybe raining. It didn’t make any difference, we had to go. But there was one teacher in Bastrop-I didn't like her, she was one of my teachers, and she was really a strict old woman, but she was nice. But, when it'd be real cold, the ice on everything, she would have us to stop at her house on the way home, and she would have some warm bricks for us to put in the car for us to put our feet on.

Sitton: Well, that was nice.

Pannell: Wasn't that nice? I didn't like her because, oh, she was a strict old woman.

Sitton: She was nicer when she was off duty, maybe.

Pannell: She wasn't really nice then, but she was very considerate.

Sitton: Well, that particular school, you would have been in a grade just with your fifth grade or sixth grade.

Pannell: Yes, we were all separate. Just that grade, which was quite a change.

Sitton: And it was Bastrop Independent School District. It wasn't a common school district.

Pannell: Not back then. They hadn't taken in the rural schools back at that time.

Sitton: But what you remember about that is just how much of a line there was between - the town people looked down their noses at people who lived in the countryside.

Pannell: Yes.

Sitton: Now, everybody, you know, living in the countryside doesn’t mean very much.

Pannell: Oh, no.

Sitton: It doesn't have that same social meaning.

Pannell: It's different now, because people in the country, they own land, for one thing. It's quite valuable, so they've really come up in this world. But if we owned land back then, just old, poor, dirt farmers. We were looked down on.

Sitton: Yeah, I know. It was different. It was very different. 
Pannell: Very different. 'Course, we all kind of resented it, but two of my brothers played football, did quite well. And the others that rode to school with us had to stay till after football practice everyday, which I didn't like having to do that, but it was something we had to do. And I always did my homework, because none of the town kids would associate with me. If they had something going on, they wouldn't invite me to come over to their house, or even out on the playground and play with them, so I sat and did my homework. Got it done every afternoon while the boys were practicing football.

Sitton: And this didn't go away, this attitude or this circumstance didn't change, because you went on through school. You never went back to Oak Hill.

Pannell: No, we stayed in school down there, all of us stayed in school there. And the only ones that was accepted pretty much was the two boys that played football.

Sitton: That'll always do it.

Pannell: That did it. They were accepted, especially my youngest brother, Jack, the youngest. He was small, but he was fast, and he was a good football player. And his nickname was Monkey. He was little and fast, and they called him Monkey. And he was always pretty well accepted.

Sitton: Could you look at people on the street and see that they were from the country? Did people from the country dress like they were from the country?

Pannell: Uh, yes. In fact, well, they didn't dress as nice - didn't have as nice a clothes, of course. And you could look at 'em and tell, pretty much, that they were from the country, not city folks.

Sitton: Well, a lot of the people in the town, like my grandfather who came in and was a druggist - he came out of the countryside. It's like the people that had their noses stuck up the highest in the air were about twenty years removed from the countryside themselves. They gave themselves the most airs.

Pannell: That's like that aunt I was telling you about. Yes. She was town, and Mother was country. Mother said, "She was looking at the other women passing - she forgot I was standing there from the country."
Sitton: That's one of those strange things about how different it was then than now, that town-country thing. Part of it was you didn't get into town. A lot of people didn't get into town that often.

Pannell: If they went to town, it was Saturday afternoon. That's when they went to town. Did their shopping.

Sitton: What would it be like in Bastrop on Saturday afternoon?

Pannell: Saturday was colored people's day in Bastrop, and the town people didn't go up there much 'cause there was all those colored people in town.

Sitton: So that's when they came.

Pannell: Yes. The colored people's day in town, and a lot of the country people went in on Saturday afternoon and did what little shopping they had to do. That's when they went into town, but the town people didn't go downtown and associate with them. They wanted their business, but that was it.

Sitton: Did the stores stay open late on Saturday?

\section{Pannell: No.}

Sitton: Well, you know, every town had sort of its own customs about what blacks were supposed to do, where they could go and when, but in Bastrop the goto-town day for black people was Saturday.

Pannell: That was Saturday. That was the custom.

Sitton: Sometimes they kind of discouraged them to go to town on other days.

Pannell: Well, most of the black people had to work all week, whether they was on their own place or working for someone. They had to work all week, and Saturday was really - Saturday and Sunday were the only free days they had, and Sunday was always church day. And Saturday was their day to go into town, do what shopping they was going to do, but visit-on the sidewalk visit. Stand and talk.

Sitton: Could they go anywhere they wanted in Bastrop, or were there some areas that they normally congregated? You know, a lot of towns had rules about that. Were there parts of the business district 
that you wouldn't see black people go into? You don't remember.

Pannell: Well, Bastrop back then, the business was Main Street - just two blocks - Main Street, and so they wanted the business, and the black people congregated just on the sidewalks visiting.

Sitton: Were there restaurants that they could go into?

Pannell: Uh, there was maybe one or two for blacks, but they weren't on Main Street. They were in the alley.

Sitton: Courthouse square? They could go around the courthouse?

Pannell: But not to hang out there. If they had business [in] the courthouse, they could go there, but not go there and hang out on the lawn.

Sitton: You wouldn't see a big crowd of them shooting the bull, you know, standing around on the courthouse.

Pannell: No, they congregated on Main Street or in the alley, which Bastrop always had alleys [in] back of their stores, and they could gather back there some. Blacksmith shop back there, and maybe a restaurant they could go to.

Sitton: That interests me a lot, you know, the customs varied from town to town. In Lockhart, they were supposed to go here, and in Bastrop they went - but Saturday was the day.

What did your family do for recreation? I mean, did anybody go hunting and fishing?

Pannell: Not too much into the fishing. Had to go to the river or over at Sandy Creek for fishing. Didn't fish a lot, and they weren't big hunters. My brothers learned to hunt, especially squirrel hunting, rabbit hunting. They learned to hunt. Gather up their friends, boys, and they'd go out hunting some, not a lot. And they learned to coon hunt at night, and my brother just younger than me, Harry, he liked to coon hunt. Never caught many or shot many coons, but he liked to go coon hunting. And a lot of young boys liked to go coon hunting. (??) out at night.

Sitton: Yeah, same with opossum hunting.
Pannell: Yeah, but they liked to go coon hunting.

Sitton: Did your mother treat y'all — home remedies?

Pannell: Yeah, castor oil.

Sitton: Was she into spring tonics and stuff like that?

Pannell: Uh, no. She didn't use tonics.

Sitton: But a lot of people-

Pannell: A lot of people were, yeah. Had to have that spring tonic.

Sitton: Cleaning you out.

Pannell: Yeah. Well, if we got a bellyache eating green peaches or something, we got a dose of castor oil. Ooh, I hated that stuff! We all did. That's what we got. That was the main medicine we got was castor oil.

Sitton: Well, a lot of times the people would rely on one thing or another. It could be something else, but it could be a kind of something bought in the store, you know, so-and-so's black draught, or something like, but your mother, castor oil was her-

Pannell: For kids, yeah. We got a bellyache or got sick with anything, why, we got a dose of castor oil. Big dose of it.

Sitton: You already said that y'all would pick berries.

Pannell: Yes.

Sitton: A lot of those in sandy land, too.

Pannell: Always a lot of wild berries, dewberries. We always picked dewberries. I love dewberry cobbler. Dewberries are blooming now; I'm going to have me one this spring, too.

Sitton: Yeah, if it doesn't stop raining. That's what you're always thinking.

Pannell: Or doesn't come a freeze like it did last year. We had a late freeze that killed all the wild fruit. We didn't have any berries or any wild berries. Had some tame berries in my garden, but there's a lot of dewberry vines now, and they're full bloom right 
now. We always had plums. There was always plum thickets around over the country. You'd just go out in somebody's pasture if they had a plum thicket; you'd go pick a bucket of plums.

Sitton: Put up plum jelly.

Pannell: Plum jelly, plum preserves. It was good.

Sitton: Are you getting tired of this interrogation?

Pannell: I just don't know where to go from here. You'll have to ask me.

Sitton: I know. It's my job to - Did y'all use any kind of wild greens - pick any kind of wild greens - pot greens of any sort?

\section{Pannell: No.}

Sitton: Some people do.

Pannell: Everybody, or nearly everybody in the country back then, in the spring they had poke salad. I don't like it; I've tried it. Tried two or three years ago. But no, my mother apparently didn't like it, and she never would use it when we were growing up, but most people did in spring, they'd pick that poke salad, and liked it. And there's some off down here a couple of years, why, I hadn't tasted that stuff in years. I'm going to cook me up a batch of it. And I cooked it, and then I tasted of it, and I took it and threw it out.

Sitton: You got to pour the water off that stuff several times before you can eat it.

Pannell: Supposed to be three times.

Sitton: Yeah, sometimes you say, Well, maybe I'll pour it off another time, but it ends. It's not too wonderful.

Pannell: I didn't like it. It didn't suit me at all, but a lot of people liked it. Still do.

Sitton: When you fished on Sandy Creek, how would you fish?

Pannell: Just with a pole. We didn't have a rod and reel and fancy things. Just had an old pole.

Sitton: Didn't put out trotlines or bait lines?
Pannell: Uh, sometimes the boys did, would put out a trotline. They didn't have a boat, so it was kind of hard to put out any kind of trotline. Mostly, well, fishing was kind of a recreational thing. Whether you caught anything or not, you just enjoyed going.

Sitton: Well, you were mainly going down there to go down to the water on the creek, and maybe go wading or swimming or picnicking.

Pannell: Uh, picnicking. That wasn't a fishing thing, that was just a picnic and swimming — wet the toe in the water.

Sitton: Did the family go into town a good bit? Like, would you go into town for family recreation on the weekend?

Pannell: No. Only time we went to town was [to] get a pair of shoes.

Sitton: It was business really. It was going to school or business for your family.

Pannell: Yes. Well, for most people. They couldn't afford to go into town much. They just couldn't afford it.

Sitton: Your father got to go into town a lot with the milk.

Pannell: Yeah, selling his milk and butter, why, he liked it. It wasn't very often any of us kids went to town when he went. We was too busy at home.

Sitton: Did he start the milk business after he was superintendent at the mine?

\section{Pannell: Yes.}

Sitton: It was mostly after that, right?

Pannell: Yes, right after that. Had to do something for money, and by then times were getting hard, so had to do something for money, and he didn't much like the farming part of it, so went into that, which my mother's mother and father were already doing that. So my mother knew pretty well how to do it anyway, so it made it easier than just starting out, not knowing anything. They knew pretty much how to do it and how to go about it. 
Sitton: Well, everybody has a cow or two, and they know how to milk the cow. So, it's kind of familiar to take it beyond that and start having more cows and producing a lot more milk and butter and selling it in town.

Pannell: Yeah, every family in the country had to have a cow to have their milk and butter. Milk and butter.

Sitton: I live in Hyde Park in Austin, and before World War I in that area-it's, you know, north of UT - most of the families that lived in Hyde Park had cows. They had cows and they had chickens. I mean, if you wanted fresh eggs and fresh milk, you know, you really needed a cow. And this is right in the middle of central Austin. Now it is.

Pannell: Yeah, quite different now. After I married, sometime after I married, we lived on East 38th Street, between what was Red River and what is now [Interstate] 35 - where 35 is built later.

Sitton: I live at 207 East 39th Street.

Pannell: You live there now? On 39th Street? Well, we lived at 1003 East 38th.

Sitton: So, just a few blocks away over toward Red River. No, I live just down the street from the Hyde Park Baptist Church.

Pannell: That's a big church now. Oh.

Sitton: It's a huge church. And of course, you know the story of the neighborhood association and the church over the years. Most of the people that attend the Hyde Park Baptist Church do not live in Hyde Park.

Pannell: They wouldn't want to live there.

Sitton: No, they wouldn't want to live there. Let's see, we're almost to the end. You know, we tried to get you to generalize about what the people in the Oak Hill area did for a living, and they raised a lot of truck crops. Did a good many others of them raise cattle, too?

Pannell: Everybody always had some, yes. Had some pastureland and raised some cattle.

Sitton: Did anybody make cedar posts?
Pannell: Not in the Oak Hill area, very little if any, but the Sayers community, and below Sayers - between Sayers, which is right over here, and the river - all that area, that was a lot of cedar, and the cedar was cut as a business there. And back before my parents were in Sayers, before 1910, the railroad was through there, and they had a spur over there built specially for loading lumber or cedar posts.

Sitton: So that was an industry based on cutting that red cedar.

Pannell: Cutting that good cedar down there, but that wasn't in the Camp area, of course. Over in the Camp area, there wasn't a lot of brush or trees in this area, but then you get back toward the sand hills - we called sand hills - why, there's a lot of pine over there, and oak. But that land wouldn't raise anything except trees. Not good for farming.

Sitton: Well, you know, I've read that McDade began as a sort of tie-cutting camp for the railroad there even before the railroad reached it. You know, I've read about all those things that happened over there at McDade - the McDade wild West era. Now, did that stuff carry over in the sense of bad blood between families in your time, or in the sense of the reputation of McDade, or was that just old forgotten?

Pannell: Well, most of 'em that were in back in those feuding areas, they were either killed or moved away, so they didn't stay there. So it didn't affect the families that lived there.

Sitton: Over there around the Knobbs.

Pannell: That was the outlaw country. That was your outlaws that come in there and camped in that area, but after it got enough law in there to take care of it, then they had to leave, or did leave. They didn't stay in McDade.

Sitton: That's right. They were literally run out. They were kind of run out of the country after - I had read about all the things that happened around - the Christmas Day, 1883, I believe.

Pannell: I've forgotten the date, yeah. That's when my Grandpa Smith came to McDade.

Sitton: There were the people hung - they cleared the saloon and hanged some people Christmas Eve, and the 
other relatives show up and find out what's happened on Christmas Day, and that's the shoot-out day.

Pannell: Yeah, that was something. And I know Mother telling me about this story. She never did know for sure it was true, but you know, McDade had an old saloon, McDade Saloon. The McDade Museum has that building now, and it's their museum now, but it was the saloon back in the early days, and she was talking about there was some guy came in from out in the Knobbs area, rode his horse in there and tied out in back of the saloon and went in that saloon, and his horse stayed out there tied for three days, and that man was never seen again. Nobody would tell what happened to him. He went in that saloon, that was the end of him. They often wondered was he killed there and buried down under the floor. They don't know.

Sitton: People just realized that nobody had ridden away on the horse.

Pannell: The horse was still tied out there, poor thing.

Sitton: Parking your car outside the motel and disappearing.

Pannell: Yeah, same principal.

Sitton: Okay, you've got four brothers and no sisters.

Pannell: That's right. Two older, two younger.

Sitton: But you all got along real well, I assume?

Pannell: Uh, pretty well, except I didn't get to do things with them very much because I was a girl and I had to stay home, I had to help in the house. I was washing dishes when I had to stand on the chair to reach the dishpan. My job was washing dishes, things like that, in the house.

Sitton: So you would have gotten gravitated into the female help-out roles, even if you might have preferred to do something outside.

Pannell: A lot of times I wanted to run with the boys and go off with them, and I wasn't allowed to. Sometimes I was, but most of the time I had to stay and help out in the house. It was a job for my mother to take care of everything. It was a lot of work, and I had to help out.
Sitton: What about washing, clothes washing? That was a big chore.

Pannell: That was a big chore, and of course I had to learn to help do that when I was still a little kid, help do that. And that's one thing my daddy did help with. Usually the men didn't; they wouldn't touch that. It was the woman's job.

Sitton: How would she do it?

Pannell: Rubboard. Old-fashioned way. And the kettle to boil the clothes in, get 'em clean.

Sitton: Boil them in the kettle, then you rinse them. No?

Pannell: You scrubbed them on the rubboard.

Sitton: What happened first?

Pannell: You scrubbed them on the rubboard first. You tried to get them clean that way, so you had this great big old pot with a fire under it and water in it - boiling water - and you put those clothes as you washed them. You put the white clothes in first, cooked them in that pot and let 'em cook a little, and that brought that dirt out of 'em. Then you would take those clothes out of there and put them in the rinse water, and you usually had to rinse them twice, then hang 'em out. And, of course, the work clothes was always last to go through the wash. And with a big family, it was a heavy chore. And as I got older, my Saturday morning chore was ironing, and the irons had to be heated on the wood cook stove. And I had to iron all our clothes. All the boys' shirts, all our school clothes for the week, I had to iron 'em. It took all Saturday morning for me to iron those clothes, but that was my Saturday morning chore.

Sitton: Well, would the clothes have been washed the day before?

Pannell: Well, whatever washday. (talking together)

Sitton: They'd have sat around - that'd been washed and they're sitting around on your Saturday-

Pannell: When they were washed, it had to be usually on a clear day, not a rainy day, 'cause they's hung outside. And most all of 'em had to be starched, and they were starched when they were rinsed, then run through the starch and hung out to dry. And then 
they were brought in, then on Saturday morning all those starched clothes, which was all the shirts, my dresses, and Mother's aprons, and some of her dresses - and all those things are starched - they had to be sprinkled down and rolled up in a towel, or something like a towel, to keep 'em damp. And I ironed them.

Sitton: And people don't understand just how you had to keep changing irons off the top of the stove. You're endlessly changing irons to keep it hot enough.

Pannell: Usually, yes. I usually had three irons on the stove - using one, the other two heating, and rotated them. So when I finished, one iron'd get cool, ready to put on the stove, there'd be another one hot ready. Just keep going till all the ironing was done.

Sitton: Well, with your father, mother and four brothers and yourself, that's a lot of ironing, right?

Pannell: It was.

Sitton: Hours, right?

Pannell: Hours of ironing. Yes, it was. Mother didn't have time. After I got big enough to take that chore on, she just simply didn't have time to do a lot of ironing too much.

Sitton: Well, you know, there are men's chores and there are women's chores, and if you'd have had another sister or two in the mix, the women's chores would have had more hands to do them, but with the one daughter situation is, you've got all - the boys split the men's chores into four parts.

Pannell: Oh, yeah, they had a heap more free time than I did.

Sitton: My grandmother was the first child-This has to do with the ironing and cleaning, which was a tremendous chore.

Pannell: Yes, I was going to tell you about ironing. Add this to the ironing story. When my oldest brother, Andrew, got old enough to date and to go to parties - we learned to go to dances, too, house dances back then - 'course he had to dress up. But he had a pair of white linen pants that had to be washed, starched and ironed every Saturday. That's what he wore. Oh, he was proud of those white pants.
Sitton: Well, that would set him apart.

Pannell: It did.

Sitton: Yeah, and linen was an elite fabric.

Pannell: Yeah, I don't know how he managed to get those linen pants, and it was easy to scorch linen, too. Oh, I had to be careful ironing those things. I hated to iron those, 'cause they was harder to iron than cotton.

Sitton: Well, when did you start going to house dances?

Pannell: Uh, I went with my older brothers before-well, when I was getting up seventeen, eighteen - we went to house dances.

Sitton: The way that would work is a family would give a dance, and would you get a formal invitation, or would you just hear that it was a come one, come all, anybody in Oak Hill?

Pannell: Anybody in the neighborhood that wanted to go to a house dance. And they would have maybe just a guitar and a fiddle for music. And they'd usually take the furniture out of one big room and dance. And they were quite popular back in the early days.

Sitton: What kind of music? What would they play?

Pannell: Just old country music.

Sitton: Were they waltzing?

Pannell: Uh, yes.

Sitton: So they'd play waltzes.

Pannell: Yes, just your regular country music.

Sitton: Local musicians?

Pannell: Yeah, usually somebody wanted to play - thought they were musicians anyway, wanted to play, and they liked to go to house dances. I know back in the Depression, I had a uncle, Luther Owen. He lived at McDade a lot of the time; worked for the railroad mostly. But he played the guitar, and he played for a dance nearly every Saturday night for extra money. Made just a little money, wouldn't be 
much, but he'd do that for extra money for a good many years. And after he quit playing for dances, he wanted to go to a dance then every Saturday night. He loved to dance, loved the music, and so he kept going.

Sitton: Well, people didn't have a lot of things to do, right? If going down to the Sayersville Mine - it's a Disneyland or a recreation - they were starved for things to do.

Pannell: Uh-huh. There wasn't many things they could do. Anything that came along they thought they could do — go see or do — why, they went. Just gather up several people and just went.

Sitton: Did y'all have any work stock, or had your father gone over to automobiles and tractors?

Pannell: Well, I guess the early days, at first did a little farming, yeah. Mules. But he didn't like that kind of farming. He liked old tractor[s], any kind of machinery, he liked it.

Sitton: But everybody was a farmer in the sense they had a big garden, and they had some kind of field crops. You had to raise corn, I guess.

Pannell: Yeah, corn was the main thing they had to raise, 'cause they had to have it for chickens and hogs, and feed it to the cows some, and for cornmeal. So, they had to have corn main thing. Most everybody had two or three mules - work mules - some of 'em more than that. So, most everybody had mules.

Sitton: Did people let their hogs out? I've heard over and over that some communities that there'd be, kind of be an agreement that after the crops were in, people would let the hogs out to go in the fields and get the acorns. Was there something like that going on in Oak Hill?

Pannell: Not where the farmers were close together, but out in the areas, like out close to the sand hills - what we called sand hills - where they had oak and lots of acorns, the people along there would turn their hogs out and let 'em run out in those sand hills, eat acorns. People had gardens almost year around, and you couldn't turn the hogs out on 'em.
Sitton: Yeah, you can't get the hogs in the sweet potato patch.

Pannell: No, and that was a fall crop-and the peanuts, fall crop.

Sitton: Is that sand hills area you're talking about, is that on the Big Swift or on the Little Swift?

Pannell: On the Big Swift. The Griffith Ranch, which was - that was a big league - forty-two hundred acres, I believe. Just sand, I mean deep, white sand. And it has pine and oak, and it belongs to the Boy Scouts now. That's what we called the sand hills.

Sitton: Okay, which is Lake Bastrop now - well part of it.

Pannell: Well, right close to Lake Bastrop, yeah, but it's not far from here across over there.

Sitton: Well, so people down there-it was less populated and they were farther apart, and they would let the hogs run out.

Pannell: In the sand hills, yeah.

Sitton: Well, you know, if you want the hogs to fatten themselves at least partially on the acorns - if you want them to be able to use the acorns, you got to let them-

Pannell: You have to let 'em run out.

Sitton: You mark their ears. Well, when you were growing up, everything in your area, everybody had perimeter fences around their places?

Pannell: Uh, yes. Maybe not very good fences like I don't have now. Everywhere I go they have good fence, but people had their places fenced.

Sitton: But they didn't probably have 'em fenced hogproof. So that meant if you had hogs, you were expected to keep them in hog pens.

Pannell: You kept 'em in your hog pen until in the fall when you wanted to go ahead and butcher 'em. You couldn't just let 'em run out. 
Interview 2-2 April 2004

Thad Sitton: When you read through this, did you think of anything that you wanted to put on there that you saw, that we hadn't talked about?

Fay Owen Pannell: Well, I can't remember what all we talked about.

Sitton: We talked about a lot. If you don't [mind], I'm going to just start fishing around, and I'm kind of fishing for details that you remember-(tape turned off) [about crops] that y'all raised. Do you remember anything more about-Now, sweet potatoes were a field crop?

\section{Pannell: Yes.}

Sitton: Anything more about what you did with the sweet potatoes? Did you keep a lot of them? Were they a subsistence crop, or did you sell them?

Pannell: Well, people kept a lot for their own use, 'cause that was one of our staple foods back then, but they did sell them. And they mostly put them in their pickup or wagon, or whatever, and went to town and just peddled them. In other words, parked in town and sold them out of their vehicle. They did that with the sweet potatoes, watermelons, cantaloupes - that's the main things, I think, they peddled in town.

Sitton: You mean Bastrop, right?

Pannell: Yeah, or some Elgin. Elgin or Bastrop.

Sitton: How would you deal with the ones that you kept for your own use?

Pannell: Oh, they just put them in the barn, kept them dry.

Sitton: Put them in straw or something?

Pannell: Maybe some people did, but they kept pretty good if you didn't pile them up, kept them scattered out. Did that with Irish potatoes, too, and the onions. Just kept them where the air could get to all of them, and they did pretty good.

Sitton: They would just put them in the barn like that.

Pannell: Uh-huh. Dark and dry, and not much of anything bothered them.

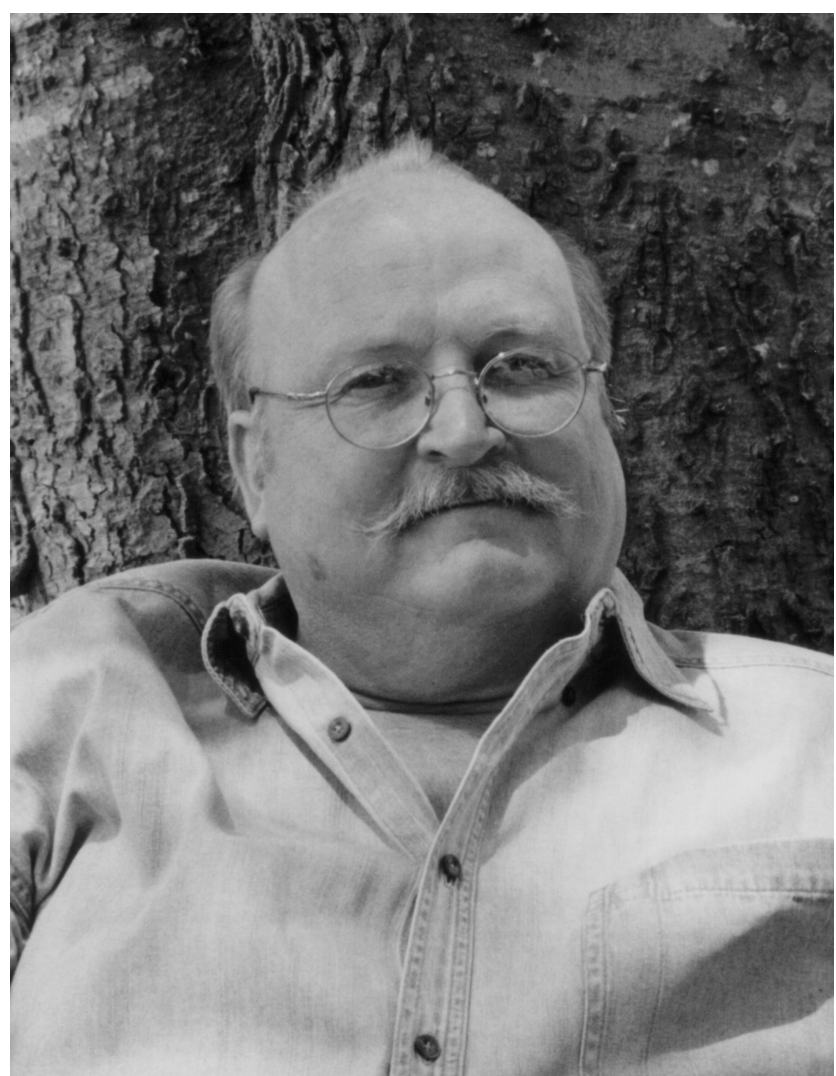

Leland Pannell

Sitton: What about the peanuts? That's a classic sandy land crop, too. How did you gather the peanuts and store the peanuts?

Pannell: Well, when they harvested the peanuts, they didn't have threshers like they have later time. They plowed the peanuts up, and they-I have a picture of it here, and I don't know who's on that picture. They put a pole down in the ground - a post - and they stacked those peanuts around that pole all the way up and make a big stack with the nuts out, with the hay part of the plant on the pole, and that's the way they dried them. Then, families had a bunch of kids, they'd sit those kids down and say "Pick these peanuts off the vines." And they saved the vines for hay for the cattle.

Sitton: Would they take them in and throw them in the barn, too?

Pannell: Yes, just throw them. And boy, I ate many a parched peanut when I was a kid, and I loved them. Most kids did. They were good.

Sitton: Well, people have told me that it was hard to starve on sandy land. 
Pannell: Well, that's true, because there's so much you could raise.

Sitton: It was hard to get rich on sandy land, too.

Pannell: You didn't get rich. You just had a stomach full.

Sitton: If we talk about these kinds of field crops, sweet potatoes and the field peas, and peanuts were the big sandy land field crops?

Pannell: Uh-huh. (talking at the same time) (to Leland Pannell) You've got a good memory for what things your grandma told you. You can add anytime.

Leland Pannell: That's my recollection. You've probably covered it pretty well.

Sitton: Did you ever remember pulling any corn?

Pannell: I didn't have to much. I had brothers that pulled the corn. 'Course, I had to help in the house - help Mother in the house with the cooking mainly. But, yeah, kids back then had to get out in the fields and work, not only boys, but girls. They worked pulling peanuts and pulling that corn, and they'd take the wagon, go down a little ways between the rows and they'd get on each side of that wagon and pull that corn off and throw it in the wagon. Get a wagon full, take it into the barn, come back, start over.

Sitton: Would you have preferred to do some of that more than working in the house?

Pannell: No. Nope, I didn't care for that field work much. It was hard work, and I was always little and never had much muscle for that type of work.

Sitton: I told you my Grandmother Sitton, she would have preferred the housework, but she was the oldest kid, so she said, "They made a boy out of me." And she had to plow. She had to plow and do that stuff, let alone pulling corn. You did what they said, anyway, back in those days. I didn't ask you about - you said the one brother was the coon hunter, and they hunted some. Did anybody trap to try to make a little money?

Pannell: No. Well, I take that back. The one that was the coon hunter, and the older brothers - he was the third boy - and ones older than him, they did do that a little bit, but a lot of the boys in the neighborhood did. They didn't have many traps; they'd just go out hunting and kill what they could - there'd be coons, opossums, and polecats, and skinned them and saved those hides and salted them. The boys made a little extra money that way.

Sitton: So they would go out and night hunt for them with dogs.

Pannell: Yeah, we had enough wild animals. But they did pretty good, they made themselves a little extra money that way.

Sitton: Well, you know, even Sears Roebuck bought hides there for a long time.

Pannell: Yeah, there was buyers in town. During a certain time of year they would buy those hides, and I know when they'd kill an animal and bring it in, then they'd have to skin it, they'd turn that hide wrong side out and then put it on the board - they had boards of a certain size for the certain animal — and put it on that board and put salt on it, and hang it up and let it dry.

Sitton: Well, Sears wouldn't take it unless it had been done like that. They didn't want an old nasty-

Pannell: They didn't want a rotten hide. It had to be preserved that way.

Sitton: So, you never did any cotton picking. The curse never fell on you?

Pannell: Well, no, we didn't raise cotton, thank goodness.

Sitton: Well, sometimes people picked for other people to make a living.

Pannell: Well, yeah, but we was kind of too far from the cotton crops. We was pretty much out of that.

Sitton: Well, you know, people tried to raise cotton in the most unlikely places.

Pannell: Well, I understand back in the early days, the land was good enough they could raise some cotton.

L. Pannell: There was a cotton gin at Oak Hill in very early times. I don't know how long it lasted.

Pannell: I don't either, but I remember- 
L. Pannell: Maybe 1880s or 1890.

Pannell: I know where the gin was, and I remember the well being there, but the gin was gone time I was old enough to know about the gin.

Sitton: He's quite right that the sandy land wore out fast for cotton, but like in the first generations - the pioneer generations - they made some pretty good, it just didn't stand up to cotton.

Pannell: No, and they didn't know how to take care of the land back then. They do a better job of it now.

Sitton: You told me your father leased the land to run cattle. What do you remember about his cattle operation? How did he do it? I guess it had a perimeter fence around the whole place.

Pannell: Yeah, you had to. And he was always having to fix fence. Fences were pretty sorry fences - old and not much good. But it was a big place - a lot of land. Not too many cattle, so they didn't have too much trouble with them getting out.

Sitton: I think you told me that, but I don't remember, where was this leased land?

Pannell: Sayers Mine. That area. That was the Dennison land, and it also took in this part of the place here. The highway wasn't here, so it came on over this way, and this was part of it.

Sitton: Well, he ran his cattle out there, and every year he would cull the yearlings in the spring. How would he sell? What would he sell?

Pannell: The young ones. Sell the young ones - take them to market as they got big enough.

Sitton: Oh, you said he didn't ride a horse.

Pannell: He did when he was young. That was his mode of transportation when he was growing up, and he wanted something better. He loved cars. And so, as soon as the cars came on the market, why, he was buying cars - any kind of old car, as long as it would run.

Sitton: What did he get first, Model T?

Pannell: A Model A. He and Mother had the store over here at Sayers, and they had it several years, and he made enough money to live on and to buy a car. He bought a brand new Model T. The Bells owned that store, and he just leased it from them. And then they saw that he had enough money to buy a car, he was making too much money, and they wouldn't let him lease the store anymore.

Sitton: He was taking too much profit out of their store.

Pannell: Well, he was paying rent, but he was making too much money, and the Bells didn't like that. You know, when folks make money, they wanted to make the money in this country. But he lost the store - that's when he lost the store.

Sitton: Well, so, he and your mother ran the store.

Pannell: Yes. She did a lot of the work in the store waiting on customers.

Sitton: What was the store like? What did it look like? What was in it?

Pannell: It was just-

Unidentified: There's a picture of it.

Pannell: A big picture in the bedroom if you want to get up and look right here.

Sitton: No, I was trying to get you to describe it.

Pannell: Oh, well it was just a country store, which was a long, very narrow building. Long. It had a front porch on it, with shelves down each side, and probably a counter, I guess, down the middle of it. But they had the living quarters in the back part of the store. They lived back there, back of the store.

Sitton: About when were they living there?

Pannell: My daddy went to work there-I don't remember just what year-but before he and Mother married. And I think they got married - I believe I said 1910 - and he'd already been working there for the Bells minding the store. So, they got married and the Bells leased him the store then. And they ran it for at least six years, maybe longer.

Sitton: So, everybody around Sayersville would have come into-I know they'd go to town for the full 
service mercantile stores, but that's the countryside store.

Pannell: That is the grocery store is what it was.

Sitton: What would they have sold? Canned goods?

Pannell: Yes, and like beans, sugar, I don't know what all. Rice. All that was in bulk in barrels, and that scoop - they'd put it in a paper bag and weighted it. I've got the scoop hanging up they used to scoop that — staple goods.

Sitton: Did the store have electricity?

\section{Pannell: No.}

Sitton: If it had cold drinks, it had to have them from ice.

Pannell: Ice. And they had cold drinks.

Sitton: Tobacco.

Pannell: Yeah.

Sitton: Why did the Bells stop running their store?

Pannell: Oh, they moved into Bastrop-I don't know just what all they did in town. But they felt like they was bettering themselves - better jobs, better business.

Sitton: They had gone uptown.

Pannell: Yes. So, they just leased out the store, and I think they tried running it then after Daddy wasn't there. Then, that didn't go over well, so they leased it out again to Evans.

Sitton: Would people come up and hang around?

Pannell: Oh, yeah, that was a gathering place. The train came there and the depot was there - just across the road was the depot. I have this picture right here. This is the depot at Sayers. They could flag the train if they wanted to go into town, and anybody wanted to go to Elgin or Bastrop, they come to Sayers and got on the train.

Sitton: People just don't understand how big a deal the railroad was at that time. It was the trail that would take you to New York if you got on it. I was going to ask you, what would you say about the roads around here back in that time? Were they bad?

Pannell: Terrible.

Sitton: Tell me about them. Tell me about the roads. Tell people about the roads.

Pannell: Well, the roads around Oak Hill were just narrow, dirt roads. They were clay. When it rained, it got slick, it was hard to get through - the clay was. And when it was dry, sand got deep, and it was very hard to get through the sand, because it just had a set of ruts, and that sand - and the same way in the clay - just a set of ruts. And you had to be thankful if you didn't meet somebody. But, I know we still had bad roads when we went to school in Bastrop. So, one time though there was a friend that lived close to us, a girl that - a little older than I am - and I don't know why she took her mother's car, old Model T, to school that day to come home early. And I don't know why - don't remember-but, she asked me if I wanted to ride home with her. And we did, and we was coming out of Bastrop and got in that sandy patch like I was telling you about - the ruts were deep - and some salesman come up behind us, and we didn't know he was back there, we was watching the road, and he honked his horn, and when he did, she automatically jerked the wheel and managed to get off the ruts, but in doing so, it broke the wheel.

Sitton: That tells you how deep the rut was.

Pannell: So, we're stranded there. The guy tried to help us, but the wheel was broken. I guess he took us on to where we could get home, on up the road. But the company that salesman worked for did pay for a new wheel to go on that car.

Sitton: They wouldn't do that today unless you sued them.

Pannell: Oh, no. Probably wouldn’t even stop.

Sitton: I was wondering if the sand made it easy to drive in all kinds of weather, but you're saying it was a problem. The ruts would get so deep and the wheels would sink in the sand, and Model Ts had those little skinny wheels.

Pannell: Oh, yeah. 
Sitton: The tires were just narrow.

Pannell: Yeah, narrow ruts. When the sand was dry, it worked out deep, but when it's wet, you can drive on it. But then when it's wet, you had the problem you'd hit a patch of clay - a clay hill. You just skidded all over it.

Sitton: I think modern people that worked back in the countryside then, they just do not realize how challenging the roads could be.

Pannell: I know. Many a person got stuck — slide off the clay hill off in the ditch, and whatever farmer was around, he'd take his mules and go pull them out, send them on their way.

Sitton: Some people made a little pocket money if they had a particularly nasty place by their farm. You know, they kept an eye out for-

Pannell: Yeah, they'd charge a little, but most of them in this area-fact, I don't know any in this area that would charge. They [were] just helpful.

Sitton: What about creek crossings and bridges? You remember anything about that on the roads?

Pannell: Well, there wasn't any creeks 'tween here and Bastrop till you get down to Piney Creek. That had that old bridge on it. Been there forever, seemed to me like. I don't know, it was built way back.

Sitton: Old wooden bridge, huh?

Pannell: It's an iron bridge, wooden floor. It's still there. It's not used, but I know when we was going to school-this picture here, this is not the one I - but, I don't have the picture, but that, I guess, is down in Piney Creek. But I know in going to school, we was going home one evening and that creek got pretty well frozen - had ice on it - and the old car we had was out of water, and so we didn't have much as maybe a tin can to put a little water. So, my oldest brother, Andrew, was driver, and he said, "Well, we'll just drive down in the creek." People used to drive across it. It wasn't deep then - just drive on across. He rolled down and drove out on it — on the ice — and the ice broke in, and when it did, it splashed the water up on the motor and killed the motor. And there it was - we was out in the creek in that icy water, and Robert, my next brother under him, had to get out, and he got out on that front fender and leaned down and cranked that car. He got it cranked, and we drove on across.

Sitton: This is similar to the photograph. It's not the same thing she's describing. This is the photograph of the car out in the middle of the creek with water up to the fenders. Looks like a Model A to me.

Pannell: Yeah, but I don't have a picture of that. This is so much like it - my brother got out on one of these fenders, laid down where he could reach the crank, and cranked that car, and we drove on across.

Sitton: Nobody's use to driving on the ice around here.

Pannell: Unh-uh. We occasionally had ice, occasionally snow, but not much. We knew there was a little ice on that creek, but didn't think about it being slick enough to drive out on it before it cracked in.

Sitton: You know, people say - your age — that it was colder, that there was more snow and ice, and if you go back and look at the actual record, it was colder and there was more snow and ice in say 1890, 1930, you know.

Pannell: Back then, yes. Back then, I can remember we had a stock tank not far from the house when I was a kid, and it froze over. And us kids went down there and taught ourselves skating. You'd just take a running start and skate on that ice on that tank. Oh, we had a ball skating.

Sitton: It must be pretty cold sometimes going into school to Bastrop.

Pannell: It was.

Sitton: Those cars weren't very-

Pannell: No, but they's open, no heat at all. But, we put up with it. We didn't know any different.

Sitton: Well, you said the disciplinarian teacher would provide hot bricks if you stopped at her house, right?

Pannell: Yeah, she did that for some-warm those bricks and wrap them up in some a newspaper or something like that, and made us put them in the floorboard of the car and put our feet on them. 
Sitton: Well, your father was a modern person who liked cars and machines. Okay, he started with a Model T. He bought the Model T when he was a young man leasing the store. Then what did he have?

Pannell: Oh, it was always some old car like that. Fact, there's a picture I think in here of him with - he'll find it, I'm sure. It's in there somewhere. Shows him in the little old-I don't know what it was-looked like a Model $\mathrm{T}$ stripped down, and it had kids on there. And, I know one time we were kids, my daddy did buy some - it wasn't his first car, but he bought one - might have been that stripped down one there. But, he bought a car, and somebody asked him, "Do you know how to drive it?" He said, no, he didn't know how to drive it. Then, he said, "I'll learn." And he got on there, and I know he had my oldest brother, Andrew, on there, and he just took off. He didn't know how to drive it, but he just took off and, 'course, wrecked it. He didn't know how to drive in the sand.

Sitton: But there wasn't anybody-like, there's no driver training around. I mean, at some point, if you're going to drive a car, you've got to just get in it and start to try to drive it around the pasture and learn how to-I mean-

Pannell: Yeah, that's the way we learned to drive. Just got in it and took off.

Sitton: Uh, peddlers would show up from time to time in cars and whatever. What do you remember about any kind of peddlers? Did the Rawleigh man ever come through here?

Pannell: Yes, and that's the only one I can remember was the Rawleigh man.

Sitton: What would he do?

Pannell: He would just mostly have liniments, small items that he could haul in a buggy - most of the time had a buggy. And he just went from farm to farm, and I remember he carried extracts, and I know Mother always bought some extracts from him. And he'd have something like pins, needles and thread, and maybe a few pots and pans. Just things like that that - I don't know what all he had. I do remember the extracts - vanilla and lemon the main ones.

Sitton: You had to have certain extracts for cakes and stuff.
Pannell: Oh, yeah. We always had that. Vanilla mainly-Mother always had some lemon and almond. She used almond some. That was pretty much it.

Sitton: Did he ever take chickens and stuff like that?

Pannell: Not that I remember. Possible, I don't remember that.

Sitton: What about-every family had to have syrup. Did anybody make syrup in Oak Hill? Do you remember anything about raising sorghum syrup?

Pannell: We didn't, but there was people in the area that did, and there was a syrup mill, and you know, I don't know just where it was. Over toward Oak Hill somewhere, maybe down towards Piney on the creek. But there was one in the area, way back-

Sitton: You had to have blacksmiths. The community had to have somebody that would do blacksmithing, and there was a man at Sayersville. Do you know anything about him?

Pannell: Uh-huh. Walter Madison had the blacksmith shop for years and years, and I don't think I have a picture of it in here, but I do have a picture of it taken recently. Don't have an old picture. But, he did all the work for the area farmers around. He was a colored man, and he was a good blacksmith. You see those two branding irons right there? He made those.

Sitton: Wow.

Pannell: They're sitting there dirty; we need to hang them up somewhere. One belonged to my daddy, [Joe] Owen, and his brother, Edgar Owen.

Sitton: What would farmers absolutely need to get done? You've got to have a branding iron, because everybody's got some cattle.

Pannell: Back then, yeah, they had to brand them - early days. Well, especially their plows. Those things would sometimes break, and they'd also need a new point. Points on the plow would wear down, and it'd need to be resharpened. Things like that.

Sitton: If you're a farmer and your plow is broken- 
Pannell: You're up the creek without a paddle in that case. You've got to either get another one or get him to try to fix it, if it was fixable.

Sitton: The people that had work stock around here, did they mostly use mules, or what did they favor?

Pannell: Mules.

Sitton: Did any of those black people-Dogwood Creek - were any of them still using ox?

Pannell: No. No, they'd go with the mules in this country.

Sitton: Yeah, ox was the old pioneer - they're slower than slow.

Pannell: Yeah.

Sitton: I think I asked you before what those people - the blacks at Dogwood Creek - what they did for a living, but they were just small farmers basically.

Pannell: Yes.

Sitton: Just like everybody else, right? Raised food crops and raised cotton, maybe.

Pannell: Well, I don't think they raised any cotton over there, but just the basic crops like we was talking about, and had their gardens - just something to survive on really, is what it amounted to, like everybody else.

Sitton: Anybody make whiskey?

Pannell: Not in the later years, but they made wine. Y'all interview Ruth. She may tell you, but her daddy, which is my uncle, and his brother, my Uncle Harvey - they lived neighbors - they both made wine back in the Depression and sold wine to survive, to feed their kids.

Sitton: Were they getting wild grapes?

Pannell: Yes, mostly. Ruth's daddy learned to raise the tame grapes. He was good at orchards. He learned that, and he was really good at it. He had good grapes. But when they made the wine, I don't know that he had the tame grapes, but there was lots of wild grapes - mustang and post oak.
Sitton: Post oak grape. Is that a little grape?

Pannell: No, it's a big grape, but it's sweeter than the mustang.

Sitton: This is the Depression. People are desperate for a little cash flow, and you're saying that he was seriously making enough to sell in town.

Pannell: Not in town. They'd have customers come to the house and get it. Usually a fruit jar at a time.

Sitton: Do you know anything about his operation? If you know where the wild grapes are-You said he had domestic grapes, too.

Pannell: When he started making wine, I don't know if he had orchard grapes. I don't know.

Sitton: Well, you know, it's kind of interesting, because they've done that research on the Frenchman's operation back in the late nineteenth century, and this was a hotbed of early viticulture in Texas, and they tried to reconstruct how he did it and the whole thing, so this is somebody - he's taking advantage of the fact that grapes grow well in this part of Bastrop County. They liked the soil, and the Frenchman must have seen that, too. Well, he would have been able to see hillsides covered with wild grapes.

Pannell: There was lots of grapes up in that area where he had his wine way up there. There was lots of wild grapes up there. And he also - he put out the tame grapes for growing those up there, too.

Sitton: So, people would basically come to his - yes, it's illegal, but it isn't very-I mean, it's not like the height of people would just come to his house and get a little, buy quart jars.

Pannell: Usually a quart jar or two of wine, and by that way made a little money, because times were hard, and he had to - each of my uncles - one of them had six kids and the other eight, I think-So, kids growing up like that, they had to do something to be able to feed that many kids. It was hard.

Sitton: I'm sure. Even if you had land that you could grow cotton, it was worth five cents a pound.

Pannell: Oh, no, that land over there where they lived wouldn't grow cotton. 
Sitton: Did you ever hear the saying-somebody would say, "That land's too poor to sprout nameless peas."

Pannell: No, I hadn't heard that.

Sitton: That's poor land. Nameless peas, you don't even know what they are. They are some kind of crazy field peas. Let's see, New Deal programs here - we're talking about the hard times of the 1930s. Did anybody in your family - were they employed as superintendents by the CCC camp?

Pannell: My two older brothers - in fact, three of my four brothers were in the $\mathrm{CC}[\mathrm{C}]$ camp.

Sitton: Tell me anything you remember about that, because that's part of - the CCC camp. What did they say about that? Tell me about it.

Pannell: Well, when it started up here - they had it in Bastrop, and I think my oldest brother went first. He went down and signed up to join, and I think he was the first one - that was Andrew. Then Robert, the next one, he went. And he was in Bastrop. Then Harry, the next one, the one just younger than me, he signed up, but he didn't stay in this area. I think he was sent as far away as California, if I remember correctly. He didn't stay here. And back - when was it the boys went out to Wyoming to fight those fires? What year, do you remember?

L. Pannell: I don't remember. Do you remember when they had the terrible fire, the forest fire, and they sent some of the CCC boys to fight it? 'Course, they weren't trained at all, and there was quite a number of them killed. And there's a park and a monument. That's Wyoming, isn't it? Well, my Uncle Andrew, her oldest brother, was a member of that group that went up there, and he was a carpenter, and they were building fish weirs on a river there, and he and another boy, or maybe a couple of more boys, were held back when they sent some out to fight the fire. They held them back because they were still carpenters and wanted them to continue to work on these fish weirs, so they went to do that that day, and of course, all their friends and everyone else in their group was killed fighting the fire that day. I think that had quite an impact emotionally on him for his whole life, that occurrence.

Sitton: Just like a combat death.
Unidentified: Sure, very similar.

Pannell: They got trapped in a canyon and some of them died.

Sitton: Just like that recent episode. You know, it boils up and just roars down the canyon. Did some of them work here? Did one of your brothers-normally, the CCC boys were sent in from outside, like when those companies came in here, there were two companies, ultimately, that I read about working, and they were mostly from outside.

Pannell: Some of them were, yes, but the ones - area boys here, most of them were kept here in Bastrop. And [they] did that park - that rock work down at the state park — that was done by the $\mathrm{CC}[\mathrm{C}]$ boys.

Sitton: And that road where nobody would ever build - the sons of the pioneers wouldn't have built a road like that. I mean, that would kill work stock to try to get up and down that.

Pannell: Yeah, but they did nice work. Those boys had to learn to do that type of work, the carpenter work, but most of the area boys were kept down there.

Sitton: So they were happy to get to do that.

Pannell: Oh, yeah. They made a little money. See, they were paid, and I think they were paid thirty dollars a month, and each boy was allowed to keep ten, and the rest was sent home to the family. So that was a lifesaver for a lot of families.

Sitton: Well, all that rock work is still there.

Pannell: Oh, yeah.

Sitton: It hasn't fallen down.

Pannell: They did good work.

Sitton: Do you remember anything about killing the cattle during the Depression? You know, they killed - your father had cattle, did that -

Pannell: I remember - yes, I think he only had nine head to be killed, I believe, as I remember. I don't remember too much about it. But they did. They were paid a little bit for the cattle, and then they came in and killed them. 
Sitton: You didn't have a choice, right? You had to reduce-

Pannell: Reduce the herd. There wasn't any market for them. People couldn't afford to buy meat.

Sitton: I know there's a picture here, but do you have any memories of the commissary at the Sayers Mine when your daddy was superintendent?

Pannell: I was pretty young. No.

Sitton: It was just a big store, right?

Pannell: Yeah, that's the picture I can't find. I think I've about got it located. And there's a picture of it in the mine pictures. Was it in the bulletin - a picture of it? So you know what it looked like? A long, big building. The bottom part was the commissary, or store, and the upstairs was the living quarters, and it was pretty bare upstairs. A lot of room up there, and big rooms. I know I've been up there sometime.

Sitton: Were the miners much of a problem? How hard was that job? Were they easy to deal with? Well, they didn't speak English. That doesn't help.

Pannell: Well, not until he learned to speak a little Spanish, it was a problem. The workers liked him. He could get along with people, and they liked him, so he didn't have too much problem with the workers.

Sitton: But you had to hang around the commissary, right, or things would -

Pannell: Disappear. Yep. He couldn't leave or be gone for very long at a time. He would come home and be with us for a few hours at a time - on weekends be home for awhile. But he couldn't come and stay.

Sitton: I'm glad you said that, because I knew - there was just a few miles away, though, right?

Pannell: About, what, two miles from Oak Hill to Sayers Mine? About two miles?

\section{Pannell: Probably.}

Sitton: I see, but he wasn't coming home every night.

Pannell: Oh, no. He never could come home and stay all night. He would come home late in the afternoon or on weekends and stay a few hours, but he had to be back there at night. If he was gone all night, why, somebody'd break in the store - manage to break in, or do some mischief there.

Sitton: So watching the commissary was part of the job.

Pannell: That, and he had to oversee the mine, and I don't know just what it consisted of. Keep up with what the men dug and brought out - had to keep up with it. Had to see to them being paid.

Sitton: These tokens in the photograph-as I understand it, they would - am I right that individuals had a code or a number or something? When they had filled a cart or whatever with coal, they would hang their tag on there, and that's the way the-

Pannell: That's the way I understood it, and when they brought that cart out, the tag would be on there so the superintendent would know who dug that -

Sitton: Number 36 had done another cartload. If you go down in the mine and just lay around, I mean-

Pannell: If you didn't send a cart out-

Sitton: You don't have to stand over somebody and beat them with whips if they're going to get paid by the cartload. Either they do it or they don't.

Pannell: Yeah, and if they didn't work, they got fired.

Sitton: Or they starved to death. What do you remember about early telephone systems? What was the telephone system like out here?

Pannell: Well, and I have the old telephone that was in the store that my parents had. They had a telephone in the store, and 'course, if anybody wanted to use the telephone they came to the store to use the phone. And it was the kind - so many rings was assigned to each house, and the phones were all connected. When anybody's phone rang, everybody's phone rang. And if you wanted to know what was going on, you just picked up and listened in. That's the way it worked.

Sitton: So your phone in your house, if you had one in the house or in the store, it was ringing all the time.

Pannell: Anytime anybody used the phone all the [homes] in the neighborhood was connected to that 
line, their phone rang, and it would be so many rings - you could tell the household they was calling by the number of rings.

Sitton: And you were always listening until it got off - if yours was three longs and a short, you would always be paying attention to the phone until it got off your code, right?

Pannell: Yeah.

Sitton: But people would come in and use the store phone.

Pannell: In that area, they was mostly colored people over there, and they didn't have phones. In fact, most of the white people didn't either. They couldn't afford it, although I don't think it cost a lot, but they couldn't afford it. They'd have to go to a neighbor's house to use the phone or, like over there, they went to the store and used the phone.

Sitton: Would it be a pay deal at the store?

Pannell: No.

Sitton: Wasn't a pay phone.

Pannell: No, they didn't have pay phones.

Sitton: The store needed a phone, and so it was just a free public service to the nearby community that here's the phone and somebody gets sick-

Pannell: Well, they didn't use it like that. You didn't go to a neighbor's house or go to the store and use the phone just to gossip. It had to be an important call.

Sitton: I see. The store phone needed to be serious. Nobody would come in there just to gossip.

Pannell: No, not on the phone. They'd come in there and gather and gossip.

Sitton: Do you think the phone system came out of Bastrop?

Pannell: It came out of McDade, but I'm not sure about that. But don't quote me on that, 'cause I don't know. Maybe somebody else can tell you.

Sitton: Well, Bastrop would have had a phone system, but there were a lot of little phone systems back then, and it was not hard to-I occasionally see remnants of those phone systems riding around in the Hill Country, and they'll come down and hit the top of a barbed wire fence and run down the barbed wire fence-little insulators - old barbed wire fence. They were pretty rinky-dink systems.

Pannell: But it served the purpose.

Sitton: Yeah. Tell me how the coming of Camp Swift affected your family.

Pannell: Well, I had just gotten married and was gone right at that time, but Andrew was still at home with the folks to help them, and they just came in here and announced Camp Swift was going to take all this property over here and have a Camp here, and started taking the land. They didn't have any choice. They had to just let them have the land. I don't know how much time they were given to move off. Do you remember, Leland, anything about that?

L. Pannell: I don't. I remember it was a pretty short period of time.

Pannell: I thought maybe your grandma talked to you about that.

L. Pannell: I'm sure she did, I just can't remember specifically. I have the impression it was a pretty short term situation.

Sitton: Were there rumors about it beforehand, or did it just come down like out of the sky?

Pannell: Well, as I remember, it just happened.

Sitton: There was a lot of political pussyfooting around for the months before, but that didn't mean that anybody out here in the countryside would have gotten wind of it.

Pannell: We didn't know it they was even considering it out here - the people lived here - no, they didn't know it - wouldn't even thought about a Camp out here in this old poor country.

Sitton: That's where you put 'em.

Pannell: They thought - Yeah, they didn't think land was good for anything out here. And that reminds me, later years, after the war-fact, a good many years 
later, before the National Guard got active like they are now, that a commissioner in Bastrop said, "The government's got all that old land out there. We think we ought to be given part of it for a county park." And, we could maybe get ten acres out here off of 95 for a park. And they had a public meeting in town, and that was brought up, as well as I'm sure other things, but I went down there to that meeting, and this commissioner said, "Well, if we could get ten acres, why don't we ask for thirty? That old land out there's not any good, and we could make a county park out there." They didn't get the land there. I'm sure they asked for it, but they didn't get it, but as we were walking out - this was in the courthouse - we were walking out, and one of Bastrop's prominent businessmen was walking out with me. I knew him - had known him always — and he said, "Well, I don't see why the government wouldn't give us that land out there. That old land out there is not good for anything."

Sitton: Well, that was kind of the attitude of the Bastrop people who were behind the Camp. I mean, it had been good for the economy, and right now, it isn't good for anything out there-We're not getting any good out of that stretch of countryside. Eighteen thousand construction workers to start off, and then umpteen troops, I mean - and it was good for business in Bastrop.

Pannell: Oh, boy. They was living high over there for a while. Bastrop's always been that way. They always had their hand out. Soon as they get any kind of grant, why, they was right there to get it.

Sitton: Well, how did people generally react out here, do you think, to learning that the government was going to take their land? Got to be patriotic, but they want to take our land.

Pannell: Well, they didn't like it at all in the first place, and in the second place they were given very little time to move off the land, and the people had no place to go. And they were paid very little for the land, one thing, and they were told that they could take the buildings if they'd move 'em in that short a time. And, of course, they had all their stock, like cattle, hogs, chickens, turkeys, all that kind of stuff to move and no place to go. Most of 'em had to find a place to move to, and lot of 'em couldn't find a place very well, and they had to get rid of what they had. And they didn't have time to tear those buildings down and save any of that lumber, and [the] army just bulldozed 'em over. Got rid of 'em.

Sitton: And the company's full of construction workers at the same time, right? I mean, you can't even drive around. The population of Bastrop County had doubled.

Pannell: Oh, yeah. And the people were unhappy. They resented the way they were treated, and I don't blame 'em. I still won't accept the way they did.

Sitton: Did they feel that they had to just suck it up - I mean, did anybody really try to fight it is what I'm asking?

Pannell: Well, there might have been a few families that tried to fight, especially the payment they got for the land. Some of 'em was very low, and they wouldn't sign and accept that low payment. And they tried to fight 'em on that, but it didn't do any good. And some of 'em got paid as low as six dollars an acre.

Sitton: That is low.

Pannell: That wasn't much money. Fact, no one got much money for the land. And that little bit of money, they had to go out somewhere else and get a place to live.

L. Pannell: How much did Grandmother and Grandpa get for their place?

Pannell: They did real well. They got twenty dollars an acre, and it was very few got twenty.

L. Pannell: And what did they pay for this place when they bought it?

Pannell: Fifteen dollars an acre, but this was a much bigger-

L. Pannell: Yeah, this was five hundred acres.

Sitton: Which grandfather and grandmother is that?

Pannell: My parents that lived over there at Oak Hill.

Sitton: Is it Owen? Does it have an $s$ on it?

Pannell: No. 
Sitton: I've seen it both ways. I thought it was Owen.

Pannell: Without the $s$.

Sitton: Your Aunt Polly Owen-tell me a little bit about her, because I'm going to read all of her columns, every one of them. Twenty years of them.

Pannell: You're going to have a job.

Sitton: That's about two thousand of them.

Pannell: Well, when you do that, if you make - you going to make copies of them? I wish you'd make a copy of her last two or three columns before they had to move out. I want to see those so bad.

Sitton: David Wharton, who did that book, The Soul of the Small Town, about McDade, he made heavy use - that's how I really learned about - he called her Mrs. Edgar Owen. But, she was discreet about what she said, but her attitude toward the takeover was - and all the papers were into "Isn't this wonderful?"

Pannell: Oh, yeah.

Sitton: And letters were being written by-

Sitton: Say her name again, because maybe that got left off.

Pannell: Vickie Wharton, and she was living over in Sayers, and she also sold some real estate, and she worked in Austin. I better not go into details about her life right now, anyway. But, the Lignite Watch - several people got together and tried to fight that - didn't want the mine down there. And so, she and, I don't know, several of them, decided to work at it and try to save the historical land, fight it that way and that way have a history of that land, and maybe that'd make an impact on 'em and help stop it.

Sitton: It's not just old poor sandy land with no history that we can tear it up.

Pannell: Yeah, but that's the only way they could figure out to fight it, and on the first issue, which I didn't help with it, the first one. They asked us to join, and I didn't much like the idea at first of what they was doing. Fact, I never did like the Lignite Watch bunch, the way they tried to fight it. And I wouldn't join them, and I did a lot of work with the history of it. But they asked me about joining, and I didn't want to. I wouldn't on the first one, but most of those pictures are in the number one issue they borrowed from my mother. Pictures from here they used. And they tried to do the history of that area down there, and so when they finished it and had it printed, and then it had to be put together and stapled, and they were doing that over at the Greenbriar School. So they asked me again, so my daughter Peggy and I went over there, and they were finishing up the number one, and we helped them finish the stapling of the number one issue. Then, I saw that they were actually doing history of the area, then I joined them. But I didn't join the Lignite Watch bunch. It became two separate bunches.

Sitton: But when you saw they were serious about - it wasn't just a purely political thing, but they were trying to do serious history of the area, that's when you -

Pannell: That's when I decided to join 'em, and I've been working with them ever since.

Sitton: And it's been a while.

Pannell: It's been a long time. See, for seven years in there, everybody pretty well dropped out. They got tired of working with it, and they dropped out, so we didn't have an issue for seven years. And we had a little over one hundred dollars in the bank, and so Mott Davis called me and told me, said, "Fay, we've either got to start up on the bulletin again, or we need to give that little bit of money to some other organization and not just keep that money setting in the bank." And he says, "Why don't we have a meeting and call everybody that's interested and have a meeting and see what people want to do about it starting it up again or just dropping it." So, we had the meeting here - right out here on the patio out here. Quite a few people came, and everybody said, Oh, let's start it up again. So, we did. Not many of us working at it, but we're still at it.

Sitton: Well, I just wanted to-
Interviews with Fay Owen Pannell
Interviewed by Thad Sitton
Dates: March 31, and April 2, 2004
Place: Sayers, Texas
Transcribed by Dan K. Utley
Year of Birth: 1916 


\title{
Abner C. Scott Interviews 1 And 2
}

\author{
By David L. Nickels
}

\section{Interview 1-29 April 2004}

David L. Nickels: My name is David Nickels. I'm the interviewer, and today is April 29, 2004. The time is nine o'clock in the morning and this interview is taking place in Mr. Abner C. Scott's home in Elgin, Texas, 155 VFW Road. This interview is part of the Texas State University-San Marcos, Camp Swift Oral History Project sponsored by the Texas National Guard and conducted in conjunction with the Center for American History, The University of Texas at Austin.

Nickels: Mr. Scott, we appreciate very much you allowing us into your home. Would you please tell me your full name and your date of birth, how old you are.

Abner C. Scott: I'm Abner Cleveland Scott. The way I got the Cleveland, my daddy was named Grover Cleveland, after President Grover Cleveland. I'm the fourth Abner Scott, you might say, but I'm the only Abner C. Scott. And, I'm proud of the Scott name, I admire my great-grandpa, Abner Scott, that more or less, settled this land between Big Sandy Creek and McLaughlin Creek, on the ridge. And, he was a pretty smart man to get there where he did, and acquire the land that he did. I want to say that I enjoyed living down there, and I was so disappointed that when I got back out of the Navy that we couldn't get the land back. My daddy and mother grieved about it until the end of their lives, because they couldn't get the land back. But I will go on from here.

Nickels: We appreciate that. What year did the Scotts arrive out there?

Scott: I'm not sure, what, what day, what year it was, but I think it was 1850. I was born in the big cabin, log cabin, and I was the oldest one of the nine children. Seven of us was born in that log cabin.

Nickels: Who built the log cabin?

Scott: Abner Scott, my great-grandfather. And I think he built it about 1860-somethin'. I'm not sure exactly what year it was. He came with his mother Martha

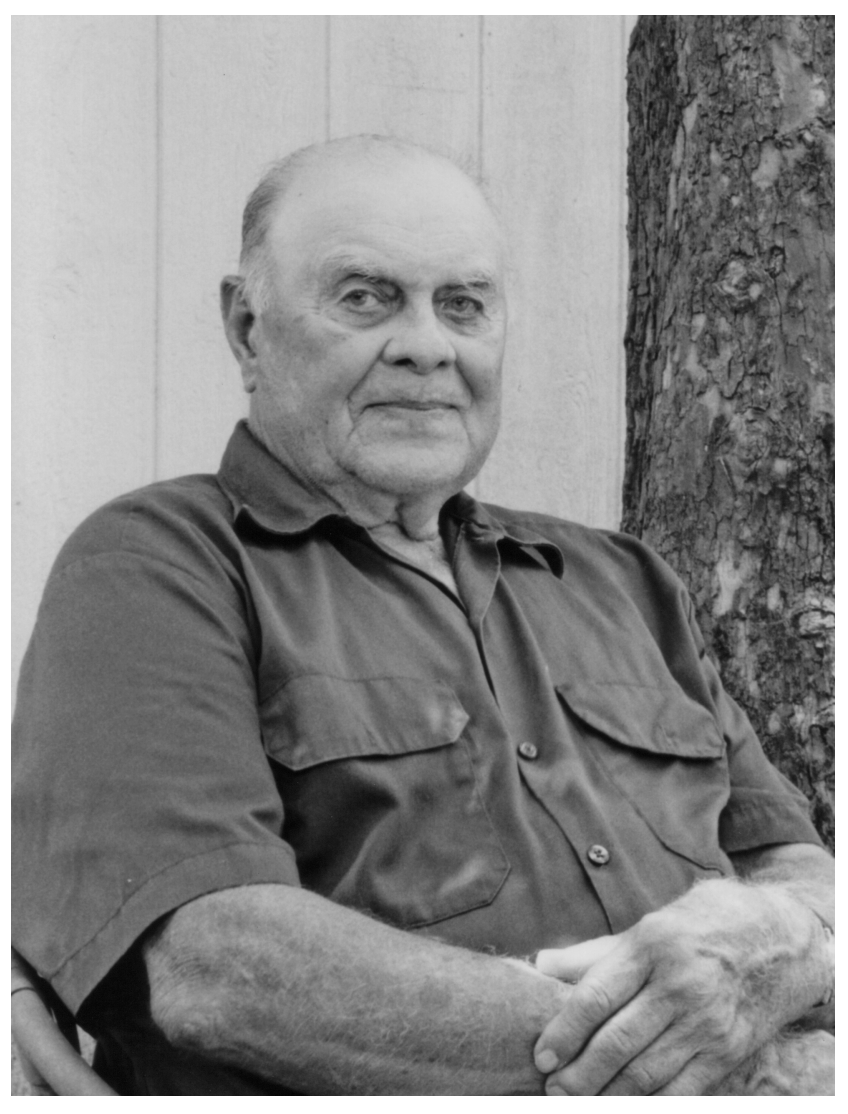

Abner C. Scott

Scott, and his daddy, Henry Scott, was either killed, or died at Fort Bend County. We never did understand exactly too much about how it happened or where he was buried, but I guess he's somewhere down there. Someday I intend to go down there and see if I can find where he's buried, and see if I can check the courthouse records and see what they can tell me. Anyway, she came up in the Runaway Scrape when the Mexicans tried to take over Texas before that. They was comin' from Fort Bend with my great-grandpa, when Abner Scott was a baby. They settled on Big Sandy Creek, and it doesn't say much about what happened. But I know that Abner Scott was the one that built the house. He was one of the older ones. And a couple of them, Napoleon, and two more, David -

Nickels: And Abner? 
Scott: And Abner.

Nickels: Now, Napoleon is?

Scott: One of them. And then there's a Jason and Jonathon. And they never had any more children other than that, that I know of.

Nickels: So they were brothers?

Scott: They were all brothers.

Nickels: And you were born there at Camp Swift in the house?

Scott: That's right. In the house that Abner built. All seven of us in the picture that I showed you.

Nickels: And the names again?

Scott: Okay, you can write them down. Abner Scott, Dan Scott, Jesse Lee Scott, the black-headed one, Mary Lou, Allen Scott, this one, and Harlan Scott; this is the one that worked for the National Guard, and his name is in this book. And this is Donald in the mother's arms. And Grover Scott's the daddy, and Ina Scott's the mother.

Nickels: What year were you born?

Scott: I was born November the third, 1923.

Nickels: And so-

Scott: They got married October the sixth, 1922. And that's when they moved in this house where it's sitting back over here. And you'll notice these shadows of this tower right here. That's a tower, and that was before we had electricity. Daddy built this tower because he was a derrick builder. He built this tower and put a wind charger on top of it. It would charge the battery so we could have radio and we could have one or two six-volt lights, and that's what we used other than kerosene lights.

Nickels: That must have been about 1939 ?

Scott: No, right after that. We got electricity right after that.

Nickels: And so there are seven children there?
Scott: Yeah. Seven children that was born there. See the neighbors come and helped Mama until the doctor got there. I don't know, I think she told me one or two of them was born before the doctor got there. My doctor was Dr. Bryson from Bastrop, and he had to come in a buggy from Bastrop. A lot of them come from, well, the rest of them come from Elgin.

Nickels: And you had ninety acres out there?

Scott: Yeah, on the home place. Before we moved out of [the] Camp, my grandpa and grandma both had died. My daddy, Grover Scott, and Walter Scott, my uncle, were part owners, of the land that was left. So, they had all of that together, counting the Chandler place and everything, they had right at six hundred acres on there. And we could raise all kinds of cows out there.

\section{Nickels: Yeah?}

Scott: On this ninety acres, we had something like, oh, I don't guess we ever had over maybe ten mama cows. And my mama would milk four of them. And we didn't have ice much then, we didn't have it. We did have a big old icebox that you could put a hundred pounds of ice in, but we couldn't go to town and get a hundred pounds of ice very often. We had what you call a milk cooler. It was a metal deal and had four legs, had the canvas around it, and water would seep down that canvas. And it kept that milk cool for a time.

Nickels: Did you have a water source running on it all the time?

Scott: Well no, it would hold so much water in the top, maybe a couple inches. And this canvas was thick, so it would gradually soak down, and mama would keep putting cool water [on it]. The water that she got out of the well was always pretty cool. I recall 70 degrees or something, but anyway it was cooler than (laughing) the other water that you could get setting around. Anyway, we had plenty of milk to drink, and we had plenty of butter that we churned. We churned the butter, we had one of them old thick, big pots that you take a stick and go up and down like this, and make the butter, which you only had so much, yet in a daisy churn you did like this. You wouldn't get but less than a pound of butter out of that daisy churn. But that other one was kind of a three-gallon crock deal, that at times you'd get three pounds of butter out of it. And, 
we always killed hogs. And that was a big day. We would kill one about the first cold norther, and it had to be pretty cold, so we could. We had a smokehouse in the back, and we'd smoke, and later on sausage, and we'd stuff it. I know Mama cleaned them entrails and stuffed that sausage. That was the best sausage that I ever ate 'cause they knew just how much sage, and how much black pepper, and how much red pepper, and so forth. Then they'd make it just hot enough that the kids could eat it, and 'course I was older, and I wanted it hotter. But anyway, it was good. I wanted to start here and tell you about when I got old enough to go to school.

\section{Nickels: Okay.}

Scott: We lived right here on Sandy Creek, and then across here to Wayside, which is on the SayersMcDade Road, and right again. And it was almost two and a half miles right across there. So I definitely couldn't walk that far by myself. And Mama couldn't walk with me every day, and we had one car. Daddy had bought a 1924 Model T, brand new. I was one year old when he got it; I don't remember it being brand new. But anyway, he would go to Luling, or Dale, or somewhere in the oil boom and build those derricks so they could drill for oil. And sometimes Mama would have Grandpa Scott's old Model T; he had a Model $\mathrm{T}$ one-ton truck. But he couldn't drive, and Mama could drive it. So she would drive over there and get Grandma and take her to town, and come back, and keep the truck at home. But she couldn't take me to school in it because when I started to school in 1929, that's when things were getting hard, and we finally quit registering it about 1930, that old Model T. And we rode a horse or walked, or went in the wagon wherever we went. So when I got old enough to go to school in '29, they decided that I would go over to Grandma and Grandpa Scott's house and stay with them. They also had the teacher; the teacher had a room there. It was only a mile to walk from right up McDadeSayersville Road towards McDade, and I'd walk with the teacher up there. That worked fine until midterm come, which was during the Christmas holidays. Well, three or four more kids was going, and they had to move somewhere else. Their parents had to go somewhere else to take care of a farm for somebody else, or something. And I was the only child left to go to school. And so, the teacher said, "When its pretty days, we'll walk to school, me and you, we'll have school as usual, just us two. But when it's raining, or bad weather, we gonna stay at your grandpa's place and we'll have school in the room I stay in." So we did that, and I enjoyed that school better than anything in the world! But, they decided, after that school year was out, that they couldn't have school there for just me, and so they didn't hire a teacher for the next year. And they sent me down to the Grandpa and Grandma Allen's, which is my mother's daddy and mama. And they lived about a mile from Oak Hill, where the cemetery we went to.

\section{Nickels: Yeah.}

Scott: They had a school there, a two-room school, and they had a church there. I was in the second grade, and I was in the church house with the second grade kids, and the older kids was in the schoolhouse. Well, that was a new experience for me. I got to go with the other kids that I hadn't got to play with and stuff, because over there where we were (laughing) we didn't see many kids! (laughing hard) Anyway, this Ruth Smith, her mama was named Birdie [Bertie], that was one of the last years that she went to Oak Hill School, then she went to Bastrop, there.

Nickels: So you went to school in the church; the younger kids went in the church?

Scott: Yes.

Nickels: And then there was a regular school there?

Scott: Yeah. They was setting right together, just, not even oh, sixty yards apart I guess.

Nickels: Was that like through the fifth or sixth grade, or something?

Scott: In '36 they got a school bus, and that's when they started going to Bastrop. But, some went to McDade would have had a high school then. And, a lot of them just didn't go no further than the seventh grade. (laughing)

\section{Nickels: Yeah.}

Scott: That's as they went. (still laughing) But when they got the school bus, why everybody was going to-McDade, I mean to Bastrop. And so when I got out of the second grade, I come back to home, and the neighbors had moved back in, and we had enough to have a school. So, the teacher stayed with us then, the new teacher that we hired stayed with us, and we rode 
a horse up there. She rode in the saddle and I rode behind her, in the third grade.

Nickels: This is back at Wayside?

Scott: Yeah, back at Wayside. We went on this horse. I remember she got in trouble one time, because her boyfriend brought two more people over there, and, they wanted to stay there and watch her get on that horse. "No, I'm not gonna get on that horse with y'all watching. Y'all have to go on." They wouldn't leave, you know. So they decided that they'd tie the horse behind the car. We had the road through here, like I drawed. That's the way we rode that horse in. So they trotted that old horse home. Daddy happened to be at home. And he got some hot about them bringing that horse behind that car. I didn't hear. They sent me in the house, because they wouldn't let me hear all of it, but I heard some of it. (laughing) He done give them a bad time, and they was saying "Oh, we're sorry, but we were just trying to have some fun." And he said, "Well your fun is over!" (laughing hard) And then in the fourth grade, Dan got old enough to go to school. And, we got another teacher. This teacher only stayed that one year. I think they got married - the one that led the horse home behind the car. (laughing) And so, the teacher said, "we can't three ride that horse." And Daddy said "I know where a buggy is, we'll go and get it. Abner's old enough that he can hook that buggy up every morning. Y'all go in that buggy." So we used that buggy for, I know four years, and Jessie Lee and Mary Lou got old enough to go. The teacher and I would set in the seat, and those two girls would sit on the floorboard there in front of us, and Dan would sit on the little floorboard behind us. It had a little deal setting back there, and he'd set back there, and he'd jump out and open the gate, and get back in, and so forth. But anyway, it's different experience than most people have going to school.

Nickels: Very interesting.

Scott: And then when I believe I was in the fourth, and fifth, and sixth, and when I was in the seventh grade, why, then we started walking. We got a different teacher and she come from McDade out there. So we didn't use the buggy anymore. We walked. One time, it come about a two-inch rain, like a downpour. See, there's one holler [hollow], you can see this thing right here.

Nickels: Um-hm.
Scott: It come down here. Said, "Y'all can't get across that creek where you cross it down there." It runs right in to McLaughlin. I said, "Well, I know where we can walk up this hollow and get across, and we'll walk down that way, on the other side." We got down there, and there Daddy was coming after us, and he got down there and he jumped across the creek. There was a narrow place, and oh, I'd say it was less than five foot, about five foot. And, all of it stayed in the banks there, where that five-foot narrow gorge was. He jumped across it, and he got to thinking: well, if I can jump across this thing, surely I can drive across it. (laughing) So he went back, and of course it was spread out, way out there. He drove off in it, and of course when the front wheels got down in the lower part, well that fan picked up the water and drowned it out. Well, he got out, and come on to the school; well, we'd done left. And there I was worried about what happened to him. There, the pickup was in the water.

\section{Nickels: Yes.}

Scott: And I didn't know whether he had drowned, or he got out, or what. (laughing) But he'd got out, and waded out, and went on behind us. People by the name of Phillips lived right across the road here. And so, I jumped where he had crossed. I knew my brother and the girls couldn't jump across there. So, they waited there, and I went back to school, and didn't see him nowhere. So I went up to Miss Phillips; there he was playing dominoes! (laughing)

Nickels: Yeah.

\section{Scott: (laughing hard)}

Nickels: And you were worried about him.

Scott: We was worried about him. (still laughing) He said, "You and Dan go on home, hook up the wagon and come back, and pull that Model A out, and we'll pull it home." Says, "I got to drain all the water out of the motor, all the water out of the transmission, and out of the rear end, and I can't start it." So, we went and got the wagon, and come back and, he got through playing dominoes, and got there. He guided it home; we pulled it on home. And he had a time. The motor stood up pretty good after I remember he had drained the water out of it, and he put kerosene, and he started it, and drained it out. The motor done all right, and the transmission done all right, but the rear end, it didn't. It didn't last long; (laughing) it went out. 
Nickels: Hmm. So that was about when you were in the seventh grade, or sixth or seventh?

Scott: Yeah, seventh, still. I went to the ninth grade there. And that was in '39, yeah. They quit having school in '39 there. They got a school bus over here at Ramsey School. And, it was over there on [Highway] 290.

Nickels: Where on 290?

Scott: Well, it was before you get to where you turn off to get to Butler. It was back this way, about, I don't know, quite a mile. They had a school bus there, and, well, they closed that school too. They had the school; and that was my cousin that drove that school bus. He was the one that lived there at Scott Falls, on the hill. And so we would walk across the creek, and not by the road, but across the creek, and up there to his house and we'd ride the school bus. He was going to Butler to pick up all the kids in Butler and Pruitt. [spelling] And then the McDade school bus picked us up, and carried us to Elgin to school. And that's the way I finished school. I finished in ' 41 . And we didn't have to move out until June of ' 42 , I believe it was.

Nickels: I see.

Scott: So yeah, I had all different kinds of ways to get to school. But, Allen, this boy right here, when he was in the first grade, by the time he started school in Elgin, in first grade, and he'd walk with us, and, and Daddy built us a bridge there that we could get across the creek on this bridge. But it would overflow on the other side. And so, I told him one day, I said "I'm gonna build a foot log from this bridge on up there to where we won't have to wade in water. So I built a foot $\log$, and put two logs together, and I got some boards and put on top of it. And we walked across that. I felt sorry for Allen one day. He was looking down at the water, and it was running under him, and he dropped his lunch in there. (laughing) Of course we had to take our lunch. But that was all kinds of experiences going to school.

\section{Nickels: Was that Big Sandy Creek?}

Scott: Big Sandy Creek, yeah. And then, I'll tell you another deal about that bridge I was telling [you] Daddy built across Sandy. We was going over to this Doll Fort's place, which is right across the creek from us. The places joined each other.
Nickels: What was the first name?

Scott: They called him Doll. (laughing) I don't know, it was mutual; I can't remember what. But anyway, somewhere in here, a Dean Fort uh, was a nephew of his. Anyway, we was going over to his place, and this one mule, when you cross a bridge, he had stepped in a hole one time, you know how a old bridge will get, they'll get rotten.

Nickels: Yes.

Scott: And he would be nervous, and I knew what he'd do, and I'd keep a tight line on him. And Daddy was driving across there, and I said "You better put a tight line on him, because he'll push that other mule off." "Aw, naw, I'll take care of it." All of a sudden he pushed over there, and pushed that mule off in that water. That scared me to death (laughing), that there mule, the one was still hooked up there, and the other one down there in the water. (laughing harder)

Nickels: What a mess, huh?

Scott: Oh, it was a terrible mess. They had to get down in that water and unhook that mule and get it out, lead the other one across. We always farmed the Aussilloux place, which was right across Sandy, and just a little bit of it right here touched. But most of the time the water was too deep there, and it had to be real dry before we could drive across there. So we was farming the Aussilloux place, and it was the best place to plant sweet potatoes, and peanuts, and watermelons.

Nickels: That would have been his upper sixty acres there?

Scott: Yeah.

Nickels: Around the house?

Scott: Yeah, around the house. See it was joining our place, just the creek was all that was between us, for a little ways there. But we had to (??) around in the rain that night. And we got our potato slips, you know, we bed out them potatoes. I guess you know what I'm talking about don't you? You cover them with dirt about, aw, and inch and a half or two inches. And them slips, them eyes is what the slips come up through there. And you'd pull them slips, and after it rained, well you'd have your land all ready. You had it bedded up, and you had it logged off, and ready to set them out. 
Nickels: What do you mean when you say logged off?

Scott: You know when you bed land, why, it just makes two furrows come together, and it's not smooth, or anything. So you put a chain on logs, say, eight-foot, or ten-foot long. And you pull this log up and down them rows. If you're getting about three at a time, then you got a nine-foot log. And, you got it real smooth, for about that far. And you set them potatoes in there. Well we'd pulled a bunch of them potatoes. I don't know how many it was, probably a couple of hundred, maybe that day. And we were on the wagon, and the water was up below the bridge, and it was fine, and we worked until, oh, it was probably - well, it was summertime. You can work until seven o'clock or so, setting them potatoes out, and come back to that bridge, and I says "Oh my goodness, what we gonna do, the water's over the bridge"? Daddy said, "Well, I know I can't drive that mule" - the one I was talkin" about. I said "I'll get out, and I'll lead him across." And sure enough, I got out and the water was just about, oh, it was about a foot deep. You couldn't see the bridge anywhere. I led him right on across, got on the other side, and got back in, and went to the house. (laughing) Not many people had the experiences I did.

\section{Nickels: No sir.}

Scott: But what I really enjoyed, was when we had our work done, and we was caught up, and it would rain like that. My Daddy had bought me a single shot .22 when I was nine years old. And most people, they can't trust them with a gun at nine years old. He said "When you don't have anything, you got free time, I got you a .22 here. And it's a single shot. And you got to make your shots count. And says "I'm not gonna give you nothing but shorts." You know, there's a short, and there's a long, and there's a long rifle. "And you'll have a box of shorts here. And you got to make them last. But, I want you to go there to the pecan tree." Said, "Them squirrels are just packing them pecans out." Said, "They'll eat a few, but they'll pack more out, and then go off any bury them, and they're wasting them. So if you've got time after a rain, go down there, kill some of them squirrels." I says "All right." So I'd walk down there, and you'd find a little trail where they'd just paddled in that mud, and it was just paddled down. And, you set up against that tree and here they come. If you're real quiet, they'll get up real close to you. There was a lot of times I'd kill four or five squirrels before I went back to the house.
This teacher that I was telling you about that rode the horse with me, her brother lived here in Elgin, and he was quite a squirrel hunter. And we had two dogs, old Joe and old Blue. They was the best squirrel dogs that I'd ever seen. But, I didn't never take them with me when I went down there to shoot them squirrels at the pecan tree, because they would be barking and scaring them off and everything. I'd just ease down there, and set up, and wait for them. But they would go all over in the woods, all around from one creek to the other one, Sandy Creek, McLaughlin Creek, all around. Them dogs treeing squirrels all the time. They'd bring in a dozen a time. And Mama would skin them. Mama would fry them up for him. And he would bring as many as four people with him, and they enjoyed - (laughing)

Me and my next brother, Dan, we'd hunt opossums, and ringtails, and we got that money, you know. Daddy always had a bunch of boards fixed, like little ironing boards. You know what I'm talking about? They go to a point, and back, and he had them fixed and we used them year after year. We'd skin them things and turn them wrong side out, and stretch them on them boards, and tack it. Back then you could get Bee Brand Powder. You can't get Bee Brand Powder anymore, but that was the handiest thing. You, sprinkled that all on, and them hides would dry, and the flies wouldn't bother them. Otherwise they'd bother them, and worms in them, and every thing. But I don't know why they, you know the environmentalists or somebody, has done away with all that good stuff. We kept black-eyed peas the year round in a five-gallon tin can. And you put that High Life in the top of that peas. It had just a little notch in it so-so much of it would come out. And you could keep them peas, (rooster crowing) and you didn't get no weevils or nothing in them. And then plant them. The way we planted them, we had two rows of corn, and a row of peas in between.

\section{Nickels: I see.}

Scott: And that's the way we planted there (rooster crowing) on our place, and of course, of course we had a whole lot more peas than we needed. And when Daddy would come home, in the morning he'd go and he'd pick some peas and take them to Austin in the evening. I didn't go to Austin. Of course I didn't drive. The only place I'd drive was to McDade when I had that old Model A. And I'd haul them watermelons to McDade, and you'd load them on freight cars. And 
you'd go down there and weigh them. Then they'd count them, and they wanted thirty-pound average. We could always get bigger melons than that. I could put thirty-three on that little old Model A pickup, (rooster crowing) and take them up there and weigh them. I could make three trips in a day.

Nickels: So they had a buyer right there at the freight yard?

Scott: Yeah, they had a buyer. He had so many cars to load up there. You just get a - weigh-in - and then go back. And weigh the pickup empty.

Nickels: What was a melon worth?

Scott: Oh, I forgot what they was paying for them, but it was something like, I don't know, maybe it was two bits a hundred maybe, or something like that, a hundred pounds.

Nickels: I see. You made some money doing that, and you sold some skins, opossum and ringtail?

Scott: Yeah. Uh-huh. They wasn't any coons back then. The first coon I saw was not too long before we moved out of there. But they're in there now. But, above Scott Falls, at Spring Branch, them dogs got after something. They come down Spring Branch by the falls. And we had a neighbor with us, and he said, "Them dogs are after a coon." I said, "We haven't never treed a coon before." Said, "Well you're gonna tree that one!" And in a big old pine tree down there before you get to Big Sandy Creek that coon, well, we went down there, shined his eyes up there. (laughing) But, we didn't kill it; we let it live.

Nickels: What other kind of wildlife was out there?

Scott: Well, I skinned a skunk one time. And you got more for a skunk than you did a opossum. But see, a opossum or ringtails, you got the most for a ringtail. But they didn't stink! (laughing) You know, these carbide lights that you put on your head? I was walking down this bit of a hollow, you know, and there's a tall bank on each side. The dogs got after this skunk. And here he come, right toward me. And I said, I can't get out of his way; I can't get up this hill. And, he kept coming. He got right at me, and turned around, and sprayed me, and of course when he did that he stopped, and I shot him. And, I carried him to the house. I skinned him, and put him on the board. I didn't have but one pair of shoes, and it had that scent on. And that teacher, "I smell something." And that fire was getting warmer, (laughing) you know. And, "What is that?" I said, "Well, I killed a skunk last night; it's on my shoes." (laughing) [She said,] "You get over there away from this fire, way at the back of the - " (laughing hard) She let me stay there all day, but, oh me! Oh, boy.

Nickels: Well, you said you had ten head of cattle, and four of them were milk cows. How many horses and mules did you have?

Scott: We had two mules. And we had this horse that I was telling you about pulling the buggy. And this one mule - as you know - there's a "fat" mule that's easy kept, and there's a poor mule you might say, that eat all, and you never get fat. But anyway, we worked him a little bit too hard. And he got to where he couldn't pull his load, so we got to hooking that horse up to the mule. And the horse was strong enough to pull. We went over there on the Aussilloux place and got a load of melons on that wagon. I told Daddy, I said, "We can't haul that many." I said, "This horse can't pull that many of them." Because we had to go down a ravine and then up. We crossed it when we come with you. But, the Army has graded it out; it ain't steep anymore. But it was steep, and sure enough, that horse got about half way up the hill, and it faltered. Daddy says, "I'm gonna make him pull that." And I said, "No, let's unload some." "No, I'm not gonna do it." I said, "Well, you'll kill him; don't beat that horse." Because I thought more of that old horse, because I could go get the mules, and not have any bridle or anything. I could jump on him, and he'd follow the mules on to the house. And, he knew he was gonna get something to eat, too. Finally we had to unload some to get it up. Oh, my daddy was a stubborn man. I got so aggravated at him. But I'm sure that's the way the Scotts was back then. My grandpa was much of a man. My daddy wasn't any taller than I am now. But he looks tall beside the rest of us because my mama wasn't but five foot two, I believe. And I was taller than her back when I was a kid.

Nickels: Well I understand that, at one time, you may have taken a shotgun to a horse.

Scott: Now how did you hear that? (laughing) Shirley told you. No, I was telling you about that one mule, and finally he played out. So when Grandpa died, he had 
a pair of mules. He had a[n] old gray mare mule. And he had a black, younger mule that he had gotten later on. And so, we brought them over to our house. I was using them, and that was the stubbornest mule - that black one. I'd gone plum down there on Sandy Creek to get them, walk back to the house, half a mile, got them up there, and he broke and run off. He done that twice. And so, Daddy had a .20-gauge shotgun, and he had a .12-gauge shotgun; he had two .12 gauges. He had the .20. I said, I'm gonna put some bird shot in that .20-gauge shotgun, and I'm going back after that mule, and if breaks and runs again, I'm gonna let him have it! Well, I thought I had him in there, and I was reaching to get the gate and close it, and here he come out, before I closed it. I didn't let him get too far away. He was making a circle around me, and was gonna head back. So I let him have it right in the shoulder, and knocked him down with that .20-gauge birdshot! (chuckling) He got up and instead of going in the pen, he went in the other pasture towards the well down there. He went down there and laid down. So, Daddy come in that day, and Mama said, "What would you do to a mule that you can't get him in the pen?" [He said,] "I'd shoot the doggone thing." "Well that's just what your older son did!” (Laughter) Man, I thought I was gonna get a beating for that.

Me and Dan got a terrible whipping one time. We thought we'd have some fun. Jessie Lee, the blackheaded girl, we was down there shucking corn in that crib. We had all we wanted, and she was shucking a couple more. I told Dan, I said, "Let's close her up in there." And boy, she was yelling and going on, and having a fit. We couldn't make up our minds which one of us fastened that door. One of us fastened that door, one of us did, I know, but I thought I held it to, and he fastened it. Anyway, here come Daddy. He heard the hollering and going on. Said, "Which one of y'all fastened that door, fastened her up in there?" [I said,] "Well, we were just having some fun. I don't know which one of us, both of us I guess." [He said,] "Well, you don't know who fastened it?" [I said,] "I can't remember, but one of us fastened it." [He said,] "Well, if you ain't gonna tell us which one of you, both of you gonna get a whipping." So we got to the house and eat supper. After supper, he got that razor strap out. You know what a razor strap is? (laughing) And he put it on us. (laughing louder)

Nickels: He did?
Scott: I guess that's the worst whipping I ever got. (laughing) We didn't mean no harm, we just having fun. You know sometimes you get into trouble. You know you get in trouble when you have other kids visiting too. He brought some boys home from the brickyard. He was working at the brickyard. And there [was] a little bachelor staying in the Aussilloux house. We went over there to get some watermelons; them kids wanted some watermelons to eat. And the old bachelor was gone, but his old Model $\mathrm{T}$ was setting under the shed out there. One of them boy from the brickyard said, "Let's let the air out of his tires." I said, "Well we could get caught. He'll know who done it." "Aw, he won't know who done it." Of course we left all our tracks when we walked over there and let the air out of the tires. When Daddy come in that evening, that old man was standing out there at the road. Stopped him, and said, "Them boys of yours and somebody else, they let the air out of my tires." So, he come on to the house and said, "Get that pump out of that old Model A, and you boys go over there and pump them tires back up." Says, "You got to walk, I'm not gonna drive you over." (laughing) So, we had to walk over there and air them tires up. (laughing)

Nickels: Yeah.

Scott: Me and Dan never would have done that thing. That's what happens.

Nickels: So your dad built wooden windmills and then he worked at the brickplant for awhile?

Scott: Yeah. He done the maintenance work over there for them. They always had sheds to build or something over there. He didn't join the union until Camp Swift. He joined the union and worked down there. So he worked as a union carpenter until he wasn't able to work.

Nickels: So you lived in the house that the log cabin was built on to?

Scott: Yeah. Lemme see, got something - You wanna turn that off a minute, and I'll - (tape recorder turned off briefly while Mr. Scott finds a hand drawn sketch of the house he was born in)

Nickels: This is the house plan? 
Scott: Yeah, my sister drawed this up. I thought she done pretty good just from being there, being a girl, you know. (smiling) This was the original log cabin.

Nickels: I see.

Scott: Of course, you used it for everything. You have a bed, and you have a living room, living room stuff and everything, and the fireplace was right here. Anyway, Abner-my great-grandfather Abner-raised six kids there. He built a kitchen on this side, (Abner's wife talking on the phone in background) the dining room on this side, and a pantry here. And this big bedroom here behind it. And this roof went all the way like this. And, this was all shed room on. And then, he had a shed room here, the bedroom. And this was a porch. And right here's where we had that picture taken right out here in front. And she was standing back here and we was facing the west sun. The garden was back there and you can see the peach trees and plum trees, and stuff back there.

Nickels: You had a big garden, huh?

Scott: Big garden. It was better than two acres back there.

Nickels: What all did you grow?

Scott: Everything that you could grow in the garden. Beets, peas, of course we had black-eyed peas down there, but I'm talking about English peas, and stuff like that. We always had a beautiful garden. We'd plant lots of tomatoes. I mean, set out lots of tomatoes.

Nickels: So you did a lot of canning, I guess?

Scott: Lot of canning. They had a home demonstration agent then that come around and show the women how to can. Mama and them bought one of them big old cookers that, I think you could put six quarts in it, or if you put cans you could put more of them, number 2 cans. And, we'd can that stuff. The work was not the cookin' and everything, it was the picking it and cleaning it, shelling it, whatever. We'd shuck that corn and silk it. That's a job, to get the silk all out of it. Mama would cut it off and can it.

Nickels: Did you take any to town, or did you just use it, all for yourselves?
Scott: No, no. The only thing we sold was peas. Now, we could sell every bushel of peas. And like I said, we had lots of peas, black-eyed peas. And we'd sell watermelons, we'd sell sweet potatoes, and peanuts. Finally they got a thrasher in McDade. Now before, we just fed the peanuts, hay and all to the cows, which is good feed with the peanuts in it. But, the hay itself, without the peanuts, is not too much.

Nickels: So, primarily in that bottomland and on the Aussilloux place it was mostly melons and peanuts?

Scott: Yeah, and sweet potatoes. Daddy planted cotton down there. I can remember one year he planted cotton down there. Blackland, they plant all kinds of cotton and they can make money out there, but on sandy land you can't make nothing. But they planted down there on that overflow land where I was telling you I planted them watermelons. And that cotton got over my head. I haven't seen a stalk like that around in Bastrop yet. You can go down to College Station on the Brazos River bottom, and you can see them stalks like that down there. But anyway, me and Dan slept right here when we were growing up.

Nickels: In a corner of the cabin?

Scott: In a corner of the cabin, here. And there's plenty of room for a bed here before you go into the kitchen. And, and we stayed warm, when the others had to have more cover, because that fireplace (noise of changing tape in backup tape recorder); we'd build a big fire in there, and they had what you call a backlog back there, that when it got a fire, you have something you put up here, $a[n]$ iron or a grate or something to keep the coals from popping out. And you had a hearth there. But a lot of time it would pop out past that, catch the carpet on fire or something.

Nickels: That was your only source of heat, though?

Scott: Yeah. That was the only source. And had a big old cookstove back there, of course. (laughing) We had lots of heat and everything; Mama always made biscuits because Daddy liked biscuits. She always made biscuits, and she made cornbread for us kids, and so forth. And most of us kids liked cornbread and sweet milk.

Nickels: On a wood stove? 
Scott: Yeah. Woodstove. See, when that teacher come and stayed with us that time, she talked her into getting a oil stove, and we put it here, but nothing didn't taste as good on that oil stove. You could taste that oil some. Man that was good eating, that cook stove, wood stove.

Nickels: What's the best wood that you used?

Scott: Uh, oak. (phone ringing) Oh. (recorder turned off temporarily)

Nickels: And electricity. Did you have electricity in the house?

Scott: Not until '39. We had it about, well we had it almost three years before we had to move out.

Nickels: But you had a wind charger?

Scott: Had a wind charger.

Nickels: And water?

Scott: Well, we had a windmill down that well, was down the hill here, you know. But, many a times I'd have to pack water up this hill.

\section{Nickels: Okay!}

Scott: (clearing his throat)

Nickels: Packing water up the hill, huh?

Scott: Yeah. That was a big job, and you had to draw it, I think it was, uh, eighty-five foot, or something like that to water. But I know the reason he put the well down there, because that hill was a good thirty foot. So, down in the bottom, to up there, that would have been that much further you'd a had to dig, up here.

Nickels: Yeah, at the house.

Scott: Yeah, at the house. So, it was dug down there. I don't know when Grandpa built all the rest of the house, but I know that he built this first. And I don't know how many of the children was born here before he started building. I'm sure he built this first, back here, this big bedroom. (pointing to drawing) And then he built the kitchen, and the dining room, and the pantry. And then he built this bedroom. And then this was the porch. And like I say, me and my brother stayed right here. And Dad and Mama had a bedroom, and they slept on this side, and the girls slept over here.

Nickels: Where would you get the lumber to build?

Scott: At the lumber yard.

Nickels: In Elgin, probably?

Scott: Yeah. But I want to tell you about the lumber in this house here. We made out good, but they would get up so early, and they'd do it and wake us up. So we talked them into screening in this porch, and we moved our bed out there. And then that was wonderful sleeping out there until it got wintertime! And we said, you want us to move back in the house, or do you want to get some windows and close that in? Daddy said, "Well, we'll just close it in." So, he put windows all the way in here; I think there was two big windows here, maybe three here, and a couple over here. So we had a sleeping porch. Yep, that was the best sleeping in the summertime, you didn't need no covers, and that breeze would come in there, and always a good breeze. So, it made a good place to live, and I enjoyed that house. So when we got the notice to move out, Daddy said, "I would like to leave the house there like it is." And they said, If you want any of that house, you better take it with you, because they'll run a tank over it, right through that thing. And Daddy said, "If you want to tear that house down for me - " Of course, he was working, he didn't have time to. Said, "You and Dan tear the house down, pull the nails, load it on that wagon - " Said, "We'll take it up here the other side of 290, to little Elf Gas Station." And so, we did. I don't know how long it took us; it took us just about a month, I expect, to tear that down. And I don't know what happened to the logs. We left the logs there, but the logs disappeared. (laughing)

Nickels: Well you showed me the potato bin that you built up there.

Scott: Yeah, a brick one. We dug down about two foot or something like that, and then built that potato house. We kept those sweet potatoes so we could bed them out, like I said, so we can get the slips. Before we done that, we would make a kind of teepee. And we'd take corn tops and stand them all the way around, and then cover that up with dirt. But that was a job to do it every time, and there in your potato house all you got 
to do was put them in there, and they would keep. I want to tell you something about my Grandpa Abner. Of course he had the garden at the same place that we got it out there. And he always set right here, with his rocking chair.

Nickels: On the porch.

Scott: On the porch. Looking out there, because he had a big blackberry patch right there. And one time, Grandma Louise, she went out the kitchen door, and went out there picking blackberries. And I guess Grandpa Abner was probably dozed off or something, but he heard this mocking bird cutting up. He woke up, he grabbed that ole shotgun: Boom! And, here come Grandma Louise - berry vines hanging all over her! "Ab! You liked to shot me!" (Abner laughing) He said, "Louiser, I didn't know you was in thar!" (Abner laughing hard) Oh, me. I tell you.

Nickels: What about when you got sick, what'd you do? You have any home remedies or anything?

Scott: Oh yes, we had all kinds of home remedies. I'll tell you what happened to Dan one time He was in Grandma's house here when he was two years old I guess, or something like that. And they always kept a, a little can of kerosene setting, I think it was on the window sill. And they would start the fire with that kerosene. You take a two-year-old kid, is getting into everything, and he come and found that can, and he picked it up and drank it. Of course, he passed out pretty quick. But it just happened to be Dad was there. If he hadn't been there, well I don't know [what] would have happened. They rushed him up to Elgin to Dr. Pannel. Of course they called him first and told him that they was bringing him in, and that he'd drink some kerosene. I don't know what he told them or anything, but some way or other he got the kerosene out of him, he got it up. Maybe he pumped his stomach out or something. I know he made Dan drink some orange juice and he never will drink orange juice anymore. He said it seems to remind him of that kerosene. Yeah see, he thinks the orange juice tastes kerosene after drinking that. (laughing) Oh, boy.

Nickels: What about poultices for colds?

Scott: Well, my Mama believed in [Vick's] Vaporub. And of course if we'd act like we had bronchitis or something, boy she'd put that Vaporub all over our stomach, and all over our back. And now I get a cold and my wife says, "Let me put some vaporub." [I say,] "No sir, you're not putting no vaporub on me!" (laughing) "I smelt that stu - " (laughing harder) Ah, no.

Nickels: What about snake bites?

Scott: You know, we was lucky. Knock on wood. (knocking on table) It was a pretty good walk to go from the top of that hill down to Sandy Creek, and back down Sandy Creek a ways to get the cows and the mules, because they always liked to go down there to that bottom. And that grass was better than everything down there. I come in from the field a little late one time, and uh, Mama said, "You got to go get them cows; they haven't come up." But I was barefooted, because I liked to plow barefooted. There's nothing feels any better that the wet, moist sand on your bare feet. I told them here a while back, "I wish I had an old mule and, and a plow, I'd get out there in the garden and plow with that thing, and pull off my shoes." Anyway, I walked down there, and of course you know how a cow trail is, weeds on each side of it. I didn't see nothing. Directly I felt something hit my blue jeans, like that. I said, "What in the world was that?" I jumped, and looked, and there was a copperhead. Of course, it was there where there was some pretty good-sized rocks. And I picked them up, picked up a couple of them, and I killed him. I said I was lucky that he hit me more or less on, the way it's kind of doubled there. He must have hit right there. Didn't get through. I don't know why, as many copperheads as there was down there, we never got bit by one. But I never seen a rattlesnake down there until after we moved out of there.

We'd get permission on Easter several times to go down there and hide Easter eggs, and have our Easter egg hunt down there where the old place was. Me and Allen was walking down that hill towards the well when we saw this rattlesnake go under that big rock that was to the right of the trail there. And he said, "That was a rattlesnake!" I said, "Well, it looked like it; it must have been." I happened to have some gas in the back of my pickup. So I went up there and got, just happened to have a can, poured some gas in that can and I come back and sloshed it under there. And we waited, waited a little bit, and here come that bugger out, and he was mad. He was about five foot long. And, he took off. I said, "You're not going to get away." I'd brought me a hoe back from the truck, and I was staying with him, trying to get a good hit at him. Finally I got him to where I could hit him in the head, 
and I hit him about three times on the head with that hoe, and brought him back to the house to show the rest of them. That's the only rattlesnake I killed. But, my Grandpa's place, there was lots of rattlesnakes over there, that mesquite place between where I showed you his house was, and where the Chandler Cemetery is. All of that land in there, mesquites. And we'd pick berries in there. We always had to be careful on account of the rattlesnakes. I remember I was at school one time. We was out there playing at recess, and of course the traffic went back and forth there. This colored man stopped, and he called me over there and he says "I want to tell you something." He said, "I just come by your grandpa's place, right below that tank." And said, "There was a rattlesnake that crossed the road in front of me." And says, "He was a good six foot long." And said, "He was bigger then my arm, right there." He says, "I know I've seen you boys picking blueberries out there, and y'all be careful." Said, "If he bites you, you'll die before you get to the house." And so, I appreciated him telling me that. That old man, when we moved out of Camp, he'd done moved down towards Sayers, on that other side of the road from Camp. And Daddy give him one of the wagons. He said uh, "Mr. Grover, what are you gonna do with that wagon?" Said, "You got that wagon, and you got your Daddy's wagon." Said, "You can't use both of them." He [Daddy] says, "You want that wagon?" And he said, "Yes sir, I sure would like to have it." So, he give it to him. (laughing) I would have liked to had some of them plow tools now, that walking cultivator. I don't know whether you've ever seen a walking cultivator, but it had two handles up here, and both of them was together where you move one, you moved the other. And you could get them just right where you could wrap that stuff up, and not cover it up, and man it made a pretty thing. You can't get that pretty a deal with a tractor. Because you could stop them mules and clean the stuff off the plow and everything. A tractor, you'll be dragging the stuff on, because, "Well maybe it'll come off; I don't want to stop and get off this tractor and clean that off the plow." But, that's the only way to get a decent job. You got to do that. But, about these snakes we talked about. It wasn't no piece from Grandpa's place, you turned off to the right, and you go back in there where one of them places was where he got coal, where he was mining the coal. One of the fellows I went to church with here in Elgin was a deacon in church; he's already died now. He was a little older than I am, but not that much older. He died fairly young; he had heart trouble. He wanted to go down there calling.
Said, "Maybe we can call up some fox, or coyotes." Had a call, which was a rabbit squealing, you know, something like that.

\section{Nickels: Yeah.}

Scott: We got them to come up at night, and you see their eyes. So he wanted to try it in the daytime, and we went right down to where one of them old mounds of dirt is. He was using that call, and nothing come up, so we started back. Just kind of walking up a cow trail. That's about all that was left there. I was fixing to take my next step with my left foot, and I jumped over thisaway, and he said, "You must have saw a snake." I said, "Yessir, a rattlesnake right there." Yessir, If I would have took one more step, he would have got me because he was thinking I was a rabbit. So he stepped back the other way, and I shot him with the .12-gauge shotgun. He was a pretty good-size snake, but he wasn't compared with the one that this colored fellow was telling me. It had nine rattlers, and it was about four foot long.

Nickels: Well, your grandpa's house burned, didn’t it?

Scott: Yes it did, yeah. And Grandpa got hurt. My uncle Edgar was an old bachelor and never did marry, and they was the only two living there. He [Grandpa] told Edgar, "Go in there and build a fire in the cook stove, and I'll cook us something for supper." So he went in there, and used that kerosene that was on the window, you know. He got too big of a fire going, and it had the old type shingle roof, not the asbestos roof, but the wood-shingled roof. And it was so dry and everything. Them sparks set them shingles on fire. Grandpa was almost eighty years old then, and he went and got the ladder. And see, this house was tall. It was off the ground, you can tell, the steps there. And, if you remember, had that brick foundation. Then they had beams and the wood stuff on top of that. You could crawl under that thing not on your knees, but you could just kind of get up on your feet; I been all under that house. And anyway, got that ladder, "Edgar, hand me a bucket of water." He got up there, and tried to get up to the top, and tried to throw that water. And if you're experienced about getting up on a ladder, you can't do things like that. Here went the ladder to the ground. It bunged him up; he had a big gash on his head. We saw the fire. I was, I was picking cotton over to the neighbor's place. I said, "I believe that's Grandpa Scott's house." He said, "We'll run over there." 
So, let's see, me and Dan, and Mama, and - the girls wasn't there. They had a baby setting job up in - Well it was my aunt that married my Uncle Alvin; he was Mama's brother. And, his wife, her sister married Sam Finch Duncan (??). They had a grocery store and barber shop next to each other on the south side. And they had a boy that was the age of Donald, a baby then. They babysat that kid while the man run the barbershop, the woman run the grocery store. So we got in that old, it was a moon; I guess you've heard of a moon vehicle. It was an old coupe. He'd built a bed in the back of it and made a pickup. And we had emptied our cotton in the back of that old moon. He said, "Well, I won't be able to get too close to the house; I got this cotton in there." We run over there, got there and of course it was all - I never seen such a hot fire. Grandpa was so particular about that house. He got on a train, and he went to Diboll over in East Texas, and picked out that lumber piece by piece. There wasn't a piece of lumber in that house that had a knot in it. I don't know how long it took him to do it, but Daddy said he picked that lumber out, they loaded it on boxcars, and it come to McDade. He went up there and unloaded it a wagon-full at a time, and hauled it out there to it. He was a particular man. I think I seen in one of these books where he was the one that built Wayside School. He was always a trustee of it, and he was a chair of the trustees to hire the teacher and so forth.

Nickels: And his name was, again?

Scott: J. H. Scott. John, John H. Scott.

Nickels: He also had a huge tank there by the house, and a cattle dipping vat.

Scott: Yeah, he had that cattle dipping place. He was quite a rancher, back in the days. Of course he had all that land. Now I'll tell you about the Chandlers. One of the younger ones loved to go on the cattle drives, all the way to Kansas, Dodge City, Kansas. He come back one time on a different horse, and somebody in McDade told him, he said, "The feller's looking for that horse." Said, "You better do something with it." Said, "You know they'll hang you here in McDade for a stolen horse." He said "I didn't steal it!" "Well, you got it. Possession is nine points of the law." And so, him and two of his brothers gathered up and moved to Montana, and didn't go through that hanging business.
Nickels: What year about would that have been?

Scott: Well, that would have to have been in the twenties. I wasn't old enough to remember it I know, but I heard Grandma say when they went to Montana, one of them, the one that, he actually changed his name to John Chandler instead, but his name was Magruder Chandler. And, he changed it to John Chandler.

Nickels: Well, was cattle a big operation there, or not?

Scott: Yeah, yeah. And he was into buying steers, and raising them on that grass, and selling them. Along about 1918 or '17, or somewhere during the — when World War I was going on - he lost a lot of money on it. And then he lost some money. He had to give up part of his land because my Uncle Walter, the oldest boy, he had a filling station and garage, mechanic garage there in McDade. And I guess he'd do things on credit for people, and they couldn't pay him, get gas and oil, and they couldn't pay him. Finally, he went in debt because he couldn't pay his expenses. And, so he lost what was known as the Herms [also pronounced Hearns] place. That was Grandpa's place back then. Otis Evans wound up with it. Well, Will Evans, his daddy, is the one that wound up with it, and then he got it from his daddy.

Nickels: Do you know why that's called the Herms place?

Scott: I don't know exactly, but seems as though somebody must have, Grandpa must have bought it from somebody named Herms.

Nickels: Hmm.

Scott: You know, there's nothing about the Hearns (??), except it was known as the Herms (??) place.

Nickels: Yes. Did you have a lot of hogs? I know you said you butchered hogs and made sausage. And what about chickens and eggs?

Scott: We always had our own chickens, and all the eggs. We didn't have to buy any eggs. And Mama would raise turkeys. She had trouble with the turkeys. We tried to keep them up at night, and we tried to keep them out of Mr. Flemings' place. Mr. Flemings owned the place that was down, right below us coming off of 
that Scott Falls Road. And we had to come through his place to get to our place. It was Belle Scott's place and she sold it to the Flemings. He always rode a horse, and he saw them turkeys down there one time. He took them two dogs of his, and sicced them two dogs on them, and they killed about twenty young turkeys. Aw, Mama got so mad. And Daddy got mad; I thought he was gonna shoot that old man. "Well, you need to keep them at home!" (laughing) We went down there and gathered up them turkeys, and cleaned the ones that wasn't tored up. That's the first time I'd eaten fried turkey, and I mean that was good! You know, they was just the right size to be fried, or cooked. Of course, I've eaten fried turkey since then, deep fried turkey. We'd builded a church over close to Waco. We wasn't building a church, we was building a parsonage. And they said, We gonna have a big meal here Wednesday night. Y'all like deep-fried turkey? I think everybody in the bunch of the retirees that was building the parsonage said, No, we hadn't - [They said], Well you're gonna get to eat some tonight. So, they had this fellow, he had one 'o them big pots. He put peanut oil in there. And so he boiled that turkey, and talk about good, now that was some good.

Nickels: At Swift did y'all get together to help your neighbor a lot?

Scott: Yes, I told you about getting together to put up that windmill that time, there at that well you know.

\section{Nickels: Oh.}

Scott: I told you about putting that windmill up there. Daddy had bought this old second-hand windmill somewhere, and I think it was practically wore out, eh, but it must have blowed down or something. There was supposed to be four legs, was it? I think it was four legs. And it had three. So he had to put a cedar post in the ground for that other one, and bolt that, that other leg to it. Anyway, they got all together, and after all the men was there they had their roping ropes, and everything. They had two or three teams of mules. They got it all figured out, and they pulled that thing up. They had all these other men on the ropes to hold it and, or, "Stop right there." And they bolted it up there. They got it to working.

Nickels: What about helping out with the farming, or picking cotton, or melons?
Scott: Well, most of that, you had to pay somebody to do it, because they was doing the same thing. We had lots of colored people that lived close to us, and we would get them to help. Especially if Daddy was working, why we couldn't keep up. And going to school, and things that had to be done. Sometimes we had a person that we knew, a white fellow, to stay with us, board with us, room and board, and plow until we could get caught up where we could do it. One of the things I enjoyed most, we planted some sugar cane one time. And this colored fellow that lived on Sandy, right past where Sandy and McLaughlin runs together, it was down below that. He had a syrup mill. And he had this press fixed from this old mule that went round and around. You had to feed that sugar cane in that press, and screw it, squeezed that juice out in a pot. And then he had a vat there to cook it. And, so, I went down there to help that day. And he assigned me, he says "Your job is to keep that mule going." I said. "Okay, I can do that." And he says, "When I say stop, you stop." And so, that worked out good. Boy, that was the best molasses that I ever eat in my life, when you got them hot biscuits, and that butter, and that fresh cooked molasses. I don't know how much we made that year, but it lasted all winter and then some. But we never did try it again.

Nickels: So he had quite a little operation going there?

Scott: Yeah, a fellow from Oak Hill. Well, he was one o' Mama's cousins, come up there, and he says, "I want you to show me where, or tell me how to get to that syrup mill." I said, "Man, I can't tell you how to, but I'll take you and show you." So, he had a Model A Ford, and the sand was pretty deep, you know. Especially if they'd been through there in a narrowtired wagon, it would make it so hard to get through in a vehicle. By time he got there, he said, "Well, I like that molasses, but I can't see hauling that sugar cane (Abner laughing) all the way up here, (laughing harder) and coming down this sandy road." And talk about neighbors getting together. The county had some what they call wood scrapers that two mules pulled. And it had like two wagon wheel, you know, it looked like wagon wheels. This Sandy Creek, you go up a hill to go by the Aussilloux place there. And the sand was so deep, like I was talking about for half a mile up there to where you turn to go out the gate, to go out of the Camp. The county agent said he would loan them neighbors them scrapers. They had to furnish the mules, furnish the driver, and they 
could haul that red clay and put on that road. Then when you got it mixed up, you wouldn't have no trouble no more, going in and out. So I was just big enough to go over there and drive one of them pair, I couldn't load the thing. You had to strip it to load it, and then strip it back, and then unload it. So, one of the older neighbors that was getting up in years, why he would dump it up there. I'd drive it back, and another one load it. And we just kept going back and forth. We got about six inches of clay on that sand, they graded it with a, they had a bulldozer but it had the old grader type, you pull behind. And they graded it, got it in clay.

Nickels: Is that the road that ran by Aussilloux's house and then down by his lower grape fields?

Scott: No, it's the county road. See, that wasn't the county road, the one that you talking about, that we come out that time. That's not a county road. The county road is the one that goes on over and makes a corner, and goes by Scott Falls.

Nickels: You were going to tell me about Aussilloux's dam, how that was built, and the gate that he had on there?

Scott: Yeah, I never did see the gates, but I know that you could tell some of the rock was gone. I would like for you to talk to my cousin who lives in San Marcos. You could probably make an appointment with him. His name is Malcolm Scott. I don't know whether he's retired and sold his drugstore, but he had a drugstore in San Marcos. He's probably sold it. I don't know whether it still goes by Scott's Drugstore, or what. It was right there on the south side of the square. I remember right where it was. His mama and daddy are dead now, and so, I don't get to see the two boys. He's got another brother named Eddie Joe, and he lives in Conroe. We used to see him quite often, but we don't see him anymore, and I don't even have his name and address. I don't know whether he moved out there. He runs cattle, somewhere close to San Marcos. But I never did know whether he built a house and moved out there, or still lived in town. I know he lived in town when he had the drugstore.

Nickels: Well I'll try to look him up.

Scott: Yeah, you can try to look him up. He's probably in the phone book: Malcom Ray Scott.
Nickels: He knows about Aussilloux's dam?

Scott: Well, he's the one that helped, like I told you. My brother-in-law and him are the ones that got that gate out of there. When that gate was closed, it built the water up so far, and I showed you a little notch in that part over there, and I told you about a chute up on the bank.

Nickels: Yes.

Scott: That went all the way down. I think I could still find some of that chute. I know the last time I walked down in there you could find remnants of it. He used regular sheet iron to make a trough. Of course, he had to start from the low point. And, he would lap it over there. He had, like, two by sixes or something on each side of it. It might have been, it was some kind of wood. It might of been of just logs that he cut, you know, small ones. He bent that tin in there like that to make a trough, and that water would just run from one to the other piece of tin, uh, all the way down there. But when the gate was open, water just run down its regular way, you see. When that gate was closed, it would build up, and run down that trough. Of course you wouldn't need to do that long, and let it run back to its regular channel at the falls. I know I spent the night, one night, at this house that was up on the hill; belonged to Ott Scott. And it rained, and it rained, and it rained better than two inches that night. And about two or three o'clock in the morning I heard this roaring, and, "What is that? What's going on?" He says, "That's that water going over that dam." And see, it, it was just going over, making such a racket, you'd think a, (laughing) a train or something going. (laughing)

Nickels: Was Ott Scott's house outside what is now Camp Swift?

Scott: Well, it was where they've got the fence for Camp Swift. It wasn't past that; it was actually on the road right-of-way now.

Nickels: I see.

Scott: Um-hm.

Nickels: Was the ditch lined with tin from the dam all the way down to his lower fields? 
Scott: Yep.

Nickels: We have traced that. We've walked that whole thing, and there's no metal there anymore; it's gone.

Scott: Couldn't find any anywhere?

Nickels: Portions of the ditch are still there.

Scott: Of course it's been several years, because you know they're so particular about you going in there unless you have a permit. Poor old Ott, he always liked to go down there, and walk down the branch to Sandy Creek, and fish. There was a hole down there, and you could catch fish. So he wouldn't say nothing to nobody, he'd just take his little cane pole and some worms, and go down there and fish, and come back. And the land on the other side of the road, he got that back. But the land on the east side, or the south side, he didn't get it back. And, he was walking down there and fished. Of course he knew he was just like all the rest of us Scotts. He enjoyed going down there. It brought back memories, and everything. He caught several little catfish, and big perch and everything. He had a pretty good string of it. (Abner chuckling) He come back up to get this truck. Instead of leaving his truck over there in his place across the road and slipping over there, he just come right on up the branch and by the dam. There that game warden was. Said, "Look like you caught a few." He said, "Yeah." "They biting pretty good?" "You want some of them?" (Abner laughing) He said, "No!" Said, "You know you're not supposed to go down there." Ott says, "Yeah, I know, but I was raised down there, and I was just wanted to go back down there. I enjoy going down there and fishing." So, he [the game warden] didn't say no more, (laughing) he let him go. (laughing hard) Oh, you'd have to know Ott, because he was a good old boy.

Nickels: Well, your uncle C. R. Nick Branton lived there.

\section{Scott: Yeah.}

Nickels: And didn't his son have a house right there by the dam?

Scott: Yes, it wasn't right by the dam. It was up the road just a little bit, but the field come right down to the dam. And that's the one my brother-in-law lived in, the one that I wanted you to talk to. They lived in that house, and Nick Branton moved out of there way before. He had to move, because he bought a grocery store in Elgin. And then he lost lots of money, you know, he let people have it on credit and everything. He had to sell that place to pay off his debts. So he sold it to a fellow by the name of Adams from Houston. And that's who, Mr. Snowden and my brother-in-law, they rented it from this fellow Adams from Houston. Of course, they didn't know what was going on about this moving out, you know. They didn't notify them, they notified Adams. And, there they'd done started a crop and everything, so there they had to move.

Nickels: That was the house on the hill?

Scott: No, that was the house that was before you get to Scott Falls.

\section{Nickels: Oh.}

Scott: On the left.

Nickels: Oh, okay.

Scott: But Ott, he knew because he was the owner, and he had to. I don't know what he done-Yeah, he tore that house down, and he built the one he's got on 290. That's right.

Nickels: Do you know anything about the mining operation out there, that lignite mine? I know that burned I think in about ' 28 , the mines did. And so, it was probably closed down before you remember it.

Scott: Well, I went over there. See, my grandma had more eggs than they could use, and they'd sell eggs in McDade. They had a buggy, and - I told you about my uncle that never got married. When I was staying there, he had wanted me to go with him. Said, "We're gonna deliver some eggs over to the mine." And so, I went over there with him. I'd open the gap for him. We took them eggs over there and them Mexicans would buy the eggs from us. They was glad to get eggs. I don't know how many dozen we took. I was really too young, and six years old. I don't know how many we took. But I can remember that mine! Yes, I took that old boy over there, that's the last time I was over there, and I hadn't been there for, from the time I delivered eggs over there until I went (laughing) that time and found that snake. That was quite an 
operation. I seen the pictures in this book. And they built that rail in, in there to it.

Nickels: Do you remember any houses there?

Scott: I can't remember much about them. They was just little, one room, box houses, you know.

Nickels: Yes.

Scott: It's what's called a box house, one by twelves standing up and down, all of them, and then you put a slat on top of the joint.

Nickels: Well, supposedly they had a little company store there, and several of those little houses.

Scott: Probably. But see, it wasn't all that far to go to Sayers. They had a store at Sayers. And they could get the main things from there. I'm sure they had to walk, and of course those Mexican people, to walk don't bother them. I hunted out at Big Bend; all of those deer on that wall there I killed in 1980. And every year I went out there, and I was always looking for a good one. Them two over there, them three top ones was the best ones. I always thought I'd get a ten point out there, but I never did. We was hunting on a Pope Ranch. And you've heard of Pope, some kin to that lawyer in Austin, Pope. Anyway, we hunted out there, and at around noon we'd go to the house and fix us a bite to eat. Other times, we didn't stand or sit anywhere. I had an old yeller truck out there in the shed out there that's a 1939 Chevrolet threequarter ton, four-speed. They're stout, old trucks. I would pull that thing behind my half-ton pickup out there. It was a little bush to pull it, but we had a thing to pull it with, and it worked pretty good. And then, if one of them tires got low or something, you had trouble, because it would go to swaying. We usually took two sets of tires, and just drive on the pavement. Then we'd take them off, and put them old, hard, sixply tires on to drive it in stickers, because everything out there got stickers on it. And drove all around. Sometimes they'd be shooting at them deer and I'd still be driving, (laughing) them running. But, we killed some good deer. My brother-in-law, Lonnie Krueger, Shirley's husband killed the best deer out there. He's got some tens, and eleven points, twelve points he killed out there.

Nickels: Were there a lot of deer at Swift?
Scott: Not when we lived there. They got to be a lot when we moved out of there. The reason they wasn't many there is because everybody had dogs and everything, and they kept them run out. They stocked the state park, Bastrop State Park with deer. And they come out of there. So they got pretty thick in there about the time that the soldiers was at Camp Swift. I know I talked with one of them, and they would, they'd go hunting at night down there; get in a jeep and go down there and shoot them at night and stuff. Then when I got our place back for grassland in ' 60 and ' 61 , and ' 62 ; I think it was ' 62 when I killed that one in there on the wall. Can you see it?

Nickels: Um-hm.

Scott: I killed it down there at the old home place.

Nickels: So the military leased back the land for grazing?

Scott: For grazing, yeah.

Nickels: Did a lot of people take advantage of that?

Scott: Well, yeah. All of that, that they wasn't using, you know. There for awhile they wasn't using it, until the Korean War come along. Then they went to using it again. I don't know why they couldn't do all their maneuvering around up at Fort Hood. They had so much room up there. They said they needed that soft, sandy ground. We have been down there and found them, what they call four by fours, and big trucks, two- ton trucks with a big winch on the front buried down there. One of them was on our place. They had pulled it, aw, maybe a hundred yards with that winch. Just hooking to cedar trees, and pull it awhile this way, then pull it awhile this way, till they run out of trees. Finally they broke that winch all to pieces, and they had to go off and leave it till it got drier weather before they could get it out.

Nickels: What kind of mail delivery did you have before you left Swift?

Scott: We had a mail carrier that come around in a car every, let's see, five days a week. I don't think he come on Saturday. Five days, Monday, Tuesday, Wednesday, Thursday, Friday.

Nickels: And what about telephones? 
Scott: We had a telephone. But my daddy had to cut the posts and put them up. I think they furnished the wire. They brought it in there by Wayside School, and, right on to our house. And they come by the Floyd place, they had a telephone, and on down to the Fleming place, and they had a telephone. But the only trouble with that telephone, when it rang everybody can go answer it. You got, like a long and two shorts, or something with your ring. And, you'd have to remember what the other people's was, (laughing) because you couldn't tell no secrets on that phone. (laughing) Everybody listened to it. (laughing)

Nickels: Well, there were several little communities out there apparently. I know there was Wayside, Oak Hill, and what other little communities existed out there?

Scott: Well, actually Wayside was different from Scott Falls, and, and they called that Spring Branch community. They didn't call it Scott Falls, Spring Branch community. And they had some little parties and stuff on Friday night, or Saturday night. Sometimes we would go to them. Sometimes the Sowells that lived over close to Grandpa Scott, they'd have a party, and we'd go to it. But, it was more stay at home.

Nickels: I wanted to ask you about the old fort that is mentioned in some of the deed records out there, possibly dating to the 1840 s or ' 50 s, somewhere in there. It's supposedly over off of McLaughlin Creek.

Scott: Yeah, they always told me it was north of McLaughlin Creek. I thought all the time, that it was on the other side of McDade-Sayers Road. But some older people said it was in the Westbrook place. But, I don't know that.

Nickels: I see.

Scott: Yeah, and there also was another school, somewhere, that was on the Westbrook place that probably my Grandpa and maybe my daddy went to it. And I know my neighbors, a Mr. Bryant Daughtry and some of them went to it. But, I don't know exactly where it is. It was somewhere between where Uncle Nick's place corners, and the Floyd place, and the Fort place; somewhere in that vicinity. But, I never did know exactly where it was.
Nickels: I see. Well Mr. Scott, I think that's all I have. And we appreciate it very much. Is there anything you'd like to conclude with?

Scott: Well, I'd just like to say that if there's ever a possibility of getting that land back, I'd like to have our part, especially that ninety acres, just for old times sake. My great-grandpa spent a many 'a day trying to get that developed to what it was when he raised his children and so forth. Them six cedar trees that was around that house, each one of his childrens set out one of them. A cedar tree is not hard to move. If you look on that side, to protect my cows, kind of, from the garden over here that way. I just sat them out to see what - And then the old saying is, "If a cedar tree ever gets big enough to shade your grave, then you'll die. (laughing) There's nothing to that. (laughing hard)

Nickels: Well, I certainly understand your feelings.

Scott: Well, until I got this book, I never did know too much about Grandpa Scott and so forth. Because they didn't talk much to younger children. They think, well, they don't know nothing, they don't need to know nothing. I know Grandpa Scott knew about them hangings over at McDade. He never would - the only person that I ever got to talk to, and I enjoyed talking to her, was Miss Flemings [Fleming], who [whose husband] was a brother-in-law to the Fleming that lived next to us down there, that had the Evans place. I mean, the Evans got it later. Her husband was Frank Flemings, and they are the grandma and grandpa of Jack Scott, who I give your name to. I don't know whether he listened to a lot of that what she said. But she was telling me about that Christmas day that them hangings took place, and they had them all down there on the depot dock. That was when you had to be careful about how you lived. That's the reason my uncles, great-uncles wound up in Montana. (laughing) He didn't steal the horse, but he traded the horse, and with some boot. He didn't know where the horse come from, and here he come back to Texas, and they gonna hang him for it.

Nickels: Well thank you very much sir.

Scott: You bet. 


\section{Interview 2-29 June 2004}

David L. Nickels: My name is David Nickels, and I am now interviewing Mr. Abner C. Scott for the second time. The first interview was conducted on the twenty-ninth of April 2004. This second interview is being conducted on the twenty-ninth of June 2004 in the living room of Mr. Scott's home at $155 \mathrm{VFW}$ Road just south of Elgin, Texas. This interview is also part of the Texas State University-San Marcos, Camp Swift Oral History project, sponsored by the Texas National Guard, and conducted in conjunction with the Center for American History, The University of Texas at Austin.

Nickels: Let me ask you about church affairs, Sunday services, or maybe revivals. Maybe where you went to church, any preachers you may remember around the Camp Swift area.

Abner C. Scott: Well you know, on the farm, and the Depression come along, and I told ya one time that we didn't register the old Model T truck. So, we went to Oak Hill in the summertime, in the wagon. And us kids were on pallets in the back o' the wagon. We went nearly every Sunday, and we had different preachers there. They, couldn't afford a Baptist preacher, and they couldn't afford a Methodist preacher, and they couldn't afford a Presbyterian preacher, but we had one, once a month from each. My mother joined the church, and it was at Oak Hill, under the arbor you know, when you was down there; I carried ya down there, and there's a[n] arbor there. They've always had a cedar-covered arbor. Now they got it covered with tin, but it was a cedar-covered arbor. They'd re-do the cedar every so often to make shade. 'Course, it would keep the rain off of 'em. And she joined when Brother Holt was the Baptist preacher that come. I remember I was about, oh, probably seven years old when she joined. She was baptized over there in the Hancock Gin tank. You know, all gins had a tank. And she wore a white dress. I can remember it. She was baptized in the muddy tank. (chuckling) It was never white again! (laughing) But, that was about most of my church goin'. I didn’t join the Baptist Church here until I got back out of the Navy. And, I had two children already. Billy was born in '46, and Sandra was born in '51. After that, my wife said, "You have to go to church with us." She was taking them to church every Sunday. So, I went, started going. I said, "I'll go, but I'm not gonna let any o' that rub off on me." I thought that the world owed me a living for sending me off to service over three years, and missed out on my hunting and fishing and everything. And I was trying to catch up on some of that when I got back. Working through the week, with Saturday and Sunday for recreation. But sure enough, about '52, why I joined the Baptist Church. Now I'm a deacon in the Baptist Church, and, I hardly ever miss a Sunday, unless I'm either sick or it's a emergency, that I miss a day.

Nickels: That's good! That's good. Did your folks go about every Sunday there at Oak Hill, at Swift?

Scott: Just in the summertime, and pretty weather.

Nickels: I see. Were there any camp meetings, or tent revivals?

Scott: Oh yes, they had revivals there, and after we got uh, see, in '33 or '34 somewhere there, well we got that Model A, and we would go to the revivals in McDade. Daddy was Church of Christ, and Mama was Baptist. (chuckling) That kind of messed us up going anywhere too much at a time. But anyway, we went several times. We even went to that Weepin' Willow Baptist Church. I remember going to it. And I was the lead carpenter on rebuilding it, here when I was working with the Baptist retirees, building mission churches. We went to a revival there when I was about seven or eight years old.

Nickels: Weeping Willow?

Scott: Weeping Willow, yeah, there in McDade, right there where you turn to go to the main part of town off of 290.

Nickels: Was it a tent revival?

Scott: It was in the building.

Nickels: Last time we talked about you trapping, and preparing pelts. And, we were wondering, did you use steel traps, or how did you trap?

Scott: Some, you know, they was expensive; I only had two or three traps. But I had a carbide light, and you could see the eyes of them, with that light, you know. They'd look at you. And of course, them two dogs, old Joe and Blue, they would tree opossums, and ringtails, and so forth. I was a pretty good shot back then. I'm not anymore, but I can still shoot, I killed a deer this past season. I could shoot that eye out if they 
was looking at me (laughing), with that .22 . And that way you didn't tear the hide any, if you shot 'em in the head. Skin 'em, and stretch 'em on them, I called 'em little ironing boards. Daddy had made a whole bunch of them, different sizes, and if you had a big opossum, you'd use the biggest one. The smaller one, you'd use for a ringtail or skunk. That skunk, why I didn't really want many of them! (laughing)

Nickels: So you had two or three traps, and did you set them any particular place, or use any particular bait, that you recall?

Scott: Well now, the main reason I used the trap was when coyotes would come, and interfere with the chickens and so forth, and turkeys. I'd find one dead that they'd eaten part of. And you hang that chicken up with a piece of baling wire, up so high, where they would jump up an' try to get it, and had the trap right underneath. I caught about three coyotes, but I never did sell one of them. (chuckling) It was a job trying to save them. They either was mangy, or the hair was coming out, or somethin'.

Nickels: We talked a little bit last time about your trips to the gin in McDade. Do recall much about the gin, and the activities around there?

Scott: Well, that's where we weighed the watermelons, it was at the gin. They had a scale there. I only went one time with a bale of cotton to the gin. I went several times with the wagon, and then later with the, the old Model A to weigh the watermelons, and then go up to a spur there that had seven, eight cars, freight cars that you'd put the watermelons on. And, unload 'em and go get another load.

Nickels: What about wild plant foods? I know you had a big garden. But what about things like wild grapes, or poke salad, or dewberries?

Scott: Yeah, we always got, in the spring, always two, at least two messes of poke salad. You had to cook that a certain way. They say it's poison if you don't pour the water off about three times. It's just like spinach or anything else you get. Heat it with cornbread 'n pour vinegar on it. We call it pepper sauce. You had vinegar and hot peppers in a little bottle, and you put that on. And we picked mustang grapes, and made jelly out of it. And dewberries, we'd pick dewberries because they would grow up on the fence rows around, especially down on the creek. We'd pick all of them we could, save all of them and Mama would make jelly out of them. Now I raise my own berries. I got Brazos, Improved Brazos blackberries from A\&M. That's a little different, where you can just go out and pick a bucketful right quick, and don't have to walk and look, watch for copperheads (laughing) like you do out in the pasture.

Nickels: Of all the pelts that you processed, what about fox hunting? Did you hunt foxes for a purpose, or were there organized fox hunts, or anything of that nature?

Scott: Well, now, some of the town people, I call 'em town people, from Elgin, come down to our place just to run fox. And they never did kill them, unless that silly fox decided to jump out in all them dogs down there. See, we'd jump coons out, and then let the dogs kill 'em. And that would make a better dog out of 'em. But, not a fox. We'd always call off the dogs, and take 'em all away.

Nickels: So that was a pretty well-organized event?

Scott: Yeah. They'd say, Listen ta that music! Listen ta old Joe. Or, Listen ta old Blue. Or, Listen to ol'-Whatever, ya know, they was talkin' about which one was gittin' the closest to the fox. (laughing) Which one was leadin' the pack!

Nickels: What could you do on your neighbor's land, and there was maybe a gentlemen's agreement, like, You can cut wood on my property, or I can run hogs on yours. And fence lines weren't really a major consideration?

Scott: Now neighbors were neighbors, and what you have is theirs, and what they have is yours. You could go on their place and pick dewberries, whatever, wild plums. It was all right. Of course, you usually went to them, and like Mr. Flemings, you'd say, "Mr. Flemings, you gonna use all them plums; looks to me like they's fallin' off, an - " "No, no, no, git what you want. Go pick you some for your mom and let her make jelly out of 'em." I know I've done that several times, and I went as far as down below Oak Hill and picked wild plums down there from Mama's cousin, a Hancock. We, we tried to preserve everything and not let it go to waste.

Nickels: Where was the Hancock Gin? 
Scott: Just below Oak Hill, about two miles.

Nickels: On a creek?

Scott: Right across Piney Creek. You've seen Piney Creek there. You would go across Piney Creek, and you'd go back that way, and then you'd go back towards McDade a little ways, and it was right there.

Nickels: What about, rabbit drives, like a social organization, or group activity; maybe boys and their dads having rabbit drives?

Scott: I never was on one. I've seen it on television and stuff, but-We had cottontails in that mesquite pasture there, and you could go down there and shoot a cottontail anytime you wanted to. Now, jackrabbits was a little different. We'd set on the fender, or in the back of that ol' Model A and shoot the jackrabbits with a shotgun. And so, whoever was driving would follow. Most of the time they knew where the stumps and where everything is so that you could keep following it till somebody shot. (laughing)

Nickels: I understand that during the Depression years, wild game such as rabbits was really important?

Scott: Yeah, a lot of people eat the rabbits. But, we had so many squirrels to eat on account of that pecan bottom we had down there, that we never did eat any rabbits. We fed the (??) to the dogs. I would kill 'em and about half skin 'em so they wouldn't get all that hair in their mouth, and let the dogs eat 'em. 'Cause we couldn't afford to buy dog food like people do now. They spend more on dog food now than they do on their children.

Nickels: Last time we talked, you told me some good stories about your mules, and your horses, and I was wondering, did anybody around here use oxen? Or, what was the advantage of using a mule versus a horse?

Scott: Well, a[n] old mule is just tougher than a horse. You ruin a horse by overloadin' 'em, and they get to where they don't have the gait that they had, you know. You just ruin a horse. A mule is just tough, and it's just built for work. You talk about oxens. Before my time - my Grandpa Scott, John Scott - where we went to see that big old tank and stuff, he had a couple of oxens. And they was tame and everything. He had them yolks, and I wanted to get them yolks, but I didn't get them. I messed around too long, and somebody else got 'em. (chuckling)

Nickels: He was the only one that used oxen that you know of?

Scott: He, he was the only one I know of.

Nickels: You fished a little bit when you were there. Other than using a line and a pole, were any other practices used, like black walnut poisoning, or maybe muddying the waters, or fish nets?

Scott: Naw, that didn't work too much. We always went down to the, even in the Depression, when we didn't have a vehicle, we'd go with the wagon and team, and several families would go down to the Colorado River, which is, aw, twelve to fifteen miles from here now. Well, it's sixteen to Bastrop; it's nearly that far to the river. Anyway, we'd go down there to spend the weekend, or three or four nights. And then, you could set trotlines across, with several hooks on them. And you seined bait out of the shallow part of the river. Put small perch, and minnows and so forth, on the line. And you'd catch enough fish to, you know, you couldn't save it long, but you could catch the fish to have several fish fries.

Nickels: So the poisoning or that kind of stuff didn't work?

Scott: No. Us kids, we had heard about muddying the water, and so, we got in a hole in Sandy Creek one time. And boy, we was just a stompin' around, and them fish'd come to the top, but you couldn't catch 'em. (laughing) We had that ol' water so muddy - (laughing harder); we was so muddy but we didn't catch no fish that way!

Nickels: We've heard from a couple of other folks about free range for hogs. And, October to February maybe letting hogs run on everybody else's land, and then you maybe penned them up.

Scott: Yeah, they let them run loose, when you lived that far away from the main highway, and stuff. You had to know your hogs and everything, and get the right ones. And of course it was a gentlemen's agreement; everybody would get their own hogs, and they wouldn't get the ones that didn't belong. I know we went down to Camp Swift one time after it was, you know, we'd slip down there and go dove hunting 
or something. Wasn't supposed to be there. And Otis Evans had left some hogs down there. They was on McLaughlin Creek, down in there. My brother-in-law got a dove, and it fell under the tree, in the middle of a bunch of scrub brush, up under this cottonwood tree, where the dove fell. And I heard him hollering, and he said, "Come here an' get me out!" (Abner laughing) This old hog was under that tree, and had some pigs, and he was goin' in under that brush, and she started chompin'. He'd clumb one of them bushes, and he was up that bush, and he said, "Come and help me get out o' here; I can't get out!" (Abner laughing) So, I went down and run the old hog off.

Nickels: Did it apply to more than hogs, any other livestock?

Scott: Well, Otis uh, told me, see I had that ninety acres fenced off, just west, to run cows on. And he said, "Open the gate and let yours out in here if you want to, if you run out of grass on that ninety acres. I can get 'em up for you." He had that big pen down there on the Fleming place, between where our mailbox was on the main road. And said, "Just let 'em out. When I get mine up, why I'll let you know, and I'll get yours up." So, that's what we done.

Nickels: The settlements out there that I know of, are Oak Hill, Wayside, Spring Branch maybe, Piney. Are there any other little communities or settlement areas out there?

Scott: Well, actually Grandpa's place was known as Duck Pond, and that was the Duck Pond community. Not the big tank that he dug, but where that McDade Road goes to Sayers. Right where you turn to the left, to go to Oak Hill, and you go by the Chandler place. Before you get to the Chandler cemetery, on the left, out in that mesquite, there was a low place in there that, in wet weather the water would just stand. It never had been dug out, and they called that Duck Pond. They call that Duck Pond Road now, out of McDade. Instead of Sayers Road, they call it Duck Pond Road.

Nickels: So, there were houses in that general vicinity?

Scott: Well, all around, yeah.

Nickels: Any other communities?

Scott: No, I don't believe so.
Nickels: What about colored folks, black folks, or Mexican communities, or little settled areas? Were they kind of segregated?

Scott: Well, kind of. They wasn't hardly any white people that lived between where we lived and of course 95 wasn't there. When they put 95 in, from Bastrop to Elgin, they wasn't any white people that lived in that vicinity down there, because it was all colored people.

Nickels: The Depression years were obviously bad here just like everywhere else. What about any CCC projects, or cattle killings? Maybe CCC projects to begin with?

Scott: Well, Daddy went to work for the county then, when they went around building cement bridges for these little, they call them culverts. They put in a bunch of them in probably '34, '35, and '36, somewhere along in there. Them old wood bridges would, you know, they just wear out, and them mules got to where they'd step through 'em and everything. They built a whole bunch of them. And you know, the CCC boys built the Bastrop State Park down there; the pavilion and the swimming pool and all of that was built by the CCC boys. My first cousin, I can't remember what year it was, but it must have been about '34, '35, they had a fire in Wyoming, and he went with a bunch of the CCC boys from Bastrop. I don't remember how many of them died, but he was one of them: Clyde Allen, my Uncle Alvin Allen's only boy. He was five years older than I was, and he burnt up in a fire up there. They was pinned on a rock, and it was so hot that it was just burning their skin. And he couldn't stay there. He started running, and that was it. The ones that stayed on that rock, I went to school with one of them, and his face was just all scarred along here. But he lived through it.

Nickels: Were there any CCC camps in the area?

Scott: Yeah, down at Bastrop; that's where it was.

Nickels: At that time, I guess President Roosevelt implemented cotton reduction, and he implemented stock reduction, and hog reduction. What do you recall about any mass cattle killings?

Scott: Well they had one. You know where we lived? We drove, by foot, up by Scott Falls, on up towards 
the Butler Brickyard, out to the old Highway 220. And that's where they was gatherin' 'em. I don't know how many we took, five or six. But you couldn't get nothin' if you sold 'em. They just wasn't - And, I remember setting on the fence and watching 'em shoot them cattle. It was sumpthin' else.

Nickels: They gave you a little bit o' money for them?

Scott: Very little!

Nickels: Do you know what they did with them after they killed them?

Scott: Well, they was a bunch of colored people that would pick different ones and take them and, and dress them, and get some meat out of them. But a lot of them was just drug off for the buzzards to eat.

Nickels: What about the limits on cotton production?

Scott: Well, that's somthing I never did know much about, was cotton you know. Cotton was raised this side of the hills, in the blackland. We'd raise, more or less, watermelons, and peanuts, and sweet potatoes, and stuff like that, and peas, that we could get cash money for. We planted cotton there one time. I don't know what we got for it, but I can remember we planted it in that overflow land, where Big Sandy got up. That cotton got higher than my head, and I was a teenage boy then. And, you didn't have to crawl along to pick the cotton; you could stand up! (laughing) I remember my Grandpa Allen was over there. Daddy was off working somewhere, and after we got this bale of cotton, I rode with him up there to the gin in McDade. Had to wait I don't know how long for them to get to our wagon, to get it baled.

Nickels: What about a hog reduction program?

Scott: Don't know anything about that.

Nickels: All right.

Scott: Most people just killed their hogs, and butchered 'em.

Nickels: Last time we talked a lot about your schooling, and where you went to school, and how you got to school. What about recess at the school? Any memories, good or bad, of recess?
Scott: Oh yeah, yes we enjoyed that recess. We was looking forward to that. 'Course, when there was enough of us, we played volleyball, that was the main thing. Usually the boys played the girls, and of course we would beat them. I enjoyed playing volleyball. We never did play much baseball, because we didn't have two teams of baseball. We had two teams of volleyball, something like that at Wayside.

Nickels: What about school closing for holidays, or for summer? Were there any particular schedules that, like some places have school closing for cottonpicking season, for instance?

Scott: No, it was a regular, I think we just went eight months to school and four out.

Nickels: I see. At Wayside or Oak Hill, what about water? Was there a well there, or-

Scott: No, they wasn't a well at either place. But each school had a sheet iron roof and gutters, and they had a cistern, underground cistern. Wayside had a little pump that we'd pump the water up and carry it in the house and put it in a, not a bucket, but it was like a water can now that you have a spicket [spigot] on it, and cups. And each one had a different cup to drink out of.

Nickels: And mostly wood stove in each one, I guess?

Scott: Yes, wood stove.

Nickels: Did they burn any coal?

Scott: No, it was wood. 'course they was plenty of wood. Usually the trustees would bring the wood up there in a wagon, and they kept plenty of wood so we didn't have to go out and hustle any. (chuckling)

Nickels: But you boys were responsible for-?

Scott: Yeah, building the fire.

Nickels: We talked about the major lignite mine operation over there. Do you know for instance, if your grandpa, or anybody out there mined their own individual lignite to burn, coal?

Scott: No, 
Nickels: You had talked a lot about your Grandpa Scott; quite a guy. And, before, you had mentioned that he was much of a man.

Scott: Yes he was; six [feet] six [inches]. I told you he didn't drive a car, and he was a constable. You know a constable goes all around to serve papers, people that's done something wrong, or stolen something. He'd get on that horse, and take the papers, go serve the papers. And he left his six-shooter at home; he never took the six-shooter. I admired that man. Everybody was scared of him, and I don't know that he ever had a fight, that I know of.

Nickels: We talked a lot about Mr. Aussilloux, and the winery operation, and his house. And one time when we were over there you had mentioned that maybe some folks thought he had buried some money. Are there any other local traditions, or what can you tell me about that?

Scott: Well, you know, we always farmed that place, because we was joining, and it seems like nobody else wanted it. And, of course, Aunt Mae was in charge of it so she'd let us have the place to farm. I don't know how many times we would go over there and see they'd dug a hole over there, looking either in the, I called it the barn part, but it really wasn't a barn. It was where they had the press to press those grapes to get the juice out of them. And down in the cellar of the house, they'd dig different holes in there looking. It didn't have a concrete floor in it; it was just a dirt floor. And that was one thing I never could figure. I've tried to all my life. The bottom of that floor was lower than the water table out there. The well was so close to the house. The water would come up higher than the floor, and yet it was dry. I couldn't understand that.

Nickels: But he basically was penniless when he died?

Scott: Well, everybody thought he had some money, but I don't know how many years it was when, I should look that up, from the time that he cut all of his grapes down, and when they had uh, what do you call it - Prohibition? They made it against the law to sell anything illicit. I know he made money off of the wine when he was living. But I don't know how many years it was after he cut the grapes down that the only income he had was like the rest of us, what he raised, and sold. He didn't have a vehicle nor anything how he could take anything to town, unless he got somebody else to do it.
Nickels: You mentioned the press was inside the barn, as we call it.

Scott: Yeah.

Nickels: What else was in there?

Scott: Well, they wasn't much left when we was farming in there. But, this old bachelor - we called him Tim - his name was Tim Bankston, he lived in that house. And he had this old Model T. But it was his, it wasn't anybody else's. It was a 1910 Model T, one of them old ones, with the real narrow tires, rubber tires; it was in there. They wasn't hardly anything else though.

Nickels: I see. We talked a lot about the crops you raised down below the house, in that sandy bottom land. Tell me a little bit more about how you cultivated certain kinds of crops.

Scott: Well, (clearing throat) we had a, a walking cultivator, just one-row deal, you know. It had two plows on this side, and two plows on this side, and it had handles in the back. And you could just take it right on each side of that row, and make a pretty furrow with it, pretty well clean it. I was aggravated with tractors. We didn't have one, but my neighbor that lived on that Fleming place did. You couldn't do anything good with that tractor, because you'd get grass, and weeds, and stuff on it. You couldn't stop and get down and clean it off. It'd take too much time. You'd drag that stuff to the end of the row, and I wasn't used to that. I'd stop them ol' mules, and clean that stuff off, and then you could go right on, get it clean.

Nickels: I'd like for you to comment a little bit more on the government taking of the land, the land seizure, maybe what was unfair about that taking. And maybe how could it have been done differently. How should it have been done to be more fair, less hardship on people?

Scott: (clearing throat) Well, You know the people in McDade, 'course it didn't affect them, except they thought they was gonna get money out of it. If we got money for our place, they would get more money. The growth, the grocery store owners and different ones thought, Well, this is gonna be a boom for us. But it was hard on the people that moved out. They couldn't buy any land to match what they had, with what little they got for it. You see what I mean? And 
so, many people like us, we wanted to save what little money we got to try to buy the place back. 'Cause they promised that we could get it back in six months, after the duration. So six months after the duration of the war, after it ended, Daddy sent them the money that he got for the place. And they kept it six months, and they sent it back to him. Said, "We've got to keep the lands." Said, "The Korean War is going on, and we've got to train down there." And, I never could figure that out, 'cause they had so, so much land up at Fort Hood. I'd worked up there on that camp they built at Fort Hood, in Killeen. They had all the training they needed up there. Yet they wanted to do it down there, where we lived. They never give us a[n] opportunity to get it again.

Nickels: So they just sent your money back?

Scott: Yeah, they sent it back.

Nickels: With a letter?

Scott: With a letter, saying they had to keep it.

Nickels: Do you think they gave enough notice to the landowners out there, enough lead time, to clear up and get out of the area?

Scott: Well, the landowners had the opportunity to get out. The ones that were renting, leasing a place, they are the ones that, that got took, because they had their crops started and everything. The landowners knew not to start, because they knew they had to move out in June, because they wouldn't have time to gather a crop or anything. But, like Mr. Snowden, he had that place over there by Scott Falls. And the landowner was a fellow by the name of Adams. He had bought that land from Uncle Nick's son. Because he had opened a grocery store in Elgin and lost so much money on it, he had to sell the land to a fellow by the name of Adams in Houston. Well he was the only one that knew about moving out, you know, because they was dealing with him. They wasn't dealing with the ones that was farming it.

Nickels: So, Noel Branton had a store in Elgin, and Noel sold the land to Mr. Adams?

Scott: Yeah.

Nickels: Well Mr. Scott, once again we appreciate it, and that's the final topics that I had for this interview. Do you have any other comments you'd like to add at this point?

Scott: No, I suppose not. I think we've pretty well covered it. And, I've enjoyed talking to you.

Nickels: Not as much as I have.

Scott: Letting me cry on your shoulder. (laughing)

Interviews with Abner Scott

Interviewed by David L. Nickels

Dates: April 29, and June 29, 2004

Place: Home of Scott, Elgin, Texas

Year of Birth: 1923 


\title{
S. J. "JACK" Scott INTERVIEW
}

\author{
By David L. Nickels
}

\section{May 2004}

David L. Nickels: My name is David Nickels. Today is the seventh of May, 2004, and this interview is taking place in McDade, Texas at the home of Mr. Jack Scott, at 211 Marlin Street. This interview is part of the Texas State University-San Marcos, Camp Swift Oral History project, sponsored by the Texas National Guard, and conducted in conjunction with the Center for American History, The University of Texas at Austin.

Nickels: Mr. Scott, first of all I want to thank you for allowing me to come into your home and ask you about Camp Swift, and pick your brain. We appreciate very much the hospitality.

S. J. “Jack" Scott: Well you quite welcome. It's a pleasure to tell what little I know about it.

Nickels: Can you tell me your full name and your date of birth?

Scott: Shelly Jackson Scott is my full name. I've went by Jack all my life. When I do some kind of business, I do it with S. J. Scott.

Nickels: I see.

Scott: Yeah.

Nickels: What year were you born?

Scott: Nineteen twenty, November twenty-second. I was eighty-three last November.

Nickels: Where were you born?

Scott: I was born in McDade. I left here for, around forty-some years, went to Houston. I come back in about '92. But I've only been in this place here about three years.

Nickels: I see. And I understand that you visited your relatives on what is today Camp Swift, many, many years ago?

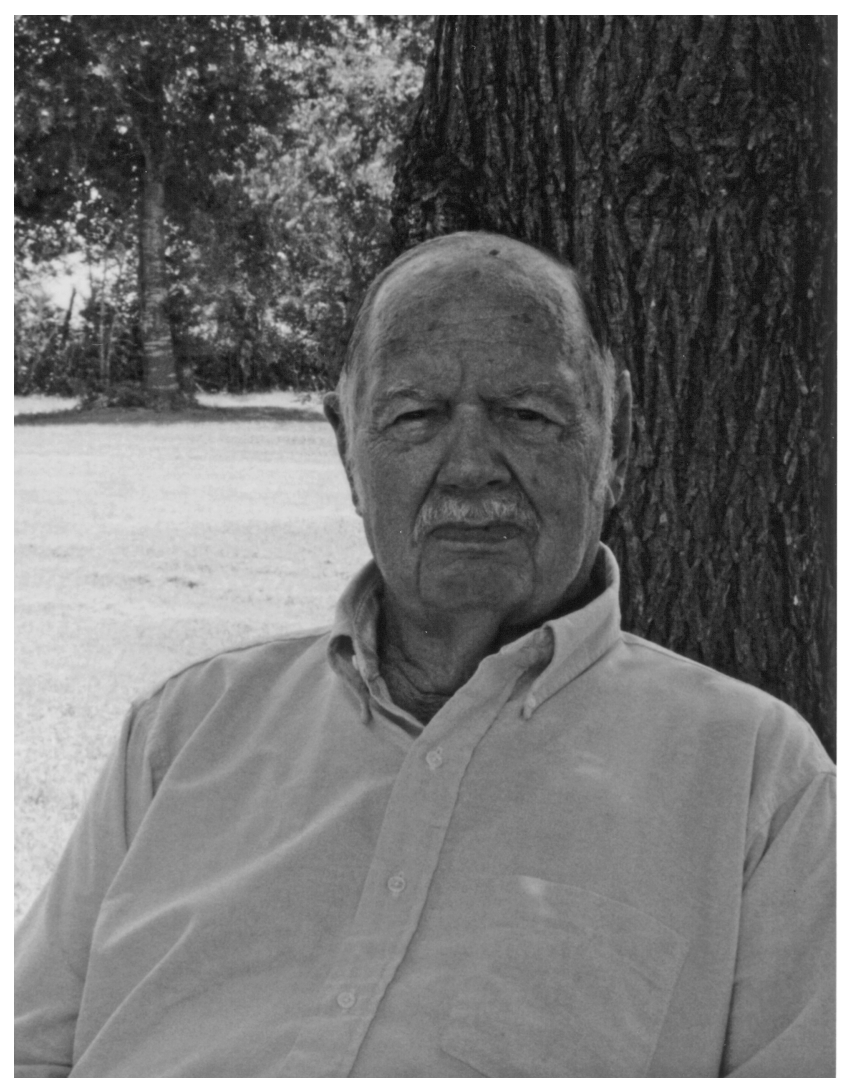

S. J. “Jack” Scott

Scott: Oh yes, my grandfather lived out there. I started there in the '20s visiting, and ' 30 s. His house burned down sometime in the late ' $30 \mathrm{~s}$. I can't remember the year. And I never been back out there since.

Nickels: I see.

Scott: The army taking it right after that. In fact, that's the reason he didn't build back, because the army was fixing to take it.

Nickels: And your grandpa's name was?

Scott: John Scott. It was J. H. Scott, but I don't know what the $\mathrm{H}$ stand for. 
Nickels: His house burned?

Scott: Yes sir.

Nickels: Did he get injured during that burn?

Scott: Yes, he did. A spark hit the shingle up there. They had a wood stove, was all they had then, and a fireplace. And they built a fire to cook supper. One of my uncles was staying there with him. And a spark hit that roof up there. But they seen it right away, and Grandpa got a ladder and clumb up there on that roof with a bucket of water. And just as he went to pour that water, that ladder slid off to the side, and he fell off there and broke his shoulder and collar bone, and all that stuff. He got over it pretty soon, the best you could get over it I guess, being his age. I think he was about seventy-two - I'm not sure — at the time.

Nickels: I have been by there, where that house stood. And there's a stock tank there.

Scott: Yeah, there's a tank down there, and the house is about two hundred yards this side of that tank, where it was. There was an old cistern out there, an underground cistern. I guess they leveled that old barn. There was a barn out there right by that cistern.

Nickels: I see. So, your earliest recollections of that place is probably somewhere in the mid-twenties?

Scott: Yeah, in the mid-twenties.

Nickels: When you were maybe five, six years old?

Scott: Well, a little later than that. But I used to go out there most every weekend. And then, when we got big enough to haul wood to McDade. We had wood stoves here back that time. Me and my brother Jeff - he's dead now - hauled wood from out there from my grandpa's farm here, so we'd have cook stove wood, and heat wood. And boy in the wintertime it would keep us busy. Every Saturday that's all we had to do.

Nickels: Yep.

Scott: Then we'd go out there and get the mules, and go to the woods and get the wood, bring it in here and unload it, and take the wagon and mules back out there.
Nickels: Did you sell the wood?

Scott: No, we never sold it, we used it here at our house to cook with. We had a house right back here on this lot right here. That's the only heat and everything. We had no air conditioning like you got now, no fans, we had nothing. That was back in hard times. All people had then, they was lucky to get plenty to eat. We did do that.

Nickels: What kind of wood?

Scott: Do what?

Nickels: What wood was it, mesquite, oak-?

Scott: No, it was mostly oak.

Nickels: And tell me about how you went about cutting it, and loading it.

Scott: Well, we cut it with a crosscut saw, me and my brother did. And load it on the wagon, bring it in here and then we'd chop it up with a[n] axe, and cut what we needed to have it tomorrow. Some of that was dead wood we used to cook in the kitchen with, my mother did. We used the other wood we cut down out there to mix in with the heating in the winter. Because that wood won't burn very good unless you got some dry wood to put in there. They was always some dry wood somewhere out there.

Nickels: You used your grandpa's mules and wagon?

Scott: Yeah, mules and wagon.

Nickels: On McLaughlin Creek, or that area?

Scott: Yeah. I think it was the name of it.

Nickels: Did you spend a lot of time at your grandpa's?

Scott: I spent some time there. When I first started going out there he was raising watermelons. I was about eight or nine years old, I remember that. He had the biggest watermelons in that part of the country. They was hauling to McDade in a wagon and a Model $T$ truck, and putting them in boxcars, about ten-fifteen cents a hundred pounds.

Nickels: I see. 
Scott, Oh, things was tough then; they wasn't no money. And the buyer come here and bought them, and shipped from McDade. They had rail cars located here, and they shipped them to Kansas City to some broker up there, and they distributed them out wherever they wanted them.

Nickels: What else did he raise out there?

Scott: Well they just raised corn. I can't remember all he had; always had a fine garden. He had a few head of cattle, maybe forty, fifty head of cattle.

Nickels: There's a dipping vat-

Scott: Yeah, that was about a hundred yards from where his house was. That old vat I'm sure is still there.

Nickels: It is. Do you recall other farmers, or ranchers, or people gathering there?

Scott: Well, Charlie Sowell and Gus Sowell lived about, oh, I guess about a mile to a mile and a half this side of where my grandfather lived. I don't know very much about them, but I know where they lived there.

Nickels: Would that be somewhere near the Oak Hill Cemetery?

Scott: No, it's back this way from Grandpa's place. There's an old dirt road come from my grandfather's place back to McDade. It comes out up here by this post office; it crosses [Highway] 290 up here. It's a dim road. I don't think you can travel it anymore, since the government had it.

Nickels: I see.

Scott: If you could, I'd be out there looking around some time, but you can't get out there. That belongs to the National Guard.

Nickels: Yes sir.

Scott: They promised to sell all that property back when the war was over, but we didn't get our part.

Nickels: Well, many people have an issue with that. Can you tell me about the thoughts and feelings of your grandpa or any relatives out there who were forced off the land at the time?

Scott: They was what?

Nickels: Any feelings that they had, emotions?

Scott: Well, I don' know. They didn't want to give their places up. But, in case of war, you have to do what you have to do.

Nickels: Yes sir. Did your grandpa ever have electricity out there?

Scott: No, no electricity. It hadn't come in yet. The first electricity I know of in this part of the country, except for McDade here, they had T. P. L. But we on Bluebonnet right here. It comes in from the back. T. P. L.'s right over here; it used to be T. P. L. It's something else now. About a hundred yards, and they never would hook on to us. LCRA come along, and they hooked up, which is now Bluebonnet. I was already gone from home when they got their first electricity, first refrigerator, and all that.

Nickels: What year, about, was that?

Scott: Nineteen forty-one.

Nickels: So everybody used kerosene?

Scott: Yeah. Wood, and kerosene.

Nickels: How about a telephone out there?

Scott: They had a telephone. Grandpa had one of them old crank telephones. One or two rings, a short 'n a long, or something like that. It was kind of a party line.

Nickels: Can you tell me about the house?

Scott: Oh, he had a nice country home. Big white home. It was a one story but it had them little old windows up in the top of it where you could store stuff, or you could have slept up there if you wanted to. Well as I remember, it had some stairs going in a closet up in there. Webbed (??) pine home. Big home.

Nickels: Have any dogs? 
Scott: Yeah, they had a dog. He only had one dog. He had milk cows.

Nickels: Do you remember making butter, or milking cows?

Scott: Well, not really, because when I stayed out there they'd get up before daylight, and I didn't. (laughing) They'd get up to do the milking and all.

Nickels: Did you like to ride his horses or mules?

Scott: Yeah I rode his. He had a couple of horses. I was riding down the road about a hundred yards from the house, and I met a tractor and grader. They used to have Caterpillar tractors and graders that they graded the road with. And they was grading that dirt road. This old horse got spooked, run through the fence with me, and tore my clothes off. Well, that's about I remember about the horseback stuff.

Nickels: How about wildlife, wild animals out there?

Scott: Well, they was squirrels and stuff like that. Just like anywhere else, there was opossums, squirrels, and polecats, and so forth and so on. And wolves, there was a wolf den about a half mile from his house, and you could used to hear them wolves howling at night. But it wasn't on his property, it was across on somebody else's property. I never did go down there and see where they was at because I was afraid of them. (laughing) I think they go in, in the daylight, and come out at night, way I been told.

Nickels: Did you fish or hunt?

Scott: No, I didn't; I never did fish out there. My uncle, my grandfather, and them hunted, and my daddy would go there and hunt. But I never did.

Nickels: Has it grown up a lot; did it grow up a lot over the years?

Scott: Do what?

Nickels: Was it mostly pasture land, or wooded?

Scott: No, it was both; he had fields over there. My grandmother was a Chandler and she married Grandpa. Those Chandlers all left down there, and Grandpa paid the taxes on that Chandler place for years and years. Just used it, but it never did belong to him. But there's about 150 acres down there that he paid the taxes on. All them years. I don't know, forty, fifty years. Of course the Chandler heirs got what little was got. They wasn't much. They didn't pay much for that land. As far as I know it was about eight dollars a[n] acre. Some got higher than that in different places, but I think that's what they got right there, is eight dollars.

Nickels: That's what the government gave them?

Scott: Yeah. And boy, if I had part of that place right now, I'd be sitting good, at the price of land.

Nickels: It's pretty.

Scott: Yeah. Of course it's growed up; you can take care of that.

Nickels: What kind of fun did you have out there, and what kind of chores did you have to do?

Scott: Aw, I didn't hardly do much. I did haul in that wood and stuff. And mess around, play like other kids. (laughing)

Nickels: Who did you play with out there?

Scott: Well, my brother would go out there with me, and Abner and them would. They didn't live but two, three miles over there. We'd get together and play. One time the Sowell children and brothers and sisters was out there. And Grandpa had an old buggy down there, and we were playing with that old buggy. Me and one of the Sowells girls was pulling it backward. There was a great big ol' prickly pear bush, and we backed into that thing, and the buggy run over us. Our parents had to burn the clothes. You can't get them prickly pears out. And we had sores on us for two months. When you start picking them prickly pears out, you don't make nothing but a sore there.

Nickels: That's one thing you don't forget.

Scott: No, don't forget that. That's one thing I remember very well.

Nickels: So your grandpa's main water source was cisterns?

Scott: Cisterns. 
Nickels: Did the creeks run high up there at times?

Scott: Well, it wasn't exactly there. There was Sandy Creek that what run over by my Uncle Grover's, Abner's place.

\section{Nickels: That's Uncle Grover's?}

Scott: Yeah, said it was. My daddy was named Walter Scott, and Grover Scott, they was the two heirs to the place there. They had a brother that lived there till after the house burnt, and they put him in a institution, a state institution, in Abilene. We went to see him a few times. You didn't have the money to go up there; it was back in pretty rough times. Me and my daddy went to see him two, three times. You see, it was a nice place up there. There wasn't nobody to take care of him. He had problems. He had epilepsy.

Nickels: I see.

Scott: Yeah.

Nickels: Did your grandpa have hogs, and chickens, and turkeys?

Scott: No. Didn't have any turkeys I know of. He had chickens and hogs. He used to sell eggs here in McDade. He'd bring them here to McDade. He had an old Model T, about a 1919 or '20, ton truck. I been with him when he brought eggs in here and sold them and went back home with it. Eggs were very cheap, fifteen, twenty cents a dozen. He'd have four, five cases of them at a time. That would be a week's run. They made a good living out there. But after he got injured that was the end of it, and his house burnt.

Nickels: Do you remember him butchering hogs?

Scott: Yeah. He had barrels that he countersunk in the ground. It had the ends cut out of them. And they'd fill them full of boiling water, and run them hogs up and down in there. They'd kill four, five at a time, get the neighbor and other people to come in and help. That's the way people did then; they helped each other. Now they'd probably kill each other (laughing), during this time.

Nickels: I understand.

Scott: And, uh-
Nickels: How did they keep that water hot in those buckets?

Scott: I don't know. He had a washpot out there that they heated it in. Then they'd pour it in them barrels. Of course there wouldn't be too much go in there because the barrels slanting, where they could run them hogs up and down in there. Then turn them around and run the other end in and out. Yeah I remember that very well. And they had a canner out there. And they used to can peas, and all kinds of vegetables. Because in the wintertime they pretty well stayed there. Sometimes they'd come in to McDade once a week. When my grandma was living she had sugar diabetes, and the doctor come out of Bastrop, till he got a automobile, by buggy. And, he'd make house calls.

Nickels: What was your grandma's name?

Scott: Minnie. Minnie Lea Scott.

Nickels: About what year did she pass away?

Scott: Nineteen thirty-six, I believe.

Nickels: Do you remember the doctor coming out occasionally, then?

Scott: I remember before then. I wasn't out there when she passed away. We went out there shortly afterward. The undertaker had already taken her when we got there.

Nickels: So at that time, her funeral would have been in Bastrop?

Scott: No, at Oak Hill. Oak Hill.

Nickels: Was there a wake for her in the house?

Scott: A what?

Nickels: Wake, a little funeral for her?

Scott: Nah, I can't remember that part, where they had the funeral.

Nickels: Well tell me a little bit more about the hog butchering, and how they processed them.

Scott: Well, they hung them up out there on some, I don't know, what you call it. Anyway, they had built 
some scaffolds out there, and they had some tables. And they'd hang them up, and take everything out of them, and cut them down. Then they put them on the table and finished cutting them up. Then they'd make that sausage. Had a sausage grinder out there, by hand. I remember that part.

Nickels: Did they have a smokehouse?

Scott: Oh yeah, they had a smokehouse. He'd put enough in there from one winter to last till the next. And might have given some of his children, some of us grandchildren part of it, at times. Yeah, he smoked them old hams. They was real good, back then. You had to do everything yourself, because there wasn't none of this bought stuff around here, because we didn't have money to buy it with. You asked me for the truth and I'm telling the best I know! (chuckling)

Nickels: We appreciate that.

Scott: Yeah, it was hard times.

Nickels: Yes sir.

Scott: I went to work up here in the filling station when I was fourteen years old. This man asked my father if it would be all right. And he said, "Yeah, I'd glad, be glad for him to work up there. Fifty cents a day, six days a week. That's three dollars a week. Well, I was the only boy around here that was working for money. And the only one that had any spending money, three dollars a week. I could go to the barber shop and get my own haircuts, and all that, pay for it myself, which wasn't but about twenty-five cents for a haircut.

Nickels: I know that there's a lignite mine operation out there. And I know that the gentleman who ran it brought in some Mexican labor, and I know there's a Mexican cemetery out there.

Scott: I don't know where that's at. There are a grave or two on my grandpa's place, but I don't think I could locate them. They used to have a little metal fence around them. But it's been till I was small when my uncle took me by there and showed them to me.

Nickels: Is that where the Chandlers are buried?

Scott: I don't know. It's somewhere in there. There's two different places they have little old cemeteries over there. I think the Chandlers might be buried on Chandler property, which is joining my grandfather.

Nickels: So there was a Scott cemetery also?

Scott: Not that I know of.

Nickels: But you think there were a grave or two on your grandpa's place?

Scott: Yeah, on my grandpa's property. And there was some on the Chandler property. But I don't know who was buried there.

Nickels: I see. Can you tell me anything at all about the lignite mine?

Scott: Yeah, they was told that there was lignite all along my grandfather's place. There was geologists that come there and checked all that before the government bought it. They said there was lignite. It's the same that's out here that ALCOA's processing, fixing to process now. That vein runs all the way to that mine down there, that lignite mine in Sayersville.

Nickels: Yes.

Scott: I haven't been to Sayersville since I was a little bitty boy, but I been down there in the wagon with my uncle. He went over there and got some kind of groceries, just a little old store once. I imagine it's gone. I haven't been over there since then. It was about two and a half or three miles from my grandfather's place to Sayersville. It's not that far from the Chandler place, but it was that far from my grandfather's place.

Nickels: So you went down there in the wagon?

Scott: Yeah. The old Model $\mathrm{T}$ truck played out sometime in the ' 30 s, and they just junked it. Them old pieces set out there till the junk man come along and hauled it off. It was a one-ton Model T truck, with a Rucksell axle. Don't many people know what that is, but it's a[n] extra gear in the rear end. You need to pull real hard, you put it in there.

Nickels: What's the name of it?

Scott: Rucksell axle.

Nickels: Rucksell? 
Scott: Rucksell. R-

Nickels: How were the roads at the time?

Scott: Well, they kept them in fair shape. But you best stay at home when it's raining. These mail carriers had some problems. Bryan Waterson was carrying the mail when I was out there. In the wintertime you didn't know when to expect him out at the place. Out this side of the Westbrook place, they called it the Bar B Holla [Hollow]. There was about a half a mile there that was almost impossible. The county would come and grading it up and they'd try to fix it. But, it was just terrible when it rained.

Nickels: Bar B Hollow? Is that, somewhere around the Wayside School?

Scott: This side of the Wayside School. Mr. Kayrow (??) Phillips used to live right straight across from that Wayside School. In a little house about a hundred yards across from it. And he had two, three girls, a couple of boys. The Westbrook was this side of him, about a half a mile. Will Evans lived in it after Westbrooks died. I guess he bought it, I didn't know. He lived in it for years. I remember one time, when I was small, my parents and them was out there at my grandpa's, and we went over to Will Evans'. He had one of them RCA Victors radios, with a big speaker, a round speaker on it. And, we went over there one Saturday night and listened to the Grand Ole Opry. It was about two, somewhere around two miles over there.

Nickels: That was a big deal then?

Scott: Oh yeah. It had one of them great big old batteries; they couldn't many people afford that. My grandfather and them didn't have a radio. He did have a telephone, but no radio. They never had any fans, or we never had any. We lived right here on this lot. There was a house right there that burnt down. When I put this in here I put it over on this side instead of the other side. I've always been superstitious about building another house at the same spot as one's burned.

Nickels: I see.

Scott: I don't know why, but I been thataway.

Nickels: Did your grandpa raise any cotton?
Scott: No, my Uncle Grover raised cotton, where Abner lived there. I went out there when I was a boy and picked cotton with them for a few cents a hundred, about ten, fifteen cents a hundred. I couldn't make a hundred pounds a day, but well it was good for me, because I didn't have any spending money. I was eight or ten years old, along in there. Of course, his family was all right out there with us, and they didn't get paid, they got, (chuckling) grocery money. I'd get my ten or fifteen cents a hundred. My aunt, Ina Scott, I used to go there a lot on account of the kids, stay two, three days a week when school was out. She'd pull a cotton sack and have a baby on the cotton sack, and pick two hundred, two hundred and fifty pounds a day. I was right along there close to her, and I couldn't get a hundred pounds. (laughing) And she'd pick two rows at a time-

\section{Nickels: Huh!}

Scott: - and pull that cotton sack with them kids, that baby on the back of it. And she lived to be ninetysomething years old.

Nickels: Good hard work.

Scott: Yeah. You had to work then, Mr. Nickels. Everybody had to work.

Nickels: Is she the one that lived up by Scott Falls?

Scott: No, that was my grandpa's sister, Mae Branton, Nick Branton's wife. Otma (??) Scott lived right by Scott Falls, but he was a cousin of my grandpa's.

Nickels: Did you ever swim at the dam?

Scott: I have. I've swam there, maybe a half a dozen times. But we didn't have too much transportation and it was too far to walk.

Nickels: There is the remains of a winery operation over there ran by Mr. Aussilloux.

Scott: Well, I don't know; that was closer to Abner's and them's place. I've heard them talk about Aussilloux, but I didn't know anything about it.

Nickels: It sounds like you may have been closer to the Wayside community area. 
Scott: Yeah, yeah. Well, my grandpa's place I can't believe, was over two miles the other side of Wayside. We didn't have no way to measure it then, I'm just guessing. But I've walked it many times. It wasn't nothing for me to walk out there. Walk home.

Nickels: You went over and played with the kids there at Wayside?

Scott: Well, I'd go to Grover's, my Uncle Grover's house, where Abner lived. He had another brother named Dan there, the two oldest ones. And then they had some girls. Donald, and another one, I can't even think of it.

Nickels: Mary Lou.

Scott: Yeah, Mary Lou.

Nickels: Jesse Lea.

Scott: Jesse Lea. That's the two girls. That one that lives in Waco, I can't think of his name. I'll think of it awhile when I don't need to. (laughing) One of them's dead. Harlan died about two years ago. He worked for the National Guard after he got out of the service for years, Camp Mabry.

Nickels: Yes.

Scott: Yeah. That's one of Abner's brothers.

Nickels: Where did you go to church?

Scott: Where did they go?

Nickels: You.

Scott: (laughing) I didn't go much; Baptist church here in McDade when I went. My Grandpa Flemings [Fleming] was a Baptist preacher here in the '20s. But when I got up to get going on my own, he'd already retired, and he died in 1931. And my Grandma Fleming died in 1937.

Nickels: There were some Flemings who owned land out there at Camp Swift.

Scott: Yeah. That was my Grandpa Fleming's brother, Andy Fleming. It was right by Grover Scott's place. That used to be Abner Scott. Not the Abner we was talking about, but my grandpa's father.
Nickels: Yes.

Scott: Grover Scott got it. He moved his family on it, or raised his family there. I don't know, as long as I can remember, they lived there.

Nickels: How about the Evans?

Scott: Well they lived out this side of Wayside about a half a mile. Big house over there; they called it the Westbrook place. That's where we went from Grandpa's over there in the wagon to listen to the Grand Ole Opry. He was the only one in that country that had a radio, that I know of.

Nickels: Otis Evans owned a place there before the government took it.

Scott: Well, that was his grandpa, Andy Flemings, and he was heir to that place of Andy Flemings. It was over by Grover Scott.

Nickels: Yes.

Scott: That's on Sandy Creek.

Nickels: Part of the land is what is known as the Herms place. Does that ring a bell?

Scott: No, it doesn't; I don't remember that.

Nickels: Okay. During the late thirties, probably early forties, they had cattle killoffs -

Scott: I think it might have been in the thirties, '29 or '30. I don't remember when it was. But they killed them cattle and they taken a grader, the government did, and graded trenches down there and buried them.

Nickels: Where did that happen?

Scott: I don't know just where it was at, but I do remember hearing it.

Nickels: Was that perhaps on what is Camp Swift today, or, not?

Scott: I think it was, but I'm not sure. I couldn't be sure on that. But I do remember them, slaughtering them cattle and they wasn't giving much for them. But they was overloaded on cattle, and no way to sell them. They had a packing place here, a cannery here 
in McDade at one time. I don't know whether they used any of that meat for that or not. But they did get vegetables from these farmers around here, and can up there. My mother worked up there one time for twenty-nine dollars a month, and some vegetables, so we'd have something to eat. My father couldn't even get a job, at one time. He finally went to work for the highway department in Bastrop.

Nickels: Some of the gentlemen who lived on Camp Swift, what is Camp Swift today, worked in Elgin or Bastrop, maybe at the brick factory. Did your grandpa or any other relatives out there work in town, and live out there?

Scott: Naw, not my grandpa. They just lived on that farm that was there, only thing that I know of. Now, Grover Scott was a carpenter. He worked out - Charlie Sowells [Sowell] that lived next to my grandpa, later on he bought him a dump truck - and he hauled for the Elgin brickyard. He used to have to haul their clay and stuff in there. And then he quit that and went to hauling for the public. If anybody wanted a load of gravel he'd go get it somewhere. Then, when the government bought that, they had to move out, and he moved to Elgin, then he moved to Austin. He got rid of all that truck and stuff. He's got a son living in Austin now. I haven't heard whether he passed away. Dale Sowell, he lived closest to my grandfather. And Shirley (??) Flowers, a black man, he lived right the other side of my grandpa, across the road, opposite that dipping vat, right up on the next hill. There was a little old bridge down there. I'm sure it's all rotted and gone. Shirley Flowers lived up there, and he had a son I think is still living Elgin, W. C. Me and him used to help my grandpa and them pack them watermelons out to the end of the row and load them, and haul them to McDade, and put them in a boxcar. Me and him's about the same age.

Nickels: Did he live north of your grandpa, then?

Scott: I'd say it was west of my grandpa's. The Sowells lived east of my grandpa's.

Nickels: How do you spell that name S-a-1-1-

Scott: S-o-w-e-1-1.

Nickels: Okay.

Scott: Far as I know.
Nickels: Well it sounds like everybody helped everybody out there.

Scott. They did. They did. That's the way it worked back then.

Nickels: What about Saturday night, or Sunday afternoon social gatherings of any sort?

Scott: Well, I can't remember much about that. If we didn't have to all work, the whole family would go out to Grandpa's and set all day on Sunday. That was before Grandma died. After that we never went out there very much. He never had any electricity. They had an old wooden icebox. He'd have to come to McDade and get a hundred pounds of ice, and take that and put it in it. I don't know how long it lasted. It kept the milk and stuff cool. Grandma used to make cottage cheese. Had that clabbered milk, and she made cottage cheese out of it. She had that diabetes, and on her diet she had to have something like that cottage cheese. I used to get into it and eat it.

Nickels: She was a good cook?

Scott: Oh yeah, yeah. All them old women was good cooks.

Nickels: Can you remember her doing washing, and sewing.

Scott: Well, they washed with a washtub, a rubbing board.

Nickels: How did you take a bath out there?

Scott: You could go to the tank. Grandpa, he had a barrel up there. He built a scaffold up above that tank, he had a barrel, why, up over it. He had a little house built there, and you get on that tank dam, and get in that little house. They'd draw that water up and pour it in that barrel. Then you just took you a shower. Or you had a washtub at the house to bathe in. I never did bathe in that. I bathed down there at the tank. But, we lived right there; we had a house that burnt down. We bathed in washtubs - had to draw the water out of a well. Me and my brother, we was about twelve, fourteen years old, we dug a well thirty-three foot deep. It had good water. I had it filled up when I come back and cleared all this brush out of here. It was solid brush here where this is. I cleared all that out. You can see out that window how far. That's my sewer system 
out there. They had to use the biggest part of that for the sewer system to make it absorb that. They said the soil wouldn't absorb that sewer like it should. It cost seven thousand dollars to get that sewer system put in there.

Nickels: Wow!

Scott: Naw, I would have loved to bought part of that place. Of course, there's other heirs, but-back whenever they was supposed to sold it back. But since the National Guard got it that ended ever selling to us.

Nickels: Well, Mr. Scott, that pretty much precludes most of the topics I wanted to touch on. Do [you] have anything you'd like to add, or any comments?

Scott: Not really. But, some of them people got a chance to buy their property back out there. If we had that property like it was when they bought it, some of us would have been living on it. And it's worth quite a bit of money, would have been. I don't know, probably not worth nothing since they put them shells; they had a firing range on my grandpa's place so I understand. But, I would have loved to lived out there. I would have probably built me a house out there. But we didn't get it back, so - that's the end of that.

Nickels: Well, it seems that every person I've interviewed has the same sentiments.

Scott: Yeah.

Nickels: I just want to tell you how much we appreciate it again, for allowing us to do this.

Scott: Yeah.

Nickels: And best of luck to you.

Scott: I don't mind it at all. I think it's my duty to tell what I know about it. But that's not very much.

Nickels: You've been very helpful, we appreciate it.

Scott: Yeah.
Nickels: Tape recorder turned off, but then Mr. Scott and I agreed to repeat an anecdote in more detail, and address a few more issues as follows.

Scott: The Sowells [Sowell] girls would play with us, and one Sowells boy, and the Fags (??). That was a brother-in-law, their cousins' children. And me and either one of them Fag girls or oldest Sowells girls was pulling that buggy backwards - I can't remember which one it was - we was going backwards, and the kids was up in the buggy, and we run up on that prickly pear bush there, that buggy run up on top of us. (laughing) Didn't hurt us bad - the prickly pears - hurt our pride more than hurt anything else.

Nickels: So, was there a fair amount of black folks out there?

Scott: There wasn't any, about that time they moved out from there. Shirley (??) Flowers and his family lived right there. And a black guy named Cunnie Flowers, Shirley Flowers' brother lived in that Chandler house there. He did a little work for Grandpa. Grandpa farmed some of that, and some of it he didn't.

Nickels: How about sharecroppers?

Scott: Not, not there, I don't think. I don't know about that.

Nickels: Mr. Kastner told me that on his place there were some Mexican sharecroppers.

Scott: Yeah, on whose?

Nickels: Kastner.

Scott: Kastner? Yeah, that was Morris Kastner.

Nickels: Yes sir.

Scott: Well he's a lot younger than I am. I know where they lived too. Their place and my grandpa's place wasn't over a mile and a half apart. That was straight through over there. But it was a long way around the road. His father died when they was young - 
Nickels: Yes.

Scott: - and his mother finished raising them.

Nickels: Most of those folks either went to Wayside School, or maybe Sayers?

Scott: No, I think the Kastner's went to McDade, I'm not sure.

Nickels: How about the Sowells?

Scott: They went to Wayside. Abner and one of his brothers went to Wayside a year or two. Abner stayed with my grandpa one year, one school year. The school teacher stayed at my grandfather's place. And her and Abner would walk to school every morning.

Nickels: What about the Fags, you said?

Scott: Yeah. I don't know what house they lived in. They was back off somewhere. But the Sowells lived next to my grandpa. And then about a half a mile this side of them was their daddy, Gus Sowell. It was Charlie Sowell that lived next to my grandpa. He's the one that had the children. And then the Phillipses right across from the school. They wasn't too many people lived out in there.

Nickels: What race were the Fags?

Scott: Do what?
Nickels: Were the Fags white, black?

Scott: Oh they was white.

Nickels: Um-hm.

Scott: Yeah.

Nickels: Farmer?

Scott: Yeah. Far as I know. But I can't get exactly where they lived. I don't think I ever knew exactly where they lived. They come to their brother-in-law's and uncle's there at Charlie Sowell's. So I don't know just exactly where they lived.

Nickels: All right.

Scott: Um-hm.

Nickels: Thank you very much.

Scott: Okay, you are welcome.

Interview with S. J. "Jack" Scott

Interviewed by David L. Nickels

Date: May 7, 2004

Place: Home of Scott, McDade, Texas

Year of Birth: 1920 


\title{
Ruth E. SMith Interview
}

\author{
By Martha Doty Freeman
}

\section{April 2004}

Martha Doty Freeman: This is Martha Doty Freeman. Today is April 16, 2004. This interview is taking place in the home of Miss Ruth E. Smith in Bastrop, Texas. This interview is part of the Texas State UniversitySan Marcos Camp Swift Oral History Project sponsored by the Texas National Guard and conducted in conjunction with The Center for American History, The University of Texas at Austin.

Ruth E. Smith: Maybe if I get something I've written, it might go faster. Huh? Then I won't have to stop. Ten years ago, I could remember all of the dates and everything, but sometimes I can't remember.

Freeman: Are those your first pages there?

Smith: Huh?

Freeman: Are those your first pages?

Smith: These?

\section{Freeman: Right here?}

Smith: Uh-huh. I start out with this. (reading from a handwritten memoir) "This document is written to research this information with input, as possible, of the tales and the facts of the way of life of the people in the Oak Hill community. Also, a ledger was found in Arthur Hancock's trunk dated July 15, 1886. I am unable to - " Let's see here. Scratched out something. "I am unable to locate a record of the community meeting of" - Well, anyway. "Community meeting to build a church school." Well, this is not. "My paternal grandmother, Edith May Harvey, was born in 1864, and she talked about going to a church, a school in her younger days in a log cabin located near the present white-black cemeteries."

Freeman: Are those the Oak Hill cemeteries?

Smith: Huh?

Freeman: Are those the cemeteries at Oak Hill?

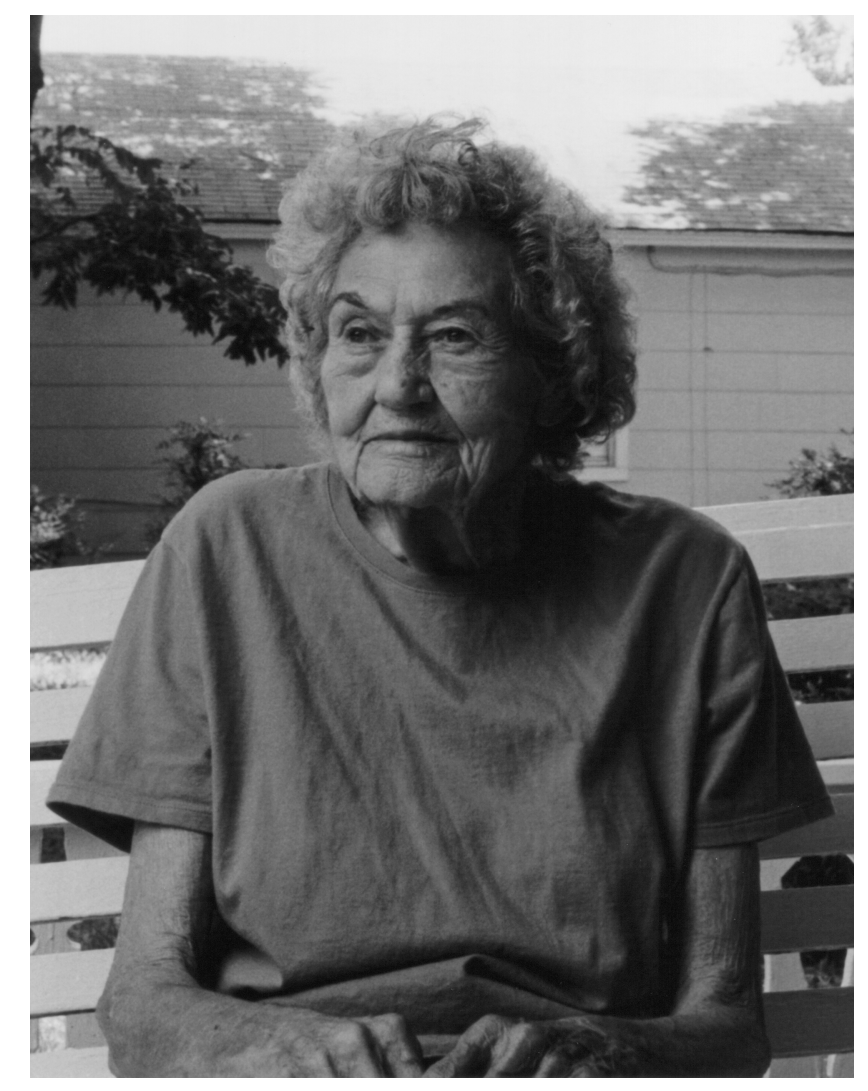

Ruth E. Smith

Smith: Uh-huh. You've been out there?

Freeman: Uh-huh.

Smith: I was president for seventeen years. (recollecting a conversation) "The car enroute here, but the engine stopped there. Never donated. Want to go right now. 'Well, I can't go right now. I'm baking a cake." And then one of them I knew, they weren't going to give any money, never had. I said, "Aren't you going to give me some donation for my gas?" [They said,] No, you get paid for it. [I said,] "I beg your pardon, nobody gets it, and it's just all free." It wasn't fun.

Freeman: That's a big responsibility. 
Smith: You want me to keep on? You got this thing off?

Freeman: I have it on, but do you just want to tell me in your own words how you got interested, or why you're interested in all this?

Smith: Well, after I retired from the U.S. government, in 1979, Ruby Furr, who had been working in the cemetery, called me and said that the lady that helped her with the cemetery had moved to Elgin. Ruby didn't have a car and didn't drive. And she wanted to know if I knew of anybody could help her work the cemetery. Back then, wages was $\$ 3.35$ an hour. And a lot of these people that are on disability didn't want to work for that. They didn't want to work. It was hard to find anybody to do yard work. Really, it just was yard work. So, I'm trying to remember if I was vicepresident or president at that time. I must have been president in the association. So I said, well, and of course before the picnic, which is the last of May, they always like to have it clean and the graves mound. So I said, "I guess I could help you do it." So, and she started working that cemetery when she was a little girl about, I think she said, eight or ten years old. And she worked for a quarter a day. So she knew about the lifestyle of a lot of people I didn't know about. So I guess that was the way I got started. I got kind of interested, and then Fay's mother gave me a lot of information that she didn't give to Fay. They really didn't communicate too good. So she started giving them to me and what she knew about the families that were buried out there. Because she lived just up the hill from the cemetery. I guess Fay's told you that.

Freeman: I met her mother.

Smith: Huh?

Freeman: I met her mother.

Smith: Oh, you did? That's Daddy's sister. So then, one day, I said to Fay, "We ought to record these tales about the cemetery." Because I had been kind of asking around if anybody knew about any records that had been kept back when they first built the church. Nobody knew anything. So I guess that's the way it got started. Mother was still living. I started asking her about her childhood and what she did, how many parties she went to and all this stuff and how long she went to school out there. And so I got information from her. I didn't know anything about her childhood at that time. And I have a sister that lives in Baytown that has a master's degree from San Marcos. You might want to look at the monument and you'll see her name on it. Her married name, her name is Gertrude Smith and she's married-After she left college, she married a Marsh. Gertrude Marsh. And her, what did she major in? She has a minor in journalism. I guess her first major is education. Teacher's certificate. She keeps after me, "We ought to write a book." She's real good at writing. Much better than I am.

Freeman: How early did your family live here in Bastrop County?

Smith: Let's see, I have to stop and think. Thirty-two, '33, '34. We left out there in '32, came to Bastrop from Oak Hill.

Freeman: Eighteen thirty-two?

Smith: Huh?

Freeman: Eighteen thirty-two?

Smith: No, 1933, mother and dad.

Freeman: Okay.

Smith: When we left Camp Swift territory, I was sixteen when I left. I went to Bastrop High School, graduated in 1935 .

Freeman: So you left before-

Smith: Yes, but I worked for Camp Swift later.

Freeman: Oh.

Smith: I had to take my examination for secretary for the government. And my appointment was to come back to Bastrop when they started building. But I didn't stay out there and work very long till they finished the Camp. When we got the headquarters built, the colonel transferred me to Dallas, me and another girl. So we got to Dallas, and they wanted us to go to Pampa. They were building an airport up there. Her parents, she was from Austin, and they had a cleaning establishment. [She said] "I'm not going to Pampa. I'll just go back home." Of course me, I didn't have, my parents didn't have the money. I wanted to 
get out and do something. I said, "I'll go." The chief of the project and myself, it took us about six weeks [getting records ready] because we did not have all the title research we had here. When I came back from there [Pampa], they sent me to Fort Worth. And then this secretary to the colonel, one night I had a date, and the boy goes, "What do you want to do?" And I said, "I want to go see my friend in Dallas."

Freeman: You wanted to see what?

Smith: My friend in Dallas. So when I got there, when we got there, she says, "They're opening up an office in Edmunton, Canada, and they want people to go to work up there." The department I was in was the real estate department. Get title. Whatever they wanted it for. So she says, "Oh, I sure would like to go, but my mother's old and she's not in very good health. She's in Tulsa, Oklahoma." So I go without her. And we took the train all the way up there. Went across Canada. It's in the center border. Went to Prince Rupert Island. Got on a little boat, and there were six girls and the rest men. And the boat held about thirty people. We go to Skagway, Alaska. So I worked up there for two years. And daddy kept writing me a letter and saying, "You better get yourself back home. The Japs are on the Aleutian Islands, and they're going to take you." So finally I came home. And that was near the end of the war at that time. I'm here talking about myself. I didn't give you any of the early history.

Freeman: That's all right. Well, I'd like to know about - You grew up out there, didn't you?

Smith: Uh-huh.

Freeman: Tell me.

Smith: Went to school out there. We had ten grades. When I got to Bastrop, "You can't graduate until you have two years of chemistry. You can't go to any college." And I thought, Where do you think the money's coming from? Pooh. I didn't say anything.

Freeman: So what was the school like out there?

Smith: It was the best rural school in the county. It really was. There is a picture here when mother was on it in 1910, and I think I counted them, and there were ninety children there. That was a booming year. The community was growing. You know, a lot of people had at least six children, eight, ten. Didn't have any protection in those days. So I had to take two years in Bastrop, instead of one. In school, we went to county meets. The girls had volleyball. They outlawed basketball about that time. We had-Years ago, with that, I said ninety children, we just had one teacher. We finally got two teachers. When I went to school, it was two teachers. We didn't have any study hall period. Had to take all of our books home at night. Geography book's about like that, (measuring) and history book. Mother made us a cotton sack bag to put over the shoulder. We trotted across the fields. A short way. We didn't go around the road. We went on a cow trail, about a mile and a half, I guess. We never missed school, except when the creek was up, that little (??) creek down there. One time we missed. They were determined that they were going to get us through high school. One reason Mother was so interested in it was that her father said that girls didn't need to go to school, so I never could get it out of her how far she went in school. But Dad went before they married, of course. He was living in McDade. He graduated from seventh grade and then he went on to Draughan's Business College.

\section{Freeman: Which business college?}

Smith: Draughan's in Austin. It's still operating, I think. He didn't finish. He was supposed to be, well he was working the kitchen for tuition. I don't think that he cooked. And he didn't get his certificate because he said he couldn't eat the food. They'd go out on the lot and kill a chicken, and it was full of blue bugs. Do you know what I'm talking about? And so he couldn't stand to eat the food so he came back. I said to myself, Yeah, he came back 'cause he had his eye on mother and he didn't want somebody else to break it up. I pulled a muscle in my shoulder a couple of months ago.

Freeman: What was your father's name?

Smith: Robert W. Smith. Robert Whitworth Smith, named after Whitworth, last name of his friends in Georgia.

Freeman: When did he move to Texas?

Smith: Daddy? Daddy was born in Texas. His father came to McDade, Texas, first, and then to Hutto from Loganville, Georgia.

Freeman: And where did they move to? 
Smith: Oh, I haven't told you about the Ransoms, the first paternal relatives? All right, Amherst and Sarah and seven kids left Chicago. Now this date, I don't remember. I'll have to look at my notes. You'll have to leave it blank. Had seven children. The oldest one was named Ed, and he was twenty-one. While Amherst was up there, he was mayor of Chicago and he operated a ferry boat across the Chicago River. Or Chicago, or Illinois River. Chicago River goes through town. Okay, they started out and they stopped in St. Louis and they worked in the lead mills. Now I don't know how long they worked before they came on to Texas. And when they got to Texas at the border, Texarkana, Amherst developed yellow fever. And there's no record of his death. Yellow fever went into pneumonia. No medicine for it in those days. He's buried in Arkansas, at Texarkana, Texas at Texarkana. I don't know how much money Sarah brought to Texas. But she came to Bastrop, and then she went back to Washington-onthe-Brazos. And I guess the whole family went with them. And all the team was built of horses. And they went back to Washington-on-the-Brazos to pick up pecans and haul them into Houston to sell them. And in 1854 , she came back to Bastrop and bought some land, three hundred acres out at Oak Hill. She paid ten dollars an acre for it. I got that from the deed record at the courthouse.

Freeman: And these were your mother's parents?

Smith: No, no. Not the ones that's come from Chicago. That's daddy's ancestors. They're all, the whole family is buried out there, Sarah and her sons, except one son. And I know you'll want to hear this. One son is buried at Mount Bethel. Have you ever been to Mount Bethel? It's a little German community right out here, and the lake took it in. It was nothing for people to walk five and ten miles. Just walk to go somewhere where they wanted to go. You haven't heard about the saloon in McDade?

\section{Freeman: Um.}

Smith: Well, now I got mixed up. Wait a minute. We talking about Mother's or Daddy's?

Freeman: The family from Chicago.

Smith: Oh. One of Sarah's sons is buried out there at Mount Bethel. Now, I haven't gone and researched whether they were just living out there at the time of this one son's death, or they had bought some land out there, about three miles out there. I didn't research it that far.

Freeman: And what was their last name?

Smith: Who?

Freeman: Did you say Ransom?

Smith: Uh-huh. You've been in the cemetery?

Freeman: Not recently.

Smith: They've got three marble tombstones. Sarah, about the middle of the old cemetery, at the driveway. They all died with yellow fever. Pneumonia they called it then. Two days apart. And of course, all the rest, most all the rest of her children are out there. My paternal great-grandmother is buried there, and then a baby girl about two years old is next to her.

Freeman: Do you know why she came to Bastrop County?

Smith: Yes, there was a turmoil. Civil War was brewing. And Texas had joined the Union at that time. She came in '54. Go west young lady. Get some land, get some oil, or whatever. Better conditions. And my own opinion was, turmoil between North and South was brewing already. They didn't bring any slaves with them. They didn't. Now my mother's, my mother's father, his dad, or I should say stepfather, brought slaves.

Freeman: And who was he?

Smith: The stepfather?

Freeman: Uh-huh.

Smith: John Erwin Hancock. Well, have to go back further. There was a lady named Mary Ann Fort, and they lived in Green County, Alabama. And she married Evan Hancock, and she had one child. She named it John Erwin Hancock. And when John was about three years old, they came to McDade, Texas, from Alabama, Green County. Wait a minute, I missed something. She married again. She married King Henry Barbee, after Hancock's death. John was about three years old and she had married Barbee. And he had some money, and she had inherited some money from the first man she married. So they stayed 
in McDade for a while. His name was King Henry Barbee. And I checked it at the courthouse. The early years McDade was being developed, and they had laid out the town in lots, King Henry bought and sold, this I don't remember, but, it seems to me like it was 121 lots, and he also opened up a cotton gin. So he had quite a little bit of money. The Barbees and John moved to Oak Hill and operated a cotton gin near the Oak Hill Cemetery. And they're both buried there, Mary Anne and King Henry. Well then, when John gets old enough to marry, he married. He was courtin' George Allen's daughter, Ruth L. Allen. George Allen came from New York. He was a tailor. Made many clothes. Came by boat to Galveston. Landed in Galveston on the day of the Battle of San Jacinto, April 21, 1836. I don't know whether-My sister had a book, and it said that machines took over men's clothing, making of the men's clothing. And he thought men's clothing was the only way. He wasn't so hept on doing it by hand, and he wanted to go to a new territory. Or was he really wanting to fight in the war? Nobody knows. We haven't been able to get any information why he came. So he came to Bastrop in the same year 1836. There was one building in Galveston when he landed, and he came on to Bastrop in the same year. And I don't know how much sewing he did, but I don't think it was very much. Mother quoted me one person he made a suit for, and that was Earl Erhart, a wedding suit. So George married Margaret Anderson, and they had Ruth, Ellen, and Lucy. Well, John Hancock was courting Ruth, and that was George Allen's daughter. She wouldn't marry him because her mother was sick. And he went off and I think he married Elizabeth Fitzgerald Dunkin. And they had four children. And I think she must have died at the birth of the fourth child. And one year later he marries Ruth, and they had little ones. They were little ones. There was three girls and one boy from the first marriage. You want their names?

\section{Freeman: Sure.}

Smith: Evie.

\section{Freeman: Evie?}

Smith: Um. Delia, Jessie, and Sam.

Freeman: Which was the second one?

Smith: Evie, Delia. Beautiful girl. Delia married at sixteen.
Freeman: Did they live in town, or did they live out there?

Smith: They never did. The one that got married, the girl, no.

Freeman: Did the family ever live here, or did they live out on the Camp Swift area?

Smith: Oh, you mean, when John was married the first time?

\section{Freeman: Uh-huh.}

Smith: Uh-huh. Yeah. 'Cause, see, Barbee had already moved to McDade. And Dunkins lived in another section of Oak Hill, towards Sayersville.

\section{Freeman: Oh.}

Smith: Okay. Then the second marriage, he married Ruth. And that's my grandmother, Mother's mother.

Freeman: So you're related to a lot of families that lived at Oak Hill.

Smith: I'm related. I was just thinking the other day, I'm related to the Forts. I didn't, Mother never told me I was related to them when I was growing up.

Freeman: Tell me about the Forts.

Smith: I don't know much about them. That was a Fort that called me. She was a Fort that called me to get somebody or help her work at the cemetery. Let's take a break.

Freeman: Okay. The Forts never owned any land?

Smith: Not the one, the girl that worked the cemetery. Her mother and dad didn't own any land. You aren't uppity-up in the community if you didn't own land. Even if your shack was falling down. You still owned land. And if you didn't work and raise your own food, you were white trash. (laughs) Didn't Fay tell you all this? What did Fay tell you?

Freeman: Well, I didn't interview her. Another person interviewed her.

Smith: Wait a minute, you sure you don't want coffee? Instant coffee? Where they lived, was the Oak Hill School. 
Freeman: So where was Wayside?

Smith: Northwest of Oak Hill borderline. (??) had the borderline of the community, but I've checked the county office here, and I told my brother that came back from Detroit after sixty-three years - he lives at Sun City - I told him that I wanted him to help me with some of this map stuff. (quoting him) "Too busy, too busy."

Freeman: So Abner Scott lived over near-He was closer to the Wayside School?

Smith: Uh-huh.

Freeman: But it wasn't big enough.

Smith: Wasn't enough people in there to have, for the state to have very much school.

Freeman: So how far did he have to walk to get over to the Oak Hill School?

Smith: Five miles. He married mother's cousin, my second cousin. Mother told me that he walked five miles to come up to the church on Saturday night when they were having the parties at the church. And I said, "There and back?" [She said,] "No, one way."

Freeman: Oh my. Tell me what the, how many families lived in that Oak Hill area? Do you have an idea of how many?

Smith: When I took over this place, it was a mess. And I'd been mowing and doing all the yard work and all that kind of stuff. So when I resigned from being president, I said, "You're going to have to get somebody else, because I may not be here all the time." So, we got Linda Watkins as treasurer. And I had been collecting names of people that moved away, Houston, all the way around. I'd get their name and address, and I'd say come to the picnic, and we'd work on donations and blah, blah, blah. Most of them, it didn't do any good. So I paid Linda. I said, "Linda, I've been wanting to get a mailing list, and since you're such a good help, you can do it." So she sends out a letter every year. (looking for the letter in her mail)

Freeman: I wanted you to tell me how many families lived out there when you were growing up.

Smith: When my mother was growing up?
Freeman: Well, when she was growing up, too.

Smith: Well, that's why, this picture, I don't have it. Somewhere around here. I think there's ninety people. And she could name all the kids, except two or three. The picture had faded. She couldn't tell who they were.

Freeman: What was there besides the school?

Smith: At Oak Hill community?

Freeman: Uh-huh.

Smith: The church-school and the cemetery. And forty acres of land.

Freeman: Were there any stores out there?

Smith: I get to that in my history there. I'm not near there. At times, there was somebody that would open up a little old store. I can only name-I'm trying to think of the name of the person that had it. I think it was Edgar Owen.

\section{Freeman: Edgar Owen?}

Smith: Uh-huh. Kin to Fay's father. Down the road from her they lived, down the road. Mother told me that, when her mother had been out of snuff — and I guess John wasn't around - she'd send the oldest boy to the store to get her some snuff. Probably got a little ol' metal can. Have you seen 'em? I said, "That's a pretty way to go for just a little bit of snuff." [She said,] "Oh he didn't walk. Got on a horse and rode over there."

Freeman: How far away was the store from your farm?

Smith: If you went around the road, or how the crow flies?

Freeman: On the road.

Smith: Whew. Go by the road, I have to draw you a picture. Let me scribble it out on some kind of paper.

Freeman: You can use this if you want to.

Smith: This is kind of looking, we're southeast. (referring to drawing) This is east, and that's southeast, 
and here we lived up here, and we come down here, and we take a road that goes that way and goes all the way around. Now, here we are. We lived up here, or here. We go that way.

Freeman: Sure, just cut if off like a triangle.

Smith: Now, we always said we walked two miles. I don't know if that meant by the road or across the fields. I know it had to be across the fields. Let me get a rough estimate in my mind. You want me on the road?

Freeman: Sure.

Smith: Hum. Nobody walked the road.

Freeman: Oh, well, then, how far was it just walking the usual way?

Smith: On the angle?

Freeman: Uh-huh.

Smith: Two miles.

Freeman: Okay. And that was to the little store.

Smith: No, that was to school. And that was past the store. About three miles.

Freeman: I know sometimes somebody had a car, maybe, and they came around and picked the kids up to go to school. Did anybody do that when you were growing up?

Smith: When I was growing up? I'm trying to think when the first car came to Oak Hill. I know the first telephone came to Oak Hill in 1913. Party line. There wasn't anybody picking up anybody, I can tell you that. Even when the horse-and-buggy days were, wasn't anybody. Everybody, most every kid could cut across the fields.

Freeman: And did you take your food, your lunch?

Smith: Yeah. We got rich one time. We got paper bags. We had, we bought corn syrup in a metal can with a lid on it and a handle, and that's what most everybody used. Want to know what we had?

Freeman: Yeah.
Smith: Biscuit, with a piece of ham or bacon, depending on what time of year it was. Sometimes Mother would make chicken salad. She always had some kind of cookies for us. And sometimes we'd have an apple. Not every day. Seemed to me like it was in the winter months. And for dessert, jelly or preserves. Biscuit, homemade biscuit. None of that light bread, Easter bread. She only made that about once a month or week. And we made peanut butter, and we had peanut butter sometimes.

Freeman: Really! Where did you get the peanuts?

Smith: Sandy land. Peanuts like sandy land.

Freeman: Did your grow them?

Smith: Uh-huh.

Freeman: And how did you make the peanut butter?

Smith: No problem. The problem is getting them shelled. And then you roast them, and in those days, instead of a blender, we had a little grinder to grind them up real fine, and just a little bit of olive oil in it and a little bit of salt, and that was it. That's all there was to it.

Freeman: You had olive oil?

Smith: Olive oil. Yeah. You could buy it at the store. McDade or Bastrop.

Freeman: Did you kids ever swap your lunches?

Smith: No. I never heard of it. I know I didn't.

Freeman: And what did you drink when you were at school?

Smith: Water. (laughs) Didn't take milk. I don't know why we didn't take milk. I guess it wouldn't spoil that fast. No, didn't have any cokes. I think we had orange coke, orange soda water. Speaking for myself, once a year, and that was when we went to the Oak Hill picnic, the guy that had the drug store and the confectionery kind of thing in his building, drugstore, he come out with ice creams and orange soda water. And I got a bottle of soda water. Nickel. One nickel.

Freeman: Tell me about the school days. You were telling me about this celebration once a year. 
Smith: Celebration?

Freeman: At the school.

Smith: At the school?

Freeman: What was the day when you had an orange drink?

Smith: Oh, that was the picnic.

Freeman: The picnic, tell me about that. Was it at the school?

Smith: Oh, it was just an annual picnic for the cemetery. Well, I don't know what everybody had, but Mother had to make us a new dress, and we had to have patent leather shoes and a black hat to wear to the picnic. It was a big social life deal. Making money, collecting money to work the cemetery. And they paid twelve and a half dollars a month to work that whole cemetery. They worked it once a month in those days. Didn't have a blade of grass growing, and the committee had inspectors that go in and inspect to see if they got all the leaves and grass out and the graves are mounded. You know where the mound comes from? The custom?

Freeman: No, tell me.

Smith: The slaves brought it over from Africa. See, they had to take care of white people, and they just did it their way.

Freeman: So what went on at the meeting at the cemetery?

Smith: Oh, they elected new officers, and usually it was the same ones over. Officers. And then in early days, back in the twenties, they had baseball games. They never did have any singing bees. But I'm trying to get a little music. I have a great-nephew that lives in Austin, and he stopped by to see me the other day, and I told him, "Bring your ukulele out there and start singing." He's an unusual personality. He won't give me a definite answer. I says, "I'll remind you of it. Get yourself out there. After all, your grandpa was buried out there." That's my brother. His daughter, when he was__(??), had a prostate operation. And they came up here, my brother, brother Woodrow, and she asked him if he wanted to be buried, where he wanted to be buried, in Corpus or in Oak Hill. And [he said,]
"I can't think of any better place than Oak Hill." (laughs) I thought that was a pretty good answer.

Freeman: It was. How far was your house from the cemetery?

Smith: The cemetery was right there with the school and church. A mile and a half. Everybody got too poor. They quit having church about the time I was, oh, eight or ten years old.

Freeman: What do you mean?

Smith: Wasn't enough people to go. Didn't have any money for a minister to come, minister to come out and preach the Gospel.

Freeman: What kind of church was it?

Smith: Non-denominal [denominational]. Baptist, Methodist. One went one Sunday and the ChristianThree of them.

Freeman: Did you all attend each other's services?

Smith: Uh?

Freeman: Did you all go to each other's services?

Smith: Oh yeah. Oh yeah. You can go. You'd do well to get there, get six or eight, ten kids to dress, and hitch up the wagon. And after you'd worked all week, did well to get there one Sunday a month.

Freeman: How many kids were there in your family?

Smith: Six. I have one named Woodrow I was just talking about. He passed away-cancer. It was too late getting that operation. And he also had a heart problem. Now daddy's father was a diabetic and he had a heart problem. Daddy died with a sudden heart attack. The first one he lived through. The next one just took him out. As far as the rest of us, I have all my three sisters. They have high blood pressure. They take medicine. But I don't.

Freeman: So how many of you are still living?

Smith: Just that one brother has passed away.

Freeman: So there are five of you left? 
Smith: Hum?

Freeman: There are five of you left?

Smith: Uh-huh.

Freeman: Are you the oldest?

Smith: I'm the oldest girl. The one who died is the oldest child. He was born in 1913, and I was born in 1916.

Freeman: So what's your first memory of living out there?

Smith: Well, they had a cedar arbor where they spread the dinner. Not in the beginning. I asked mother, "When did you build the first arbor?" She says, "In 1916." I was born in March and the picnic is, I think they had it in July back then so that they could get the crops in. She says, "I pushed you in the arbor in a buggy." Mother had a good memory.

Freeman: What was her first name?

Smith: Bertie Lee.

Freeman: Bertie Lee?

Smith: Bertie Lee Hancock. There's a picture around here of three girls, a photograph. A real good photograph. My brother that came back from Michigan goes around and shows everybody the three girls, mother and her two sisters. Then he's got one of us, of we four girls. It was taken in 1942, here in Bastrop, and I told my sisters, I says, "We don't get down to the photographer"- because I think I was on my way to Alaska, or something - "We'll never get together again." He takes that picture around and shows it to everybody.

Freeman: What's your first memory of your farm?

Smith: I don't know what it was. First day I went to school.

Freeman: Oh, really?

Smith: The teacher asked me a question. And I says, "No." [The teacher said,] "Don't talk to me that way. "You're going to say 'Yes, please,' or 'No, please' to me."
Freeman: Strict disciplinarian.

Smith: Huh?

Freeman: Strict disciplinarian. Did you ever get spanked at school?

Smith: Not as many times as at home. All Mother had to say, when Daddy's out in the field, and we were fussing around, "You all stop that or I'm going to tell your [father]." We wouldn't like it, so we'd do what Mother said.

Freeman: What did your house look like? You've got a picture. Did your parents build this house?

Smith: Sarah Ransom's son built it. And, uh, Mother's father bought it from Walter Ransom who built it and added on a big kitchen and dining room here. And used, went down here to the sawmill and got the cheapest lumber you could possibly get, and it didn't last very long. And every year Daddy'd say, "I'm gonna build a new house." And we had some wooded land. (interrupted by a telephone call) My paternal grandparents had thirty-two grandchildren. One had ten, one had eight, and daddy had six, and one had five, and Aunt Sue had three. We went to our grandparents house for Christmas dinner, and we always had an Easter egg hunt at their house.

Freeman: Where was their house?

Smith: Eighth of a mile from this one. We got a picture of that house that Ed Ransom built, and it doesn't look that bad, but it's nothing, nothing to look at. But she had, when they moved to that place, they went down close to Houston. Grandmother's brother had bought some land down there, and it was, Daddy was nine years old. He was the oldest child. What year was the Galveston Storm?

Freeman: Nineteen hundred.

Smith: They came back then. They went to Alief, and it rained and rained and rained, and those boll weevils ruined the cotton, and so they left. And started back. And they got to Brenham in the storm, and so they went to McDade and stayed up there for a while, and then they moved out there to that house close to this one. And by that time, they had started a dairy, my grandparents. And she had a carbine [carbide] lamp system. Nineteen hundred? You sure? 
Freeman: Uh-huh.

Smith: Well, Daddy was nine years old. He was born in 1890 , so they didn't get out to Oak Hill, probably for several years. Three or four, at least. They moved out there and started a dairy. And she had, Grandpa had developed diabetic [diabetes]. He was a diabetic, and mother always said he was lazy before they found out he had diabetes. But he probably didn't have any energy to do anything else. All he did was sit on the porch and read the Houston paper and go to town. Deliver the butter and milk. So Grandmother had a fig tree and she had a strawberry patch right beside her well that had a pump on it so that she could water 'em real good. And when my sister younger than me, three years younger than me, we palled around together, worked together, and we'd say, Mother, can we go see Grandma? And what we wanted, we wanted some strawberries. One afternoon, just about dark, (??) close to the yard fence - and this was kind of in front of the fenced yard - we stopped to get two or three strawberries. Grandma came out and caught us. She says, "You kids better never come back in my strawberry bed again." And so, I guess, years later I told Mother, and she says - and she has all these beautiful flowers, roses, pretty flowers because she'd hauled some cattle manure into her flower beds - and when I told mother about it years ago, she said, "Yeah, I know, she's that way. She wouldn't even give me a rose bloom." Well, as hard as she had to work, and her husband's insulin cost him eleven dollars a day at that time. I don't criticize her myself.

Freeman: How did they, how did they prepare their milk and butter? Did they have a churn and everything, or did they do it with a machine there before they took it into town?

Smith: Uh-huh. They separate, we had a machine. Dad couldn't live without butter. Most everybody did. If you didn't, you'd let your milk clabber, and the cream would come to the top, and you'd skim it off with a saucer in a big crock bowl and take that and churn it. Do you see my churn?

Freeman: Yes. Did you have anything to keep the milk cool?

Smith: No. When McDade got an ice house, when Daddy would go to, or Bastrop either, bring home a hundred pounds of ice. We didn't have, we might have had an old, I guess we had an old wooden ice box that was insulated so it would keep it for a while, the ice, but we never depended on that. The food that you cooked one day, you didn't eat the next day unless it was light yeast bread. Cornbread was fresh every day. Biscuits were fresh every day. No screens. No running water. We had, one thing we had was a good well. Hundred feet down, ice cold when it came up. That part of the country we was on had underground springs. I went to a lecture on it one time, and it comes from Elgin across there.

Freeman: Do you have any idea who dug the well, or when, how old the well was?

Smith: The Ransoms must have dug it, because in 1925 , during the drought, everybody was coming to our well to get water. It never went dry. It was about a hundred feet down to the water, and somehow or another Daddy, I guess it was about to cave in, so this was a big operation. It scared me. Mother's brother-inlaw was a well man. And he had to buy, I guess they were going to brick it up. The water was flowing in there so fast they couldn't brick it up, so they put five of those big old round cement, what do you call them? Wheels, or something.

Freeman: Like a pipe, a concrete pipe?

Smith: About three feet in diameter.

Freeman: Oh, really?

Smith: Uh-huh.

Freeman: How big was the opening to the well?

Smith: It was at least four feet.

Freeman: Wow! And it went down a hundred feet. That's amazing.

Smith: Now, Mother's mother, who lived on the other side of us about a half a mile from that water well, they never had water up on their hill. They had to haul it from down there, kind of in a valley. There's a well there. One thing we were blessed with was a good well. Like I told Darrell, this guy that helps me with my yard work, we had most everything in this shack. You wouldn't believe it. We - Mother and Daddy in the back bedroom back here. When it came time to raise food for the family, they had a kerosene incubator to hatch little chickens. A hundred. We never did suffer 
for food. It was kind of slim during the Depression when it was hard to get enough money to buy flour and sugar and stuff like that.

Freeman: So they kept the incubator in their bedroom?

Smith: Uh-huh

Freeman: What did the kitchen look like? What was in the kitchen?

Smith: Wooden cook stove and a table - it was longer than this one, not quite as wide; a cabinet that they bought when they got married in 1912. It had a bin where you poured a sack of flour and sugar in there. Not together, separate. It fell apart because it rained on this side of the building, but it didn't rain on the other side, the south side. So I guess it got too damp for it and it fell apart. Seems to me like it did.

Freeman: Uh-huh. So your mother cooked on a wood stove.

Smith: When we kids got out of school, we had to go to the fields to work. She'd go with us if the baby wasn't-Like Bonnie, Gertrude and Bonnie-Mother's holding Bonnie here. (referring to a photograph) I don't know, I don't know where Amy was and my brother, Woodrow. But Mother's holding Bonnie, the youngest one, and this is Gertrude, the next, before Bonnie. See? We would go, and yeah, we must of - after we got out of school she'd go with us, she took us out to the fields to work the fields, field crops. And she always had an old quilt that she, and there was always a tree or something to put 'em under.

Freeman: She'd put the babies on there? What were the field crops that your father raised?

Smith: The first year they were married, I don't know how many acres that was. I would say it was maybe ten, fifteen acres. He had fifteen acres in cotton and he made five bales of cotton. Now a bale, a small bale was four - fifty [four, five hundred] pounds - and the larger one is five hundred. Say it was five hundred pounds after it was ginned. Seed taken out. It was selling for twenty cents a pound. Five bales of cotton was pretty good money in those days. And the next year the boll weevil came along and ruined the crop. Some bugs started coming, everything. Corn and maize, about the only crop that they raised there. For the animals to eat. He had to buy some when he went to the store. He didn't raise enough for the year around. He had to buy some food.

Freeman: Would he come into Bastrop to buy groceries?

Smith: Uh-huh. Sometimes he'd come to Bastrop, sometimes we'd go to McDade. Well, in fact, he worked, in my childhood days, he'd go to McDade, and mother wouldn't go unless she wanted to buy some material at the general store. If she had a baby. So long as the girls or boys could go with him to buy the groceries. General store in McDade. The drugstore was there - the one that came out to the picnic and brought the soda water and ice cream. The first time I got a malt, they had those two little tables for kids, and chairs. I went out the back door and vomited it up.

Freeman: Oh, it made you sick!

Smith: I don't know what it is about malt. I wasn't sick, [it] just wouldn't stay down.

Freeman: Couldn't keep it on your stomach.

Smith: I didn't have any pains. It just came up. So I, ever since then, it's just a milk shake, no malt. I imagine I, I imagine I could have a malt now and it wouldn't bother me.

Freeman: Did your house have a cistern also?

Smith: Did my house what?

Freeman: Have a cistern as well. I mean, it had this wonderful well, but was there a cistern there too?

Smith: Yeah, yeah. Yeah it was here. But one time we were looking at this and trying to find out where the cistern was, but it, it had to be right here where they joined on. I think there was sometime wrong with it. It wasn't working when we lived out there. It needed, brick had fell down or something. It was bricked up.

Freeman: And was any part of that house log?

Smith: Any part of the house what?

Freeman: Log. Was it made out of logs?

Smith: I didn't hear you, hon. 
Freeman: $\log$.

Smith: No.

Freeman: It was all frame.

Smith: Cheap lumber. Raw lumber.

Freeman: And where was the mill?

Smith: Out here in the park.

Freeman: Oh.

Smith: That's where all the pine lumber came from in the early days. Bastrop, all around.

Freeman: Where did your mother get the wood for the stove?

Smith: We had a wooded section of land on the hundred acres. You got to have, you had to have, couldn't get rid of all the wood. I mean the trees, because you had to, it was oak that you had to burn. Cedar in the fireplace pops out. So we mostly burned oak lumber, oak wood.

Freeman: Did she have a garden for the house? Did she have a garden?

Smith: You mean a vegetable garden?

Freeman: Uh-huh.

Smith: She and Daddy both, and I had to carry the water from the well to water the plants. We had the prettiest - One year iceberg, iceberg lettuce, and I had it in February. And when they put those plants out, they grew their own plants from seed, two long rows out there. Nothing but clay, red clay, and I had to carry the water from the well to water them. But anyway, it made pretty heads of lettuce, I know, and they took it to Bastrop and sold it.

Freeman: Was there a store where he sold it in Bastrop, or was there a market?

Smith: No, he just went to the store, sold it. Ed Ravenberg had bought out a store from Dad's cousin. I think he, he had a meat market and butter and milk, and I imagine that's where he sold it.
Freeman: What else did they grow in the garden?

Smith: Everything. Most everything. The main thing was pinto beans, green beans, and raise them up and let 'em make the pull bean and dry and cook 'em dry, like we'd go to the store now and buy 'em dry and packaged up. And also black-eyed peas the same way. And we had a fall garden in the wintertime, turnips and mustard and collards. I don't recall anything else. Then we had, in the summertime we had tomatoes. One year we - And corn. Not field corn, sweet corn. A lot of people fed it to the horses, but we didn't. Corn, tomatoes, cantaloupes, watermelons. That's another money crop. Cantaloupes and watermelons would grow out there. And squash and bell pepper.

Freeman: Did you do canning?

Smith: Um?

Freeman: Did you do canning?

Smith: Hundred quarts of tomatoes a year. Hundred pints of corn, preserves, canned fruit. Had a bunch of grapes.

Freeman: What did you do with the grapes?

Smith: He [Dad] thought he was going, Texas was going to (??). I never did, I haven't understood the issue. Law business. And when we legalized liquor in Texas. When was that? In '25.

Freeman: I don't know.

Smith: Somewhere along there. He was going to raise grapes. Dad tried everything to make some money. Grow grapes to sell them to the wineries. It was voted out. It didn't come in. And we had all these grapes. We drank grape juice and we made grape jelly. That's about it. There isn't much else you can do with grapes.

Freeman: Did he have a special variety of grape?

Smith: Uh-huh.

Freeman: It wasn't just mustang grapes, then.

Smith: Concord and Spanish grape. Concord was the one that was much better for canning and all that. 
He had a white grape. I believe he called muscadine. That's the only three I can remember.

Freeman: So Concord, muscatine, and-

Smith: Concord, muscadine, Spanish.

Freeman: Spanish grape.

Smith: Little bitty old black grape — sweet.

Freeman: Now, did your neighbors raise grapes too?

Smith: No.

Freeman: Was there a winery somewhere in the area?

Smith: No, it was voted out.

Freeman: So it never got started.

Smith: Not then. I don't know when it came in. I didn't keep up with it. But I guess we had left there and left his brother in charge of it until Camp Swift came along. Of course, I went back out there once after I came back here to live. Wasn't any grapes around. Not any peach trees or anything like that.

Freeman: Tell me about the canning. How did you do the canning?

Smith: Oh, we had a pressure cooker and a sealer. We even canned a beef, butchered a beef one year and sealed it in the can. And everybody in the community said that, They'll poison themselves.

Freeman: Were there any beef clubs where people shared beef?

Smith: Unh-uh. No, that wasn't a sharing community. I don't know of anything they shared. Like Grandmother's [strawberries]. Of course my paternal grandparents, she wasn't going to share anything with you.

Freeman: And where was the cotton gin?

Smith: It wasn't very far from our house. You had to go around the road about a mile. We were on a little knoll, and Grandmother's and Mother's mother lived a little piece and just down, 'cause that little slough where they had to have a pond to make the steam for this thing to work. And Esther (??) bought it, and then along about World War I John Hancock bought it for his two boys, Ray and Arthur. And Ray went to the service, and Arthur never did go. Ray was the oldest, was older than Arthur. Then Mother. So, they got in a feud over the money. It was a partnership, and handed down the story to me was that Arthur didn't have any money for Ray when he got out of the service from his cotton gin, so they split. And they closed up the gin. Turned out that people didn't raise cotton out there. Land got too, wasn't suitable for it, or boll weevils got it, or something.

Freeman: Did everybody raise cotton at some point?

Smith: At one point and the other they did.

Freeman: And who owned the gin before the Hancocks?

Smith: Ah.

Freeman: You mentioned a name.

Smith: Right now I can't think of his first name. Earl Esberger had a gin in McDade.

Freeman: Esberger?

Smith: And Barbee had it, the gin there at Oak Hill, but not in the same location that Esberger had built his. Barbee was up, was down in a slough close to the church out there.

Freeman: Did they operate at the same time?

Smith: Unh-uh. Barbee, one gin's enough. Barbee, Esberger, then Hancocks. I'll have a section about the gin in the story, what I know about the little grocery store, convenience store, and molasses mill.

Freeman: Where was that?

Smith: You know when you get on the Mc - No you can't get on the McDade Road today. You know where the (??) is?

\section{Freeman: Yes.}

Smith: You know the hill. Up on that, some people by the name of Wilford lived there, and that's where they had the molasses mill. Most everybody in the community had to grow sugar cane and cut it at the 
right time and take it to the mill, and they cooked it and got the juice out of it and then they boiled it down at a high temperature. It became syrup.

Freeman: Did everyone use that one mill?

Smith: I don't think two mills operated at one time. And some, ah, I don't understand the mechanism of the gin, but some part of the gin, when the gin was in operation you could take your corn over there and get cornmeal made. Now, my brother Kenneth, he could do it. I don't know whether I'll ever get him to write anything, help me to write anything for this Oak Hill business or not. Because his, before he moved back here, his wife died with cancer. And the girls had to, well, she never did work very much. From the time she developed cancer, Kenneth had retired from his job, so he took care of her while she lived with this cancer. One time when he made a trip down here when Mother was getting real old, he said that he probably would move back to Texas after Dorothy passed away because her, she didn't come from a line of people that lived long lives like we do. And that's the way it happened. And I didn't think he'd ever come back, because when we talked to him over the phone, "Oh, it was snowing so good." Well, I said, "What do you want to leave for?" And he said he's coming back down here. "What do you want to leave for? I thought you like to shovel that snow." [He said,] "No, I'm tired of that snow!" So, anyway.

Freeman: Well, when you took-I'm thinking about that molasses plant again. How did you get the molasses back to the farm? To the house?

Smith: Well, you had to take your own jug. Clay jug.

Freeman: What kind?

Smith: A clay jug, McDade made. They had a clay factory. That churn was made in McDade. All kinds of stuff. We used an old corn cob for a stopper. (laughs)

Freeman: So you'd go over there in a wagon with your jugs and bring it back over to the house.

Smith: Uh-huh. That's the way it was.

Freeman: And what did you use the molasses - Go ahead.
Smith: Uh, Mr. Wilbert had gone to town. It was on a Saturday when John Hancock was always there with his cane. Cane. Sugar cane. Sugar cane. And so his wife said, well, she guessed she could do it. Mother told me this. So, when he got home, whenever they were eating, the syrup probably was on a meal like this for breakfast, butter and bread, hot biscuit, syrup on them. So John would say, "Pass me Florence's syrup." And the reason, John always had a name for somebody, a name for everything. So, the reason he called it Florence's syrup was that she didn't cook it long enough to get thick. And my maternal grandmother had a sister and she'd get her husband to hitch the buggy, hitch the horse to the buggy, and she'd take off. Every woman that gave birth to a child, why she'd go visit them the next day. So, had a chicken that had some kind of disease in its craw. Was hanging down. Grandmother's sister's name was Lucy. And every time he'd say something about that chicken, he'd call it "Lucy the chicken."

Freeman: I wondered if there were any special foods that your mother fixed that you especially liked.

Smith: That I especially liked?

Freeman: Uh-huh.

Smith: Or she took to the picnic? All the cooks tried to, well, I wouldn't say they all tried to outdo each other because they had better food than some of the other families. That was, the Smiths had better food. I'm trying, we had fried chicken, potato salad of course, no pinto beans. That's everyday food. Had to be something special. For a few years at the picnic they served barbecue, but that didn't last too long. About five years, I think.

Freeman: Why was that? Why didn't that go on?

Smith: Because everybody in the county heard that they weren't charging for your lunch and they'd have as many as five hundred people come out there. That's my guess. I really don't know. Because the people in the community donated the beef to barbecue.

Freeman: So at that meeting, did people usually come from outside the community, or was it mostly just Oak Hill?

Smith: No, they come from all over. Back up into the twenties. Up into-The people hadn't run down 
before we left out there. Wasn't any big deal like it used to be.

Freeman: Did people start moving away?

Smith: Yeah, they had to move away. See, nobody had any land to sell and there wasn't, the tracts weren't large enough like a big ranch. Two people could make a living on the tract, the land they owned. If you owned 200 acres, you were doing good out there. Because, see, Mark Mul (??), out of his league he sold 150 acres and then somebody else come along and he bought another 150 acres, but before that land was more plentiful up until the Civil War. That's when it, all the grants had taken and I don't what year it was, but along in that age.

Freeman: So when would you say the most people lived out there?

Smith: Where did they live?

Freeman: When did the most people live out there?

Smith: Oh, why, that guy that got to be county tax collector told me one time that it was early in the 1900s, it was a swinging community on Saturday night. And after the 1890s, see Daddy was born, Daddy was born in 1890, and say he didn't get married until 1912. Only reason he went over there was after mother, and he had good reason to be, because she was real pretty. Oh, and he didn't go to any parties after they got married. Wasn't no use to go to any parties.

Freeman: So there were lots of people who lived there until about World War I?

Smith: Ah, let's see, maybe say that again, I'm sorry.

Freeman: Were there a lot of people who lived there until the 1920s?

Smith: Nineteen twenty, I would have started school. I would have been seven years old. No, there were about two people in my grade.

Freeman: So it was already on the downhill.

Smith: Uh-huh.

Freeman: Where did they go? Where did the kids go?
Smith: Well, the Ransoms, when, let's see, not the railroad. What's the name of that road? Takes you to and from work.

\section{Freeman: Streetcar?}

Smith: Yes. When Galveston got the streetcar, the Ransoms went down there. Walter Ransom, after my grade, I really don't know what he did - along in those-

Freeman: What about the drought in 1925? Tell me about that.

Smith: About the drought?

Freeman: Uh-huh. Tell me about that.

Smith: Well, it didn't rain any in the spring is what I've been told. I don't remember. Oh, Daddy made some money that year.

Freeman: How did he do that?

Smith: Had a freak shower on his watermelon patch. One of those, what do you call them, two-bit showers.

Freeman: Two-bit showers?

Smith: Two-bit shower. Sandy land. And somebody came out and stole some of them. He made four hundred dollars on an acre of watermelons that year.

\section{Freeman: Wow!}

Smith: Twenty-five. And they had a black neighbor right there by the mailbox. We just lived on the other side of the hill. And Daddy told him, he says, "I'm going to take my shotgun over there and stay up all night and see who's getting my watermelons." And this black guy said, "You better not. You might shoot your best friend." And it was Willie Watson, and he was married to Hemphill. Oh, Willie Watson, and they were friends, and they're not kin to us. They were just friends, really just a friend.

Freeman: Did you play with his kids?

Smith: Did I what?

Freeman: Did you play with his kids? 
Smith: No, because he lived around McDade. No, you didn't go anywhere to play. You played with your own brothers and sisters. Now McDade (??), her father was always going. I guess you saw that picture on the wall in the dining room with all those people on it. Mother's on it. I'm on it. Joe's always going in the community with his truck and taking us to the fair or something like that.

Freeman: Who was that? Who did that?

Smith: Joe. Fay's father.

Freeman: So he'd come around to different farms and pick the kids up?

Smith: That's the only time I remember anybody picking up anybody.

Freeman: And where would he take you?

Smith: To county fair. The women always took some fruit jelly or something, see if they could get a prize. Didn't get any money. What else do you want to know?

Freeman: What was it like living out there during the Depression?

Smith: (laughs) Well, wasn't much different than it was since I was born than it was Depression days, except you just couldn't get a job or you couldn't sell, get any money if you had some produce to sell like watermelons or cantaloupes or something like that. Couldn't get any money together. We didn't miss any school. Might not have had anything but beans. We always had biscuits and cornbread because Daddy wasn't too crazy about cornbread.

Freeman: Did you all raise cattle?

Smith: Not for selling at the market. Butchering. No, we just used 'em for milk cows. I don't know how many times he butchered and canned the beef, but it wasn't very many times.

Freeman: I wondered if you all lost any cattle during that cattle shoot in the 1930s - when the government came around?

Smith: Oh, what kind of disease did they have? Anyways they dipped them. Now we dipped. There was a dipping vat on Daddy's father's, right by the road. It stood there for years.

Freeman: What did it look like?

Smith: The vat? I never did go up, just saw it from the road. Just, I don't know. Come to think of it I don't know whether they poured the solution on them and put them in that pen or had the cows get in the vat. Must have been in their feet. Was it in their feet? I don't know. I forget about that.

Freeman: Well they tried to dip the whole animal.

Smith: Huh?

Freeman: They tried to dip the whole animal.

Smith: I don't know. I don't even remember what it was for. What disease was plentiful?

Freeman: It was ticks.

Smith: Oh, for ticks?

Freeman: The ticks were carrying the disease. So did neighbors use that same cattle dip?

Smith: I didn't hear of anybody using the one up there.

Freeman: You said your neighbor was a black man?

Smith: Uh-huh. Half, I think. His name was Watson, named after some - slaves took up the master's name a lot of time. I guess most all the time.

Freeman: You mentioned that you and your brothers and sisters played games. What did you [do]?

Smith: Played what?

\section{Freeman: Games.}

Smith: Played games?

Freeman: Uh-huh. Played with each other. What kinds of - Did you go fishing, or what did you do for-

Smith: No, we didn't go fishing. That cost money. I'm trying to think what we did do. [By the] time we went to school and worked all the time we didn't have much 
time to play games. We'd play, Daddy was a pretty good checkers player. He played with the checkers once in a while. I was about grown when we got a deck of cards. I think my brother brought 'em in. I don't think Daddy and Mother bought 'em. We didn't play dominoes.

Freeman: Did you read?

Smith: Huh?

Freeman: Did you read?

Smith: Read? Just what I had to for school. Now, Gertrude, the one that's by that, what is that, what is the name of it? In San Marcos. What's the name of the plaque that's got Lyndon Johnson and all those?

\section{Freeman: Southwest Texas?}

Smith: Yeah, but you have to have high grades, or something. Don't you? To get your name on? Do you know what I'm talking about?

Freeman: No.

Smith: I haven't seen it.

Freeman: But her name is on there?

Smith: Uh-huh.

Freeman: What did she do?

Smith: I think she made high grades. Like valedictorian. How they grade you in college, A, B, C. She must have been an honor student. That's what it is, honor student. I haven't seen it myself. I think she went over there years ago when she found out it was there, they had put up the plaque. It's on the outside of the building.

Freeman: Did you all go to dances?

Smith: No.

Freeman: Why not?

Smith: The people that held the dances in their homes, they were the ones that made liquor illegally. Couldn't go.
Freeman: So were their stills in the countryside?

Smith: Stills? No I don't know what they had. Probably an old barrel. (laughs) Don't know how they made it.

Freeman: Did you ever have music?

Smith: Have what?

Freeman: Music.

Smith: Daddy could play the harmonica, but he didn't teach me how. I tried to learn on my own. I got a book on it when I was about sixteen, I think. It wouldn't have been hard to learn. Mother said she couldn't carry a tune, though.

Freeman: What did you do at Christmastime?

Smith: Christmastime? Nothin'. She shopped at Sears by mail. One year I got, Santa Claus left me a little doll buggy. It had two little wheels and a little cart with a handle on it. Cost eight-nine cents. We always had apples and oranges on the tree. Usually we were short of money on Christmas. They were. We had, usually had a big tree with - Put it - my sister and myself had one bedroom - usually put it in our bedroom. And Christmas Eve, why mother was in the kitchen, I guess getting the turkey ready to cook on the next day, and we were giggling, I don't know why. And she came in and said, "Y'all better get to sleep. I hear Santa Claus on the roof and he's not going to stay if y'all don't get to sleep."

Freeman: Did you and your sister have to share a bed, or did you have separate beds?

Smith: We had to share a bed. It wasn't like each one having their own bed.

Freeman: Your parents had their own bedroom. And then where did each of you kids sleep?

Smith: Where did the kids sleep? Mother had a youth bed in her room. The babies always slept. I think she got it when my brother Kenneth was born. He's, he was eighty-three in March. And I'm eighty-eight. You see, he could sleep in the youth bed in Daddy and Mother's room until Gertrude came along. And then he goes to sleep with the brother older than me. 
Freeman: Did they have their own bedroom?

Smith: Yeah. Four bedrooms, four rooms. The main bedroom where Dad and Mother slept, and the youth bed was, was this one. There was a porch there. Amy and I were over here, and Mother and Dad were here. And then the youth bed was there. And then there was two back rooms back there. By, I don't know, by the time Bonnie was born, when my brother Woodrow had left home and started to college at San Marcos, probably, I'd have to stop and figure it out.

Freeman: How many of the children went to college?

Smith: Three. The oldest one that passed away, and Kenneth, the other boy, and then Gertrude, who was Who's Who, All American in high school. Everything anybody could win in high school, she got it. And a classmate went to the superintendent and says, "If I drop one of my grades, I could beat Gertrude by a half a point." He said, "I wish you wouldn't do it." So there was kind of a feud in her graduating class.

Freeman: And did she go to Oak Hill also?

Smith: Bonnie was in the second grade when we moved to town and I-One time Gertrude told me that I made a misfit out of her. I said, "What are you talking about?" [She said,] "When you taught me how to get out of the first grade and get promoted to the third grade when [I] started to school at Oak Hill." I said, "I didn't tell you. I was trying to study my own lesson, and you come over here with the little primer and said, 'What's this word and that word?"' And so it went on until I suggested, "Read it until you get it straight." She wanted to. Did it just perfect. Everything she'd asked me. All the books we could keep in those days. Why she got with me because Mother and Dad were busy doing something at night. Or maybe they were getting too tired to do anything. She graduated in May when she was fifteen. She would have been sixteen on the thirtieth of June. She was almost sixteen. And along about my senior year, we'd go home for lunch from school, and she'd get herself the newspaper and, well it was some column she was reading and it said school was already out. And Mother'd say, "Gertrude, come on." [She would say,] "As soon as I get through with this story." Well, she never got through with this story. And she didn't know how to boil water when she got out of high school and went straight to San Marcos on a scholarship, see. She learned how to cook at the college co-op where she stayed.
Freeman: Why did you all move into town?

Smith: Hum?

Freeman: Why did you all move into town?

Smith: Mother had, there was a doctor in McDade that was named Dr. Sullivan. And when Mother got married and she was having these children, why, she wasn't going to have a midwife. So Dr. Sullivan came out with his medical bag. She had Woodrow, myself, Amy, and Kenneth. I'd hear him talking to Daddy. "That's all we're going to have." So, time went by, and she had two more. And Dr. Bryson had to come from Bastrop. I don't know, he and Dr. Bryson may have been chummy with everybody. I don't know.

Freeman: Well, did the doctors come out to the area pretty frequently?

Smith: Uh-huh. Oh yeah, to help deliver the baby. You didn't go to the hospital. If you did, there was something wrong. So I'm trying to think what I want to say. How it came about. I wasn't there. She'd ship us off to Grandma.

Freeman: So she would know that she was going to go into labor, and she would send you off to your grandmother?

Smith: Uh-huh. It must have been with Gertrude, he told Dr. Bryson. I don't know how much he gave to come out, whether it was five dollars-ten dollars, whatever it was. Never did hear what it was. We didn't talk about those things in front of children in those days. But my daddy told him, "I hope this is the last trip you have to make out there." But she had Bonnie. She nursed all six of us. She didn't wash any bottles until, she nursed us for a year, then we got cow's milk in a bottle.

Freeman: Did you help take care of your younger siblings?

Smith: I was supposed to be taking care of Kenneth, but he sat in a pan of hot water when she was operating a separator right by there. (laughs) It wasn't more than warm water to rinse out the separator after she got through with the milk. I let him fall into a pan of water that was sitting on the floor. See, I was only six years. I might have been eight then. I think he was about ready to walk. Oh yeah, I had my share of taking care 
of 'em. Gertrude and Bonnie in the last few years, financially, have been giving me large gifts, and they don't say it, and I don't mention it, but I think they do it in appreciation for what I did for them when they were babies. Because I, when I get home from school, I'd have to care for the baby while my mother took care of some errands. I'd have to get on the front porch in the rocker and keep 'em from crying. It didn't suit me either, because I wanted to play.

Freeman: How early did you all get up in the morning?

Smith: Five o'clock.

Freeman: And what would you do?

Smith: Eat breakfast. Get dressed. Go to school. Or go to work when school was out. Go to work in the field. Garden.

Freeman: Did you do any work before you went to school?

Smith: No, it was dark. Did it when we came home. Had to milk the cow, feed the chickens, cut the wood. Remind me to show you the table I had made in remembrance of (??) Amy and I played with it (??) It's on the back porch.

Freeman: Okay. Were there any peddlers who came around?

Smith: Oh, yes!

Freeman: Tell me about those.

Smith: Old man Bright.

Freeman: Brighton?

Smith: Bright.

Freeman: Bright.

Smith: Lived at Lexington. Drove a buggy and peddled grape cuttings and peach cuttings and all that. Pear. And he usually stayed at our house. I don't know where he slept. Stayed at somebody's house when he went peddling that stuff around.

Freeman: What did he bring besides the cuttings?
Smith: Besides the what?

Freeman: Cuttings.

Smith: Cuttings?

Freeman: What else did he bring?

Smith: I didn't know of anything else he brought. Just fruit trees, grapes.

Freeman: Did anybody bring around pots and pans and that kind of thing?

Smith: Well, he didn't. Now, this one guy (sound indistinguishable), he had a hack, they called it, and a mule, horse, and he went around fixing people's sewing machines. Most every family had to have a sewing machine. Couldn't get by without it. So he'd stay at somebody's house and fix their machine free of charge for room and board that night. He went into Travis County and Lee County and Bastrop County. Was gone several days. And he took food to eat, like cheese, probably homemade cheese. Daddy made cheese. Daddy tanned his own leather and repaired our shoes. And we should have had new shoes when we were growing so fast. That made a corn on my toe, (laughs) and I carried Gertrude and Bonnie this way, and I got a curve in my spine.

Freeman: Did anybody bring around patent medicines?

Smith: No, never did come to our house with that. We, the only thing we ever had, I don't know if we even [had] an aspirin or not. Cough syrup, (??), turpentine. Not to eat, drink. We used kerosene for cuts.

Freeman: What did you do? I mean, did your mother just take care of cuts and things like that?

Smith: Do you want me to tell you the time I got a splinter in the ball of my foot?

\section{Freeman: Yeah.}

Smith: We were over at her house on a Sunday, and she scrubbed her floors with lye. And they were rough. And they had a big hallway like this house has. And I was about eight years old. And I was running around barefoot and I got a splinter in the ball of my foot. 
Right in the middle of it. And Daddy happened to be there. He got a razor and cut that thing open, and it was big. And mother was holding me down. They got it out and bandaged it up, and I walked on my heel for a while and I guess it got all right. Washed it in salt water, not full strength. I don't think I've had an aspirin my whole life until I had this operation. The heart specialist told me when, Dr. Mabry told me to go to the specialist. He said, "There's nothing wrong with your heart, but I want you to take a baby aspirin every day in your life." We never - One time we went to the doctor. Came down here to Bastrop. I think we had the whooping cough. And my sister that's younger than I, Dr. Bryson said that her case was almost, she was almost pneumonia, pneumonia patient. I guess her lungs were clogged up.

Freeman: Did anybody get that terrible flu in $1918 ?$

Smith: I haven't had the flu in my life. Had one shot and it was a couple of years ago.

Freeman: Did you know of anybody in the area getting that bad flu?

Smith: No, I don't think so. What year was that?

Freeman: Nineteen eighteen.

Smith: I was too young to remember that. But I didn't ever hear anybody talking about it.

Freeman: When your father farmed, what kind of animals did he use?

Smith: Horses pulling a cultivator and a turning plow and a plow. Horses pulled it along. You just guided it where you wanted it to go.

Freeman: Did he ever use mules?

Smith: Huh?

Freeman: Did he ever use mules?

Smith: Ever use what?

Freeman: Mules?

Smith: I didn't hear it.

Freeman: Mules.
Smith: No. I don't know why. They were hard to handle, I think.

Freeman: So where did he get the horses, I wonder.

Smith: Well, when he got married, his best friend gave him a horse, and they named it old George. He lived a long, long time. I don't know, he bought them from somebody. He might have gotten 'em from his father. They didn't talk about what went on when we went to school. Especially when animals were matin'. I could feed them and I could milk the cows, but when they mated, why, "Go to the house."

Freeman: Did they raise hogs?

Smith: Raised hogs, chickens, ducks. We had geese for feathers. Had to pick those geese for feathers [to] make pillows.

Freeman: What about turkeys?

Smith: Oh yes. Turkeys was a money crop.

Freeman: How did you raise them?

Smith: You had to have an old gobbler and some hens. One year the gobbler disappeared. I guess she had two that year. Mother raised the turkeys. All we did, the kids, was help her. The gobbler disappeared. Two years later, the gobbler came home. You know where the Oak Hill Road is, and you turn to the right? The Flemings lived there. And she figured that old gobbler got off out of his territory and she penned him up. And she let him out and he came home. I think that she raised enough turkeys that the buyer came out and picked them up from McDade. The sale of turkeys amounted to around $\$ 125$. That was around the first of November. And of course they used that for Christmas. They ran, I can see mother, must have been when she was pregnant with Bonnie. She penned the old turkey hen up when she was ready to lay an egg and go down to the wooded area, which wasn't very far from the house. She penned him up and she goes around and around, squawking and squawking, turkey talk, she wants to get out and go lay that egg. See, she probably had [a nest]. Most of the time it was under a cedar tree. And there was a good ol' lane going down the road from the barnyard, and mother was pregnant. And she, that old turkey, he run so fast, my Mother had to run real fast to keep up with her so she could find the nest because the chicken snakes would come along 
and eat the eggs. And I had a notion it was Bonnie, she was pregnant. So I guess all the work she had to do to survive. She got enough exercise that she didn't have any problems giving birth to her children.

Freeman: Did you all bell your turkey? Did you put a bell on it?

Smith: On the gobbler.

Freeman: And did you ever, did anybody ever drive turkeys? Did they have turkey roundups, or anything like that?

Smith: Ever do what?

Freeman: Did they ever have turkey roundups, where they rounded 'em up?

Smith: For what?

Freeman: For market.

Smith: For market. Oh yeah, you had to have 'em penned up or, so they could come out and won't have any trouble picking 'em up.

Freeman: How did you get 'em in?

Smith: Oh, they come home at night. Put 'em in the pen where they can't fly out.

Freeman: Did you have any trouble with predators, like bobcats?

Smith: Like what?

Freeman: Bobcats, or coyotes, or anything like that.

Smith: No. No. Let's see, what were those coyotes eating? You kill one and the county would pay you five dollars for it. But I don't know what they were eating though. I don't think that we ever lost any turkeys from the coyotes. Another thing, money-making crop, my father, you know where that big ranch is below the cemetery? Four thousand acres. That was a grant. And I haven't researched that and know just how it all came about. The land. Anyway, it was four thousand acres. It wasn't fenced. And they called it the sand hills, and it was wooded. And Alum Creek went through and all that kind of stuff. And people in Oak Hill community used it to go, even McDade, the men would go hunting with their dog and their rifle to kill opossum and skunk and ringtail, was about all they could get. And ringtail was five dollars a skin at one time. Seemed to me like, and I got pictures of - Wait a minute, I'm too far ahead of my story. So Daddy had a little dog that was named Prince. He was a smart little dog. And he could, he had a carbide cap with a light on it, and it had a rifle, and he'd go about, say nine o'clock, take that little dog, nine o'clock in the evening, take that little dog and go into that wooded place, that ranch. It was unoccupied, never had been fenced. And when he came home, I don't know whether he stayed all night or not, but he probably stayed until almost three o'clock. I don't recall him coming and going, but I know when he got up in the morning he had made himself a, what do you call it, I'll call it an outfit where he could put the skin. Where did he skin 'em? Did he skin 'em while he was out in the woods? I guess he did. Just bring the skins back. And pretty quick he had to get 'em on that board and take all the fat off, whatever, scrape it and salt it down. And then I think he had, he sold 'em to the buyer in McDade. I don't think they came out. Opossums, and called 'em skucks [skunks]. And ringtail.

Well, by that time, after so many years he's hunting, why, to save money he starts making leather. He used the bark from the oak trees in a homemade vat, was one method of making. He built a big old vat, about as big as a wagon bed. He used the leather for repairing his own bridles and stuff that the horses used and anything they needed around the farm, plus, he soled our shoes. So then, he was going to have his office, be a taxidermist. That never did materialize. But he made mother a skunk collar and mother, she needed a coat, winter coat, and I got opossum. I got pictures of all of us except Woodrow, in the picture, Kodak. And I guess the Depression came along, after that. Amy and the rest of them never did get a fur collar.

So, another time, when he was nine years old and they lived in Hutto, his mother, I always heard when I was a kid, had a millinery shop in Hutto. It was Aunt Tex's store - and she went down there and worked, worked in the store, and what she did was decorate the hats that women wore. Put a little rose on it, or something. And Dad would come home from school, and she would tell him, "Do not make a fire in the stove, cook stove." One day, he decided he wanted some candy, and he made him some candy and he couldn't eat it all, so he took it out and buried it before his mother got home. So Daddy later buys a copper kettle during 
Depression days. It fits down on the wooden stove, and a candy thermometer. He's going to have a candy factory. Going to make candy. One day, Brenda - she was attached to her grandfather, more than any of the other children, grandchildren - but one day Daddy, that's the candy he made, and I helped him. He always had somebody to help him because if you don't get it taken care of at the right temperature, it doesn't work right. So I was helping him that day. I was strong. I really worked and I came home for a weekend, or something, and he said "Ruth, when I'm gone, you can have this copper kettle."

\section{Freeman: Do you still have it?}

Smith: He didn't put it in his will. So, I had the big, old, Dutch oven settin' in - I made a stand for it - a kettle that had two handles. Made a stand. Was sitting in there in front of the fireplace, plus a bunch of other stuff. You couldn't shine it up, you know. And I really didn't have room for it. And I said to her one day, I said, "Brenda, you don't have room for it in your house, but I sure don't have room in this house." And so she said, well, she'd pick it up some day. Well, when she picked it up, she just picked up the candy kettle and the big Dutch oven. I didn't say anything to her because he was so fond of her and I just-So Gertrude came up one time, and she had a habit of going through the house and seeing if there was anything missing. "What did you do with Daddy's candy kettle?" I said, "Brenda took it." She didn't say anything else.

Freeman: What kind of candy did he make?

Smith: Oh, all kinds. Dipped chocolates, put pecans in it. Strawberry-flavored, vanilla-flavored, coconutflavored, pralines. When we were going to school, he made kisses. He'd work that ball of sugar until it was smooth and the right temperature. So a lot went on in this house. We weren't so poor. This was the house. It just deteriorated real fast.

Daddy mounted a skunk.

Freeman: He did what?
Smith: A whole skunk. Mounted it. You know, tanned it and stuffed it. When we left the farm, Woodrow was out in Eagle Pass, working before he went to college, and he wrote us to see if he wouldn't come on and fence what little crop was out there. And Woodrow was, and the Owen boys, and I don't know who else, some of the women around the community out there. I was gone, already out and gone, working, and Woodrow, after all the people were there, brought the skunk in, and it liked to scare some of the women. Oh, a live skunk!

Freeman: Were there many deer out there when you were?

Smith: Unh-uh. There were deer when Daddy was a young man, and from, I don't know what happened to them, about what year it was, but the deer disappeared. And when the park was built, they brought in some deer and they kept them in the cages, and they got out and started to roam the countryside, and that's how we got some deers out there. I don't know if they are plentiful or not. I don't think they are. I haven't heard of anybody living out there seeing any.

Freeman: I would have thought people would have shot them, you know, for food.

Smith: They did. I don't think Daddy liked it. You know, when he was a young man. I don't think, I think he might have shot them somewhere before they got (??). I don't think Daddy liked the meat, because they didn't know how to, Mother never did learn how to do like I cook. I can change the taste of meat or something, or vegetables, with herbs. All she had was chili powder and black powder and salt and pepper. Not even an onion.

\author{
Interview with Ruth E. Smith \\ Interviewed by Martha Doty Freeman \\ Date: April 16, 2004 \\ Place: Home of Smith, Bastrop, Texas \\ Year of Birth: 1916
}




\title{
W Alter L. Thomas InTERVIEW
}

\author{
By Thad Sitton
}

\section{April 2004}

Thad Sitton: This is Thad Sitton. Today is April 15, 2004. This interview is taking place in Elgin, Texas, with Walter Thomas at his home. This interview is part of the Texas State University-San Marcos, Camp Swift Oral History Project, sponsored by the Texas National Guard and conducted in conjunction with the Center for American History, The University of Texas at Austin.

Sitton: I'd like to ask you about the place that you grew up on over there. Now, I know you were just a kid when the government took it, I know that, but I also know that you know from your daddy - Can you describe that place that you grew up on?

Walter L. Thomas: All right, it wasn't too far from a little stream. My mother's dad, Jackson Morgan, is the one who bought the land. He bought it right after slavery. Jackson Morgan, called him Uncle Jackson. It was about, I'll say, about a half a mile from a little stream called Spring Branch. And up-let me see-coming from McDade, they tell me he had to go trade, they used to trade in McDade. Aw, I'd say it was about five miles from McDade-five miles. And the way you would get there was coming from the brickyard. There is a Brickyard Road that goes eastward from [Highway] 95, and then the road that leads up to our place comes westward. Now, let me see, I think the Scotts face a portion back down there. The Scotts, they were familiar with the Scotts, that was Abner Scott or whatever, but a lot of the Scotts lived there.

Sitton: But it was on Spring Branch?

Thomas: Spring Branch, yeah, right.

Sitton: And the land went way back — the ownership?

Thomas: Yeah, it went way back. Jackson bought it, he was the one who bought it, 'cause I heard how they cleared it off. Them old men would sit by the fire at night and cook sweet potatoes up under the fire.

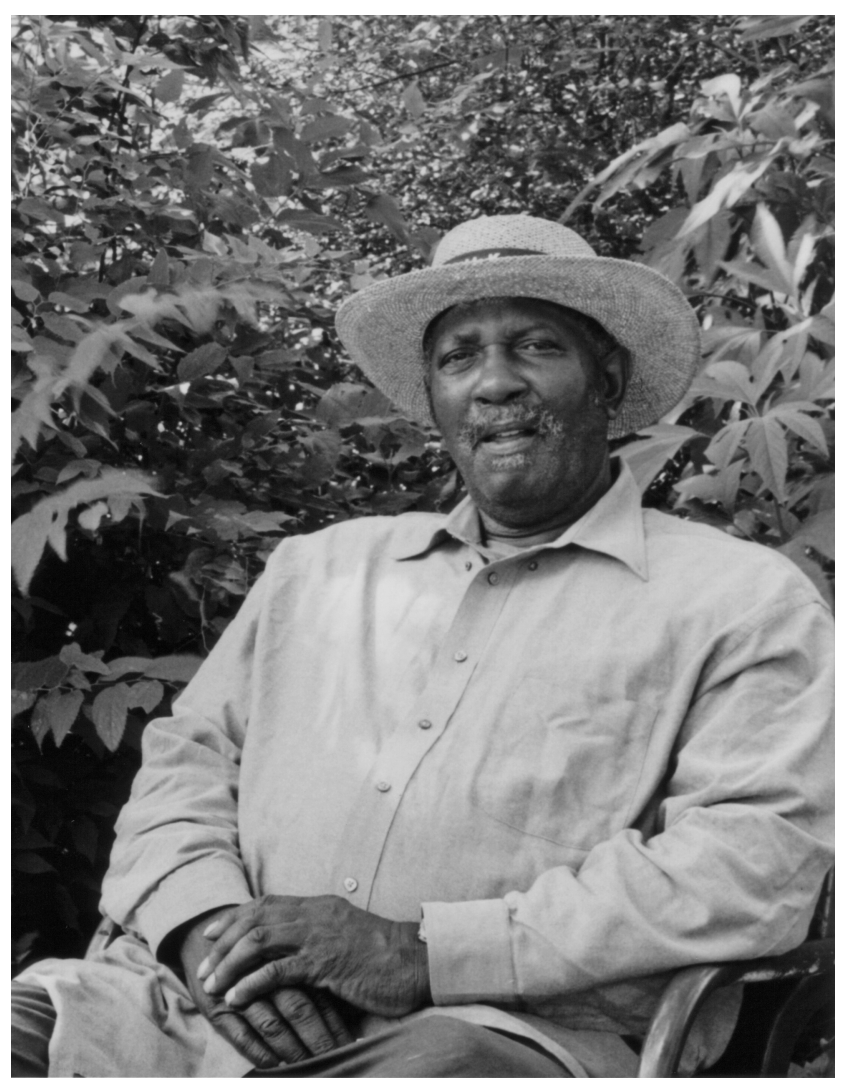

Walter L. Thomas

They mostly made their meals off of sweet potatoes, sweet potatoes went a long way, back then. I used to eat them and so did your people. I don't know why we used it, just raised that way, but I used to see them cut that sweet potato and sit down and eat it. And them old men could eat that sweet potato and go on about their business. That was one sweet potato.

Sitton: Well, the sweet potato would grow in the sandy land, and you could grow a lot of sweet potatoes in a little patch. And they had a lot of calories, and they'd keep you going.

Thomas: Right, right! I don't know why the younger generation eat that food and maintain their ability to go about. I don't know if any of them had that idea. They used to could eat that corn. They could take a 
bag of corn, that parched corn, and march miles eating that old corn. 'Course, I don't know.

Sitton: Well, did any word get passed down about how this Morgan got that land?

Thomas: Jackson Morgan? I think he bought that land some kind of way. Nobody gave it to him, eightythree acres. But they tell me the camp only paid-I know that was big money in those times - say, uh, the camp only paid my mother, she was the one, about three hundred and some odd dollars, for eighty-three acres. Boy, you couldn't even get a quarter, not a tad! (laughs) But I guess back in that time that was big money. But three hundred and some odd dollars for eighty-three acres! Lord have mercy, Jesus. And they didn't get no mineral rights or nothing, you know.

Sitton: Most people don't think that they got paid the going rate, and I don't think they really did. Well, what did your daddy raise on the place? What sort of a farmer was he? Was he a farmer?

Thomas: Yeah, uh, my father, he was a big farmer, he did a lot of farming. He tried to raise cotton down there, they say. They showed me a place right beside the road where you come in, said he raised cotton there. He raised peanuts and had hogs and so on like they do, people was hard then.

Sitton: What was your grandfather's name?

Thomas: Jackson Morgan.

Sitton: Oh, he was Jackson Morgan. I thought he might be a generation farther down the line.

Thomas: Naw, he had to have been old, my mother was begotten when he was at an old age. 'Cause, them old men, I don't guess they had used up their-(laughs) Yeah, I think he was very old. I had a cousin who'd get children. When I was young I thought, my, that man is old! Why is he to get children? Some people say the children might be deformed or something like that when they be got by older people, and so on like that, but nothing -

Sitton: So, your grandfather was really a big farmer.

Thomas: Yeah, Jack Morgan. Okay, my daddy, Isiah Thomas, they called him Scram, he was a World War I veteran. 'Course, he never went over to France, just
San Antonio's where he went. And he married my mother, I ain't gonna say why he married her. (laughs) He got a good deal, he was a soldier (??), he married my mother, and when my grandfather had got old, he took care of him. But it was really my mother's place, and so on like that. My daddy, he came in by being married to my mother. Yeah, yeah, right. Then the camp moved them out, you know when Camp Swift came in.

Sitton: But that's all the money they got?

Thomas: Yeah, three hundred and some odd dollars. Yeah, right. They built an old house over there. I think this property here was cheap - you know, this whole hill here. They could of bought a whole lot of land. Wasn't nothing but cheap land. But they would of had to pay taxes on it. My daddy, he wasn't that much of a person who would, you know, be very industrious. To go out on his own, he wasn't that type.

Sitton: Did he work in town some, or did he mainly farm?

Thomas: Well, my daddy, he would do a little farming, but in his younger days he did construction and something like that. Right. He didn't make no great deal of money or nothing like that, my daddy didn't. There was money to be made, though, but he just didn't make none.

Sitton: Can you remember living there?

Thomas: Living there? Oh, yeah!

Sitton: What can you remember? Anything you can remember is history about that farm. A child's perspective is good, as good as anybody's.

Thomas: Oh yeah, right, that big elm tree! I'll tell you who else lived down there, the Kemps did. One of their ancestors is Martha Kemp. All right, the Kemps lived down on Big Sandy if you want to call it, I call it the creek. Abner Scott up there (??) that stay back up here, that was a big clearing back over there, back west also, and there was this big elm tree, where our house sit, right up under the big elm tree. This postman would cut down to the road coming down, let me see, elm tree, this road came down this way, that was the road come down this way, then it went back to the brickyard I'd say about the end of our place. Went back there toward the brickyard. And back over 
here - Ben Colter stayed over here-back there on the north side. Uh, there was a lot of elm trees down there. The big elm tree-We had an old shack and the Kemps stayed back farther from there. Then across that creek there was a man named Aussilloux. Old man Aussilloux, they say he was from France, he had a vineyard. Right. They claim that Aussilloux died over there on that place. Lot of people have wanted to go over there, think he hid some money, say he was digging in the ground over there, say he had dug a hole in the ground, trying to stay alive or whatever. But they found a hole right close to him. And say he made money down there, he was in grapes, you know, they made that wine. And said he would send some of that money back over to France, yeah, when World War I was going on.

Sitton: Well, I had heard that he was found lying dead there. Some neighbor went over there, and he had just, you know, died of natural causes, I guess. But there were some holes dug?

Thomas: Yeah, they claim it was like he was trying to dig in the ground or something like that. I've heard my mother and them say - they'd say that he had hid money. Yeah, but it was a natural death. I don't know how good people were with autopsies in those days. I don't know how tricky could people be and how smart. You know, some people can make you look like you're having a natural death.

Sitton: Yeah, I know.

Thomas: (laughs) There's some people can-can say things that shock you and make you have fear. Now you take a-I don't know, a lot of black people have died a death from drugs and so on like that, and they say, Well, they had a heart attack, but they never would indicate that drug was the one that took them away. They didn't know those people were on drugs, and they just let it be, they didn't know he had an overdose.

Sitton: Well, he probably had money at one time anyway, because as I understand it he had run a successful vineyard, or whatever, in the back time. Well, did this community where they lived, did it have a name?

Thomas: That never did have a name; people called it by that creek.
Sitton: Where did people go to school from there?

Thomas: They had to walk clean over to Sayers. They had a little jack, my daddy and them had a little donkey or jack, whatever you want to call it, and they would ride that little jack to school. Right.

Sitton: Your brothers and sisters.

Thomas: Right, right, the older. They all dead. I have one sister, she's still alive down in Bastrop.

Sitton: Is she older than you?

Thomas: Yeah, right. She's older than me.

Sitton: When? What year were you born?

Thomas: I was born in '37. I had some pictures, too! I'm glad you-You want to see them? These are some pictures of Sayersville, but you don't want to know about Sayersville right now. I have some photographs, and if you wait here a minute I'll find those photographs. (taping interrupted)

Sitton: I think that you're one of those people that's talked to older people and-What do you know about other people who came on to that land after slavery? Did you hear anything, was anything passed down?

Thomas: No, the land was cheap, and I don't know how he got that. I heard he paid somebody about a quarter an acre for land.

Sitton: Well, you know it wasn't really good cotton land - not over there. Over here it is.

Thomas: No, no, not the sandy land. Well, okay, now I heard that they couldn't buy those heavy plows, metal plows like the Swedish people. They had to buy wooden plows - the plows was made out of wood with sharp edge on it - and they would knock it up. And then they have to take a hoe, you know, make some kind of crop out of it. Those people from the foreign places - Sweden and so on like that - they would clear those prickly pears there (??). And my granddaddy, they cut the brush, they called it the brush, the trees and all like that, and they burned that brush, and that's where they put the sweet potatoes.

Sitton: What you're remembering is people helping each other out. 
Thomas: Right, right! Yeah, they would do that. We call it giving each one strength, some people call it backboning - they used to call it backboning — strengthening my brother, and so on like that.

Sitton: Backboning, strengthening your brother?

Thomas: Yes. Strengthening your brother.

Sitton: Neighborly helping out.

Thomas: Right, right, right, right! That's was the method that people used to survive and get on their feet.

Sitton: There was nobody to turn to, really, but your neighbors. If somebody gets sick in crop season and can't work the crops, who's going to help but the neighbors or the family?

Thomas: Well, I'll tell you, black and white would help each other out. There's a lot of white people down there back in those days that didn't have much of anything, and when you go to work for them they had to pay you off with a little piece of meat, a hog they had killed, which was meat, or some kind of vegetable. You wouldn't look for no clothes or nothing, people'd want something to eat. I heard my mother say she worked a many a day for some eggs and certain items that would help her out in the kitchen. People were just about in the same boat together.

Sitton: Well, you know, it's hard to get rich on that sandy land. If you've got a big sandy land farm, you're not going to get a whole lot richer than somebody that's got a smaller one.

Thomas: Naw. Watermelons, now, that was the chief crop, now you can go a long way - See, watermelons will not grow on black land, and people liked to eat watermelons. (laughs) But watermelons don't last too long, you know.

Sitton: So, what did they-Everybody grew corn, right? Had to have corn.

Thomas: Right. Well, you know, George Washington Carver brought in the idea of peanuts, you could get a lot of products from peanuts, and so on like that. I think they might have grew a few peanuts, but the government put a restriction on the growing of peanuts. Like back there in Georgia, they tell me that President Carter, when he was president, he became well off growing peanuts. Right.

Sitton: They grew peas and peanuts, I've heard people talk about growing field peas.

Thomas: Uh-huh. Black-eyed peas, corn - But they didn't have a deep freeze or nothing to preserve food. Yeah, they put them up, not, I take that back, they were canning, 'cause my mother could can. Yeah, they eating on that, let me take that back about the deep freezes. Aw, you didn't have to need no deep freeze, then. Some of those people knew how to can, 'cause I've seen her can. People knew how to use a resource that's going around. They'd make their own tobacco, grow their tobacco, make their own syrup. They had little syrup mills back down and around. Take your cane there and get some syrup made. People didn't go to all these clubs then, they had these parties at home, they called them suppers.

Sitton: What would happen at one of those suppers?

Thomas: Well, there would be a lot of fun making, somebody could play a guitar or somebody could play a fiddle, a fiddle man, and they had a lot of spirit then. People could sing, they could almost beat a tub - take a stick and beat a tub - you know, that African rhythm in them (laughs); it was still there. They'd make their own little drinks, that old beer and little bootleg whisky or whatever you want to call that old stuff. Some kind of liquor to make them funny, have fun.

Sitton: Would that be usually on the weekend, those suppers?

Thomas: Yeah, Saturday night.

Sitton: And people would give that in their home, and the word would get out that we're going to have a supper, and people would come in from all around.

Thomas: Right.

Sitton: And maybe buy some food, or-

Thomas: Yeah, they'd buy some food, but some home brew. Maybe some neighbor would come by and get him a little of that home brew. They knew how to make it. 
Sitton: You know Dean Fort in McDade?

Thomas: Yeah, I heard of Doll Fort and all them. Now, that name came back, Doll Fort and them.

Sitton: Yeah. Dean, it was his great-uncle, Doll Fort, made home brew big time for a while.

Thomas: Right, right, right. I've heard them mention that name.

Sitton: He was, he was, on a poor little farm, he needed to make home brew.

Thomas: Well, about every guy back there - in a way back there community - back there - What did they call it? Beaukiss! [Williamson County] Did you ever hear of that community called Beaukiss? Man, that's back in the wilderness back there. They got a church back there. And if you want to go back to 1870 something, go to Beaukiss. B-e-a- u-k-i-s-s, Beaukiss. Them people are there from the Civil War days and all like that. They got (??) back there, boy you going back in time when you go down to Beaukiss. And that guy, I forget his name, he could make all that kind of moonshine, any kind of drink you want to know - out of watermelon, dewberries, and anything. Yeah. Back in there, they still got the recipe. It is weird in Beaukiss, they a little strange back there. If there ever was history, it's back in there at Beaukiss.

Interview with Walter $\mathbf{L}$. Thomas

Interviewed by Thad Sitton

Date: April 15, 2005

Place: Home of Thomas, Elgin, Texas

Year of Birth: 1937 


\title{
Irene Fleming Watson Interview
}

\author{
By Thad Sitton
}

\section{June 2004}

Thad Sitton: This is an interview with Irene Fleming Watson by Thad Sitton. The date is June 15, 2004. Mrs. Watson is being interviewed in Johnson City, Texas. Her son, John Watson, is present at the interview and is also heard on the tape. This interview is part of the Texas State University-San Marcos, Camp Swift Oral History Project, sponsored by the Texas National Guard and conducted in conjunction with the Center for American History, The University of Texas at Austin.

Sitton: I thought I'd start out asking you about the Oak Hill School-your memories of the Oak Hill School - and I know you went all the way through the grades there and then you worked. You had an extra year, is that right?

Irene Fleming Watson: Yes, the next year, because I wanted to go into nursing school, and there were subjects there that I had not had. So, I went an extra year, because I had nothing else to do.

John Watson: But regular school there, Mother, in your day, was grades one through eleven, not grades one through twelve, is that right?

\section{Watson: Yes.}

J. Watson: And so the extra year you spent wasn't a thirteenth year, rather it was what all high school people do today. Namely, you went twelve years. Was it a one-room school?

Watson: Unh-uh. Two rooms.

Sitton: What did it look like? When you were in your grade school years there, what did it look like? Can you describe the school?

Watson: Well, there was two rooms, and 'course, the first six grades were the primary, and then the other five grades or six grades, whichever, we went to the others. It was two rooms, this room and this room, and

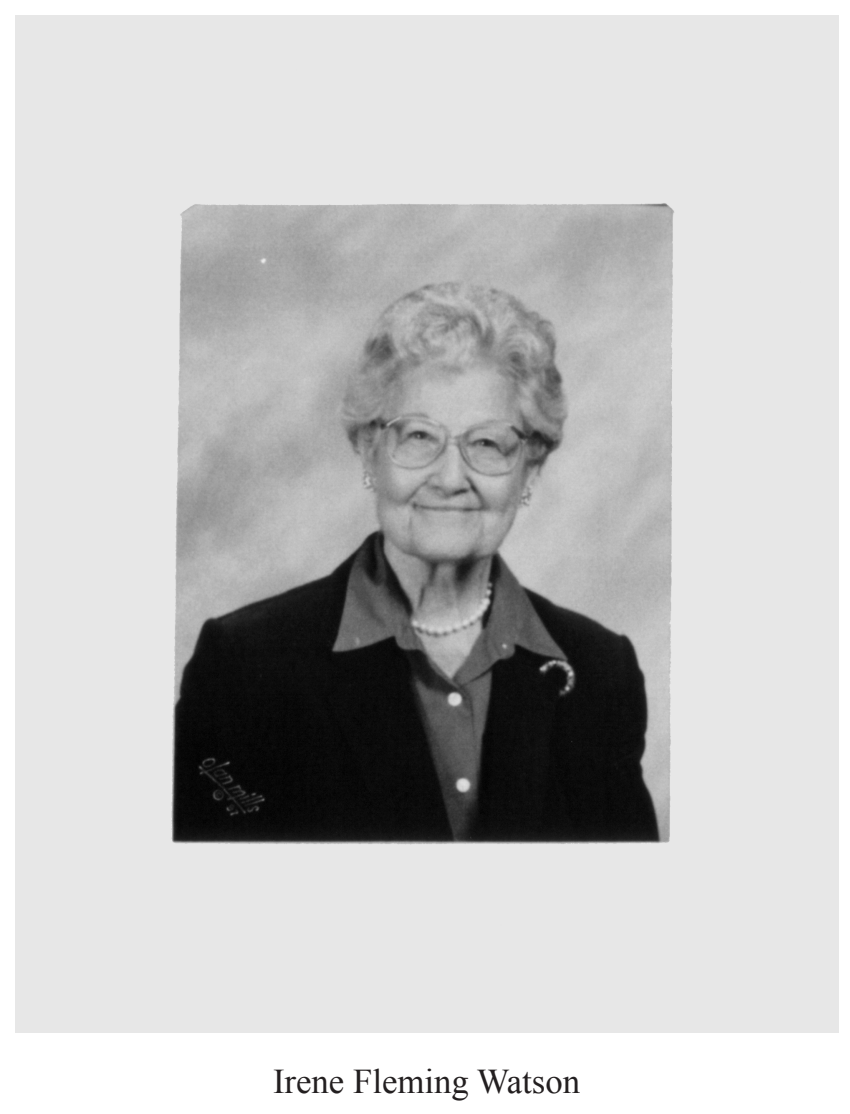

we had two teachers, one teacher for each room. And that's was all the education we could expect, out there.

Sitton: Yeah. How was the school heated, and where did you get your water?

Watson: We had a cistern, and we drew it up in a bucket. So, we had no trouble with water, we would draw it up, it'd be cool from the cistern down there, and we would have cool water all the time.

Sitton: Was it cold in winter?

Watson: Yes, it was cold in the winter. The teachers would try to get there early and build a fire, because the kids would come in and their feet would be wet. By the time you'd walked two or three miles your feet were wet, you were cold, and you know. Some kids 
gave up, but we, my dad saw that we never gave up. We kept going.

Sitton: How far did you have to walk?

Watson: About two miles, three.

J. Watson: Mother, didn't you have to cross a major creek, Piney Creek, between your house and the school? And I believe you told me before some sort of adventures that resulted from having to cross a creek.

Sitton: Yeah, those creeks were a lot of trouble for school kids.

Watson: Yeah, because the creek, when it would rain, my dad would ride a horse, come over to meet us on a horse. And he'd ride us across one at a time. If it was he thought dangerous he would leave us on the other side with a friend and neighbor, and so that's where we spent the nights and days.

Sitton: Well, you didn't have any weather forecast. You went off to school every day, and you weren't sure, you didn't know it was going to rain and Piney Creek was going to come up.

Watson: No, you had no idea what it was going to be like.

Sitton: Well, you would have the same teacher for several grades if she didn't go away, right?

Watson: The teachers taught several classes, so-

J. Watson: Didn't you have - ? One of the teachers was a woman who later married one of your older brothers. Was Mayme a teacher there?

Watson: Yeah, uh-huh.

Sitton: What do you remember about the teachers, what were they like? I mean, I can remember some of my early teachers, and it's good and bad, too.

Watson: Of course now the teachers were not as educated as they are today, because you could go to what you call vocational, and they could go down there and you know go to school for a while and get their - Well, they didn't have to do too much going to school, because - And then having to teach so many different subjects, too.
Sitton: I don't know how they did it.

Watson: Well, I don't either, but they did.

Sitton: I mean, the part I don't know how they did was to have all those different - I mean, elementary school teachers today teach various subjects, but they don't have five grades in a classroom.

Watson: Yeah. Well, one class would be reciting while these other kids were sitting there trying to study. Anyway.

J. Watson: It's probably individual, but Mother's always been an excellent speller, she did well enough in math, and I doubt if you had any science there, but you became a registered nurse. Whatever they did seemed to be somewhat effective.

Sitton: Well, you must have liked school.

Watson: I did, I loved school. And 'course we didn't have but eight months out of the year. Because, being farmers, we had to help our daddy start the farm, and then as early as we could, we had to help him gather it. Because we didn't have any — Well, we had hired help later on, but usually the kids helped with the gathering of the farm - everything.

Sitton: Did some of the kids stay out of school late in the fall to pick?

Watson: Yes, uh-huh, but Papa never did let us do that.

Sitton: But them, others - The enrollment would go up as you got into November, right?

Watson: Yeah.

Sitton: Well, how about discipline? What discipline did the teachers use at Oak Hill School? What were their techniques?

Watson: Well, they could spank them if they wanted to, because that's the only way they had. They'd switch 'em, paddle 'em. You know, the kids weren't too bad. I remember one time we had two families, the Duncans and the Paces, and one of them was all boys and the other was all girls, and they went at it tooth and toenail.

Sitton: So, there [was] a feud between- 
Watson: Two families, yeah.

Sitton: Well, I've heard that often between the boys of two families, but I haven't heard of a boy-girl thing.

Watson: Yeah, but we did.

J. Watson: Wasn't it also the case, Mother, that if you got a whipping at school, be ready, because you were going to get another one when you come on home that afternoon.

Watson: Absolutely. We used to tell ours, Now, you get a whipping at school, you'll get a whipping when you get home.

Sitton: So, it was a double whammy.

Watson: Yeah.

Sitton: Well, I have read some of the columns that Polly Owen, Mrs. Edgar Owen, did over the years, and there's many things in there about Oak Hill School. And Oak Hill School had various kinds of programs. What do you remember about the programs that they would have during the year? There was, you know, Christmas and-

Watson: Oh, yeah, and we always had a big thing at Christmas. We'd put up a Christmas tree, of course, and that's the only time the whole community got together. Transportation was so bad, you didn't go anywhere or do anything other than just going to school. You just went in (??).

Sitton: I try to get people to talk about that, because I don't think people today understand just how bad the roads were. What do you remember about the roads? Now, it was deep sand country, right?

Watson: Yeah, or red clay. When you left home, you didn't know - Transportation was bad! We had wagons and buggies, which were pulled by horses, and well you were pretty sure that you were going to get where you were going. But when you got enough to get a Model T, you were not sure that you were going to get there when you left home.

J. Watson: Progress! Mother, were the road layouts different? Wasn't the main outlet to go back out to Highway 21 and into Bastrop, rather than the way we would go now? Or am I misremembering that?
Watson: Oooh, well, the thing of it is, I left home in '29, and so - I went into nursing school in ' 29 - so I was not there when some of this was going on.

Sitton: But there weren't any hard surface roads by the time you left, right?

Watson: Oh, no. It was all mud and everything. My brother when he was - I don't know which child was born, I went to town with him and we didn't have any good transportation. The doctor came out and looked at her and checked her, and I believe it was the second child that was born, and we had to take him into town and get him born.

\section{J. Watson: Into what town, Mother?}

\section{Watson: Bastrop.}

Sitton: Did McDade have a doctor there? Was there a doctor at McDade?

Watson: There was at one time, but I never knew of McDade's doctor because Bastrop had a doctor, and that's where we went.

J. Watson: Mother, didn't you tell me once of an incident, and it might be this same one, I believe you're talking about your brother Curtis's wife, Mayme, when she had her second child. And y'all crossed a flooded creek, and you lost a shoe or-

Watson: Eyeglasses! But I've lost my shoe, too, because I had to go in - lost it in the mud and I had to go into Bastrop barefooted, and back in those days, you didn't go barefooted.

J. Watson: Was that in connection to this birth that you're talking about?

Watson: Uh-huh, yeah.

Sitton: So, the creek was up, and you were walking beside-

J. Watson: What did you do, get out of the car and have the car go across first without your weight in it, and you tried to wade, you waded across?

Watson: Yeah, then I bogged up in the mud. (laughter) Sitton: Well, that can happen, that'll pull your shoe off. 
Watson: Yes, it will, and it did mine.

Sitton: Well, let me ask you about the place where you grew up on. What sort of a farm did your family have?

Watson: Well, it was an ordinary farm. We farmed it, Papa did, with the kids. We had seven kids.

Sitton: There were seven of you? You were the labor force, or a big part of it.

Watson: Yeah, uh-huh. That's what I said, he had to depend on us for his labor.

Sitton: How big was the place do you think?

Watson: Oh, I think it must have been about seventyfive acres, maybe a hundred.

Sitton: Where was it relative to-The only thing I know absolutely where it is, is the Oak Hill Cemetery. How far was it from the Oak Hill cemetery?

Watson: We must have been, uh-'Course, the kids walked to school, so they walked straight.

Sitton: Yeah, they cut across country.

Watson: But when you go right in the road, it must have been two or three miles.

Sitton: And the school was close to the cemetery, is that right?

Watson: Yeah. We had the school, and then we had the church, and then the cemetery all out there in a little squad.

J. Watson: Wasn't there a general store there at one time as well, Mother - by the church and the school?

Watson: I don't know, I can't remember.

Sitton: But in your time the only thing there was the church, and the school, and the cemetery, and they were all kind of in sight of each other.

Watson: Oh, yeah. And when you got to be a senior, if the teacher was sick, the oldest child or the most capable child would take over and teach.
Sitton: Because everybody's going to show up at school, there's no way for the teacher to say, "Your teacher is sick, we don't have school today." They're going to get there, so the oldest-Did you ever do that?

Watson: Oh, sure.

Sitton: You would say, “The teacher's not here, I'm going take over."

Watson: Yeah, I did that several times. And another time when my sister-in-law Mayme was teaching school in a, another small school down at Fair Oaks, I went - She was sick, and so I had to go down and teach a week for her.

Sitton: Where was that school?

Watson: Fair Oaks, over on Texas 290.

Sitton: Do you remember, did that seem just the same, teaching over there, or did the kids, did it seem different?

Watson: Well, we thought they were, we thought they were not as bright as we were and everything. But they were just as bright as we were.

J. Watson: How much older than you was Mayme? There were a lot of young teachers in your day and time.

Watson: Oh, I imagine she was probably three or four years.

Sitton: Did the teachers use the older students to help her teach, even when she was there?

Watson: Yeah.

Sitton: Say you were an older student, what would she ask you to do? To take a certain class, go show them this? I know they did that, because they needed help.

Watson: Yeah, they did, because they had five or six grades. You just got off in a corner and held class.

Sitton: They're little mini-classes be going on all the time, the teacher started this group doing that and this group doing that, and she might have put somebody in the small group in charge of whatever she's told them to do. 
Watson: Yeah.

Sitton: What did y'all do at recess at Oak Hill School? What do you remember about recess? And lunchtime, you played at lunchtime, too.

Watson: Yeah. We had ball courts, everything. Had baseball and volleyball, basketball. And we'd go after it tooth and toenail, because we would play the other country schools.

Sitton: What do you remember about that? Nobody has told me about that. I've heard about recess, but I haven't heard about playing the other country schools.

Watson: Well, you would just play each other until you got to be pretty good, then the teachers would contact each other, and on Friday afternoon, they would go and have a game.

Sitton: So, you'd go over there, or they'd come to you.

Watson: Yeah, and boy, you can think of the competition! It went on. Fair Oaks, Cedar Creek, and uh-

Sitton: What about that - What is it? Oh, there was another school on the land that became Camp Swift, and it was Wayside?

Watson: Wayside.

Sitton: Was the Wayside School still going on when you were going to Oak Hill?

Watson: Uh, some, but it was, we thought inferior to our school.

Sitton: Well, it was certainly little, because somebody interviewed Abner Scott, and he was the only student there one year. The school trustees said, We're not going to have a school until we get more students than Abner Scott. And he went to Oak Hill.

Watson: Yeah, well my Daddy was like that, and his sister, they went to Oak Hill.

J. Watson: Did they live in Wayside though, or was that -
Watson: Yeah, um-hm. But they rode horses.

Sitton: I was going to ask you-I'm sure a lot of kids walked to school, but other kids rode horses, right?

Watson: Yeah, some of them. Two girls were lucky enough to have a buggy with a horse.

Sitton: But y'all just cut across the country, you took the shortest, the beeline, right?

Watson: Yeah.

Sitton: Well, didn't you have fences to go through?

Watson: Oh, sure. Time you got to the school, half your clothes were torn off. (laughter)

J. Watson: They didn't shoot you for trespassing in those days, did they?

Watson: No.

J. Watson: Mother, you were born in 1911, and so you were starting school roughly in 1917. Were there any, or many, motorized vehicles out there then? Cars or pickup trucks?

Watson: No, buggies or wagons. I remember when we got our first pickup.

Sitton: That was a big event.

Watson: Oh, yes. Papa, the first one he got, he bought it from a black man. There's a black man would always borrow money from Papa. Well, got ready to pay it back, he didn't have any money, so he'd go off and get a car he'd managed to get ahold of.

Sitton: So, it was kind of a repossession? I don't have any money, but you can have this -

\section{Watson: Yeah.}

Sitton: That suggests to me it might not have been bright, shiny, new. Did it run okay?

Watson: Yeah, it did. Then when we bought our first new car, my daddy went off and bought a new, brand new, truck, and he would pile the kids on that truck, no cover on it. 
Sitton: It's just a flat-bed truck, and you got to hang on, on a flat-bed truck. No sides on it is what you're saying, right?

Watson: No. And anyway, that's the way we went, and pushing it the biggest part of the way.

Sitton: Well, did the sand get so deep around there that people would get stuck in the sand?

Watson: Oh, sure.

J. Watson: Did y'all carry like shovels and boards to help you push out? Because they went to their axles, I've seen that with my own eyes.

Sitton: Had those skinny tires that would just go in. Well, we had started talking about y'all's place. If somebody said, "How did y'all make a living?", what would you say? What did y'all do for money? What did your father raise in the field?

Watson: Well, I'd say for money crops he would raise watermelon and sweet potatoes, things like that - something that was harvested before the regular crops were gathered.

Sitton: Well, those are the great sandy land crops that you described - sweet potatoes and watermelons and peanuts - and they don't generally fail.

\section{Watson: No.}

Sitton: You generally get enough rain to make some of that, but you don't always get enough for the cotton. So, how much cotton do you think he had when you were growing up? Or did he have it?

Watson: Yeah, he had cotton, 'cause he gave us all a piece of land, and we grew, the last year of our schooling we'd grow our own cotton. One year I had a good piece of land, so I had a pretty good cotton crop.

J. Watson: That was by way of an allowance to allow you to make some cash money before launching out into the world. Is that right?

Watson: Yeah, and the last year, my brother younger than myself, we had a piece of land together, but we didn't grow anything. We didn't even have to run a sack through the cotton patch, because we didn't have any cotton.
Sitton: If it doesn't rain, you don't have any cotton.

Watson: And if it rains too much, the boll weevils eat it up.

Sitton: There's lots of ways not to have any cotton.

Watson: Yeah, oh yeah.

Sitton: So, he would do this the kid's last year in school as a sort of - He would give them a plot of land to grow. An acre, a couple of acres?

Watson: Oh, I imagine, depending on the richness of the land.

Sitton: But it wasn't a sure thing, it's just here's this opportunity, you can have this land, but you got to do all the work, and the rain has to fall and the boll weevils have to stay away.

Watson: Yeah, yeah.

Sitton: How much cotton do you think he raised - the family cotton? How many bales do you think — did-y'all's farm would produce in a good year?

Watson: I really don't know, I never checked. I picked a many a sack, but I didn't do the book work. There was more land in cotton [than watermelons or sweet potatoes]. He depended on cotton, because that was the crop. And that's when the failures came in, when you didn't have anything.

Sitton: But you had to have corn, too, right?

Watson: Yeah.

Sitton: That was the other one. When you said the main crops, you meant cotton and corn.

Watson: Uh-huh, yeah. You did, because you couldn't depend on your grass for the livestock.

Sitton: What do you remember about picking cotton? Some people didn't like to pick cotton too much. (laughter)

Watson: Well, I don't care whether you like it or not, you picked it. You would get out there and pick cotton, and the cotton would be, the sand would be, so hot, 
that you could hardly stand it, because you never wore shoes. We just went barefooted.

J. Watson: Did you have special sacks that were made for the children that were somewhat smaller than maybe the older kids used or the adults, Mother? Or did you drag around one of those great big old long ones?

Watson: Oh, we all went out together, and the little ones, we'd put them on a cotton sack and pull them up and down the rows.

Sitton: So, the whole family - everybody went out to the cotton field, and adults were going to pick, too, and so that meant that even the little kids that weren't going to pick, needed to go out there, right?

Watson: Yeah, well, you didn't have any babysitters.

Sitton: Mama couldn't afford to stay back there and be a babysitter, because she needed to pick.

Watson: Yeah, she had to be out there and work.

Sitton: So, you might be pulling along one of your younger brothers and sisters on your cotton sack.

Watson: Yeah.

Sitton: Where were you in the order of the seven?

Watson: I was third, third from the oldest. Had two older brothers.

Sitton: How were you as a picker? Were you a pretty good picker, average or bad or what?

Watson: Well, I guess I was average. My oldest brother, he just couldn't pick at all. My brother next to me, just older than me, he was a good picker, but I'd say I was about average.

J. Watson: I don't know, I remember during the war we moved to Millington, Tennessee, my dad was in the Navy, and they have a navy station there, naval air station, and the only housing we could find was on a farm outside town, and you remember, Mother, you went into the cotton fields and I thought impressed the regular hands out there with both your cotton chopping and your cotton picking ability.
Watson: Well, I did, I knew how, and so I just pitched in and did it.

Sitton: How high would the cotton get there? Now you just see that little low stuff. Would it get up waist high?

Watson: Well, yeah, I think it got that high. It was pretty high.

Sitton: Did you kneel or did you bend over to pick? There's two ways, and people have said they're both bad.

Watson: Well, a lot of people, they weren't good farmers, period. We always considered that we're better farmers than most of the rest of them.

Sitton: What about, can you explain - what would y'all be doing when you say "chopping cotton"?

Watson: Well, we'd have a hoe, and I guess they were about six inches, the blade, well, you'd come along and you'd chop the rows, and you'd take out the weeds and the surplus cotton.

Sitton: So, you would be thinning the cotton plants and also getting -

Watson: The weeds out, yeah. And you did all of that at the same time.

Sitton: What about the corn, did the corn require a lot of weeding, too? Did you chop the corn?

Watson: Yeah, well it had some [weeds], and we had to chop it, too. Nothing grows without some care.

Sitton: Well, I've heard people say that grass grows very well in sandy land. And would you cultivate up the middles with a mule? Like a sweep plow? Or did you rely just on the hoe?

Watson: No, we had plows, we had cultivators.

Sitton: Was it the riding cultivator, or was it the sort that you walk behind?

Watson: Papa tried to have the riding [sort]. Russ, my brother, wanted to do all the plowing, because he thought he was the best. So, he would hook up a pair of mules and away he'd go. 
Sitton: Well, somebody has to pay attention on a riding cultivator, or they can tear everything -

Watson: Yeah, but he was a good plow hand. He was good. He had a job with a Mr. Griffith who had that land down there on the Griffith place. He hired Russ to ride that fence around five hundred acres. He was considered a capable kid.

Sitton: So, he was a neighbor, and he knew your brother. You tended to know people, you knew who you wanted to do something and who you didn't want to do something.

J. Watson: I guess the Griffith League Ranch you're talking about was over four thousand acres, and Mr. Griffith, probably more than most of y'all, and he didn't have a big family, he needed hands like Russ and others.

Watson: Well, Russ would get on his horse, and away he'd go. On Saturday morning, because we were out of school, then.

Sitton: So, that operation was mainly a ranch, that we're talking about, and so he was hiring your brother to ride fence.

Watson: Yeah.

Sitton: Did y'all run any cattle, did your father run cattle?

Watson: Yeah.

Sitton: Tell me about that.

Watson: Well, it took eight or ten head to have enough milk for the family.

Sitton: Well, talking about chores, what were your chores? I know you did the field work, but did you have particular chores that you did?

Watson: Yes, I milked the cows! (laughter)

Sitton: So, that's a lot of cows to milk.

Watson: Yeah.

J. Watson: What about chickens, did you have chickens to feed?
Watson: Yeah, chickens too. And hogs to slop.

Sitton: How did y'all keep your hogs? Did you keep them penned all year, or did you let them run out any time of the year?

Watson: Papa always built a pretty good space for them so they'd have enough area for them to run.

Sitton: So, he had a hog pasture?

Watson: A hog pen, yeah.

Sitton: But he never turned them out? Like in the fall, some places they would turn them out after the crops were in, the gates were opened.

\section{Watson: No.}

Sitton: Sometimes that was the neighborhood custom, and sometimes it wasn't.

Watson: No, it wasn't the custom with us. We never let our hogs run out on other people.

Sitton: Well hogs can be-

Watson: Destructive.

Sitton: And the regular barbed wire fences of course don't stop a hog.

Watson: No.

Sitton: You remember anything about hog killing?

Watson: Kill three or four. You'd wait for a cold norther to come, you'd get all your preparations ready, your fire and your pot to heat your water. If it wasn't real cold, we wouldn't kill them, because we had no refrigeration, we had to depend on the cold weather to cure them out. We'd hang them up on some poles and dip them. Then we'd salt them down — the sides - for the bacon, but the hams we would always have them ready to cure, too. We'd smoke them, hang them up, build a fire under them just enough, we used buckets, put coals in there. Had a smokehouse.

Sitton: So, fires in the buckets in the smokehouse, that's good. That way you can take the bucket out, do what you want with it. But you wanted to keep the smoke going continuously in there for-for days? 
Watson: Yeah, yeah. So, that's the way we smoked them.

Sitton: And did you keep them hanging up in the smokehouse for storage?

Watson: Yeah, and we could keep them for months.

Sitton: Well, what about-We talked about the cash crops, and now we're starting about the side of the farm where you tried to grow and produce for yourself. Y'all didn't sell milk, right?

Watson: No.

Sitton: You probably didn’t sell pork, either, you just were producing for yourselves. What kind of garden did you have, what did you grow, and how did you preserve the food? Anything about that.

Watson: Yeah, Mama always took care of the garden. We grew every kind of vegetable, and she would of course can it. We ate mostly fresh vegetables and then some canned vegetables, because we didn't have any refrigeration.

J. Watson: Did you have a springhouse out there, Mother, for cooling?

Watson: No. Oh, we had this contraption that we called a cooler, and we'd put a clean sheet around that and pour water around that to keep it wet and cool, and that's the only kind that we had.

Sitton: Was that kind of a piece of kitchen furniture that stood up off the floor, and you put the water in the top and then the water came down on the canvas around the -

Watson: Yeah, um-hm, the outsides.

J. Watson: That wasn't the same thing that was called a safe, was it, Mother?

Watson: No.

Sitton: I haven't asked you to talk about the house, what do you remember about the house? Can you give me a tour?

Watson: Well, it was a - The house was very bare, and 'course beds were kind of crammed up, because you had a big family in a two-bedroom house. It was cold in the winter and hot in the summer, because we wouldn't know what an electric fan was, air conditioning was unheard of. We opened the windows, and mostly we'd put the beds, pull the mattresses out, on the porch or in the yard, and sleep out there in the summer. Be lucky if the ants or mosquitoes didn't get you, but-

Sitton: But it was better than the hot house.

Watson: Yeah, yeah. Because our houses just had small windows, didn't have anything elaborate. Just had single-walled houses.

Sitton: Had up and down boards on the outside?

\section{Watson: Yeah.}

Sitton: And it didn't have a wall inside?

\section{Watson: No.}

Sitton: And were there cracks you could see through?

Watson: Oh, sure! You could almost pitch one of the kids through there. But we thought we had a good house.

Sitton: Well, it was about like everybody's house. Did you have a ceiling, was it ceiled? Did you have a ceiling and an attic?

Watson: Yeah, I believe we did have a ceiling.

Sitton: Well, what was in the kitchen?

Watson: A cook stove, and it was wood. 'Course, some people graduated up to oil, but we never did, we always just had a wood-burning stove. And we didn't have running water, had to carry all our water from the outside.

Sitton: The cooler thing was probably in the kitchen, too, right?

Watson: Yeah, or on the back porch.

Sitton: Or on the back porch, because it drips?

Watson: Yeah. You tried to put it in the coolest place, where the breeze would blow and water would evaporate. 
J. Watson: I wonder, Mother, seems to me I've heard you say in the past that the climate, you thought, was somewhat different. Of course you're living in a house with cracks big enough to throw somebody through, it would seem colder. But do you remember the climate in the late teens and the twenties being substantially different than it was in the fifties, sixties, or even later?

Watson: Yeah, I think it was, because when we were kids going to school we often had tanks froze over, and we didn't have substantial clothing for that kind of weather.

Sitton: And now, years can pass over there before any of the stock ponds, the tanks, will get even a film of ice. And it snowed more, right?

Watson: Yeah! It got much colder than it does now.

J. Watson: But you had the quilting bees, right, so you had plenty of quilts?

Watson: Oh yeah, we had to. I've seen the time that we put all the quilts and blankets on the beds, and sometimes we'd have heavy coats and things that we'd pile on top. I'd tell my sister, I'd say, "Move over, you're taking up all the cover." And she'd move over, she was asleep, and I'd just move her over out of her warm spot into the cold spot.

Sitton: I read one lady's memoir, someone you would know. Their house wasn't finished, just had quilts hanging over the windows and doors, and one day it was so cold they just got up, ate breakfast, and went back to bed. They thought it was so cold it was dangerous.

Watson: Yeah, what else could you do?

J. Watson: Speaking of food preservation, has anybody described hominy making to you?

Sitton: Not in the course of these-Did your family do that?

Watson: Yeah, in the wash pot. We'd shell corn and take all the silks out of it and sometimes put ashes on it, in the pot with it, to take off the hulls off of the corn, and we've eaten many a pot of hominy. And like brains out a hog, my mother always took out the brains and scrambled eggs with them, and we thought that was a delicious thing to eat.

Sitton: Well, people tried to eat everything from the hog that they could, and there wasn't a whole lot that didn't get used up somehow.

J. Watson: Did y'all make sausage, Mother, when you butchered a hog, and use the innards as stuffing?

Watson: Sure. It was much better to have the insides to stuff the sausage with than it was to have pan sausage, but we did eat pan sausage a lot. And boy, that ham with hot biscuits is hard to beat.

Sitton: Y'all didn't eat a whole lot of beef, right?

Watson: No. You don't kill the beef because you didn't have any way of keeping it. When I left home we didn't have a refrigerator.

Sitton: No electricity until the government.

Watson: Yeah, and they tore down everything.

J. Watson: I think you've told me before that when the Great Depression hit, that it had some impact out there on the family. What happened during that period? Didn't they come out and make y'all do something with the cattle?

Watson: We had to shoot them and pitch them in a hollow.

J. Watson: Already had a hollow, and they made you kill the cows.

Sitton: Were you there when that happened, or had you already left? How did that come about?

Watson: Well, you couldn't sell your cattle for anything, and so they thought it would be cheaper on everything and everybody to sell [shoot] them. Then you wouldn't have to feed them.

Sitton: About the government killing the cattle, what do you remember about how they killed them on your place?

Watson: They shot them.

Sitton: In the pen? 
Watson: Yeah.

J. Watson: No. Didn't they move them out to where they wanted them to topple into a ditch or hollow, Mother?

Watson: Yeah.

J. Watson: This place has a lot of ravines that we call down there "hollers," as you've probably heard. It's a very erosive landscape, you can't walk without stumbling over petrified wood, the geology of the area is fascinating. But didn't they move them? You couldn't drag them out of the pen.

Sitton: So they drove them out to a good place to kill them, then they shot them.

Watson: Yeah, and they'd fall down here, in that hollow.

Sitton: Did they burn them? Some places they burned them. It's hard to burn-

Watson: Hard to burn a cow, yeah. But we ate some.

Sitton: Well, was this milk cows that were getting shot?

Watson: Yeah.

Sitton: Just any cow, it wasn't just feeder cattle or stocker cattle or something like that.

Watson: No.

Sitton: How many sisters did you have and how many brothers?

Watson: I had four brothers and two sisters.

Sitton: Did any of your brothers get involved in those CCC programs? Government work?

J. Watson: Jack went in the CCC, Mother.

Watson: Did he?

J. Watson: He was the youngest of all the children, and don't you remember he went into the CCC and I think maybe he was there at Bastrop for a while - when they built the park.
Watson: Well, he joined the National Guard, he was in the National Guard when war broke out.

Sitton: Well, he was going to get in the war fast, then.

Watson: He got in fast, right on the get go.

Sitton: How did it come about, and I know it's not the most pleasant thing that people like to remember, but the government taking the land in 1942? You were away, you were not there, but how did it work out for your family?

Watson: Well, my daddy went to McDade, and 'course my mother was one of nine kids, and her daddy and mother moved up there and bought a house. And then Grandpa, I don't know, did he die? I guess he did, 'cause then Papa bought his house. And so it wasn't too bad for them, they had money to buy a house, which a lot of people did not have. And most of their kids were grown.

Sitton: So, most of the kids were already away, and they didn't have-

Watson: Any little ones to feed and look after.

Sitton: But how did they feel about losing their land?

Watson: Well, they weren't happy about it, because they'd been on that land a good long time. It upset them.

Sitton: But they made the adjustment better than some people, is what you're saying.

\section{Watson: Yeah.}

Sitton: Because sometimes the government didn't pay people enough that they could set themselves up again on some more land.

\section{Watson: No.}

J. Watson: Do you remember what was paid per acre?

Watson: Sure, Papa and them, I think the government paid them nine dollars an acre.

Sitton: You know, people got all sorts of different amounts, there wasn't anything like a uniform- 
J. Watson: Well, some of them protested, or negotiated, but I think - Do you know whether or not Papa said, "To hell with nine dollars an acre," and wanted more. I thought I remembered Grandma saying thirteen dollars an acre, but they might have paid different prices for different parts.

Watson: When the government got ready to sell the land back to Papa and them - to Mama, because Papa had died - they paid them fifteen dollars.

J. Watson: Charged them fifteen dollars - when they bought it back, you mean.

Watson: Yeah, charged them fifteen dollars, they had to pay fifteen dollars.

Sitton: So, the land had gone up, the government made money, right?

Watson: No.

J. Watson: No, didn't they make a commitment? Because I remember Grandma always saying she was going to hang on and put that money in the bank and save it, because they said that, Someday we may not need this land anymore, and we will offer it back to you or your descendants for the same price. I don't even know if they adjusted it for anything that we paid. But they just basically, most of the people out there, families I've talked to, it was very little argument, they didn't run and go hire a lawyer like me that would fight a condemnation case and say, No dice, we don't accept that price. Some of them no doubt were a little more sophisticated and did negotiate or bargain, but by and large I don't believe our family did.

Watson: I don't think so, no. 'Cause, people were patriotic in those days, and they thought it was not very patriotic to fight your government.

Sitton: Well, if you read your Bastrop Advertiser, the paper from that period, right after we were in the war, you realize just what it would have meant for somebody to really say no, because it was like we're all together in the war, and here are the photos of all the Bastrop County boys going off to risk their lives, and you can just get the sense that it was difficult to protest it at all.

Watson: Yeah, that's what I'm saying. They didn't really protest the government, because they thought - Well, they were getting, the government thought enough of them to use their land.

Sitton: It was their chance for a patriotic contribution to the war effort.

Watson: Uh-huh.

J. Watson: Well, and in fact, all of your brothers went into the military service, and both of your sisters went in as nurses into the military service. You were married with two young children is the only reason you didn't go into the military service, correct?

Watson: Yeah.

J. Watson: So every one of you, everyman-jack, and you went back to work at the hospital in Bastrop even though we were quite young because they needed nurses so desperately in the civilian sector, having soaked up so many into the military.

Watson: I worked in the hospital there at Bastrop. We delivered lots of babies before the government started delivering them.

Sitton: Well, the population of Bastrop County had increased a whole lot. There were fifty thousand troops, that will get your population up, but then there were all the workmen that came in to build the base, there were thousands of them, so the whole world had been turned upside down in Bastrop County.

Watson: Yeah, we had ninety thousand men.

J. Watson: And everybody but the farmers that were ousted from the land made money on it. Nothing changes, does it? (laughter)

\section{Watson: No.}

Sitton: Well, the Bastrop County political leaders and businessmen tried very hard to get the base there. And a few people will have to be moved off the land, but they really wanted the Camp.

Watson: That's right. (taping interrupted)

Sitton: Let me ask you about this, did your brothers do any hunting and fishing? Did y'all hunt and fish, or were you one of those families that didn't do much of that? 
Watson: Well, we were too busy working. I had two small boys, and my older brother had three boys, and so we were trying to raise a family.

J. Watson: But back in your childhood, Mother, I know there were .22 rifles around the place. You shot the hogs usually or hit them in the head with an axe. Did any of the boys or your dad go out and potshoot anything from jackrabbits to deer? That was a highly cultivated community, it's all pasture now, it's totally different than what it looked like in those days. The woodlands portions were outnumbered by a hell of a long shot by the cultivated land.

Sitton: Yeah, now it's all grown up again, right?

Watson: Yeah.

Sitton: So, you didn't have a big trapper-hunter brother. And a lot of it has to do with your-Was your father a pretty much no-nonsense, stick-to-business sort? He was a farmer, right?

Watson: Yeah. Absolutely. And he didn't want anybody trying to run over him, he was honest, and he wanted to give everybody a square deal, and he wanted them to give him one.

J. Watson: Tell me, why do you think none of your brothers or sisters, or brothers I guess in particular, went into farming? I know Curtis did for a brief time.

Watson: Yeah.

J. Watson: Was it because of the land disappearing into the government, the Camp? Or would they have anyway, they wouldn't have done it anyway?

Watson: I don't think they would have made farmers. We went back after my mother died, and she left each one of us an equal part of the land.

J. Watson: But she was up in her sixties and a widow woman at the time the government in the 1950s offered the land back, right? She took her money that she'd socked in the bank out and bought it, and she sort of never gave up wanting to move back down there, did she, Mother?

Watson: No.
Sitton: Well, farming had changed, and it was hard to go back to living on that kind of farm, small family farm. And the land gets more broken up, and after World War II not many people were able to go back.

Watson: They didn't have any money. The government paid them so little money to buy their land.

J. Watson: And it had been at least ten years. A lot of them were like your mama and daddy, they were too old, really, to farm, so to speak. And all the kids had to go off and find another livelihood in the meantime. The land didn't have an opportunity to pass down to the person in the family that wanted to be the farmer.

Sitton: Well, you must have wanted to get off the farm, or you wouldn't have gone to nursing school, it seems to me.

Watson: Well, back in my day, if you weren't a teacher or a nurse, you had no chance. We didn't have any chance of going to school. My mother's sister was a nurse, and I think my dad admired Aunt Maude, and she had been pretty prosperous in her own way.

Sitton: But there weren't many careers for a woman, if you wanted to have your own career other than wife, farmwife, or something.

Watson: No.

Sitton: And you went to nursing school where?

Watson: Brackenridge. Then my sisters followed me, all three of us became nurses. (taping interrupted)

We often did go to church, because we didn't have church.

J. Watson: The church out at Oak Hill didn't conduct regular services throughout the year.

Sitton: That was kind of a union church, wasn't it?

Watson: Well, anybody could come and use the church.

Sitton: But nobody had a regular preacher, who came out once a month?

Watson: No. 
Sitton: Well, what do you remember, anything at all, about the summer revivals, the summer meetings?

Watson: They would all meet over there and cut fresh cedar and build a thick new arbor cover for the - Then people would come, people would put their kids in a wagon, and put something in there for them to sleep on, or to eat, and everything, because kids get hungry. And we just enjoyed it immensely to have a preacher come and preach.

J. Watson: Did you spend a few days up there or overnight at all, or did you go back home?

Watson: Well, it depended on if you were close enough to go back home.

Sitton: But some people would probably stay, because they had come further.

Watson: Yeah.

Sitton: Well, you're using the brush arbor because it's cool, you can't go in the church in the middle of the summer. Would they have evening services, or would they just be in the daytime?

Watson: They'd have it late in the evening, that's when I remember it. Cooler in the evening.

J. Watson: People were through with their chores, too, or their work.

Sitton: But the novelty was having a real preacher show up. This was regarded as a good and entertaining thing, right?

Watson: Well, I don't know if it was entertaining, but it got pretty hot sometimes.

J. Watson: I imagine you didn't have much chances to hear orators or speakers, and no TV, radio, and what not, and you got together with a whole bunch of other folks.

Watson: That's the only time you had a chance, that and the Oak Hill picnic.

Sitton: Talk about, tell me about how the Oak Hill picnic was when you were a girl? What do you remember about it? I know it's not quite like what they do today.
Watson: No.

Sitton: But what used to happen, is what I'm asking.

Watson: Well, you'd make preparations for the meal. Grandpa always prepared the meat. They dug a pit longer than this table, and they would do it all night, and they would make coffee in a wash pot.

Sitton: But then what happens on the day of the picnic?

Watson: Well, you get up, and you finish off your cakes and pies and your chicken and potato salad and all that kind of stuff that you wanted to take. And you went over and had the - oh, all I remember is red soda water!

Sitton: So, that was the biggest treat from your point of view?

Watson: Yeah.

J. Watson: Was there like a program, or did people speak, did they mainly gather and eat?

Watson: Well, if it was a political year, they would often have political speakers.

Sitton: They didn't have that cover. Where did they set up the picnic, did they have boards between trees?

Watson: Yes.

J. Watson: Did they build an arbor for the picnic, or just open air?

Watson: Open air.

Sitton: What would the kids do?

Watson: Run and play like any bunch of kids do when they get together. The kids were so glad to see each other.

Sitton: Well, you didn't get to see a whole lot of kids, didn't get a whole lot of people to play with.

Watson: No, you sure didn't.

J. Watson: One aspect that I don't know if you've talked to others about, there were some African American 
families across the road from the home place, Mother. I believe some of them were either former slaves or the children of former slaves. There was a good deal of association between the families, as I understand it.

Watson: Yeah.

Sitton: How did they make a living, the colored families that lived around there?

Watson: They worked mostly for the farmers.

Sitton: Did they own their own land, or were the renters?

Watson: Well, some of them owned their own land. The Jetts, you know, John, that man, he had a bunch of kids.

Sitton: Did your father ever hire him?

Watson: Oh, yeah. He did.

Sitton: Well, there are certain times in the year you need all the help you can get.

Watson: Oh, yeah.

J. Watson: They all had their own house and land, didn't they, Mother? I mean, they weren't sharecroppers living on somebody else's land. I don't know if it was the forty acres and a mule situation, I don't know the history of it, but as kids y'all played with them, and they came over, some of them, and helped out with the family babysitting - I say babysitting, tending kids maybe while Grandma went out to the fields.

Sitton: How would they help?

Watson: There was one family lived across the road, they didn't have a lot, and one of the daughters that lived at home with her family she had an infirmity and she couldn't work, but she could talk enough to be understood, and she would kind of tend to the kids. 'Cause, my oldest brother was walking behind me and cutting my hair.

J. Watson: Kind of a prank, you mean?

Watson: Yeah.

Sitton: Would y'all play with them?
Watson: Yeah, and the thing is, some of them - not the Jett kids but the Fleming kids - had the same name we did. And there's one we called Aunt Aggie, and she would kill a opossum and cook it with sweet potatoes, and my youngest brother and sister would go down there and eat with her.

J. Watson: There was a good deal of interaction between the families.

Sitton: But opossum wasn't, you didn't get any opossum at home, you had to go over there to get opossum, right?

Watson: Yeah, that's right.

J. Watson: Opossum and the eels that were caught in some of the creeks were considered to be black people's food and not necessarily white people's food at that time, weren't they, Mother? They were in my childhood.

Watson: No.

J. Watson: What about politics, Mother? I know that when the DeGlandon family's reunion started in the twenties, your particular crowd were forbidden by your daddy from going.

Watson: He wouldn't go.

J. Watson: He wouldn't go and told y'all not to go because of why? There was a political disagreement between your daddy and his father-in-law. Or his own daddy, which one?

Watson: Grandpa.

J. Watson: Mama's daddy, his father-in-law. Was it over the Fergusons, Ma and Pa Ferguson?

Watson: Yep, that was it. 'Course, kids didn't think much about that stuff.

Sitton: You father had strong opinions about the Fergusons?

Watson: Oh yeah, he didn't think they were worth gunpowder.

Sitton: Well, the Fergusons, they were governors that people had strong opinions about. 
J. Watson: And families fell out over.

Watson: Yep.

J. Watson: Mother, what about the flu epidemic of 1918? You would have been about seven or eight years old, do you have any specific memories about how it affected the community out there?

Watson: Well, I know that I was the only one in our family that had it. I almost died of it.

Sitton: And nobody else got it?

Watson: Yeah.

J. Watson: What treatment, if any? Was there any treatment, or just nothing to do?

Watson: Nothing to do.

Sitton: That's a different kind of flu than we have today, they say. What was it like to get sick with the 1918 flu?

Watson: I just was so sick, it was the first time I had to ever sleep with my daddy. I was so sick he had me to sleep with him - you know, because I was so sick.

Sitton: There's so many graves in the graveyard with 1918 on them, and that's true in the Oak Hill Cemetery, too.

Watson: Yeah.
Sitton: You were talking about one of your brothers, he got kicked in the head by a mule?

Watson: Well, we were going across to get this pony. I stopped in the hollow and used the bathroom, and Russ went on, and he got over there and that pony kicked him right in the face. And 'course I ran to the house and got my daddy.

Sitton: Did it knock him out?

Watson: Yeah, it did. And we got old Aunt Aggie, the old black woman, and she sat there and prayed for him all evening.

J. Watson: Did you put a poultice on it, did you apply home remedies or what?

Watson: Oh, yeah.

J. Watson: Did you take him in to the doctor in Bastrop?

Watson: I don't know, I can't remember, but I know he was unconscious.

Interview with Irene Fleming Watson with contributions by her son, John Watson

Interviewed by Thad Sitton

Date: June 15, 2004

Place: Johnson City, Texas

Year of Birth: 1911 


\title{
Evelyn Cottle Wilson Interview
}

\author{
By Martha Doty Freeman
}

\section{June 2004}

Martha Doty Freeman: This is Martha Doty Freeman. Today is June 4, 2004. This interview is taking place at the home of Evelyn Cottle Wilson, 4150 Desert View, San Antonio, Texas. This interview is part of the Texas State University-San Marcos Camp Swift Oral History Project, sponsored by the Texas National Guard and conducted in conjunction with The Center for American History, The University of Texas at Austin.

Freeman: Why don't we start, talking about your family.

Evelyn Cottle Wilson: All right. My name was Laura Evelyn Cottle. My parents were Albert and Laura Cottle. I had three older brothers. And I'm the only one left in my immediate family. We lived on what was known as the Coulson place. We didn't speak of farms. We spoke of places. My father rented the farm. It was a large farm, about four hundred acres. But about two years before World War II, he had an opportunity to buy a farm at a very reasonable price. It was known as the Washington place. And so he bought that, and of course at the time it was very difficult for us to move. My family had moved to the Coulson place before I was born, and I was fifteen when they moved from there. They had quite an accumulation of farm equipment and household goods. It took several days to move to the new place, which was about three miles from the Coulson place. Neighbors helped us move.

Freeman: Did you have grandparents who lived anywhere in the area?

Wilson: Yes. My mother's parents lived in Ridgeway Community, about ten miles from where we lived, and they also had to move. There were my grandparents, an old bachelor uncle, and a spinster aunt. And they, too, had to move from their home place where they had lived for many, many years. They moved a short distance into another area.

Freeman: What were your mother's parents' names?

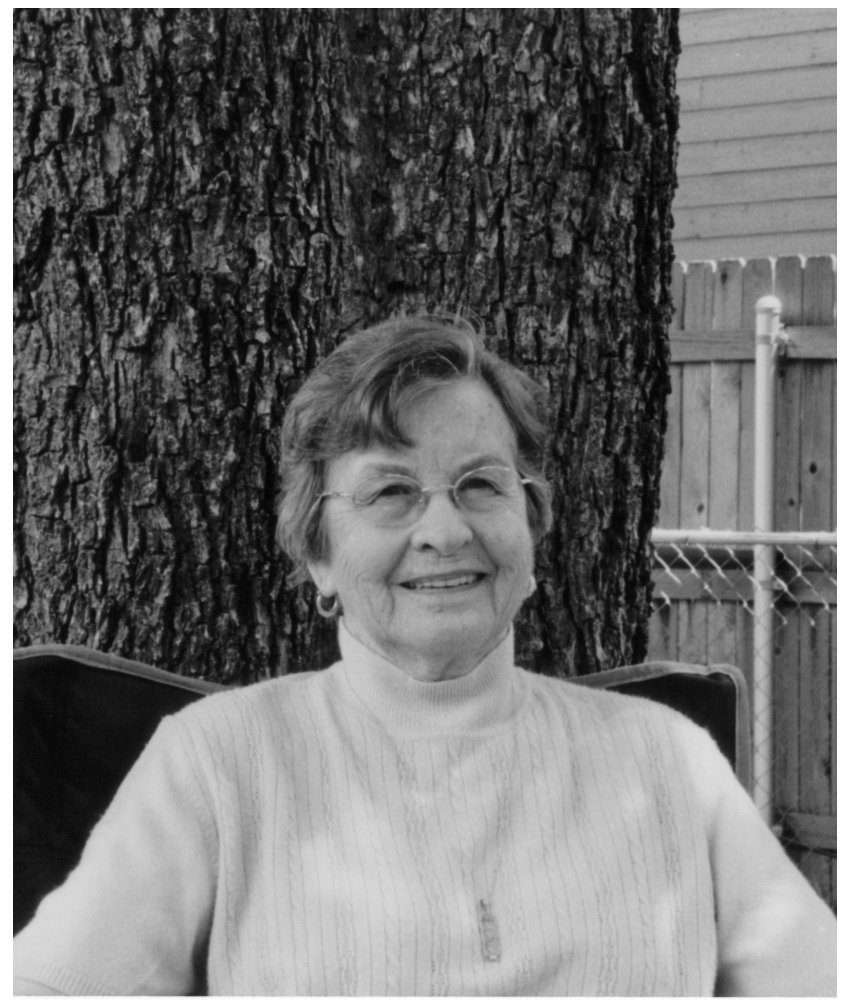

Evelyn Cottle Wilson

Wilson: Lewis. My grandfather's name was Samuel Alexander Lewis, and my grandmother's name was Marsaleete Orline McKinney. Most people called her Leetie. Of course, I called her Grandma.

Freeman: How far did they live from you?

Wilson: About ten miles in the Ridgeway Community on a farm. At that time, ten miles was a nice little distance. We didn't visit every week. But my grandmother used to come to our house and spend sometimes two, three weeks at a time. I always enjoyed listening to her and my mother talk about their pasts and how they lived.

Freeman: Where was the farm that you lived on as a child? Where was it relative, say, to Oak Hill? 
Wilson: It was in the Oak Hill community. It was about three miles from McDade, and the second place I lived was actually in a different school district. Not the Oak Hill School District, but it was known as the Wayside District. We moved there the year before I was a senior in high school. My dad had served eighteen years on the school board in Oak Hill, and most of that time he was president of the board. He was also president of the cemetery association for several years. Even though we moved out of the Oak Hill District, the trustees at Oak Hill allowed me to ride the school bus to Bastrop my senior year. I walked a mile each way, which didn't seem like much to me then. We walked a lot.

Freeman: What was the house like that you lived in when you were very young?

Wilson: That house was built during the Civil War, and I was only the second baby born in that house. It was in very good condition, and possibly would, at some time, have become an historical site. It was a large and well-built house. One-story. There was a large room that had a cedar floor, and my mother used to scrub that floor with soap and water, and that red cedar was just beautiful and very fragrant. My parents hosted many parties for the young people and moved all the furniture out of the cedar room, as we called it. We didn't square dance, but we sang and played games, and when you gave a party in those days, you didn't send out invitations. You just put out the word, "There'll be a party at the Cottles this Saturday night." And everybody came. From other communities, from McDade, and some from Bastrop. And all the rooms were large. There were three bedrooms, a living room, a kitchen, a large pantry, and a dining room. And an L-shaped porch. And in that L, my mother had her flower garden. She could grow everything. She had beautiful flowers, as well as pot plants. My dad, even though he didn't own the land, put out a pecan orchard and a peach orchard. There were wild plums and wild persimmons. We also had a berry patch of dewberries and blackberries, so my mother didn't have to go into the woods to pick berries. We always had a bountiful garden, spring and summer, raised chickens, and we raised most everything that we ate, except the staples. My father also took dried corn to the grist mill and had it ground into cornmeal.

Freeman: Did you have enough left over to sell?

Wilson: Well, he farmed. Primarily, he was a truck farmer. Of course, he raised feed for the livestock, but he grew watermelons and cantaloupes, and he marketed those. He had an old Model T truck, and he'd load that truck with watermelons or cantaloupes, and he'd travel to Austin, peddling those melons. And sometimes my mother went with him, and it was always an adventure. They even ventured over to Kyle one day. (laughs) And then sometimes he would go to Bastrop, and also trucks came to our house, and that was exciting for us. The trucks came to the house to buy the watermelons and cantaloupes.

Freeman: Do you know where they came from? Were they big trucks?

Wilson: Yes, large trucks. And, of course, they were buying the melons. My dad also shipped watermelons by train out of McDade. One year he loaded a freight car by himself, just from his crop of melons. This was during the Depression. There was no market, and he sent those out on consignment and eventually received seven dollars for a carload of watermelons. (laughs)

Freeman: Hardly worth the effort, I'm sure. (laughs)

Wilson: Those were the Depression days. I try not to dwell on those because they were tough.

Freeman: Did he raise peanuts?

Wilson: Oh, yes, in later years. However, when I was real small, he didn't raise peanuts, nor did any of the other farmers in that area. They began raising peanuts later. He raised corn. I believe he sold some corn. And of course we needed corn for the livestock and for our own use. Before World War II began, some of the farmers who were better off financially than we began to farm with tractors, but my dad always took note of the fact that they had more weeds in their fields than he did. (laughs)

Freeman: Do you remember the names of any of the farmers who bought tractors? Were there any there in your neighborhood?

Wilson: Yes, at Oak Hill. I remember Howard Fleming. He was one of the first to buy a tractor. And I don't remember the others. But there were others who were buying tractors.

Freeman: So, what did your father use? 
Wilson: Mules. Not horses. Mules. And a plow. He had a riding cultivator at one time, but I think most of the time he walked behind that plow, or cultivator, or whatever he was using. There were times when he would hire some of his work done. He would hire people to come in and hoe. He didn't like weeds growing in his crops.

Freeman: Do you remember his cultivating cotton at all?

Wilson: Yes, some cotton. And he would haul it in to the gin. He had an old Model T truck, and he used to haul cotton to the gin.

\section{Freeman: And where was that?}

Wilson: Let me think. I don't think it was in McDade. Where was that gin? I think he had to take his cotton to Elgin to have it ginned.

Freeman: Did he grow much of it?

Wilson: Not by today's standards. I would say no. But I remember counting it in bales. But it didn't begin to compare with today, where they just have so many bales of cotton. This was on a much smaller scale.

Freeman: Now, when were you born?

Wilson: I was born in 1923.

Freeman: And tell me about your brothers, their names and when they were born.

Wilson: All right. There was Aubrey, my oldest brother. He was born in 1912. My brother Gordon was born in 1918. He died of pneumonia just before his thirteenth birthday. Rex, my brother three years older than I, died four years ago. His widow is still living, and Aubrey's widow is also living. She lives in Bastrop, and Rex's widow lives in College Station.

Freeman: Well, what was it like growing up as the only girl?

Wilson: (laughs) My dad called me Baby, which in later years embarrassed me terribly, especially when I started dating. (laughs) My brothers thought I was spoiled, but I don't think I was. (laughs) I was my dad's pride and joy, but I think sometimes I was a thorn in my mother's side. (laughs) She loved me, but she had to deal with me on a daily basis, an hourly basis.

Freeman: So, did you stick around the house mostly with her?

Wilson: Oh yes. My father did not want me to work in the fields. He grew up on a farm. There was a large family, and all his sisters had to work in the fields. So when I was born, he said, "I don't want her to ever have to go to the fields and work." My mother was thirty-nine when I was born, and my dad was forty, and yes, I was pampered by him. He did not do more for me than he did for my brothers, but he was just really proud to have a daughter.

Freeman: How long did you live in this big old house?

Wilson: Coulson house? Until I was fifteen, and then we moved shortly before I was sixteen. We moved in 1939. I finished high school in Bastrop in 1940, and I would have liked to go to college. I would have liked to go to Southwest in San Marcos because that was where most of my friends went, but we absolutely could not afford it. And I realized that, and so I really studied hard in high school because I knew I would have to get a job. An attorney in Bastrop, C. B. Maynard, hired me and trained me to be a legal secretary. He had a lot of patience with me. I was scared to death the day I went to work. He called me in to dictate a legal document, and I had no idea what he was talking about. (laughs) I had taken shorthand, typing, and bookkeeping in high school. When he finished dictating, he said, "Now, you go to your typewriter and type what you got of this and I will fill in the blanks." And he did. Once you learn legal terms, there is no problem preparing a legal document. He was very patient with me, and he encouraged me to grow and do better. We were formal. He was Mr. Maynard, and I was Miss Evelyn.

Freeman: How did you meet your husband?

Wilson: He was a construction worker. He went to Bastrop to work at Camp Swift. His cousin introduced us. I did not meet his parents until after we married. They welcomed me into their family, and I thought that was unusual. But my parents welcomed him. They were concerned that we hadn't known one another very long, and of course they were in the turmoil of moving, first of all finding a place to live. They were 
in their fifties. I never heard them complain. Well, they never complained about much of anything. They accepted whatever was handed to them. They were ambitious, and they wanted their children to do well. But they never complained about their lot in life, and I never heard them complain about the move when the government took over the land.

Freeman: Do you have any memory of how that all came about? Were you at home?

Wilson: I was working in Bastrop, and, of course, life in Bastrop was very exciting. New people were coming in. New businesses were opening. Life was changing for everyone.

Freeman: Did you help your parents move?

Wilson: My oldest brother helped them. The government did not want those houses [at the Camp]. I think they torched the ones that were left. And some people did just move out and leave their homes, but my parents hired someone to tear their house down, and my brother moved the lumber to the place where they relocated about ten miles from Elgin.

Freeman: Were they able to buy some land?

Wilson: They bought some river bottom land, and my dad continued to farm until my mother died in 1948, and then he sold the farm and went to work at the Butler Brick plant near Elgin. Later, he remarried. He had known this lady for several years, and she had been a widow for about twenty years. And they married, and they had over twenty years together. He outlived her by about three years. She was a lovely lady, and she made a good home for him. They lived in Elgin.

Freeman: I wanted to go back to the first old house where you lived and just kind of - You were talking generally about what it looked like. Did it have chimneys, fireplaces?

Wilson: It had a double fireplace. There was a large fireplace in the cedar room. And then on the other side, there was a small fireplace in the bedroom next to the cedar room. Of course, we had plenty of wood to burn.

Freeman: What do you mean, on the other side?
Wilson: On the other side of the wall. Okay, here's the wall and the large fireplace is over here and the smaller one is here, and there was this enormous chimney.

Freeman: Was it stone, or brick?

Wilson: Ah, brick, as best I recall. Brick.

Freeman: And what rooms did those fireplaces feed into?

Wilson: The large cedar room, that we used as a bedroom. But also in the wintertime it was our living room and bedroom. Also, that is where the large fireplace was. Incidentally, during this time one of the teachers at the Oak Hill School roomed and boarded with us, and she was a delight. She was really good for our family, and so my parents made the living room into a bedroom and put a heater in there for her.

\section{Freeman: What kind of heater?}

Wilson: Just a wood heater. There had to be a chimney there somewhere. So I don't remember the opening. Of course they just used a stovepipe for the heater. There was also a stovepipe for the kitchen stove.

Freeman: What sorts of things would your mother fix? What were typical meals?

Wilson: We ate lots of vegetables from the garden, and then in the spring we had fried chicken. Lots of fried chicken because they raised the chickens. They also raised turkeys for the market, and Mama took care of the turkeys most of the time. We always had turkey for Christmas dinner and usually for Thanksgiving dinner. Any time there was a special occasion, when she really wanted a fine meal, she would kill one of her turkeys and dress it and prepare turkey and dressing. She was a good cook. Red beans and cornbread. That really was our staple diet. Evidently it didn't hurt us because most of were healthy. For my age, I am extremely healthy. And my dad was very healthy. $\mathrm{He}$ lived to be ninety-two.

Freeman: What did she grow in her garden?

Wilson: We had tomatoes. Oh, and my dad raised tomatoes on a large scale and he did market some of the tomatoes. We had lots of tomatoes. My mother did a lot of canning, and of course that was done in the hot summertime over a wood stove. And on the day that 
we canned corn, that was a family project. The men went to the field and gathered the corn, shucked it and silked it, and then the women took over. And usually neighbors would come in and help when there was a big canning day, and then we, in turn, would try to help them. But she canned a lot of corn and tomatoes, tried to have enough to last through the winter. We raised a lot of greens and radishes, and I don't remember carrots very much. I'm sure there were carrots, but evidently they didn't do well in our garden. We also grew green beans, peas, sweet potatoes and white potatoes. We called these Irish potatoes. There were lots of cucumbers. Mama made pickles. And my dad marketed sweet potatoes. And Mama also planted rows of flowers in the vegetable garden.

Freeman: What was the reason for that?

Wilson: She loved flowers. I remember when a threeyear-old neighbor boy died of diphtheria. His favorite color was yellow, and his family wanted all the yellow flowers they could get for his funeral, so they brought washtubs to our house and gathered yellow mums from Mama's vegetable garden. When there was an outbreak of diphtheria, my dad loaded the school kids who were in the Oak Hill School, loaded them in the old Model T truck, and took them into town for their shots. And I know at least twice, he did that.

Freeman: What was the reason for the diphtheria? Why was it so common?

Wilson: I don't know. Because we don't hear of it any more. Babies were not given the DPT shots at that time. Because of the shots, diphtheria is a rare disease today.

Freeman: Could it have had something to do with the water source?

Wilson: I don't know. We had pure water. We had a spring, and my dad had to haul water from the spring to the house. And then my mother came up with this clever idea. Instead of hauling water to the house to do her laundry, she took her laundry to the spring. They put up clotheslines, and she did her washing down there. Took the wash pot down there where she boiled most everything, I suppose. Some of the things she did not put in the wash pot, but she was meticulous with her laundry.

Freeman: How far was the spring from the house?
Wilson: Oh, we had to cross a public road, but not far. I'm not good with distances. It might not have been more than about a quarter of a mile. It was in a lovely spot, and the water was pure. My brother and I used to delight in taking our water to school when the chemistry professor would test water, and ours always checked out one hundred percent pure because it came from a spring. And in dry years, people would come from miles around, asking if they could haul a barrel of water from our spring. Most years we had enough to share, but some years my dad would just have to say, "I'm sorry, the spring is so low that we don't have much water."

Freeman: Was it, was it built up around the spring at all?

Wilson: Yes. Probably my father did that. Was just like a water well where you have the stone, or cement, or brick around it. It was located in a small glade of trees, and it was an absolutely beautiful spot. Sometimes people from churches and other organizations would ask if they could have a picnic there. And sometimes we would go down there and have a picnic. But people were well aware of that spring of water.

Freeman: Was there a well or a cistern at the house?

Wilson: We had a cistern that leaked. Everything on that place was huge, including that old cistern. And it was in Mama's flower garden, but we never used the water from it.

\section{Freeman: Why was that?}

Wilson: Well, for one thing, it leaked, and it didn't hold the water. I'll tell you what Mama did do. In the summertime, she put milk or something she wanted to keep cool in that cistern. She used a rope and basket to lower milk into the cistern. We did not have a refrigerator. For years and years, we didn't have a refrigerator. And she put milk or something like that down in that cistern to keep it cool. One day our cat fell in it. (laughs) Well, we didn't use that water, but he was an adventuresome cat.

Freeman: Did the house have a central hall?

Wilson: No, it was built in an L shape. The only two rooms that were connected by a doorway were the kitchen and dining room. A porch rested inside the 
L. In order to go from one room to another, it was necessary to go out on the porch.

Freeman: Did you say it was $\log$ ?

Wilson: No.

Freeman: It was frame.

Wilson: It was frame. There were no logs in it. There was a log cabin on the property that usually a hired hand lived in, and occasionally it was rented out. But most of the time a hired hand lived there. It burned to the ground when we were there.

Freeman: Did you have a smokehouse there?

Wilson: Oh, yes.

Freeman: Tell me about that.

Wilson: Okay. I'm glad you brought that up. That was the old slave quarters that were still standing. You know, most smokehouses are not much larger than that little storage building in my yard. Ours was huge, and it was used. And then in front of the smokehouse there was a loft that had been sleeping quarters for the slaves. It rested on wooden poles, and there was a ladder. I climbed the ladder and played up there a lot. It was large. Everything on that place was larger than anywhere else, the smokehouse, the house, and everything.

Freeman: Now, where did you hear that it was a slave quarters?

Wilson: Well, the owner of the property was still living at the time the government took the property. She lived in Austin and she never married. There was a large family, and she was the last one. And all of them are buried at the Oak Hill Cemetery.

Freeman: Do you remember her name?

Wilson: E. Onieta Coulson. C-o-u-1-s-o-n. And in the cemetery at Oak Hill, there's just a long row of Coulson graves. They were all boys except two. Most of them had died even by the time I was born. But she had one sister. But Miss Nate, as we called her, was still living at the time we moved, and so most of this came from her because she grew up there. And she remembered all of that.
Freeman: Did your family actually use the smokehouse as a smokehouse?

Wilson: Yes. Oh, that was another thing. We raised hogs. I think my dad sold hogs. We were always getting little pigs, so I'm sure he sold some of them. But we ate a lot of pork. In the wintertime we ate pork, and in the spring we ate chicken, and in the summer we ate meatloaf. I mean on Sundays. That was our Sunday meal.

Freeman: So they would slaughter a cow every once in a while?

Wilson: No, hardly ever. I'm going back far beyond your day to one of President Franklin D. Roosevelt's relief programs, trying to get people through the Depression. Have you ever heard anything about the cattle being slaughtered? Okay. Cattle were brought to our place for slaughter. My mother left home for the day. She could not handle that. I think they shot the cattle. She said she just could not stay there and listen to that.

Freeman: And I assume that she took you with her. Or were you allowed to stay?

Wilson: I was in school.

Freeman: I wonder why they chose your place.

Wilson: That place was well-known for several reasons. It wasn't located right on the main road going through there. It was several hundred feet back off the road, and there was a lane going up to the house, and I remember a large open area there. We had several livestock pens. I was in school that day and didn't witness any of that. I think the slaughtering took place out in this open area in front of our house. Not our yard. We also had a large yard. Like I said, everything was big. And I think that's where it actually took place. Like I said, we had different livestock pens, cow pens, and hog pens.

Freeman: So did your - did any of your parents' cattle get shot during that cattle shoot?

Wilson: I think so. There was some kind of program in which the beef was taken and canned. It was one of Roosevelt's relief programs, and the owners of the cattle got a certain amount of the canned beef and the rest went to a relief program. And I think that's the way it worked. 
Freeman: Did you all participate in any other relief programs? I know in some places they distributed cheese or butter, and in other places they had projects like the CCC or the WPA.

Wilson: The butter and cheese distribution happened in later years. My two brothers who grew to manhood were in the CCC. My oldest brother drove a truck when he was in the CCC. And he hauled cedar from Bastrop to Fort Davis, the cedar that was used to build Indian Lodge. My husband was in the CCC in Brownwood, Texas, where he learned woodwork.

Freeman: Well, what kinds of chores did you do? How did you help out around the house?

Wilson: Well, as I told you before, my dad did not want me to work in the field. He said his sisters had worked in the fields and he just didn't believe women should do hard labor like that. And, too, he realized that my mother needed help around the house, and so I helped her. I cooked my first meal when I was eleven, and so on wash day, when I wasn't in school, I would cook the noon meal. Our main meal was at noon, and we snacked in the evenings. And my job was to keep the house, do the sweeping, the dusting.

Freeman: So, what time would you get up? Say it was a school day. When would you get up so that you could do your chores and get to school and whatnot?

Wilson: All I had to do on school days was make my bed. My mother made our lunches. And I think she continued to make my lunch after my brothers finished school, after Rex graduated. I was two years behind him. But my main job was to get up and eat breakfast. Breakfast was always a family affair. We kept it that way in our family, my husband and I. The family had breakfast together. And my daughter carries on the tradition. They must have the evening meal together. They did all the time their children were growing up, and she and her husband continue the tradition.

Freeman: So, would you all sit in the kitchen together?

Wilson: In the dining room. Yes, and we didn't have electricity for many, many years.

Freeman: Did you ever have electricity?

Wilson: Yes. We never had electricity in the Coulson place. But [we did] after we moved to the other place.
And of course that was only two years before I married. And they had electricity there.

Freeman: What did you use for lighting at the Coulson place?

Wilson: Coal oil lamps. That was one of my chores. Every Saturday I had to clean all the lamps and fill them with oil.

Freeman: How many were there in the house?

Wilson: We had one in each bedroom, I think, and one in the kitchen, one in the dining room.

Freeman: So, what time would you have to start off for school to get there?

Wilson: I don't remember. We always got up early, and of course in the wintertime it was before daylight, and I really don't remember exactly what time we got up. Mama always cooked breakfast. Oh, my dad helped her cook breakfast. He helped her a lot in the house. She was a large, heavyset woman and not in good health. She died when she was sixty-two. And he helped her a lot because her work was difficult.

Freeman: Ah, one thing I wanted to ask was, you were talking about all the canning. Where did they store that?

Wilson: We had a large pantry. Lined with shelves on three sides. Oh, I'll tell you another thing that went on then. We had the weekly newspaper, which I suppose there's still the Elgin Courier and the Bastrop Advertiser, and that's where we got all our news. And in each community there was a reporter who sent in the community news every week. Who was visiting whom and just whatever was going on. There at Oak Hill we had a brush arbor, and there were lots of meetings. I don't think people generally speaking were that religious, but it was a social affair. (laughs) Now that's true. I don't mean to belittle anyone because I myself am a very religious person. But I think it was really somewhat of a social affair. Trying to get together and visit and find out what was going on. But anyway, I remember one year, Mama was so proud of all the canning, and I had to help her a lot. I had to wash those jars and sterilize them. That was not an easy task. I remember one year Mama called the reporter in our community to tell her how many jars she had canned, and it was reported in the paper. 
(laughs) Mama also made lots of jelly and preserves, also pickles and relishes.

Freeman: That's great.

Wilson: We did get a Sunday paper. In fact, one of my brothers used to deliver the Sunday paper in the community.

Freeman: Well, did you have a telephone?

Wilson: Most of the time we did. Our ring was three shorts and a long. But during the Depression, eventually, we had to give up our telephone.

Freeman: So did you notice a change from the twenties to the thirties in the Depression?

Wilson: Ah, well, I think my parents tended to talk about the good old days, because they had seen better days. And during the Depression, oh, we had the sandstorms that blew in.

Freeman: Tell me about those.

Wilson: Well, we'd never seen anything like it. Now that's what drove the Oklahoma people to California in the thirties, and we had sandstorms. Well, it was disagreeable. You couldn't keep anything clean around there. I can remember walking to school and going home in the afternoon and just walking through this blowing dust and sand because we had a lot of sand there. I did witness things becoming progressively worse. Well, like, we had our telephone taken out. A lot of our neighbors did the same thing. Eventually my father sold that old Model T truck.

Freeman: Well, how did you all get around then, other than walking?

Wilson: Just mostly walking, and neighbors were very neighborly. They would take us to church, and then my dad would go into town in a wagon. We were three miles from McDade. And every Saturday he went in the wagon to McDade. Then, neighbors generally did look after one another, because I can remember that we had elderly people living near us, and he was so old he had reached the point he couldn't farm, and this relief program started, and my dad just, oh, he just pleaded with them, with these people, and finally got them, this elderly couple, on relief. When he would go into town on Saturday, he always stopped by the home of an elderly couple and got their grocery list and bought their groceries for them. I remember the poor old man was trying to farm, and one year the neighbors had to go help him with his crops. But we were a community and helped one another.

Freeman: We were talking about sort of hierarchies of families and how some of them are so desperately poor. Were there any of those in your neighborhood?

Wilson: Oh, yes, and as poor as we were, we referred to them as "the poor people." There was one family in particular, and nobody would have anything to do with them. But my parents, if we had mistreated one of those children, and they found out about it, would have punished us. And they tried to help them. One year there was a Mexican family living very close to us, and the parents had gone to another part of Texas to pick cotton. Their grandmother was staying with the children, and the children came to our house - it was either Christmas Eve or Christmas morning - wanting, it sounded like, chichamaroni. [chicharrones] My parents took them through the kitchen and showed them everything in the kitchen. They started out with macaroni. (laughs) No, no, no. And some way my mother felt that these children were really hungry. Their grandmother had sent them up there. My mother, as little as we had for Christmas, had made candies and cakes and things like that, and she gathered up a big lot of stuff and sent home with those children. But when the parents returned, my dad asked the father what the children wanted, and he replied, "Hog cracklin's."

Freeman: Did your family go to church every Sunday?

Wilson: Uh, not every Sunday. They were Methodist, but we went to hear anyone preach. And like I said, they were religious people, but there were times that we didn't go to church, and after my brother died, there were neighbors who belonged to the Church of Christ who started taking my brother and me to Sunday school because we were not going to the Methodist Church. And this eventually led to my entire family going into the Church of Christ.

Freeman: So, you had something in common already with your future husband from Abilene, I assume.

Wilson: Well, no. (laughs) He was a Methodist. 
Freeman: I thought everyone in Abilene was Church of Christ.

Wilson: No, well there is a Baptist university and a Methodist university there.

Freeman: That's true.

Wilson: No, he, in fact he was very prejudiced. But he became a member of the Church of Christ and later went to Abilene Christian, got a degree and preached for several years. He started out as a carpenter and he became a preacher, and that's one reason we moved so much. And then, as he got older, he decided to go into social work, and he went to work for the state. He worked in Child Protective Services. That's the reason we came back to San Antonio.

Freeman: Well, what denomination was the little church at Oak Hill?

Wilson: Non-denominational. Let me tell you something else. First and second grades went to school in that church building. Now, how would that fit into today's society? It was a community church building. We had a two-room school house, but the first and second grades went to school in that church building.

Freeman: In the church. So the school building was for the older children?

Wilson: Yes, we went to Oak Hill through seventh grade. Evidently in the summer months the school desks were stored and old wooden pews were used. But the meetings primarily were held under a brush arbor. I was excited Saturday when I saw the nice sturdy shed that had been built on the site of the old brush arbor.

Freeman: Ah, tell me about your clothing. Where did you get that?

Wilson: My mother made almost everything I wore until I went into high school and then we would go to Austin, Bastrop, or Taylor to shop. My mother shopped on Sixth Street in Austin, which was a retail district at that time. When I was in high school, I was fortunate enough to occasionally buy a dress at Lauterstein's in Bastrop.

Freeman: Well, where did she get the fabric to make your clothes?
Wilson: Well, she bought it by the yard, and I can remember when fabric, cotton fabric, sold for about twenty cents a yard. The problem was finding the sixty cents to get three yards of fabric. But she sewed for me, and she was a good seamstress. She made her own clothes. She was a large woman, and she wore house dresses that hung from her shoulders. They were comfortable for her. Oh, when did I wear my first pair of pants? After I graduated from high school, I suppose. My father learned to tolerate pants, but he never liked them on women. That was not women's clothing, but he got used to it eventually.

Freeman: What about shoes?

Wilson: Shoes? We shopped primarily in Bastrop. McDade had grocery stores but not clothing stores. We had our school shoes and our Sunday shoes. We didn't call them dress shoes. They were Sunday shoes. And I can remember putting cardboard in the soles of my shoes because I knew my parents really couldn't afford to buy new shoes, and I would put cardboard in there to reinforce the soles. I don't know if they ever knew.

Freeman: Was anybody in your family musical?

Wilson: My mother bought a piano for me, paid twentyfive dollars for it. It wasn't new. And the books, how to play, were in the bench of that piano, and I taught myself to play. I didn't play well, but I could play that piano. My parents thought it was great. I remember when I learned "Beer Barrel Polka." You probably don't now what that is.

Freeman: Yes, I do.

Wilson: I think it has come back a little. It was very popular in the forties, early forties. I learned to play that, and I learned notes and learned to sing alto by reading notes. But I didn't ever sing well, but I could sing well enough to get by. But my voice is failing, and I don't think my brothers sang that much either. Mama used to sing a lot around the house. My oldest brother played the Jew's harp.

Freeman: Did you and your brothers ever play together or do things outside together?

Wilson: Not much. I was little, and I was a girl. I wasn't supposed to play with them. I remember one time, I climbed up in a tree to read a book, and I fell out of 
the tree. It wasn't very high. And I didn't get one bit of sympathy. My dad told me little girls weren't supposed to climb trees. (laughs) And, no, my brothers really didn't like to play with me, and I learned to entertain myself. I have a vivid imagination. I visited Paris via books. I read a lot, and I still like to read. Believe it or not, I don't have that much time to read anymore. Reading and my imagination got me through my younger years. But I was pretty much a loner. And I would go play with neighbor girls, who taught me the facts of life. (laughs)

Freeman: What do you remember most about growing up out there? Do you have any general impressions of it?

Wilson: Ah, let me think. Well, I may have complained at the time, and I may have thought that I was mistreated. I can tell you a funny story about that. But I look back on it, and I had a good childhood, considering the times. And as I used to tell my daughter, the thing about growing up in the Depression is that almost everybody was poor. Some were poorer than others, and so we were not alone. And there were some who were poorer than we were. You know what clabber is?
When I was a child, I used to eat clabber and pretend I was eating ice cream. And I told my daughter, and she said, "Mother, I have cried over that." I said, "Sharon, it didn't hurt me."

Freeman: A childhood of deprivation. (laughs)

Wilson: The thing about it, we weren't wealthy when she was growing up. Most everybody had a little more than we had. But she said, "Well, I never felt deprived." And I said, "Well, to some extent, you were." About [my parents] lot in life and all this turmoil of moving at their age. Now, I know - I think fifty-ish was older than it is now-because we're more mobile than we were then. But I never heard them complain. It was a fact of life, and it was up to them to deal with it. And they never complained.

\section{Interview with Evelyn Cottle Wilson \\ Interviewed by Martha Doty Freeman \\ Date: June 4, 2004}

Place: Home of Wilson, San Antonio, Texas

Year of Birth: 1923 


\section{INDEX}

Abilene, Texas, 245, 304, 305

Academy, Texas, 63

Adams, Mr., 230, 239

African American, 294. See also blacks; colored

agriculture, 2, 3. See also farming alcohol, 51, 88, 100, 133, 139, 209, 264, 269, 277, 278, 279; beer, 88, 100, 278; bootlegging, 100; bootleg whiskey, 278; home brew, 88, 100, 278, 279; liquor, 264, 269, 278; moonshine, 279; stills, 269; whiskey, 100, 139, 209, 278; wine, 38, 48, 86, 89, 209, 277. See also grapes: viticulture; Prohibition; winery

Alief, Texas, 124, 261

Allen, Alvin, 227, 236

Allen, Clyde, 15, 236

Allen, Donald, 227

Allen, Ellen, 257

Allen family, 12

Allen, George, 148, 257

Allen, Grandma, 217

Allen, Grandpa, 217, 237

Allen, Lucy, 257

Allen, Margaret Anderson, 257

Allen, Ruth L. See Hancock, Ruth L. Allen

Alum Creek, 73, 111, 273

Alvin's place, 117

Anderson, Margaret. See Allen, Margaret Anderson

Arthur, Ava, 25

association meetings, 36,37

Aunt Tex's millinery, 273

Aussilloux, Antoine, 89, 119, 127, 133, 209, 238, 247, 277; Aussilloux house, 222, 229; Aussilloux place, $128,219,221,223,228$

Austin, Texas, 2, 15, 16, 23, 25, 38, 42, 44, 51, 60, 92, 96, 100, 114, 139, $141,144,155,163,172,176,177$, 199, 214, 220, 231, 249, 254, 255, 260, 298, 302, 305

automobiles, 11, 16, 18, 21, 31, 44, 70, $73,75,76,77,85,88,96,97,98$, 100, 104, 107, 112, 114, 117, 118, $121,127,129,134,141,143,144$, $155,156,157,163,168,173,174$, 176, 179, 186, 195, 202, 203, 205,
206, 207, 208, 217, 218, 220, 221, $222,225,227,228,230,231,233$, $234,235,238,243,245,246,249$, 259, 268, 283, 285, 286, 298, 299, 301, 303, 304; Model A Ford, 75, $77,85,96,205,207,218,220,221$ 222, 228, 233, 234, 235; Model T Ford, 11, 16, 44, 77, 96, 97, 100, 127, 129, 173, 205, 206, 208, 217, 222, 233, 238, 242, 245, 246, 283, 298, 299, 301, 304

backboning. See neighbors helping neighbors (backboning)

bacon, 30, 97, 105, 120, 132, 151, 155, 165, 174, 192, 259, 288. See also hams; hogs; sausage

banks and banking, 119, 120

Bankston, Tim, 238

Barbee Hollow (Bar B Holla), 247

Barbee, King Henry, 147, 148, 256, 257

Barbee, Mary Ann Fort Hancock, 147, 256, 257

barber shops, 28, 112, 149, 227, 246

barn raisings 117

bartering, 5, 24, 53, 74, 88, 96, 115, 159, 174, 271

Barton, Brenda, 14

Barton, Carolyn, 14

Barton, Doug, 14, 21, 22

Barton, Gertrude (Dunkin) 7, 9-24

Barton, James, 21

Barton, Max, 11, 15

Barton, Nancy, 14

baseball, 19, 27, 237, 260

basketball, 27, 78, 130, 184, 255, 285

Bastrop Advertiser newspaper, 34, 35, 87, 187, 292, 303

Bastrop County, 5, 7, 25, 34, 50, 92, $102,107,119,124,125,148,164$, 181, 209, 213, 254, 256, 271, 292

Bastrop High School. See under school

Bastrop Independent School District. See under school

Bastrop newspaper. See Bastrop Advertiser newspaper

Bastrop school. See under school Bastrop State Park, 13, 15, 45, 92,
$119,121,125,164,175,176,210$, 231, 236, 274, 291

Bastrop, Texas, 2, 5, 14, 27, 28, 31, 39, 41, 42 50, 58, 59, 62, 76, 77, 84, $85,87,94,103,104,106,109,111$, $112,122,127,139,144,148,155$, $158,159,163,164165,167,175$, $176,179,185,186,191,196,197$, 203, 206, 207, 210, 212, 213, 216, $223,235,236,245,249,254,256$, 257, 259, 262, 263, 264, 272, 277 , 283, 296, 298, 299, 300, 303, 305; Bastrop hospital, 111, 122, 124, 157, 292; Bastrop lodge, 79

bathing, 139, 172, 249

Battle of San Jacinto, 117, 257

Baytown, Texas, 254

Beaukiss, Texas, 279

bedding: mattresses, 58, 80; pillows, 58,272 . See also quilts

Bee Brand Powder, 220

beef, 23, 80, 95, 137, 167, 265, 266, 268, 290, 291, 302

beef clubs, 95, 158, 265

beer. See under alcohol

bees. See under bugs and insects

Bell, Mr., 172

Benford, A. G., 180

Benford, John Billy, 180, 184

Benford, Mary Lou (Reese), 7, 25-40, 180

Benight, Joe, 164

bicycle, 87, 97, 140

Big Bend, Texas, 231

Big Sandy Creek, 25, 28, 34, 68, 87, $88,94,95,104,127,131,148,189$, 197, 198, 215, 217, 219, 220, 221, $222,225,228,230,235,237,245$, 248, 276

Billingsley hat shop, 155 births at home. See home births biscuits, 14, 17, 22, 23, 38, 45, 78, 99 , 106, 129, 155, 165, 167, 170174 193, 223, 228 259, 262, 266, 290. See also bread; cornbread

blacks, 11, 18, 43, 57, 59, 93, 94, 116, 129132 141, 151, 152, 153, 172, 180, 184, 185, 191, 196, 197, 209 236, 249, 250, 251, 253, 277, 278, 285, 295, 296. See also African American; colored 
blacksmiths, 28, 144, 197, 208. See also occupations

black walnut poisoning. See walnut poisoning

Blackwell, Bettye. See Light, Bettye Lynn Blackwell

Blackwell, Ethel Kelton, 41

Blackwell family, 41

Blackwell, George, 42, 45, 52, 59, 60

Blackwell, John Lindsey, 41

Blackwell, Julius Watson, 41

Blackwell, Leola. See Carman, Leola (Blackwell)

Blackwell, Mary Smith (Grandma Blackwell), 41, 44, 49, 58

Blackwell, Willie, 41, 113

Boomer, Mr., 77

bootleg whiskey. See under alcohol

bounties (on wildlife and hides), 113, 273. See also hunting; wildlife

Boy Scouts, 202

branding irons, 208

Branton, C. R. "Nick", 230, 232, 247

Branton, Mae (Aunt Mae), 238, 247

Branton, Noel, 239

Brazos River, 223

bread, 31, 45, 105, 132, 155 165, 165, 259, 266. See also biscuits; cornbread

Brenham, Texas, 261

Brice, Manch, 153

Brice, Mex, 152, 153

Brice, T., 152, 153

brick factory, 249

brick plant, 222

brickyard, 78, 89, 91, 95, 97, 116, 118, 222, 237, 275, 276

Brickyard Road, 275

bridges, 75, 207, 219, 220, 236, 249

Bright, Mr. (peddler), 271

brush arbors, 29, 156, 190, 233, 294, 303, 305

Bryson, Dr. John Gordon, 12, 21, 50, 111, 113, 124, 157, 216, 270, 272

Buffa family, 149; Buffa, Faustina, 148

buggies, 112, 115, 124, 139, 151, 159, 208, 216, 218, 221, 230, 244, 245 $250259,266,271,283,285$

bugs and insects: ants, 289; bedbugs, 43; bees, 23, 54 (see also honey); bugs, 43, 103, 151, 181, 255, 263; flies, 154, 159, 220; grasshoppers, $5,70,94,103,181$; insects, 54, 181, 268; mosquitoes, 289; ticks, 268; weevils, 96, 220, 263, 265, 286

bulldozers, 229 bulls. See under cattle

buried treasure, 238, 277

burros, 74. See also jennies;

livestock; mules

Burton, Texas, 182

buses, 19, 45, 59, 111, 118, 144, 156,

$158,160,217,219,298$

businesses, 227, 229

Butler Brick plant, 300

Butler Brickyard, 118, 237

Butler, Texas, 219

butter, 5, 13, 17, 22, 23, 46, 78, 91, 103, 104, 110, 125, 152 163, 166, 179, 186, 193198 199, 216, 228, 244, 262, 264, 266, 303; butter churn, 262; butter churning, 17, 23, $166,179,216,262,266,267,268$

cakes, 17, 94, 156166 174, 193, 208, 294, 304

California, 33, 102, 108, 123, 148, $149,180,210,304$

camping, 34

camp meetings, 29, 233

cancer, 260, 266

candles, 184

candy, 18, 46, 100129 141, 156, 173, $184,273,274,304$

cane, 166, 266. See also molasses; ribbon cane; sorghum; sugar cane; syrup

canning, 13, 16, 56, 58, 63, 6470,75 80 81, 95, 108115 128, 138, 166, 171, 194, 206223 245, 264, 265 , 268, 278, 289, 300 301, 302, 303, 304; cannery, 58, 248; canning plant, 108

carbide lights, 188, 221, 233, 261, 273

Carman, Charles, 52

Carman, Leola (Blackwell), 7, 41-60 Carter Drive, 82

Carver, George Washington, 278

Carter, President, 278

cash, 5, 10, 18, 22, 34, 36, 39, 50, 53, $54,56,58,63,7071,75,80,82,83$, $88,90,93,97,97,98,100,101,102$, 106, 107, 108, 110, 113, 114, 115, $116,119,120,123,124125,129$, 130, 132, 133, 134, 137 138, 141, 143, $148151155,158159,163,165$, 167, 168, 169, 170, 173, 174, 175, 179, 181, 182, 185, 186, 189, 194, 195, 196, 198, 199, 201, 202, 203, 204, 205, 209, 210, 211, 212, 213 , $220,221,223,227,230,234,235$, 237, 238, 239, 242, 243, 244, 245,
$246,247,249,254,255,256,257$, $259,260,262,263,264,267,268$ $269,270,271,272,273,274,276$, 277, 278, 285, 286, 289, 291, 292, 293, 298, 299, 300, 301, 302, 305, 306, 103. See also money

catalogs, 14, 19. See also magazines; Progressive Farmer; Sears

Roebuck catalog

cats, 53, 174, 301

cattle, 5, 13, 22, 23, 90, 91, 97, 103

104, 137, 138, 143, 147, 149, 158,

179, 180, 199, 205 208, 213, 221,

229, 243, 268, 288; bulls, 23, 107,

158; cattle buyers, 141; cattle clubs, 23; cattle dipping, 159; cattle dipping vats, 227, 243, 249, 268; cattle drives, 107, 125, 227, 236; cattle killings, 13, 107, 159, 175, 210, 211, 236, 237, 248, 268, 290, 291, 302; cattle pens, 145, 236, 268 , 290, 302; cows, 23, 30, 32, 44, 63, $70,80,81,91,93,95,96,102,103$, $106,107,110,114,116,125,128$, $137,140,141,142,145,151,152$, $154,159,163,165,168,169,171$, $173,175,179,180,185,199,216$, $221,223,225,226,232,236,244$, $255,261,262,268,270,271,272$, 288, 291, 302; dairy cows, 103, 110; grazing cattle, 142, 143. See also beef; beef clubs; livestock

CCC. See Civilian Conservation Corps (CCC)

cedar, 108, 298, 303; cedar arbors, 261, 294; cedar posts, 93, 128, 199, 228; cedar trees, 76, 84, 93 99, 128 174, 199, 231, 232, 272; cedar wood, 93, 108, 199, 233, 261, 264, 298, 303

Cedar Creek School. See under school

cemeteries and graveyards, 20,33, 47, $52,59,92,117,122,125,134,141$, 156, 164, 167, 168, 179, 180, 190, 191, 236, 243, 246, 253, 254, 256 , 260, 261, 284 296, 302; Chandler Cemetery, 236, 246; Herron Cemetery, 117; McDade Cemetery, 92, 104, 125; Mexican cemetery (at Sayers Coal Mine), 246; Mount Bethel Cemetery, 256; New Hope Cemetery, 191; Oak Hill Cemetery 2, 10, 11, 20, 22, 23, 33, 45, 59, $87,88,89,92,99,122,143,149$, $156,159,164,167,168,179,180$, 190, 191, 243, 253, 254, 256, 257, 
260, 261, 284, 296, 302; Oak Hill Cemetery Association, 2, 253 254, 260, 298; Piney Creek Cemetery, 191; Ridgeway Cemetery, 20, 23, 191; Sayers Cemetery, 191

chamber pots, 139. See also outhouses

Chandler Cemetery. See under cemeteries and graveyards

Chandler family, 227, 244

Chandler house, 250

Chandler, John, 227

Chandler, Magruder, 227

Chandler place, 216, 236, 246

cheese, 5, 166, 303; cheese curd, 103; cottage cheese, 103, 154, 168, 249

chickens, 5, 13, 17, 22, 36, 38, 39, 44, $54,55,56,58,70,76,80,88,91,93$, $94,96,98,106,115,124,127,128$, $133,137,140,142,147,150,154$, $156,159,163,166,168,174,181$, 192, 193, 199, 202, 208, 213, 227 , 234, 245, 255, 262, 266, 271, 272, 288, 294, 298, 300, 302; chicken brooder, 150; chicken incubators, 262, 263

chicken salad, 259

Child Protective Services, 305 chocolate school. See under school chores, 17, 26, 32, 33, 35, 44, 48, 50, $54,55,76,95,102,106,109,121$, $124,133,140,143,144,149,151$, $154,165,167,168,177,179,187$, 200, 201, 204, 228, 237, 244, 263, $268,270,271,282,286,287,288$, 294, 299, 303

Christmas, 18, 28, 36, 46, 71, 79, 89, $98,103,128,129,132,133,155,166$, 174, 176, 182, 184, 199, 200, 217, $232,261,269,272,283,300,304$ churches, 10, 20, 21, 27 29, 31, 35, 36, $37,4757,72,73,76,79,117,129$, $141,149,154,155,156,163,168$, 169, 173, 176, 185, 189 190, 191, 196199 217, 226, 228, 233, 248, 253, 254, 258, 260, 279, 284, 293, 294, 304; Baptist churches, 20, 29, 72, 129, 176, 189, 233, 248, 260; Christian church, 260; Church of Christ, 156, 233, 304, 305; Elgin Methodist Church, 129; Hyde Park Baptist Church, 199; Lutheran church, 141; McDade Baptist Church, 248; McDade Church of Christ, 156; McDade Lutheran church, 141; Methodist churches, 29, 72, 73, 117, 129, 149, 189, 260,
304; Mount Pleasant Methodist Church, 73; non-denominational churches, 260, 293, 305; Oak Hill Church, 189, 293, 305; Pleasant Hill Baptist Church, 29; Ridgeway Church, 191; Sayers Baptist Church, 129; Sweet Home Church, 29; union church, 293; Weeping Willow Baptist Church, 233. See also preachers, ministers, deacons cisterns, 10, 12, 13, 17, 20, 46, 57, $108,109,131,138,150,152,171$, 172, 181, 184, 237, 242, 244, 263, 281, 301. See also water; wells Civilian Conservation Corps (CCC), 15, 58, 85, 164, 175, 210, 236, 291, 303. See also government programs Civil War, 50, 125, 148, 256, 267, 279, 298

clabbered milk, 103, 168, 249, 262, 306. See also milk

Clark, Charlie, 67

Clark, Edward "Tobe", 67

Cleveland, President Grover, 215

Clopton, Hettie, 112

clothing, 14, 19, 49, 50, 54, 70, 71, $94,120,124,130,131,134,144$, $155,169,176,182,190,196,201$, 233, 244, 257, 260, 263, 273, 278, 285, 290, 305; dresses, 14, 19, 54, 120, 124, 131, 144, 169, 201, 233, 260, 305; Lauterstein's dress shop; 305

coachwhips. See under snakes coal, 118, 171, 237

coal mines, 148, 170. See also Sayers Coal Mine

coal mining, 109, 163, 164, 167, 172,

174, 188, 211, 226. See also Sayers Coal Mine

coal oil, 36, 165, 303. See also kerosene (as fuel)

coastal grass. See under grass coffee, 5, 10, 132, 155, 170, 171, 257, 294

colleges and universities, 270, 274, 299, 305; Abilene Christian College, 305; Baptist university, 305; Baylor University, 2; Brackenridge Nursing school, 293; Draughan's Business College, 255; Methodist University, 305; Southwest Texas College, San Marcos, 269, 299; Texas A\&M University, 234

College Station, Texas, 223, 299

Colorado River, 90, 118, 189, 199, 235 colored, 71, 72, 89, 104, 116, 119, 141, 180, 185, 191, 196, 208, 212, 226, 228, 236, 237, 295. See also African American; blacks

Colter, Ben, 277

community: development, 3; gatherings, 16, 17, 20; life, 2 cookies, 193, 259

cooking, 10, 11, 13, 14, 15, 16, 17, 19, $22,36,37,42,55,57,68,73,75,79$, $80,81,87,94,95,97,98,99,105$, $106,108,109,110,124,128,129$ $132,134138,152,154,155,156$, 159, 165, 166, 167, 168169,180 , 189, 193, 194, 198, 204 220, 223 224, 228234 235, 242, 249262 , 263, 266, 269, 270, 273, 274, 275, 289, 290, 294, 295, 300302,303 cooking oil, 17

cooling, 12, 17, 20, 81, 95, 103, 105, $108,109,113,128,167,168,181$, 186, 191, 193, 216, 224, 242, 243, 247, 249, 262, 278, 281, 288, 289, 290, 294, 301

corn, $13,15,1626,32,33,35,43,48$, $54,63,65,69,70,77,88,91,94,96$ $106,107,138,142,145,153,154$, $163,164,166,167,171,180,182$, $192,194,202,204,220,263,264$, $266,275,276,278,286,287,290$, 298, 301; cornbread, 15, 63, 65, 99, $105,106,132,154,166,175,223$, 234, 243, 262, 268, 300; corn cribs, 96, 142, 222; corn grinders, 15; cornmeal, 15, 16, 63, 96, 192, 202, 266, 298; corn pulling, 33, 70, 204; corn shelling, 63, 96, 142, 192, 222, 223, 290, 301; corn shucking, 70, 142, 222, 223, 301; corn stalks, 64; corn syrup, 259; corn tops, 32, 33, 142, 224; maize, 54, 65, 70, 153, 263; silking corn, 223, 290, 301. See also grain; hominy; vegetables

Corpus Christi, Texas, 99, 260 cottage cheese. See under cheese

Cottle, Albert, 11, 45, 297

Cottle, Aubrey, 299

Cottle, Evelyn. See Wilson, Evelyn (Cottle)

Cottle family, 12, 45

Cottle, Gordon, 299

Cottle, Laura (Evelyn Cottle Wilson's mother), 11, 297

Cottle, Rex, 11, 299, 303

Cotton, Mr. See Cotton's Dairy

cotton, 5, 14, 15, 16, 17, 26, 29, 32, 33, $54,58,63,64,65,66,68,69,70,71$, 
cotton (continued), 75, 77, 80, 82, 88, 92, 94, 97, 107, 110, 118, 132, 138, $139,142,145,152,153,163,164$, $165,167,173,181,185,187,194$, 204, 209, 223, 226, 227, 228, 234, 236, 237, 247, 255, 263, 265, 276, 277, 286, 287, 299, 304; cottonseed, 44, 97, 142; cottonseed hulls, 44; cottonseed meal, 106

cotton gins. See gins

Cotton's Dairy, 44

Coulson, E. Oneita (Miss Nate), 302

Coulson family, 302

Coulson house, 299

Coulson place, 297, 303

Coulters, Boss, 132

county fair, 268

courting, 82, 121, 189, 257, 299

cows. See cattle

crackers, 170

cracklin's. See under hogs

cream, 103, 125, 152, 185, 262. See also milk

Creel, Leroy, 15

Crisco, 17. See also lard (grease)

Crockett, Texas, 30

curds, 5. See also milk

dairy, 124, 193, 261, 262. See also milk

dairy cows. See under cattle

daisy butter churn, 216

Dale, Texas, 217

Dallas Fair, 153

Dallas, Texas, 92, 176, 254, 255, 173

dams, 171

dances, 21, 51, 82, 118 176, 189, 201, 202, 269, 298

Daughtry, Bryant, 232

Davis, Mott, 214

Deed of Gift, 2

DeGlandon, Alcide, 104, 112, 116, 124,125

DeGlandon, Elizabeth Margaret

"Lizzy" Stagner (Grandma

DeGlandon), 112, 122, 124

DeGlandon family, 12, 19, 102, 109, 124, 295

DeGlandon house, 109

DeGlandon, Mann (Mr. DeGlandon), 106, 107

DeGlandon, Maude, 293

DeGlandon place, 109

Dennison farm, 61, 66

Dennison, Frank, 61, 63, 71, 83, 188

Dennison, Jimmy, 61
Dennison land, 205

Dennison Mine. See Sayers Coal Mine

Dennison place, 63, 65, 72, 73

Dennison property, 179

Depression, 31. See also Great Depression

Diboll, Texas, 39, 227

diesel gins. See under cotton gins discipline, 18, 46, 66, 76, 82, 112, 130, 154, 183, 195, 207, 211, 218, 221, 222, 261, 282, 283, 304

diseases and illnesses, 60, 266, 268, 301; bronchitis, 225; colds, 225; diabetes, 19, 21, 245, 249, 260, 262; diphtheria, 12, 301 (see also medicines and home remedies: DPT shots); epilepsy, 245; flu, 124; flu epidemic, 12, 111, 170, 272, 296; heart attacks, 260; high blood pressure, 260; leukemia, 176; pneumonia, 125, 149, 157, 256, 272, 299; staph infection, 122; tuberculosis, 165, 176; typhoid fever, 170; whooping cough, 272; yellow fever, 256. See also health; home remedies and medicines doctoring, 11, 24, 50, 51, 75, 76, 111, 113, 117, 124, 131, 139, 157, 158, 170, 197, 208, 225, 271, 272 296, 301. See also home remedies and medicines

doctors, 12, 21, 50, 101, 124, 131, 139, 144, 157, 165, 170, 216, 225, 245, 270, 283. See also home remedies and medicines; hospitals dogs, 18, 22, 35 52, 53, 69, 91, 113, $120,160,173,174,204,220,221$, 228, 231, 234, 235, 243, 244, 273

Dogwood Creek, 71, 93, 185

Dogwood Creek community, 30, 71, 93, 185, 191, 209

dolls, 111, 124, 155, 174, 269

donkey (jack), 277. See also livestock

Doobie family, 93

doves, 52, 235, 236

dresses. See under clothing

droughts, 24, 26, 87, 91, 175, 262, 267

Duck Pond community, 236

Duck Pond Road, 236

ducks, 38, 70, 272

Duncan family, 282

Duncan Pottery, 119

Duncan, Sam Finch, 227

Dungan, Clyde, 107

Dunkin, Adele, 9

Dunkin, Bernice, 20
Dunkin, Clyde, 9, 12, 13, 16

Dunkin, Dee, 10, 12, 21

Dunkin, Doris, 9, 11, 12, 17, 22

Dunkin, Elizabeth Fitzgerald

Hancock, 148, 257

Dunkin, Ellen, 10

Dunkin family, 157, 257

Dunkin, Garland Huff, 9

Dunkin, Grandpa, 16

Dunkin, Jess, 9, 18

Dunkin, Katherine, 9, 11

Dunkin, Laverne, 9, 12, 14

Dunkin, Lawrence, 9, 12, 15, 17, 20

Dunkin, Leon, 9, 13, 21, 22

Dunkin, Max, 17, 21, 23

Dunkin, Naoma, 9, 11, 157

Dunkin, Ola Mae, 9, 12, 14

Dunkin, Sweetie, 12

Dunkin, Woodrow, 9, 12, 14, 15, 17

Dutch oven, 274

dyes and bluing, 48, 169, 171

Eagle Pass, Texas, 274

early settlement, $119,125,143,148$, $164,186,215,256,257,262,267$, $275,279,302$

Easter, 225, 261

East, Leonard, 103

East Texas, 55, 56, 85, 90, 173, 227

economy, 6, 10, 13, 14, 18, 26, 34, 36, $39,64,70,71,75,80,90,93,96$, $97,98,100,107,108,110,115,116$, $119,120,123,124,125,129,130$, $132,133,137,138,139,141,143$, $148,151,155,158,159,163,165$, $167,168,169,170,173,174,175$, $179,181,182,185,186,189,194$, 195, 196, 198, 199, 201, 202, 203, 204, 205, 209, 210, 211, 212, 213 $217,220,221,223,227,230,234$, $237,238,242,243,244,245,246$, $249,255,256,257,259,260,262$, 263, 264, 267, 268, 269, 270, 272, 273, 274, 278, 285, 286, 289, 291, 292, 298, 299, 300, 301, 302, 304, 306

Eden, Texas, 96, 97

Edinburg, Texas, 112

education, 2. See also colleges and universities; school

eggs, 105, 5, 14, 15, 17, 22, 45, 53, 80, 87, 91 95, 96, 106, 110, 115 124, 127 $128,138,150,155,163,165,166$, $169,181,193,199,227,230,245$, $261,272,273,278,290$

electricity, 20, 57, 81, 87, 99, 108, 133, 
$140142,165,180,181,186,193$, 206, 216, 224, 243, 249, 289, 290, 303

Elf Gas Station, 224

Elgin brickyard. See Elgin Standard Brick Company

Elgin cotton gin. See under cotton gins

Elgin Courier newspaper, 187, 303

Elgin Methodist Church. See under churches

Elgin School. See under school

Elgin Standard Brick Company, 89, 90, 96, 249

Elgin, Texas, 2, 5, 21, 28, 31, 34, 44, 54, 57, 61, 69, 76, 81, 86, 88, 90, 97, 98, 99, 100, 133, 135, 138, 139, 144, $147,148,160,164,173,185,186$, 191, 203, 206, 215, 216, 220224 , 225, 226, 233, 234 236, 239, 249, 254, 262, 275

elm trees, 189, 276, 277, 30 employment. See occupations entertainment, 11, 36, 51, 53, 99, 124, 153, 160, 173, 294, 306. See also games; recreation; social gatherings

Erhart, Earl, 257

Esberger cotton gin. See under cotton gins

Esberger, Earl, 265

Eschberger. See Esberger

Evans, Anna, 30

Evans, Charlie, 28, 81

Evans family, 29, 93, 248

Evans, Otis, 227, 236, 248

Evans place, 232

Evans, Sam, 30

Evans, Will, 227, 247

eyeglasses, 283

Fag family, 250, 251

Fair Oaks School. See under school family gatherings, 121, 122, 129, 166, 225, 261, 297, 303

family sizes, 9, 10, 11, 64, 88, 102, $110,124,127,129,130,139,143$, $144,147,148,153,163,165,179$, $180,194,200,209,215,247,255$, 256, 257, 260, 261, 276, 284, 287, 288, 291, 295, 297

farm equipment: cultivator, 226, 238, 272, 287, 288, 299; graders, 244; plows, 5, 64, 167, 208, 225, 226, 238, 272, 277, 287, 299

farming, 5, 14, 15, 17, 21, 25, 26, 28
$30,32,33,34,41,42,54,59,61,63$, $65,65,69,77,88,90,97,110,114$, $116,124,127,152,153,156,158$, $164,167,179,180,185,188,191$, 209, 228, 263, 276, 277, 286, 287, 293, 298. See also agriculture

fences, 22, 32, 86, 90, 93 122, 143, $145,167,171,182,187,199,202$, 205, 212, 244, 273, 274, 285, 288

Ferguson, Governors $\mathrm{Ma}$ and $\mathrm{Pa}, 295$ fertilizer, 70, 109, 262

feuds, 199, 265, 270, 282, 283, 295 , 296

fireplaces, 13, 14, 109, 142, 150, 165, $167,176,223,274,300$

firewood, 10, 14, 17, 32, 55, 76, 82, 93 105, 109, 133154 163, 171, 174, 180, 184, 224, 234, 242, 264, 271, 300

fireworks, 31, 36, 46, 47

fishing, 34, 51, 68, 69, 71, 87, 92, 94, 95, 114, 142, 157, 173, 189, 197, 198, 230, 233, 235, 244, 268, 292

Fleming, Andy, 248

Fleming, Aggie (Aunt Aggie), 295, 296

Fleming, Curtis, 283, 293

Fleming family, 19, 71, 272, 295

Fleming, Frank (Grandpa Fleming), 232, 248

Fleming, Howard, 298

Fleming, Jack, 291

Fleming, Mayme McCright, 19, 111, 282 283, 284. See also under schoolteachers

Fleming, Mr., 227, 234

Fleming, Mrs. Frank (Grandma Fleming), 232, 248

Fleming place, 232, 236

Fleming, Russ, 287, 288

flies. See under bugs and insects

flour, 5, 10, 31, 72, 97, 138, 152, 163, 171,263

flour sack, 113, 144

flowers (gardens \& decorations), 12, 48, 49, 147, 151, 153, 157, 192, 262. 298, 301. See also gardens

Flowers, Cunnie, 250

Flowers family, 250

Flowers, M. C., 249

Flowers, Miss, 11

Flowers, Mrs. O L, 63, 65

Flowers, O L, 7, 27, 37, 94, 61-86

Flowers, Pallie, 64, 131

Flowers, Shirley, 64, 249, 250

Flowers, S T, 64, 65, 77

Floyd place, 232

football, 196 forest fires, 15, 236

fort (old), 119, 133, 232

Fort, Auss, 87

Fort Bend County, 215

Fort Davis, Texas, 303

Fort, Dean, 7, 219, 279, 87-100

Fort, Doll. See Fort, John W. "Doll"

Fort family, 257

Fort Hood, Texas, 1, 231, 239

Fort, John W. "Doll”, 87, 88, 89, 91, 93, 98, 99, 100, 219, 279

Fort, Mary Ann. See Barbee, Mary Ann Fort Hancock

Fort place, 232

Fort Sam Houston, Texas, 81

Fort Worth, Texas, 10, 130, 255

Freeman, Martha Doty, 1, 7, 9-24, 147-161, 163-177, 253-274, 297-306, 41-60

freezers, 81, 108, 109, 128, 193, 194, 278. See also refrigerator

fried chicken, 11, 38, 154, 156, 168, 266, 300

fried turkey, 228

fruit, 15, 16, 17, 18, 19, 34, 46, 48, 94, 95, 112-113, 137, 166, 174, 181, 194, 197, 264, 268, 271; apples, 19, 155, 174, 184, 259; blackberries, 225, 234, 298; blueberries, 226; cantaloupes, 5, 10, 88, 97, 103, 107, 110, 114, 140, 194, 203, 264, 268, 298; dewberries, 13, 16, 18, 38, 57, 75, 91, 166, 197, 234, 279, 298; dewberry cobbler, 197; dewberry jelly, 22, 91, 166, 234; dewberry juice, 16; figs, 262; grapes, 16, 38, 48, 49, 89, 113 138, 155, 166, 209, 234 238, 264, 265, 271, 277; grape jelly, 16, 38, 49, 128, 166, 234,

264; grape juice, 16, 113, 166, 264; huckleberries, 112, 113; improved Brazos blackberries, 234; lemons, 112; oranges, 19, 155, 174, 184, 260; orange juice, 225; peaches, 18, 94, 112, 138, 154, 166, 181, 197 , 223, 265, 271, 298; peach jelly, 94; pears, 112, 181, 271; persimmons, 298; plums, 18, 75, 89, 91, 113, 138, 166, 181, 198, 223, 234, 298; plum jelly, 22, 91, 198, 234; strawberries, 16, 262, 265; watermelons, 5, 9, 13, $14,15,1635,54,55,66,70,71,86$, $88,94,97,98,103,107,110,114$, $127,132,133,140,145,153,154$, 163, 164, 185, 194, 203 219, 221, 222, 223, 228, 234, 237, 242, 243, 249, 259, 264, 267, 268, 278, 279, 
fruit (continued), 281, 286, 289, 298; watermelon pulling, 35 . See also jelly and preserves; orchards; vegetables

Fuller Brush Salesmen, 39

funerals and burials, 117, 134, 141, 190, 192, 245, 301; burials, 12, 88, 99, 117, 190, 191, 200; caskets, 12; graves, 117, 134, 190, 191, 232, 246, 254, 260, 296, 302; wakes, 245. See also cemeteries and graveyards

Furr, Ruby, 254

furs, 34, 53, 113, 114, 120, 173, 204, 220, 221, 233, 234, 273. See also hides; pelts

Galveston Hurricane (storm of 1900), 124, 261

Galveston, Texas, 90, 98, 257, 267

games, 11, 14, 19 27, 36, 46, 52, 73, $75,78,79,92,109,124,130,132$, $140,144,149,157,168,172,177$, $183,196,217,218,237,255,260$, 267, 268, 269, 285, 294, 298, 305. See also entertainment gardens, 5, 9, 12, 14, 15, 26, 28, 37, $43,48,56,63,64,69,70,74,88$, $91,109,131,132,138,151,152$, 154, 160, 163, 166, 181, 193, 194, $197,202,209,223,225,232,243$, 264, 271, 289, 298, 300, 301. See also corn; flowers (gardens \& decorations) fruit; vegetables gas, 165, 171, 225

geese, 5, 58, 272; goose pluckings, 117

Georgetown, Texas, 147

Gest family (Guest). See Guest family (Gest)

gins, 82, 83, 266; Barbee cotton gin, 257, 265; Bastrop cotton gin, 83 , 165; cotton gins, 16, 82, 83, 139, 144, 149, 152, 165, 204, 205, 237 , 257, 265, 299; diesel gins, 83; Elgin cotton gin, 299, 300, 83, 97; Esberger cotton gin, 265; Hancock cotton gin, 83, 149, 151, 152, 158, 233, 234, 235, 265; McDade cotton gin, 83, 88, 110, 145, 234, 237, 265, 299; Oak Hill cotton gin, 110, 204, $205,257,265$; steam gins, 82,83 , 265 .

Glenham Coal Mine, 62, 163, 167

Glenham School. See under school Glenham, Texas, 7, 163, 167, 171, 172
Goerlitz, Alice, 120

Goerlitz, Louise (Smith), 7, 101-125

Goerlitz, Erhard Jr., 112, 120

Goerlitz, Erhard Oscar, 7, 101-125

Goerlitz, Frank, 104

Goerlitz, Grandpa, 107

Goerlitz, Janice, 120

goose pluckings. See under geese

government programs, 19, 58, 64, 80, $107,110,113,114,115,119,159$, $166,175,210,223,236,248,273$, 278, 290, 291, 292, 302, 303, 304.

See also Civilian Conservation

Corps (CCC); New Deal programs; Workers Progress Administration (WPA)

grain, 54; hygear, 65, 145; milo, 54; rice, 206; wheat, 106

Grand Ole Opry, 247, 248

grapes, 16, 38, 48, 49, 89, 113138 , 155, 166, 209, 234 238, 264, 265, 271, 277 (see also under fruit); grape fields, 229 (see also vineyard); viticulture, 209. See also wine; winery

grass: Bermuda, 90; coastal, 90, 104; Johnson, 104

grasshoppers. See under bugs and insects

graveyards. See cemeteries and graveyards

grazing cattle. See under cattle grazing lands, 90, 104, 231 grease. See lard

Great Depression, 13, 14, 56, 107, 114, 120, 158, 174, 179, 201, 209, 210, 217, 233, 235, 236, 263, 268, 273, 290, 298, 302, 304, 306. See also Depression

Greenbriar School. See under school

Griffin Enterprises, 159

Griffith League Ranch, 202, 288

Griffith, Mr., 288

Griffith place, 288

groceries, 19, 28, 31, 71, 80, 88, 97, $98,99,120,129,138,141,144,155$, $156,171,181,206,227,230,238$, 239, 246, 247, 263, 265, 304, 305

Grosse boys, 107

Grosse, Mr., 107

Guest family (Gest), 168

guineas, $5,13,39,70,95,96,137$, 169,174

gumbo, Ruby Johnson's, 129

gypsies, 39 hack. See buggies

hams, 17, 30, 91, 105, 128, 132, 168, 192, 246, 259, 288, 290. See also bacon; hogs; sausage

Hancock, Amy, 270, 273

Hancock, Arthur, 111, 147, 148, 149, 253, 265

Hancock, Bertie Lee, 148, 261

Hancock, Bonnie, 263, 270, 271, 272, 273

Hancock cotton gin. See under cotton gins

Hancock, Delia, 257

Hancock, Dorothy, 266

Hancock, Elizabeth Fitzgerald. See Dunkin, Elizabeth Fitzgerald Hancock

Hancock, Eva, 148

Hancock, Evan, 147

Hancock, Evie, 257

Hancock, Harrell, 147

Hancock, Jessie, 257

Hancock, John Erwin, 147, 148, 256, 257, 265, 266

Hancock, Kenneth, 266, 269, 270

Hancock, Lucy, 148, 149

Hancock, Mary Ann. See Barbee, Mary Ann Fort Hancock

Hancock place, 83

Hancock, Ray, 59, 148, 149, 265

Hancock, Russ, 296

Hancock, Ruth L. Allen, 148, 149, 150, 155, 156, 157, 158, 257

Hancock, Sam, 148, 149, 257

Hancock, Seth, 147, 156

Hancock, Tabitha, 148

Hancock, Vivian, 147

Hancock, Woodrow, 270, 273, 274

hangings, 125, 186, 199, 227, 232

Harris County, Texas, 124

Harvey, Edith May, 125, 253

Harvey family, 125

hay, 32, 104, 145, 151, 180, 203, 223

health, 10, 11, 12, 15, 19, 21, 23, 50, $51,54,60,81,103,111,113,117$, 118, 124, 125, 133, 139 147, 149, $157,161,165,170,176,190,192$, $197,212,225,226,245,249,250$, $256,257,260,262,266,272,277$, 284, 295, 296, 299, 300, 301, 303. See also diseases; home remedies and medicines

heating, 13, 46, 47, 56, 57, 109, 118, $133,139,150,165,171,180,184$, 195, 207, 223, 237, 242, 281, 290, 300 
Herms (Hearns) place, 227, 248

Herron Cemetery. See under cemeteries and graveyards

Herron land, 117

Herron Road, 149, 151

hides, 18, 34, 113, 114, 120, 204, 220, 221, 233, 234, 273. See also furs; leather making; pelts

highways, interstates, and loops: Highway 1704, 96; Highway 20, 97; Highway 21, 84, 92, 191, 283; Highway 220, 237; Highway 2336, 88, 92; Highway 290, 87, 88, 89, $92,94,123,144,145,219,224,230$, 233, 243, 284; Highway 47, 90, 86, 57, 92, 94, 118, 129, 132, 153, 205, 213, 236, 275; Highway 969, 90; Interstate 35, 199; Loop 223, 87; Old Highway 20, 101, 144

hill country, 212

hobos, 174

Hoffman, Jake, 45

hogs, 5, 23, 30, 44, 52, 69, 70, 90, 91, 93, 97, 103, 104, 106, 107, 110, 118, $128,137,138,140,147,151,158$, $163,192,193,213,217,227,234$, $235,236,236,245,272,276,278$, 288, 290, 302; cracklin's, 105, 106, 304; hog killings, 17, 30, 52, 64, 65, 91, 97, 104, 105, 118, 128, 138, 151, 167, 168, 192, 202, 217, 227 , 237, 245, 246, 288, 289, 290; hog pennin-up time, 106; hog turninout time, 106; marking hogs, 91. See also bacon; hams; livestock; pork; sausage

home births, 11, 101, 102, 127, 137, 139, 157, 215, 216, 270, 298

home brew. See under alcohol

Home Demonstration Agent, 57, 223, 115

Home Demonstration Club, 115 home remedies and medicines, 11, 50, $75,76,113,124,131,139,157,159$, $170,175,197,208,225,256,260$, 271, 296; aspirin, 271, 272; Baby Percy Medicine, 113; bandages, 115; Black Draught, 11, 170, 197; castor oil, 11, 113, 170, 197; chicken-pip tea, 76; cough syrup, 139, 271; DPT shots, 301; kerosene (as home remedy), 11, 111, 124, 271; liniments, 103, 113, 131, 174, 208; poke salad, 38, 75-76 124, 125, 198, 234; poultices, 131, 225, 296, 296; prickly pear, 51; spring tonic, 75, 197; Syrup of Pepsom, 113; tonics, 197; turpentine, 271; Vicks Vaporub, 113, 157, 225. See also doctoring; doctors; hospitals; Rawleigh; Watkins

hominy, 290

honey, 23, 54, 139, 193. See also bugs and insects: bees

horses, 5, 30, 42, 44, 52, 57, 61, 65, $71,73,74,76,91,94,104,105,112$, $115,124,125,130,131,133,138$, $139,143,145,147,151,152,153$, $157,159,179,188,200,205,217$, $218,220,221,227,232,235,238$, $244,258,259,264,271,272,273$, 282, 283, 285, 288, 296, 299. See also livestock

hospitals, 54, 111, 120, 122, 124, 149 157, 270, 292; Austin State Hospital, 149; Bastrop hospital, 111, 122, 124, 157, 292

house fires, 10, 21, 122, 123, 135, 226, $227,241,242,245,247,249,302$

houses, 10, 12, 13, 33, 42, 43, 47, 59, 81, 86, 94, 102, 108, 109, 110, 124, 128 135, 138139 142, 144, 150, 152 $165,180,222,22,226,231,243$ 261, 263, 269, 270, 277, 287, 289, 290, 298, 300, 301, 302; log cabins, $15,215,222,223,224,253,302$; log houses, 13, 263, 264, 302; porches, 12

Houston County, Texas, 30, 36

Houston newspaper, 262

Houston, Texas 11, 92, 144, 176, 230, 239, 241, 256, 258, 261

Howery, Mr., 121

Hudler, Jeff, 115

Huff, Byron, 16

Huff, Clifton, 16

Huff, Grandma, 23

Huff, Levi, 16

hunting, 8, 34, 35, 51, 53, 68, 69, 92, $97,113,114,120,142,160,173,174$, 197, 204, 220, 221, 226, 231, 233, 234, 235, 236, 244, 273, 292, 293. See also rabbit drives; wildlife

Hurley, Jessica, 1, 2, 3

Hutto, Texas, 255, 273

Hyde Park, Texas, 199

ice (for cooling), 81, 103, 113, 186, 193, 206, 216, 249, 262. See also under weather iceboxes, 103, 105, 109, 110, 113, 168,
$186,193,216,249,262$

ice cream, 10, 31, 37, 165, 193, 263, 306

ice houses, 193

illness. See diseases and illnesses

Indian Lodge, 303

insects. See bugs and insects

Interstate 35. See highways,

interstates, and loops

ironing, 12

irrigation, 89, 229, 230

jelly, 16, 22, 38, 45, 49, 91, 94, 108, $128,154,155,165,166,170,194$, 198, 234, 259, 264, 268, 304; dewberry jelly, 22, 91, 166, 234; grape jelly, 16, 38, 49, 128, 166, 234, 264; peach jelly, 94; plum jelly, 22, 91, 198, 234; Sure Gel, 108, 194; watermelon preserves, 154. See also fruit

jelly cake, 128

jennies, 74, 76. See also livestock

Jett family, 295

Jett, John, 295

Jewell T. Baking Goods, 159

Johnson City, Texas, 2, 281

Johnson grass. See under grass

Johnson, President Lyndon, 269

Johnson, Ruby Mae Thomas, 7 , 127-135

Juneteenth (Nineteenth of June), $30-31,73,79$

Kastner, Arthur, 143, 145

Kastner, Cecil, 143

Kastner Fritz 89, 143

Kastner, Julius (Grandpa Kastner), 143, 145

Kastner, Kelly, 143

Kastner, Martin, 143, 145

Kastner, Morris J., 7, 137-146, 250

Kastner, Mrs. Julius Kastner (Grandma Kastner), 145

Kelton, Ethel. See Blackwell, Ethel Kelton

Kelton, Eva Mae Smith, 41

Kelton family, 122

Kelton, Oscar, 41

Kemp family, 276, 277

Kemp, Martha, 276

Kemp, Mr., 131

kerosene (as fuel), 5, 36, 57, 81, 108, 140, 150, 216, 218, 225, 226, 243, 
kerosene (continued), 262. See also coal oil; lamps

Knobbs, Texas, 110, 115, 116, 123, 199, 200

Korean War, 59, 231, 239

Kreuger, Lonnie, 231

Kreuger, Shirley, 221, 231

Kyle, Texas, 298

Lake Bastrop, 60, 202

lamps, 12, 36, 57, 108, 140, 165, 184, 188, 261, 303. See also kerosene; lighting

land acquisition (including property taking and acquisition), 2, 5, 21, 30, $34,41,42,58,59,61,72,86,87,88$, $89,98,99,108,109,122,124,125$, $134,135,137,139,141,143,147$, $150,152,160,177,212,213,214$, $215,224,230,232,238,239,241$, 243, 244, 250, 257, 267, 273, 275, 276, 277, 286, 291, 292, 293, 295, 297, 299, 300, 302, 306

lanterns, 100, 184, 188. See also lighting

lard (grease), 17, 38, 65, 94, 95, 97, $98,105,106,118,134,138,140,151$

laundry, 10, 43, 57, 59, 140, 150, 153, 169, 171 200, 201, 249, 301, 303

law and order, 144, 159, 160, 188, 199, $200,211,227,230,232,238,264$. 267, 285, 299

LCRA. See Lower Colorado River Authority (LCRA)

leased land, 205, 143, 145, 231

leather making, 273. See also hides

Lee County, Texas, 116, 271

Lewis, Don (Uncle Don), 151, 152, $154,157,159$

Lewis family, 23

Lewis, Marsaleete "Leetie" Orline McKinney, 297

Lewis, Samuel Alexander, 297

Lexington, Texas, 86, 144, 271

Light, Bettye Lynn Blackwell 42, 43, $4448,49,56$

lighting, 12, 31, 36, 56, 57, 108, 109, 140, 165, 184, 188, 216, 221, 303.

See also lamps; lanterns

lignite mine, 118, 133, 214, 230, 231 , 237, 246, 159

lignite watch, 214

Ligon family, 12

Lillian, Mr., 23

Lindener family 59

liquor. See under alcohol literature, 53, 55

Little River, Texas, 63

Little Sandy Creek, 129

livestock, 22, 23, 30, 44, 63, 65, 74, 93, 103, 107, 124, 128, 138, 141, 213, 221, 272, 286, 298, 302. See also cattle; donkey (jack); hogs; horses; jennies; mules

Lockhart, Texas, 2, 9, 115, 197

log cabins. See under houses

logging, 85

logging off fields (bed land), 219, 220

Lower Colorado River Authority (LCRA), 6, 243

Lufkin, Texas, 75, 90

Luling, Texas, 217

lumber, 84, 85, 93, 122, 141, 142, 160, $163,171,199,213,224,227,261$, $264,300,303$

lye, 15, 111, 118, 134, 151, 171, 271

Mabry, Dr., 272

macaroni, 304

Madison, Walter, 208

Magalene, Texas, 72

magazines, 40, 53, 55, 158. See also newspapers; Progressive Farmer mail, 27, 115, 120, 133, 140, 141, 151, 231, 236

mail carriers, 115, 133, 231, 247

maize. See under corn

Majors, JoNell (Hancock), 7, 45, 147-161

Marsh, Gertrude Smith, 254, 263, 269, 270, 271, 274

Martinez, Margarita, 144

Maynard, C. B., 299

McDade Pottery, 119, 120, 266;

McDade Road. See Sayers-McDade Road

McDade-Sayers Road. See SayersMcDade Road

McDade School. See under school

McDade, Texas, 2, 5, 6, 7, 10, 16, $18,19,22,27,32,33,41,42,44$, $51,57,58,61,65,66,68,71,82$, $83,86,88,89,90,94,97,98,101$, $102,103,104,107,112,113,115$, $116,117,118,121,124,125,127$, $133,137,138,143,144,148,155$, 163, 164, 167 175, 185, 186, 194, 195, 199, 200, 201, 212, 217, 220, 223, 227, 230, 232, 233, 235, 238, $241,242,243,245,249,255,256$, 257, 259, 261, 263, 268, 270, 272, $273,275,279,283,291,298,304$,
305; McDade Bank, 119; McDade Cannery, 249; McDade Cemetery (see under cemeteries and graveyards); McDade history, 199; McDade Ice House, 262; McDade Museum, 200; McDade Saloon, 256; McDade, Soul of a Small Town, 214; McDade VFW, 122; McDade Watermelon Festival, 194

McKinney, Marsaleete "Leetie" Orline. See Lewis, Marsaleete "Leetie" Orline McKinney

McLaughlin Creek, 104, 215, 218 , $220,228,232,242$

meals, 98, 124, 132, 138, 152, 154, $165,166,167,168,188,193,228$, 266, 275, 294, 300, 302, 303; breakfast, 22, 23, 43, 99, 132, 152 , 154-155, 165-166, 167, 193, 266, 271, 291, 303; dinner (at social gatherings), 11, 20, 22, 31, 261; dinner (lunch), 17, 19, 45, 46, 49, $78,120,124,129,132,154-155$, $156,166,170,193,182,219,259$, 266, 270, 285, 303; dinner (Sundays and holidays), 98, 193, 261, 300, 302; supper, 132, 154, 222, 226, 242; supper (at social gatherings and box suppers), 189, 278

meat, $13,15,23,30,38,56,58,64$, 73, 78, 80, 81, 91, 95, 105, 106, 107, $108,115,128,138,151,167,168$, $169,192,193,211,237,249,264$, 274, 278, 291, 294, 193

meatloaf, 302

medicines. See home remedies and medicines

Memoir Introduction, 2

Merriman Place, 117

mesquite trees, 140, 142, 226, 235 , 236, 242, 272

mesquite wood, 142

Mexicans, 62, 116, 141, 144, 170, 172, $188,215,230,231,236,246,250$, 304

milk, 5, 12, 13, 14, 17, 19, 23, 46, $80,91,93,95,96,102,103,104$, $110,113,116,123,124,125,137$, $152,155,163,165,168,179,180$, 185, 186, 193, 198, 199, 216, 221, 223, 244, 249, 259, 262, 264, 268, 270, 271, 272, 288, 291, 301; milk cooler, 216; milk separators, 179, 180, 185. See also clabbered milk; cream; curds; whey

Miller, Angie, 164

Miller, Bobby, 177 
Miller, Bryson, 164

Miller, Cerilus, 164

Miller, F. L., 164

Miller, Foster, 52, 164

Miller, Gilbert, 164

Miller, Gordon, 164

Miller, J. B., 175, 177

Miller, Jephty, 163

Miller, Jeppie, 164

Miller, Jodie, 164

Miller, Martha, 164

Miller, Mary, 164

Miller, May Belle. See Morriss, May

Belle (Miller)

Miller, Mr., 84

Miller, Sallie Benight, 163

mills, 13, 37, 57, 63, 66, 96, 104,

132, 192, 228, 256, 264, 265, 278,

298; grist mill, 298; lead mills,

256; lumber mill, 264; molasses

mills, 13, 22, 66, 67, 104, 265,

266; sawmill, 84; sugar cane mill,

104; syrup mills, 104, 208, 228 ,

278; Wilford Molasses Mill, 265;

windmills, 222, 224, 228

Milton place, 117

mining, 5, 31, 32, 61, 62, 148, 163, $167,170,174,179,187,188,202$, 205, 211, 226, 230, 231, 237, 246. See also Sayers Coal Mine

Model A Ford. See under automobiles

Model T Ford. See under automobiles

molasses, 23, 66, 69, 78, 228;

molasses cane, 63, 65, 66. See also

cane; ribbon cane; sorghum; sugar

cane; syrup

money, 10, 12, 13, 14, 15, 18, 19, 21, $22,23,24,34,36,39,44,46,50$, $53,54,56,58,63,70,71,74,75,80$, $82,83,84,88,90,93,97,98,100$, 101, 102, 103, 106, 107, 108, 110, $113,114,116,119,120,123,124$, $125,129,130,132,133,134,137$, 138, 141 143, 148, 151, 155 158, 159, $163,165,167,168,169,170,173$, 174, 175, 179, 181, 182, 185, 186, 189, 194, 195, 196, 198, 199, 201, 202, 203, 204, 205, 209, 210, 211, 212, 213, 220, 221, 223, 227, 230, $234,235,237,238,239,242,243$, $244,245,246,247,249,254,255$, $256,257,259,260,262,263,264$, $265,267,268,269,270,271,272$, 273, 274, 276, 277, 278, 285, 286, 289, 291, 292, 293, 298, 299, 300, 301, 302, 305, 306. See also cash Montgomery Ward, 120
Moon, Mr., 132

moonshine. See under alcohol

Moore, Bob, 32

Moore, Maggie, 3

Morgan, Andrew, 186

Morgan, Edith May Ransom, 186

Morgan, Jackson, 275, 276

Morriss, May Belle (Miller), 7, 163-177

mosquitoes. See under bugs and insects

Mount Bethel Cemetery. See under cemeteries and graveyards

Mount Pleasant Methodist Church. See under churches

muddying (fishing), 68, 69, 94, 95, 235

mules, 5, 10, 21, 23, 30, 33, 37, 44, $62,63,64,66,67,74,77,82,83$, $85,96,100,104,127,137,138,139$, $140,142,143,145,185,188,202$, 207, 209, 219, 220, 221, 222, 225, $228,235,236,238,242,244,271$, 272, 287, 295, 296, 299. See also livestock

Mundine family, 93

music, 20, 21, 29, 33, 35, 51, 52, 56, $79,153,163,165,173,174,175,176$, $177,201,234,260,269,278,298$, 305

Nacogdoches County, 180

Nacogdoches, Texas, 77

Navy, 52, 215, 233, 287

neighbors helping neighbors

(backboning), 12, 14, 20, 23, 27, 30, $35,37,43,70,71,78,80,81,90,93$, $95,97,106,111,114,117,118,127$, 131, 132, 133, 134, 140, 141, 142, $151,153,158,165,166,168,172$, $174,180,182,184,190,192,202$, 207, 212, 214, 216, 217, 226, 228 , 234, 235, 236, 237, 245, 249, 250, 262, 265, 266, 277, 278, 282, 288, 295, 297, 299, 300, 301, 304

New Deal programs, 80, 210. See also government programs

New Hope Cemetery. See under cemeteries and graveyards

newspaper, use of, 43, 175, 207 newspapers, 53, 98, 156, 187, 214, 270, 303, 304. See also Bastrop Advertiser; Elgin Courier; Houston newspaper, 262

New York, 206, 257

Nickels, David L., 3, 7, 101-125, 127-
135, 137-146, 215-251, 241-251

Nineteenth of June. See Juneteenth non-denominational churches. See under churches

nuts, 46, 112; acorns, 5, 104, 202; hickory nuts, 112; peanut butter, 170, 259; peanuts, 5, 9, 13, 15, 16, $54,63,69,83,84,97,118,140,153$, 167, 168, 185, 194, 202, 203, 204, 219, 223 237, 259, 276, 278, 286, 298; pecans, 5, 24, 112, 142, 220, 235, 256, 274, 298. See also walnut poisoning

Oak Hill community, 5, 6, 7, 21, 24, $32,33,35,48,53,57,87,93,97$, $102,104,115,118,119,124,125$, $148,155,173,179,180,183,186$, 187, 188, 191, 192, 194, 195, 199, 201, 202, 206, 208, 211, 213, 217, $228,232,233,234,235,236,245$, 253, 256, 257, 258, 262, 266, 273, 297, 298, 303; Oak Hill Cemetery (see under cemeteries and graveyards); Oak Hill Cemetery Association (see under cemeteries and graveyards); Oak Hill store (see under stores)

Oak Hill Picnic, 92, 124, 148, 190, 258, 259, 260, 261, 263, 266, 294

Oak Hill Road, 272

Oak Hill School. See under school oak trees, 93, 99, 199, 202, 273

occupations (outside employment and income), 51, 56, 59, 60, 61, 77, 78, $82,83,84,85,91,96,110,112,120$, $121,127,130,143,149,151,156$, $157,158,160,171,173,175,176$, $180,181,187,188,196,199,208$, 210, 211, 213, 216, 217, 222, 228 , $229,233,236,242,246,247,248$, 249, 254, 255, 256, 257, 273, 276, 288, 291, 292, 293, 299, 302, 303, 304,305

Ocho, Jesus, 144

Ocho, Marcelino, 144

Ocker, Mr., 159

oil, 217, 224, 289, 303

Old Blue (dog), 220, 233, 234

Old George (horse), 272

Old Joe (dog), 220, 233, 234

Old Potato Road, 143

Old Sayers Road. See Sayers-McDade Road

oleo, 193

olive oil, 259 
orchards, 103, 137, 138, 140, 142, 154, 209, 223, 298. See also fruit; nuts outhouses, 14, 46, 109, 139, 151. See also chamber pots

Owen, Andrew, 11, 17, 37, 75, 201, 207, 208, 210, 212

Owen, Andrew (Uncle Andrew), 210

Owen, Edgar, 194, 208, 258

Owen, Elgitha "Githa" Smith, 179, 181, 186, 187, 188, 190, 193, 196, 197, 198, 200, 213

Owen family, 11, 12, 23, 28, 214, 274

Owen, Fay. See Pannell, Fay (Owen)

Owen, Grandmother, 181

Owen, Harry, 17, 197, 210

Owen, Jack "Monkey", 75, 196

Owen, Joe (Joe, Jr.) 75

Owen, Joseph "Joe" (Joe, Sr.), 186, 208, 268, 213

Owen, Luther, 201

Owen, Mrs., 181

Owen, Polly (Aunt Polly, Mrs. Edgar Owen), 87, 91, 92, 97, 158, 187, 194, 214, 283

Owen, Robert, 207, 210

Owen, T. W. (Grandfather), 181

oxen, 57, 73, 74, 209, 235. See also livestock

Pace family, 282

Paige, Harlan, 84

Paige, Texas, 9, 16, 21, 23, 50, 84, 102, 104, 112, 115, 124, 143, 144, 191

Pampa, Texas, 254, 255

Pannel, Dr., 225

Pannell, Fay (Owen), 28, 29, 37, 7, 11, $57,63,66,67,71,72,75,78,80$, $92,93,116,118,159,160,254,257$, 268, 179-214

Pannell, Leland, 179, 203-214

Pannell, Peggy, 214

Parker, Mrs., 123

patriotism, 99, 122, 213, 292

Patschke, Marie, 112

Payne, Janice, 101-125

Payne, Roger, 101-125

Pearl Harbor, 16, 42, 44, 56, 58

peddlers, 5, 24, 39, 106, 115, 125, 141, $148,159,174,206,208,271,298$ pelts, 34, 113, 114, 204, 220, 221, 233, 234, 273. See furs; hides

Pershing Avenue, 42

Phelan Coal Mine, 148

Phelan, Texas, 7, 163, 172, 174

Phillips family, 218, 251
Phillips, Kayrow, 247

pickles and relishes, 301, 304; beet pickles, 194; cucumber pickles, 194; peach pickles, 194; sauerkraut, 108. See also canning

pies, 17, 94, 156, 166, 294

pigeons, 38

pine trees, 84, 85, 93, 191, 199, 202, 221, 264

pine wood, 243, 264

Piney community, 83, 93, 111, 125, 208, 236

Piney Creek, 42, 72, 73, 207, 235, 282

Piney Creek Cemetery. See under cemeteries and graveyards

Pleasant Hill Baptist Church. See under churches

plowing, 5, 17, 26, 44, 48, 63, 64, 77, $82,107,110,114,132,142,167$, 203, 204, 208, 209, 225, 226, 228, 238, 272, 277, 287, 288, 299

plumbing, 139, 181, 289

poke salad. See home remedies and medicines

politics, 212, 214, 292, 294, 295

popcorn, 128

Pope Ranch, 231

pork 91, 94, 95, 98, 151, 155, 167, 289, 302. See also bacon; hams; hogs; livestock; sausage

post offices, 27

potash, 111, 113

potatoes, 43, 44, 47, 48, 64, 69, 91, 106, 154, 220; bedding potatoes, 219; Irish potatoes, 17, 103, 107, 140, 166, 167, 193, 203, 301; potato bin, 224; potato salad, 156, 266, 294; potato slips, 219, 224; white potatoes, 301. See also sweet potatoes

pottery kilns, 119, 120, 133, 266

preachers, ministers, deacons, 20, 29, 98, 156, 189-190, 226, 233, 260, 293-294, 305; Baptist preachers, 233, 248; Brother Holt (Baptist preacher), 233; Methodist preachers, 149, 233; Presbyterian preachers, 233. See also churches

Press, Dr. (Mr.), 131

Prince (dog), 273

Progressive Farmer, 53, 54. See also magazines

Prohibition, 88, 133, 238, 264. See also alcohol

property acquisition. See land acquisition

property taking. See land acquisition property values, 21, 22

Pruitt, Texas, 219

pulling corn. See corn

quilts and quilting, 13, 18, 20, 47, 49-50, 117, 118, 263, 290

rabbit drives, 35, 114, 235. See also hunting

radios, 53, 56, 99, 118, 140, 216, 247, 248, 294. See also entertainment railroads, 25, 27, 38, 51, 85, 97, 103, $107,113,118,120,145,163,171$, 174, 186, 194, 199, 206, 220, 221, 227, 231, 234, 243, 249, 298

Ramsey School. See under school ranching, 227, 231, 236, 288

Ransom, Amherst, 256

Ransom, Ed, 256, 261

Ransom, Edith May Morgan, 186

Ransom family, 125, 256, 262, 267

Ransom, Sarah, 124, 125, 186, 256, 261

Ransom, Walter, 261, 267

rattlesnakes. See under snakes

Ravenberg, Ed, 264

Rawleigh: extracts, 103; liniment company, 113; salesman, 39, 103, 115, 208; salves, 103. See also home remedies and medicines record players, 189

recreation, $11,14,18,27,36,46,52$, $53,56,62,73,75,78,79,82,89,92$, $109,111,118,121,124,130,132$, $140,144,149,157,160,168,172$, 177, 182, 183, 188, 189, 190, 196, 197, 198, 207, 217, 218, 222, 232, 233, 234, 237, 244, 247, 248, 250, $254,255,260,267,268,269,271$, 285, 294, 298, 305, 306

Red Rock, Texas, 22, 23

Reese, Dovie, 32, 33, 36

Reese, Earlie, 26

Reese, Ernest, 26

Reese family, 180

Reese, Isom, 26, 31, 153

Reese, Mary, 36

Reese, Mary Lou, 25, 180. See Benford, Mary Lou (Reese)

Reese, Ruben, 26

Reese, Sam, 26

Reese, Viola, 153, 29, 30

Reese, Woodie, 26

refrigerators, 103, 243, 290, 301. See also iceboxes 
religion, 2, 5, 18, 20, 29, 31, 40, 45, 47, 72, 73, 129, 131, 141, 149, 154, $155,156,163,168,173,176,185$, 189, 190, 196, 199, 226, 228, 233, 248, 253, 258, 260, 279, 284, 293, 294, 296, 303, 304, 305. See also churches

revivals, 29, 168, 169, 189, 190, 233, 294

Rhodes, Joe Lee, 111

ribbon cane, 69. See also cane; molasses; sorghum; sugar cane; syrup

Ridgeway community, 191, 297; Ridgeway Cemetery (see under cemeteries and graveyards); Ridgeway Church (see under churches); Ridgeway Picnic, 20, 191

Rio Grande Valley, 112

Rivers, Mr., 97

roads, $5,58,71,74,75,85,88,96$, $112,129,130,132,142,143,171$, $174,185,186,206,207,210,228$, 229, 231, 243, 244, 247, 255, 259, 283, 286

Rockdale, Texas, 10, 148

Rockne, Texas, 17, 22, 23

rodeos, 130

Roosevelt, President Franklin D., 107, 110, 119, 236302

root cellars, 15, 17, 113, 142, 167

Rosenwald School. See under school Rucksell axle, 246, 247

safe (cooler), 168, 289.

Saint John Community, 36

saloons, 148, 199, 200, 256

San Angelo, Texas, 96, 2, 45, 61, 85, 148, 149, 276, 297, 305

Sanders, Arlie, 115

Sanders, Joe Lee, 111

sand hills, 53, 84, 87, 88, 91, 99, 107, 199, 202, 273

San Marcos, Texas, 149, 229, 254, 269, 270, 299

sauerkraut, 108

sausage, 17, 91, 95, 104, 105, 106, 128, 138, 151, 192, 217, 227, 246, 290. See also bacon; hams; hogs Sayers(ville) community, 2, 5, 6, 7, 25, 26, 28, 29, 31, 37, 57, 61, $66,68,71,72,73,76,83,116$, $119,127,129,153,185,189,191$, 199, 205, 206, 208, 214, 257, 277; Sayers Baptist Church (see under churches); Sayers Cemetery (see under cemeteries and graveyards); Sayers Depot, 206; Sayers Road, 66, 236; Sayers Store. See under stores

Sayers-McDade Road, 64, 143, 217, 226, 232, 236

Sayers Coal Mine, 32, 61, 62, 63, 72, 118, 133, 179, 187, 188, 202, 205, 211, 246. See also mining

Sayers Coal Mine Commissary

(Dennison's store). See under stores

Sayers School. See under school

Sayersville community. See

Sayers(ville) community

Sayersville Elm, 189

Sayersville Historical Society, 2, 29

Sayersville Mine. See Sayers Coal Mine

Sayersville-McDade Road. See Sayers-McDade Road

Scarborough, Aunt Mame, 149

Scarborough, Ida, 148

Scarborough, William, 148, 149

school buses, 19, 45, 111, 118, 144, 156, 158, 160, 219, 298

schools and school districts, 5, 10, $17,19,25,27,31,42,43,44,45,46$, $47,50,57,61,76,77,78,79,87,93$, $109,111,112,116,118,122,124$, $127,129,130,137,140,141,144$, $149,152,155,156,157,160,163$, $170,171,172,179,182,183,184$, $185,187,189,195,196,206,207$, 217-219, 227, 228, 232, 237, 247, $251,254,255,257,258,259,260$, 261, 267, 268, 269, 270, 271, 277, 281, 283, 285, 298, 300, 301, 302, 305; Bastrop High School, 254, 299; Bastrop Independent School District, 195; Bastrop school, 7, 19, 45, 46, 111, 156, 157, 160, 183, 195, 196, 206, 207, 217, 255, 298; Cedar Creek School, 285; chocolate school, 116; Elgin School, 7, 127, 130, 144, 161, 219; Fair Oaks School, 284, 285; Glenham School, 7, 163, 170; Greenbriar School, 214; McDade School, 7, 111, 118, 124, 137, 141, 144, 217, 219; Oak Hill School, 7, 19, 42, 87, 109, 111, $115,119,124,149,156,157,163$, $170,179,182,183,184,187,195$, 196, 217, 237, 254, 257, 259, 260, 261, 267, 270, 281, 283, 285, 300, 301, 305; Oak Hill School Board, 298; Oak Hill School District, 298;
Ramsey School, 219; Rosenwald School, 79; Sayers School, 7, 25, 27, 61, 76, 78, 79, 129, 130, 184, 185, 251, 277; Wayside School, 7 , 93, 217, 218, 227 232, 237 247, 251, 258, 285; Wayside School District, 298

school teachers, 11, 19, 27, 28, 46, 50, 76, 78, 111, 130, 144, 156, 183, 184, 195, 207, 217, 218, 220, 221, 224, 227, 251, 254, 255, 261, 281-282, 284, 285, 293; 300; McCright, Mayme, 19, 111, 282, 283, 284 (see also Fleming, Mayme McCright); McDade, Miss (Sayers schoolteacher), 130; Griffith (Griffin?), Dot, 46; Holland, Miss (Oak Hill schoolteacher), 111; Sanders, Jewell Rhodes, 111; Sanders, Mrs. (Miss) Joe Lee, 111; Smith, Mr. and Mrs., 111; Stagner, Marie, 11, 19, 46, 156; Stagner, Miss, 46; Stagner, Mozelle McCright 111

school trustees, 156, 227, 237, 285, 298; Oak Hill School Trustees, 298

Scott, Abner (Grandfather), 217, 223, 225, 232

Scott, Abner Cleveland, 7, 66, 119, 215, 216, 244, 245, 247, 248, 251, $258,275,276,285,215-251$

Scott, Allen, 216, 219, 225

Scott, Belle, 228

Scott, Billy, 233

Scott, Dan, 216, 218, 220, 222, 223, 224, 225, 227, 248

Scott, David, 215

Scott, Donald, 216, 248

Scott, Eddie Joe, 229

Scott, Edgar, 226, 230, 245

Scott Falls, 5, 6, 7, 86, 87, 89, 89, 90, 189, 219, 221, 229, 232, 236, 239, 247. See also Spring Branch community

Scott Falls Dam, 229, 230

Scott Falls Road, 94, 228

Scott family, 71, 88, 93, 119, 215, 221, 275

Scott farm, 66, 82

Scott, Grover, 216, 226, 245, 247, 248, 249

Scott, Harlan, 216, 248

Scott, Henry, 215

Scott, Ina, 216, 221, 223, 225, 227, 247

Scott, Jack, 232

Scott, Jason, 216 
Scott, Jeff, 242

Scott, Jesse Lee, 216, 218, 222, 248

Scott, John Henry (Grandpa), 226, 227, 232, 235, 238, 241, 242

Scott, Jonathon, 216

Scott, Louise (Grandma), 225

Scott, Malcolm Ray, 229

Scott, Martha, 215

Scott, Mary Lou, 216, 218, 248

Scott, Minnie Lea, 245

Scott, Mr., 131

Scott, Napoleon, 215, 216

Scott, Otma (Ott), 89, 90, 229, 230, 247

Scott place, 89, 127

Scott, Sandra, 233

Scott, Shelly Jackson (S. J. "Jack"), 7, 241-251

Scott, Walter, 216, 227, 45

Sears Roebuck catalog, 120, 124

seasonings (herbs, spice, extracts), almond extract, 208; chili powder, 274; cinnamon, 17; herbs, 274; lemon extract, 208; pepper, 17, 97, 128, 217, 234, 274; pepper sauce, 234; sage, 17, 128, 217; salt, 5, 10, $11,17,64,97,105,106,108,128$, 151, 152, 157, 168, 170, 193, 204, 259, 272, 273, 274, 288; vanilla extract, 14, 208. See also honey

segregation and non-segregation, 57, $71,75,89,116,119,129,132,135$, $141,144,151$ 152, 153, 154, 157, $159,170,172,180,184,185,191$, 195, 196, 197, 212, 236, 257, 268, 278, 285, 294, 295, 296

sewing, 48, 49, 50, 54, 120, 121, 124, $144,148,149,169,249,257,305$

sewing machines, 50, 148, 149, 169, 271

sharecroppers, 116,120, 137, 138, 139, 140, 141, 142, 144, 192, 250, 295, $32,61,63,65,83$

sheep, 91. See also livestock shelling beans. See vegetables: beans shelling corn. See under corn shelling peanuts. See nuts: peanuts shelling peas. See vegetables: peas shoe repairman, 121

shoes and boots, 19, 51, 121, 145, 158, $169,174,175,182,183,198,221$, $225,260,273,283,287,305$

shopping, 10, 13, 14, 18, 19, 28, 31, 39, $50,54,62,71,72,88,97,99,120$, 124, 129, 130, 133, 138, 141, 144, $148,155,165,171,181,195,196$, 197, 206, 211, 227, 231, 246, 258,
259, 263, 269, 273, 275, 304, 305.

See also stores

shortening, 163

sickness. See diseases and illnesses

silking corn. See under corn

Singer sewing machines, 149

singletree, 105

Sitton, Grandmother, 26, 204

Sitton, Thad, 3, 7, 179-214, 25-40,

275-279, 281-296, 61-86, 87-100

Sixth Street, Austin, Texas, 305

slavery, 30, 34

slaves, 256, 260, 268, 275, 277, 295, 302

slingshot, 142

Smith, Alice Louise. See Goerlitz, Louise (Smith)

Smith, Amherst Harvey, 103, 109, 124, 125, 199

Smith, Andrew Morgan, 124, 125

Smith, Bertie, 217

Smith, Brenda, 274

Smith, Buela, 124

Smith, Edith May, 50, 102, 103, 106, 108, 109, 112, 124, 125

Smith, Elgitha. See Owen, Elgitha

"Githa" Smith

Smith, Elizabeth Sowell, 49

Smith family, 44, 122, 157, 186

Smith, Gertrude. See Marsh, Gertrude Smith

Smith, Gloria, 46, 124

Smith, Grace DeGlandon, 102, 124

Smith, Harvey, 48, 124, 125

Smith, Harvey Jr., 113, 118

Smith, James, 114

Smith, John W. "Doll”, 107

Smith land, 124

Smith, Lorraine, 114

Smith, Louise. See Goerlitz, Louise (Smith)

Smith, Pansy, 187

Smith, Robert Whitworth, 255

Smith, Ruth E., 7, 41, 46, 48, 209, 217, 253-274

Smith, Sula (Aunt Sula), 112

Smith, Thurber, 187

Smithville, Texas, 14

Smith, Violet, 187

Smith, Woodrow, 112, 260

smokehouses, 15, 30, 64, 91, 95, 105, $128,132,138,142,151,167,192$, $217,246,288,289,302$

snakes, 11, 14, 22, 68, 75, 111, 113, $124,130,131,132,149,169$, 170, 225, 226, 230, 234, 272; chicken snakes, 22, 169-170, 272; coachwhips, 11, 22, 130, 131; copperheads, 11, 14, 22, 111, 124, 131, 225, 234; rattlesnakes, 22, 131, 170, 225, 226; spreadin' out snake, 132

Snowden, Mr., 230, 239

snuff, 258

soap, 15, 17, 43, 118, 134, 140, 151, 171,298

social gatherings, $20,21,22,23,27$, $31,46,49,51,53,55,58,68,73,79$, $82,89,90,92,97,98,114,117,124$, $148,155,156,157,164,168,175$, 176, 180, 184, 187, 188, 189, 190, 191, 196, 197, 198, 201, 202, 206, $212,232,233,234,235,249,253$, 254, 258, 260, 261, 266, 267, 268, 273, 274, 278, 283, 290, 294, 298, 301,303

soda water, 10, 156, 259, 263, 294

Somerville, Texas, 114

sorghum, 54, 69,166; sorghum cane, 69; sorghum syrup, 166, 167, 208.

See also cane; molasses; ribbon cane; sugar cane; syrup

South Carolina, Gaffney, 55

Southern, Dr., 101

Sowell, 50

Sowell, Charlie, 243, 249, 251

Sowell, Dale, 249

Sowell family, 244, 249, 250, 251, 232

Sowell, Gus, 243, 251

Spring Branch community, 5, 6, 7, 221, 232, 236. See also Scott Falls Spring Branch Creek, 275

Spring Branch, Lee County, Texas, 116

springhouse, 289

springs, 85, 89, 130, 171, 172, 262, 301

Stagner, Bradford, 11

Stagner, Elizabeth Margaret "Lizzy," 124, 125. See DeGlandon, Elizabeth Margaret "Lizzy"

Stagner

Stagner family, 12, 20, 125

Stagner, Great-grandpa, 125

Stagner, Horace, 11

Stagner, Marie, 11, 14, 19, 156. See

also under schoolteachers

Stagner, Mildred, 11

Stagner, Will, 115

Stanley salesmen, 103

steam gins. See under cotton gins

stock pens, 107

stonemason, 90

stores, 10, 19, 25, 28, 30, 31, 43, 62, 
$71,72,74,75,80,81,83,85,88,96$, 97, 98, 102, 106, 112, 114, 120, 130, $133,138,141,143,144,148,155$, $156,158,159,165,171,227,229$, 230, 231, 238, 239, 243, 246, 258, 259, 263, 264, 265, 273, 284, 305; Bell store, 188, 205; drugstores, 229; Evans Store (Sayers Store), 81, 130, 206; Hillman's grocery store, 156; McKann Store, 96; Oak Hill store, 88, 258, 259, 284; Owen's store (Edgar and/or Polly), 158, 159; Phelan Store, 159; Sayers(ville) Store, 81, 188, 205, 206, 211, 246; Sayers Coal Mine Commissary (Dennison's store), 71, 81, 188, 211, 231; Scott's Drugstore, 229, 120, 124, 204, 269. See also shopping storm cellars, 24

streetcars, 267

strychnine, 114

sugar, 5, 10 14, 17, 65, 67, 72, 152, 163, 171, 193, 194, 206, 263, 274 sugar cane, 22, 26, 37, 38, 54, 57, 96, 104, 142, 145, 228, 265, 266, 278.

See also cane; molasses; ribbon cane; sorghum; syrup

Sullivan, Dr., 270

Sullo, Shellie, 1

Sun City, Texas, 258

Sweet Home Church. See under churches

sweet potatoes, $5,9,13,15,16,38,63$, $64,65,66,69,77,97,107,114,129$, $132,133,138,140,151,152,165$, 166, 167, 193, 194, 202, 203, 204, 219, 223, 224, 237, 275, 277, 286, 295, 301. See also potatoes

swimming, 14, 52, 68, 86, 89, 90, 172, 189, 198, 236, 247

syrup, 37, 38, 54, 57, 67, 96, 104, 165, $182,193,208,262,266,278$

taxes, 22

taxidermist, 273

Taylor, Green, 57

Taylor, Texas, 103, 106, 173, 305;

Taylor Creamery, 103, 125; Taylor Lodge, 79

tea, 132,193

telephones 20, 81, 111, 116, 117, 133, 140, 172, 211, 212, 231, 232, 243, 247, 259, 304, 53, 99, 294

Texarkana, Texas, 256

Texas Parks and Wildlife Department, 6
Texas Ranger, 121

Thanksgiving, 18, 79, 103, 155, 182, 300

Tharns, Lydia, 130

Thiele, Alton, 83

Thomas, Buck, 135

Thomas, Curly, 131

Thomas, David, 131

Thomas family, 129

Thomas, Irena, 135

Thomas, Isiah (Scram), 276

Thomas, Walter L., 7, 275-279

thrashing peanuts. See peanuts

tie cutting, 199

tobacco, 5, 81, 93, 94, 206, 258, 278

Todd Drydock, Galveston, Texas, 98

Todd Shipyard, Galveston, Texas, 90

Townsend, Sheriff Woody, 107

tractors, 74, 137, 202, 226, 238, 244, 298

trails, 187, $226255,259,285$

transportation, 28, 31, 42, 44, 45, 59, 64, 70, 73, 74, 76, 82, 94, 96, 97, $98,107,111,112,114,117,118,121$, $124,125,127,129,130,134,139$, $140,141,143,144,145,151,152$, $155,156,157,159,160,163,165$, $166,167,168,170,171,173,174$, $176,179,182,185,186,187,191$, 195, 196, 202, 203, 204, 205, 206, 207, 208, 216, 217, 218, 219, 220 , 221, 222, 224, 225, 226, 227, 228, 230, 231, 233, 234, 235, 237, 238, $242,243,244,245,246,247,248$, $249,255,258,259,260,266,268$, $271,277,281,282,283,284,285$, 286, 288, 294, 298, 299, 301, 303, 304. See also automobiles; buggies; horses; jennies; wagons

trapping, 34, 35, 46, 120, 204, 233, 234, 293

Travis County, Texas, 85, 98, 107, $117,134,151,173,179,186,203$, 217, 218, 221, 225, 227, 230, 231, 243, 246, 249, 268, 285, 286, 298, 299, 303

turkeys, 5, 13, 17, 22, 38, 39,54, 55, 70, 71, 95, 96, 98, 102, 103, 120, 124, 128, 137, 140, 142, 147, 150, $151,154,155,169,181,182,192$, 213, 227, 228 234, 245, 269, 273, 300

union church. See under churches university. See colleges and universities utilities, 20

Utley, Dan, 100

Utley, Texas, 29

vagrants, 159

Valley (Rio Grande), 112

vegetables, 5, 10, 26, 28, 34, 48, 70, $88,91,108,110,127,132,133,151$, 152, 194, 245, 249, 264, 274, 278, 289, 300-301; beans, 15, 19, 58, 152, 154, 155 166, 167, 194, 206, 264, 266, 268, 300, 301; beets, 70, 152, 193, 223; cabbage, 14, 108, 132, 152, 193; carrots, 70, 193, 301; collard greens, 132, 264; cucumbers, 70, 166, 301; greens, 132, 193, 198, 264, 301; lettuce, 264; mustard greens, 264; okra, 13, 15, 77, 129; onions, 203, 274; peas, $5,10,13,15,28,37,48,69,97,129$, $133,138,152,154,166,185,193$, 194, 204, 210, 220, 223, 237, 245, 264, 278, 301; peppers, 138, 166, 234, 264; pumpkins, 48; radishes, 301; spinach, 70, 234; squash, 15, 48, 70, 264; tomatoes, 10, 15, 43, $48,58,91,110,115,116,138,151$, 152, 166, 193, 194, 223, 264, 300, 301; turnips, 15, 193, 264. See also corn; grain; potatoes; sweet potatoes

veterinarians, 153

Victrola, 189

vinegar, 91, 166, 234

vineyard, 277. See also winery

volleyball, 19, 78, 237, 255, 285

Waco, Texas, 248

wagons, 5, 10, 13, 14, 16, 20, 21, 28, 29, 31, 32, 33, 36, 44 64, 67, 68, 73, $82,83,84,85,94,97,100,112,137$, 139, 151, 165, 166, 167, 168, 171, 173, 191, 203, 204, 217, 218, 220, $224,226,227,233,234,235,237$, 242, 246, 248, 260, 266, 283, 294, 304

Wallace, Gus, 107

walnut poisoning, 68, 235

Washington-on-the-Brazos, Texas, 256

Washington place, 297

washtubs, 10, 106, 139, 172, 249, 301

water, $10,12,13,14,16,17,20,26$, 43, 46, 51, 54, 57, 65, 80,81, 85, 87, $89,91,92,94,99,105,106,108$, 
$109,113,119,131,138,139,142$, $143,146,150,151,152,157,166$, 171, 172, 180, 181, 184, 207, 216, $218,224,229,233,234,237,238$, 242, 244, 262, 263, 264, 298, 301. See also cisterns; wells

Waterson, (Joe) Bryan (mail carrier), $115,133,247$

Watkins: big salve, 131; liniment, 131; product, 159; salesmen, 39, 103, 115; salve, 24, 131. See also home remedies and medicines

Watkins, Linda, 258

Watson, Hemphill, 267

Watson, Irene (Fleming), 7, 281-296

Watson, John, 281-296

Watson, Walter L., 7

Watson, Willie, 267, 268

Watson, Willy, 115

Wayside community, 5, 6, 7, 20, 93, $115,116,119,144,191,217,232$, 236, 247, 248, 258, 285

Wayside School. See under school Wayside School District. See under school

weather, 24, 26, 42, 44, 47, 87, 91, $105,122,124,143,151,175,181$, 182, 190, 191, 195, 197, 206, 207, 217, 218, 219, 229, 231, 233, 236, 247, 255, 261, 262, 263, 267, 281, 282, 283, 286, 290, 304; ice, 170, 175, 195, 207, 290; rain, 10, 16, 20, $24,26,28,44,47,48,65,69,75,91$, $109,122,124,143,171,175,195$, 197, 200, 206, 217, 218, 219, 220, 229, 231, 233, 236, 247, 255, 263,
267, 282, 283, 286; sandstorms, 175, 304; snow, 24, 170, 175, 207 , 290; storms, 24; tornadoes, 151, 175; wind, 24, 175.

Webberville, Texas, 90, 96, 97

Weeping Willow Baptist Church. See under churches

wells, 12, 43, 57, 80, 94, 109, 122,

131, 172, 180, 205, 216, 224, 225,

237, 238, 249, 262, 264, 301. See

also cisterns; water

Westbrook Place, 232, 247, 248

Wharton, David, 214

Wharton, Vickie, 214

whey, 5. See also curds; milk

whiskey. See under alcohol

Wilbert, Florence, 266

Wilbert, Mr., 266

wildlife, 113, 140, 173, 204, 221, 235, 244; bobcats, 170, 273; civet cats, 140; coyotes, 53, 140, 170, 182, 226, 234, 273; deer, 69 92, 173, 231, 233, 274, 293; eels, 295; foxes, 53, 170, 182, 226, 234; gophers, 140; opossums, 34, 35, 69, 114, 140, 197, 204, 220, 221, 233, 234, 244, 273, 295; polecats, 34, 204, 244; rabbits, $35,53,68,92,95,97,114,142,173$, 197, 226, 235, 293 (see also rabbit drives); raccoons, 34, 69, 140, 197, 204, 221, 234; ringtails, 114, 220 , 221, 233, 234, 273; skunks, 34, 46, 52, 53, 114140 221, 234, 273, 274; squirrels, $68,92,95,114,173,197$, 220, 235, 244; wolves, 53, 113, 129, 130, 244; See also hunting; snakes
Wilford family, 265

Williams, Diane E., 3

Williams, Gabe, 43

Williamson County, Texas, 279

Williams, Payne, 120

Wilson, Evelyn (Cottle) 7, 11, 45 , 297-306

Wilson, Minnie, 80

Wilson, Sharon, 306

wind charger, 216, 224. See also mills: windmills

wine. See under alcohol

winery, 119, 133, 238, 247, 264, 265; wine press, 238. See also alcohol: wine; grapes

winters, 24, 42, 43, 47, 64, 70, 71, 94, 109, 114, 124, 133, 138, 145, 151, $167,175,182,183,193,195,197$, 207, 217, 224, 228, 242, 246, 247, 273, 281, 288, 290, 300, 301, 302, 303. See also weather

wood stoves, 13, 42, 46, 47, 56, 57, 99, $128,139,165,167,171,180,223$, $224,226,237,242,263,274,289$. 300

Workers Progress Administration (WPA), 58, 303. See also government programs

World War I, 12, 16, 149, 199, 227 , 265, 267, 276

World War II, 1, 5, 7, 15, 16, 54, 57, $58,60,81,84,88,90,98,99,115$, $117,118,121,153,233,255,291$, 293, 297, 298

WPA. See Workers Progress Administration (WPA) 
